\title{
Case Studies of
}

Energy Efficiency Financing in the Original Five Pilot States, 1993-1996

Barbara C. Farhar, Ph.D.

Nancy E. Collins, Ph.D.

Roberta Ward Walsh, Ph.D.

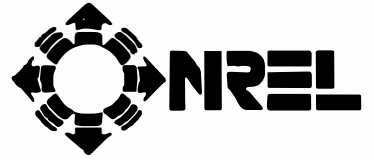

National Renewable Energy Laboratory 1617 Cole Boulevard

Golden, Colorado 80401-3393

A national laboratory of the U.S. Department of Energy Managed by Midwest Research Institute for the U.S. Department of Energy under Contract No. DE-AC36-83CH10093

Prepared under Task Nos. AS575440 and BE514102 


\section{NOTICE}

This report was prepared as an account of work sponsored by an agency of the United States government. Neither the United States govemment nor any agency thereof, nor any of their employees, makes any warranty, express or implied, or assumes any legal liability or responsibility for the accuracy, completeness, or usefulness of any information, apparatus, product, or process disclosed, or represents that its use would not infringe privately owned rights. Reference herein to any specific commercial product, process, or service by trade name, trademark, manufacturer, or otherwise does not necessarily constitute or imply its endorsement, recommendation, or favoring by the United States govemment or any agency thereof. The views and opinions of authors expressed herein do not necessarily state or reflect those of the United States government or any agency thereof.

Available to DOE and DOE contractors from:

Office of Scientific and Technical Information (OSTI)

P.O. Box62

Oak Ridge, TN 37831

Prices available by calling (423) 576-8401

Available to the public from:

National Technical Information Service (NTIS)

U.S. Department of Commerce

5285 Port Royal Road

Springfield, VA 22161

(703) 487-4650 


\section{Acknowledgments}

The evaluation research on which this report is based was managed and conducted at the National Renewable Energy Laboratory (NREL). It was funded by the U.S. Department of Energy (DOE). Cognizant DOE program managers for the effort were Jabob Kaminsky, Louis V. Divone, and John Reese.

The report contains the results from the five pilot-state case studies with corresponding background material. The case studies relate process evaluation information on each of the states' experiences in implementing programs linking energy efficiency financing with home energy rating systems as mandated under the Energy Policy Act (EPAct) of 1992.

Several organizations contributed to the case studies. Foremost were the respondents in the pilot states and federal agencies who provided much of the data included. NREL funded each of the major HERS provider organizations in the pilot states to provide data for this study and to further develop their own data and evaluation systems. Among pilot state respondents were Barbara Collins in Alaska; Carol Cales in Arkansas; Jay Luboff in Colorado; Michael Martin in California; Richard Faesy in Vermont; and Christine Lowrie in Virginia. Among the federal officials providing data were David Dwyer and Virginia Holman, U. S. Department of Housing and Urban Development (HUD); Walt Patton, Rural Housing Service (RHS); and Kathleen Mangold, Department of Veterans Affairs (DVA).

Author Barbara Farhar of NREL managed the project and was responsible for the Virginia case study and collection of national-level data. Co-author Nancy Collins with $\mathrm{Q}^{4}$ Associates in Oakland, California, was responsible for case studies in Alaska and California. Co-author Roberta Ward Walsh, with the University of Vermont, Burlington, prepared the Arkansas and Vermont case studies.

Reviewers included Ron Judkoff, NREL; John Reese, DOE; Diane Pirkey, DOE; and Malcolm Verdict, Alliance to Save Energy, Washington, DC. At NREL, Jan Eckert and Laura Vimmerstedt assisted in collecting national data on energy efficiency financing. Janet Saunders, Mary Anne Dunlap, Kathleen O'Dell, Kay Vernon, Irene Medina, Stefani Cairns, and Dawn Griffin completed the report's editing and word processing. 


\section{Executive Summary}

Creation and subsequent institutionalization of energy efficiency financing (EEF) products linked with home energy rating systems (HERS) are gaining momentum across the nation and, in the process, transforming the housing marketplace by improving the energy efficiency of the housing stock. Energy efficiency financing is a consumer mortgage or home improvement loan that enhances a borrower's ability to qualify based on the increased cash flow gained from a more efficient home. Because energy improvements generally reduce home energy costs more than the increase in the loan payment, lenders can use this effective "added income" to qualify borrowers to finance the costs of the improvements in the larger mortgage loan amount. When these loans are based on a quality home energy rating, lenders can have more confidence that the improvements made will result in a positive cash flow for the consumer.

In concert with the U.S. Department of Energy (DOE), the Federal Housing Administration (FHA), the Rural Housing Service (RHS, formerly the Farmers Home Administration), the Department of Veterans Affairs (DVA), the Federal National Mortgage Association (Fannie Mae), and the Federal Home Loan Mortgage Corporation (Freddie Mac), states are supporting the development of EEF products linked with HERS. States in the forefront of these developments include the five selected to pilot a U.S. Department of Housing and Urban Development (HUD) program requining that existing homes be rated in order to qualify for FHA energy-efficient mortgages (EEMs): Alaska, Arkansas, California, Vermont, and Virginia. In October 1995, HUD extended EEMs to new and existing homes in all 50 states; the DVA program also offers EEMs in all states. In addition, Colorado and Virginia are in the process of piloting a Fannie Mae program that offers both EEMs and energy improvement mortgages (EIMs).

The National Energy Policy Act (EPAct) of 1992 and the Housing and Community Development Act of 1992 required that the Federal Housing Administration (FHA) of the U. S. Department of Housing and Urban Development (HUD) conduct an energy efficient mortgage (EEM) pilot program in five states. In 1993, HUD/FHA selected Alaska, Arkansas, California, Vermont, and Virginia where pilot programs would be implemented to underwrite energy efficient mortgages linked with home energy raings. In 1994, NREL worked with the pilot states, and representatives of federal agencies and the secondary mortgage markets, to develop a detailed evaluation plan to provide data for use by the states, as well as a costeffective method for aggregating evaluation data at the national level. The evaluation was intended to provide data required by federal statutes and to provide information for states interested in pursuing EEF programs to improve the efficiency and affordability of housing.

As a basis for a comparative analysis, NREL and the HERS provider organizations in the pilot states developed case studies documenting EEMs implementation. The evaluation plan, published in 1994, guided the data collected. The case studies focus on the years 1993-1996 when the EEMs program was originally being tested and additional EEF products were being developed.

The HUD/FHA EEMs program was expandod nationwide in 1995; more states are starting rating programs and national-level activities are moving forward rapidly. A greater variety of financing products is becoming available to consumers. Monitoring state and national progress on a larger scale will provide better indicators of success. However, because FHA EEMs were available only in the five pilot states through the end of fiscal year 1995, the numbers of EEMs reported nationally are relatively small. In future years, these numbers will better indicate progress in the acceptance and use of EEF products. To further understand the market potential for EEF products, of which the FHA/EEM is one, additional data are needed on the total housing market. 


\section{Contents}

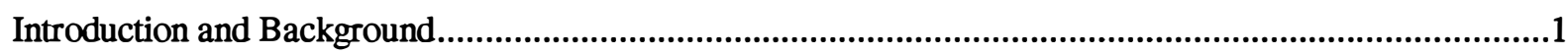

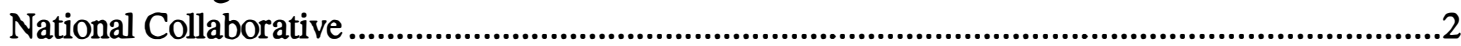

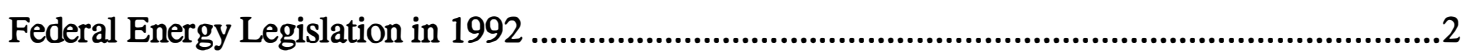

Voluntary National Rating System .......................................................................................

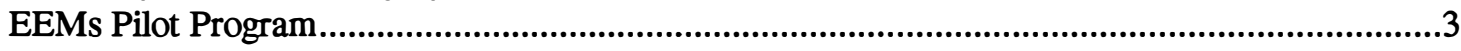

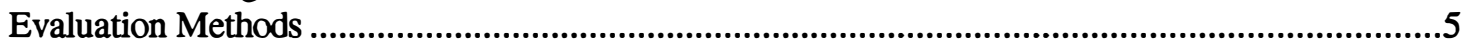

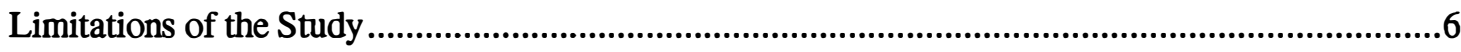

Comparative Analysis ....................................................................................................................

EEF Products ..........................................................................................................................

Organization of This Report.....................................................................................................9

Chapter 1: The Virginia Experience with Energy Efficiency Financing: An Evaluation Case Study ........11

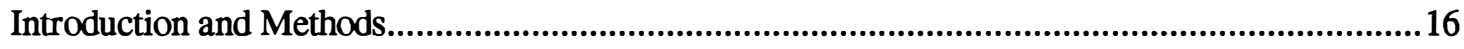

Background and Overview .....................................................................................................17

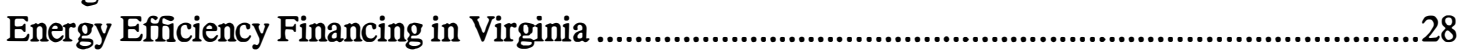

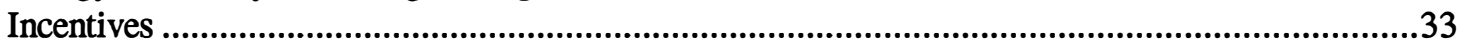

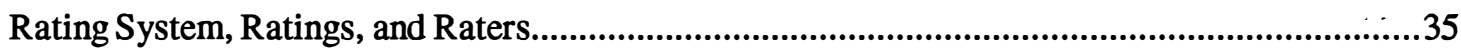

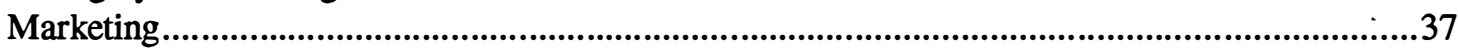

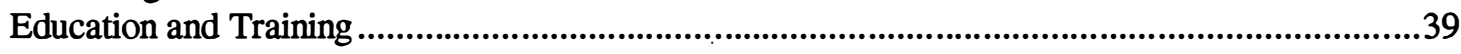

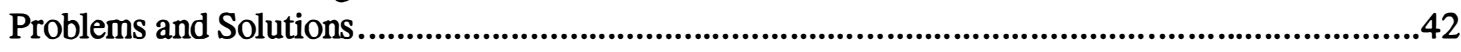

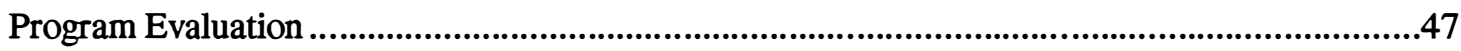

Future Plans and Prospects of the Virginia Program (including an Epilogue for 1996).................51

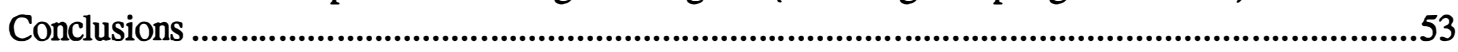

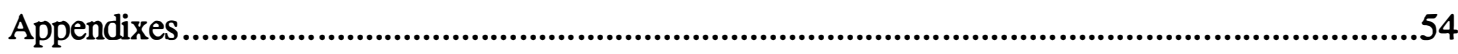

Chapter 2: The California HERS/EEMS Pilot Program and Related Efforts: A Case Study

Covering the Years 1984 - 1995...................................................................................113

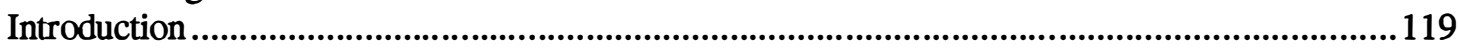

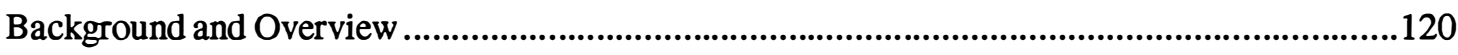

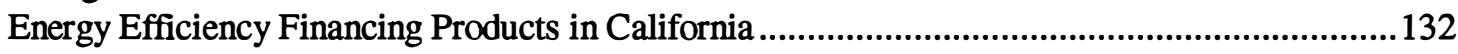

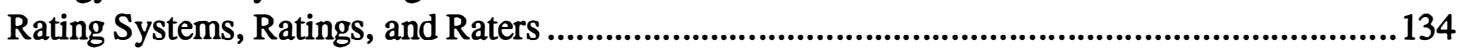

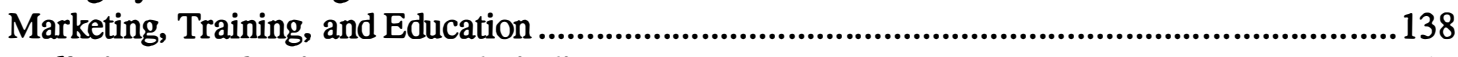

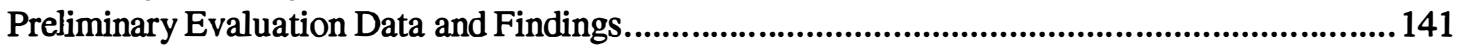

Problems and Solutions, Successes, and Future Directions.....................................................143

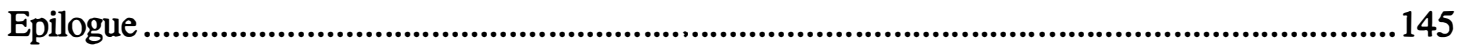

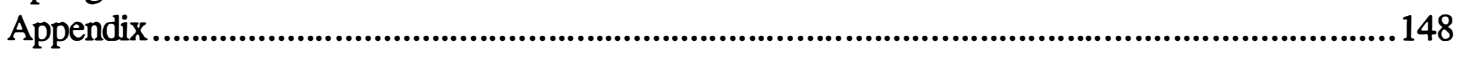

Chapter 3: The Alaska HERS/EEMs Pilot Program and Related Efforts: A Case Study

Covering the Years 1981 - 1985........................................................................................165

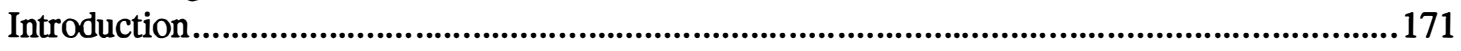

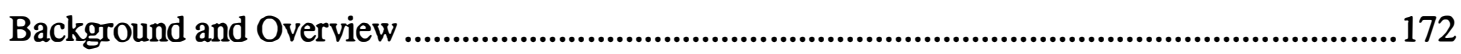

Energy Efficiency Financing Products and Incentives in Alaska ............................................185

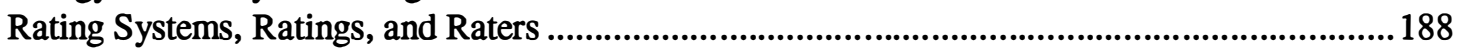

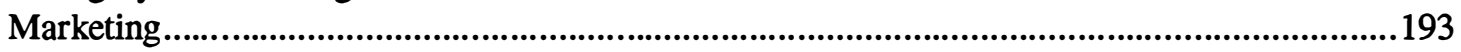

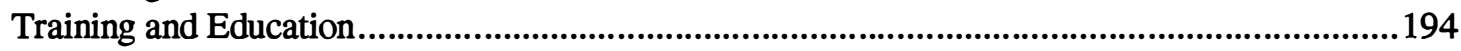

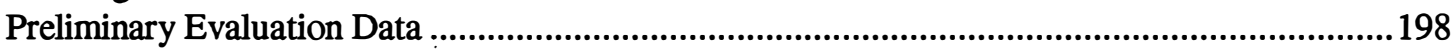

Problems and Solutions, Successes, and Future Directions.........................................................202 


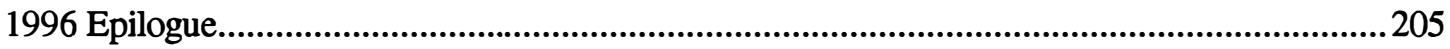

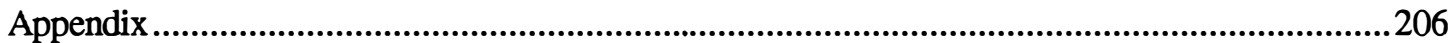

Chapter 4: Process Evaluation Case Study: Vermont Home Energy Rating Systems/Energy

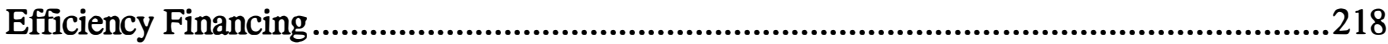

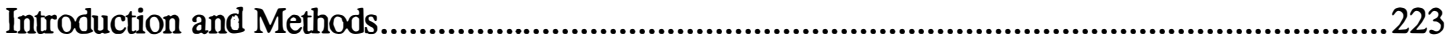

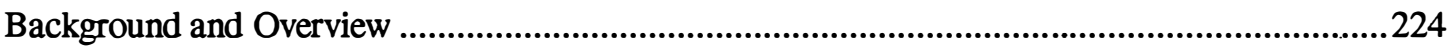

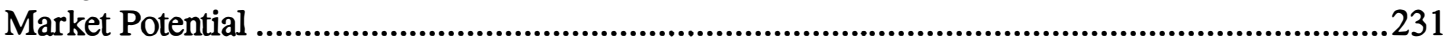

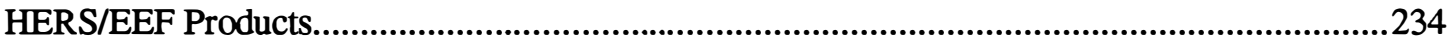

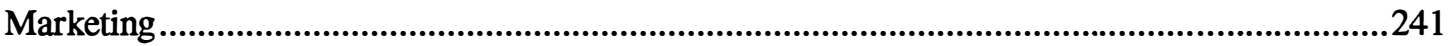

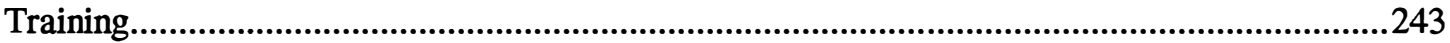

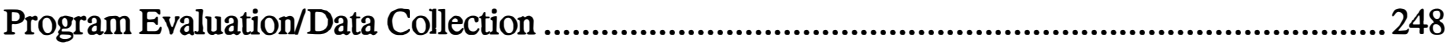

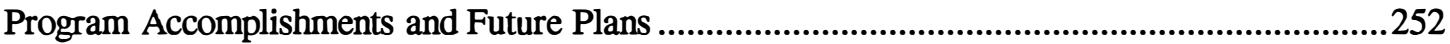

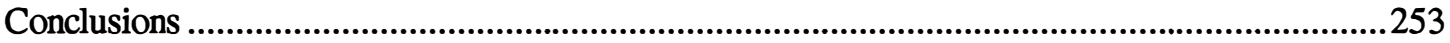

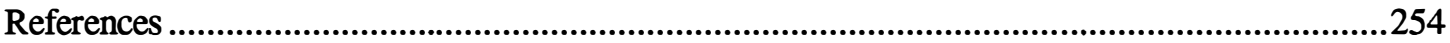

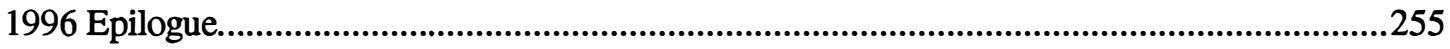

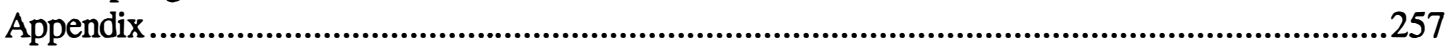

Chapter 5: Process Evaluation Case Study: Arkansas Home Energy Rating Systems/Energy

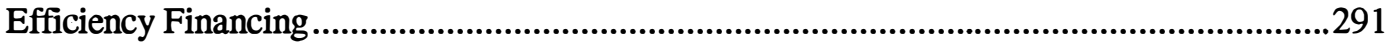

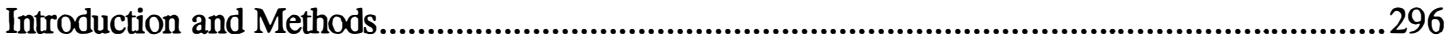

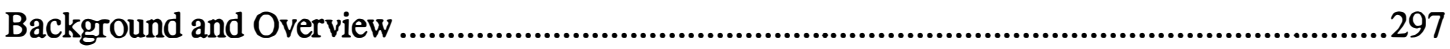

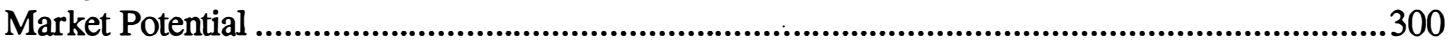

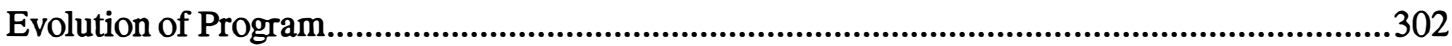

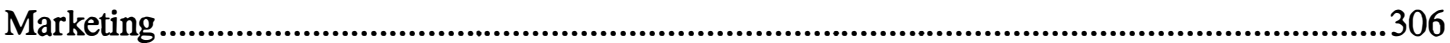

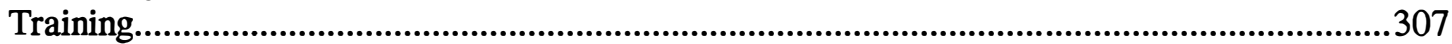

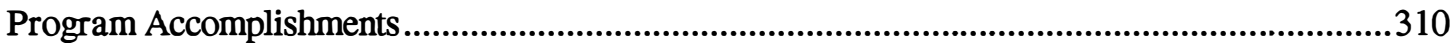

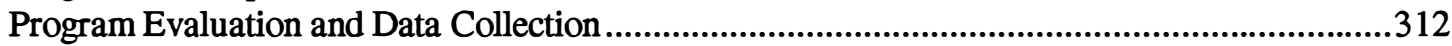

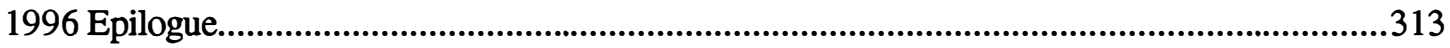

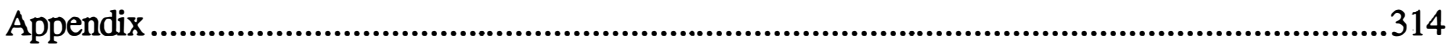

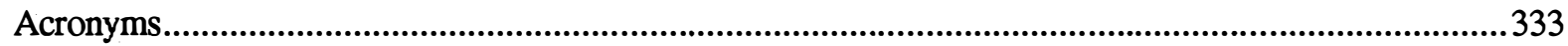

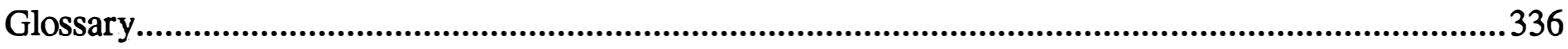

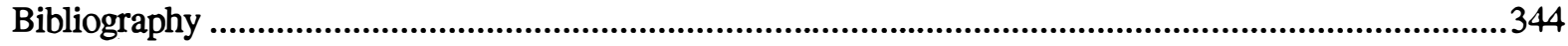

\section{Appendix}

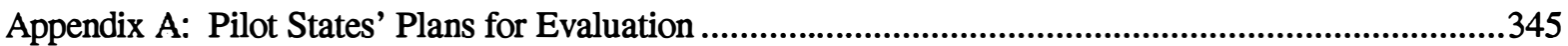

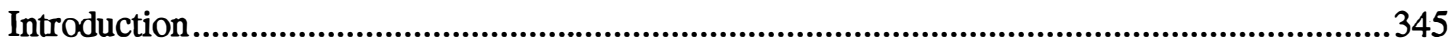

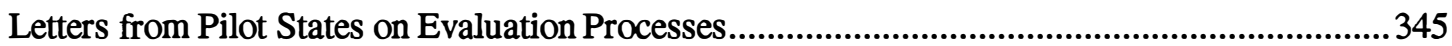




\section{Introduction and Background}

The purpose of this report is to document progress in state-level programs in energy efficiency financing (EEF) programs linked with home energy rating systems (HERS). The experience in the five states selected to pilot a federal program to amortize the costs of home energy improvements, reported in the five case studies that follow, can provide valuable lessons for other states. The case studies are contributing to analyses comparing pilot states' experiences that will provide guidelines for program implementers in other parts of the country. In addition, information has been developed that can be used by federal agencies to fulfill their mandated reports to Congress and to further develop their programs and policies relevant to EEF linked with HERS.

An immense potential for improving the energy efficiency of the nation's housing stock exists. HERS offer the technical basis for customers to decide how to invest in cost-effective energy improvements. Energy efficiency financing (EEF) offers a way to remove the most important barrier to improving the efficiency of housing - first cost - by amortizing the costs of energy improvements over the length of the mortgage. However, in institutionalizing EEF as part of the nation's banking and real estate processes, some problems remain to be resolved. These include accreditation of rating systems, credible data on the default rates of energy efficiency loans compared with regular loans, and information on the energy improvements actually being made in housing and their impacts. As programs are created and implemented to stimulate and meet consumer demand with EEF products, ways can be created to deal with these problems that are effective, affordable, and a normal part of business practice.

Cost-effective energy-efficient technologies exist today to reduce dramatically the $\$ 100$ billion spent in the United States each year on utility-supplied energy in housing. Creation and institutionalization of EEF products linked with HERS are gaining momentum across the nation, and, in the process, transforming the housing marketplace by improving the energy efficiency, comfort, and affordability of the housing stock. EEF provides a consumer mortgage or home improvement loan that enhances a borrower's ability to qualify based on the increased cash flow gained from a more efficient home. Because energy improvements generally reduce home energy costs more than the increase in the loan payment, lenders can use this effective "added income" to qualify borrowers to finance the costs for the improvements in the larger mortgage loan amount. When these loans are based on a quality home energy rating, lenders can have more confidence that the improvements made will result in a positive cash flow for the consumer.

During the 1980s, organizations in several states developed HERS and certification programs. Energy Rated Homes of America was a pivotal organization in developing and disseminating home energy rating software in several states. The cities of Fort Collins, CO, and Austin, TX, have their own rating programs. By 1993, the Good Cents and Super Good Cents certification programs were carried out in nearly 400 utilities nationwide, especially in the South and the Pacific Northwest. But energy ratings did not necessarily result in energy-improved housing because they were not linked with EEMs to create a viable system of amortizing the cost of effective energy improvements in housing.

Although energy efficient mortgages (EEMs) have been in existence since 1980, they had not been widely used by the end of the decade. In 1990, recognizing the potential for HERS and EEMs to stimulate home energy efficiency, the U.S. Department of Energy (DOE) decided to convene an ad hoc task force representing the secondary mortgage markets, mortgage bankers, HERS advocates, builders, utilities, and other affected stakeholders to plan a voluntary national program that would link HERS and EEMs. 


\section{National Collaborative}

In 1991 and early 1992, DOE, in cooperation with the U.S. Department of Housing and Urban Development (HUD), established a National Collaborative on HERS and EEMs. The National Renewable Energy Laboratory (NREL) coordinated the National Collaborative's meetings for DOE. The Collaborative was composed of representatives from 25 stakeholder organizations (state energy offices, the mortgage finance community, real estate professionals, builders, remodelers, consumer and environmental interests, utilities, and existing HERS programs).

The Collaborative's purpose was to involve stakeholders at a national policy level to develop a plan leading the nation toward a voluntary system linking HERS with EEMs. The Collaborative, although made up of participants with sharply different perspectives, reached consensus on most issues. In only one area the EEMs program -members "agreed to disagree" on some of the provisions of a uniform national approach. Even here, there was a broad consensus on many actions that could be taken. After 14 meetings, the Collaborative reached consensus on a final draft plan published by NREL in 1992: A National Program for Energy-Efficient Mortgages and Home Energy Rating Systems: A Blueprint for Action. NREL also published a companion volume to the Blueprint which contained the issue papers prepared as part of the Collaborative process. This report, Going National with HERS and EEMs: The Collected Papers of the National Collaborative, presents 52 one-page papers on technical issues.

\section{Federal Energy Legislation in 1992}

After the Blueprint was published, some members of the Collaborative lobbied Congress for inclusion of HERS/EEMs provisions in federal legislation passed in 1992. Three 1992 federal laws accelerated implementation of energy efficiency financing linked with home energy ratings:

- The Energy Policy Act (EPAct), which directed the U.S. Department of Energy (DOE) to develop guidelines for a uniform, voluntary HERS, to evaluate the effectiveness of the U.S. Department of Housing and Urban Development (HUD)/Federal Housing Administration (FHA) pilot EEMs program, and to document training activities.

- The Housing and Community Development Act, which, along with EPAct, directed HUD/FHA to conduct energy efficient mortgage (EEM) pilot programs in five pilot states. The program's purpose was " . . to promote the purchase of existing energy-efficient residential buildings and the installation of cost-effective improvements in existing residential buildings."

- The Veterans Home Loan Program Amendments, which require the U.S. Department of Veterans Affairs (DVA) to conduct an EEMs demonstration program for veterans and reservists in the 50 states.

${ }^{1}$ EPAct also required HUD and the U.S. Department of Agriculture's Rural Housing Service (formerly the Farmers Home Administration) to establish and promulgate energy efficiency standards for new homes receiving loans made, guaranteed, or insured by these agencies as of October 1993. 


\section{Voluntary National Rating System}

As directed by EPAct, DOE publishod a Notice of Proposed Rulemaking (NOPR) on July 25, 1995; the public comment period ended October 23, 1995. NREL worked closely with the HERS Council Technical Committee and DOE to develop voluntary guidelines for HERS in the nation. NREL also developed HERS BESTEST (Building Energy Software Test), a method for testing the credibility of HERS rating software. HERS BESTEST has been recommended as a basis for certification of HERS software in the procoedings of several state HERS rule-makings, including California and Florida. BESTEST is also in the process of being adopted as an ASHRAE Standard Method of Test. DOE evaluated public comments on the NOPR after reopening the public comment period on the three items of the NOPR on April 3,1996, and closing the comment period again on May 9, 1996. The three items were fuel coefficient factors, infiltration, and accreditation and certification. DOE had not decided on final publication of voluntary guidelines for HERS as of December 31, 1996.

The system proposed in the NOPR provides four pieces of information to home buyers and lenders:

- A mumerical rating (on a scale of 0-100 points) that assesses the efficiency of the home based on the climate zone and fuel source; $80+$ points meets or exceeds the national consensus Model Energy Code (MEC)

- A star rating (on a scale of 1-5 stars) to permit quick understanding of a home's energy performance. Four stars is equivalent to 80 points. Stars can be used as a marketing tool for efficient houses

- The home's predicted operating costs for heating, cooling, and hot water

- Recommended cost-effective energy improvements that would make the home more efficient and less costly to operate; and an estimate of the cost of those improvements.

The rating tool can provide a present value calculation for the recommended energy improvements that lenders can use in evaluating a borrower's application for energy efficiency financing.

\section{EEMs Pilot Program}

FHA began implementing the pilot program on May 24, 1993. FHA selected five pilot states-Alaska, Arkansas, California, Vermont, and Virginia to test the EEMs concept, in large measure because these states already had existing home energy rating systems in place. The output of home energy ratings was a required component for loan originators to make EEMs available to prospective mortgagors of existing single-family homes. Under the program, individuals residing in any of the five pilot states, with approved income and credit records, were eligible to apply for EEMs. The legislation stipulated that the cost of energy-efficiency improvements could be added to the mortgage in the amount of 5\% of the loan amount (up to $\$ 8,000$ ) or $\$ 4,000$, whichever is greater.

The legislation allowed lenders to:

- Permit final loan amounts to exceed the loan limits established by the National Housing Act by an amount not to exceed $100 \%$ of the cost of the cost-effective energy-efficiency improvements.

- Hold in escrow all funds provided to the mortgagor to undertake the energy-efficiency improvements unil the improvements were actually installed. 
- Transfer or sell the EEM to an appropriate secondary market agency after the mortgage was issued; either before or after the improvements were actually installed.

- Grant the escrow amount to the mortgagor without additional qualification.

HUD/FHA announced the new EEM pilot program through Mortgagee Letter 93-13 dated May 24, 1993, informing lenders and underwriters in the pilot states to provide EEMs, and providing guidance about the rules of their use. The letter, from Assistant Secretary for Housing/Foderal Housing Commissioner Nicolas P. Retsinas, addressed some 12,000 recipients on "Single-Family Loan Production-Energy Efficient Mortgage Pilot Program." Using those FHA guidelines, lenders were responsible for making the loans and underwriters for underwriting them.

The HUD EEM pilot program was unprecedented in mortgage lending. It allowed loans to be insured by HUD under the following conditions:

- If the energy improvements were estimated to pay for themselves through lowered utility bills, based on estimates resulting from an accepted home energy rating, then $100 \%$ of their cost could be added to the amount of an FHA-insured mortgage without an appraisal and without further credit qualification

- The EEM could exceed traditional loan limits by the amount of the energy improvement; the maximum mortgage amount for a single-family unit is, for example, $\$ 155,250$ in Richmond, Virginia (the actual dollar amount varies by geographical area) plus the cost of the eligible energy-efficiency improvements

- EEMs were available to borrowers wanting to refinance their properties

- The program provided that up to $\$ 200$ of the cost of a rating could be financed as part of the total EEM.

Lenders in the pilot states were required by law to obtain a signed disclosure statement that all eligible borrowers had been told about the availability of EEMs. This disclosure statement was filed with the loan's closing papers.

On October 6, 1995, after 1.5 years of experience with EEMs in the pilot states, Commissioner Retsinas issued a second mortgagee letter (95-46) expanding the EEM program to all 50 states and to new housing. The EEM program encompasses one- and two-unit properties. The mortgagee letter specified that the cost of energy improvements and the estimate of energy savings must be detennined based upon a physical inspection of the property by an accredited HERS or qualified energy consultant. The letter specified that, for new construction, the energy improvements must be "over and above those required for compliance with the current FHA energy conservation standards for new construction" (p. 2). These standards are Council of American Building Officials (CABO) 1992 Model Energy Code (MEC). An optional worksheet was attached allowing each eligible improvement to be assigned its own useful life. In addition, the mortgagee letter repealed the requirement that all applicable borrowers receive a separate disclosure statement informing them of the FHA EEM program. Instead, language would be added to the FHA disclosure notice, "Important Notice to Homebuyers," informing them of the availability of EEMs. 


\section{Evaluation Methods}

Once HUD had selected the five pilot states in May 1993, DOE established two working groups to support the development of the HERS/EEMs pilots: (1) the Pilot States Working Group; and (2) the Evaluation Working Group (EWG). DOE facilitated meetings between representatives of the HERS provider organizations in the pilot states and HUD/FHA officials to share experiences from the field, refine procedures, and define and resolve problems. The Pilot States Working Group met several times during 1993 and 1994. In FY 1995, DOE provided funding to each of the HERS provider organizations in the five pilot states to support program implementation and evaluation.

One conclusion reached by the National Collaborative was the importance of evaluating the development of HERS/EEMs, estimating the impacts of the pilot state efforts, and sharing the results with other states. Therefore, in 1993 and 1994, DOE supported NREL in establishing an EWG. NREL included national- and state-level stakeholders in developing a detailed evaluation plan that would provide national data for use by the states, as well as an approach to aggregating state data at the national level (Collins et al. 1994).

The evaluation plan covered three types of evaluation: (1) short-term process evaluation and feedback (monitoring and market response) to identify implementation barriers and learn how they were overcome; (2) traditional process evaluation, focusing on comparing characteristics of the various approaches to determine the program characteristics associated with the most successful programs; and (3) impact evaluation, which collects data for a causal analysis linking programmatic actions with key outcomes such as loan default rates and housing affordability. Because of resource constraints, the case studies focus primarily on the first type of evaluation.

NREL had developed a protocol for gathering evaluation data that was originally used to gather data from nearly all 50 states on their development of HERS (Farhar and Eckert 1993). Working with the EWG, NREL developed the protocol further in the evaluation plan and used it as a guide to collecting evaluation data in the five pilot states. Although different evaluation researchers gathered the data in the different pilot states, each followed the same protocol.

The protocol identified both the impact and the process data to be collected in each state. These included: background of the rating programs; evolution of loan products; implementation costs and participants; rating systems and use of ratings; training and education; marketing and outreach; market transformation achieved; program evaluation and data collection systems; barriers encountered and overcome; lessons learned; successes; and near- and long-term plans.

To develop the case studies, researchers interviewed, in person, representatives of the principal organizations involved in HERS/EEF (some several times) for each case study. Program documents were collected and reviewed. In addition, NREL gathered data such as numbers of mortgages at the pilot state level from national and state agencies such as FHA and DVA. ${ }^{2}$

Unless noted otherwise in the text or under tables and figures, the sources of the data reported in the five case studies were the HERS provider organization in the pilot states.

\footnotetext{
${ }^{2}$ A more detailed description of the HUD/FHA database containing information on loans insured by FHA (called "CHUMS") is presented as part of the Virginia case study because the system, in relation to the EEMs pilot program nationwide, was observed and described first in connection with Virginia pilot program activities.
} 
In the Virginia case study, the sections on "Problems and Solutions" and on "HUD's CHUMS System," although based on data actually collected in Virginia, apply as well to other states (unless steps have been taken locally to resolve the problems identified).

Although the case studies were guided by the same data collection protocol, they vary somewhat in presentation and emphasis because conditions in the states differed and evaluation researchers capitalized on the best data available. Dr. Barbara Farhar of NREL prepared the Virginia case study and provided data from the national databases for each pilot state. She also managed the project. Dr. Nancy Collins prepared the Alaska and California case studies and Dr. Roberta Ward Walsh prepared the Arkansas and Vermont case studies. NREL funded each pilot state HERS provider organization for its participation in providing data and developing evaluation databases and processes.

\section{Limitations of the Study}

The resources available for the case studies were not extensive enough to permit systematic interviews with lenders, real estate professionals, builders, appraisers, and consumers to reveal their perceptions and experiences with either the HUD/FHA EEMs or other loan products for financing energy improvements. Therefore, the viewpoints provided in the case studies are based on a limited group of respondents who tended to represent the most actively involved advocates.

Among the limitations to the data collection effort were the following:

- National-level data on the number of HUD/FHA EEMs and other EEF products were just being developed and were not as reliable as might be hoped

- Monitoring events was similar to shooting at moving targets because programs operate in the volatile housing and mortgage markets. Events occurred late in 1995 or during 1996, beyond much of the data collection period, that changed how some rating organizations operated or had other profound impacts on program successes. To capture some of the most significant changes, epilogues for the 1996 events have been added to the case studies

- DOE funding did not actually reach HERS provider organizations until sometime in calendar year 1995; their ability to carry forward their programs quickly was hampered by delays in receipt of federal funding. Therefore, most of the progress reported in the case studies between 1993 and 1995 was based on other funding sources

- The HERS provider and other organizations in the pilot states did not always have available the data needed for the case studies; however, the evaluation effort supported them in improving their data and record keeping functions for future use.

NREL wanted to encourage state HERS provider organizations to set up databases and evaluation systems to track uses of ratings by homeowners in obtaining loans or mortgages that linked HERS with EEF. Such evaluation is key to improving the administration of these programs and in demonstrating their successes. One ultimate measure of success is the number of homes actually receiving energy improvements-a number that is only partially reflected in the number of EEMs and other EEF products. Another ultimate measure of success is the default rates for EEF products and whether they are better than those for regular loans. Each pilot state HERS provider organization reported on its progress in record keeping, database development and management, and evaluation processes. These reports from the states are presented in Appendix A 


\section{Comparative Analysis}

This report is not intended to present comparisons among the pilot state case study data. NREL published a preliminary comparative analysis, Linking Home Energy Rating Systems with Energy Efficiency Financing: Progress on National and State Programs, in October 1996 using data from the pilot state case studies and the national level data from federal agencies and federally chartered financial institutions (Farhar, Collins, and Walsh 1996). A report on guidelines for successful HERS/EEF programs is planned during 1997, as is an updated comparative analysis of the pilot states' experiences modeled after the Linking report.

\section{EEF Products}

Several EEF products, in addition to the HUD/FHA EEM, were available to borrowers in the pilot states, and were therefore of interest to the HERS provider organizations. In all states, HERS provider organizations made an effort to work with utilities, lenders, and others to develop additional EEF products that would rely on rating outputs as a basis for amortizing the cost of energy improvements. Those unique to each state are included in the case study for each state. Briefly described here are the EEF products that were available in the original five pilot states, or came to be available in the pilot states during the course of the study from 1993-1996. ${ }^{3}$ These specific EEF products include the following.

\section{2\%-Stretch EEMs}

Under the 2\%-stretch policy, underwriters for conventional mortgages are permitted to "stretch" the amount for which borrowers can qualify by $2 \%$ for an energy-efficient home, once underwriters have already taken into account other determining factors (such as income and credit history). The $2 \%$ stretch is an allowance for the improved energy efficiency of the home based on a home energy rating of the costeffective improvements to the home. Although the 2\%-stretch EEM has been available for many years, neither Freddie Mac nor Fannie Mae has included an indicator for loans using this feature in the national database on mortgages. Therefore, no data are available on the penetration of these loans at the national level. Anecdotal information from Freddie Mac and Fannie Mae officials suggests that the 2\%-stretch EEMs have not been widely used.

\section{FHA 2\%-Stretch for Energy-Efficient Homes}

FHA also offers to insure a $2 \%$-stretch loan when a borrower is purchasing or refinancing an energyefficient home (EEH). The higher housing expense and debt-to-income ratios are justified because of anticipated energy cost savings and become $31 \%$ and $43 \%$, respectively. Local FHA offices determine whether a property qualifies for the EEH designation. The original documentation attesting to energy efficiency is required on resales.

\footnotetext{
${ }^{3}$ No commonly accepted terminology yet exists to disinguish types of EEF products. However, an agreed upon classification scheme will ultimately be useful in accurately evaluating their performance. A full discussion of the complexities involved in how such a classification scheme might be developed is beyond the scope of this report.
} 


\section{FHA EEMS}

HUD/FHA will underwrite EEMs that permit an addition of up to $\$ 4,000$ or $5 \%$ of the appraised value (up to $\$ 8,000$ ) to the loan amount for cost-effective energy improvements based on ratings for new and existing single-family homes. To qualify for the EEMs, these improvements must pass a net present value test for cost effectiveness. That is, the total cost of the improvements (including maintenance costs) must be less than the total present value of the energy saved over the useful life of the improvements. Several HERS providers are providing lenders with not only the rating information on residences, but also the results of the net present value calculations to expedite the EEMs lending process.

If the energy improvements pay for themselves through lowered home energy bills, then $100 \%$ of their cost can be added to the amount of an FHA mortgage without an appraisal. The EEM can exceed traditional loan limits by the amount of the improvements. EEMs also are available to borrowers who wish to refinance their properties.

Although FHA initiated its EEM program in 1993 in five pilot states and limited the mortgages to existing housing, FHA EEMs are now available (as of October 6, 1995) in all 50 states for both new and existing housing.

\section{DVA EEMS}

DVA allows the addition of $\$ 3,000$ without analysis for energy improvements or up to $\$ 6,000$ for improvements if energy savings will be greater than the increased monthly payment. Amounts greater than $\$ 6,000$ are subject to appraisal. These loans are available to veterans and reservists in all 50 states. Energy-efficiency improvements covered include solar heating and cooling systems (i.e., both active and passive systems); caulking and weatherstripping; furnace efficiency modifications; clock thermostats; ceiling, attic, wall, and floor insulation; water heater insulation; storm windows and doors; and heat pumps. In some states, DVA is using rating information for its EEMs.

\section{Energy-Efficient New Homes}

After April 24, 1994, newly constructed homes insured by HUD/FHA or made by RHS were required to meet or exceed the 1992 CABO MEC. This means that all HUD/FHA and RHS mortgages insured or made after that date have been for more energy-efficient new homes than was previously the case. All properties meeting the 1992 CABO MEC are considered energy efficient and are thus eligible for FHA's EEH $2 \%$-stretch ratios.

\section{HUD Title I Home Improvement Loans}

These loans are available to any homeowner whose mortgage is insured by FHA. Up to $\$ 25,000$ can be borrowed for 15 years; interest rates vary. Although these loans are not directly linked with energy ratings, borrowers are encouraged to obtain a rating to identify cost-effective energy improvements.

\section{HUD 203(k) Loans}

HUD finances rehabilitation and improvements of homes up to a maximum amount based upon local mortgage limits. Although not directly linked to ratings, these loans can be combined with HUD/FHA EEMs and with HUD Title I loans to finance energy improvements in housing being rehabilitated. Eligible improvements include insulation; efficient doors and windows; and efficient heating, ventilating, and airconditioning systems. 


\section{Reverse Mortgages}

These products use equity from a home to provide income to homeowners age 62 and over. In some states, up to $10 \%$ of the funds given to the homeowner can be used for energy-efficiency improvements that will decrease the home's utility bills and extend the length of time that a homeowner can be supported by the equity in the house.

\section{Organization of This Report}

This report contains the case studies for five pilot states. Because each case study was approached somewhat differently by the researchers to capture each state's unique history, the case studies are presented with the two higher-population states first, followed by the three lower-population states.

1. Because of its proximity to Washington, DC, Virginia's experience with the FHAVEEMs was more affected by a national orientation than were the other pilot states. The Virginia case study documents some national information about the HUD EEMs system and other national perspectives that pertain to all of the other pilot states, as well.

2. The California case study - reflecting the activities of the most populous pilot state with a reputation of being a leader in energy efficiency - is presented next. California utilities had devoted relatively massive resources to the development of a home energy rating system prior to the state being selected as a pilot state.

3. The Alaska case study documents the longest-lived HERS program, having begun its activities in 1984. Alaska used both financial incentives and EEF products to foster efficient housing. It emphasized efficiency in new housing by working closely with builders. The Alaska case study also highlights how HERS/EEF activities can work effectively by networking within a limited geographic area within a low-population state.

4. The Vermont case study also focuses on how a program can succeed in a largely rural state; it documents efforts begun in 1986 to use ratings to improve housing efficiency largely through technically oriented leadership. Most recently, the Vermont HERS organization has become more closely tied with utilities in delivering services.

5. The Arkansas case study, again focusing on a largely rural state, shows the development of a program that originally planned to depend on federal subsidies for its long-term survival but changed its policy during 1996 to become more oriented toward self-sufficiency.

The first two case studies focus on higher-population states and the last three case studies are grouped to emphasize the situation in lower-population states. The dynamics among these two types of states differ along several significant dimensions. Comparisons were reported in the Linking report referenced earlier and lessons learned from these comparisons will be reported in the future. 


\section{Chapter 1}

\section{The Virginia Experience with Energy Efficiency Financing: An Evaluation Case Study}

Barbara C. Farhar, Ph.D., National Renewable Energy Laboratory, Golden, Colorado 


\section{Acknowledgments}

This evaluation case study was completed in cooperation with the Virginia Home Energy Rating Organization (V-HERO), especially Christine Lowrie, Executive Director and Steven Lowrie, President of National Home Energy and Resources Organization, Inc. (N-HERO). The Richmond, Virginia Field Office of the U.S. Department of Housing and Urban Development also contributed information for this study. The author gratefully acknowledges the comments of Christine Lowrie, Virginia Holman, Steven Lowrie, John Reese, Nancy Collins, Roberta Walsh, and Ron Judkoff. All information contained herein is the sole responsibility of the author.

The work on which this case study is based was funded by the Office of Building Technologies, Office of Energy Efficiency and Renewable Energy, U.S. Department of Energy. The work was begun under the direction of Jacob Kaminsky, continued under the direction of Louis Divone, and completed under the direction of John Reese. 


\section{Executive Summary}

The Virginia Department of Energy (DE) contracted with Energy Rated Homes of America in 1989 to develop a HERS program for Virginia. To provide oversight, DE established a task force consisting of builders; real estate professionals; heating, ventilating, and air-conditioning industry representatives; solar and weatherization contractors; utility representatives; and home inspectors. DE decided that a nonprofit corporation, Energy Rated Homes of Virginia (ERHV), incorporated in July 1992, should be established to administer the program. A parallel nonprofit organization, the Virginia Home Energy Rating Organization (V-HERO), which trains and certifies raters and performs the actual ratings, was established in February 1993.

V-HERO was intended to become self-supporting through rating and membership fees. In April 1993, ERHV became the Virginia Residential Energy Foundation (VREF), ending its affiliation with Energy Rated Homes of America. As these organizations evolved, V-HERO emerged as the central nonprofit rating organization in Virginia and, in January 1995, VREF signed its assets and liabilities over to VHERO and ceased to exist.

The Virginia program has been unique in its approach to marketing activities. V-HERO has used a multifaceted marketing strategy based on galvanizing the consumer demand its directors believed existed. The array of marketing techniques V-HERO has used include major network and cable television advertising, media events with high-level DOE officials, radio advertising, human interest articles in newspapers, stories in trade publications, public speaking, telephone calls, direct mailings of brochures, distribution of educational materials to schools, and direct advertising in real estate racks.

From the outset, the program directors stressed the importance of linking their efforts with those of other cognizant organizations. V-HERO has formed partnerships at the national level with DOE, the HERS Council, the Alliance to Save Energy, the National Association of Home Builders, and the U.S. Environmental Protection Agency. V-HERO has formed financial parnerships with more than 45 lending institutions doing business in Virginia, and with Fannie Mae in developing an EEM pilot program for the conventional housing market. In addition, V-HERO has worked closely with utility companies in the state, including Virginia Power on its Energy Saver Four-Star Home and Energy Saver Plus Five-Star Home Programs, certifying homes for new construction that will qualify for EEF products. V-HERO has actively sought out relationships with members of the Appraiser Institute, the Virginia Association of REALTORS ${ }^{\oplus}$, the Virginia Association of Home Builders, and private energy firms providing ratings and energy services.

During 1995, V-HERO created a model for pilot programs aimed at saturating loans in small geographic markets for all types of borrowers, from those wishing to exceed their normal borrowing capabilities (such as FHA EEMs borrowers) to those wishing to borrow well below the amount for which they can qualify. V-HERO's ultimate goal is to become an organization that is financially self-sufficient, providing valued services to improve the energy efficiency of housing at all income levels.

In 1995, a separate entity was created in Virginia, the National Home Energy and Resources Organization, Inc. (N-HERO), which was incorporated on August 1 in the State of Virginia. N-HERO is a national HERS provider organization. Its purpose is to make it economically feasible to develop HERS provider services in other locales without duplicating administration services, rating software, rater training and certification, and marketing services. 


\section{Contents}

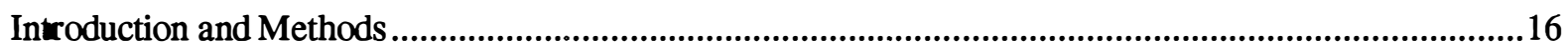

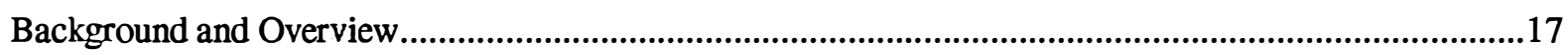

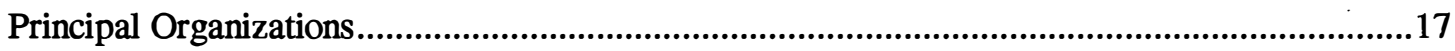

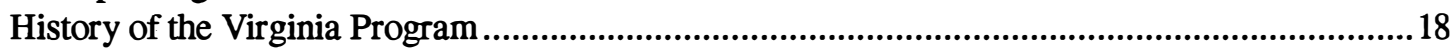

Operating Environment and Relationship to Activities at the National Level................................21

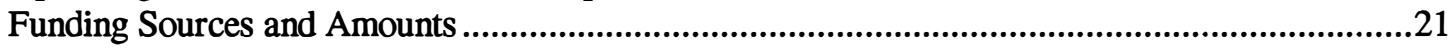

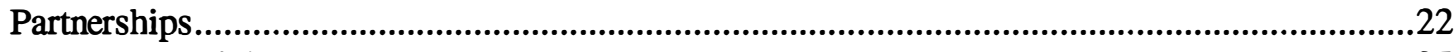

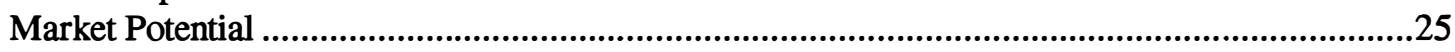

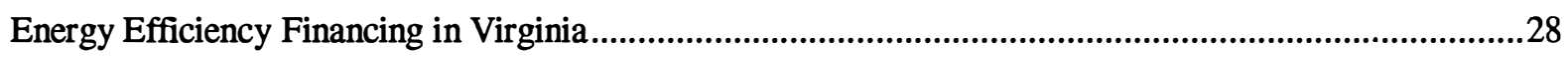

Energy Efficiency Financing Products ................................................................................2

Energy Efficiency Financing Activity ...............................................................................

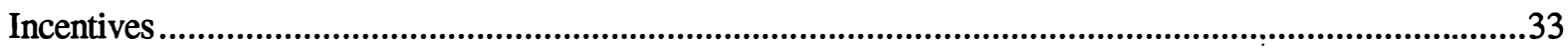

Utility Incentives for Residential Energy-Efficiency Retrofits...............................................33

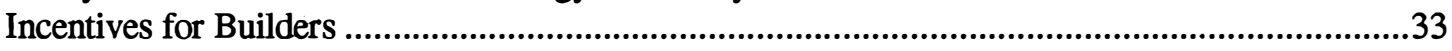

EEMs as An Incentive to Lenders through the Community Reinvestment Act..............................33

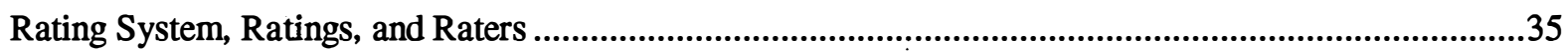

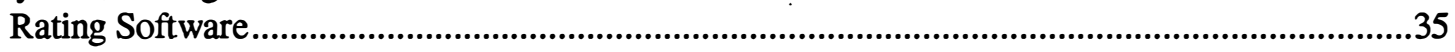

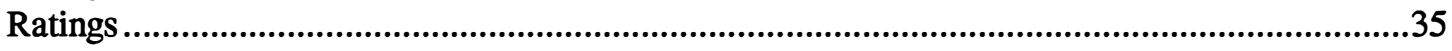

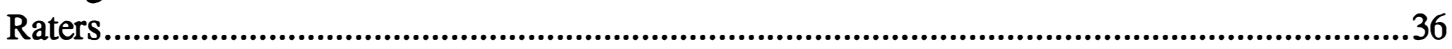

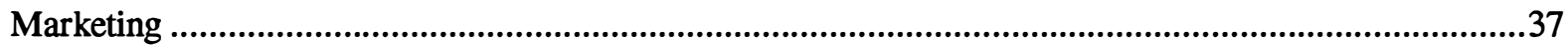

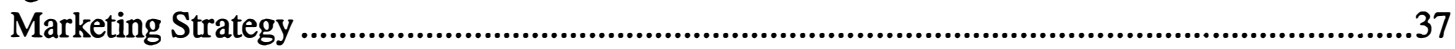

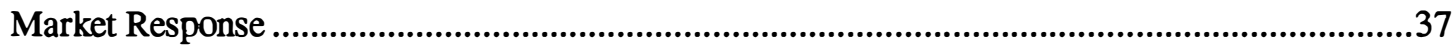

Information and Services Transfer: National HERS Provider Organization .................................38

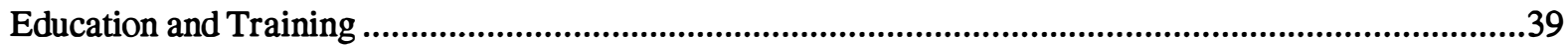

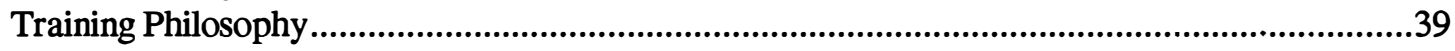

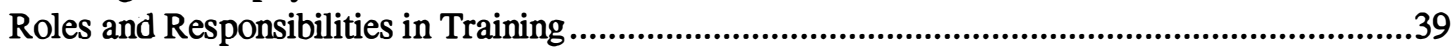

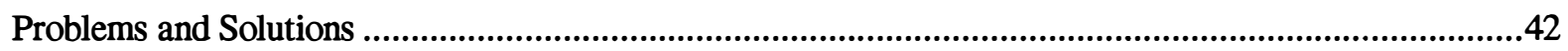

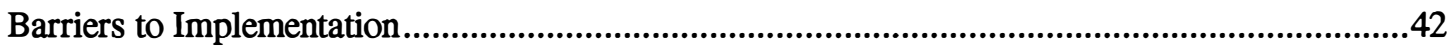

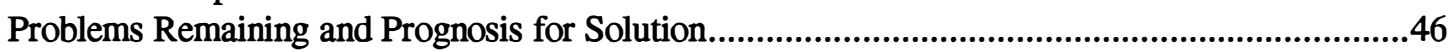

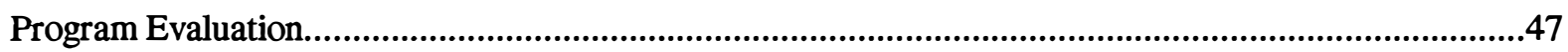

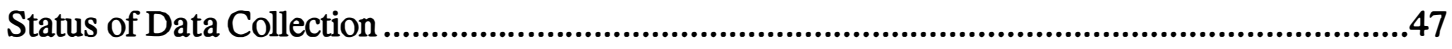

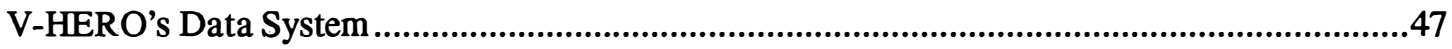

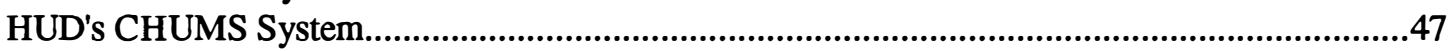

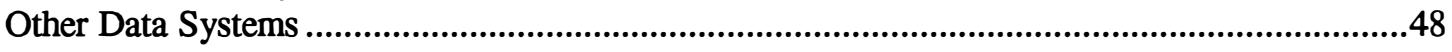

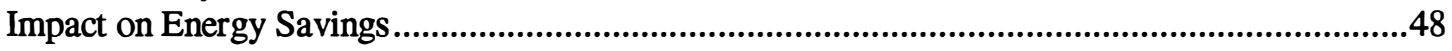

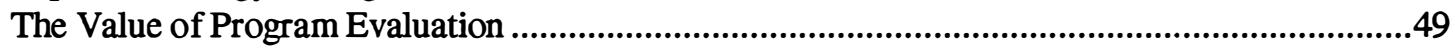

Future Plans and Prospects of the Virginia Program (including an Epilogue for 1996) ............................51

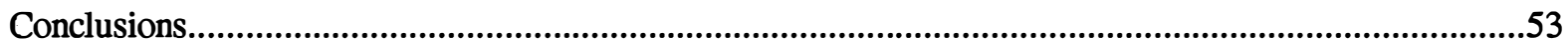




\section{Tables}

Table 1-1. Virginia Chronology of HERS/EEMs-Related Events....................................................20

Table 1-2. V-HERO Funding and Funding Sources, by Calendar Year ..............................................22

Table 1-3. FHA Insured Loans in Virginia, by Fiscal Year ..............................................................25

Table 1-4. HUD/FHA New Home Loans in Virginia, by Fiscal Year .............................................26

Table 1-5. Rural Housing Service Direct Loans in Virginia, by Fiscal Year ..........................................26

Table 1-6. Rural Housing Service Guaranteed Loans in Virginia, by Fiscal Year ................................26

Table 1-7. U.S. Department of Veterans Affairs Mortgages in Virginia, by Fiscal Year .......................26

Table 1-8. Numbers of Housing Market Professionals................................................................22

Table 1-9. Energy Efficiency Financing in Virginia, FY 1993 - 1995 ............................................31

Table 1-10. Number of EEF Loans Completed in Virginia, by Calendar Year.......................................31

Table 1-11. Number of Ratings Completed in Virginia, by Calendar Year .........................................35

Table 1-12. Number of Raters Certified in Virginia, by Calendar Year ...............................................36

Table 1-13. Number of Raters in Other States Trained by N-HERO....................................................36

Table 1-14. Investments in Energy Improvements and Their Impacts ................................................49

\section{Appendixes}

Appendix 1-A. Virginia Process Evaluation Data.............................................................................55

Part 1. Organization Contacts and Descriptions ......................................................................55

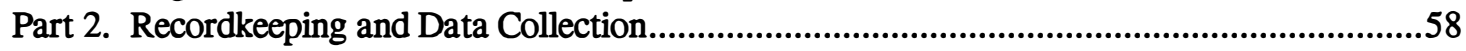

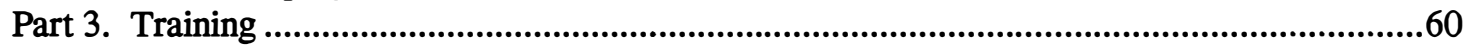

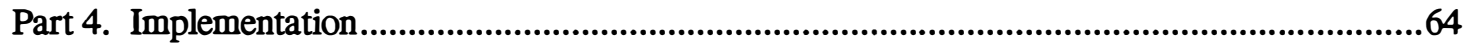

Appendix 1-B. V-HERO Rating Output Form Example ..................................................................66

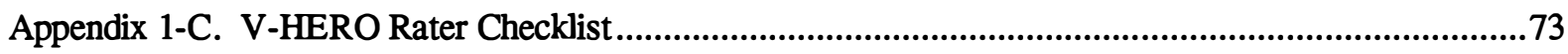

Appendix 1-D. V-HERO Promotional Piece for Real Estate Professionals ..............................................81

Appendix 1-E. Consumer Brochures Used by V-HERO .................................................................83

Appendix 1-F. New List of Participating Mortgage Companies ..........................................................8 88

Appendix 1-G. List of V-HERO Certified Raters Active as of December 31, 1996 ...............................93

Appendix 1-H. List of Active Raters in DC, Delaware, Maine, Maryland, and New Jersey ....................97

Appendix 1-I. List of Virginia Utilities Exhibiting the Potential for Future Partnerships...................... 106 


\section{Introduction and Methods}

This case study focuses on HERS and EEMs activities in Virginia from 1992 through December 1995, with emphasis on events during 1993, 1994, and 1995. A brief epilogue updates activities in this fastmoving field for 1996. The study's original focus was on the linkage between HERS and the FHA EEMs and how this linkage was being institutionalized in Virginia. However, it soon became clear that the Virginia HERS provider organization, including its board, were actively seeking to develop other EEF products and partnerships with the relevant players in the state, including lenders, builders, and real estate professionals.

The author conducted three site visits with the Virginia Home Energy Rating Organization (V-HERO) directors and its board members (in March 1995, July/August 1995, and May 1996). These multi-day site visits were marked by several hours of interviewing and gathering of pertinent documents. In addition, numerous brief telephone interviews between January 1995 and January 1997 clarified specific points. The author also personally visited and interviewed the EEMs program director at the HUD Field Office in Richmond and briefly perused on-site documents relevant to the EEMs program. Field notes were prepared on the site visits and files of documents were prepared.

The purpose of the data collection was to tell the story of how HERS/EEMs was originated and developed in Virginia, by whom, when, and why. The interviews were focused on this story, but were also designed to gather specific information that was being gathered in each pilot state (see Appendix 1-A). Although the persons interviewed had slightly different perspectives, the author has attempted to present as accurate and balanced a picture of the Virginia story within the constraints of the study. Not all individuals and organizations involved could be interviewed because of funding limitations. Still, it was deemed important to gather as much of the story as possible from the HERS provider organizations funded by the U.S. Department of Energy to improve the energy efficiency and the affordability of housing -in the case of Virginia, this was the Virginia Home Energy Rating Organization (V-HERO). Contact with the HUD Field Office was also considered essential to cover the perspective of the mortgage community. HUD has designed V-HERO as a qualified HERS provider organization for the nationwide EEM program.

The resources available for this evaluation research were not extensive enough to permit systematic interviews with Virginia lenders, real estate professionals, builders, appraisers, utility personnel, and consumers to discover their perceptions and experiences with either the HUD/FHA EEMs or other loan products for financing energy improvements, although many of these stakeholders are represented on the VHERO board. Therefore, the viewpoints provided by V-HERO and HUD staff members were not independently verified. 


\section{Background and Overview}

This section of the case study gives a brief history of the Virginia program, describes the principal organizations involved, in the Virginia program, discusses the program in the context of related national activities, describes how the program has been funded, discusses partnerships formed, and provides some contextual information on the market potenial for HERS/EEF programs in Virginia.

\section{Principal Organizations}

The major organizational players involved in delivering home energy rating system services and working to develop energy efficiency financing have been:

- Virginia Home Energy Rating Organization, Inc.

- Virginia Division of Energy

- Virginia Power

- Volt VIEWtech

\section{Virginia Home Energy Rating Organization, Inc. (V-HERO)}

V-HERO's mission is to coordinate the training and certification of home energy raters, encourage energy efficiency, and provide home energy rating reports and services to Virginia consumers to increase the availability of affordable housing and reduce harmful emissions.

The organization performs the following functions:

- Provides home energy ratings on new and existing homes in Virginia

- Recruits and schedules training for new raters

- Provides marketing and outreach services for the FHA EEMs pilot in Virginia

- Develops, in concert with other financial organizations, EEF products beyond the FHA EEMs

- Increases name recognition for HERS and EEF products in Virginia and monitors the increase in use of both ratings and EEF products

- Promotes institutionalization of a functioning infrastructure of financing for energy improvements in housing linked with ratings

- Forms parmerships with real estate professionals and appraisers to develop a system of valuing energy efficiency in Virginia properties.

Although the program covers the Commonwealth of Virginia, V-HERO staff at first focused on the Tidewater, Northern Virginia, and Richmond regions (the Golden Crescent area of the state). Marketing in the western part of the state became more active during 1995. 


\section{Virginia Division of Energy}

Instrumental in the original establishment of the HERS program in Virginia, the Division of Energy (DE) provided seed funding for two years, and supplied the program with fumishings and the initial ERHA software. Since October 1994, DE has not supported or been directly involved with the program.

\section{Virginia Power}

Virginia Power has offered several loan products to foster energy efficiency, including the Virginia Power Loan Program, the Energy Saver New Home Construction Program, and the Five-Star Energy Saver Home Plus Program.

\section{Volt VIEWtech}

Volt VIEWtech, a loan serving company, developed rating software, called Rateview, with the cooperation and support of V-HERO. Volt VIEWtech also provides loan servicing for almost all V-HERO energy efficiency financing programs. Loans are maintained by the lending entity, but servicing (billing/accounting/underwriting/processing, etc.) is handled by Volt VIEWtech at a fee.

\section{History of the Virginia Program}

In 1987-88, following the examples of states like Vermont and Alaska, the Virginia Department of Mines, Minerals, and Energy's Division of Energy (DE), convened a Technical Advisory Committee representative of builders, utilities, realty, and mortgage bankers to help define an energy efficiency home rating program for Virginia and to determine the software that would best meet the program's needs. DE conducted an inhouse review of several existing HERS programs, including the California Home Energy Efficiency Rating System, Good Cents, and Energy Rated Homes of America (ERHA). DE selected the ERHA system, which could be used to rate both new and existing homes, was fuel neutral, and had been accepted for the 2\% debt-to-income ratio stretch EEMs allowed by Fannie Mae and Freddie Mac.

In 1989, DE contracted with ERHA for $\$ 80,000$ for assistance in developing an Energy Rated Homes Program for Virginia. In cooperation with ERHA, DE established a task force consisting of builders, real estate professionals, HVAC, solar and weatherization contractors, utility representatives, and home inspectors to help develop a HERS program for Virginia. A Steering Committee provided program oversight and direction and a Technical Advisory Committee provided the necessary technical assistance. These committees worked with ERHA to adapt the ERHA program to Virginia's needs. DE decided that a nonprofit corporation should be established to administer the program.

In March 1992, the DE launched a pilot test of the rating program in Manassas, Virginia, to obtain data on 50 homes using E-Z Rater, the ERHA, Inc. software. The pilot concluded in July 1993. The data obtained on the Manassas homes have been stored by V-HERO in hard copy format. The pilot program provided much evidence as to the lower-than-expected performance of the E-Z Rater software and ERHA program. Because ERHA deemed E-Z Rater software as proprietary, the program directors could not ascertain exactly how the software performod its calculations, and were thus unable to answer to their satisfaction questions they might have about the rating outputs using this rating tool. 
In July 1992, Energy Rated Homes of Virginia, Inc. (ERHV) was incorporated as a 501(c)(3) nonprofit corporation. The initial board of directors consisted of a mortgage banker, a home builder, a real estate professional, electric and gas utility representatives, a solar industry representative, a home inspector, and two at-large members. The state allocated $\$ 300,000$ in PVE funds to support the operation of the nonprofit-\$150,000 each during FY 1992 and FY 1993.

In October 1992, ERHV began administering Virginia's HERS program using an adaptation of ERHA software. Ratings were conducted on both new and existing homes. At that time, DE contracted for rater training and certification through Conservation Management Corporation in Bethesda, Maryland.

In February 1993, a parallel nonprofit trade organization-the Virginia Home Energy Rating Organization (V-HERO)—was established to train and certify raters and to administer and procuce ratings. V-HERO was a 501(c)(6) organization intended to become self-supporting through rating and membership fees. In April 1993, the two organizations (VREF and V-HERO) launched a marketing campaign to promote a linkage between HERS and EEMs. Promotional activities included:

- Holding a press conference on the V-HERO, Inc. rating program and its link with EEMs

- Sponsoring educational seminars for local boards of real estate professionals, home builder associations, and lending institutions to introduce and explain the lineage between HERS and EEMs

- Securing a commitment from Fortune 500 companies based in Virginia (14 have company headquarters in Richmond) to publicize V-HERO in their advertising and employee newsletters.

In April 1993, having experienced field problems with ERHA software and systems, ERHV became the Virginia Residential Energy Foundation (VREF), ending its affiliation with Energy Rated Homes of America. As these organizations evolved, V-HERO emerged as the central nonprofit rating organization in Virginia and, in January 1995, VREF signed its assets and liabilities over to V-HERO and ceased to exist.

In May 1993, HUD selected Virginia as one of the five states participating in the FHA EEM Pilot Program. By August 1993, at least 30 Virginia banks were prepared to offer EEMs, and this number had increased to 52 by May 1996.

In May 1993, V-HERO trained and certified 19 independent raters throughout the state. Sixty percent of these raters were affiliated with weatherization programs and served homes in rural and mountainous areas. VREF and V-HERO trained the independent rating contractors to market the rating program to consumers.

Beginning in 1994, V-HERO worked with Virginia Power to increase the energy-efficiency standards of the utility's Energy Saver Home Program In 1994, the Richmond-based electric utility expanded its program to include an Energy Saver Plus Home. Homes with this designation qualify for a V-HERO 5-star rating.

Early in 1995, VREF signed its assets and liabilities over to V-HERO; V-HERO assumed responsibility as the sole HERS provider organization in Virginia. DOE awarded a grant to V-HERO in 1995 to aid in its efforts to implement EEF linked with ratings.

In August 1995, V-HERO staff members incorporated the National Home Energy and Resources Organization, Inc. (N-HERO) as a Virginia cocporation to provide information, technical assistance, and services to other states interested in developing HERS programs. During 1995, V-HERO began to develop its marketing strategy to stimulate consumer demand; train raters, lenders, real estate professionals, and 
appraisers; and conduct ratings. In 1994, V-HERO completed 250 ratings; in contrast, during 1995, VHERO completed 7,635 ratings.

V-HERO staff also developed the concept of a "micro-focus pilot" that was designed to saturate a neighborhood with ratings leading to energy improvements. The organization also began developing its television spots to advertise the availability of the rating linked with financing for energy improvements that were used on major network television in 1996.

Table 1-1 provides a chronology of key events in the development of the Virginia program.

Table 1-1. Virginia Chronology of HERS/EEMs-Related Events

\begin{tabular}{|c|c|}
\hline Date & Event \\
\hline $1987-88$ & $\begin{array}{l}\text { VA Division of Energy (DE) convened Technical Advisory Committee of } \\
\text { stakeholders to develop HERS program }\end{array}$ \\
\hline 1989 & $\begin{array}{l}\text { DE contracted with ERHA to develop a HERS program for Virginia using } \\
\text { E-Z Rater software; DE convened task force of stakeholders }\end{array}$ \\
\hline July 1992 & $\begin{array}{l}\text { ERHV was incorporated with board of directors representing key } \\
\text { stakeholders }\end{array}$ \\
\hline March 1992 & ERHV launched Manassas pilot test \\
\hline October 1992 & $\begin{array}{l}\text { ERHV began administering Virginia's HERS program across Virginia } \\
\text { using an adaptation of ERHA software }\end{array}$ \\
\hline September 1992 & ERHV implemented ERHA program in Virginia \\
\hline December 1992 & ERHV holds first certification class for raters \\
\hline February 1993 & $\begin{array}{l}\text { V-HERO was incorporated as a } 501(\mathrm{c})(6) \text { nonprofit organization to train } \\
\text { and certify raters, perform ratings, and administer the rating program }\end{array}$ \\
\hline April 1993 & $\begin{array}{l}\text { ERHV and V-HERO launched markeling campaign linking HERS with } \\
\text { EEMs }\end{array}$ \\
\hline May 1993 & $\begin{array}{l}\text { VA selected as HUD pilot state; VREF and V-HERO trained } 19 \text { raters } \\
\text { around Virginia to perform ratings and market the program }\end{array}$ \\
\hline 1994 & $\begin{array}{l}\text { Virginia Power expanded its program to include Energy Saver Plus Home } \\
\text { (with 5-star rating) }\end{array}$ \\
\hline January 1995 & VREF signed assets and liabilities to V-HERO and ceased to exist \\
\hline July 1995 & 1995 DOE grant is signed allowing first marketing budget \\
\hline August 1995 & $\begin{array}{l}\text { Fannie Mae authorizes pilot in Virginia and work begins on infrastructure } \\
\text { development for training lenders and appraisers }\end{array}$ \\
\hline August 1995 & $\begin{array}{l}\text { National Home Energy Resources Organization, Inc. (N-HERO) was } \\
\text { incorporated as a Virginia corporation on August } 1\end{array}$ \\
\hline September 1995 & Kickoff of first Micro-focus Pilot in Chesterfield County \\
\hline October 1995 & $\begin{array}{l}\text { V-HERO wins contracts from Summerford Builders for the first 5-Star } \\
\text { multi-builder community in the United States }\end{array}$ \\
\hline November 1995 & $\begin{array}{l}\text { V-HERO wins HERS Council } 1995 \text { award for Best HERS Provider } \\
\text { category }\end{array}$ \\
\hline March 1996 & V-HERO kicks off first televised ad campaign for HERS in Virginia \\
\hline
\end{tabular}




\section{Operating Environment and Relationship to Activities at the National Level}

From the outset, the program directors stressed the importance of linking their efforts with those of other cognizant organizations. V-HERO has formed partnerships at the national level with DOE, the HERS Council, the Alliance to Save Energy, the National Association of Home Builders, and the U. S. Environmental Protection Agency. V-HERO has formed financial partnerships with more than 45 lending institutions doing business in Virginia, and with Fannie Mae in developing an EEM pilot program for the conventional housing market. In addition, V-HERO has worked closely with utility companies in the state, including Virginia Power on its Energy Saver Four-Star Home and Energy Saver Plus Five-Star Home Programs, certifying homes for new construction that will qualify for EEF products. V-HERO has actively sought out relationships with members of the Appraiser Institute, the Virginia Association of REALTORS $^{\oplus}$, the Virginia Association of Home Builders, and private energy firms providing ratings and energy services.

In addition to supporting HERS program implementation, V-HERO has provided technical assistance to states interested in the development of HERS through N-HERO. This work supports DOE in administering a technical assistance network in 20 states. $^{1}$ In cooperation with other states, V-HERO has worked to evolve a uniform program in the marketplace including a common rating method, common forms, and quality control.

V-HERO's Executive Director, Christine Lowrie, is also Chair of the Board of the national Home Energy Rating System Council (HERSC), which assisted DOE in preparing a Notice of Proposed Rulemaking (NOPR), published in the Federal Register on July 25, 1995, on voluntary minimum guidelines for home energy rating systems to be accredited and certified in the United States. In this capacity, V-HERO has supported the development of a uniform national system of energy efficiency financing linked with home energy rating systems for residential housing.

\section{Funding Sources and Amounts}

Prior to 1992 , DE spent $\$ 80,000$ for the ERHA software and approximately $\$ 60,000$ for the contractor (James Smith) to administer the program start-up. In addition, DE expended $\$ 60,000$ for the production of rater training course materials and supported the Steering Group meetings for 3 to 4 years.

Table 1-2 summarizes V-HERO's funding amounts by sponsors for the calendar years 1992-1995. The total funding for the organization for the 4-year period was $\$ 745,000$. This funding made possible the range of activities involved in institutionalizing a rating system linked with energy efficiency financing in Virginia. These activities include staffing, preparing proposals, training and certifying raters, running rating software and producing rating outputs, forging partnerships with other organizations whose interests and activities are germane to the program's success, educating and training, and marketing. The diversity and breadth of these activities required a staff with professional qualifications in private-sector management, program development, marketing and communications, financing, and energy ratings - a juxtaposition of skills particularly suited for organizations with such a variety of activities.

${ }^{1} \mathrm{AR}, \mathrm{DE}, \mathrm{FL}, \mathrm{GA}, \mathrm{IL}, \mathrm{KS}, \mathrm{MA}, \mathrm{MD}, \mathrm{ME}, \mathrm{MO}, \mathrm{MN}, \mathrm{NC}, \mathrm{NH}, \mathrm{NJ}, \mathrm{NY}, \mathrm{OK}, \mathrm{OR}, \mathrm{PA}$, WA, and WV. Levels of assistance vary markedly from a few calls to entire packages. This activity is discussed further in the section on marketing/information transfer. 
Table 1-2. V-HERO Funding and Funding Sources, by Calendar Year (\$000)

\begin{tabular}{|c|r|r|r|r|r|r|r|r|}
\hline CY* & $\begin{array}{c}\text { VA } \\
\text { PVE } \\
\text { Funds }\end{array}$ & $\begin{array}{c}\text { State } \\
\text { of VA }\end{array}$ & $\begin{array}{c}\text { Member } \\
\text { Dues }\end{array}$ & $\begin{array}{c}\text { Utility } \\
\text { Certificate } \\
\text { Fees }\end{array}$ & DOE & NREL & $\begin{array}{c}\text { Foun- } \\
\text { dation }\end{array}$ & Totals \\
\hline 1992 & 75 & 0 & 0 & & & & & $\mathbf{7 5}$ \\
\hline 1993 & 150 & & 5 & & 25 & & 15 & $\mathbf{1 9 5}$ \\
\hline 1994 & $\mathbf{7 5}$ & 35 & 15 & 35 & 85 & & & $\mathbf{2 4 5}$ \\
\hline 1995 & & & 25 & 35 & 165 & 10 & & $\mathbf{2 3 5}$ \\
\hline Totals & $\mathbf{3 0 0}$ & $\mathbf{3 5}$ & $\mathbf{4 5}$ & $\mathbf{7 0}$ & $\mathbf{2 7 5}$ & $\mathbf{1 0}$ & $\mathbf{1 5}$ & $\mathbf{7 5 0}$ \\
\hline
\end{tabular}

*Note: Figures shown represent awards to V-HERO, not its operating budgets.

In all, then, approximately $\$ 1$ million had been spent by the end of calendar year 1995 to initiate a comprehensive HERS/EEF program in the Commonwealth of Virginia. This expenditure guaranteed the involvement of stakeholder groups critical to its success in the program's creation.

\section{Partnerships}

A rating organization must develop partnerships with a variety of cognizant organizations for a HERS/EEF program to become effective and institutionalized within a state. For an effective EEF program, several types of partnerships are needed: (1) system, (2) financial, (3) rating, (4) utility, and (5) real estate and appraisal industry partnerships. In general, the greater the number of partnerships, the more widely used energy efficiency financing products will be. In Virginia, V-HERO staff and board members have invested substantial effort into forging partnerships with relevant organizations and networks.

System partnerships are needed with other organizations active in the state whose interests overlap those of the HERS provider and whose cooperation is essential to successful program implementation.

For example, V-HERO created the Virginia Housing and Environment Network (VAHEN) in order to widen the circle of involved professionals in EEF to those whose interests were strictly ecological. New partners through this group include:

- American Institute of Architects (AIA)

- Department of Environmental Quality

- Association of Community Planners

- The American Lung Association

A member of the Virginia Solar Power Association is chairman of V-HERO's board of directors. The relationship between the two organizations has allowed use of solar energy, along with energy efficiency, to enter more mainstream status in Virginia as a viable energy choice.

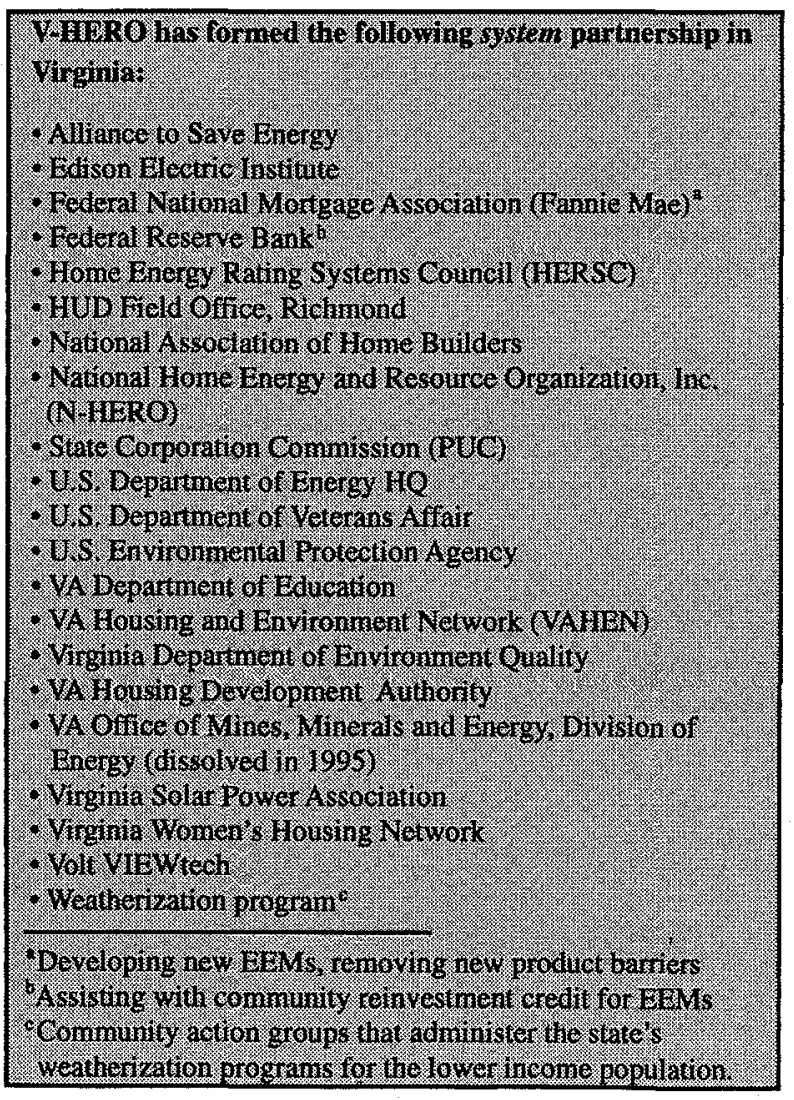


Financial partnerships are important in providing the resources that consumers need to purchase costeffective energy improvements for housing. The rating organization cannot provide these financial resources; it depends on working partnerships with institutions whose role it is to provide financial services.

For example, Signet Mortgage Corporation was the first lender in Virginia to fund an EEM in July 1993 and offered the products statewide by March 1994. Signet Banking had $\$ 11.7$ bn in assets with 239 branches in Virginia, Maryland and DC. The bank offered conventional EEMs as well as FHA-insured EEMs and those guaranteed by the Veterans Administration under its 50-state demonstration program. Signet Mortgage President Randy Wyckoff said that EEMs were more complicated than lenders prefer, but that they were worth the effort because the loans help lenders meet their community reinvestment and affordable housing requirements (National Mortgage News, Jan. 3, 1994, no page given). The FHA EEM was perceived as accommodating low- and moderate-income borrowers in a price range where even small fluctuations in their monthly expenses can affect their borrowing ability.

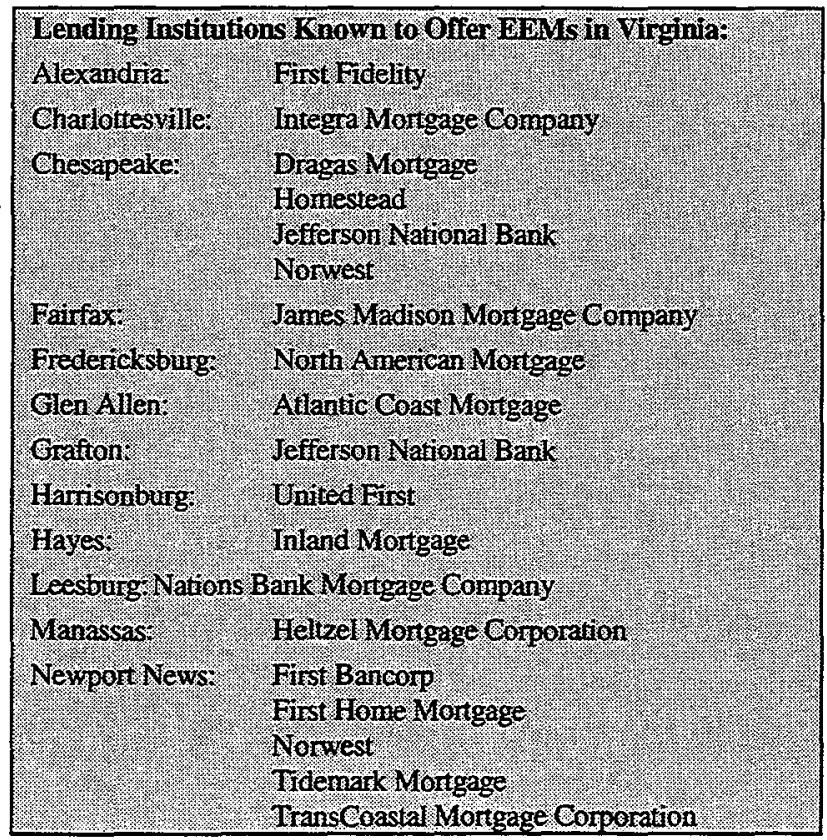

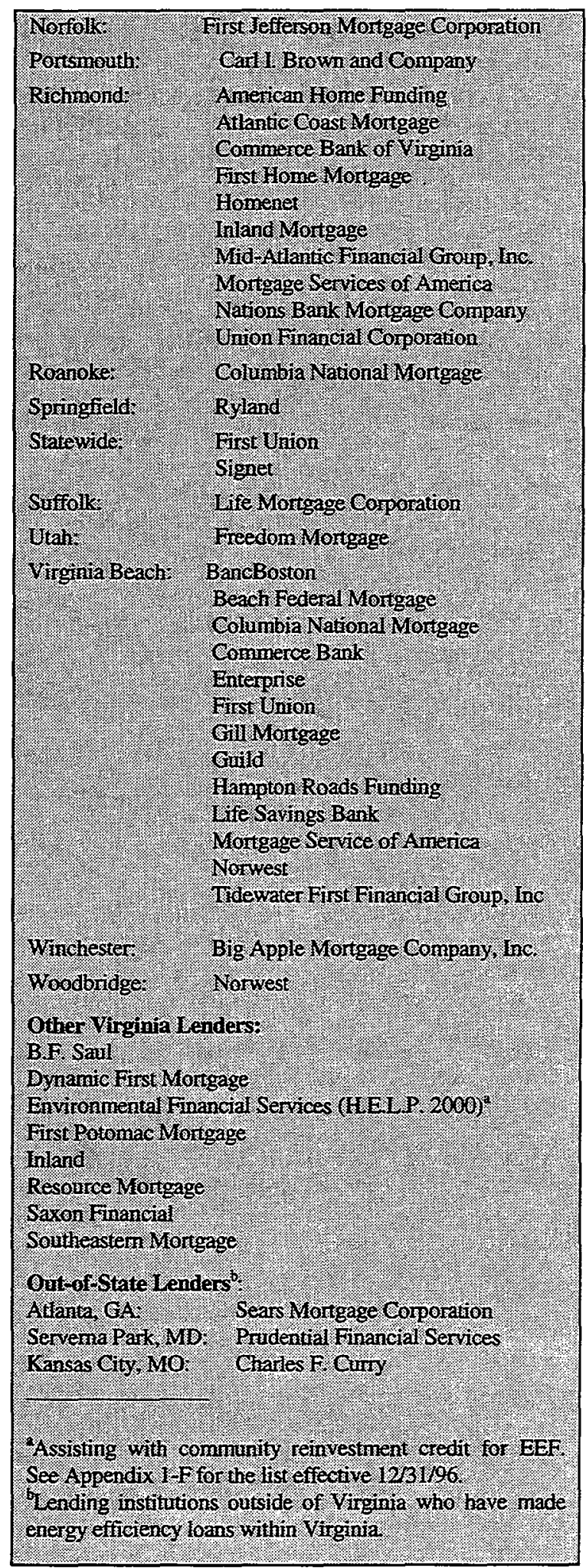


Rating partnerships have been crucial to VHERO's success because the HERS provider does not employ raters, but instead contracts with them to provide rating services to consumers. V-HERO processes the data acquired by raters and provides the rating output to the consumer requesting the rating. The consumer can then take the rating output sheet, as a borrower, to the lending institution providing the financing for the housing being purchased so that an energy-efficient loan can be processed. Organizations in rating partnerships with V-HERO provide training and certification services.

An example of a rating partnership is the relationship between V-HERO and the Virginia Electric Energy Council (VEEC). A VEEC representative serves on the V-HERO board of directors. VEEC employs a certified rater trainer and offers a reduced-rate certification program through Cooperative Extension at Virginia Poly-technical nstitute in Blacksburg, VA.

Utility partnerships have been important in EEF efforts in Virginia. V-HERO has been proactive in establishing working partnerships with Virginia utility companies. By creating utility partners, VHERO has expanded its reach to consumers. In addition, these partnerships have resulted in utility loan funds being made available for cost-effective energy retrofits in existing housing, as assessed by V-HERO's home energy rating, and in the construction of energy-efficient new housing.
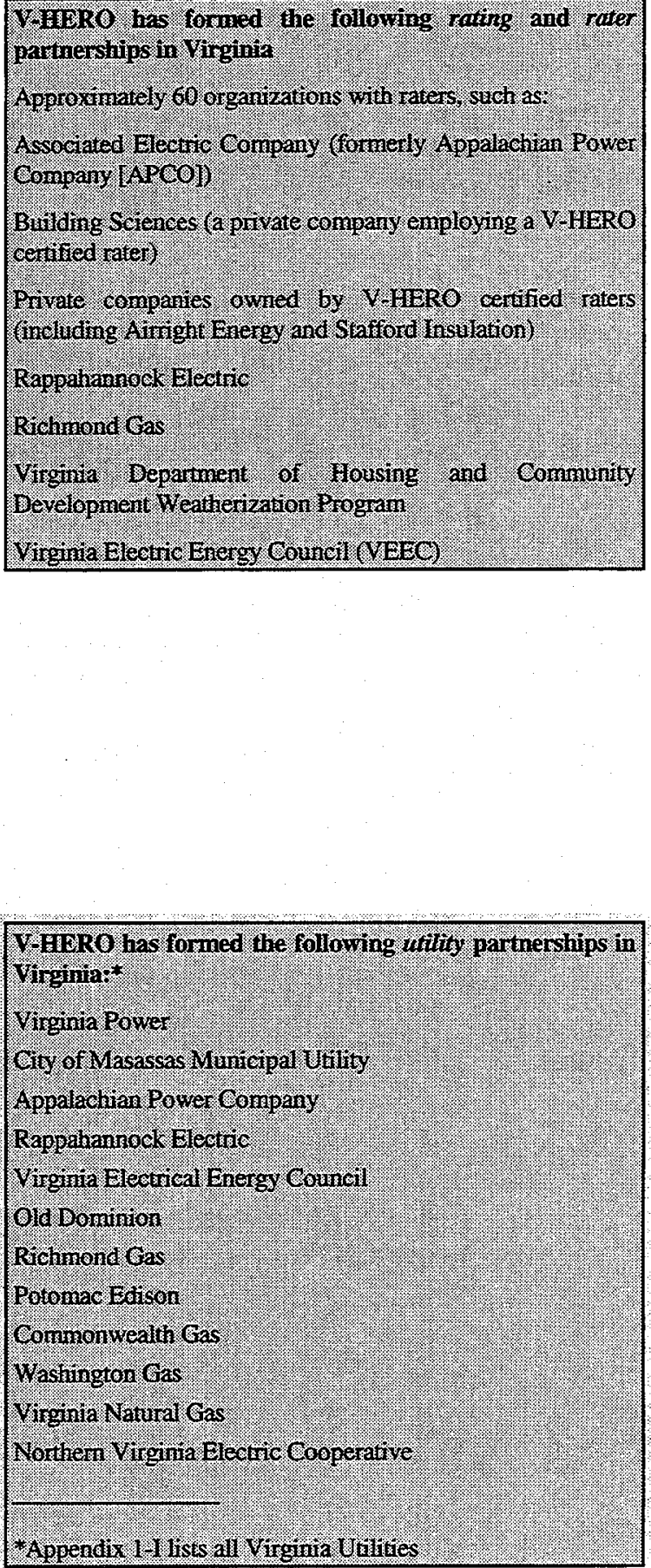
Real estate and appraisal industry partnerships are critical to V-HERO's success because these entities provide a crucial marketing function for ratings and energy efficiency financing. Their part in arranging and consummating real estate and lending transactions makes them pivotal players for any successful ERS/EEF program. In addition, real real

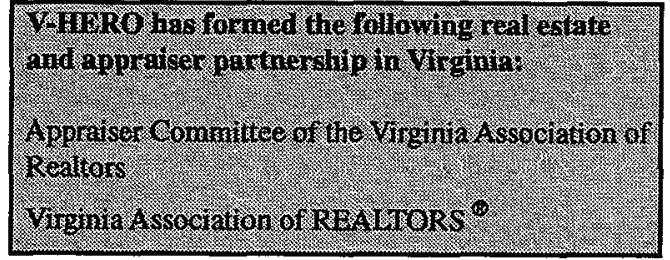
estate personnel can be instru-mental in arranging for the routine listing of a property's energy rating in the multiple listing service (MLS) used in the state or locality. Some Virginia real estate personnel have begun to market energy efficiency financing because they perceive benefits to the real estate business. If these professionals believe that including rating information on properties in MLS listings will be helpful in marketing, they may actively work to routinely list rating information. The voluntary nature of this activity is probably important to its successful adoption in MLS systems. V-HERO has stated that it will facilitate the industry in Virginia when it decides to develop an MLS system that includes rating information.

\section{Market Potential}

Impacts of introducing rating systems linked with EEF must be evaluated in the context of many variables, such as the size of the housing market, housing tumover rates, new housing starts, and population characteristics. In addition, data on utility electric and gas generation and prices affect market potential for efficiency. Public perception and preferences about energy and the environment also affect the market for efficiency and renewables, as do mortgage interest rates, unemployment rates, tax policies, and other regulations. The number of housing market professionals, such as builders, lenders, and underwriters, that must be trained also influences the near-term potential for program success because these professionals must incorporate changes into their routine business practices. The resources available for this study did not permit the collection of data on all of these variables. The Virginia case study focused on mortgage and EEF activity and on the numbers of housing professionals in the state who would need to be involved for program success.

In 1994, the population in Virginia was 6.6 million. Tables 1-3 through 1-7 show regular mortgage activity insured or financed by federal agencies, including HUD/FHA, RHS, and DVA for FY 1993, 1994, and 1995. These tables demonstrate the enormous market potential for energy efficient housing. In 1995 alone, 40,235 mortgages totaling $\$ 3,828,190,000$ were made, guaranteed or insured by the federal government. These totals do not include the vast numbers of conventional mortgages held by banks, backed by the secondary mortgage markets (such as Fannie Mae and Freddie Mac), and held by private individuals.

Table 1-3. FHA Insured Loans in Virginia, by Fiscal Year

\begin{tabular}{|c|c|c|c|}
\hline Fiscal Year & Number of Mortgages & $\begin{array}{c}\text { Total Volume } \\
\text { in } \mathbf{\$ 0 0 0}\end{array}$ & $\begin{array}{c}\text { Average Value } \\
\mathbf{\$}\end{array}$ \\
\hline 1993 & 36,884 & $3,070,194$ & 83,239 \\
\hline 1994 & 54,171 & $4,563,169$ & 84,236 \\
\hline 1995 & 16,215 & $1,215,000$ & 74,930 \\
\hline
\end{tabular}

Source: Constructed by the author using data from HUD/FHA 
Table 1-4. HUD/FHA New Home Loans in Virginia, by Fiscal Year

\begin{tabular}{|c|c|c|c|}
\hline Fiscal Year & Number of Mortgages & $\begin{array}{c}\text { Total Volume } \\
\text { in \$000 }\end{array}$ & $\begin{array}{c}\text { Average Value } \\
\mathbf{\$}\end{array}$ \\
\hline 1993 & 2,395 & 208,917 & 87,230 \\
\hline 1994 & 2,540 & 242,315 & 95,399 \\
\hline 1995 & 1,836 & 183,062 & 99,707 \\
\hline
\end{tabular}

Source: Constructed by the author using data from HUD/FHA

Table 1-5. Rural Housing Service Direct Loans in Virginia, by Fiscal Year

\begin{tabular}{|c|c|c|c|}
\hline Fiscal Year & Number of Mortgages & $\begin{array}{c}\text { Total Volume } \\
\text { in } \mathbf{\$ 0 0 0}\end{array}$ & $\begin{array}{c}\text { Average Value } \\
\mathbf{\$}\end{array}$ \\
\hline 1993 & 799 & 37,844 & 47,364 \\
\hline 1994 & 829 & 41,884 & 50,524 \\
\hline 1995 & 594 & 24,747 & 41,661 \\
\hline
\end{tabular}

Source: Constructed by the author using data from RHS

Table 1-6. Rural Housing Service Guaranteed Loans in Virginia, by Fiscal Year

\begin{tabular}{|c|c|c|c|}
\hline Fiscal Year & Number of Mortgages & $\begin{array}{c}\text { Total Volume } \\
\text { in } \mathbf{\$ 0 0 0}\end{array}$ & $\begin{array}{c}\text { Average Value } \\
\mathbf{\$}\end{array}$ \\
\hline 1993 & 535 & 39,438 & 73,715 \\
\hline 1994 & 409 & 30,611 & 74,844 \\
\hline 1995 & 340 & 27,900 & 82,058 \\
\hline
\end{tabular}

Source: Constructed by the author using data from RHS

Table 1-7. U.S. Department of Veterans Affairs Mortgages in Virginia, by Fiscal Year

\begin{tabular}{|c|c|c|c|}
\hline Fiscal Year & Number of Mortgages & $\begin{array}{c}\text { Total Volume } \\
\text { in } \mathbf{\$ 0 0 0}\end{array}$ & $\begin{array}{c}\text { Average Value } \\
\mathbf{\$}\end{array}$ \\
\hline 1993 & 34,265 & $3,653,826$ & 106,634 \\
\hline 1994 & 47,946 & $4,980,875$ & 103,885 \\
\hline 1995 & 21,054 & $2,354,000$ & 111,808 \\
\hline
\end{tabular}

Source: Constructed by the author using data from DVA

Table 1-8 shows the numbers of relevant housing market professionals or organizations that would need to be reached through training and education programs on EEF for such financing to be routinely used. VHERO, HUD, and the professional associations involved have worked to provide such information dissemination in Virginia. 
Table 1-8. Numbers of Housing Market Professionals

\begin{tabular}{|l|r|r|r|}
\hline \multicolumn{1}{|c|}{ Housing Market Professionals } & CY 1993 & \multicolumn{1}{c|}{ CY 1994 } & \multicolumn{1}{c|}{ CY 1995 } \\
\hline Real estate agents (VAR members) & 26,000 & 25,000 & 24,000 \\
\hline Realty offices & 3,500 & 3,000 & 2,100 \\
\hline Multiple Listing Services & 31 & 28 & 20 \\
\hline Mortgage banking professionals & MD & MD & MD \\
\hline Appraisers & 2,100 & 2,350 & $2,600+$ \\
\hline Home builders & MD & MD & 3,500 \\
\hline Commercial lending institutions & MD & MD & 106 members \\
\hline
\end{tabular}

MD: Missing data

Note: No licensing is required for home inspectors in Virginia; no Virginia Chapter of the American Society of Home Inspectors exists. 


\title{
Energy Efficiency Financing in Virginia
}

\author{
Energy Efficiency Financing Products
}

\section{FHAVEMS}

EEMs permit the addition of $\$ 4,000$ or $5 \%$ of the loan amount, up to $\$ 8,000$ (whichever is greater) to the approved loan amount for cost-effective energy improvements based on a home's rating. EEMs can be used for single-family homes, multi-family owner-occupied homes up to four units, or manufactured homes, previously owned or on the market at least a year. The cost of the rating is an allowable closing cost up to $\$ 200$. Improvements must be made within 90 days of closing. The EEMs program, which went nationwide on October 6, 1995, has been extended to include new homes and FHA 203(k) loans.

\section{HUD 203(k) Loans Combined with EEMs}

In Virginia, these loans began to be marketed in March 1995. HUD guarantees these loans to finance the acquisition and rehabilitation of existing housing. The owner can also get an EEM addition of 5\% of value, but not greater than $\$ 8,000$ for cost-effective energy improvements, as determined by a rating. A problem with part of the housing stock is that it is of such poor quality it is difficult to get adequate financing for repairs. The money that was traditionally available had to be used to shore up basic structural integrity and could not be spent on energy improvements. The 203(k) mortgage combines the acquisition/refinance of a property and the rehabilitation costs of at least $\$ 5,000$ into one loan. The EEM would be in addition to this loan. The combination of EEMs with 203(k) has to be handled in such a way that the items that have appraisal value (such as central heating, windows, and air conditioning) are financed through the 203(k) portion and the items without traditional appraisal value (such as insulation) are financed through the EEM portion. The greatest advantage of combining these two loans is that it leaves behind a house that has additional value and is less expensive to operate.

\section{HUD Title I Home Improvement Loans}

This home improvement loan is a second mortgage. Up to $\$ 25,000$ can be borrowed for 15 years at current market rates. Because the loan is a second mortgage that requires no equity, Virginia lenders began to demand that cost-effective energy improvements should be identified by a rating. Upon closing a mortgage, a borrower can borrow an extra $\$ 25,000$ under Title I, if qualified.

\section{Virginia Power Loan Program}

In October 1993, Virginia Power, serving 70 to $80 \%$ of the state's customers, joined with Volt VIEWtech (as servicer) to provide loans for total electric customers who wished to upgrade the HVAC and water heating electric equipment in their homes. Through the auspices of V-HERO, the utility included the combination improvement packages resulting in the highest efficiency with the lowest interest rate. Audits conducted in conjunction with the loan program (in fact all Virginia Power audits) must be conducted by V-HERO certified raters, by ruling of Virginia Power.

Virginia Power financed the loans directly and sold them to Signet Mortgage Corporation in Virginia. A prior arrangement with Volt VIEWtech servicing the loans for Virginia Power was canceled August 1, 1995. During the period when the mortgage market was slow, the Virginia Power loans were active, possibly because home owners were looking for a way to improve their houses rather than move. 
As of August 1, 1995, Virginia Power had closed $\$ 21,870,000$ in loans to 4,943 housing units.

\section{Virginia Power Energy Saver New Home Construction Program}

Under this program, new homes are certified by V-HERO and built to energy-efficiency standards - in CY 1994, 3,100 homes were constructed, and in CY 1995, 7,000 new energy efficient homes were constructed. Virginia Power stopped processing Energy Saver Homes on July 31, 1996 because the new building code in Virginia had achieved their 4-Star level.

\section{Virginia Power Five-Star Energy Saver Home Plus Program}

V-HERO certifies these new homes; 200 were completed in CY 1995. These new homes use 30\% less energy than the reference house for the 1992 CABO Model Energy Code (ASHRAE 90.2)

Volt VIEWtech provides turnkey program administration for these Virginia Power loans. A phase started in February 1995 permitted homeowners to borrow up to $\$ 15,000$ for 5 years for high-efficiency heat pumps, air conditioning units, and other energy-efficiency improvements. Also, qualifying small businesses became eligible for loans up to $\$ 25,000$. Interest rates from $6 \%$ to $12.45 \%$ are inversely related to the efficiency of the equipment installed, with the lowest rates for the most efficient equipment. Until 1996 these were only available through a few organizations (e.g., Water Furnace).

\section{Fannie Mae Pilot Program}

In late August 1995, Fannie Mae approved Virginia lenders to offer its new pilot loan as part of a major kick-off for EELs (Energy Efficient Loans) within the state. The greatest difference between this loan product and any other currently available is that it instructs the appraiser to take the usual value of a home arrived at by the "neighborhood comparative" method, and add to that value the lower of the installed price of cost-effective energy improvements or the present value of energy savings to arrive at the new appraised value.

\section{Micro-Pilot Program}

In August 1995, V-HERO initiated a "Micro-Focus HERS/EE Financing Pilot," nicknamed the "Chesterfield pilot," in three closely contiguous planned residential communities in Chesterfield County, south of Richmond: Brandermill, Woodlake, and Harbour Point, totaling 7,500 households. The area is widespread geographically with homes from $\$ 35,000$ to $\$ 500,000$. Age of area housing ranges from new construction to about 18 years old, with varying quality of construction. Known energy-efficiency problems include extensive north-facing glass and epidemic duct leakage.

The concept guiding the pilot program was to custom fit various EEF products with diverse borrowers. First-time home buyers might wish to avail themselves of the FHA EEMs; more affluent borrowers could use ratings with conventional financing to incorporate the cost of cost-effective energy improvements into their mortgages. The Chesterfield pilot's overall goal was market penetration of 30 to $40 \%$ of all loans transacted in this neighborhood.

Program partners are V-HERO, Fannie Mae, FHA, DVA, and Volt VIEWtech Virginia Power, H.E.L.P. 2000, EPA, Greenstone Industries, and the Home Builders Association of Virginia (HBAV) are also involved. Signet Lenders and Century 21 are the program's real estate sales agents. 
The Virginia Home Builders Association and a DC-area consulting firm conducted builder education in connection with the project. A V-HERO Board member and member of the Virginia Mortgage Bankers Association trained area lenders. V-HERO staff, in cooperation with the VAR, trained real estate professionals and appraisers.

Virginia Power reported to V-HERO having made 100-150 loans by the end of 1995 and having completed 20-25 EEMs. As a result, Summerford, a 350-home, multi-builder development became a Five-Star, Energy Star development, the first of its kind in the country.

\section{H.E.L.P. 2000 in Virginia ${ }^{2}$}

These loans, which first became available in October 1995, are offered by Environmental Financial Services (EFS) in cooperation with Saxon Financial, Volt VIEWtech, and V-HERO. EFS was a equipment-leasing finance company specializing in developing and marketing finance programs for sale of energy conservation equipment. It has financed more than $\$ 30$ million in sales since 1993. EFS, which received an EPA Energy Star approval, is the marketing arm of the enterprise.

Volt VIEWtech, a company that provides program management and services to utilities serving more than 60 million customers in the United States and Canada, provides loan origination and servicing for H.E.L.P. 2000. Volt VIEWtech uses a V-HERO rating to originate H.E.L.P. 2000 loans in Virginia.

Saxon Financial, which provides the funds for H.E.L.P. 2000, is an affiliate of Resource Mortgage Capital, Inc. (Resource), with $\$ 3$ billion in assets. Resource has funded more than $\$ 16$ billion in mortgage loans since its inception in December 1987. Part of Resource Mortgage Capital was recently sold to Saxon Financial, and then again sold to Dominion Resources, which also owns Virginia Power. The remainder of Resource Mortgage Capital is now called Dynex Financial, Inc., a Richmond-based firm.

V-HERO, through its certified raters, is supplying applications for H.E.L.P. 2000 financing to customers obtaining ratings in Virginia who are not also obtaining mortgages.

\section{Nonconforming and Jumbo Loans}

Each loan program has its own limits. Fannie Mae's limit in Virginia is $\$ 225,000$ and Freddie Mac's is $\$ 260,000$. The highest amount FHA will insure in Virginia is $\$ 151,000$. A conforming loan follows prescribed guidelines set forth by the secondary mortgage market. The conforming lender looks at gradations of income bands for qualification purposes. Houses in a certain price band require down payment percentages and a sliding Mortgage Insurance Premium (MIP). Nonconforming means a lender will make loans that do not meet these guidelines. Secondary mortgage markets agree to buy EEM loans if lenders are willing to make them. Signet and Crestar are doing these loans on a case-by-case basis for EEMs.

Jumbo loans may have the same criteria as a conventional market loan, but exceed the limits, such as a $\$ 500,000$ loan. The highest mortgage that V-HERO has ever dealt with was $\$ 1.3$ million. Even though the loan was for such a large amount, the borrowers still wanted an escrow account for their energy efficiency improvements. The interest rate was lower than what they could earn on the investment market.

\footnotetext{
${ }^{2}$ H.E.L.P. stands for Home Energy Loan Program
} 


\section{Energy Efficiency Financing Activity}

Table 1-9 shows the EEMs activity reported by HUD/FHA and DVA for FY 1993, 1994, and 1995. Although these numbers are small, and may not accurately reflect EEF activity owing to possible data problems discussed later in the Virginia case study, they show a yearly increase in the number of such mortgages.

Table 1-9. Energy Efficiency Financing in Virginia, FY 1993 - 1995

\begin{tabular}{|c|r|r|r|}
\hline EEM Programs & \multicolumn{1}{|c|}{ FY 1993 } & \multicolumn{1}{|c|}{ FY 1994 } & \multicolumn{1}{|c|}{ FY 1995 } \\
\hline $\begin{array}{c}\text { HUD/FHA EEMs: } \\
\text { Number of mortgages }\end{array}$ & 17 & 47 & 72 \\
\hline Total volume $(\$ \mathrm{mn})$ & $\$ 1,235$ & $\$ 4,085$ & $\$ 7,377$ \\
\hline Average value & $\$ 72,673$ & $\$ 86,914$ & $\$ 102,461$ \\
\hline $\begin{array}{c}\text { DVA EEMS: } \\
\text { Number of mortgages }\end{array}$ & 12 & 71 & 124 \\
\hline Total volume $\$ \mathrm{mn})$ & $\$ 1,452$ & $\$ 9,780$ & $\$ 16,104$ \\
\hline Average value & $\$ 121,014$ & $\$ 137,742$ & $\$ 129,873$ \\
\hline
\end{tabular}

Sources: Constructed by the author using data from HUD/FHA and DVA

Table 1-10. Number of EEF Loans Completed in Virginia, by Calendar Year

\begin{tabular}{|c|c|c|c|c|c|}
\hline $\begin{array}{c}\text { Completed } \\
\text { Loans }\end{array}$ & CY 1993 & CY 1994 & CY 1995 & $\begin{array}{c}\text { CY 1996 } \\
\text { (to 4/30/96) }\end{array}$ & Totals \\
\hline FHA EEMs ${ }^{\mathrm{a}, \mathrm{b}}$ & 0 & 125 & 104 & 51 & 280 \\
\hline $\begin{array}{l}\text { FHA 2\%-income } \\
\text { stretch }^{c}\end{array}$ & 0 & 0 & 500 & 300 & 800 \\
\hline HUD 203(k) EEM ${ }^{a}$ & 0 & 25 & 25 & 6 & 56 \\
\hline DVA $^{\mathrm{a}}$ & 0 & $\overline{50}$ & 100 & 11 & 161 \\
\hline $\begin{array}{l}\text { Virginia Power Loan }{ }^{d} \\
\text { Number }\end{array}$ & 217 & 2,945 & 3,420 & 1,000 & $\mathbf{7 , 5 8 2}$ \\
\hline Total \$ & $\$ 870,000$ & $\$ 13,000,000$ & $\$ 15,300,000$ & $\$ 4,500,000$ & $\$ 33,670,000$ \\
\hline $\begin{array}{l}\text { Fannie Mae } \\
\text { Home Improvement } \\
\text { Loans (Form 70-A) }\end{array}$ & & 50 & 10 & $\begin{array}{l}\text { New Fannie } \\
\text { Mae pilot } \\
\text { loans : } 5\end{array}$ & 65 \\
\hline Totals & 217 & $\overline{3,195}$ & 4,159 & 1,373 & 8,944 \\
\hline
\end{tabular}

These EEF products use V-HERO ratings.

${ }^{b}$ These are calendar year data on EEMs based on V-HERO files; the data do not match HUD/FHA's CHUMS database. Database problems are discussed in the section on Program Evaluation in this case study.

This product uses ratings provided by V-HERO or engineering reports connected to ESH ratings. If builders meet building code, technically they can qualify their customers for this loan. These numbers are estimates.

'This product uses either audits or ratings.

This product uses ratings or appraiser estimates of energy savings. 
The records kept by V-HERO on the actual use of rating output by lenders for EEMs appear to show a higher number of EEMs than the data in the CHUMS database, although the two are not strictly comparable: CHUMS data are summanized by fiscal, and V-HERO's by calendar, year. More detailed monthly comparisons of the data would more clearly define the discrepancies. However, V-HERO staff reported that informal spot-checks of the V-HERO records on EEMs with HUD Field Office records showed that many loans in V-HERO's records were not being captured in the CHUMS database. 


\section{Incentives}

Incentives to increase the efficiency of Virginia homes are related to offering EEF products. Three examples of such incentives in Virginia are utility incentives for retrofits, incentives for builders, and EEMs as an incentive to lenders.

\section{Utility Incentives for Residential Energy-Efficiency Retrofits}

The Virginia Power Loan Program offers loans ranging from $\$ 600$ to $\$ 10,000$ for up to 60 months to customers who own homes on permanent foundations. Homeowners can use the money to add insulation, weatherstripping, caulking, storm windows or doors, programmable thermostats, load management systems, heat pump water heaters or superheaters, duct modifications or repairs, ventilation products, and high-efficiency electric heating and cooling systems. The financed measures must result in at least 15 percent savings in the energy used for space conditioning and water heating. Virginia Power issued a chart to help homeowners determine which energy improvements would save energy and utility costs, or owners were advised to have V-HERO ratings. To promote installation of higher efficiency heat pumps, Virginia Power offered a lower interest rate (6\% for 15 SEER) than was made available for less efficient units (8.45\%). Through March 1994, 730 loans were approved and 34 were pending; the average loan amount was $\$ 4,231$. Most of the loans were used for new or replacement heat pumps. V-HERO, because of the program's reasonable interest rate and consumer loan design, referred more than 1,000 consumers to this program before making applications for H.E.L.P. 2000 loans directly available to customers through its raters.

\section{Incentives for Builders}

During 1995 and 1996, the Five-Star Energy Star Home Plus program brought together the efforts of Virginia Power, Volt VIEWtech, Greenstone Industries, and V-HERO to form incentive packages to convince builders of the marketing advantage of building super-efficient homes. Packages in Virginia include:

- Increased appraised value (because of the availability of Fannie Mae trained appraisers)

- Rebate of $\$ 10$ per month for 10 years from Virginia Power

- Automatic Energy Star status with the U. S. Environmental Protection Agency (EPA)

- Utility guarantee through Greenstone Cozy Home/Comfort Home.

\section{EEMs as an Incentive to Lenders through the Community Reinvestment Act $^{3}$}

Banks report on every mortgage to the Federal Reserve Bank. Because the Federal Reserve holds the charters of the banks, they have some control over banking behavior. Banks cannot expand or take other actions without the penmission of the Federal Reserve Bank, the Federal Reserve Bank essentially regulates banks.

${ }^{3}$ V-HERO staff provided this information on the potential of EEMs as an incentive to lenders through its relationship with the Community Reinvestment Act; Federal Reserve Bank recognition of EEMs in crediting banks' compliance with CRA was not validated through other sources. No data were collected on the lending institution perspective on EEMs as a possible CRA-related incentive. 
The Home Mortgage Disclosure Acts (HMDA) of 1983 and 1984 require banks to report on their mortgages to the Federal Reserve Bank. Congress passed the Community Reinvestment Act (CRA) in 1986 as an outgrowth of HMDA, requining banks to practice community revitalization and to provide loans on a nondiscriminatory basis to lower-income borrowers. Banks must regularly demonstrate to the Federal Reserve Bank that they are lending a certain percentage of their portfolios to such borrowers. Bank lending portfolios are required to match the ethnic and income demographics of the communities they serve and banks receive CRA credits for doing so. Banks receive the most credits for low-income lending, they can lose their licenses if they fail to comply with CRA requirements.

Because FHA EEMs help lending institutions reach CRA goals by increasing the probability of home ownership among lower- and middle-income consumers, banks' use of EEMs can help them reach CRA requirements and receive credits for meeting community development goals. V-HERO's policy is to make lenders aware that they can receive CRA credits when they use EEMs for lower-income borrowers. 


\section{Rating System, Ratings, and Raters}

The Virginia rating program began with E-Z Rater, the ERHA software. For each rating completed, VHERO paid \$15 to ERHA for processing the rating data and archiving the output. ERHA retained the rating data in electronic form in its databases; the Virginia HERS provider had no rating data when VHERO emerged as the HERS provider organization in Virginia in 1995.

This section discusses the rating software (see also Appendix 1-B for an example of the V-HERO Rating Output Form used in 1995). V-HERO has had the responsibility of training and certifying qualified raters for Virginia consumers to hire as contractors; V-HERO does not employ raters. This training program has been expanded by N-HERO to a curriculum for rater training in other states. This has been particularly useful in states where Weatherization program funds were cut, and knowledgeable former employees of these programs could readily be trained as capable home energy raters.

\section{Rating Software}

During 1995, V-HERO abandoned use of E-Z Rater, which was the rating software originally licensed to Virginia through its contract with ERHA, headquartered in Little Rock, Arkansas. ${ }^{4}$ To replace E-Z Rater, V-HERO developed new state-of-the-art software in collaboration with Volt VIEWtech, called "Rateview." In the view of the V-HERO director, this rating software package complies with the proposed NOPR guidelines, has 15 years of verified accuracy against actual utility bills, and is user friendly.

Although V-HERO is still field testing the Rateview software, the program's director is optimistic that the software will ultimately become an industry standard.

\section{Ratings}

Table 1-11 summarizes the number of ratings by calendar year.

Table 1-11. Number of Ratings Completed in Virginia, by Calendar Year

\begin{tabular}{|l|c|}
\hline \multicolumn{1}{|c|}{ Calendar Year } & $\begin{array}{c}\text { Number of Ratings } \\
\text { Completed }\end{array}$ \\
\hline July 1992-March 1993 & 40 (Manassas Pilot) \\
\hline 1994 & 250 \\
\hline 1995 & 7,345 \\
\hline Total & $\mathbf{7 , 6 3 5}$ \\
\hline
\end{tabular}

${ }^{4}$ In using the ERHA software, V-HERO staff and its Board of Directors experienced continual unresolved problems with what they perceived as a combination of outmoded language, programming incapabilities, and inability to verify accuracy in results. These problems led to the decision to replace the rating software used in Virginia. 


\section{Raters}

Table 1-12 summarizes the numbers of raters trained and certified by V-HERO by calendar year beginning in 1993 and ending December 31, 1995. During 1995, Virginia had 78 certified raters working in the state.

Table 1-12. Number of Raters Certified in Virginia, by Calendar Year

\begin{tabular}{|c|c|}
\hline Calendar Year & Number of Certified Raters \\
\hline 1993 & 38 \\
\hline 1994 & 23 \\
\hline 1995 & 17 \\
\hline Total & $\mathbf{7 8}$ \\
\hline
\end{tabular}

The number of raters being certified each year has declined for two reasons: (1) a declining base of qualified trainees with five or more years of relevant experience and references and (2) a decline in activity to recruit raters - V-HERO only recruits when raters are needed Appendix 1-G lists the 100 raters active in Virginia as of December 31, 1996.

In addition to the raters trained in Virginia, N-HERO trained 20 raters who worked in 1995 in six other jurisdictions and 31 who worked in 1996 in two additional states. Table 1-13 shows that information.

Table 1-13. Number of Raters in Other States Trained by N-HERO

\begin{tabular}{|l|c|c|}
\hline \multicolumn{1}{|c|}{ State } & CY1995 & CY 1996 (to May) \\
\hline District of Columbia & 1 & 18 \\
\hline Maine & & 28 \\
\hline Maryland & 4 & 15 \\
\hline Massachusetts & 1 & 2 \\
\hline New Hampshire & & 22 \\
\hline New Jersey & & \\
\hline New York & 1 & \\
\hline North Carolina & 1 & \\
\hline Pennsylvania & 12 & \\
\hline
\end{tabular}

Appendix 1-H lists active raters in the District of Columbia, Delaware, Maine, Maryland, and New Jersey, trained by N-HERO, as of December 31, 1996. 


\section{Marketing}

V-HERO has, from the outset, used a multifaceted marketing strategy based on galvanizing the consumer demand its directors believed existed in the marketplace. Four CBS network television commercials- two 4 minutes, one 30 seconds, and one 15 seconds in length-are running on the CBS Good Morning program, and on cable television and radio, in the Washington, DC; Richmond; Charlottesville; and northern Virginia areas. These ads are generating extensive customer inquiries.

\section{Marketing Strategy}

V-HERO's multifaceted marketing strategy has included the following features:

- Target marketing efforts on real estate professionals

- Provide effective education/training for lenders, including one-on-one training with loan officers and underwiters

- Network with representatives from the state's housing agencies, organizations, and others

- Develop links with utility personnel

- Use "earned media" (any unpaid media exposure; e.g., articles published through public relations efforts) to market the program

- Secure funds for paid advertising through the Virginia Association of Broadcasters

- Educate elementary school children about energy efficiency.

V-HERO has approached marketing using an array of accepted marketing techniques, including (1) human interest articles in newspapers, (2) programmatic stories in trade publications, (3) public speaking engagements at trade meetings, (4) direct mailings including letters and brochures to lenders and real estate professionals, (5) distribution of instruction materials to elementary school teachers, (6) direct advertising brochures in real estate racks, (7) WTVR, Channel 6, subsidized by V-HERO, which pays approximately one out of each three ads run and television advertising in the Washington, DC, Richmond, and Charlottesville metro areas, carried also on cable television and on radio, and (8) public service announcements from these efforts.

During 1995, V-HERO created a model for small-focus pilot programs, a micromarketing tool aimed at saturating the loans in small geographic markets, crossing the boundaries of all types of borrowers, from those wishing to exceed their normal borrowing capabilities (such as customers for the FHA EEMs) to those wishing to borrow well below their borrowing limits.

\section{Market Response}

The most successful marketing techniques to date have been the network television advertising, carried also on cable TV and on radio, and the brochures in real estate racks. After the TV ads began to appear, VHERO staff have had to spend at least $50 \%$ of their time responding to customer inquiries and sending information packages to those wishing to pursue EEF, and the number of ratings has tripled. 


\section{Information and Services Transfer: National HERS Provider Organization}

The National Home Energy Resources and Energy Organization (N-HERO), evolved to provide costeffective technical assistance to other states. To share the cost of basic services, N-HERO planned to serve as a central hub for other states, providing consulting support, training and certification of raters, and computation of ratings. The rating program in each state could have its own nonprofit organization, with a board of stakeholders in that state to make certain that the program is adapted to the state's unique conditions. That organization would control the program in that state. Use of N-HERO services would prevent the necessity, though, of each state having to duplicate office, staff, computers, software, and so on, by providing centralized services.

\section{N-HERO has two parts:}

1. Service Bureau. Includes processing of information on ratings of homes from a diverse group of programs, with climatic and utility information specific to the areas. That information produces ratings specifically branded for those programs. The ratings are the product of each state's program, printed to their standards.

2. Marketing Bureau. Provides in-depth, in-state interface with the stakeholders, and also includes negotiations at a higher regional and national level to bring new effective lending products into that program's operational arena. The rationale for this is that, because N-HERO has a national track record in program establishment, then national-level organizations will accept state-level programs more readily if they are part of the N-HERO network.

$\mathrm{N}$-HERO is supported by each statewide organization paying for the services it receives; for example, the rating service. The system would be completely open, with each state retaining its own rating data, along with $\mathrm{N}-\mathrm{HERO}$, thus aiding in monitoring and evaluation.

States would also be responsible for marketing budgets. State budgets would be derived, for example, from the housing finance authority, economic development office, and private sources. State programs would focus on marketing and forming partnerships with utilities and financial institutions.

During 1995, N-HERO assisted various entities in 20 states in developing their ideas on HERS programs of their own, including Connecticut, Delaware, Florida, Georgia, Mlinois, Kansas, Maine, Maryland, Massachusetts, Minnesota, Missouri, New Hampshire, New Jersey, New York, Oklahoma, Oregon, Pennsylvania, Washington, West Virginia, and Wisconsin. 


\section{Education and Training ${ }^{5}$}

\section{Training Philosophy}

Because of a degree of skepticism in the lending community about EEMs, V-HERO discovered that oneon-one training with lenders was a more effective method of training them to actually perform EEMs than classroom situations. V-HERO staff believed that the mortgagee letter was of almost no help in promulgating the EEMs program, because several hundred mortgagee letters a year are sent from HUD/FHA to lending institutions. The lenders and underwriters just can and do file them because they are highly tochnical and take too much time to fully understand Loan originators tend not to be highly trained, but rather are more junior administrators told to conform to certain rules that underwriters approve. If loans turn bad, underwriters' names are on the line; therefore, they tend to be conservative. Their performance is highly quantifiable in terms of the numbers of their loans that succead or fail. 'Underwriters' first reaction to any loan application is whether approving it will expose them to criticism

The Virginia experience was that, once lenders are trained by a credible source-another informed lender - they would then look for opportunities to do EEMs. Lenders call V-HERO and check to see if they have the most up-to-date rater list to provide to the consumer. V-HERO processes the rating, does the present value calculation, and sends both to the lender. At times, lenders call because the closing date is soon and they want to get the rating more quickly.

If lenders are untrained, they can give consumers poor advice. Sometimes they state that their bank does not offer EEMs. Some consumers have reported back to V-HERO that their lenders (untrained by VHERO) say they can get vinyl siding or septic systems through EEMs, and that their utility bills would go down as a result. V-HERO has to step in and correct those situations with both consumers and lenders.

\section{Roles and Responsibilities in Training}

When Congress mandated the FHA/EEMs pilot, it appropriated no funding to HUD/FHA to promulgate or implement the program. Its implementation fell to an already overworked staff within HUD who could devote only small portions of time to it. The mortgagee letter was HUD/FHA's mechanism of choice in such a situation. Indeed, the fact that EEMs have gotten as far as they have in some pilot states is testimony to the dedication of certain HUD staff in the Field Offices in those states. These federal employees worked overtime traveling to speak with lenders in their states to acquaint them with the new procedures.

\footnotetext{
${ }^{5}$ Appendix 1-A provides details on training activities, dates, and numbers trained. Rater training was covered in the section on raters.
} 
Although V-HERO was charged from the outset with rater training and certification responsibilities, it had not been directly responsible for training lenders and other cognizant stakeholders. These education and training efforts flowed naturally from V-HERO's marketing efforts and formation of parnerships within and beyond Virginia. The more V-HERO staff worked to communicate clearly the nature and procedures of HERS linked with EEF products, the more cognizant they became of the necessity for education and training. In fact, one of their more innovative wishes-yet to be realized—is to develop a set of curriculum materials for elementary schools in Virginia relevant to energy-efficient housing.

V-HERO staff carries $90 \%$ of the responsibility for training lenders, real estate professionals, and builders on HERS/EEF products. Staff taught certification courses until October 1993, when the Board of Directors certified the first rater trainer. There are now four certified rater trainers in Virginia.

\section{V-HERO Training in Virginia}

From the outset, the directors of the Virginia program's staff understood that training of industry partners was critical to program success. Training raters was obviously of first priority because no program could exist without them. Training lenders, builders, real estate professionals, and appraisers was also central to delivering EEF to home buyers. Since the program's inception, V-HERO staff members have addressed approximately 4,000 real estate professionals through speaking engagements at the monthly meetings of local real estate associations or real estate offices, state real estate conventions, and through articles in association publications. V-HERO staff have also been in contact with 30 of the state's 33 real estate boards to make them aware of the program. In addition, staff and board members have talked with lenders on the telephone. V-HERO has provided one mass mailing on HERS/EEMs to Virginia lenders. In 1996, after publication of an article on Fannie Mae in the Appraiser Newsletter, V-HERO trained the first 12 appraisers in the state.

\section{HUD Training in Virginia}

HUD's training is aimed primarily at underwriters. Subsequent to the mortgagee letter being issued in 1993, the Virginia HUD Field Office provided a one-half hour training on EEMs as part of their regular trainings. Now, HUD's Single Family Production (SFP) Branch in Richmond, under Virginia Holman's direction, provides regular lender training on EEMs and 203(k) EEMs. The branch has also trained raters as 203(k) consultants to reduce renovation and retrofit costs to consumers.

\section{Centralized Underwriting}

Many underwriters deciding on Virginia loans are located outside of Virginia; for example, in Texas, California, Georgia, and other states. The HUD office in Virginia would have no way of knowing how many underwriters are involved in reviewing Virginia-based loans. The 200 lending companies in Virginia have 3 to 6 underwriters apiece, but not necessarily located locally. These underwriters might not have received any training other than receiving the original mortgagee letter itself from HUD/FHA. The common lending practice of centralized underwriting with personnel untrained in the use and interpretation of the EEMs product could well have affected the use of EEMs in Virginia and in the other pilot states.

Virginia Holman of the HUD Richmond Field Office visited each of the five chapters of the Virginia Mortgage Bankers Association meetings during 1994 and 1995 to speak on EEMs. The audience comprised loan officers and underwriters; she estimated that approximately 300 were reached each year. 
With the support of HUD in providing a mailing list, V-HERO did a mailing of the mortgagee letter announcing the EEM program in 1993 to loan officers, underwriters, and appraisers in Virginia. Every company received at least one mailing, although a number of address changes in the mailing list caused many of them to be returned. Updates are sent out regularly by HUD and are now posted on the Internet on HUD's home page (www.hud.gov). 


\section{Problems and Solutions}

This section discusses barriers to implementation, how these barriers were addressed and resolved, remaining problems, and their relative tractability to solution.

\section{Barriers to Implementation}

Barriers to the institutionalization of energy efficiency financing linked with home energy rating systems have been profound because they require changes in the roles and responsibilities of real estate transactions and financing communities. Such shifts are always difficult because these transactions occur in carefully structured systems that are intricately linked Changing one aspect of one role therefore reverberates through the entire system of shared understandings, roles, and responsibilities.

Perceptions of program barriers vary to some extent by role, institutional type, and specific organizational location. Thus, barriers are discussed from HUD's perspective, V-HERO's perspective, and the evaluator's perspective. No data are yet available on the perspective of other important stakeholders, such as builders, lenders, real estate professionals, and appraisers.

\section{From the HUD Field Office Perspective}

More than 200 lending institutions are FHA-approved in the State of Virginia. The HUD Field Office in Richmond identified several barriers to the implementation of the FHA EEM program. As of August 1995, the office reported that they have received "very few calls" about the program from lenders. "Every now and then" a borrower called after reading the required EEMs disclosure statement at loan application. HUD processes 2,000 to 2,200 loan applications a month through its Richmond office. Although the EEMs designations are to be noted in the insuring binder and entered into HUD's nationwide database on insured loans (called "CHUMS"), the database is not necessarily accurate or consistent. Although there was a slow start, 203(k) lenders are now beginning to combine the 203(k) and EEM loans.

Lender hesitance. Many Virginia lenders do not offer the FHA EEMs as a regular product in Virginia because, according to the HUD official, their lending and underwriting staff members do not understand the program. HUD's perception was that Virginia lenders were not actively marketing the program to consumers, although they do respond to a customer's request for an EEM. The HUD official said that lenders believed EEMs were more complicated to process than other loans, and indeed, lenders believed that they were more complicated than they actually are. Field office staff believed that loan officers were not adequately informing consumers about the EEMs option; they were simply having borrowers sign the required disclosure statement as part of loan closing while telling borrowers that they were not offering EEMs. According to the HUD official, loan officers themselves remained inadequately trained and therefore could not give the necessary information to borrowers. ${ }^{6}$

\footnotetext{
${ }^{6}$ V-HERO staff commented that Signet has done a number ofEEMs with V-HERO, including the first one in the state, and the first 203(k) EEM.
} 
Risk aversion. HUD staff believed that Virginia lenders were not interested in part because of their concern about the marketability of EEMs in the secondary mortgage markets. The lenders' concern, according to HUD, was that although Fannie Mae might buy the loans, the banks' own particular investors would not. The energy-improved properties were often being financed at very high loan-to-value ratios, which made them appear to be riskier investments than others available. Another reason for lender hesitance noted by HUD was that lenders did not need to know about these products to make money. When the market for refinancing slowed down in 1995, lenders then became more active in processing 203(k) loans. Because national lenders set policies that affect lending nationwide, their posture toward energy efficiency financing would affect lending in Virginia as well as in other pilot and nompilot states.

Processing difficulties. In addition, several Virginia lenders reported to HUD that they had some problems with customers in connection with EEMs: energy improvements were installed improperly; the installation process exceeded the escrow period permitted; and other stories about difficulties circulated among lenders about these loans.

Futility of FHAVEEMs disclosure statement. Another barrier is that the decision to apply for an EEM basically needs to be made before the lender is involved. The availability of an EEM disclosure statement comes too late in the process when it occurs at loan application. Perhaps the disclosure statement should come earlier in the real estate transaction through real estate professionals so that borrowers learn of the option early enough to do something about it. ${ }^{7}$

Lack of incentives for HUD staff. HUD headquarters sets numerical goals for each HUD Field Office in terms of quotas for the number of loans processed by each type. For example, each Field Office has to fill a goal of a certain number of 203(k) loans; in Virginia's case, the quota of 203(k) for FY 1996 is 380. Commissioner Nicolas Retsinas' office sets these goals, which vary by HUD Field Office around the country. For EEMs, unlike for 203(k) loans, HUD has not set mumerical production goals or quotas. At this time, HUD headquarters has given higher priority to the 203(k). Part of the problem for EEMs, according to the HUD official, is the uncertainty that operating costs would actually be reduced as a result of the energy improvements, thus allowing a greater portion of income to be available for mortgage payments. Also, insuring loans to $110 \%$ of value is a concern that could have a negative impact if HUD acquires a EEM property and has to resell it at a loss. The default rate will be important in HUD's evaluation of EEMs.

Lack of incentives for lenders. For 203(k) loans, HUD policy allows lenders to receive a 1.5-point additional origination fee plus some other fees. An $\$ 8,000$ increment in a mortgage (such as an EEM) does not result in much profit for lenders unless done in volume; there is no other financial incentive for lenders in connection with EEMs.

EEMs not used for HUD Homes. In Virginia, nothing had happened by May 1996 to encourage the use of EEMs in connection with HUD Homes (homes insured by FHA that had to be repossessed because of foreclosures). HUD always wants to sell the properties as quickly as possible; therefore, HUD may not wish to take the time to have these properties rated and energy improved before putting them on the market. Apparently the HUD headquarters staff in charge of the HUD Homes program have either decided against EEMs or have not yet decided about including EEMs as in integral part of their program. Two arguments

\footnotetext{
${ }^{7}$ HUD repealed its requirement for the Disclosure Statement when the EEM program went nationwide; Florida repealed its disclosure through real estate professionals in April 1996.
} 
used against the use of HERS for HUD Homes are that HUD cannot bear the cost of the rating and that the electricity, which is neaded in performing a rating, is shut off during the repossession period.

Uninformed real estate professionals. HUD staff perceive that real estate professionals are not well informed about the availability of EEMs and how to use them in marketing real estate.

Rating organizations in Virginia. The HUD Field Office indicated a belief that a lack of competition among rating organizations could be a barrier to more widespread use of EEMs. However, V-HERO points out that it is a HERS provider organization. Raters themselves provide the competitive aspect in ratings because they are employed by businesses that provide rating services. Now that more rating businesses comprehend the eaming potential of performing ratings, their competition appears to be increasing rating volume.

Credibility of new HERS provider organization. V-HERO- the one organization providing ratings in Virginia - may have experienced a credibility problem with the Virginia lending community as a result of their offices being closed for a time during 1994 while the various Virginia rating organizations were being consolidated. For a few months, V-HERO business was transacted from the Executive Director's home office. All ratings were performed, including necessary post-tests, but it was difficult for lenders and consumers to reach V-HERO through usual channels. The confusion was finally resolved in January 1995 when V-HERO occupied its current Richmond offices.

Lack of sufficient consumer information. The Virginia HUD official believed that most consumers in Virginia would call Virginia Power if they were interested in energy-efficiency programs. Virginia Power could make a referral to a lender offering EEMs or to V-HERO. Staff at Virginia Power who receive this type of call may possibly need more training on the program and its participants to know how to best refer the calls.

\section{From the V-HERO Perspective}

V-HERO staff outlined several reasons that the growth of EEF has been slower than hoped in Virginia as well as elsewhere in the nation. These barriers can be classified into four categories: (1) lack of adequate funding, (2) misperceptions about the market for EEMs, (3) obstacles because of routine real estate transaction practices, and (4) rating program leadership.

Misperceptions about the market for EEMs.

- Programs often lack adequate funding for marketing; they may have insufficient administrative support staff and minimal advertising and promotional budgets

- No funding has been available for V-HERO to market the program; marketing has relied on the resources of allied industries more than V-HERO staff would have preferred. 1995 funding from DOE finally made enough resources available for TV ads. Consumer response, originally 75 to 100 calls a week, settled down to 30 to 40 calls a week by mid-1995

- Misperceptions and misunderstanding of the markets on the part of allied industries; for example, that consumers are not motivated to participate in energy-efficiency programs, that energy-efficiency improvements are too costly, and that the processes involved are complex and slow. This problem has been overcome by experience, but more significantly by consumer demand. 


\section{Problems with routine practices in real estate transactions.}

- Lender and real estate forms commonly used do not convert readily to include financing of energyefficiency products

- Mortgage insurance premiums, which increase because of higher amounts borrowed, offset energy cost savings that could be realized by consumers

\section{Problems with rating program leadership.}

- Board of directors often have technical qualifications and wish to set public policy and marketing standards. However, they might not have policy or marketing expertise neaded for success

- Leadership may be motivated by social welfare concerns, such as those of the Weatherization Assistance Program, rather than by creating market-driven revenues

- Consumer behavior can be a program impediment. For example, one consumer wanted new windows and an HVAC system. Yet, his house had no attic, wall, or floor insulation and leaked so badly that a blower-door test could not be performed. Once he received his rating and mortgage, the customer spent $\$ 3,400$ on incorrectly installed windows, even though only $\$ 1,000$ had been allocated to windows on the rating sheet. He had the insulation installed incorrectly as well. Post "improvement," the house was leakier than it had been before the rating. The windows contractor was threatening to sue the consumer because the escrow hadn't been released; that, in turn, occurred because windows installation failed to pass the post-installation inspection. The consumer began to complain that his wife and children were freezing. A rater took an infrared scanner to the house and found no insulation in the wall cavity. This experience led V-HERO to include on their report to consumers a statement to the effect that they can only obtain the loan if they complete the recommended improvements. V-HERO estimates that approximately half of the consumers want to make an improvement to their home that is not approved by the rating.

- Fuel assistance program staff members are prevented by the ethics of confidentiality from talking with staff of Weatherization Assistance Programs. This can block the provision of needed expertise along with rating information to low-income borrowers.

V-HERO staff believe that some barriers may exist in other HERS/EEF programs that do not exist in Virginia.

- Lack of marketing experience that prevents rating organizations from taking advantage of the incentives that could be realized by potential trade allies. For example: for utilities, peak load shaving and avoided costs; for builders, selling upgrades to increase margins; for real estate professionals, decreasing "breakage" and facilitating closings; and for lenders, lending more and maintaining or decreasing risk levels.

- Lack of experience with the effective use of advertising. This prevents rating organizations from using paid advertising to promote customer action and public relations activities to build image.

- Failure to differentiate the rating product from utility audits. Rating organizations may see themselves as competitors of utility companies; customers fail to perceive the differences between ratings and utility audits, except for the costs (ratings are much more expensive). 


\section{Problems Remaining and Prognosis for Solution}

Funding and stafiing remain V-HERO's central interrelated concerns. The number of consumer inquiries has risen in response to program advertising particularly major network television advertising in northern Virginia and the metropolitan DC area. The more routine aspects of handling inquiries could be handled by administrative staff. A critical mass of funding was insufficient to permit hiring neaded staff by the end of 1996; however, resources permitted adding a technical staff person to perform ratings and an administrative assistant as of January 1, 1997. 


\section{Program Evaluation}

\section{Status of Data Collection}

This section briefly describes V-HERO's, HUD's, and other Virginia data systems. The description of HUD's CHUMS data system applies not only in Virginia but also across the nation.

\section{V-HERO's Data System}

Through the end of 1995, V-HERO maintained a hard copy filing system only. Beginning in 1996, VHERO has data collection and retrieval potential through its new rating software.

\section{HUD's CHUMS System"}

Lenders can access CHUMS (HUD's national database containing information on loans insured by FHA) directly through the CLAS system (CHUMS Lender Access System). The lender is supposed to check a box on the Request for Insurance form (item 22 of HUD 54111) if the application is for an EEM. Or, the lender can enter this designation directly into the CHUMS system. HUD currently does not check whether the lender correctly enters this information on the form or into the CHUMS database. The system requires an answer ( $\mathrm{Y}$ or $\mathrm{N}$ ) as to whether a loan is an EEM. " $\mathrm{N}$ " is often the default answer.

An error in classifying a loan as an EEM can go either way: (1) the lender could check that the loan is an EEM when it isn't, or (2) the lender could neglect to check the box when the loan is an EEM. Inconsistency in the definition of EEM also creates a data problem.

The lending process, with its concomitant data collection, was described as follows:

1. The loan originator takes the application from the borrower.

2. The processor at the lending institution gathers materials to support the loan application (income verification, employment verification, and so on).

3. Underwriters work for lending institutions (but their offices might be in another state; central underwriting is being used by many lending institutions). Underwriters recommend the loans for approval/funding. The underwriter looks over the material (including a rating if there are 29 and 41 ratios). The EEM is added on after the borrower is qualified. There is some flexibility if there are "compensating factors," such as an income that wasn't used as effective. The rating must go to the underwriter at least 72 hours before closing.

4. The closing staff at the lending institution prepare a package for closing (e.g., deeds, HUD 1, etc.) While there is no special EEM rider, the closer has the rating information in the file and sets up the escrow account.

\footnotetext{
${ }^{8}$ Inf ormation provided by the HUD Richmond Field Office.
} 
5. The shipping staff put together the package for HUD insurance; they fill out the HUD 54111 form Unless they have been trained, these staff members would not know if the loan is an EEM. However, the underwriters' worksheets should indicate whether the loan is an EEM. The shipping staff complete and assemble the case binders to send on to HUD headquarters. The shipping staff could access CHUMS at this point and enter the data that the loan is an EEM.

6. HUD closing clerks (often contractors) take the binder and review the closing documents (deed, note, HUD 1), to make sure everything is in order. They enter data into the CHUMS database, completing the electronic entry on the loan. HUD has not yet mandated lenders to enter the mortgage data into CHUMS. Because of inconsistent definitions, new construction loans with stretch ratios may be noted as EEMs. This suggests that errors are being introduced into the CHUMS database, although no evidence exists as to the rate of errors or in which direction errors tend to occur.

7. After HUD insures the loans (the final step), a random sample is selected for technical review for quality control purposes.

A case number is assigned for all HUD-insured mortgages and a 3-digit ADP code is assigned for 203(k) loans, but not for EEMs. Most ADP codes relate to programs required by statute. Although EEMs are required under the Energy Policy Act of 1992, they have not yet been assigned an ADP code.

\section{Other Data Systems}

Virginia Power has audit/rating data, loan data, and energy consumption data in-house. Case study resources were insufficient to gather these data. No organization has kept data on the use of the 2\%income stretch mortgages for already energy efficient property, such as Energy Saver Homes.

\section{Impact on Energy Savings}

V-HERO staff members have long been concerned about the impact of energy improvements on actual energy consumption in housing and on energy costs at the household level. For six months during 1994, the organization collected data on actual cases, showing original utility cost and mBtu use for each. In addition, V-HERO calculated the percentage of Btu and cost savings. The amounts invested in the energy improvements for each case is also provided. Table 1-14 summarizes the data for this small, nonscientific sample, shown for illustrative purposes only. The cases were selected by blindly pulling 10 case files from a file drawer, one at a time, moving from front to back of an alphabetical file. 
Table 1-14. Investments in Energy Improvements and Their Impacts

\begin{tabular}{|c|c|c|c|c|c|c|c|}
\hline Case No. & $\begin{array}{c}\text { Original } \\
\text { \$/Improved }\end{array}$ & $\begin{array}{c}\text { Original } \\
\text { mBtw/ } \\
\text { Improved }\end{array}$ & \$ Saved & $\begin{array}{l}\text { mBtu } \\
\text { Saved }\end{array}$ & \% Savings & $\begin{array}{c}\text { BTU } \\
\% \text { Savings }\end{array}$ & $\begin{array}{c}\$ \\
\text { Investment }\end{array}$ \\
\hline 01 & $1421 / 771$ & $127 / 46$ & 650 & 81 & 46 & 36 & 4571 \\
\hline 02 & $1222 / 864$ & $81 / 34$ & 358 & 47 & 29 & 58 & 4000 \\
\hline 03 & $1581 / 1353$ & $116 / 95$ & 228 & 21 & 14 & 18 & 2380 \\
\hline 04 & $3277 / 1932$ & $149 / 163$ & 1345 & $\begin{array}{r}+14 \text { (fuel } \\
\text { switch to } \\
\text { gas) }\end{array}$ & 41 & -9 & 6000 \\
\hline 05 & $1527 / 874$ & $179 / 47$ & 653 & 132 & 43 & 74 & 5290 \\
\hline 06 & $1253 / 1030$ & $54 / 43$ & 223 & 9 & 18 & 17 & 2325 \\
\hline 07 & $972 / 674$ & $81 / 51$ & 298 & 30 & 31 & 37 & 3324 \\
\hline 08 & $2606 / 1354$ & $220 / 84$ & 1252 & 136 & 48 & 62 & 4200 \\
\hline 09 & $2088 / 1048$ & $161 / 94$ & 1040 & 67 & 50 & 42 & 4500 \\
\hline 10 & $1708 / 1019$ & $100 / 59$ & 689 & 41 & 40 & 41 & 3921 \\
\hline Averages & $1765 / 1092$ & $127 / 72$ & 673 & 55 & 36 & 38 & 4051 \\
\hline
\end{tabular}

Although not a scientific representation of energy and cost savings impacts, the data in Table 1-14 represent an encouraging pattern of evidence that, if broadly supported, shows that EEF products based on HERS outputs could result in positive cash flows that reduce housing operating costs. If findings like these can be credibly supported, it could potentially mitigate any existing mortgage industry concerns about increased mortgage industry risk involved in the use of EEF products.

\section{The Value of Program Evaluation}

V-HERO and N-HERO directors appreciated the value of process and impact evaluation for the long-term establishment of EEF products in the national market. The reasons they gave for evaluation's importance is as follows:

- Evaluation results assist in seeding the national effort. These results will document "lessons learned" - which tochnologies and attitudes made the programs work and which did not

- The desired outcome is to establish EEF in the marketplace; the case study and other evaluation methods demonstrate what neads to happen to reach this outcome. Market-driven principles should apply to all HERS/EEF programs and products

- Evaluations help map the road to program self-sufficiency. The federal government would like to avoid supporting these programs indefinitely

- HERS providers need to understand the messages and modes of disseminating information that will be effective in getting other important stakeholder organizations cooperatively involved

- HERS and EEF providers need to recognize who the team players are and motivate and reward them

- The Virginia program found the exercise of working on its evaluation more useful than reading reports. The process itself affected the design of their files and their new rating software. It underscored the importance of their relationship with the HUD Richmond Field Office and with DOE headquarters and caused them to develop these relationships further 
- V-HERO can use evaluation information for its future business plan

- The case study and other evaluation and customer preference reports will be critical in providing useful information to other states

- The documentation of a goal of self-sufficiency combined with a for-profit posture and a market-based approach is in contrast to a government-supported effort that pnimanily promotes goals of social equity

- The evaluation data can be used for fundraising, selling, and new product development in the future. 


\section{Future Plans and Prospects of the Virginia Program (including an Epilogue for 1996)}

V-HERO plans to increase its marketing activities during the balance of 1996 and into 1997. It plans to target three niches in particular: (1) FHA EEMs (already at 10\% market penetration); (2) Fannie Mae, and (3) nonconforming loans within the state. In addition, V-HERO plans to foster the use of energyimprovement loans to begin to penetrate the home improvement market with non-mortgage financing products.

The marketing strategy planned is to create replicable programs, human interest news stories, advertisements through the Virginia Association of Broadcasters (VAB), pay for one advertisement, arrange two public service announcements, and arrange events to draw coverage and attention toward energy efficiency financing.

V-HERO prepared a business plan for self-sufficiency by December 31, 1996. Its goal is to be financially self-sufficient by June 1997.

Following is a description, dated January 22, 1997, prepared by Christine Lowrie, Executive Director, summarizing V-HERO's 1996 progress for DOE.

The FY 1996 grant [from DOE] for V-HERO was approved on September 18, funding was requested on October $1^{\text {st }}$, the work plan was activated on October $10^{\text {th }}$, and funds were received on November $15^{\text {th }}$. Because of the delay in funding, many of the projected dates on deliverables listed on the grant proposal and projected from a July start date will be set back several months.

However, much progress was made by the program during the last quarter of 1996 (the first quarter of the funding period).

More than 175 mortgage-related Ratings were performed during that period, the greatest portion of which were HUD 203K EEMs, which seem to be totally fulfilling their promise to be the ulimate lending tool for accomplishing energy retrofit in the country.

Additionally, in September, V-HERO began processing "plan reviews" for Greenstone Industries, a new construction program which allows builders to blend the customer peace of mind of a utility guarantee program with the financing benefits attached to 5-Star housing to create the best marketing tool for EE Housing ever. To date, 87 plans have been reviewed, representing more than 1700 new 5-Star homes, currently in the "Rated on Plans" status.

The addition of new staff members have made it possible for previously unavailable databases to be created. ... We are now working at creating a database of all consumers who have utilized the program, so that we can accomplish a satisfaction survey which VHERO plans to complete as part of its 1997 work plan.

V-HERO's progress through 1996 is also documented by the following appendixes:

- Appendix 1-B. V-HERO Rating Output Form Example 
- Appendix 1-C. V-HERO Rater Checklist

- Appendix 1-D. V-HERO Promotional Piece for Real Estate Professionals

- Appendix 1-E. Consumer Brochures Used by V-HERO

- Appendix 1-F. New List of Participating Mortgage Companies, now totaling 126

- Appendix 1-G. List of V-HERO Certified Raters Active as of December 31, 1996, totaling 100

- Appendix 1-H. List of Active Raters in DC, Delaware, Maine, Maryland, and New Jersey, trained by N-HERO as of December 31, 1996

- Appendix 1-I. List of Virginia Utilities Exhibiting the Potential for Future Partnerships 


\section{Conclusions}

V-HERO believes that the following are critical components of program success in linking home energy ratings with energy efficient financing, both in Virginia and in the nation.

- Accepted industry standards for performance of rating systems

- Financial feasibility of the rating organization as a self-sustaining organization

- Training and certification of raters, including inspection certification, and training of those contractors in construction and retrofit

- Participating in cooperative programs with utility companies

- Recruiting and ecucating lenders

- Forging alliances with appraisers and real estate professionals

- Developing new financing products as incentives

- Developing incentives for home builders

- Continuous evaluation, feedback, and ongoing quality improvement

- Increasing market penetration.

The market-driven approach coupled with an aggressive outreach and major network television advertising resulted in positive leaps forward in the Virginia program in terms of consumer response and percentage increases in ratings.

The in-person participation of DOE's Assistant Secretary for Energy Efficiency and Renewable Energy and of the Deputy Assistant Secretary for the Office of Building Technologies (now the Office of Building Technologies and Community Systems) in significant media events with V-HERO executives provided panache and greater program credibility than elsewhere in the country. 


\section{Appendixes}




\section{Appendix 1-A. Virginia Process Evaluation Data}

\section{Part 1. Organization Contacts and Descriptions}

\section{Virginia Home Energy Rating Organization, Inc. (V-HERO)}

Key contact: Chris Lowrie, Executive Director

Type of organization: Nonprofit, 501(c)(6)

Address: 804 Moorefield Park Drive, Ste. 101 Richmond, VA 23235

Phone: (804) 560-9134

Fax: (804) 560-9139

Date formed: July 1992

Number of staff: 1 full-time staff/ 1 contractor

Type of staff:

Executive director: Directs activities of V-HERO, public outreach, marketing, and public relations, negotiates for new finance products

Director of National Development (contract staff) supports new HERS program implementation, provides technical assistance to states interested in the development of home energy ratings systems, oversees development of National HERO

Staff support totally clerical

Mission:

Coordinate the training and certification of home energy raters, encourage energy efficiency, and provide home energy rating reports and services to Virginia consumers to provide for affordable housing and reduced harmful emissions

\section{Home Energy Ratings/Residential Energy-Efficiency Services and Education}

Program head: Chris Lowrie

Date formed: Incorporated July 1992

(Operational September 1992)

Formative sponsor(s) Virginia Division of Energy

Program sponsor(s) and funding:

- Virginia Association of Realtors (VAR) [ability to use their facilities for training] 
- Virginia Power ( $\$ 5000$ plus $\$ 35,000$ for quality assurance/certification of new construction programs)

- Appalachian Power Corporation (APCO) (\$5K)

- Virginia Electric Energy Council (VEEC) (in kind) annual meeting space plus accommodations for 75-100 people for state annual meeting ( $\$ 3000$ in-kind)

- Solar Energy Industries Association (SEIA) (\$500)

- U.S. Department of Energy (DOE) (\$164,000 in FY 1995)

Program functions:

V-HERO has ten functions

(1) Provide home energy ratings on new and existing homes in Virginia

(2) Recruit and schedule training for new raters

(3) Provide marketing and outreach services for the FHA FiveState EEMs Pilot program in Virginia

(4) Serve as central administrator for DOE regional technical assistance network of 25 states

(5) Create and have the means to monitor greater name recognition for home energy rating and energy efficiency loan products

(6) Facilitate energy-efficiency improvements on homes

(7) Create a broad, smoothly functioning infrastructure to accomplish these improvements

(8) Work with the other pilot states to evolve a uniform program in the marketplace, to include a common rating method, common forms, and quality control

(9) Form partnerships with the Virginia Association of Realtors and Appraisers to develop a system of listing property energy ratings on the Multiple Listing Service (MLS)

(10) Achieve self-sufficiency

V-HERO annual budget:

- Total of $\$ 300,000$ in PVE funds over two years from the Virginia State Energy Office (last payment in July 1994)

- No more PVE dollars after July 1994

- Foundation grants and corporate contributions for special projects

- V-HERO, Inc., receives some income from membership dues (as of 12/31/95 there were 61 members who provide a total of $\$ 30,000$ in dues) and pay $\$ 35$ for each rating processed (approximately $\$ 10,500$ per year)

- $\$ 164,000$ in FY 1995 from DOE; approximately $\$ 30,000$ in certificate fees from utilities for a quality assurance and certification program as of 1995 . They certify the utility's Energy Saver Home and Energy Saver Plus Programs which meet V-HERO's 4- and 5-star levels

- V-HERO supplies certificates and pays raters to do post-tests on Energy Saver Plus Homes. 
Other partnerships:

- Appalachian Power Company

- Appraisal Institute

- Commonwealth Gas Company

- Environmental Financial Services

- Escrow Management Development Corporation

- Federal Reserve Board

- Homebuilders Association of Virginia

- HUD

- VA Dept. of Mines, Minerals and Energy

- Virginia Association of Mortgage Bankers

- Virginia Housing Development Authority

- Virginia Power Company

- Volt VIEWtech

- Virginia Housing and the Environment Network (VAHEN)

Geographic coverage:

State of Virginia. V-HERO staff have focused on the Tidewater (40\% are FHA loans), Northern Virginia, and Richmond regions (the Golden Crescent area). Marketing in Western areas is now active. Assistance with developing Home Energy Rating Organizations (HEROs) has been provided in 24 states and the District of Columbia ${ }^{9}$

\section{U.S. Department of Housing and Urban Development (HUD) - Richmond Field Office}

Key contact:..................................... Virginia Holman

Type of organization: ...................... Federal agency (Field Office)

Address: ....................................... Mortgage Credit Branch

HUD

3600 West Broad Street

Richmond, VA 23230

Phone:

(804) $278-4546$

Fax:.

(804) $278-4516$

Number of staff: 8 full-time staff

${ }^{9} \mathrm{DE}, \mathrm{FL}, \mathrm{GA}, \mathrm{IA}, \mathrm{II}, \mathrm{KS}, \mathrm{KY}, \mathrm{MA}, \mathrm{MD}, \mathrm{ME}, \mathrm{MN}, \mathrm{MO}, \mathrm{NC}, \mathrm{NH}, \mathrm{NJ}, \mathrm{NY}, \mathrm{OH}, \mathrm{OK}, \mathrm{PA}, \mathrm{TN}, \mathrm{WI}, \mathrm{WV}, \mathrm{VA}$, WY, and DC. Levels of assistance vary from a few calls to provision of whole packages. Technical assistance has been both proactive and reactive; some states might not ask for help. 


\section{Part 2. Recordkeeping and Data Collection}

Forms used:

- V-HERO rater data sheet and lending information sheet

- Examinations and evaluations on rater trainees

Organization(s) with responsibility

for collecting and storing data ........ V-HERO; HUD through its CHUMS database

Method for storing data:................. Computer database and hard copy (cannot access computer data once they have been stored). Data are archived in ERHA's database. New software, Rateview, allows access to database and can be programmed to sort for correlations.

Number of ratings completed.......... 7,635

Number of EEMs in system: .......... 275 as of May 1, 1995

Number of EEMs completed: ......... • 137 (as of Sept. 1995)

- 50 (Fannie Mae and Freddie Mac)

- 50 V.A.

- 25 HUD 203Ks

- 3,272 on Energy Saver Homes (new)

Data for CY 1996:

- 3,500 Energy Saver Homes

- 500 FHA EEMs

- 25 Fannie Mae

- 100 Buyer's Choice

- 50 DVA

- 100 H.E.L.P. 2000

EEM tracking method:

When rating inspection sheets are returned to the V-HERO office, full files are developed. V-HERO staff do not actually know if the loan is closed, until a post-test is conducted.

Are there EEM case numbers? ....... Yes

Assignment method: Tracking numbers are assigned during input. They include state, date, and rater certification number.

Number of other loans for energy

improvements: See data above. Approximately 300 ratings have been done without loans being completed.

Any description of these loans:....... Utility loans, signature, and collateralized loans

Any state or local

reporting requirements: No 
Any federal reporting

requirements

A-133 Audit, reports to Deputy Assistant Secretary, Office of Building Technologies and State programs, DOE; DOE Region 3 contracting office; NREL

Software used for ratings:

Originally, the program used ERHA software. As of May 1, 1995, V-HERO changed to Rateview software, which was developed by Volt VIEWtech and V-HERO.

Number of energy-improved

homes:

7,372 as of July 1995

Projected in 1995-1996:

Utility programs $13,000^{10}$

Loans $\quad 500$

Average dollar value of energy

improvements:

HUD/VA/Fannie Mae $\$ 5,000$ (est.)

Utility

$\$ 7,000$ (est.)

${ }^{10}$ Virginia Power stopped processing Energy Saver Homes for new construction as of July 31, 1996 because the new building code in Virginia reached the utility's 4-star level. All homes built after that date would have been "energy improved." 


\section{Part 3. Training}

\section{Rater Training}

Organizations and individuals

sponsoring/conducting training....... V-HERO sponsors and monitors all training; administers examinations; and its board of directors reviews and certifies all candidates. Energy Conservation, Inc.; Energy Pro!; Lori Marsh; and James Flippen.

Number trained: 80

Date(s) of training: December 15-18, 1992

February 25-28, 1993

April 26-28, 1993

August 16-18, 1993

April 25-27, 1994

May 2-4, 1994

July 18-19, 1994

September, 1994

April 3-5, 1995

June 5-7, 1995

June 28-30, 1995

July $10-12,1995$

Sept. $10-12,1995$

Length of Training: 3 days

Number of certified raters: 78 (as of December 31, 1995)

Additional training plans: Training is ongoing

Method of marketing: Through authorized trainers, and through V-HERO program staff. Two new trainers were approved during 1995.

\section{Lender Training}

Organizations sponsoring/

conducting training: HUD and V-HERO

Number trained: Approximately 500 loan officers and underwriters in total during 1993 through $1995^{11}$

\footnotetext{
${ }^{11}$ 203(k) EEM training was initiated in 1996; 24 were trained in January, 80 in April and 80 in May.
} 
Date(s) of training:

Length of training:

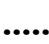

August 25, 1993

September 25, 1993

December 15, 1993

February 15, 1994

and each month following

2 hours (August 1993)

1 hour (December 1993 and February 1994)

Additional training plans:

Method of marketing:.
2 EEMs training sessions were held by HUD in Washington, DC. (Trainers were unfamiliar with EEM products). Virginia Holman has traveled through Virginia speaking at Virginia Association of Mortgage Bankers meetings to expose lenders to the EEMs product.

Direct mail to 1300 FHA-approved underwriters in Virginia (35\% $-40 \%$ returned because the addresses were incorrect.)

Sue Bauman, mortgage loan officer and V-HERO Director conducted one-on-one training with loan officers and underwriters throughout the state in 1995 . She trained approximately 200 loan officers and underwriters in 15 offices in 1995.

\section{Real Estate Professional Training:}

Organization sponsoring/

conducting training:

Number trained:

Date(s) of training:

Length of training:

Additional training plans:

:.......... .. Through Virginia Association of REALTORS ${ }^{\otimes}$ (VAR), through state evaluation and data entry requirements for continuing education through direct contact with local association executive officers.

Method of marketing: V-HERO makes telephone contact with senior members of real estate firms and executive officers of local associations.

\section{Appraiser Training:}

Organization sponsoring/

conducting training: V-HERO 
Number trained:

20 by December 31, 1995

Date(s) of training:

August 28, 29th; September 6, 1995

Length of training: 2 hours

Additional training plans: V-HERO worked with the VAR to develop a continuing education course for appraisers

Method of marketing:

- Through VAR newsletter

- Direct marketing of the Fannie Mae pilot program through referrals of participating lenders

Lenders trained for

Fannie Mae pilot program

- Central Fidelity, 13200 Hull Street Road, Midlothian

- Central Virginia Bank, Market Square, Midlothian

- County Bank of Chesterfield, Hull Street Road

- Crestar, 13001 Hull Street Road, Midlothian

- Fidelity Federal, Harbour Pointe Village Shopping Center, Midlothian

- First Jefferson, Norfolk

- Inland Mortgage

- Mid Atlantic Financial Group, Courthouse Road, Richmond

- Nationsbank, 13500 Harbour Parkway, Midlothian

- Norwest Mortgage, Midlothian Turnpike, Midlothian

- Resource Mortgage, Cox Road, Innsbrook

- Ryland Mortgage, Midlothian

- Signet Bank, Brandermill, Market Square, Midlothian

- Virginia Federal, 10710 Midlothian Tumpike

- Virginia First, Huguenot Road, Richmond

\section{Builder/Contractor Training:}

Organization sponsoring/

conducting training:

D\&R International, Ltd.

Number trained:

V-HERO has assisted builders associations in training more than 200 builders in Virginia

Date(s) of training:

National Association of Home Builders trains Virginia builders in energy efficient construction

Length of training:

One-on-one/hands on/in their own construction

Additional training plans:

V-HERO worked with Dick Covert (Executive Director of Home Builders Association of Virginia-HBAV) to develop programs

Method of marketing: Through HBAV

Length of training: 3 days 


\section{Marketing}

Types of marketing used: ............... (1) Articles in newspapers and trade publications

(2) Public speaking engagements at trade meetings

(3) Direct mail

(4) Letters and brochures to lenders and real estate professionals

(5) Direct ads in real estate rack brochures produced 100 times the response of all other methods

(6) Television advertising campaign on CBS network affiliate, March - July, 1995

Since the program's inception, V-HERO, Inc., staff have addressed approximately 7,000 real estate professionals through speaking engagements at the monthly meetings of local real estate associations or real estate offices, state real estate conventions, and through articles in association publications. V-HERO, Inc., staff have been in touch with 30 of the State's 33 local real estate boards. In addition, the staff trains and has been in contact with lenders through phone conversations and numerous mass mailings on HERS and EEMs. If funding is available, V-HERO, Inc., staff would like to hold an informational open house on HERS and EEMs at a local hotel to which all lenders would be invited.

Marketing strategy:

(1) Target marketing efforts on real estate professionals

(2) Strong effort in lender education

(3) Network actively with representatives from different housing agencies, organizations, and others to develop links with utilities

(4) Educate elementary school children about energy efficiency

(5) Use earned media to market program

(6) Secure funds for media

(7) Direct training programs, one-on-one with loan officers and underwriters. 


\section{Part 4. Implementation}

\section{Significant obstacles to program implementation:}

- Inadequate financing for V-HERO, Inc., marketing and education activities in the past (for example, paying for advertising space in newspapers and trade publications, developing and printing more materials on the program). Utilities have been generous in their support (for example underwriting the costs of printing a new brochure on EEMs) but V-HERO, Inc., staff do not want to exhaust this resource.

- Small staff size has limited what V-HERO, Inc., can accomplish. There are only 1.5 FTE to do personal appearances and training.

- The FHA EEM cap on maximum allowable improvement costs is too low and will not support HVAC system replacement costs. 203(k) has improved this.

- Lenders have been misinforming customers about home energy ratings (e.g., that EEMs slow down closings and affect loan approval decisions) to dissuade customers from pursuing EEMs. Although this still happens, it is not as frequent.

- FHA is a low percentage (4\%) of overall state mortgage lending

\section{Problems resolved:}

Some real estate professionals and lenders who recalled difficulties with previous EEMs products (for example, they are difficult to document, hard to process, and will increase paperwork) have been resistant to FHA EEMs. Through intensive outreach efforts to these groups, V-HERO, Inc., staff have been able to dispel many of these concerns. Also, V-HERO sent a Board of Directors member to lender offices to train lenders. These lenders have become repeat customers. V-HERO has found that in-office training is particularly effective for lenders.

\section{Most successful aspects of the program:}

Program staff have been most successful in marketing V-HERO, Inc., ratings in conjunction with FHA EEMs and Virginia Power Company loans. Since staff began marketing V-HERO ratings and EEMs together, consumer demand for ratings has increased significantly. Builder incentive packages, including utility cost guarantees, have increased appraised value (Fannie Mae) and been very successful. The VHERO ad campaign has also been quite successful.

\section{Six-month milestones:}

(Immediate organizational survival; begin national marketing campaign to ease the difficulty of state efforts.)

\section{Long-term goals:}

- Work with Fannie Mae, Freddie Mac, DVA, Farmers Home Administration and others to develop concrete EEMs products for mortgagors at all income levels. 
- Work on effective energy efficiency loans, branded loan, unsecured loans

- Increase the energy efficiency of 30,000 homes in Virginia. 


\section{Appendix 1-B. V-HERO Rating Output Form Example}




\section{HOME ENERGY RATING REPORT}

April 24, 1996

Dan Early

5408 Lucas Road

Richmond, VA 23228

Dear Mr. Early:

Re: Home Energy Rating for

5408 Lucas Road, Richmond, VA 23228

We are pleased to inform you that an Energy Rating for the home located at the above address has been completed.

The enclosed package contains the following information:

$\square$ Home Energy Rating Certificate, showing the Energy Rating based on the current energy features of the home.

$\square$ Existing Conditions Summary, which describes the key energy and construction features of the home used in the calculation of the Rating. An energy consumption and cost profile of the home is also included.

$\nabla$ Recommended Improvements, measures that can improve comfort and reduce utility costs, with estimated savings, implementation costs, payback and useful life, along with the effect the measures would have on the Rating. V-HERO recommends that you obtain bids and references from more than one source when selecting your contractor. Remember, all improvements must be accomplished for escrow to be released.

$\square$ Energy Efficiency Mortgage Calculation, an analysis used by a lender to qualify the property for an Energy Efficiency Mortgage loan, and which illustrates the total savings that you may experience over the cost-effective life of the improvements.

$\checkmark$ Notes on the Home Energy Rating System and the Rating Scale.

If you have any questions, please don't hesitate to contact me.

Sincerely,

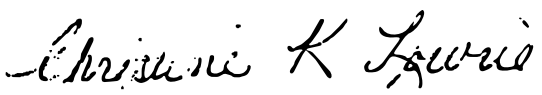

for VHERO

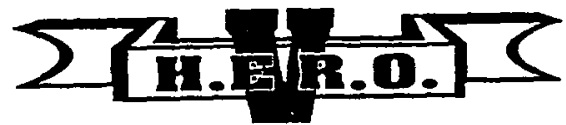




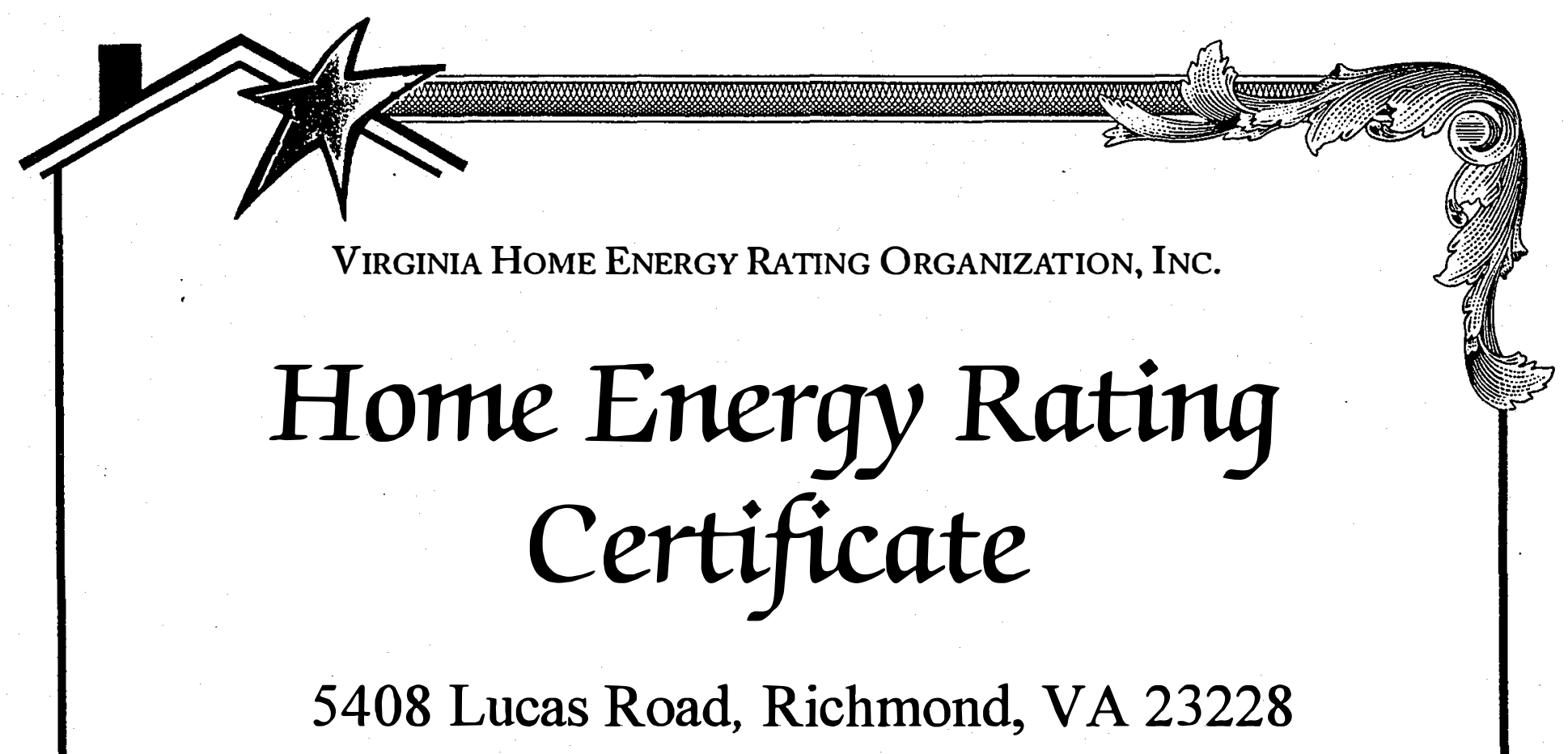

\section{has achieved 62 points on the 0-100 scale, equivalent to an Energy Rating of

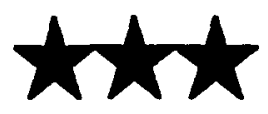

Rating Organization

Rating performed by Rater ID number Rating Date Certificate Issue Date
VHERO

Gary Treaster 93001

April 10, 1996

April 24, 1996

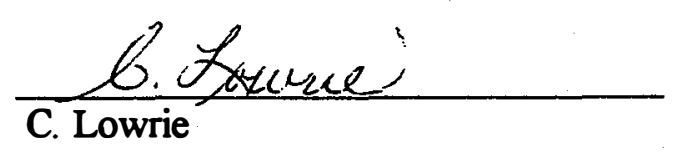




\section{Existing Home Energy Rating $62 \star \star \star \star t$}

\section{Existing Conditions}

\section{Envelope Characteristics}

This is a one story home with $868 \mathrm{ft}^{2}$ of conditioned floor area. Insulation levels: Floor $=\mathrm{R}-0$ to 11 , Walls $=\mathrm{R}-0$, Ceiling/Roof $=\mathrm{R}-15$. Windows are single glazed. The home has an overall infiltration of 1.08 air changes per hour, as determined by an on-site "blower-door" test.

\section{Space Heating, Cooling \& Domestic Water Heating Systems}

The space heating system consists of an oil central hot water boiler furnace and the cooling system consists of an electric window / wall unit. The space conditioning system is controlled by a manual thermostat. The domestic water heating system consists of a 50 gallon other water heater.

$\begin{array}{lll}\text { Energy Source } & & \text { Utility } \\ \text { Electric: } & & \text { Virginia Power } \\ \text { Natural Gas: } & & \text { None } \\ \text { Other Fuels: } & \text { oil }\end{array}$

\section{Estimated Annual Energy Use \& Costs}

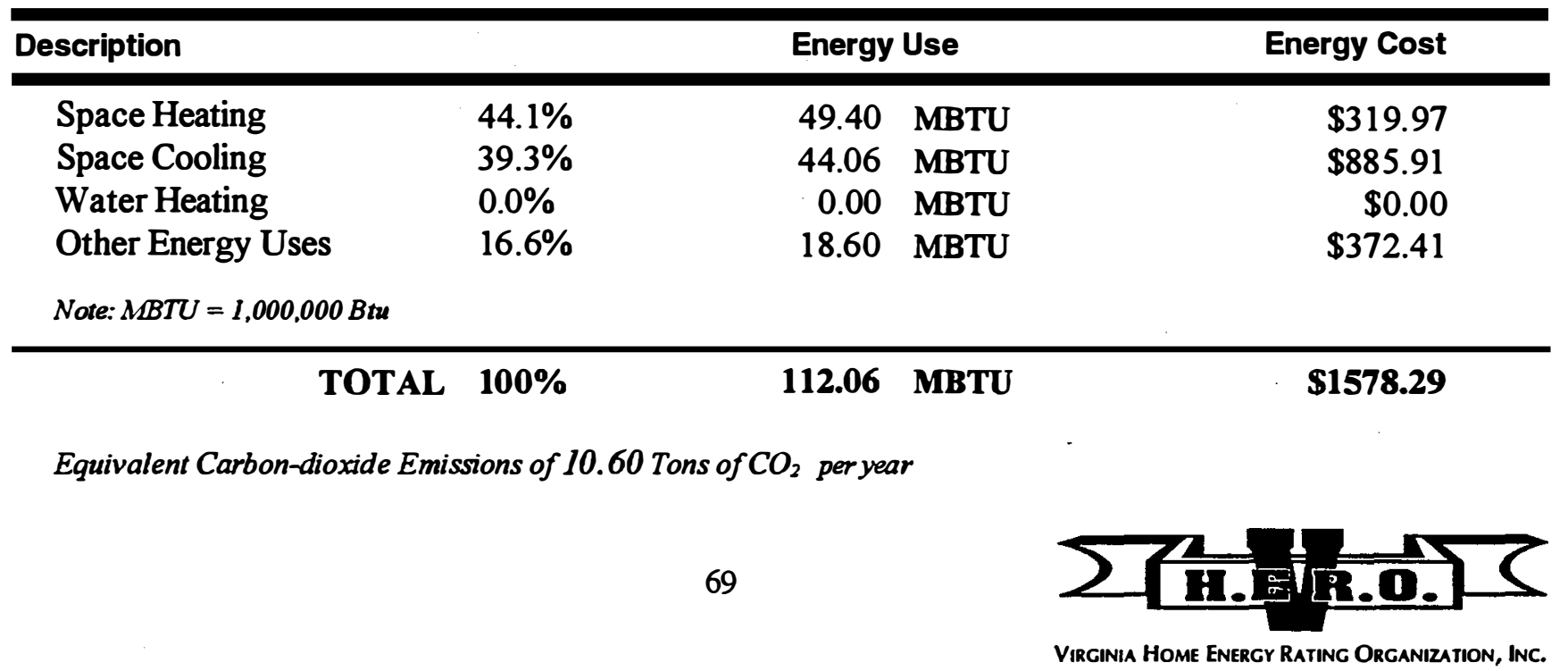




\section{IMPROVEd ENERGy Rating $85 \star \star \star \star \star$}

\section{RECOMMENDED IMPROVEMENTS}

\section{Envelope Characteristics}

This is a one story home with $868 \mathrm{ft}^{2}$ of conditioned floor area. Insulation levels: Floor $=\mathrm{R}-19$, Walls $=\mathrm{R}-0$, Ceiling/Roof $=\mathrm{R}-30$. Windows are single glazed. The home has an overall infiltration of 0.50 air changes per hour, as determined by an on-site "blower-door" test.

\section{Space Heating, Cooling \& Domestic Water Heating Systems}

The space heating system consists of an oil central hot water boiler furnace and the cooling system consists of an electric central air unit. The space conditioning system is controlled by a manual thermostat. The domestic water heating system consists of a 50 gallon other water heater.

\begin{tabular}{|c|c|c|c|c|}
\hline MEASIJRE & Immal Sin inge: & lypicial cinsl & $\begin{array}{c}\text { Simple l'ablach } \\
\text { INs) }\end{array}$ & l'still I ili!̣! \\
\hline Install heat pump & $\$ 814.00$ & $\$ 1280.00$ & 1.57 & 15.00 \\
\hline Install plastic storm windows & $\$ 59.00$ & $\$ 113.00$ & 1.90 & 30.00 \\
\hline Install crawl space insulation (R-19) & $\$ 14.00$ & $\$ 270.00$ & 19.28 & 30.00 \\
\hline Caulk ceiling/doors/floors/walls/windows & $\$ 205.00$ & $\$ 958.00$ & 4.67 & 30.00 \\
\hline Weatherstrip attic access/doors/windows & $\$ 35.00$ & $\$ 246.00$ & 7.03 & 30.00 \\
\hline Insulate heating pipes ( $1^{\text {" Fiberglass Wrap) }}$ & $\$ 1.00$ & $\$ 18.00$ & 18.20 & 30.00 \\
\hline Install ceiling insulation ( $R-15)$ & $\$ 25.00$ & $\$ 1115.00$ & 44.6 & 30.00 \\
\hline Evaluated as package & $\$ 1153.00$ & $\$ 4000.00$ & & - \\
\hline
\end{tabular}

This package of measures has the following effect on estimated annual energy costs and Energy Raling.

\begin{tabular}{llrlr}
\hline Description & & \multicolumn{2}{c}{ Energy Use } & Energy Cost \\
\hline Space Heating & $50.1 \%$ & 21.75 & MBTU & $\$ 140.85$ \\
Space Cooling & $7.1 \%$ & 3.07 & MBTU & $\$ 59.54$ \\
Water Heating & $0.0 \%$ & 0.00 & MBTU & $\$ 0.00$ \\
Other Energy Uses & $42.8 \%$ & 18.60 & MBTU & $\$ 367.97$
\end{tabular}

Note: $M B T U=1,000,000 \mathrm{Btu}$

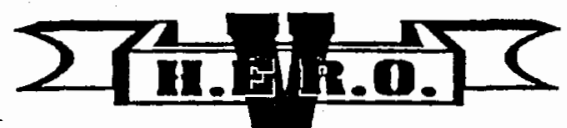

Virginia Home Energy Rating Organization, inc. 


\section{Energy Efficiency Mortgage Calculation}

If the borrower is an acceptable credit risk for the mortgage amount requested before adding the cost of the energy efficiency items, complete the worksheet below to determine if the cost of the energy efficiency improvements may be added to the mortgage amount.

1. Mortgage Interest Rate

2. Expected Useful Life

3. Present Value Factor (from chart)

4. Expected Monthly savings

5. Expected Yearly Savings

a. Minus Expected Yearly Maintenance

b. Equals Net Yearly Savings
$8.500 \%$

30.00

10.747

$\$ 84.16$

$\$ 1009.93$

$\$ 0.00$

$\$ 1009.93$

6. EE Premium $=($ Net Yearty Savings $) X($ Present Vahue Factor $)=$ Present Worth of Estimated Savings

$$
(\$ 1009.93) \times(10.747)=\$ 10853.71 \mathrm{EE}
$$

7. Installed Cost

$\$ 4000.00$

\section{COMPARE EE-PREMUM TO INSTALLED COSTS}

8. IfEE Premium (Line 6) is less than Installed Cost (Line 7), the energy efficient items may not be financed into the mortgage.

If EE Premium (from Line 6) exceeds Installed Cost (Line 7), answer the following questions to determine the amount that may be added to the mortgage amount:

Does Installed Cost (Line 7) exceed \$4,000? If NO, show Installed Cost (Line 7) here $\$ \quad$ and add to base mortgage amount. If YES (Installed Cost exceeds \$4,000), does Installed Cost exceed 5 percent of the appraised value of the property? If $N O$, show the lesser of $\$ 8,000$ or the Installed Cost (Line 7) here \$ amount. If YES (Installed Cost exceeds 5 percent of appraised value), show the lesser of $\$ 8,000$ or 5 percent of the appraised value here $\$$ amount. and add to the base mortgage

The amount calculated above is the maximum amount that may be added to the mortgage previously calculated on Line 14g of the HUD-92900-WS, Mortgage Credit Analysis Worksheet. Line 6a, 6b, and $6 c$ of the analysis worksheet will reflect the addition of the EE premium in the new mortgage amount. Be certain to identify in the "Remarks" section of the worksheet why the final mortgage exceeds the Line $14 \mathrm{~g}$ and also show the revised loan to value ratio and borrower qualifying ratios for the higher mortgage amount. A copy of this Attachment B must be attached to the worksheet. The up-front MIP must be calculated on the mortgage amount including the energy efficient improvements.

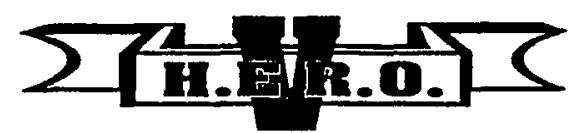




\section{Rating System Methodology}

To deternine the rating, two estimates of annual purchased energy consumed for heating, cooling, and domestic hot water are made: an estimate of the energy usage of the rated home built (or proposed), and an estimate of the energy usage of the rated home, if it were re-configured to exclude and/or include specific energy efficiency features - reference home. For ratings to identify energy efficiency improvements, an additional estimate must be made of the rated home, re-configured to include the proposed energy-efficient measures.

Comparison of these estimates will yield the energy efficiency rating of the home and/or the home with the proposed conservation measures installed. The energy efficient reference home (EERH) is assumed to score 80 points on a 0 to 100 point scale. A rated home with the same annual purchased energy as its associated with the reference home would also score 80 points.

Every 0.05 decrease in the ratio (from 1:1) of the rated home's total purchased energy use to the reference home's total purchased energy use will increase the rated home's score by 1 point. Similarly, an increase of 0.05 in the ratio will decrease the rated home's score by 1 point (see Table 5 herein). The reference home represents a fixed rating point that shall not change over time. A home's rating is valid until modifications have been made to the home which affect its energy efficiency.

Table 5. Score and Star Scales for Rated Homes

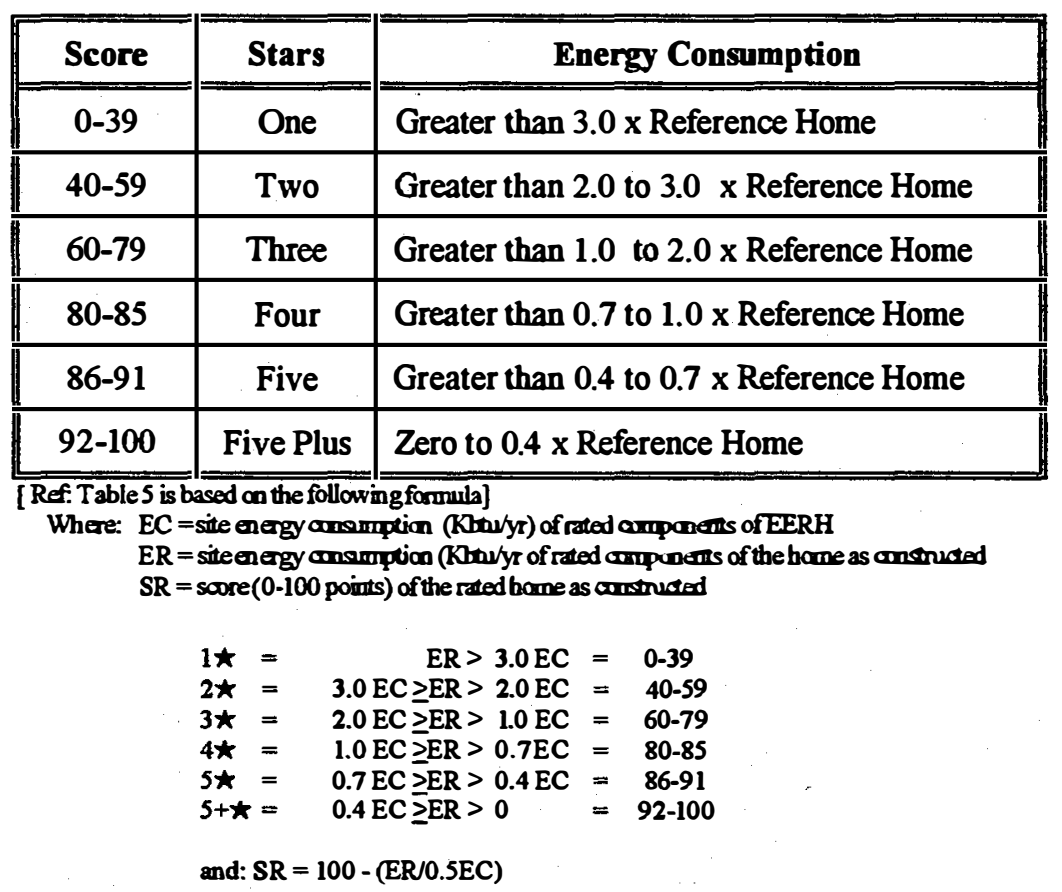


Appendix 1-C. V-HERO Rater Checklist 


\section{Vingin.1.18.0.5}

Customer Information

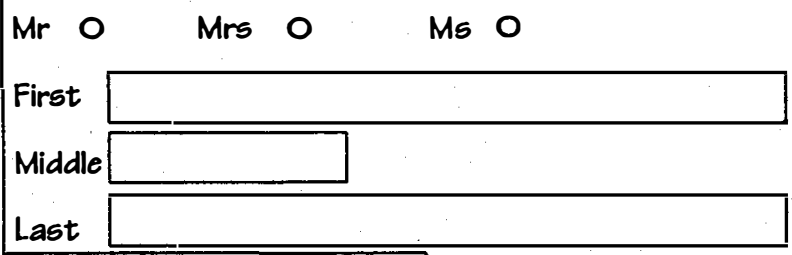

Rated Home Address

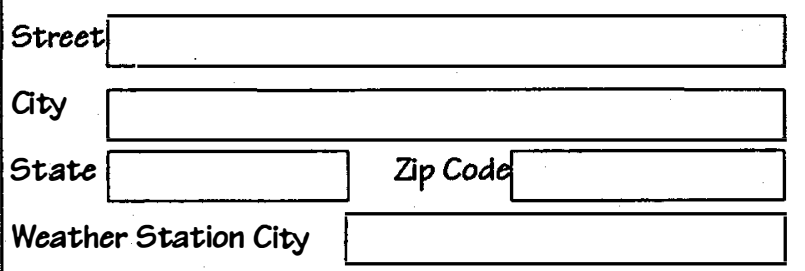

Mailling Address
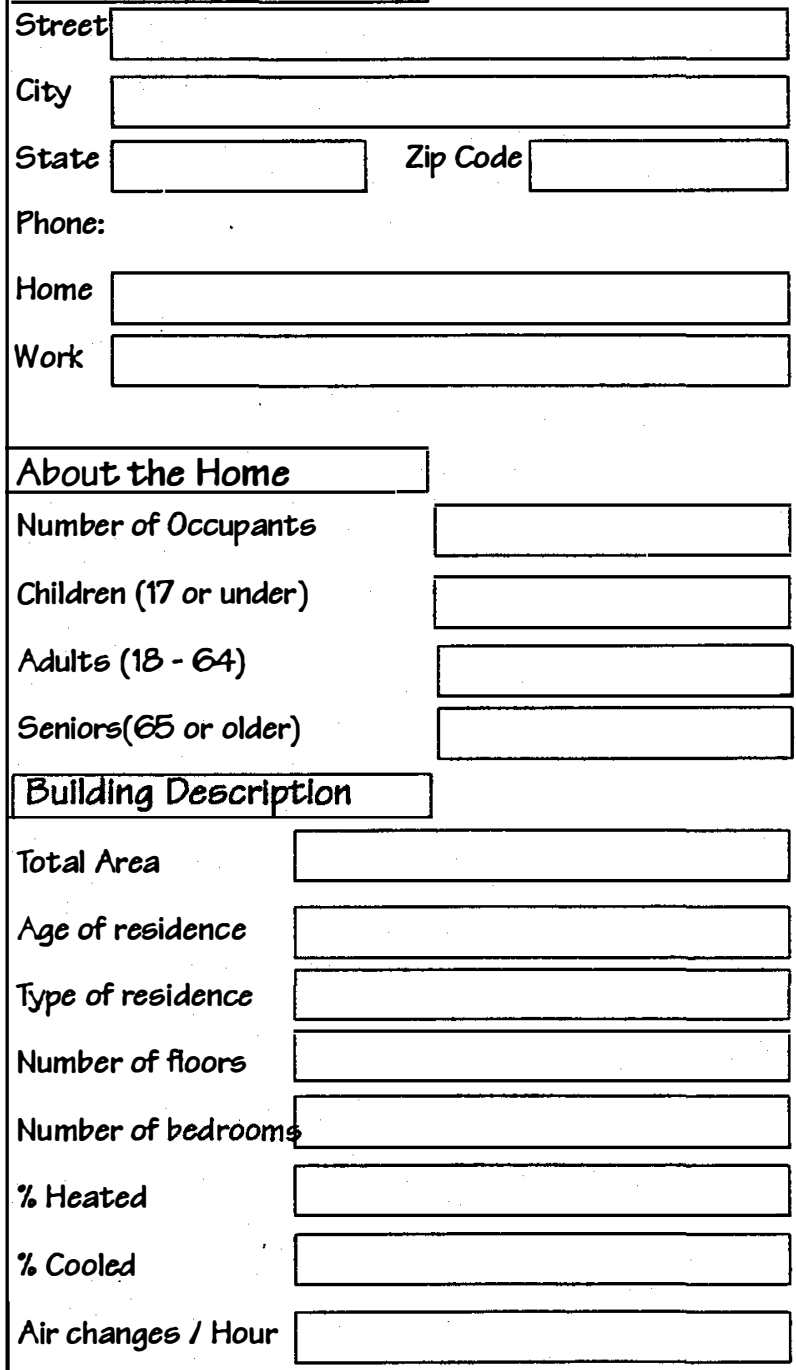

Rater Checklist

\begin{tabular}{l} 
Mortgage / Loan Info \\
Lender \\
Loan Officer \\
Phone \\
Type of loan \\
Interest Rate \\
Loan Amount \\
Appliances \\
Number in the Home: \\
Ceiling Fan \\
Dishwasher \\
Dryer - Electric \\
Dryer - Gas \\
Microwave Oven \\
Pool Pump \\
Range/Oven - Electric \\
Range/Oven - Gas w/Pilot \\
Range/Oven - Gas w/o Pilot \\
Refrigerator \\
Washer - Clothes \\
\hline
\end{tabular}




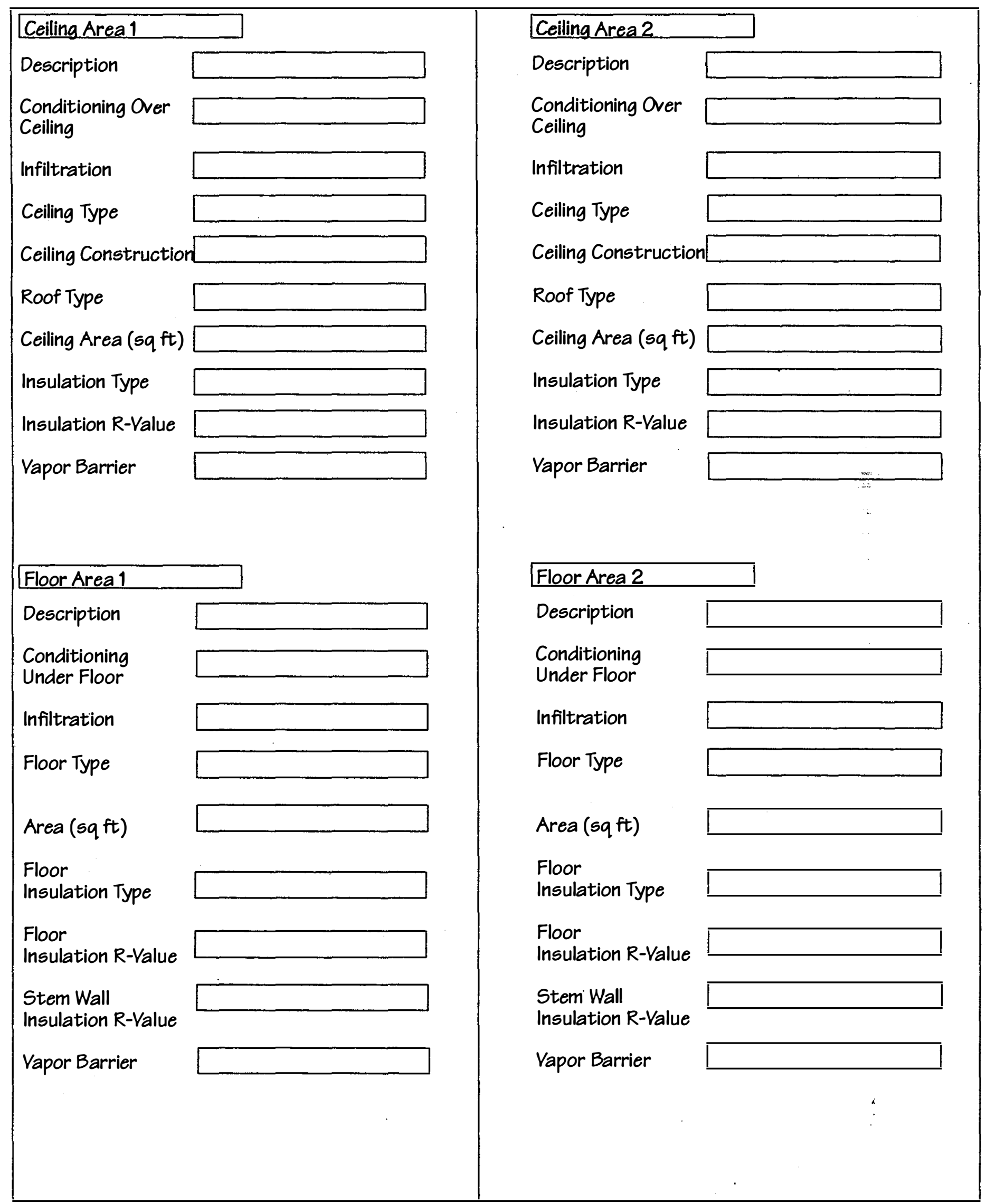




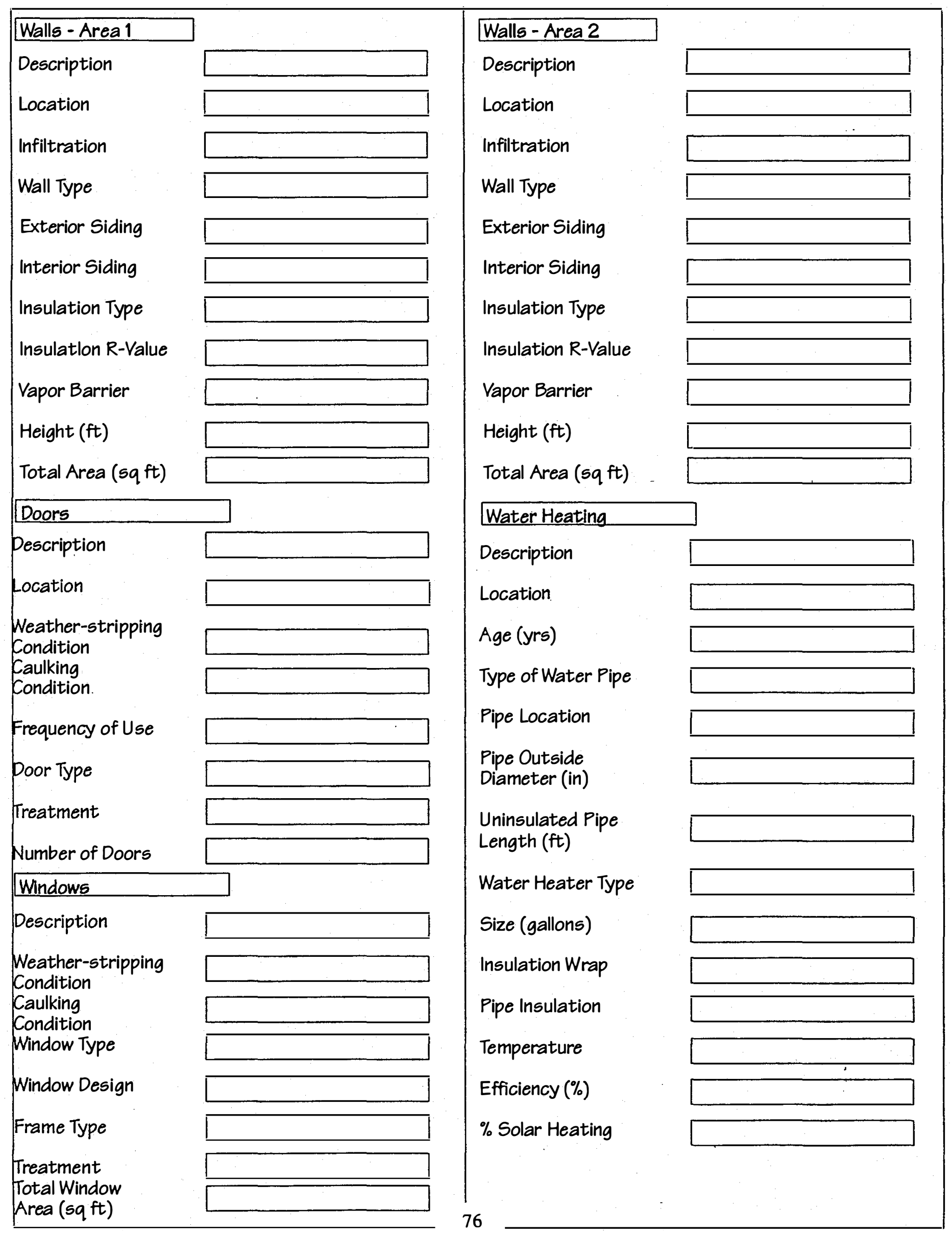




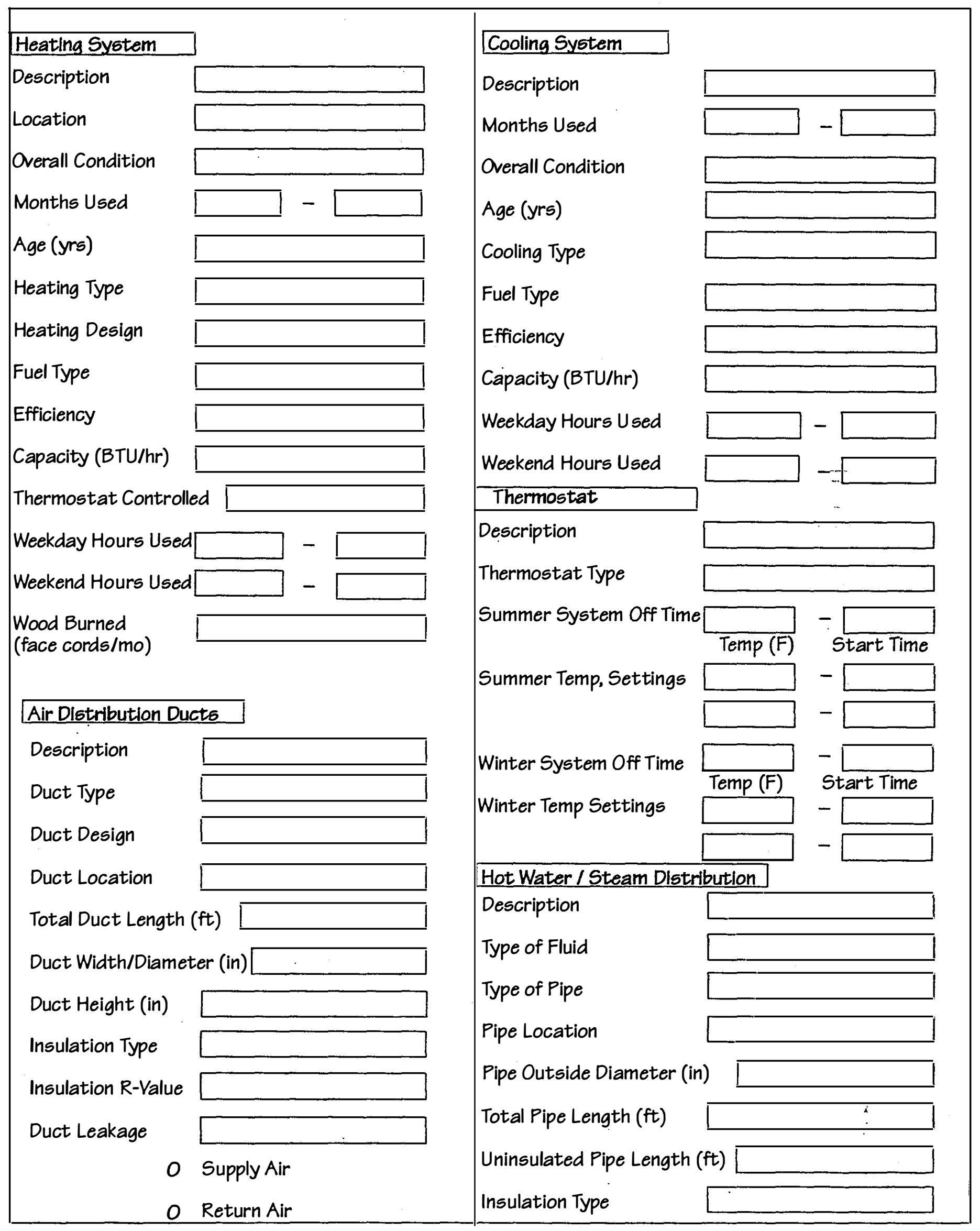




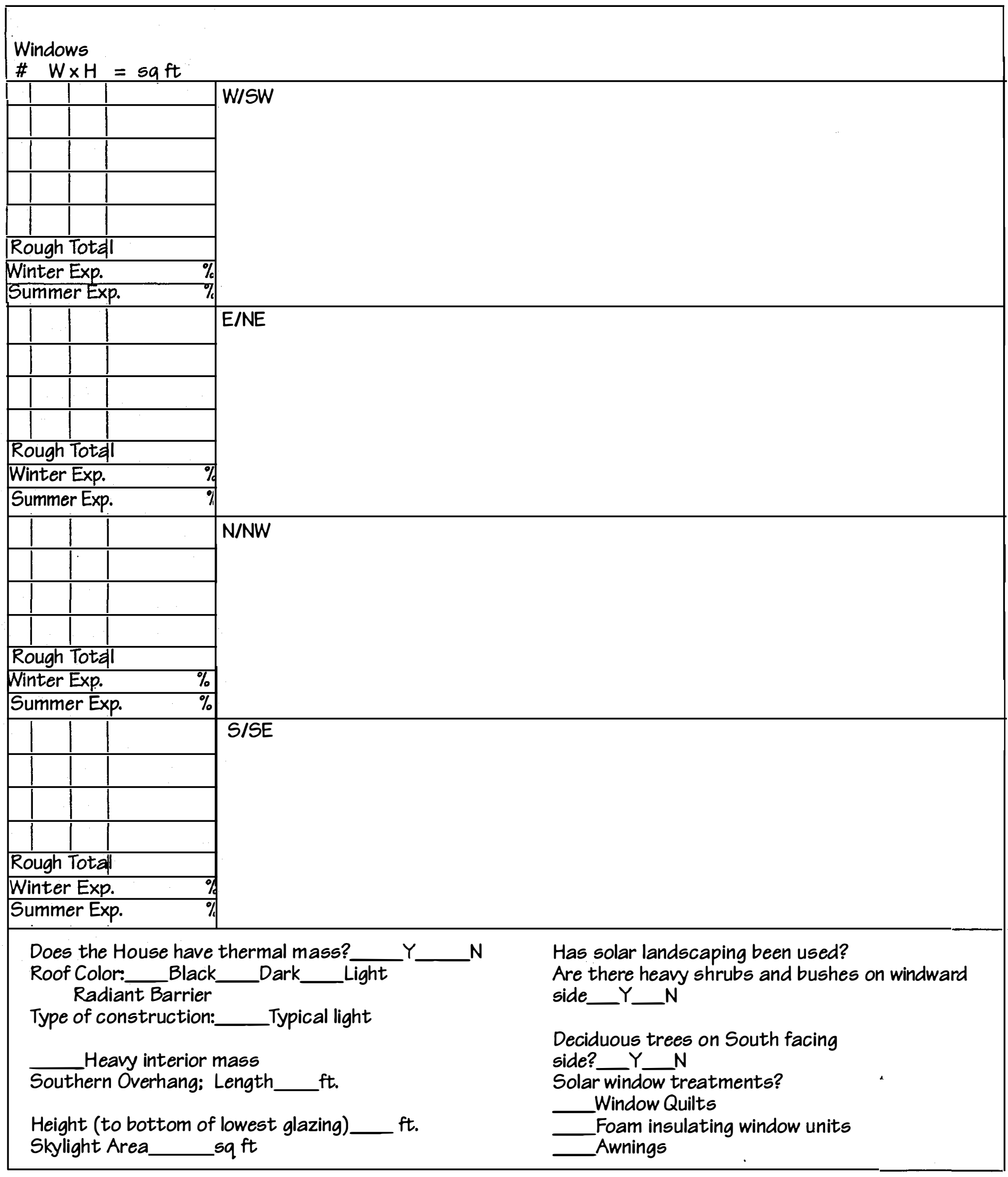




\section{HOUSE FOOTPRINT}

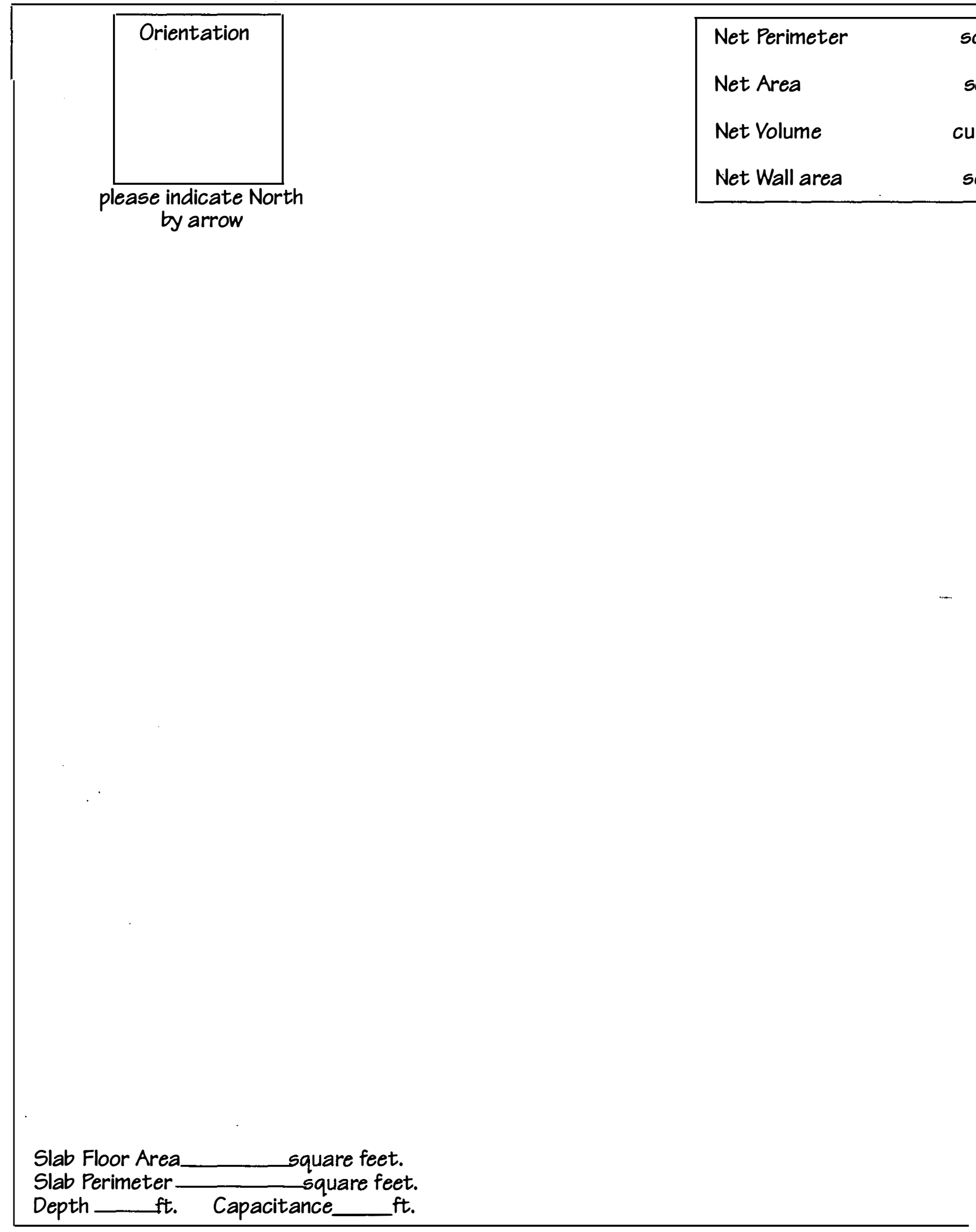

General Comments; 


\section{Wrap Up Page}

List characteristics of home which would make improving energy efficiency level unusually difficult

(e.g., floored or inaccessible attics, lath walls, etc.)

Utilities

Electric

Gas

I give my permission for the representative of the Home Energy Rating Organization to receive information from my utility companies regarding the energy consumption of my residence.

Utility Utility

Account \#

Account \#

House Address

City State ZIP

Date

\section{RATER ATTESTATION}

"I certify, that to the best of my knowledge and belief, the information contained in this report is true and accurate and I understand that the information in this report may be used in connection with an application for an energy efficiency mortgage to be insured by the Federal Housing Administration of the United States Department of Housing and Urban Development or to be purchased by other governmental or quasi governmental agencies of the U.S."

Rater Signature

Date of Inspection

Rater Certification Number 


\section{Appendix 1-D. V-HERO Promotional Piece for Real Estate Professionals}




\section{Turn this...}

\section{Into this...}
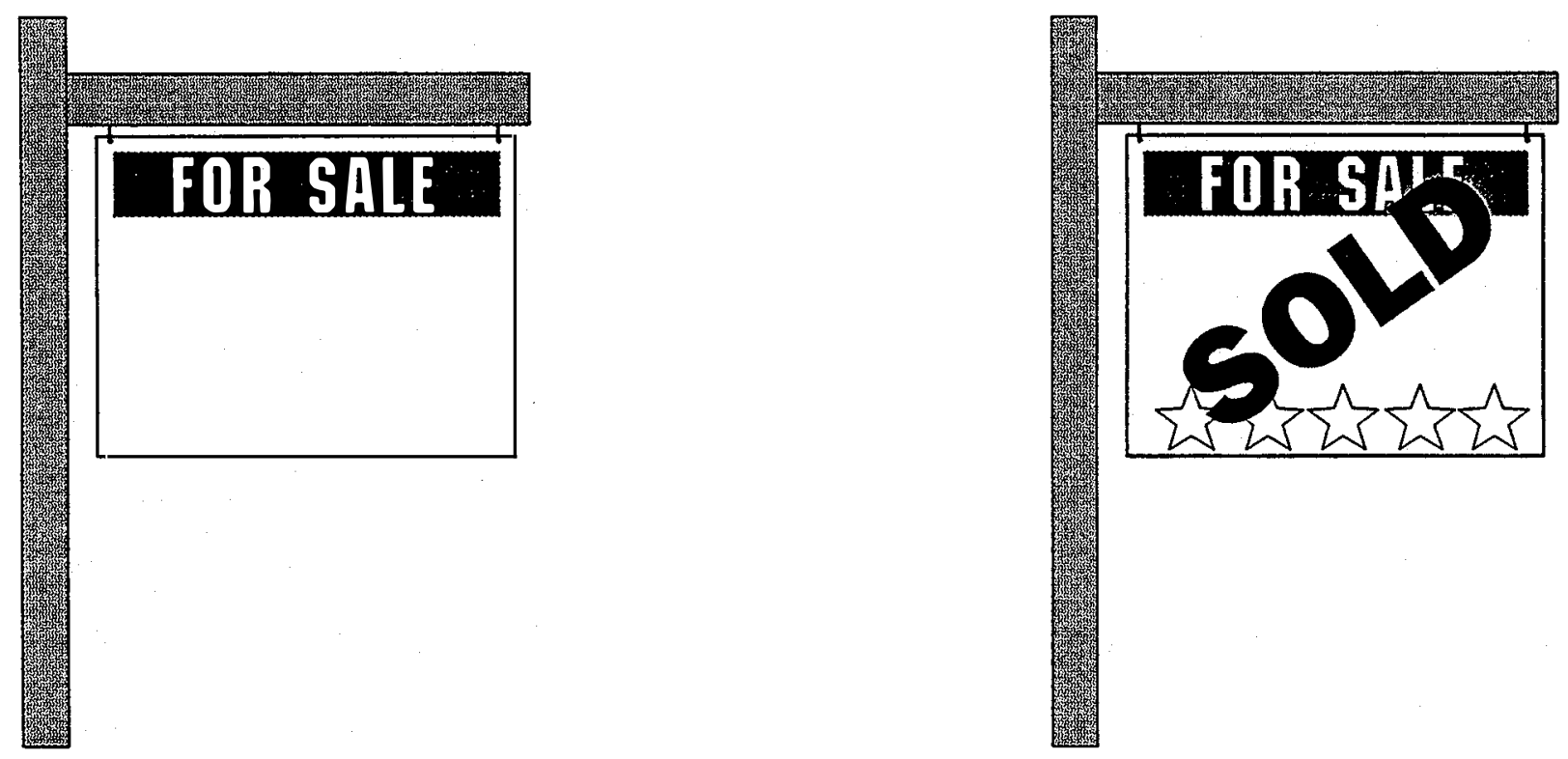

\section{With this...}

\section{Energy Efficient Mortgages}

An Energy Efficient Mortgage (EEM) is an opportunity for your customers to obtain the home of their dreams, while being able to make the house more comfortable and efficient.

EEMs, which have been in existence since the Carter administration, are experiencing a resurgence in interest. These mortgages reward homebuyers for either buying energy efficient homes, or upgrading a home's efficiency through energy retrofits. Many times the efficiency of a house is determined by an energy rating. The Virginia Residential Energy Foundation is the recognized home energy rating system for the state of Virginia.

Virginia has been selected as one of only five states to take part in a new FHA EEM pilot program sponsored by HUD. The new FHA EEM allows a buyer who qualifies for the base loan to acquire an additional loan of up to $\$ 8,000$ to make energy efficient improvements to the property. The borrower does not have to qualify for the additional loan amount. The amount of the loan is determined by a rating of the house by VREF. To qualify, the monthly amount added by the improvement loan must be less than the monthly savings on utilities. The loan is held in escrow until the improvements are made, and the house is re-rated by VREF. The loan amount is then added to the mortgage.

All primary and secondary mortgage companies, as well as all major lending institutions now participate in EEMs. The attached sheet gives a breakdown of the various EEMs available. For more information, contact your mortgage representative, or the Virginia Residential Energy Foundation at (804) 358-0892. 


\section{Appendix 1-E. Consumer Brochures Used by V-HERO}

Comfort, Safety, Savings is a brochure sent to callers in response to a television advertisement. This represents a later evolution of a customer brochure with these three key words asking consumers why they are interested in this type of financing.

How Can I Make My House More Energy Efficient? is a brochure for 203(k) EEMs and FHA EEMs, and the like. It was also sent to callers responding to a television advertisement. 
Call or write for more information on:

Utility Loan Programs

Participating Lenders

Ėnergy Efficient Mortgages

Non Equity or Equity Based Home Loans

For Energy Improvements

Do-it-Yourself Savings

Certified Raters

Rater Career Opportunities

\section{Comfort Safety Savings}

Three little words and five little stars that can make a world of difference to your home...

Indoor Air Quality

Energy Conscientious Home Builders and Contractors

State of the Art Materials and Equipment

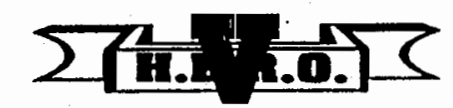

Virginia Home Energy Rating Organization, Inc. 804 Moorefield Park Drive Suite 101

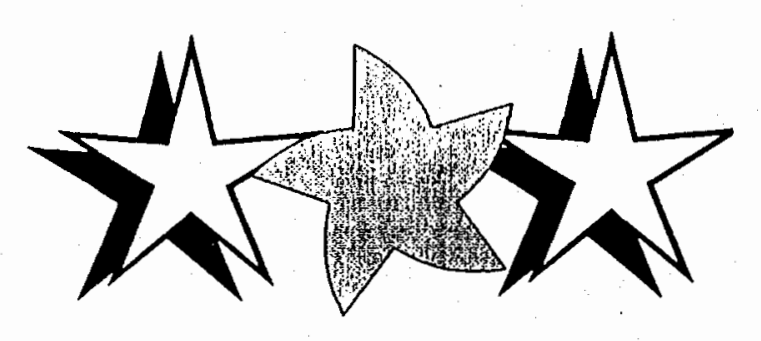




\section{Existing Home Programs}

Energy Efficient Loan Programs operate on a three-part assumption:

1. Money spent on energy efficiency improvements such as insulation, weatherstripping, and new heating and cooling equipment, results in an cven greater savings on utility costs than the amount expended.

2. This means that you'll have more money to spend each month on other things, including your mortgage or loan payment.

3. Therefore a pre-qualified buyer or borrower should be allowed to borrow extra monies for this purpose without further qualification.

Guidelines for Energy Efficient Mortgages have been developed by all five of the federal and quasifederal agencies which buy, guarantee or insure mortgages from local lenders - these are the Federal National Mortgage Association (Fannie Mae); the Federal Home Loan Mortgage Corporation (Fannie Mac); the Federal Housing Administration (FHA); the Department of Veterans Affairs (VA); and the Farmers Home Administration.

Verification of those improvements required, their costs, and the resulting savings on utility bills, is provided by your energy rating report accepted by participating lenders across the state.

Currently, Virginia is the only state offering the Fannie Mae Pilot Loan, which instructs Appraisers to increase the market value of your home to reflect its gain in energy efficiency if you should decide to sell.

And now the HELP 2000 loan is available through your Rater and V-HERO. This loan allows homeowners who are not moving or refinancing to borrow up to $\$ 25,000$ for cost-effective improvements with a certified Rating. This loan can be a consumer loan, or a second mortgage against your property, making it tax deductible, as well as energy saving.

\section{New Home \\ Programs}

New Homes which are built to high standards for energy efficiency reward their owners in many ways, first and foremost by offering a more comf ortable, safe and healthy environment; but also by operating more cost effectively and allowing more disposable income for their family's use.

This is true right from the moment of purchase, when an energy efficient home allows the borrower an "income stretch" evergy efficient loan. This means that a lender can râise your maximum allowable mortgage payment to $31 \%$ of your income (from the usual $29 \%$ ) in consideration of the amount you will not have to spend on energy bills.

In simple terms, this means that you can buy more house than you would normally be eligible for. On a mortgage financed at $8 \%$, for instance, this stretch allows the following additional mortgage amounts to various income levels:

$\begin{array}{cc}\text { Monthly Income } & \text { Additional Mortgage } \\ \$ 2,000 / \text { mo. } & \$ 5,451 \\ \$ 2,500 / \text { mo. } & \$ 6,814 \\ \$ 3,000 / \text { mo. } & \$ 8,177 \\ \$ 4,000 / \text { mo. } & \$ 10,902\end{array}$

In addition to this advantage, the income stretch energy efficient mortgage will allow many people to qualify for a new home purchase who might otherwise not be able to buy a home at all. The Joint Center for Housing Studies estimates that this could be true for as many as 250,000 families in the United States.

And, now, through the Fannie Mae Pilot Loan Program, your home will actually be valued higher than its neighbors the day you move in, as Appraisers add value reflecting the energy savings of the property.

\section{Do any of the following apply to You?}

- High Utility Bills?

- General Discomfort from Cold or Drafts?

- Old or Inefficient Heating \& Cooling Equipment?

- Unusual Allergic or Other Health Problems Related to Indoor Air Quality?

- Lack of Storm Windows?

- Insuf ficient Insulation?

Would you like to make sure that you and your Builder create the most efficient, comfortable and healthy house possible?

A variety of Energy Efficient Loan programs are now available to residents of Virginia, to help you correct these problems and others. The Virginia Home Energy Rating Organization can help you obtain an Energy Rating which will identify the specific problems in your home and the most cost effective ways to correct them.

These loan programs are designed to ensure that you save more on your energy bills than the cost of the energy loan payments.

\section{CALL:}

Virginia Home Energy Rating Organization direct to obtain a list of our trained and certified energy raters, participating Builders, Lenders, Realtors, and Utilities. 


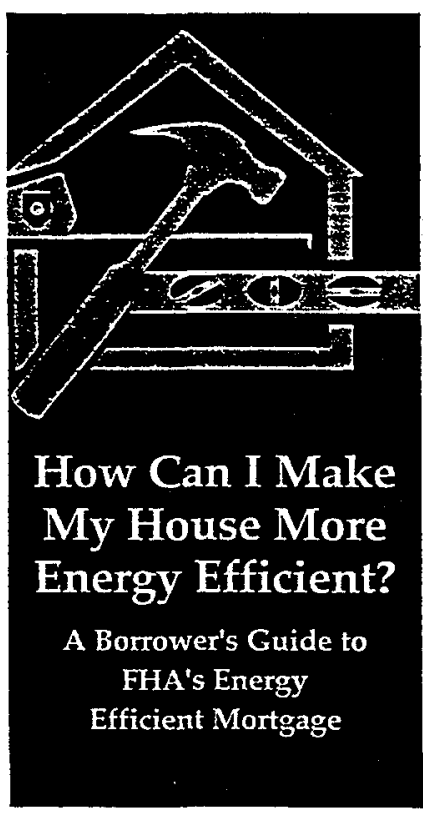

V-HERO.

804 Moorefield Park Drive, Suite 101 Richmond, Virginia 23235 $804560-9234$ Fax 804-560-9139
How Can I Make My House More Energy Efficient?

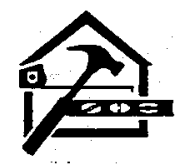

A Borrower's Guide to FHA's Energy Efficient Mortgage

What is the Eregry

Efficient Mortgage (EEMO?

Unider the EaM, a borrower can finarce in to an FHA mortgage $100 \%$ of the cost of "cost effective" energy improvements, subject to certain dollar limitations, without an appraieal of the energy improvements and without further cedit qualifiation.

These improvements will make a house more energy efficient and will save encoure you will save on save ency becau uthly costs you can probably spend more of your income a mortgage payment.

What improoements can be included?

Any energy saving improvenent that is "cost efferive", i.e., the total cost of the improvements (inctuding maintenance) must be less than the total present value of the energy saved over the useful life of the improvements. The improvements can include heating and cooling systems, insulation, weatherstripping windows, etc. The improvements must be part of the real property.

What FHA mortgages can the EEM be added to?

A mortgage for the purchase or refinance of a house or condominium can include an EEM. An EEM Can also be done with a $203(\mathrm{k})$ Rehabilitation loan:

With a streamline refinance, your new payment must be less than your current payment, to be able to include an EEM.

What properties are eligible for an EEM?

Only one and two unit existing properties are eligible for an EEM Loans for new construction cannot include an EEM.

How large can the EEM be?

The cost that can be added to the FHA mortgage is $5 \%$ of the properny value (not to exceed $\$ 8,000$ ) or $\$ 4,000$ whichever is greater.

What is the maximum loan amount?

The maximum loan limit varies by trom 578,660 to 5155250 . This limit may be exceeded by the amount of the EEM. Your lender of the local HUD office can teil you the amount for your area. 
Is there a mortgage

insurance premium?

The upfort FHA mortgage isourano premiun will be $225 \%$ of the total loan amount, including the EEM. The annual premium will be $1 / 2 \%$. If you are getting a $203(\mathrm{k})$ loan, there will be no upfont premium, and the monthy premium will be $1 / 2 \%$ of the total loan amount

What is the interest rate?

As with all FHA loans, the interest rate and discount points are negotiated between you and the lender. A mortgage with an EMM an be a fixed rate or an ARM

Horv is the cost of the improvements and the estimate of the energy saved decided?

A home energy rating system (AIERS)" or an energy consulant will make a physical inspertion of the property, and then, working with you, will decide the package of improvements that are reasonable. Then, the HERS or the energy consultant will decide the cost of the improvements (including maintenance) and will estimate the energy saving and prepare a report for you and your lender. Usually, the HERS or the energy consultant will also decide the improvement pacikage that is "cost effective" Sometimes, the lender will decide.

If you are doing a $203(\mathrm{~K})$ loan, the energy inspection muss be done before the work write-up.
How can I find a HERS

or बrefy consultant?

A HERS or energy consulant may be a utility company; a loal, state or Federal government agency; an entity approved by a loal, state or Federal government agency to provide energy ratings; or a nonprofit organization experienced in conducting home energy ratings on residental properties.

If you are doing a $203(k)$ loan, your enery consulant may also be your $2000 \mathrm{k}$ consultant

Your lender or the local HUD offoce an give you infurmation on HIERS or energy

consultants in your area.

How mach will the HERS

or erergy consultart charge?

The charge will vary, but, you an finance up to $\$ 200$ as part of your closing costs. For a $203(\mathrm{k})$ losn, this chage would be besides your $2030 \mathrm{~K}$ ) consulant's charge

\section{Who will do the}

orery improocments?

If you have the necsesary skills, you an make the improvements yoursel.

If you decide to use a contractor, you should get at least 3 quotes/oids before loan dosing. This will assure you and your lender that you an get the work done for the amount of the EaM set by the HIERS or energy consultant. When you select your contractor, be sure to 8 t references and to look at work done on other projects.

The contractor cannot be related, directly or indirectly, to the HIERS or energy consulant Your lender an give ou list of cont rour lender an other borrowers have successfully worked

\section{When will the roork be done?}

The installation of the energy improvements will be done after the loan is closed.

At dosing your lender will establish an escrow account for the amount of the EEM. You then have 3 months to complete the work Your lender will release the funds when there is an inspection or other notifation assuring the lender that the work has been satisfactorily completed. If the work is not completed within the 3 months, the now will be used to prepay the mortgage.

If you are using a $203(k)$ loan, the EEM funds will be placed in the Rehab funds will be placed in the Rehab Eccow Account, and you will have the same time to complete the energy improvements as the whole rehab project. The funds will be released

How will I know the actual loar amounts for my house?

Working with the HERS or energy consultant, your lender an provide the specife numbers for you.

However, this example of a purchase may help.

The existing property is sold for $\$ 60,000$, its appraised value. The HERS or energy consultant has identified $\$ 2,000$ of energy efficient improvements that have a useful life of 7 years and an annual utility savings of $\$ 420$. The borrower's closing costs are $\$ 1,200$ including \$200 for the energy review. The infercs rate on the FHA mortgage is $\mathbf{8 \%}$. The maximum loan is $\$ 58,650$, with a 5\% downpayment.

The present value of the energy saved is $\$ 2,186$. Since this is greater than the cost of the improvements, the $\$ 2000$ for the improvements can be added to the loan amount, giving a new loan amount of $\$ 60,650$.

An example of $203(\mathrm{~K})$ loan may also be An exa
hel prul

The existing property is sold for $\$ 60,000$. The HERS or energy consultant has identified $\Omega 000$ of energy efficient has identified $\Omega 000$ of energy efficient improvements that have a useful life of 7 years and an annual utility savings if \$410. The borrower's closing cost total $\$ 1200$, including $\$ 200$ for the energy loan is $8 \%$. The cost of the rehab estimated by the $203(\mathrm{k})$ consulant is $\$ 20,000$. The afterimproved value is $\$ 90,000$. The maximum loan is 577,600 , with a $5 \%$ downpayment.

The present value of the energy saved is $\$ 2,186$. Since this amount is greater than the cost of the improvements, the $\$ 2,000$ can be added to the mortzage amount, giving a new loan of 579,600 .

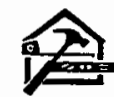


Appendix 1-F. List of Participating Mortgage Companies as of December 31, 1996 


\section{Participating Mortgage Companies}

17-Jan-97

\begin{tabular}{|c|c|c|c|c|c|c|c|}
\hline Contact Name & Lender: & Address & City & State & Zip & Phone Number & Fax Number \\
\hline Linda Gaskins & 1st Home Mortgage & 825 Diligence Drive, Suite 130 & Newport News & VA & 23606 & (757) 873-3377 & (757) 873-4609 \\
\hline Billy Call & 1st Home Mortgage & 7231 Forest Avenue, Suite 303 & Richmond & VA & 23226 & $(804) 288-8400$ & $(804) 288-8486$ \\
\hline Rick Strickler & 1st Jefferson Mortgage & 18 Koger Executive Ctr., Ste 206 & Norfolk & VA & 23502 & (757) 461-0909 & $(757) 466-8662$ \\
\hline Gwen Cooke & Accubank Mortgage & 101 Gateway Parkway, 6th Floor & Richmond & VA & 23235 & $(804) 775-3960$ & $(804) 730-3159$ \\
\hline Steven Edelstein & AMCA & 20 Blanchard Road & Burlington & MA & 01803 & \begin{tabular}{|l|}
$(617) ~ 229-1999$ \\
\end{tabular} & (617) 2298765 \\
\hline Susan Bauman & Ameribanc Mortgage & 780 Lynnhaven Pkwy, Suite 300 & Mirginia Beach & VA & 23452 & (757) 468-7650 & (757) 468-6971 \\
\hline Betsy Perez & American Funding & 5501 Greenwich Road, Ste 100 & Virginia Beach & VA & 23462 & (757) 456-5600 & (757) 456-9358 \\
\hline John Purnell & American Home Funding & 5501 Greenwich, Suite 100 & Virginia Beach & VA & 23462 & (757) 456-5600 & (757) 456-9358 \\
\hline Johnny Olivero & Atlantic Coast Mortgage & 7814 Carousel Lane, Suite 300 & Richmond & $\sqrt{\mathrm{VA}}$ & 23294 & (804) 527-0714 & (804) 527-1840 \\
\hline Charlie Hargest & Atlantic Coast Mortgage & 12700 Fair Lakes Circle, Ste 400 & Fairfax & VA & 22033 & (703) 802-2424 & (703) 631-9478 \\
\hline Dan Early & Atlantic Coast Mortgage & 1100 Boulders Pkwy., Suite 101 & Richmond & VA & 23225 & $(804) 330-4300$ & $(804) 330-4391$ \\
\hline Herb Pettison & Atlantic Coast Mortgage & 1100 Boulders Pkwy., Suite 101 & Richmond & $\overline{V A}$ & 23225 & (804) 330-4300 & (804) 330-4391 \\
\hline Cindy Lamb & Atlantic Coast Mortgage & 1100 Boulders Parkway, Ste 101 & Richmond & VA & 23225 & (804) 330-4300 & (804) 330-4391 \\
\hline Gwen Rogers & Atlantic Coast Mortgage & 7814 Carousel Lane, Suite 300 & Richmond & $\mathrm{VA}$ & 23294 & (804) 527-0714 & $(804) 527-1840$ \\
\hline Zane Frye & Atlantic Coast Mortgage & 1100 Boulders Pkwy., Suite 101 & Richmond & VA & 23225 & (804) 330-4300 & (804) 330-4391 \\
\hline Elyse Stack & B.F. Saul Mortgage & 9211 Arboretum Pkwy & Richmond & VA & 23236 & (804) 323-3500 & \\
\hline Jerry Mabry & B.F. Saul Mortgage & 9211 Arboretum Pkwy., Ste 100 & Richmond & $\mathrm{VA}$ & 23236 & (804) 323-3500 & (804) 560-7290 \\
\hline Steve Ellis & Banc Boston Mortgage & 621 Lynnhaven Parkway & Nirginia Beach & VA & 23452 & (757) 431-5480 & (757) 431-1967 \\
\hline Ellen Ellsworth & Bank United & 4490 Holland Office Pk, Ste 100 & Virginia Beach & $\overline{\mathrm{VA}}$ & 23452 & (757) 456-0155 & $(757)$ 456-9672 \\
\hline Maria Hundley & Bank United Mortgage & 8545 Patterson Ave., Ste 106 & Richmond & VA & 23229 & $(804) 741-3990$ & $(804) 740-2188$ \\
\hline Richard Core & Beach Federal Mortgage & 2101 Parks Avenue, Suite 103 & Nirginia Beach & VA & 23451 & (757) 491-4111 & (757) 422-8944 \\
\hline Thao Nguyen & Beach Federal Mortgage & 5040 Corporate Woods Dr. Ste 120 & Nirginia Beach & VA & 23462 & (757) 499-8300 & (757) 4995402 \\
\hline Dwayne Starling & C \& F Mortgage & 300 Arboretum Place, Ste 245 & Richmond & $\overline{V A}$ & 23236 & (804) 330-8300 & (804) 330-8413 \\
\hline Michelle Finegan & Central Fidelity & 5844 Mapledale Plaza & Woodbridge & $\overline{V A}$ & 22193 & (703) 827-1240 & (703) 827-1244 \\
\hline Priscilla Cash & Central Fidelity & 13200 Hull Street Road & Midlothian & $\overline{\mathrm{VA}}$ & 23112 & (804) 762-4200 & (804) 739-8481 \\
\hline Sharon Dunavant & Central Fidelity & 614 Princess Anne Street & Fredericksburg & $\overline{V A}$ & 22401 & (540) 899-0131 & \\
\hline Susan Ward & Central Fidelity & 1021 East Cary Street & Richmond & $\overline{\mathrm{VA}}$ & 23261 & (804) 697-6816 & (804) 697-7173 \\
\hline Vicki Alvarez & Central Virginia Bank & 4901 Millridge Pkwy., East & Midlothian & $\overline{V A}$ & 23112 & (804) 744-1784 & (804) 7440016 \\
\hline Shane Brewer & Charles F. Curry & P.O. Box 13105 & Kansas City & MO & 64199 & $(800) 432-8779$ & (816) 842-1834 \\
\hline Steve O'Neil & Charles F. Curry Co. & 720 Main Street & Ficios City & MO & 64105 & $800) 821-5476$ & (816) 691-8828 \\
\hline
\end{tabular}




\begin{tabular}{|c|c|c|c|c|c|c|c|}
\hline Contact Name & Lender & Address & City & State & Zip & Phone Number & Fax Number \\
\hline Klm Holmes & Chartway Federal Credit Union & 160 Newtown Road & Virginia Beach & VA & 23462 & (757) 552-1000 & \\
\hline Donna Paxton & Chase Manhattan & 7201 Glen Forest Drive, Ste 203 & Richmond & $\overline{\mathrm{VA}}$ & 23226 & (804) 288-1200 & (804) 288-9252 \\
\hline Mark Johnson & Columbia Mortgage & 1 Columbia Center, Suite 703 & Virginia Beach & VA & 23462 & $(757) 490-8300$ & (757) 490-9287 \\
\hline Wanda Phillips & Columbia National Mortgage & 2917 Penn Forest Blvd., Suite 10 & Roanoke & $\overline{V A}$ & 24018 & $(540) 774-4870$ & (540) 7749214 \\
\hline Theresa Melnyczyn & Country Wide Mortgage & 1601 Willow Lawn Drive, Ste 314 & Richmond & VA & 23230 & (804) 285-1400 & $(804)$ 285-1483 \\
\hline Marilynn Hardy & Crestar & 13001 Hull Street Road & Midlothian & $\overline{\mathrm{VA}}$ & 231.12 & (804) 782-5045 & (804) 782-5067 \\
\hline George Llakos & Crestar & 11817 Canon Blvd., Ste 203 & Newport News & $\overline{\mathrm{VA}}$ & 23606 & (757) 873-7921 & \\
\hline Ronald Harrell & Crestar & 9211 Forest Hill Ave., Ste 200 & Richmond & VA & 23235 & (804) 320-9099 & \\
\hline Katie Smith & Crestar Mortgage & 349 Piney Forest Road & Danville & $\overline{\mathrm{VA}}$ & 24540 & (804) 792-0363 & (804) 792-0603 \\
\hline Bob Hewey & Crossland Morgage Corp & 568A Main Street & Sanford & ME & 04073 & (207) 490-9893 & (207) 490-9894 \\
\hline Terry Spruill & CTXMortgage Corp. & 621 Lynnhaven Pkwy., Ste 330 & Virginia Beach & VA & 23452 & (757) 463-1400 & (757) 463-3481 \\
\hline Rick Capobianco & DeWolfe Mortgage & 21 Worthen Road & Lexington & MA & 02173 & $(617) 863-8585$ & $(617) 862-1125$ \\
\hline Donna Morgan & Dragas Mortgage & 4538 Bonney Road & Virginia Beach & $\overline{V A}$ & 23462 & (757) 499-4303 & (757) 499-5660 \\
\hline Jennifer Mayberry & Eastern Mortgage Systerns & 3895 Adler Place & Bethelem & $\overline{P A}$ & 18017 & $(610) 9548400$ & (610) 954-7954 \\
\hline Janet Moore & Enterprise Mortgage & 525 Viking Drive & Virginia Beach & VA & 23452 & (757) 486-4111 & (757) 498-0527 \\
\hline Ron Harmon & Fairfax Mortgage & 7133 Rutherford Road & Baltimore & MD & 21244 & (410) 298-1300 & (410) 298-2188 \\
\hline Sandy Flason & First Bancord Mortgage & 688 J. Clyde Morris Blvd. & Newport News & VA & 23601 & $(800) 850-5363$ & (757) 599-6310 \\
\hline Mac Mekonnen & First Bancorp Mortgage & 5000 New Point Road, Suite 1202 & Williamsburg & VA & 23188 & (703) 698-9160 & (703) 698-9249 \\
\hline Richard Ray & First Jefferson Mortgage & 1818 Koger Exec. Ctr., Suite 206 & Norfolk & VA & 23502 & (757) 461-0909 & (757) 466-8662 \\
\hline George Temple & First Jefferson Mortgage Corp. & 18 Koger Exec. Center, Ste 206 & Norfolk & $\overline{\mathrm{VA}}$ & 23502 & (757) 461-0909 & (757) 466-8662 \\
\hline Mark Kittrell & First National Mortgage & 1001 Boulders Pkwy, Suite 100 & Richmond & $\overline{V A}$ & 23225 & (804) 320-0399 & (804) 320-0650 \\
\hline Donna Janus & First Union Mortgage & 208 Golden Oak Court & Nirginia Beach & $\overline{\mathrm{VA}}$ & 23452 & (757) 431-5800 & (757) 431-5915 \\
\hline Carmen Vogt & First Virginia & 555 Main Street, 10th Floor & Norfolk & $\overline{V A}$ & 23510 & (757) 628-6730 & (757) 628-6735 \\
\hline William Stevenson & First Virginia Bank & 13644 Hull Street Road & Midlothian & $\overline{V A}$ & 23112 & (804) 739-5670 & $(804) 697-5295$ \\
\hline Greg Robbins & Freedom Mortgage & 2363 South Foothill Drive & Salt Lake City & UT & 84109 & (800) 324-6801 & (801) 234-7012 \\
\hline Lori Marler & Freedom Mortgage & 2362 South Foothill Drive & Salt Lake City & UT & 84109 & (801) 276-6500 & (800) 409-7608 \\
\hline William Sharp & GMAC Mortgage Corp. & 9211 Forest Hill Ave., Suite 104 & Richmond & VA & 23235 & (804) 272-0105 & (804) 272-3738 \\
\hline Elaine Mussick & Guild Mortgage & 4455 S. Boulevard, Suite 100 & Virginia Beach & VA & 23452 & (757) 490-0088 & |(757) 490-3988 \\
\hline Chris Engel & Guild Mortgage & 4435 South Blvd., Suite 100 & Virginia Beach & VA & 23452 & (757) 490-0088 & (757) 490-3988 \\
\hline Susie Fields & Hampton Roads Funding & 1206 Gaskin Road, Suite 101 & Virginia Beach & VA & 23451 & (757) 491-6300 & (757) 491-6933 \\
\hline Claudette Yamin & HomeNet Mortgage & 7202 Glen Forest Drive, Ste 100 & Richmond & $\overline{V A}$ & 23226 & (804) 257-0189 & (804) 285-7246 \\
\hline Sam Zimmer & HomeNet Mortgage & 7202 Glen Forest Dr., Ste 101 & Richmond & $\overline{V A}$ & 23226 & (804) 285-8121 & (804) 285-7246 \\
\hline Linda Chambers & Homestead Mortgage & 2612 Taylor Road & Chesapeake & $\overline{V A}$ & 23321 & (757) 488-2700 & (757) 488-6911 \\
\hline Karen Couffith & Inland Mortgage & P.O. Box 1130 & Hayes & VA & 23072 & (757) 642-3523 & |(757) 642-3534 \\
\hline Beth Honea & Inland Mortgage Corp. & 1238 Holland Road, Suite 111 & Suffolk & $\overline{V A}$ & 23434 & (757) 925-4900 & \\
\hline Mark Hood & Inland Mortgage Corp. & 808 Moorefield Park Dr., Ste 113 & Richmond & VA & 23236 & (804) 323-1077 & (804) 323-3373 \\
\hline
\end{tabular}




\begin{tabular}{|c|c|c|c|c|c|c|c|}
\hline Contact Name & Lender & Address & City & State & Zip & Phone Number & Fax Number \\
\hline Bud Smith & Inland Mortgage Corp. & 808 Moorefield Park Dr., Ste 113 & Richmond & VA & 23236 & (804) 323-1077 & (804) 323-3373 \\
\hline Betty Jenkins & Inland Mortgage Corporation & 808 Moorefield Park Dr., Ste 113 & Richmond & $\overline{V A}$ & 23236 & (804) 323-1077 & (804) 323-3373 \\
\hline Mike Wood & Inland Mortgage Corporation & 808 Moorefield Park Dr., Ste 113 & Richmond & $\overline{V A}$ & 23236 & (804) 323-1077 & (804) 323-3373 \\
\hline Earl Foreman & Jefferson National Bank & 202 N. Loudon Street & Winchester & $\overline{V A}$ & 22601 & (540) 665-2600 & \\
\hline Phillip Morton & \begin{tabular}{|l} 
Jefferson National Bank \\
\end{tabular} & P.O. Box 711 & Charlottesville & $\overline{V A}$ & 22902 & (804) 972-1155 & \\
\hline George Yancey & Jefferson National Bank & 4109 Plank Road & Fredericksburg & $\overline{V A}$ & 22401 & (540) 786-9485 & \\
\hline Andrew Spooner & \begin{tabular}{|l} 
Jefferson National Bank \\
\end{tabular} & P.0.Box 26363 & |Richmond & $\overline{V A}$ & 23260 & (804) 782-6248 & \\
\hline Debora Moore & \begin{tabular}{|l} 
Jefferson National Bank \\
\end{tabular} & P.O. Box 399 & |Locust Grove & $\overline{V A}$ & 22508 & (540) 927-2177 & \\
\hline Alexis Daughter & Life Savings Bank & 601 Lynnhaven Parkway & Nirginia Beach & VA & 23452 & (757) 340-8750 & |757) 486-6280 \\
\hline Kevin Reynolds & Mid-Atlantic Financial & 717 N. Courthouse Road & |Richmond & $\overline{V A}$ & 23236 & (804) 794.7665 & (804) 7947937 \\
\hline Michelle Curley & Mid-Atlantic Financial & 10001 Patterson Avenue & Richmond & $\sqrt{V A}$ & 23233 & (804) 741-0599 & \\
\hline Carol Holbrook & Mid-Atlantic Financial & 10001 Patterson Avenue, Ste 202 & Richmond & $\overline{V A}$ & 23233 & (804) 741-0599 & (704) 741-0775 \\
\hline Joan Burnette & Mid-Atlantic Financial & 717 North Courthouse Road & Richmond & $\overline{V A}$ & 23236 & (804) 794-7665 & (804) 794-8603 \\
\hline Alice Oldaker & Mid-Atlantic Financial Group & 717 N. Courthouse Road & Richmond & $\mathrm{VA}$ & 23236 & (804) 794.7665 & (804) 794-8603 \\
\hline Brent Garrison & Mid-Atlantic Mortgage & 10001 Patterson Avenue & Richmond & VA & 23233 & (804) 741-0599 & (804)741-0775 \\
\hline Jennifer Scale & Mortgage Services America & 3957 Westerre Pkwy., Ste 270 & Richmond & $\overline{V A}$ & 23233 & (804) 527-1974 & |(804) 527-2742 \\
\hline Eileen Bernard & National City Mortgage Co. & 484 Viking Drive, Suite 100 & Virginia Beach & $\overline{V A}$ & 23452 & (800) 344-5051 & (757) 463-8707 \\
\hline John Myers & NatlonsBank & 9211 Forest Hill Ave., \#204 & Richmond & $\overline{V A}$ & 23235 & 804 330-8090 & (804) 330-4412 \\
\hline Michele Britt & NallonsBank & 13500 Harbour Pointe Pkwy & Midlothian & $\overline{V A}$ & 23112 & (804) 639-6323 & (804) 639-6321 \\
\hline Lucy Blevins & NationsBank & 9211 Forest Hill Ave., \#204 & Richmond & $\overline{V A}$ & 23112 & (804) 330-8090 & (804) 330-4412 \\
\hline Chuck Martin & NatlonsBank & 9211 Forest Hill Ave., Suite 204 & Richmond & $\overline{V A}$ & 23112 & (804) 330-8090 & (804) 330-4412 \\
\hline Beth Hawkins & North American & 4343 Bank Road, Suite 200 & Fredericksburg & $\overline{V A}$ & 22407 & (540) 786-5600 & (540) 786-9712 \\
\hline Leslie Lose & North American Mortgage & 4343 Poark Road, Suite 200 & Fredericksburg & VA & 22407 & (800) 451-7435 & (540) 786-9712 \\
\hline Mike Kao & North American Mortgage & 7501 Boulders View Dr., Ste 430 & Richmond & VA & 23225 & (804) 330-4330 & (804) 330-2816 \\
\hline Sue Hoffman & Norwest Mortgage & 732 N. Thimble St., Suite 906 & Newport News & $\overline{V A}$ & 23606 & (757) 873-3308 & (757) 873-3878 \\
\hline Bobbi Dickerson & Norwest Mortgage & 3130 Golansky Blvd., Suite 101 & Woodbridge & $\mathrm{VA}$ & 22192 & (703) 551-0120 & (703) 551-0121 \\
\hline Donna Thomas & Norwest Mortgage & 4456 Corporation Lane, Ste 164 & Virginia Beach & $\overline{V A}$ & 23462 & (757) 490-4544 & (757) 499-0791 \\
\hline Ken Bair & Norwest Mortgage & 860 Greenbrier Circle, Suite 208 & |Chesapeake & $\overline{V A}$ & 23320 & (757) 420-6162 & (757) 420-5970 \\
\hline Jeff Aftanas & Norwest Mortgage & 4456 Corporation Lane, Ste 164 & Nirginia Beach & VA & 23462 & (757) 490-4544 & (757) 499-0791 \\
\hline R. Daniel Schmidt & Norwest Mortgage & 6800 College Blvd., Suite 440 & Overland Park & KS & 66211 & (913) 345-8227 & (913) 338-0707 \\
\hline Joan Nowek & Norwest Mortgage & 100 South Fifth Street, Ste 800 & Minneapolis & $\overline{\mathrm{MN}}$ & 5 & (612) 904.7659 & (800) 333-4233 \\
\hline Jane Kwock & Norwest Mortgage & 6116 Executive Blvd., Suite 109 & Rockville & MD & 20852 & (301) 816-1009 & (301) 816-0183 \\
\hline William Herbert & One Valley Bank & 2120 Langhorne Road & Lynchburg & $\overline{V A}$ & 24505 & (804) 847-3820 & (804) 847-3825 \\
\hline Terry Ann Hepler & PaineWebber & 1901 Research Blvd., Ste 210 & Rockville & $M D$ & 20850 & (800) 999-3087 & \\
\hline Neil Brown & PHH Mortgage Services & 6000 Atrium Way & Mt. Laurel & $\overline{\mathrm{NJ}}$ & 08054 & (800) 4460964 & (609) 439-6775 \\
\hline Linda Thompson & Planters Bank & P.O. Drawer 1309 & Staunton & $\overline{V A}$ & 24402 & $(540 ; 385-1232$ & (540) 885-2471 \\
\hline
\end{tabular}




\begin{tabular}{|c|c|c|c|c|c|c|c|}
\hline Contact Name & Lender & Address & City & State & Zip & Phone Number & Fax Number \\
\hline Bob Lavach & Preferred Mortgage & 7923 Jones Branch Drive, Ste 300 & McLean & VA & 22102 & (703) 893-1050 & (703) $893-1710$ \\
\hline Bob Dunn & Prosperity Mortgage & 6001 Montrose Road, Suite 706 & Rockville & $\overline{M D}$ & 20852 & (301) 770-5772 & $(301) 770-1054$ \\
\hline Sandy Dickson & Prudential Financial Services & 470 D. Ritchie Highway & Severna Park & $\widehat{\mathrm{MD}}$ & 21146 & (301) 261-1444 & (301) 261-1408 \\
\hline Debra Branham & Resource Mortgage & 7301 Forest Avenue, Suite 325 & Richmond & VA & 23226 & (804) 673-7200 & (804) 282-2409 \\
\hline Rob Roland & Resource Mortgage & 7301 Forest Avenue; Suite 325 & Richmond & VA & 23226 & (804) 672-7200 & (804) 282-2409 \\
\hline Jim Tripodi & Ryland Mortgage & 10045 Midlothian Tnpk, Ste 100 & Richmond & $\overline{V A}$ & 23235 & (804) 560-4060 & $(804) 560-4088$ \\
\hline Gina Slonecker & Ryland Mortgage & 6225 Brandln Avenue, Ste 340 & Springfield & $\overline{\text { VA }}$ & 22150 & $(703) 866-5400$ & (703) 866-5401 \\
\hline Samuel Wilson & Seasons Mortgage Group & 804 Moorefield Park Dr., Ste 302 & Richmond & VA & 23235 & (804) 323-1680 & (804) 323-7517 \\
\hline Harry Lehman & Shoshone First Bank & P.O. Box 1330 & Cody & $\overline{W Y}$ & 82414 & (307) 587-4237 & (307) 527-5365 \\
\hline Linda Simoneau & Shoshone First Bank & P.O. Box 1330 & Cody & WY & 82414 & (301) 587-8627 & $(307) 527-5365$ \\
\hline Pat Hickman & Signet & 4460 Corporation Lane, Ste 302 & Nirginia Beach & $\overline{V A}$ & 23462 & (757) 640-4621 & $(757) 640-4472$ \\
\hline Lynn Ann Marano & Signet & 4900 Millridge Parkway & Midlothian & $\overline{\mathrm{VA}}$ & 23112 & (804) 771-7555 & (804) 7444297 \\
\hline Judith Snyderman & Signet & 11013 W. Broad Street Road & Richmond & $\sqrt{\mathrm{VA}}$ & 23260 & (804) 747-2278 & \\
\hline Joseph Pornroy & Signet & 210 N. Guilford Avenue & Baltimore & MD & 21203 & (410) 625-4010 & \\
\hline Sandra Krajaclch & Signet & 4900 Millridge Parkway & Midlothian & VA & 23112 & (804) 771-7555 & (804) 7444297 \\
\hline Linda Durham & Signet & 4900 Millrldge Parkway & Midlothian & $\overline{\mathrm{VA}}$ & 23112 & (804) 771-7554 & (804) 7444297 \\
\hline Arild Trent & Signet & 804 Moorefield Park Dr., Ste 200 & Richmond & VA & 23236 & (804) 343-6690 & $(804) 272-7330$ \\
\hline Sarah Steadfast & Signet Mortgage & 4460 Corporation Lane, Ste 302 & Nirginia Beach & $\overline{\mathrm{VA}}$ & 23462 & (757) 640-4621 & $(757) 640-4472$ \\
\hline Carmen Amado & Tide Mark & 301 Hilder Boulevard & Newport News & $\overline{V A}$ & 23606 & (757) 599-1430 & (757) 599-1351 \\
\hline Crystal Pierce & Tidewater Mortgage & 3630 South Plaza Trial & Virginia Beach & $\overline{V A}$ & 23452 & (757) 340-7525 & (757) 340-8136 \\
\hline Gloria Wright & United First Mortgage & P.O. Box 1152 & |Harrisonburg & $\overline{V A}$ & 22801 & (540) 433-7149 & (540) 433-7169 \\
\hline Lee Moore & Weyerhaeuser Mortgage & 825 Diligence Drive, Suite 226 & Newport News & VA & 23606 & (757) 872-0545 & (757) 873-1489 \\
\hline
\end{tabular}




\section{Appendix 1-G. List of V-HERO Certified Raters Active as of}

December 31, 1996 


\section{Virginia Home Energy Rating Organization Raters}

17-Jan-97

\begin{tabular}{|c|c|c|c|c|c|c|c|c|c|}
\hline Rater ID & First Name & Last Name & Company Name & Address & City & State & Zip & Work Phone & FAX \\
\hline 93010 & Donald & Alexander & Lynchburg C.A.P. & 1310 Church Street & Lynchburg & VA & 24504 & $(804) 846-2778$ & (804) 845-1547 \\
\hline 94057 & J.R. & Bailey & Virginia Power & 11200 Iron Bridge Road & Chester & VA & 23831 & & \\
\hline 94058 & Douglas & Barrett & Virginia Power & 11200 Iron Bridge Road & Chester & VA & 23831 & & \\
\hline 96015 & W. Ben & Blanks & Chester VA Power & 11200 Iron Bridge Road & Chester & VA & 23831 & $(804) 751-4071$ & \\
\hline 96005 & Stephen & Bleau & Comfort Home & 780 Eden Road & Lancaster & $\overline{P A}$ & 17601 & $(717) 581-8848$ & $(717) 581-8847$ \\
\hline 93003 & Boyko & Bohdan & Willamsburg CAA & BoxHK & Williamsburg & VA & 23187 & $(804) 229-9332$ & \\
\hline 94039 & Charles & Bowles & Energy Consortium & Route 3, Box 426 & Glen Allen & $\overline{\text { VA }}$ & 23060 & (804) 271-1756 & (804) 883-6427 \\
\hline 93011 & Steve & Brooks & |RADA Weatherization Program & 101 Willow Street & Gate City & $\overline{V A}$ & 24251 & (703) 386-6441 & \\
\hline 96009 & Carlo & Bruce & Comfort Home & 780 Eden Road & Lancaster & $\overline{P A}$ & $\longdiv { 1 7 6 0 1 }$ & (717) 581-8848 & $(717) 581-7747$ \\
\hline 93021 & Doug & Burgess & Burgess Home Inspections & 11106 Mayapple Terr. & Richmond & VA & 23236 & (804) 794-1423 & (804) 379-9931 \\
\hline 93012 & Tom & Canning & Energy Conservation Services & 132 Hillcrest Drive & Fredericksburg & $\overline{\mathrm{VA}}$ & 22401 & (540) 898-2279 & \\
\hline 96010 & Mary Ann & Capp & Horizon Energy Services & 725 Davis Street & Blacksburg & VA & 24060 & $(540)$ 381-3626 & \\
\hline 96001 & H. Edward & Carr & Comfort Home & 780 Eden Road & Lancaster & $\widehat{P A}$ & 17601 & (717) 581-8848 & (717) 581-8847 \\
\hline 94040 & Craig & Carter & Air-Right Energy Design & 12170 Stoners Lane & Catharpin & $\overline{\mathrm{VA}}$ & 22018 & (703) 754-7262 & $(703) 754-1224$ \\
\hline 93032 & Don & Cass & & & & & & & \\
\hline 96002 & Sidney & Coup & Comfort Home & 780 Eden Road & |Lancaster & $\overline{\text { VA }}$ & 17601 & (717) 581-8848 & (717) 581-8847 \\
\hline 93014 & Anthony & Cox & & 401 Vermillion Street & Dublin & $\overline{\text { VA }}$ & 24048 & (540) 674-9119 & \\
\hline 93023 & Donna & Craver & Stafford Insulation & 4809 Ewell Road & Fredericksburg & $\overline{\mathrm{VA}}$ & 22408 & $(540) 898-7788$ & (540) 898-6176 \\
\hline 95115 & Darryl & Davis & Russell's Heating \& A/C & 841 Juniper Crescent, Ste 114 & Chesapeake & $\overline{\mathrm{VA}}$ & 23320 & $(757) 424-1000$ & \\
\hline 93029 & Andrew & DeMaury & & P.O. Box 2506 & Christiansburg & VA & 24073 & (540) 552-2414 & \\
\hline 94056 & Glen & Dickey & CMC & 7300 Pearl Street & Bethesda & $\overline{M D}$ & 20814 & (301) 951-6088 & \\
\hline 95114 & Sidney & Dobbs & & 213 Glen Haven Drive & Clifton Forge & VA & 24422 & $(540) 862-7834$ & \\
\hline 94061 & Sharon & Dockery & MECCA Foundation & 112 West Washington Street & Suffolk & $\overline{\mathrm{VA}}$ & 23434 & (757) 925-4444 & \\
\hline 93024 & Don & Dukstein & Option Insulation & 4850 Streets Run Road & Pittsburgh & PA & 15236 & (412) 884-6700 & \\
\hline 96028 & Kenneth & Dunleavy & Quantico/USMC & 3252 Barnett Ave./Sect B041-7 & Quantico & $\overline{\mathrm{VA}}$ & $\overline{22134}$ & (703) 784-3973 & \\
\hline 95113 & Charles & Echols & AEP-VA & P.O. Box 2021 & Roanoke & VA & 24022 & $(540) 985-2345$ & \\
\hline 94049 & Charles & Elmore & Johns Brothers & 986 Bellmore Avenue & Norfolk & $\longdiv { \mathrm { VA } }$ & 23501 & $(757) 622-4687$ & \\
\hline 94059 & Mark & Fink & Virginia Power & 11200 Iron Bridge Road & Chester & VA & 23831 & & \\
\hline $2+650$ & $\overline{\text { Keith }}$ & Flerning & & 110 Glant Drive, Slita C & Richmond & $\overline{\mathrm{VA}}$ & 23224 & (804) 233-2827 & $\longdiv { ( 8 0 4 ) 2 3 0 - 0 7 7 8 }$ \\
\hline 93019 & James & Flippen & Residential Energy Mgmt. & 1326 Lone Cedar Court & Mechanicsville & $\overline{\mathrm{VA}}$ & 23111 & $(804) 559-4214$ & $(804) 559-4214$ \\
\hline
\end{tabular}




\begin{tabular}{|c|c|c|c|c|c|c|c|c|c|}
\hline Rater ID & First Name & Last Name & Company Name & Address & City & State & Zip & Work Phone & FAX \\
\hline 96020 & $\sqrt{\text { Mark }}$ & Gede & Gede Insulation & $\longdiv { 6 2 1 \text { West Division Street } }$ & Dover & $\overline{D E}$ & 19904 & (302) 678-1782 & $\longdiv { ( 3 0 2 ) 6 7 8 - 3 1 0 3 }$ \\
\hline 94051 & Greg & Gllotte & HomeChek of Tidewater & 4516 Greendell Road & Chesapeake & $\overline{V A}$ & 23321 & (757) 545-1885 & (757) 483-7920 \\
\hline 93025 & Rick & Graham & Air-Right Energy Design & 12170 Stoners Lane & Catharpin & $\overline{V A}$ & 22018 & $703) 754-7262$ & (703) 754-1224 \\
\hline 96007 & Jesse & Green & Comfort Home & 780 Eden Road & Lancaster & $\overline{P A}$ & 17601 & (717) 581-8848 & (717) 581-8847 \\
\hline 93020 & Fred & Gross & People Inc. & 988 West Main Street & Abingdon & VA & 24210 & (540) 628-9188 & $(540) 628-2931$ \\
\hline 94052 & Michael & Grothe & & 7895 Cessna Avenue, Suite B & Gaithersburg & MD & 20879 & (301) 948-5953 & \\
\hline 96021 & Brent & Hadäway & Delmarva Power & P.O. Box 1739 & Salisbury & $M D$ & 21802 & (410) $860-6212$ & (410) 860-6077 \\
\hline 93015 & David & Hall & RADA Weatherization Program & 101 Willow Street & Gate City & VA & 54038 & (540) 386-6441 & \\
\hline 96013 & Dr. Sam & Hancock & Advanced Construction System & 9702 Gayton Road, Sulte 222 & Richmond & VA & 23233 & (804) 378-3742 & \\
\hline 95116 & T.Patrick & Herlihy & & P.O. Box 1408 & Hampton & VA & 23661 & $757) 625-0018$ & \\
\hline 93037 & Chris & Heslep & VA Mountain Housing & 606 Massanutten Avenue & Front Royal & $\overline{V A}$ & 22630 & (540) 382-2002 & \\
\hline 96022 & Robert & Hill & Delmarva Power & P.O. Box 1739 & Salisbury & MD & 21802 & (410) 287.7161 & \\
\hline 94042 & Russell & Hinton & Virginia Power & 11200 Ironbridge Road & Chester & VA & 23831 & & \\
\hline 94043 & Scott & Horseman & Horseman Heating \& Cooling & Route 1, Box 248 AA & Gladys & VA & 24554 & (804) 283-5501 & \\
\hline 93038 & Cecil & Houchin & American Bldg. Insp. Svcs. Inc. & 5144-B Princess Anne Road & Virginia Beach & VA & 23462 & (757) 490-0007 & \\
\hline 93028 & Drew & Howard & HomePro Inc. & 506 Oak Trail & Lynchburg & $\overline{V A}$ & 24502 & (804) 239-0116 & (804) 239-8092 \\
\hline 95119 & J. Grant & Huneycutt & Nansemond Heating \& Cooling & 5268 Godwin Boulevard & Suffolk & $\overline{\mathrm{VA}}$ & 23434 & 757) 255-4524 & (757) 255-0829 \\
\hline 94053 & Larry & Jones & Virginia Power & 4321 Henpeck Road & Quinton & VA & 23141 & (804) 932-9815 & \\
\hline 94044 & Amie & Katz & Alternative Energy Corp. & P.0. Box 12699 & Research Triangle & NC & 27709 & (919) 361-8029 & \\
\hline 96026 & Bill & Kee & Energy Consultants, Inc. & 1439 Great Neck Rd., Ste $202 \mathrm{~L}$ & Virginia Beach & VA & 23454 & (757) 481-2500 & |(757) 481-1126 \\
\hline 96014 & Claude & Kingery & & 5014 Worwick Court & Prince George & VA & 23875 & (804) 458-3240 & \\
\hline 95103 & David & Knowles & Honeywell DMC Services Inc. & 4311 Old Cave Spring Road & Roanoke & VA & 24018 & (540) 734-0209 & \\
\hline 93005 & John & Langford & J\&J Weatherization & Route 8, Box 140C & Lynchburg & $\overline{V A}$ & 24505 & (804) 847-5487 & \\
\hline 95111 & Mike & LaScola & Appalachian Power Co. & P.O. Box 2021 & Roanoke & VA & 24022 & (540) 985-2371 & \\
\hline 93006 & David & Lee & & 2516 Woodland Drive & Charlottesville & VA & 22903 & (804) 977-5066 & \\
\hline 93033 & Robert & Lilley & Kearney \& Sons, Inc. & 1641 West Pembroke Ave. & Hampton & $\overline{V A}$ & 23661 & (757) 722-6311 & \\
\hline 95117 & Bob & Logston & Home Energy Mgmt Svcs & 1400 Moreland Avenue & Baltimore & MD & 21216 & (410) 566-8200 & \\
\hline 93009 & Al & Maddox & & 2329 Old Forest Road & Lynchburg & VA & 24501 & $804)^{384-5108}$ & \\
\hline 95101 & Lori & Marsh & VPI \& SU & 210 Seitz Hall & Blacksburg & $\overline{V A}$ & 24061 & (540) $231-6815$ & (540) 231-3199 \\
\hline 93030 & William & Mashburn & Appalachian Power Company & P.0. Box 2021 & Roanoke & $\overline{V A}$ & 24022 & (540) 985-2300 & \\
\hline 96012 & Greg & Mays & Greg Mays \& Associates & 14126 Bermuda Point Court & Chester & $\overline{V A}$ & 23831 & $804)^{530-1435}$ & $804)$ 530-1015 \\
\hline 94045 & Kenneth & Melton & & 2104 Eagle Rock Road & Virginia Beach & $\overline{V A}$ & 23456 & (757) 471-2281 & \\
\hline 96025 & Mike & Minarek & Shelter Alternatives & P.0. Box 355 & Blacksburg & $\overline{V A}$ & 24063 & (540) 953-3357 & (540) 953-3357 \\
\hline 96016 & Martin & Mitchell & & 10427 Jordan Parkway & Hopewell & $\overline{V A}$ & 23860 & (804) 383-3763 & \\
\hline 96019 & Alvin & Mizelle & Thermal Energy Consultants & P.0. Box 276 & Hertford & NC & 27944 & (919) 426-8348 & (919) 426-8346 \\
\hline 95105 & Erik & Mollin & Honeywell DMC Services & 4311 Old Cave Spring Road & Roanoke & $\overline{V A}$ & 24018 & (540) 734-0209 & \\
\hline
\end{tabular}




\begin{tabular}{|c|c|c|c|c|c|c|c|c|c|}
\hline Rater ID & First Name & Last Name & Company Name & Address & City & State & Zip & Work Phone & FAX \\
\hline 93008 & Gary & Moore & & 508 West Market Street & Leesburg & VA & 22075 & $\sqrt{(703) \pi 7-8637}$ & \\
\hline 95102 & Robert & Muller & DMC/Delanson NY & RDI Box 217 & Delanson & $\overline{\text { NY }}$ & 12053 & (518) 872-1002 & \\
\hline 96024 & Russell & North & Central VA Electric Cooperative & P.O. Box 247 & Lovingston & VA & 22949 & (804) 263-8339 & \\
\hline 96017 & Kevin & O'Kelly & & 8083 Elder Trail & Mechanicsville & VA & 23116 & $(804) 559-3711$ & \\
\hline 93026 & Tom & Perkins & Energy Prol & 5144-B Princess Anne Road & Virginia Beach & VA & 23462 & (804) 490-7595 & (804) 490-7732 \\
\hline 95110 & Clayton & Preas & Appalachian Power Company & P.O. Box 2021 & Roanoke & $\overline{\mathrm{VA}}$ & 24022 & (540) 985-2590 & \\
\hline 93016 & Brittan & Quinn & Building Science & 9291 Laurel Grove Road & Mechanicsville & VA & 23111 & (804) 559-8830 & (804) 559-2101 \\
\hline 95104 & Glen & Radford & DMC/Roanoke & 4311 Old Cave Spring Road & Roanoke & $\overline{\mathrm{VA}}$ & 24018 & $(540) 7340209$ & \\
\hline 93017 & Carl & Rasnic & VA-HCD & 501 North 2nd Street & Richmond & VA & 23219 & $(804) 371-7025$ & \\
\hline 94054 & Thomas & Reinsel & & 10624 Colony Park Drive & Fairfax & VA & 22032 & (703) 250-0308 & \\
\hline 94046 & George & Richeson & Blue Ridge Home Inspections & 1160 Port Republic Road & Harrisonburg & VA & 22801 & $(540) 4349963$ & $(540)$ 432-0449 \\
\hline 94047 & Steve & Ringley & Stafford Insulation & 4809 Ewell Road & Fredericksburg & $\overline{\mathrm{VA}}$ & 22408 & (540) 898-8200 & \\
\hline 96027 & Kenneth & Schaal & Commonwealth Solar & 12433 Autumn Sun Lane & Ashland & $\overline{\text { VA }}$ & 23005 & (804) 798-5371 & \\
\hline 96011 & Chris & Simone & E.C.I., Inc. & P.O. Box 1644 & Chesterfield & $\overline{\mathrm{VA}}$ & 23832 & $(804) 748-0283$ & $804) 590-0653$ \\
\hline 94055 & Javoun & Smallwood & MECCA Foundation & 112 W. Washington St, Ste 710 & Suffolk & VA & 23434 & $(757) 925-4444$ & (757) 925-0997 \\
\hline 96004 & Bruce & Smith & Comfort Home & 780 Eden Road & Lancaster & PA & 17601 & (717) 581-8848 & (717) 581-8847 \\
\hline 95109 & Jennifer & Smoll & DMC & 4311 Old Cave Spring Road & Roanoke & VA & 24018 & $(540) 734-0209$ & \\
\hline 96023 & Randy & Southworth & Rappahannock Electric Cooper. & P.O.Box 7388 & Fredericksburg & $\overline{V A}$ & 22404 & $(540) 633-4669$ & \\
\hline 94048 & \begin{tabular}{|l} 
Jill \\
\end{tabular} & Stoneman & Virginia Power & 11200 Iron Bridge Road & Chester & VA & 23831 & & \\
\hline 93007 & Neil & Sullivan & Building Science & 9291 Laurel Grove Road & Mechanicsville & $\overline{V A}$ & 23111 & $(804) 559-8830$ & $(804) 559-2101$ \\
\hline 93036 & Thomas & Sweet & SEDA-COG & R.R. \#1, Box 372 & Lewisburg & PA & 17837 & (717) 524-4491 & \\
\hline 93001 & Gary & Treaster & E.C.I., Inc. & P.O. Box 1644 & Chesterfield & $\overline{\text { VA }}$ & 23832 & $(804) 748-0283$ & $(804) 590-0653$ \\
\hline 95118 & Gene & Ward & RJK Design \& Construction Mgt & 47 Redding Ridge Drive & Gaithersburg & $\overline{M D}$ & 20878 & (301) 340-1986 & $(301) 3090474$ \\
\hline 95100 & Scott & Webb & DMC & 4311 Old Cave Spring Road & Roanoke & $\overline{V A}$ & 24018 & (540) 734-0209 & \\
\hline 93018 & Billy & Weitzenfeld & New River C.A. \& Head Start & \begin{tabular}{|l} 
P.O. Box 470 \\
\end{tabular} & Christiansburg & VA & 24073 & $(540)$ 382-1975 & \\
\hline 96003 & Charles & White & Comfort Home & 780 Eden Road & Lancaster & $\overline{P A}$ & 17601 & $(717) 581-8848$ & $(717) 581-8847$ \\
\hline 93027 & Dan & Williams & AC Incorporated & 207 Pennsylvania Ave, SE \#2 & Washington & $\overline{\mathrm{DC}}$ & 20003 & (202) 546-4566 & \\
\hline 96006 & Matthew & Williamson & Comfort Home & 780 Eden Road & Lancaster & $\overline{P A}$ & 17601 & (717) 581-8848 & (717) 581-8847 \\
\hline 95112 & Joanne & Willis & DMC & 4311 Old Cave Spring Road & Roanoke & $\overline{V A}$ & 24018 & (540) 734-0209 & \\
\hline 96008 & James & Wismer & Comfort Home & 780 Eden Road & Lancaster & $\overline{\mathrm{PA}}$ & 17601 & $(717) 581-8848$ & $(717) 581-8847$ \\
\hline 93031 & Kenneth & Zenzel & Energy Prol & 5144-B Princess Anne Road & Virginia Beach & VA & 23462 & (757) 490-7595 & (757) 490-7732 \\
\hline 96018 & Shaun & Zenzel & Energy Prol & 5144-B Princess Anne Road & Virginia Beach & VA & 23462 & \begin{tabular}{|l}
$(757) 490-7595$ \\
\end{tabular} & (757) 490-7732 \\
\hline
\end{tabular}


Appendix 1-H. List of Active Raters in DC, Delaware, Maine, Maryland, and New Jersey 


\begin{tabular}{|c|c|c|c|c|c|c|c|}
\hline \multicolumn{8}{|c|}{$\begin{array}{l}\text { DC Raters } \\
13-\sqrt{ } a n-97\end{array}$} \\
\hline Rater ID & First Name & Last Name & Address & City & State & Zip & Work Phone \\
\hline DC96001 & Peter & Bauwell & 401 M. Street SW & Washington & D.C. & 20460 & (202) 233-9408 \\
\hline DC96002 & Robert & Berridge & 401 M. Street SW & Washington & D.C. & 20460 & (202) 233-9033 \\
\hline DC96016 & Lisa & Bloomfield-Resch & 501 3rd Street NW & Washington & D.C. & 20001 & (202) 233-9790 \\
\hline DC96003 & Eric & Carlson & 401 M. Street & Washington & D.C. & 20460 & (202) 233-9023 \\
\hline DC96004 & Glenn & Chinery & 401 M. St SW & Washington & D.C. & 20460 & (202) 233-9784 \\
\hline DC96005 & Blaine & Collison & 401 M. Street SW & Washington & D.C. & 20460 & 233-9139 \\
\hline DC96006 & Michael & Conchilla & 9300 Lee Highway & Fairfax & VA & 22031 & (703) $218-2688$ \\
\hline DC96008 & Angela & Coyle & 401 M. Street SW & Washington & D.C. & 20460 & (202) 233-9719 \\
\hline DC96009 & Jay & Hall & 9300 Lee Highway & Fairfax & VA & 22031 & (703) 934-3074 \\
\hline DC96010 & Caterina & Marzullo & 401 M. Street SW & Washington & D.C. & 20460 & (202) 233-9676 \\
\hline DC96011 & Donald & Mauritz & 1250 Maryland Ave SW & Washington & D.C. & 20024 & (202) 484-0880 \\
\hline DC96012 & Carol & May & 501 3rd Street, N.W. & Washington & D.C. & 20001 & 233-9787 \\
\hline DC96013 & David & Meisegeier & 9300 Lee Highway & Fairfax & VA & 22031 & (703) 934-3119 \\
\hline DC96014 & Stephen & Offutt & 401 M. Street & Washington & D.C. & 20460 & (202) 233-9791 \\
\hline DC96007 & Sam & Rashkin & 401 M. Street SW & Washington & D.C. & 20460 & 233-9786 \\
\hline DC96015 & Eric & Werling & 9300 Lee Highway & Fairfax & VA & 22031 & (703) 934-3224 \\
\hline
\end{tabular}




\section{Delaware Raters}

13-Van-97

\begin{tabular}{lllllll}
\hline Rater ID & First Name & Last Name & Address & City & State & Postal Code Work Phone \\
\hline \hline DE96001 & Joseph & Green & P.O. Box 600 & Greenwood & DE & 19950
\end{tabular}




\section{Maine Raters}

13-Jan-97

\begin{tabular}{|c|c|c|c|c|c|c|}
\hline First Name & Last Name & Address & City & State & Zip Code & Work Phone \\
\hline David & Adams & P.O. Box 278 & South Paris & ME & 04281 & (207) 743-7716 \\
\hline Bruce & Benube & 11 Cottage Street & Sanford & ME & 04073 & (207) 324-5762 \\
\hline Rick & Breton & P.O. Box 278 & South Paris & ME & 04281 & (207) 795-4065 \\
\hline Randall & Bridges & P.O. Box 1162 & Bangor & ME & 04402 & (207) 973-3608 \\
\hline Randy & Burguess & P.O. Box 200 & E. Wilton & ME & 04234 & (207) 645-3764 \\
\hline Bob & Carr & P.O. Box 280 & Milbridge & ME & 04658 & (207) 546-7544 \\
\hline David & Clements & P.O. Box 130 & Belfast & ME & 04915 & (207) $338-6810$ \\
\hline Pete & Delano & P.O. Box 1116 & Presque Isle & ME & 04769 & (207) 768-3023 \\
\hline Tom & Donahue & P.O. Box 130 & Belfast & ME & 04915 & (207) $338-6811$ \\
\hline George & Duranleau & 11 Cottage Street & Sanford & ME & 04072 & (207) $324-5762$ \\
\hline Kenneth & Feller & P.O. Box 1116 & Presque Isle & ME & 04769 & (207) 768.3023 \\
\hline Larry & Horvath & P.O. Box 130 & Belfast & ME & 04915 & (207) $338-6810$ \\
\hline Erik & Kindblom & P.O. Box 743 & Wiscusset & ME & 04578 & (207) 882-4025 \\
\hline Dan & Manning & P.O. Box 1162 & Bangor & ME & 04402 & (207) 973-3554 \\
\hline Grondin & Mark & 35 Market Square & South Paris & ME & 04281 & (207) $743-7716$ \\
\hline Gary & Mathews & P.O. Box 280 & Milbridge & ME & 04658 & (207) $546-7544$ \\
\hline Donald & Mercier & 510 Cumberland Ave & Portland & ME & 04101 & (207) $874-1140$ \\
\hline Carlton & Pinney & 283 Harlow Street & Bangor & ME & 04401 & (207) 973-3606 \\
\hline Randy & Rattray & P.O. Box 1116 & Presque Isle & ME & 04769 & (207) 764-3023 \\
\hline Wes & Riley & P.O. Box 72 & Sanford & ME & 04073 & (207) 324-5762 \\
\hline Gerry & Smith & 101 Water Street & Waterville & ME & 04903 & (207) $873-2122$ \\
\hline Eddie & St. Pierre & P.O. Box 280 & Milbridge & ME & 04658 & (207) $546-3034$ \\
\hline Edward & Stevens & 101 Water Street & Waterville & ME & 04903 & (207) $873-2122$ \\
\hline George & Tobin & P.O. Box 116 & Presque Isle & ME & 04769 & (207) 764-3721 \\
\hline
\end{tabular}




\begin{tabular}{lllllll}
\hline \hline First Name & Last Name & Address & City & State & Zip Code & Work Phone \\
\hline \hline David & Verboncoeur P.O. Box 808 & Rockland & ME & 04841 & $(207) 596-0361$ \\
Nornan & Wacker & 101 Water Street & Waterville & ME & 04903 & $(207) 873-2122$ \\
Andrew & Wynn & 59 State House Statio & Augusta & ME & 04333 & $(207) 287-8457$
\end{tabular}




\section{Maryland Raters}

13-Jan-97

\begin{tabular}{llllllll}
\hline \hline Rater ID & First Name & Last Name & Address & City & State & Postal Code & Work Phone \\
\hline \hline MD96003 & James & Battaglia & P.O. Box 1937 & Hughesville & MD & 20637 & $(301) 274-4339$ \\
MD96004 & Kevin & Clark & P.O. Box 1937 & Hughesville & MD & 20637 & $(301)$ 274-4416 \\
MD96002 & Lawrence & Harding & 9222 W. Stayman Drive & Ellicott City & MD & 21042 & $(410) 418-4785$ \\
MD96005 & Kathy & Nutter & P.O. Box 1937 & Hughesville & MD & 20637 & $(301) 645-3636$ \\
MD96001 & John & Porter & 6522 Blackhead Road & Baltimore & MD & 21220 & $(410) 335-3667$ \\
MD96007 & Mike & Rubala & P.O. Box 1937 & Hughesville & MD & 20637 & $(301)$ 274-4338 \\
MD96006 & Richard & Skinner & P.O. Box 1937 & Hughesville & MD & 20637 & $(301) 274-9290$ \\
MD96009 & Shawn & Sparks & P.O. Box 430 & Denton & MD & 21629 & $(410) 479-0380$ \\
MD96010 & Thomas & Tyndall III & P.O. Box 430 & Denton & MD & 21629 & $(410) 479-0420$ \\
MD96008 & Dave & Viar & P.O. Box 1937 & Hughesville & MD & 20637 & $(301) 274-9287$
\end{tabular}




\section{New Hampshire Raters}

13-Jan-97

\begin{tabular}{|c|c|c|c|c|c|c|c|}
\hline Rater ID & First Name & Last Name & Address & City & State & Postal Code & Work Phone \\
\hline NH96001 & Dennis & Biddle & 220 Main Street & Berlin & NH & 03570 & (603) 752-7105 \\
\hline NH96002 & Peter & Bilodeau & 220 Main Street & Berlin & $\mathrm{NH}$ & 03570 & (800) 552-4617 \\
\hline NH96003 & Peter & Bilodeau & $69 \mathrm{Z}$ Island Street & Keene & $\mathrm{NH}$ & 03431 & (603) 352-7512 \\
\hline NH96004 & Red & Boynton & P.O. Box 1016 & Concord & $\mathrm{NH}$ & 03302 & 225-3295 (603) \\
\hline NH96005 & Dean & Davignon & P.O. Box 547 & Dover & NH & 03820 & (603) 742-3372 \\
\hline NH96006 & Darren & Duffy & $69 \mathrm{Z}$ Island Street & Keene & NH & 03431 & (603) 352-7512 \\
\hline NH96007 & Keith & Dunfey & P.O. Box 5040 & Manchester & NH & 03108 & (603) 668-8010 \\
\hline NH96009 & Daniel & Girard & P.O. Box 5040 & Manchester & $\mathrm{NH}$ & 03102 & (603) 668-8010 \\
\hline NH96008 & Dan & Hartrey & 162 Beech Road & Eliot & ME & 03903 & (603) 431-2911 \\
\hline NH96010 & George & Hunton & 57 Regional Drive & Concord & $\mathrm{NH}$ & 03301 & (603) 271-2611 \\
\hline NH96011 & Philip & Koenig & 57 Regional Drive & Concord & $\mathrm{NH}$ & 03301 & (603) 271-2611 \\
\hline NH96012 & James & Mathes & P.O. Box 160 & Dover & $\mathrm{NH}$ & 03821 & (603) 749-1334 \\
\hline NH96013 & Michael & McQueeney & 1000 Elm Street, P.O. Box 330 & Manchester & NH & 03105 & (603) 634-2287 \\
\hline NH96014 & Thomas & Nickerson & P.O. Box 160 County Farm Rd. & Dover & NH & 03820 & (603) 749-1334 \\
\hline NH96015 & Gerald & Spaulding & P.O. Box 1016 & Concord & NH & 03301 & (603) 225-3295 \\
\hline NH96016 & John & Viele & 7 Junkins Avenue & Portsmouth & $\mathrm{NH}$ & 03801 & (603) 431-2911 \\
\hline NH96017 & Charlie & Wishart & P.O. Box 585 & \multicolumn{2}{|c|}{ N. WoodstockNH } & 03262 & (603) 745-6776 \\
\hline NH96018 & Patrick & Young & 18 Courtland Street & \multicolumn{2}{|c|}{ Farmingham NH } & 03835 & (603) 755-2689 \\
\hline
\end{tabular}




\begin{tabular}{|c|c|c|c|c|c|c|c|}
\hline \multicolumn{8}{|c|}{$\begin{array}{l}\text { New Jersey Raters } \\
\text { 13-Jan-97 }\end{array}$} \\
\hline Rater ID & First Name & Last Name & Address & City & State & Postal Code & Work Phone \\
\hline NJ96002 & Luis Anthony & Alicea & 88 West 12th Street & Bayonne & $\mathrm{NJ}$ & 07002 & (201) 437-7222 \\
\hline NJ96003 & John & Becker & 70 Elliot Street & Passaic & NJ & 07055 & (201) 472-7342 \\
\hline NJ96004 & Kevin & Cain & 6 Fox Cove Drive & Milville & NJ & 08332 & (609) 852-3884 \\
\hline NJ96005 & William & Craft & 718 S. Rt. 130 & Burlington & NJ & 08016 & (609) $386-5800$ \\
\hline NJ96006 & Shirley & Curry & 101 Broad Street & Trenton & NJ & 08645 & (609) 292-6140 \\
\hline NJ96007 & Joseph & Diaz & 815 Elizabeth Avenue & Elizabeth & NJ & 07201 & (908) 351-7727 \\
\hline NJ96008 & Dow & Ellis & 101 S. Broad Street & Trenton & NJ & 08625 & (609) 292-6140 \\
\hline NJ96009 & Michael & Fiorentino & 40 Washington Street & Toms River & NJ & 08202 & (908) 244-5333 \\
\hline NJ96010 & Alfred & Gunter & 10 Washington Street & Bridgeton & NJ & 08302 & (609) 455-5900 \\
\hline NJ96001 & Albert & Hairston & 40 Washington Street & Toms River & NJ & 08753 & (908) 244-5399 \\
\hline NJ96011 & Harold & Hasting & 550 Cookman Avenue & Asbury Park & NJ & 07712 & (908) 774-3100 \\
\hline NJ96012 & John & Korp & 350 Marshall Street & Phillipsburg & NJ & 08865 & (908) 454-4778 \\
\hline NJ96021 & Jorge & Martinez & 3700 Bergenline Avenue & Union City & NJ & 07087 & (201) 862-3871 \\
\hline NJ96013 & Carl & Marvin & P.O. Box 225 & Rancocas & NJ & 08073 & (609) 267-1535 \\
\hline NJ96020 & Douglas & McCleery & 15000 Commerce Parkway & Mt. Laurel & $\mathrm{NJ}$ & 08054 & (609) 722-9799 \\
\hline NJ96014 & Kenneth & Moll & 1310 Rt. 23 North & Wayne & $\mathrm{NJ}$ & 07470 & (201) 305-5731 \\
\hline NJ96015 & Eduardo & Montanez & 804 Willow Avenue & Hoboken & $\mathrm{NJ}$ & 07030 & (201) 864-3774 \\
\hline NJ96016 & Leonardo & Moreno & 101 South Broad Street & Trenton & $\mathrm{NJ}$ & 08645 & (609) 292-6140 \\
\hline NJ96017 & Kim & Rogers & 640 S. Broad Street, Room 422 & Trenton & $\mathrm{NJ}$ & 08650 & (609) 989-6959 \\
\hline NJ96018 & Jose & Sanchez & 101 Broad Street & Trenton & $\mathrm{NJ}$ & 08645 & (609) 292-6140 \\
\hline
\end{tabular}




\begin{tabular}{llllllll}
\hline \hline Rater ID & First Name & Last Name & Address & City & State & Postal Code & Work Phone \\
\hline NJ96019 & Richard & Townsend & 30 Montgomery Street, Room 408 Jersey City & NJ & 07302 & $(201) 661-2936$
\end{tabular}




\section{Appendix 1-I. List of Virginia Utilities, Exhibiting the Potential for Future Partnerships}

City

Abingdon:
(Zip: 24210)

Aldie:

Altavista:

(Zip: 24517)

Appalachia:

Appomattox:

Arlington:

Ashland:

Bedford:

Big Rock:

Big Stone Gap:

(Zip: 24219)

Blacksburg:

(Zip: 24060)

Bowling Green:

Bristol:

(Zip: 24201)

Brookmeal:

Buena Vista:

(Zip: 24416)

Castlewood:

Charlottesville:

Chase City:

Chesapeake: (Zip: 23320)

\section{Utility Name}

Appalachian Power Co

Abingdon Gas \& Appliance Co FerrellGas

Aldie Electric Inc

Altavista Power District

Southside Electric Co-op

Old Dominion Power Co.

Central VA Electric

EEA Development Inc.

Virginia Natural Gas

City of Bedford

Columbia Natural Resources Inc

Coastal Oil \& Gas Corp

Old Dominion Power Co

United Cities Gas Co

Virginia Tech Electric Service

Rappahannock Electric

Bristol City Utilities Board

United Cities Gas Co

Suburban Propane

Commonwealth Gas Svc Inc

Virginia Power

Wohlfopo Gas Co

Quality Gas Co

Virginia Power

Mecklenburg Electric Co-op

Centran Corp.

Virginia Power
Address

238 W. Main St.

1264 W. Main St.

Highway 11

(22001)

602 Lynch Mill Rd.

Rd 712

410 W Main St. (24216)

(24522)

1700 N Moore St. (22209)

504 Whitesel Rd. (23005)

P.O. Box 807 (24523)

Route 610 Conaway Crk (24603)

Cloverleaf Square, Bldg G 224 Wood Ave. E

112 Country Club Dr. 1421 N Main St.

Route 2 (22427)

300 Lee St.

816 Shelby

Hwy 501 N (24528)

$141 \mathrm{~W} 21^{\text {st }}$ St.

2307 Beech Ave.

RR 3 (24224)

709 Sonoma St. (22902)

1719 Hydraulic Rd (22901)

State Hwy 92 W (23924)

860 Greenbrier Cir.

801 Battlefield Blvd. S
Phone

(703) 628-9571

(703) 628-7262

(703) 429-2131

(703) $327-6969$

(804) 369-5668

(804) $369-5295$

(703) 565-0157

(804) $352-8442$

(703) $525-1600$

(804) 798-3162

(804) 299-5011

(703) $530-7878$

(703) 523-5003

(703) 523-1104

(703) 951-9184

(703) 231-6437

(804) 633-5011

(703) 669-4112

(703) 628-9511

(804) $376-2211$

(703) $261-3800$

(703) $261-2151$

(703) $762-7720$

(804) 977-1245

(804) $980-6700$

(804) $372-6200$

(804) $366-0188$ 
City

Chester:

(Zip: 23831)

Christiansburg:

Clifton Forge:

Clinchco:

Clintwood:

Clover:

Conaway:

Covington:

Crewe:

Culpeper:

Dale City:

Danville:

$\begin{array}{ll}\text { Dayton: } & \text { Shenandoah Valley Electric } \\ \text { Eagle Rock: } & \text { Columbia Gas Transmission Corp } \\ \text { Eastville: } & \text { A \& N Electric Cooperative } \\ \text { Emporia: } & \text { Mecklenburg Electric Co-op } \\ \text { (Zip: 23847) } & \text { Petrolane Gas Svc } \\ \text { Ewing: } & \text { Old Dominion Power Co } \\ \text { Exmore: } & \text { Delmarva Power \& Light Co } \\ \text { (Zip: 23350) } & \text { Greenbrier Chrysler Plymouth } \\ \text { Fairfax: } & \text { Fairfax Propane Ctr } \\ \text { Farmville: } & \text { Suburban Propane } \\ \text { Fieldale: } & \text { Appalachian Power Co } \\ \text { Fishersville: } & \text { Virginia Power }\end{array}$

Chesterfield Power Station

Virginia Power

Appalachian Power Co

Petrolane Gas Svc

East Tennessee Natural Gas Co

Apalachian Power Co

Old Dominion Electric Co-op

Columbia Gas Transmission Corp

Commonwealth Gas Svc Inc

Southside Electric Corp

Commonwealth Gas Svc Inc

Northern Virginia Electric

Abercrombie LP Gas Div

Abercrombie Oil Co

Chatham Oil Co

Chatham Oil Co

Suburban Propane
Address

500 Coxendale Rd

11200 Iron Bridge Rd

412 Roanoke Rd (24073)

419 E Ridgeway St. (24422)

Rt 654 (24226)

P.O. Box 490 (24228)

Rt 600 (24534)

Conaway Creek (24603)

153 N Maple Ave. (24426)

Hwy 460 (23930)

1202 S Main St. (22701)

14500 Minnieville Rd (22193)

200 River St. (24540)

2930 W Main St. (24541)

108 S. Main St. (24541)

3730 Hwy 29 N (24540)

1103 Piney Forest Rd (24540)

185 Huffman Dr. (22821)

RR 1 Box 66 (24085)

Lower Peninsula (23347)

1413 Pleasant Shade Dr

302 W. Atlantic St

Main St. (24248)

Rt 13, P.O. Box 608

Bank St.

9754 Lee Hwy (22031)

Hwy 460 W (23901)

Rt 57 A \& 883 (24089)

Rt 250 (22939)
Phone

(804) 796-7081

(804) 748-5868

(703) 745-3771

(703) $862-4148$

(703) $835-1114$

(703) $926-4688$

(804) 454-7962

(703) 530-7106

(703) $962-1181$

(804) 645-7721

(703) $825-8541$

(703) $878-6100$

(804) 793-5811

(804) 792-8022

(804) 432-0251

(804) 836-2209

(804) 836-6335

or 793-2144

(703) 879-2551

(703) $884-2473$

(804) 678-7633

(804) 634-8168

(804) 634-9595

(703) 445-5397

(804) 336-3176

(804) $442-4600$

(703) $352-5788$

(804) 392-5151

(703) 627-1246

(703) $949-8371$ 
City

Franklin:

Fredericksburg:

(Zip: 22408)

\begin{tabular}{|c|c|}
\hline Gainesville: & Northern Virginia Electric \\
\hline $\begin{array}{l}\text { Galax: } \\
\text { (Zip: 24333) }\end{array}$ & $\begin{array}{l}\text { Appalachian Power Co } \\
\text { Suburban Propane }\end{array}$ \\
\hline Gate City: & Appalachian Power Co \\
\hline $\begin{array}{l}\text { Glen Allen: } \\
\text { (Zip: 23060) }\end{array}$ & $\begin{array}{l}\text { Old Dominion Electric Co-or } \\
\text { Rental Tools \& Equipment }\end{array}$ \\
\hline Glen Lyn: & Appalachian Electric Power \\
\hline Gretna: & Mecklenburg Electric Co-op \\
\hline Grundy: & Appalachian Power Co \\
\hline Hampton: & $\begin{array}{l}\text { Virginia Power } \\
\text { Virginia Power }\end{array}$ \\
\hline
\end{tabular}

Harrisonburg: Commonwealth Gas Svc Inc

(Zip: 22801) Harrisonburg Electric

Herndon:

(Zip: 22070)

Hillsville:

Independence:

Kenbridge:

Lebanon:

Leesburg:

(Zip: 22075)

Lexington:

(Zip: 24450)

Lovingston:
Hadson Power II

Commonwealth Gas Svc Inc

Rappahannock Electric Co-op

Virginia Power

Columbia Gas Transmission Corp

Virginia Power

Appalachian Power Co

(24343)

Appalachian Power Co

Commonwealth Propane Inc

Appalachian Power Co

Northern Virginia Elec Co-op

Virginia Power

Columbia Gas Svc

Columbia Gas Transmission Corp

Central Virginia Electric Co-op $\underline{\text { Address }}$

30134 General Thomas Hwy (23851)

10710 Columbia Dr.

247 Industrial Ct

980 Warrenton Rd

5399 Wellington Rd. (22065)

502 Main St. S

405 Railroad Ave. S

185 E. Jackson St. (24251)

4201 Dominion Blvd. 11875 S Washington Hwy

Route 460 (24093)

Route 40 (24557)

Route 460 W (24614)

P.O. Box 9001 (23670)

902 G St (23661)

126 W Bruce St.

89 W Bruce St.

11000 Leesburg Pike

101 Elden St.

Hickory Hills Shopping Ctr

(24348)

210 Main St. (23944)

Route 4 (24266)

349 E Market St.

620 Sycolin Rd. SE

113 S. Jefferson St.

Borden Rd.

Front St (22949)
Phone

(804) 562-0692

(703) 898-2817

(703) $825-8373$

or $898-8500$

(703) $752-8811$

(703) 754-6711

(703) 238-2967

(703) 236-3281

(703) $388-3851$

(804) 747-0592

(804) $550-2978$

(703) 728-3191

(804) $858-1288$

(703) $935-2153$

(804) $928-2000$

(804) 247-1241

(703) 434-7696

(703) 434-5361

(703) $759-2115$

(703) $934-9660$

(703) $728-2711$

(703) 773-3535

(804) 292-3706

(703) $889-1130$

(703) 777-2041

(703) $777-2050$

(703) 463-4821

(703) $463-3138$

(804) 263-8336 
$\underline{\text { City }}$

$\begin{array}{ll}\text { Lowmoor: } & \text { Virginia Power } \\ \begin{array}{ll}\text { Luray: } \\ \text { (Zip: 22835) }\end{array} & \begin{array}{l}\text { Potomac Edison Co } \\ \text { Southern States Co-op Inc Svc }\end{array} \\ \text { Lynchburg: } & \begin{array}{l}\text { Appalachian Power Co } \\ \text { Commonwealth Gas Svc Inc. } \\ \text { Suburban Propane }\end{array} \\ & \begin{array}{l}\text { Potomac Edison Co. }\end{array}\end{array}$

Madison Heights: Commonwealth Propane Inc

Manassas:

(Zip: 22110)

Marion:

(Zip: 24354)

Martinsville:

(Zip: 24112)

Midlothian: Virginia Power

Millboro: Barc Electric Cooperative

(Zip: 24460) Barc Electric Cooperative

Mineral: $\quad$ North Anna Information

Mt. Crawford: Shenandoah Valley Electric

Mt. Jackson: Shenandoah Valley Electric

New Castle: Craig-Botetourt Electric Co-op

Newport News: FerrellGas

(Zip: 23606) Virginia Natural Gas

Nora:

Norfolk:

Norton:

(Zip: 24273)

Onley:
Equitable Resources Inc

Energy Marketing Exchange Inc Virginia Natural Gas Co
Address

IH 64 (24457)

2 Mechanic St

201 Williams St

800 Main St (24504)

P.O. Box 6160 (24505)

2150 Airport Rd (24502)

203 Washington St (22727)

2111 Amherst Hwy, \#C (24572)

8900 Mathis Ave.

10323 Lomond Dr.

10201 Balls Ford Rd

121 Broad St

555 S Main St.

904 Fisher Rd.

757 Stultz Rd.

208 Lester St

14500 Midlothian Tpke (23113)

100 Main St

107 High St

North Anna Pwr Sta (23117)

Rt 2, Hwy 257 (22841)

P.O. Box 424 (22842)

P.O. Box 265 (24127)

510 Muller Lane

P.O. Box 6200

P.O. Box 313 (24272)

125 Saint Pauls Blvd (23510)

5100 E. Virginia Beach Blvd

(23502)

530 Kentucky Ave. SE

1000 Park Ave. NW

Old Esserville Rd

US Route 13 (23418)
Phone

(703) $882-7001$

(703) 743-4582

(703) 743-6518

(804) $522-4800$

(804) 847-7721

(804) 239-1004

(703) 832-7457

or $948-4526$

(804) $522-8588$

(703) $361-3181$

(703) $335-0503$

(703) $368-3255$

(703) $783-5188$

(703) $783-5101$

(703) 632-5485

(703) 632-9808

(703) 632-5662

(804) $379-4848$

(703) 997-9124

(703) 839-2955

(703) $894-4394$

(703) $434-2200$

(703) $477-3168$

(703) $864-5121$

(804) 249-1284

(804) 873-1322

(703) 835-9134

(804) 640-7534

(804) 466-5536

(703) 679-2331

(703) 679-1171

(703) 679-4422

(804) $787-1567$ 
Palmyr

Parksley:

Pearisburg:

(Zip: 24134)

Pennington Gap: Old Dominion Power Co.

Petersburg:

(Zip: 23803)

Portsmouth: Commonwealth Gas Svc Inc

Pulashi:

(Zip: 24301)

Radford:

(Zip: 24141)

Richmond

$\begin{array}{ll} & \text { Roanoke Gas Co } \\ \text { Seaford: } & \text { Walsh Electric Co } \\ \begin{array}{ll}\text { South Boston: } \\ \text { (Zip: } 24592)\end{array} & \begin{array}{l}\text { Suburban Propane } \\ \text { Virginia Power }\end{array} \\ \text { Springfield: } & \begin{array}{l}\text { Virginia Power } \\ \text { Washington Gas Co }\end{array} \\ & \begin{array}{l}\text { Arrington Oil Co. } \\ \text { St. Paul: } \\ \text { (Zip: } 24283)\end{array} \\ \begin{array}{ll}\text { Old Dominion Power Co } \\ \text { (Zip: } 24401)\end{array} & \begin{array}{l}\text { Columbia Gas } \\ \text { Shenandoah Valley Electric }\end{array} \\ \text { Sterling: } & \text { JED Mechanical Contractors } \\ \text { Stuart: } & \text { Appalachian Power Co }\end{array}$

Roanoke
Central Virginia Electric Co-op

A \& N Electric Cooperative

Appalachian Power Co

Commonwealth Gas Svc Inc

Commonwealth Gas Svc Inc

Virginia Power

Appalachian Power Co

United Cities Gas Co

Claytor Hydro Plant

United Cities Gas Co

Columbia Gas Propane Corp

Dominion Resources Inc

Doswell Limited Partnership

Richmond Utilities

Stonewall Gas

U C Operating Svc

Virginia Power

Virginia Power \& Electric Co

Whittle Electric Inc

Appalachian Power Co
(22963)

(804) $589-8342$

19058 Greenbush Rd (23421)

(804) $665-5116$

315 N Main St

(703) 921-3777

(703) $921-4570$

105 E. Morgan Ave. (24277)

(703) $548-1171$

22 S Sycamore St.

1340 E Washington St

(804) $882-0600$

(804) $862-8870$

800 Loudoun Ave. (23707)

(804) $393-7200$

34 W Main St

(703) $994-1140$

403 Jefferson Ave. $N$

(703) $980-2720$

RR 1, Box 300A

$10131^{\text {st }}$ St.

(703) 839-2881

(703) 639-1661

800 Moorefield Park Dr (23236)

901 E Byrd St, Fl 7 (23219)

(804) $323-5300$

(804) $775-5700$

(804) 354-0878

(804) 644-3000

(804) 780-0064

(804) 672-7640

(804) $756-2000$

(804) 771-3000

(804) 271-0024

7518 Whitepine Road (23237)

40 Franklin Rd. SW (24011)

519 Kimball Ave. NE (24016)

(703) $985-2300$

(703) 344-6651

505 Seaford Rd. (23696)

(804) $890-0636$

1719 Seymour Dr.

2601 N. Main St.

(804) $572-2451$

(804) 572-2941

7888 Backlick Rd (22150)

(703) 934-9670

6801 Industrial Rd. (22151)

(703) $750-9500$

Russell St.

(703) $762-7358$

(703) 762-5077

107 S. Coalter St.

(703) $885-1241$

1209 Richmond Ave.

(703) $885-8971$

105 Douglas Ct (20166)

(703) $742-0550$

Blue Ridge St (24171)
(703) 694-3776 
City

Utility Name

Suffolk

Virginia Natural Gas Co

Surry:

Virginia Power

Tangier:

Tazewell:

(Zip: 24651)

Appalachian Power Co

Appalachian Power Co

Temperanceville: Tri-County Gas Co

Verona: $\quad$ Dixie Gas \& Oil Corp

Victoria:

VEPCO (23974)

Virginia Beach:

FerrellGas

Roger's Electrical of Virginia

Virginia Power

Virginia Power

White Electric Co

Warrenton: Virginia Power

Warsaw: $\quad$ Nortbern Neck Electric Co-op

Waverly:

Winchester:

Windsor:

Woodbridge:

(Zip: 22191)

Woodstock: Virginia Power

Wytherville: Appalachian Power Co

(Zip: 24382)
Appalachian Power Co

Suburban Propane

United Cities Gas Co
Address

Phone

130 S. Commerce St. (23434)

(804) 539-2376

P.O. Box 315 (23883)

(804) $357-3184$

(23440)

(804) $891-2325$

Route 460 W

(703) $988-5561$

W Main St

(703) 964-2373

(23442)

(804) 824-6261

4833 Lee Hwy (24482)

(703) $248-6273$

(804) 696-2018

109 Freight Lane (23462)

789 Seahawk Cir. (23452)

4901 Princess Anne Rd (23462)

525 First Colonial Rd (23451)

1364 London Bridge Rd (23456)

Route 643 (22186)

(703) $347-4421$

1102 St. Johns St (22572)

(804) $333-3621$

7103 General Mahone Hwy

(804) 834-2424

47 S. Cameron St (22601)

Rt 11 S (22603)

I-81 at Exit 79 (22601)

(703) 662-3466

(703) $665-0115$

(703) 869-1111

$52 \mathrm{~W}$ Windsor Blvd (23487)

(804) 242-6181

1329 Horner Rd

(703) $890-3112$

1303 G St.

1901 Reddy Dr.

(703) 494-9050

(703) 494-5111

1133 Hisey Ave. (22664)

(703) $459-2110$

P.O. Box 561

680 W. Main St.

(703) 688-4041

(703) 228-5531

(703) 228-3251

290 Cassell Rd

(703) 228-3137 


\section{Chapter 2}

\section{The California HERS/EEMs Pilot Program and Related Efforts: A}

Case Study Covering the Years 1984 - 1995

Nancy E. Collins, Ph.D., Q ${ }^{4}$ Associates, Oakland, California 


\section{Acknowledgments}

The author appreciates the cooperation and contributions of the following people through interviews, telephone conversations, printed materials, data, reviews of drafts of the report, and continuing updates, September 1995 through November 1996:

- CHEERS: Michael Martin; Tom Hamilton

- PG\&E: Aslina Abdullah; David Altscher

- California Energy Commission: Carroylin Threlkel; Randel Reidel

- HUD/FHA Sacramento Office: Patti Anderson

- Energy Plus: David Peterson

This case study was prepared under funding from the National Renewable Energy Laboratory, Barbara C. Farhar, Technical Monitor. 


\section{Executive Summary}

California promotes energy efficiency financing linked with energy ratings. This case study addresses the evolution, status, and future direction of such promotion efforts. It is based on information obtained between July 1995 and March 1996 from interviews with and information provided by personnel in the organizations playing key roles in instituting home energy ratings systems and energy efficiency financing (HERS/EEF) in the state. The time period covered in the report begins in the early 1980s and concludes December 31, 1995, although occasional reference is made to preliminary 1996 data, activities, and goals.

Organizations highlighted in the report and whose staff were interviewed include: the Califormia Home Energy Efficiency Rating System, Inc. (CHEERS); Energy Plus, Inc.; the Califomia Energy Commission (CEC); the U.S. Department of Housing and Urban Development (HUD) Federal Housing Administration (FHA) Sacramento Field Office; Pacific Gas \& Electric Company (PG\&E); and Lawrence Berkeley Laboratory (LBL). Many other housing, lending, and consumer associations are involved in HERS/EEM. activities through contracts with CEC, and private sector lenders and realty agencies offer their own incentives.

The CEC initiated development of an acceptable rating tool and system in the early 1980s, field tested it, contracted for further development and research on HERS in the late 1980s, became responsible per state legislation (SB 1207) for issuing HERS guidelines and oversight of the HERS industry in the early 1990s, and currently is implementing a state-mandated (SB 314) and funded marketing, training, and consumer information program. The State's energy-efficiency building performance standards (Title 24) exceed CABO-MEC'92.

With the support of the CEC, a consortium of California utilities formed CHEERS (a public/private partnership) for the purpose of developing and testing a rating tool and system that would be used in conjunction with their demand-side programs and incentives. Once field-testing was completed in mid1994, CHEERS began the difficult transition toward becoming self-sufficient by the end of 1996 . One action is developing a market for ratings that goes far beyond HUD EEMs and utility incentives (which have been largely phased out in response to deregulation of the electric utilities in California). During 1993-1995, CHEERS completed 15,270 ratings. That only 2\% of these were done in 1995 (and these were primarily repeat ratings), demonstrates the market problem faced by CHEERS. Its goal is 600 per month by mid-1996 and 2,000 per month in 1997. Two ways of achieving these goals are to offer financing through CHEERS and to expand to other states.

California is unique (at this time) in that a second organization (a private company) also offers ratings in the Central Valley. The two raters who own Energy Plus, Inc., which began operating in March 1994, completed 71 ratings in 1994, 204 in 1995, and 62 in the first two-and-a-half months of 1996. Their approach is totally market-based. Working with EEM brokers and spending considerable time in one-onone meetings with lenders and real estate agents, they focus on rating homes that have a high probability of

obtaining HUD EEMs. This approach has resulted in 190 (61\%) completed EEMs. In 1995, they leamed that focusing on repossessed HUD properties was even more successful in producing EEMs. Energy Plus has set a 1996 goal of 400-500 ratings and 300-350 EEMs. They, too, plan to go national and begin training others. 
As of September 1995, 1,048 EEMs were underwritten in California for a total value of $\$ 131.5$ million. These numbers must be viewed within the context of the size of California and its housing market. The state's population is 31 million, with 10.9 million single-family homes, of which about half a million are sold each year for a total volume of mortgages exceeding $\$ 100$ billion. The number of professionals serving the housing industry is, accordingly, enormous-nearly 100,000 real estate agents belonging to CAR, 70,000 mortgage banking professionals, and 450 multiple listing services.

Despite the daunting task of reaching these large numbers of homebuyers/owners distributed throughout an equally large geographic area, considerable attention has been paid by the CEC, HUD, the utilities, and CHEERS to providing consumers with information (225,000 EEMs disclosure booklets printed in 1995) and training real estate agents (about 2,650 in 1995), lenders (about 450 in 1995), and contractors (about 200 in 1994-95). CHEERS has trained 213 raters, of whom about 80 are "active." 


\section{Contents}

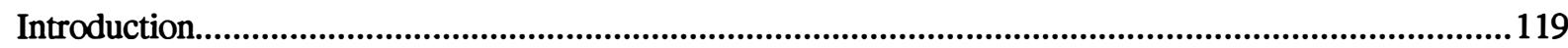

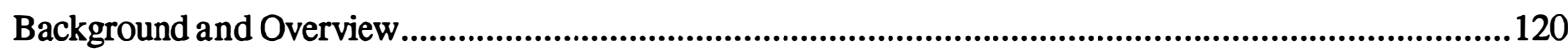

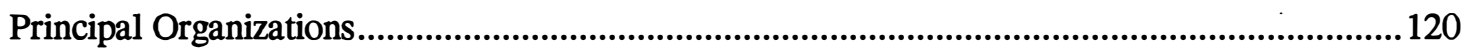

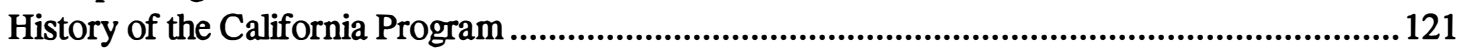

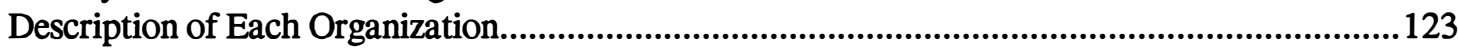

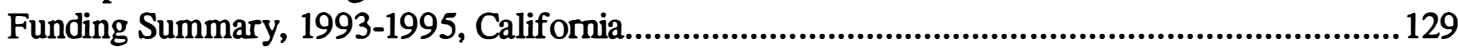

Operating Environment and Relationship to Activities at the National Level..............................130

Other Background Material.........................................................................................................130

Energy Efficiency Financing Products in California............................................................................132

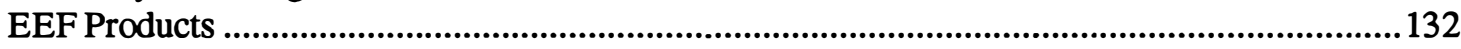

Energy Efficiency Financing Incentives ................................................................................. 133

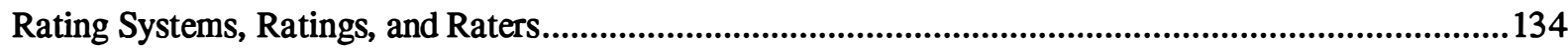

The California Rating Systems ............................................................................................134

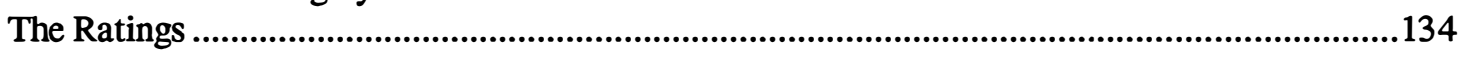

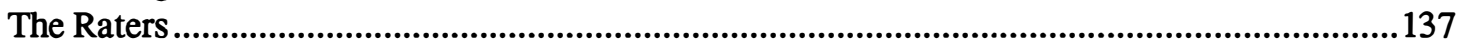

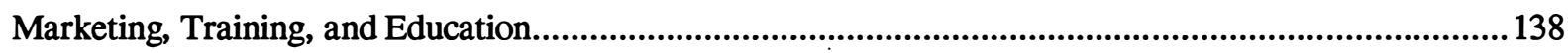

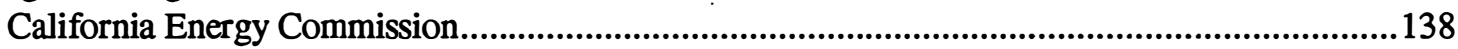

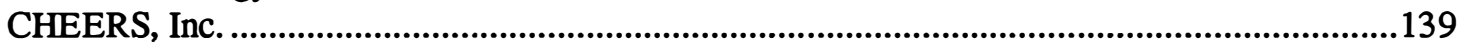

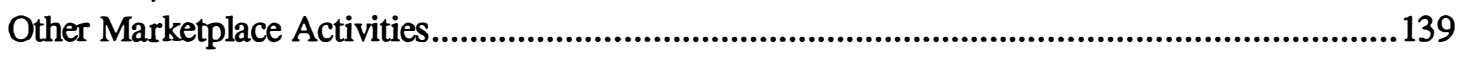

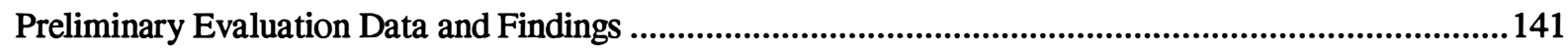

Problems and Solutions, Successes, and Future Directions .............................................................143

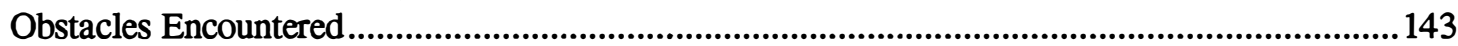

Strategies for Overcoming These Obstacles ...................................................................................143

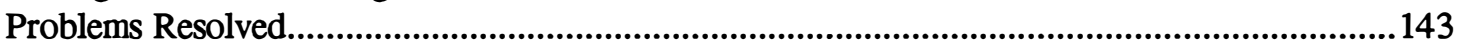

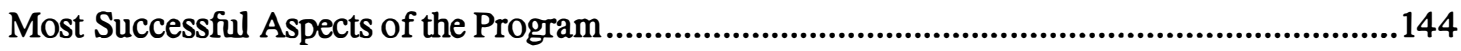

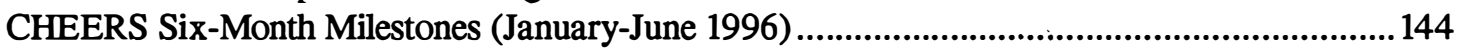

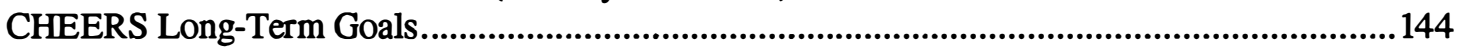

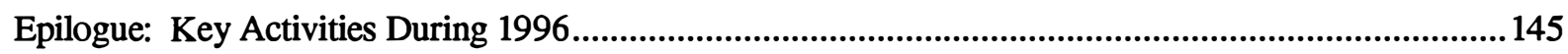

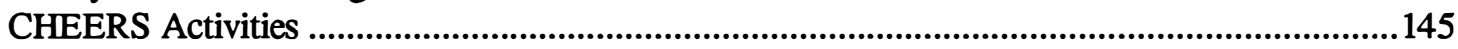

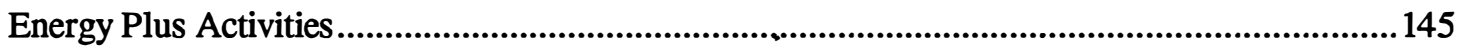

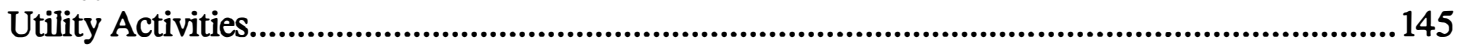

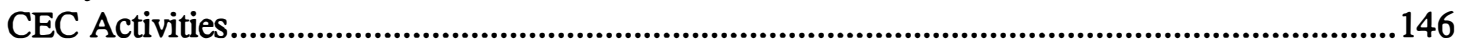

Other Marketplace Activities.................................................................................................147 


\section{Tables}

Table 2-1. Chronology of Events, California HERS/EEM ..........................................................122

Table 2-2. Funding Sources and Estimated Amounts, 1993-1995 .....................................................129

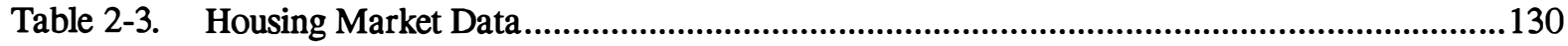

Table 2-4. HUD/FHA Mortgage and EEM Activities .........................................................................130

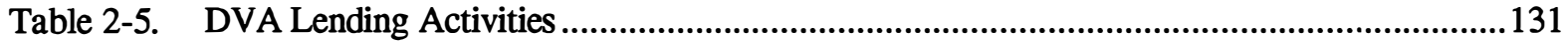

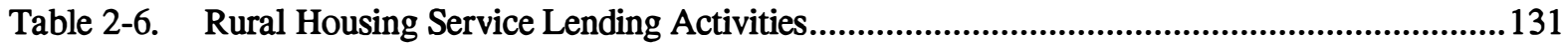

Table 2-7. Number of Housing Market Professionals..........................................................................131

Table 2-8. Number of Ratings Completed by Calendar Year.............................................................135

Table 2-9. CHEERS Ratings by Category ....................................................................................135

Table 2-10. Homes Receiving Ratings (with Utility, Fuel Type, and Field Office)...............................136

Table 2-11. CEC Contractors for Training and Education.............................................................138

Table 2-12. CEC Training Activities Using DOE Funds via a Subcontract with the Building Industry Institute, 1994-96.

Table 2-13. CEC Training Activities with State Funds ....................................................................140

Table 2-14. Descriptions of CHEERS Ratings, 1993-1995 ................................................................142

Table 2-15. Description of Energy Plus Ratings, 1994-95 ...............................................................142

\section{Figures}

Figure 2-1. Use of Energy Plus Ratings in Obtaining HUD/FHA EEMs 141

Figure 2-2. Use of CHEERS Ratings for Financing Energy Efficient Mortgages, 1993-1995

\section{Appendix}

Appendix 2-A. California Process Evaluation

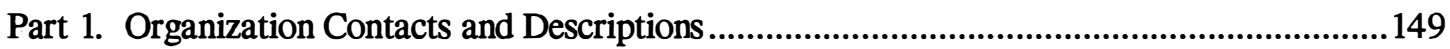

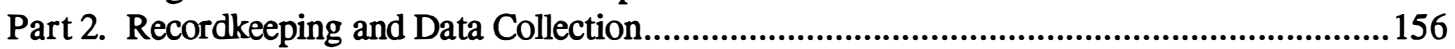

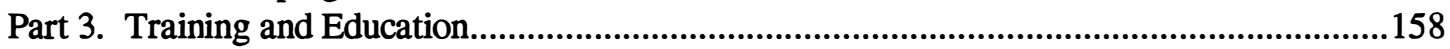

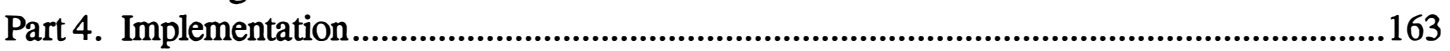




\section{Introduction}

This report focuses on HERS and EEMs activities in California from the time actions were first taken in the mid-1980s through December 1995, with emphasis on events during 1993, 1994, and 1995, and particular attention to activities related to California in implementing its HUD pilot state status. The author conducted on-site interviews in September 1995 with staff representing the following organizations:

- California Home Energy Efficiency Rating System, Inc. (CHEERS), Costa Mesa

- HUD FHA Regional Office, Sacramento

- California Energy Commission (CEC), Sacramento

- Pacific Gas \& Electric Company (PG\&E), San Francisco

Telephone interviews were held with:

- Energy Plus

- Lawrence Berkeley Laboratory (LBL)

- California Association of REALTORS ${ }^{\circledR}$

The approach taken in consolidating interview information and data was to "tell the story" of events, organizations, and progress toward achieving success in voluntarily linking HERS with EEMs. The interviews themselves focused on clarifying information that had been obtained by NREL during the last several years and understanding conflicting and confusing data. Prior to conducting interviews, copies of the list of information needed for the study were sent to those scheduled for interviews; the results are shown in Appendix 2-A and are the basis for much of the narrative in the body of this case study. It was not unusual to find that each person interviewed had a slightly different version or view of certain key events, problems encountered, and degree of success of HERS and EEMs. It was this author's job to fairly and accurately describe events in California based on the collective interviews, since each interview (and subsequent rounds of review and phone conversations) added new pieces to the puzzle. Due to funding limitations, not all organizations and individuals involved over the years could be interviewed. NREL provided guidance on who to talk with, and those people were helpful in obtaining information from others who were not interviewed.

Late in 1996, when it became clear that the case studies might not be printed and distributed until early 1997, those people previously interviewed were recontacted for updates on what significant events had transpired during 1996. This brief summary is found as an addendum to this case study. 


\section{Background and Overview}

\section{Principal Organizations}

Key organizations and their roles in California HERS/EEMs activities are described in this section. Contact information is in Appendix 2-A.

- California Energy Commission (CEC), Energy Efficiency Division. The CEC supports HERS and EEMs activities by coordinating training and educational programs; it also certifies rating organizations and carries out mandated legislation.

- California Home Energy Efficiency Rating System, Inc. (CHEERS). This group trains raters; maintains database of ratings; markets HERS/EEMs; operates an 800 number; and refers callers to raters, contractors, facilitators, lenders, and others.

- Energy Plus. Energy Plus conducts and calculates ratings for home buyers who are interested in HUD EEMs.

- HUD/FHA Field Offices. HUD/FHA endorses and underwrites EEMs and other financing products; participates in educational seminars, particularly for home buyers, real estate agents, and lenders.

- State Legislature. The legislature establishes building standards and authorizes CEC program funds.

- California Association of REALTORS ${ }^{\oplus}$ (CAR) and the California Department of Real Estate (DRE). CAR develops continuing education courses on HERS/EEMs for real estate professionals; DRE approves courses for continuing education units (CEUs).

- EEM Service Companies. Brokers in these companies put together packages linking HERS and EEMs, including arranging for ratings.

- Pacific Gas and Electric Company (PG\&E). PG\&E led a consortium of utilities in developing a rating tool and field testing it; offered rebates for the performance of CHEERS ratings; supports use of ratings, facilitates CHEERS training; provides CHEERS with training facilities, markets the CHEERS program to the trade professionals and consumers; and holds continuing education courses on CHEERS and EEMs for Realtors and Lenders.

- Southern California Edison (SCE). SCE holds continuing education course for real estate agents and lenders jointly with PG\&E.

- Other Major Electric and Gas Utilities. Provided support for CHEERS through 1995; from time to time, offered energy-efficiency rebates, incentives, and loans. 
- Professional Associations. California Bankers Association; California Building Industry Association; Insulation Contractors Association; California Real Estate Inspectors Association; Califormia Association of Redevelopment Agencies; California Association of Real Estate Appraisers; California Mortgage Bankers Association; Western Savings League; California Association of Sheet Metal and Air Conditioning Contractors; Building Industry Institute; Sacramento Home Loan Counseling Center; and Association of Professional Mortgage Women.

- Others. Natural Resources Defense Council; California Institute for Energy Efficiency; the Community Development Council; Consumer Action; Western Affordable Comfort Conference; and Pacific Coast Builders \& Remodelers Conference.

\section{History of the California Program}

The development of home energy rating systems in California has involved actions by diverse entitiessometimes in coordinated and collaborative activities and sometimes singly. A chronology of key events is provided in Table 2-1.

In the early 1980s, Lawrence Berkeley Laboratory developed a "slide rule" rating and labeling tool for the CEC. The CEC piloted the tool in three areas of the state: Roseville, Santa Rosa, and Pasadena. The demonstration pilots were directed to six groups of potential users of ratings: homebuyers and renters, homeowners (sellers), real estate agents and brokers, primary and secondary lenders, appraisers, and local government officials. Subsequently, the CEC contracted with the California Building Industry Association (CA BIA) to develop a new home labeling program.

In 1990, PG\&E asked for the support and participation by the CEC in creating a HERS/EEMs program. As a result, a consortium of California utilities underwrote the formation in October 1990 of the California Home Energy Rating System (CHERS) for the purpose of developing and pilot testing a home energy rating tool. Although the LBL tool was considered, it was not used by CHERS. Rather, a computer-based tool that was based on California's Title 24 energy-efficiency building code was developed; a home meeting the state's standards would be rated in the 70-80 range.

The CHERS office was established in the Los Angeles area and utility personnel were detailed to serve as its staff. The validity of the rating system was tested in 1992 and then expanded to other parts of the state. CHERS was renamed CHEERS, Inc., in late 1992. During 1993, PG\&E estimated that 7,000 ratings were completed (PG\&E offered 7,000 coupons good for free ratings) and 35 EEMs were written. After California was named a pilot state by HUD in April 1993, CEC formed a task force to design the pilot program. Members were from CEC, HUD and DOE regional offices, major utilities, and CHEERS. HUD provided funding to help CHEERS reach trade allies during the remainder of 1993.

In mid-1994, after the field tests were completed, the CHEERS staff returned to their utilities, and permanent staff were hired. In late 1994, the utility consortium announced that it would not fund CHEERS beyond 1996. The new CHEERS executive director discovered, upon taking over the organization in early 1995, that the number of ratings had fallen dramatically (only 12 completed in February 1995). He interpreted this dramatic fall-off as being due to a change in the primary function of CHEERS. During 1993-94, its function was that of validating the rating system and promoting and marketing the program, though not necessarily promoting EEMs. In other words, there was no market base. In 1995, CHEERS began "reinventing" itself, with emphasis on a market-driven system, becoming self-sustaining financially, and expanding services beyond California. 
On a path parallel to the creation of CHEERS, the Califomia Legislature passed two bills: (1) SB 1207 (September 1992) called for the CEC to develop HERS guidelines, promote EEMs, and conduct a pilot program demonstrating both; and (2) SB 314 (September 1993) provided $\$ 200,000$ for training activities in support of the HERS/EEMs program. The CEC also has the responsibility for regulating the "industry" by certifying rating programs and organizations offering HERS (not the rating systems themselves). In addition, DOE is supporting development of the HERS/EEMs infrastructure by providing funds for training activities to CEC and CHEERS.

On the private sector side, one independent private company (Energy Plus) has begun offering ratings in the Central Valley, working with other entrepreneurs to identify potential clients, conduct the ratings, arrange financing, make contact with the HUD field office, and help complete the paperwork. Several banks are very active, offering their own EEMs and more and more real estate agents are finding HERS and EEMs to be unique marketing tools.

Table 2-1. Chronology of Events, California HERS/EEM

\begin{tabular}{|l|l|}
\hline Date & Event \\
\hline 1984 & $\begin{array}{l}\text { Slide rule rating tool developed by LBL for the CEC; consisted of bill desegregation } \\
\text { and on-site evaluation }\end{array}$ \\
\hline Mid-1980s & $\begin{array}{l}\text { CEC established a small pilot HERS program in the Central Valley using the slide } \\
\text { rule tool }\end{array}$ \\
\hline $\begin{array}{l}\text { June 1987-June } \\
1988\end{array}$ & $\begin{array}{l}\text { CEC contracted with California Building Industry Association to develop a labeling } \\
\text { and/or rating program that would be acceptable to the state's housing industry }\end{array}$ \\
\hline $\begin{array}{l}\text { June 1989 - March } \\
1990\end{array}$ & $\begin{array}{l}\text { CEC contracted with O'Neill and Company to evaluate HER systems throughout the } \\
\text { U.S. to determine reasons for success or failure of each }\end{array}$ \\
\hline 1990 & $\begin{array}{l}\text { PG\&E requested CEC's support and participation, including serving on the Board of } \\
\text { Directors, to establish a HERS/EEMs program in California }\end{array}$ \\
\hline $\begin{array}{l}\text { June 1990 - August } \\
1991\end{array}$ & $\begin{array}{l}\text { CEC contracted with NEOS Corporation to design and develop a simple evaluation } \\
\text { system to determine the energy efficiency of new and existing single family } \\
\text { residences }\end{array}$ \\
\hline September 1990 & $\begin{array}{l}\text { CHERS, Inc., in place-a public/private nonprofit partnership initiated by a } \\
\text { consortium of electric and gas utilities in Califormia }\end{array}$ \\
\hline $1991-1992$ & CHERS, Inc., participated in HERS/EEMs National Collaborative funded by DOE \\
\hline September 1992 & $\begin{array}{l}\text { California legislation (SB 1207) passed requining that the CEC develop criteria for a } \\
\text { statewide HERS program }\end{array}$ \\
\hline November 1992 & Rating software completed; CHERS name changed to CHEERS, Inc. \\
\hline $\begin{array}{l}\text { May - November } \\
1992\end{array}$ & $\begin{array}{l}\text { A very large statewide collaborative effort developed to work with mortgage industry } \\
\text { representatives to reach agreement on rating system and underwriting procedures }\end{array}$ \\
\hline February 1993 & CHEERS implemented in Northern California; goal of 1200 ratings in six months \\
\hline April 1993 & $\begin{array}{l}\text { California selected as a HUD pilot state; task force formed by CEC to design the } \\
\text { pilot program (CEC, HUD and DOE regional offices, major utilities, and CHEERS) } \\
\text { CHEERS expanded to Southern Califormia }\end{array}$ \\
\hline May/June 1993 & CHEERS launched for "trade allies" (\$55,000 from HUD for training) \\
\hline June 1993 &
\end{tabular}


Table 2-1. Chronology of Events, California HERS/EEM (Cont.)

\begin{tabular}{|c|c|}
\hline September 1993 & $\begin{array}{l}\text { California legislation (SB 314) passed requining support of the HUD EEMs } \\
\text { program; } \$ 200,000 \text { for CY 1994 allocated to the CEC for the program, which } \\
\text { includes developing a pilot program for training members of the housing, realty, and } \\
\text { lending industries, and preparation of a consumer booklet disclosing to buyers the } \\
\text { availability of EEMs }\end{array}$ \\
\hline December 1993 & $\begin{array}{l}\text { G\&E proposed to work with Fannie Mae to provide unsecured loans for energy- } \\
\text { ficiency improvements }(\$ 2,500 \text { to } \$ 10,000 \text { for } 60 \text { months @ 9-10\%); not linked } \\
\text { ith ratings }\end{array}$ \\
\hline 1993 & $\begin{array}{l}\text { G\&E completed } 7,000+\text { CHEERS ratings in its service territory; } 35 \text { EEMs } \\
\text { ompleted; certified } 110+\text { raters }\end{array}$ \\
\hline January 1994 & $\begin{array}{l}\text { second rating company, Energy Plus, received approval from HUD to conduct } \\
\text { tings }\end{array}$ \\
\hline 1994 & $\begin{array}{l}\text { G\&E's goal: "Be first in country to reach } 10,000 \text { ratings and } 500 \text { EEMs" } \\
\text { UD Sacramento staff served on Evaluation Working Group funded by DOE }\end{array}$ \\
\hline March 1994 & $\begin{array}{l}\text { DCalEd proposed a one-year pilot Home Energy Loan Program (HELP), up to } \\
5,000 \text { for } 60 \text { days @ } 6 \% \text { (not related to ratings) } \\
\text { nergy Plus conducted its first rating }\end{array}$ \\
\hline April 1994 & $\begin{array}{l}\text { G\&E loan program began } \\
\text { acramento HUD office listed } 12 \text { approved EEMs lenders }\end{array}$ \\
\hline July 1994 & $\begin{array}{l}\text { affing at CHEERS changed from utility personnel on loan to permanent CHEERS } \\
\text { nployees }\end{array}$ \\
\hline November 1994 & tility consortium decided to stop fu \\
\hline 1994 & nergy Plus completed 71 ratings, $\mathrm{n}$ \\
\hline February 1995 & $\begin{array}{l}\text { New Executive Director takes over CHEERS; few ratings are being done } \\
\text { PG\&E and SCE began offering their EEM seminars }\end{array}$ \\
\hline June 1995 & $\begin{array}{l}\text { Program design completed and subcontracts in place for CEC training and consumer } \\
\text { activities using the appropriated } \$ 200,000 \text { (SB 314) and DOE funding }\end{array}$ \\
\hline Aug & Correspondence course on HERS/EEMs for real estate agents published by CAR \\
\hline November 1995 & $\begin{array}{l}\text { New CHEERS rating software phased in; CHEERS expanded to Nevada in the Reno } \\
\text { and Las Vegas markets }\end{array}$ \\
\hline 1995 & EEERS completed $~ 350$ ratings in 1995; Energy Plus cor \\
\hline mid-1996 & Leand oy 2 \\
\hline August 31,19 & \\
\hline
\end{tabular}

\section{Description of Each Organization}

\section{California Energy Commission (CEC)}

The CEC has been active in promoting and encouraging development of a home energy rating system in California for a decade, in keeping with the state's leadership in improving energy efficiency in housing. 
CEC involvement began with funding a pilot test of the slide rule rating tool in the early $1980 \mathrm{~s}$. The contract required 11 tasks: (1) participate in project planning with the CEC; (2) announce the project and solicit participation from real estate, lending, and civic communities and the media; (3) identify the needs, concerns, and special areas of interest/expertise of key user groups; (4) identify goals and marketing options via literature, media presentations, and public seminars/presentations; (5) prepare promotional literature and participate with LBL in training on use of the rating system; (7) mail literature to all user groups, emphasizing real estate agents; (8) initiate a publicity campaign; (9) perform ratings on existing residences; (10) participate in a local government workshop in April 1984; and (11) conduct a final evaluation.

Following the pilot, the CEC contracted with CA-BIA to develop a new home labeling program. From June 1987 to June 1988, CA-BIA was to: (1) design the technical, marketing, and administrative components of a program to be presented to the housing industry; (2) collect and analyze building data and associate them with levels of compliance with Title 24 ; (3) develop a labeling and/or rating program that would be accepted and used by the housing industry; (4) outline and prepare application forms and marketing materials and packages; (5) provide services and information to builders about the program; (6) provide support for an official "unveiling" event; (7) arrange for presentation of builders' awards; and (8) write a report on results and recommendations, including labeling for new construction and the cost for implementing the program statewide.

During 1989-1990, the CEC contracted with O'Neill and Company to evaluate the various ratings systems around the country, and determine reasons for success or failure of each. The process included identifying implementation structures, inclusion and omission of key players, AND conduct focus groups about HERS issues. The final report included recommendations for HERS activities that could be conducted by the CEC. The CEC then contracted with NEOS Corporation to design a simple checklist evaluation system using a tiered list of energy conservation measures ranked by cost effectiveness. In conjunction with the latter contract, a marketing plan was developed and piloted with 50 homes. The results were used by CHEERS in developing its marketing plans.

In 1995, in support of the HERS/EEMs program and to carry out state legislation, the CEC's Energy Efficiency Division had five roles:

- Cerify HERS organizations (an on-going function)

- Develop a consumer information booklet for distribution to homebuyers disclosing the existence and availability of HERS and EEMs (SB 1207)

- Implement training and information programs via trade organizations per state legislation (SB 314 provided \$200,000) from 1994-1996

- In 1995, extend the SB 314 activities with DOE funding $(\$ 90,000)$ by working with trade organizations to train lenders one-on-one, and then with builder sales staff (to meet needs of new construction) and remodelers (to meet needs of existing housing)

- Develop a Notice of Proposed Rulemaking (NOPR) establishing guidelines for ratings (final guidelines take effect on August 31, 1996). 
In 1995-96, the CEC focused on several specific areas, using funds from DOE $(\$ 90,000)$ and the state $(\$ 200,000)$. With the DOE funds, CEC has contracted with the Building Industry Institute to provide oneon-one training to lenders and sales representatives to understand, utilize, and promote energy efficiency financing products. In addition, seminars and training sessions will be held for builders, remodel contractors, lenders, and real estate agents. The State funds have been subcontracted to eight organizations and two utilities for a variety of purposes-training courses, seminars, conferences, and information materials.

Staffing. Staff time involved in the contracting process was about .75 person year (PY). About 2 PYs were spent on the NOPR and about .25 PY will be required to maintain a database on ratings.

Funding. The $\$ 200,000$ appropriated by SB 314 had to be obligated by June 30,1995 , the resulting contracts must be completed by the end of CY 1996. The contracts let for the $\$ 90,000$ from DOE will be completed by December 31,1996 . The CEC estimated that $\$ 165,000$ had been spent on staff time through June 30, 1995. In addition, DOE provided $\$ 35,000$ to Southern California Gas for production of a video on EEMs. The NOPR development is unfunded

\section{California Home Energy Efficiency Rating System, Inc. (CHEERS)}

CHERS was formed in October 1990 as a public/private nonprofit parnership. It was renamed "CHEERS, Inc." in November 1992. Its mission is to improve the energy efficiency of housing-not just to "do ratings"-by developing an infrastructure for a market-driven system. This includes convincing members of the real estate community that ratings are great sales tools and informing consumers of the availability of HERS/EEMs. In the four years it has been operating, CHEERS has moved from an R\&D phase to a demonstration phase and now to becoming a nationwide, market-based HERS provider.

CHEERS has been supported by utilities and by construction, real estate, financial, environmental, and consumer advocacy organizations. Funding has come largely from the major energy utilities in Califomia during the time required to create an independent provider of rating services. CHEERS is currently going through the transition from being $100 \%$ subsidized to being self-sufficient through ratings, software sales, and marketing services.

CHEERS' functions include the following:

- Develop, maintain, and upgrade computer software for its home energy rating and labeling system

- Enter rating data submitted by raters and generate rating reports

- Train, certify, and recenify raters; track the quality of their work; maintain a network of raters

- Hold educational seminars and training sessions for members of the housing industry and for homeowners

- Develop literature (brochures, fact sheets, etc.) for broad distribution and provide access to information via an 800 number (1-800-4CHEERS) and an internet site

- Promote consumer awareness of the societal and environmental benefits of energy efficiency

- Market the concept of ratings and their financial benefits; facilitate the means to finance energyefficiency measures

- Provide full-service contact and communication via a consumer information and referral network 
In 1995-96, CHEERS is using DOE funds for activities that have a national focus by (1) working toward a nationally uniform HERS through involvement with RESNET and the HERS Council and (2) supporting other states developing HERS programs through RESNET. At the state level, DOE funds are being used for (1) incentives to raters when they provide market and evaluation data and (2) development of consumer education and marketing material.

The 1995-96 NREL funds were used to provide material for this case study and to set up an evaluation data collection system. Four areas are the focus:

1. Modify the CHEERS Rating Request Forms to gather information on the financing applied for and the real estate agents, contractors, lenders, and facilitators involved.

2. Expand the property features component of the database to include all items recommended by the HERS Council guidelines and the CEC HERS regulations.

3. Develop appraiser accessible databases for Residential Energy Improvement information and establish protocols for maintaining these data sources, working with the California Association of Real Estate Appraisers.

4. Continue working with the independent MLS companies in California to add the energy rating score to the listing information.

CHEERS completed 1,200 ratings during the San Jose pilot testing in 1992. In 1993-95, 15,020 ratings were completed-6,369 in 1993; 8,307 in 1994; and 344 in 1995.

Staffing. CHEERS is staffed by an executive director, marketing manager, technical services manager, training and quality assurance coordinator, field marketing coordinator, and administrative assistant, all full-time. Plans call for an additional four field marketing coordinators in 1996. Current total FTE: 6.25.

Funding. Base funding of $\$ 500,000-\$ 600,000$ a year has been provided by a consortium of major California utilities. Utility funding for 1996 will range between $\$ 49,000$ and $\$ 294,000$, depending upon CHEERS market penetration. Additional funding comes from DOE and NREL grants $(\$ 180,000)$, ratings, software sales, and interest. Funding in 1993 totaled $\$ 788,000$; in 1994, \$832,000; and in 1995, $\$ 810,300$.

\section{Energy Plus}

Energy Plus, the second rating organization in California, is a private not-for-profit organization begun by two former PG\&E employees (trained as auditors and raters) who saw ratings linked with EEMs as a real business opportunity. After applying for and receiving approval to use their rating system by HUD in early 1994, they began doing ratings specifically for home buyers interested in getting HUD EEMs. Clients are referred to Energy Plus by one of three EEM service companies, all located in Northern California. In other words, the Energy Plus approach is from the market side-instead of conducting ratings and hoping people will then pursue EEMs. Energy Plus works closely with lenders and HUD office staff to promote EEMs and see that paperwork is completed. They spend considerable time meeting one-on-one with major lenders and real estate agents, looking for the "right" people in the organizations to work with over the long term The owners stress the importance of having a credible professional helping the loan applicant by removing all fears, handling all paperwork, scheculing the contractors, and scheduling inspections to make sure the work was installed correctly. 
For the period March 1994 (first rating completed) through December 1995, 275 ratings resulted in more than 190 EEMs (61\%). In 1995, Energy Plus discovered the advantage of focusing on HUD repossessed properties. Energy Plus does not rate new construction. They are preparing to offer services nationwide in mid-1996 and to begin training other raters.

Staffing. Two parmers own the company and do the ratings.

Funding. Energy Plus does not receive government funding or other subsidies. It is self-sufficient by charging fees for its services.

\section{HUD/FHA Pilot EEMs Program}

California was selected as one of the five pilot states to test the concept of using ratings to determine eligibility for HUD EEMs. The HUD field offices endorse and underwrite EEMs as well as other financing products described in Section 2. Staff involvement varies among the six field offices (Fresno, Los Angeles, Sacramento, San Diego, San Francisco, and Santa Ana). One staff member in the Sacramento office, for example, makes presentations, holds workshops, answers questions by phone, reviews applications, and assists real estate agents and lenders one-on-one with paperwork Specific functions of the HUD field offices include:

- Provide local policy guidance

- Distribute memoranda encouraging use of EEMs

- Offer technical assistance

- Attend local lender training sessions

- Write articles on EEMs for publication in trade journals

- Speak at association meetings, home buyers fairs, and state agencies

Staffing. None specifically assigned

Funding. There is no specific funding in the budgets for the HUD FHA field offices for EEMs, nor are there performance goals associated with EEMs as there are for other HUD products (including selling repossessed properties).

\section{State Legislature}

The Legislature has passed three key pieces of relevant legislation:

Title 24 Energy Efficiency Standards for New Residential and Nonresidential Buildings. Established in 1978, Title 24 is a performance standard with prescriptive alternatives, as opposed to CABO-MEC'92, which is a prescriptive standard with a "system" alternative. Title 24 was revised substantially in 1992, resulting in a more than $10 \%$ increase in stringency statewide. Comparison of the revised standard to CABO-MEC'92 resulted in the conclusion that Title 24 clearly exceads CABO-MEC'92, with differences in stringency varying by climate. 
$S B$ 1207, September 1992. This legislation requires that the CEC establish cerification criteria for a statewide HERS. The criteria must provide for (1) consistent, accurate, and uniform ratings based on a single statewide rating scale; (2) reasonable estimates of potential utility bill savings and reliable recommendations on cost-effective measures to improve energy efficiency; (3) training and certification procectures for raters and quality assurance procedures to promote accurate ratings and to protect consumers; (4) a centralized, publicly accessible database; and (5) labeling procectures that meet the needs of home buyers, home owners, renters, the real estate industry, and mortgage lenders. The CEC must also prepare a consumer information booklet for homebuyers that discloses the availability of EEMs based on ratings.

$S B$ 314, September 1993. In order to determine how best to inform home owners of the availability, methods, and benefits of obtaining an EEM, the CEC was required by this legislation to conduct a pilot program. The program had to be designed to familiarize mortgage lenders, real estate agents, home appraisers, home inspectors, utilities, energy service providers, and others with EEMs. The objective was to develop methods to incorporate EEMs into the regular business practices of all persons involved in the sale, refinancing, and remodeling of residential real estate and encourage a home energy rating as a precondition to qualifying for an EEM. The CEC was allocated $\$ 200,000$ for the program.

\section{California Association of REALTORS ${ }^{\circ}$ (CAR) and the California Department of Real Estate}

CAR is regulated by the California Department of Real Estate (DRE), as are real estate agents. Courses offered for continuing education credits must be approved by DRE. This was the case for the free EEMs course published in August 1995 under a contract with CEC as part of the SB 314 program. California's MLS systems are independent of CAR and DRE. However, CAR's MLS Policy Committee is working with CHEERS to encourage the addition of energy ratings to MLS records.

\section{EEM Service Companies}

In the early 1970s, the Energy Efficient Mortgage Service Company was formed to broker financing for installation of solar energy measures. It now focuses on brokering EEMs and being involved in HERS/EEMs issues at the national level as the National Association of Energy Efficient Mortgage Service Companies. Other private companies that act as facilitators in the HERS/EEMs process are Federal Energy Services, H\&L Energy Savers, and Mortgage Training Services. The latter developed the CAR training course and participates in the PG\&E/SCE training courses.

\section{PG\&E and SCE}

PG\&E was the major driver in the group of utilities belonging to the consortium that formed CHEERS. PG\&E wanted the rating system to serve as an umbrella to broker DSM products, and they wanted an industry rating system in place before the State forced utilities to adopt a rating system that they had not developed themselves. On the other hand, PG\&E encourages the development of a consistent statewide uniform rating system because it would reduce confusion on the part of utility customers. In 1992, PG\&E beta-tested the CHEERS software by conducting 1,200 free ratings in the San Jose area during a threemonth period through contracts with five raters. PG\&E expanded this program in 1993 and 1994 with $\$ 100$ rebates for ratings; the majority of CHEERS ratings in those years were prompted by rebates. SCE was to have done the same in southern California, but instead it offered a $\$ 40$ rebate for a rating, so few were done. The PG\&E service territory (4.3 million residential customers) was the locale for $90 \%$ of the ratings in 1993 and 1994, and for 70\% in 1995. 
Another approach used jointly by PG\&E and SCE to encourage the use of ratings was to develop a DREcertified training course for real estate agents and lenders at a registration cost of $\$ 40$ per person.

\section{Other Utilities}

The other utilities that supported development of CHEERS are Southern California Gas (SoCal Gas), Southern California Edison (SCE), Los Angeles Department of Water and Power (LADWP), Sacramento Municipal Utility District (SMUD), and San Diego Gas \& Electric (dropped out at the end of 1994). Staff from PG\&E, SCE, SoCalGas, LADWP, and SMUD serve on the CHEERS Board of Trustees and Advisory Committee.

\section{Professional Associations}

Professional associations are playing important roles in California actions. By their involvement in developing training material and informational material directly targeted to their own members, they are helping overcome several barriers: (1) mistrust of government agencies that offer training; (2) the difficulty that non-members have in gaining access to meetings, planning, and data about the associations' industries; and (3) lack of coordinated efforts of many organizations when it comes to a single issue (albeit that HERS/EEMs is an effort to modify an entire market and mindset of all members, not simply to introduce a single new product).

\section{Funding Summary, 1993-1995, California}

Although the information in Table 2-2 is incomplete and does not reflect all funding, in-kind contributions (e.g., utility staff detailed full-time to start up CHEERS), and rebates/incentives, the annual totals show the considerable resources required during 1993-1995 (probably greater than $\$ 3,000,000$ ) to market ratings and EEMs, train raters, and develop a support structure that encourages the use of ratings for EEMs.

Table 2-2. Funding Sources and Estimated Amounts, 1993-1995

\begin{tabular}{|c|c|c|c|c|c|}
\hline Organization & 1993 & 1994 & 1995 & Totals & 1996 (est.) \\
\hline $\begin{array}{c}\text { California Energy Commission } \\
\text { State funds } \\
\text { DOE } \\
\text { In-house staff } \\
\end{array}$ & $\sim \$ 45,000$ & $\sim \$ 60,000$ & $\begin{array}{r}\sim \$ 350,000 \\
200,000 \\
90,000 \\
\sim 60,000\end{array}$ & $\begin{array}{r}\$ 455,000 \\
200,000 \\
90,000 \\
\sim 165,000\end{array}$ & $\begin{array}{r}\text { Much of the } \\
\text { State and DOE } \\
\text { funds will be } \\
\text { spent in } 1996\end{array}$ \\
\hline $\begin{array}{l}\text { CHEERS } \\
\text { Utility consortium } \\
\text { DOE } \\
\text { NREL } \\
\text { Interest and sales } \\
\text { Ratings } \\
\end{array}$ & $\begin{array}{r}\$ \$ 787,647 \\
611,484 \\
8,453 \\
167,710 \\
\end{array}$ & $\begin{array}{r}23,246 \\
184,973 \\
\end{array}$ & $\begin{array}{r}\mathbf{\$ 8 1 0 , 3 4 3} \\
507,701 \\
70,500 \\
196,257 \\
35,885 \\
\end{array}$ & $\begin{array}{r}\$ 2,429,894 \\
1,742,870 \\
70,500 \\
227,956 \\
388,568 \\
\end{array}$ & $\begin{array}{r}\geq \$ 409,500 \\
\sim 300,000 \\
99,500 \\
10,000 \\
\mathbf{M D} \\
\mathbf{M D} \\
\end{array}$ \\
\hline $\begin{array}{l}\text { Utilities } \\
\text { In-house } \\
\text { Rebates (PG\&E) } \\
\text { DOE (SCE) } \\
\end{array}$ & $\begin{array}{l}\text { MD } \\
\text { MD }\end{array}$ & $\begin{array}{l}\text { MD } \\
\text { MD }\end{array}$ & $\begin{array}{r}\geq \$ 35,000 \\
\mathrm{MD} \\
\mathrm{MD} \\
35,000 \\
\end{array}$ & $\geq \$ 35,000$ & MD \\
\hline Totals & $\$ 832,647$ & $\$ 891,904$ & $>\$ 1,195,343$ & $>\$ 2,919,894$ & $>\$ 409,500$ \\
\hline
\end{tabular}

MD: Missing data 


\section{Operating Environment and Relationship to Activities at the National Level}

Staff at CHEERS, HUD, and the CEC are very involved with HERS/EEMs activities in other states. The CHEERS executive director attends and participates in national meetings, offers advice to others wishing to start programs, and promotes a consolidated nationwide program. One task for CHEERS under its DOE grant is to participate as a partner with other pilot states to provide technical and program support to states interested in implementing HERS systems. This support comes through RESNET, the HERS Council, and direct contact. The CEC anticipates ongoing active coordination with DOE, the HERS Council, and stakeholders in California to ensure that effective home energy ratings become used increasingly as a tool for consumers, lenders, real estate agents, and builders to accurately compare the relative efficiency of California homes and promote cost-effective, energy-efficient improvements.

\section{Other Background Material}

Activities regarding the impacts of rating systems on marketplace activities must be viewed within the context of the size of the housing market and number of professionals involved, giving a sense of market potential and progress made to date. California has a population of about 31,000,000. In October 1995, 28 utilities produced greater than 1 million $\mathrm{kWh}$ each. Total generation was 9,261 million $\mathrm{kWh}$ ( $4 \%$ of the total produced in the U.S.) and 1,762 million $\mathrm{kWh}$ were sold for residential use (62\% of production) at an average $11.5 \notin \mathrm{kWh}$ ( \pm 0.4\% standard deviation). Tables 2-3 through 2-7 describe California in 1992-95.

Table 2-3. Housing Market Data

\begin{tabular}{|l|r|r|r|r|}
\hline \multicolumn{1}{|c|}{ Characteristics } & \multicolumn{1}{c|}{ CY 1992 } & \multicolumn{1}{c|}{ CY 1993 } & CY 1994 & \multicolumn{1}{c|}{ CY 1995 } \\
\hline $\begin{array}{l}\text { Total single-family homes, } \\
\text { California }\end{array}$ & $10,900,000$ & MD & MD & MD \\
\hline New home mortgages & $\mathrm{MD}$ & 70,000 & $\mathrm{MD}$ & $\mathrm{MD}$ \\
\hline $\begin{array}{l}\text { Existing home sales, } \\
\text { California }\end{array}$ & 428,000 & 470,000 & 483,000 & 430,000 \\
\hline Average cost, U.S. & $\mathrm{MD}$ & $\mathrm{MD}$ & $\mathrm{MD}$ & $\$ 180,200$ \\
\hline Average cost, California & $\$ 224,100$ & $\mathrm{MD}$ & $\mathrm{MD}$ & $\mathrm{MD}$ \\
\hline Average cost, San Francisco & $\mathrm{MD}$ & $\mathrm{MD}$ & $\mathrm{MD}$ & $\$ 254,300$ \\
\hline Total value of mortgages & $\mathrm{MD}$ & $>\$ 100$ billion & $\mathrm{MD}$ & $\mathrm{MD}$ \\
\hline
\end{tabular}

MD: Missing data

Table 2-4. HUD/FHA Mortgage and EEM Activities

\begin{tabular}{|l|r|r|r|r|}
\hline \multicolumn{1}{|c|}{ Activity } & \multicolumn{1}{c|}{ FY 1993 } & \multicolumn{1}{c|}{ FY 1994 } & \multicolumn{1}{c|}{ FY 1995 } & \multicolumn{1}{c|}{ Total } \\
\hline New loans and refinances & 84,000 & 135,000 & 69,000 & \multicolumn{1}{c|}{$288,000 \mid$} \\
\hline Total value & $\$ 8.3$ billion & $\$ 13.7$ billion & $\$ 7.3$ billion & $\$ 29.3$ billion \\
\hline Average value $^{\mathrm{a}}$ & $\$ 99,300$ & $\$ 101,600$ & $\$ 105,800$ & $\$ 101,700 \mid$ \\
\hline EEMs & 47 & 261 & 740 & $1,048 \mid$ \\
\hline Total EEMs value & $\$ 5,400,000$ & $\$ 26,900,000$ & $\$ 79,500,000$ & $\$ 111,800,000 \mid$ \\
\hline Average EEMs value & $\$ 114,900$ & $\$ 103,000$ & $\$ 107,400$ & $\$ 106,700$ \\
\hline
\end{tabular}

${ }^{2}$ During FY92-FY94, 17,652 homes were repossessed and 12,732 were sold.

Source: Constructed by author using HUD/FHA data provided by NREL 
Table 2-5. DVA Lending Activities

\begin{tabular}{|l|r|r|r|}
\hline Activity & FY 1993 & FY 1994 & FY 1995 \\
\hline Loans & & & \\
Number & 39,030 & 75,601 & 22,605 \\
Total value & $\$ 5,082,000,000$ & $\$ 9,843,000,000$ & $\$ 3,076,000,000$ \\
Average value & $\$ 130,208$ & $\$ 130,197$ & $\$ 136,076$ \\
\hline Energy improvement loans & & & \\
Number & 11 & 65 & 27 \\
Total value & $\$ 1,700,000$ & $\$ 9,400,000$ & $\$ 3,700,000$ \\
Average value & $\$ 154,545$ & $\$ 143,979$ & $\$ 137,037$ \\
\hline
\end{tabular}

MD: Missing data

Source: Constructed by author using DVA data provided by NREL

Table 2-6. Rural Housing Service Lending Activities

\begin{tabular}{|l|r|r|r|}
\hline Activity & FY 1993 & FY 1994 & FY 1995 \\
\hline Direct loans & & & \\
Number & 1,309 & 1,677 & 1,041 \\
Total value & $\$ 75,900,000$ & $\$ 110,900,00$ & $\$ 62,300,000$ \\
Average value & $\$ 57,991$ & $\$ 66,143$ & $\$ 59,845$ \\
\hline Guaranteed loans & & & \\
Number & 207 & 308 & 672 \\
Total value & $\$ 18,000,000$ & $\$ 29,200,000$ & $\$ 62,500,000$ \\
Average value & $\$ 86,798$ & $\$ 94,947$ & $\$ 92,949$ \\
\hline
\end{tabular}

Source: Constructed by author using RHS data provided by NREL

Table 2-7. Number of Housing Market Professionals

\begin{tabular}{|l|r|r|r|}
\hline Professional Group & $\mathbf{1 9 9 3}$ & $\mathbf{1 9 9 4}$ & $\mathbf{1 9 9 5}$ \\
\hline Real estate agents (CAR members) & 115,000 & 105,000 & 98,000 \\
\hline Realty offices & $\mathrm{MD}$ & $\mathrm{MD}$ & 27,000 \\
\hline Multiple Listing Services & $\mathrm{MD}$ & $\mathrm{MD}$ & $\mathbf{4 5 0}$ \\
\hline Mortgage banking professionals & $\mathbf{7 0 , 0 0 0}$ & $\mathrm{MD}$ & $\mathrm{MD}$ \\
\hline Lending institutions & 11,000 & $\mathrm{MD}$ & $\mathrm{MD}$ \\
\hline Appraisers & 14,000 & $\mathrm{MD}$ & $\mathrm{MD}$ \\
\hline Residential contractors & $\mathrm{MD}$ & $\mathrm{MD}$ & $\mathrm{MD}$ \\
\hline
\end{tabular}

MD: Missing data

*Note: CAR had 100,000 members in CY 1996 


\section{Energy Efficiency Financing Products in California}

The original intent of the HUD pilot programs was to forge a link between the use of ratings and EEMs and, therefore, the NREL evaluation design began by limiting its focus to EEMs offered by FHA, DVA, and RHS. However, as the design evolved, it bocame clear that other entities were offering financial incentives for energy efficiency that were also linked to ratings. These included utility rebates, home improvement loans, and interest rate reduction programs. The EEF products offered in the nation and described in the report's introduction, were, of course, available in California. The range of products offered that are unique to California are described in this section.

\section{EEF Products}

- Financial Institutions. The CEC maintains a list of "participating lenders" who provide mortgages to fund energy-efficiency improvements based on ratings' recommendations. Downey Savings and Loan offers fixed and adjustable rate conventional EEMs up to $\$ 750,000$ with terms up to 40 years. In 1996, Downey opened its portfolio EEM program to Mortgage Brokers ("Wholesale") who have completed a required training course on EEMs.

- HUD/FHA Energy Efficient Mortgages for New Homes. New homes that meet or exceed CABO MEC (i.e., comply with Title 24) are eligible for a $2 \%$ stretch in debt-to-income ratios when qualifying for mortgages. In California, this means a home buyer can qualify for an increase in value of $\$ 7,000$ to $\$ 10,000$. There are no additional charges associated with this loan. These loans are now referred to as EEMs.

- SCE Home Energy Loan Program (HELP). In its proposal to the CEC in early 1994, SCE would provide the capital for the loans and an outside bank would administer the program. As much as $\$ 5,000$ could be borrowed for up to 5 years at the federal government's prime rate. Improvements would not be based on ratings. Second-hand information on the status of this program indicates that it was not widely used and is being modified at this time.

- PG\&E Home Energy Savings Loan (HESL). These fixed rate loans for $\$ 1,000$ to $\$ 15,000$ can be used to finance central air conditioning, weatherization measures, and windows. The funding is provided by Fannie Mae and loans are processed by Volt VIEWtech. Loans are currently offered at about $9 \%$ interest rate and length depends on the measure, but may be up to 10 years. At this time, loans are not linked to ratings, but this may change as the program is offered throughout the service territory. In the first two months of operation, the program loaned about $\$ 5.3$ million to about 600 homeowners (single-family detached homes only), averaging about $\$ 5,000$ per loan.

- Fannie Mae. Fannie Mae's energy conservation loan program will finance energy improvements (up to $15 \%$ of appraised value) through partnerships with utilities. Although it has existed since the Carter administration, few people know about it. A new program has been launched that will finance energy improvements to homes through partnerships with utilities, banks, public housing authorities, and housing finance agencies. See PG\&E description of HESL above. 


\section{Energy Efficiency Financing Incentives}

There are no incentive programs currently in effect in Califomia. 


\section{Rating Systems, Ratings, and Raters}

\section{The California Rating Systems}

Three rating systems have been developed in California: ${ }^{1}$

1. The computer program designed and field-tested by CHERS in the early 1990 s and used by CHEERS (CHEERS 1.0).

2. A Windows-based software program (CHEERS 2.0 ${ }^{\mathrm{TM}}$ ) developed by CHEERS eliminates the need for raters to do complex calculations by hand, thereby shortening the time needed to do a rating, eliminating potential math errors, and reducing the length of training sessions.

3. The computer program developed by Energy Plus.

Both the CHEERS and Energy Plus systems use 100-point scales where a score of 75-80 meets California's Title 24 energy-efficiency building code, which exceads CABO-MEC'92. Both organizations are considering attaching a "star" system under the DOE HERS guidelines to make the ratings easier to interpret at a glance. Both utilize or simulate blower door and duct leaking tests, and take into account local urility costs and regional climate differences.

The CEC is required by legislation to develop guidelines for home energy rating systems. The legislation called for them to be completed by mid-1994, but because the CEC hoped to coordinate them with the DOE guidelines, publication of the California NOPR was delayed until mid-1995. However, since the DOE guidelines still had not been published, the two NOPRs are different, especially in the way regional differences are handled. CHEERS plans to make additional changes in the CHEERS 2.0 ${ }^{\text {TM }}$ software to be compatible with the final rules when the standards are finalized. CHEERS has been deeply involved in building bridges between the HERS Council, ERHA, RESNET, NASEO, Fannie Mae, and FHLMC regarding resolution of many NOPR-related issues.

\section{The Ratings}

The total number of ratings completed each calendar year by CHEERS and Energy Plus are given in Table 2-8. The Energy Plus ratings for 1994 covers 10 months since they did their first rating in March. During January through mid-March 1996, Energy Plus completed 62 ratings, with a goal of 400 to 500 ratings in 1996. During its 1992 field testing phase, CHEERS rated 1,200 homes. Ratings by CHEERS are broken down in two ways in Table 2-9-new vs. existing homes and "as is" vs. "post improvement." The reason for the "flip-flop" in "as is" vs. "post improvement" ratings from 1993-94 to 1995 is that virtually all ratings in 1995 were EEM transactions that were post-rated to verify completion of the energy efficient improvements. In 1993 and 1994, almost all ratings were done under the PG\&E subsidized coupon program and typically did not result in improvements being performed, so few post ratings were conducted.

\footnotetext{
${ }^{1}$ A slide rule tool was developed by LBL for the CEC in the mid-1980s. Originally a physical slide rule was used to calculate factors, using information obtained during an on-site inspection; it is now public domain software named CALRES that will be available via the World Wide Web. However, not all cognizant parties consider CALRES a rating system.
} 
Table 2-8. Number of Ratings Completed by Calendar Year

\begin{tabular}{|c|r|r|}
\hline Year & CHEERS & Energy Plus \\
\hline 1993 & 6,369 & NA \\
\hline 1994 & 8,307 & $\mathbf{7 1}$ \\
\hline 1995 & 344 & 204 \\
\hline Totals & $\mathbf{1 5 , 2 7 0}$ & $\mathbf{2 7 5}$ \\
\hline
\end{tabular}

Table 2-9. CHEERS Ratings by Category

\begin{tabular}{|l|r|r|r|r|}
\hline Rating Type & 1993 & 1994 & 1995 & Total \\
\hline New homes & 6,319 & 8,257 & 334 & 14,910 \\
\hline Existing homes & 50 & 50 & 10 & 110 \\
\hline "As is" & 6,349 & 8,277 & 34 & 14,660 \\
\hline "Post improvement" & 20 & 30 & 310 & 360 \\
\hline Totals & 6,369 & 8,307 & 344 & 15,020 \\
\hline
\end{tabular}

Because California is such a large state (by itself, the eighth largest economy in the world), a breakdown of CHEERS ratings by utility service area provides an interesting view of the level of activity for 1993-95, in Table 2-10. Note that one home may be counted as many as three times in this table, depending on how many fuel types are associated with it. For example, a house served by PG\&E is most likely counted once in "PG\&E Electric" and again in "PG\&E Gas" (the difference between the two numbers is probably the number of all-electric homes that were ratod). HUD field office locations are noted in this table for the purpose of showing how, in the future, ratings could be matched to EEMs associated with each office.

Raters pay CHEERS $\$ 15$ to process each rating; this fee will increase to $\$ 30$ in mid-1996. CHEERS enters the rating data in its database and prepares a numbered certificate for the homeowner that provides the following information:

- $\quad$ Rating (overall, specifically broken down by heating, cooling, and hot water)

- Estimated annual energy cost (overall, heating, cooling, and hot water)

- Recommendations for improvements in ten areas, with estimated annual energy savings, approximate cost, useful life of the improvement, and payback in years for each

- Rating if all recommended improvements were made

- Total annual energy savings if all recommended improvements were made

- The phone numbers for both the electric and gas utility

- Summary of housing characteristics (year built, stories, square footage, orientation, climate zone, insulation in attic/walls/floor, window orientation and glazing type, specifications of heating and cooling equipment, description of water heater, and shade around the building) 
Table 2-10. Homes Receiving Ratings (with Utility, Fuel Type, and Field Office)

\begin{tabular}{|c|c|c|c|c|c|c|}
\hline Utility & $\begin{array}{c}\text { Fuel Covered } \\
\text { by Ratings }\end{array}$ & 1993 & 1994 & 1995 & Total & $\begin{array}{c}\text { Most Probable HUD } \\
\text { Field Office(s) } \\
\end{array}$ \\
\hline MID & Electric & 3 & 105 & 3 & 111 & Fresno \\
\hline PG\&E & Electric & 5,751 & 7,496 & 248 & 13,495 & $\begin{array}{l}\text { Fresno, San Francisco, } \\
\text { or Sacramento }\end{array}$ \\
\hline PG\&E & Gas & 4,925 & 6,998 & 241 & 12,164 & $\begin{array}{l}\text { Fresno, San Francisco, } \\
\text { or Sacramento }\end{array}$ \\
\hline LAPWD & Electric & 13 & 0 & 4 & 17 & Los Angeles \\
\hline Pasadena & Electric & 0 & 0 & 1 & 1 & Los Angeles \\
\hline N/A & Propane & 150 & 308 & 36 & 494 & N/A \\
\hline Biggs & Electric & 0 & 2 & 0 & 2 & Sacramento \\
\hline Gridley & Electric & 0 & 61 & 0 & 61 & Sacramento \\
\hline Lassen & Electric & 1 & 0 & 0 & 1 & Sacramento \\
\hline Lodi & Electric & 0 & 14 & 0 & 14 & Sacramento \\
\hline PP\&L & Electric & 0 & 3 & 1 & 4 & Sacramento \\
\hline Redding & Electric & 22 & 181 & 4 & 207 & Sacramento \\
\hline Roseville & Electric & 0 & 5 & 2 & 7 & Sacramento \\
\hline Shasta & Electric & 0 & 29 & 0 & 29 & Sacramento \\
\hline SMUD & Electric & 10 & 210 & 57 & 277 & Sacramento \\
\hline Ukiah & Electric & 442 & 97 & 3 & 542 & Sacramento \\
\hline SDG\&E & Electric & 43 & 1 & 11 & 55 & San Diego \\
\hline SDG\&E & Gas & 0 & 0 & 11 & 11 & San Diego \\
\hline Southwest Gas & Gas & 0 & 2 & 1 & 3 & San Diego \\
\hline Alameda & Electric & 0 & 56 & 8 & 56 & San Francisco \\
\hline Palo Alto & Electric & 2 & 0 & 0 & 2 & San Francisco \\
\hline Palo Alto & Gas & 2 & 0 & 0 & 2 & San Francisco \\
\hline Santa Clara & Electric & 4 & 9 & 0 & 13 & San Francisco \\
\hline Banning & Electric & 0 & 0 & 1 & 1 & Santa Ana \\
\hline Riverside & Electric & 0 & 1 & 1 & 2 & Santa Ana \\
\hline SoCalEd & Electric & 77 & 31 & 55 & 163 & $\begin{array}{l}\text { Santa Ana or } \\
\text { Los Angeles }\end{array}$ \\
\hline SoCalGas & Gas & 631 & 652 & 70 & 1,353 & $\begin{array}{l}\text { Santa Ana or } \\
\text { Los Angeles }\end{array}$ \\
\hline Totals & & 12,079 & 16,261 & 758 & 29,098 & \\
\hline
\end{tabular}




\section{The Raters}

CHEERS is the only organization in California that actively trains raters. Energy Plus does not at this time, but will in the future. Currently, there are 80 "active" raters in California associated with CHEERS, although 213 had been trained through 1995. (To be considered "active", a rater must complete at least 4 or 5 ratings every six months.) Raters are trained in a five-day course conducted by CHEERS staff. The cost is $\$ 395$ plus $\$ 395$ for the software. Fewer than 5\% fail because the training staff works with individuals to ensure as great a success rate as possible. Plans call for training another 120 raters during 1996. In 1993, eight training sessions were held; in 1994, six; and in 1995, five. In Southern California, training is held at CHEERS' offices; in Northern California, at PG\&E's training center in Stockton.

CHEERS reviews the first five ratings by a newly trained rater for quality control. As raters gain experience, the number of ratings reviewed is gradually reduced to $10 \%$. The "best" raters also do quality control on other raters. Once a rater is certified, he or she works independently, but gets referrals from CHEERS and must pay an annual fee of $\$ 120$ to remain on the list. There is no specific recertification process, but a rater who has not done a rating in 12 months must retake the test to stay on the list. As of December 31, 1995, any raters who have not renewed their dues are considered new raters and must pay new rater training fees and participate in new rater training to reactivate.

Referrals are made to active raters when requests are received by CHEERS via its 800 number. Although raters are not employees of CHEERS, they are required to act professionally, return calls, and adhere to standard business practices. In turn, CHEERS offers follow-up training in marketing, selling, and financial products to the raters that are part of developing the rating process as a business opportunity.

CHEERS raters set their own fees, usually about $\$ 200$ - the same as Energy Plus. Some CHEERS raters are contractors (e.g., insulation) who either use their status on the list to track events and obtain customers who have had ratings performed by other raters or as a supplemental source of income by doing occasional ratings themselves. 


\section{Marketing, Training, and Education}

The organizations primarily responsible for marketing, training, and education are the CEC (with many subcontractors involved, as shown below), CHEERS, and PG\&E. In marketing and education, each has its own projects; in training, they frequently collaborate. CEC emphasizes education and training.

\section{California Energy Commission}

The legislature appropriated $\$ 200,000$ in 1993 for CEC's "EEM Market Transformation Program." This amount is supplemented by $\$ 90,000$ from DOE in FY1996. The CEC contracted with major industry groups to hold conferences and seminars, develop continuing education courses, make presentations, and give scholarships to attend Western Affordable Comfort Conferences (WACC). The Sacramento Home Loan Counseling Center (SHLCC) is developing an "Economic Development Template and Tool" for use by state and local community policymakers. SHLCC is also compiling a database index of the HERS/EEMs reference library that will be available via the Internet at the Web Site of the CEC. Contractors and amounts budgeted for their tasks are summarized in Table 2-11.

Table 2-11. CEC Contractors for Training and Education

\begin{tabular}{|l|r|}
\hline \multicolumn{1}{|c|}{ Contractor } & \multicolumn{1}{c|}{ Budget } \\
\hline CAR & $\$ 35,000$ \\
\hline Association of Professional Mortgage Women & $\$ 15,500$ \\
\hline California Mortgage Bankers Association & $\$ 9,500$ \\
\hline Sacramento Home Loan Counseling Center and Institute & $\$ 26,000$ \\
\hline SCE & $\$ 35,000$ \\
\hline PG\&E & $\$ 35,000$ \\
\hline Pacific Coast Builders Conference & $\$ 2,500$ \\
\hline International Heating and Air Conditioning Institute & $\$ 6,500$ \\
\hline Air Conditioning Trade Association & $\$ 7,500$ \\
\hline Insulation Contractors Association & $\$ 4,500$ \\
\hline Western Affordable Comfort Conference & $\$ 23,000$ \\
\hline Total & $\$ 200,000$ \\
\hline
\end{tabular}

The DOE funds are used to target lenders, builder sales staff, and remodelers in the three largest FHA markets in the state--Sacramento, Fresno, and Santa Ana-and focus on use of 2\%-stretch loans for new homes and EEMs for existing homes. These activities began in late 1994 and conclude at the end of 1996. Responsibility, participation, number of events, and purpose/product for CEC- and DOE-funded activities are shown in Tables 2-12 and 2-13. 
Table 2-12. CEC Training Activities Using DOE Funds via a Subcontract with the Building Industry Institute, 1994-96

\begin{tabular}{|l|l|c|c|}
\hline \multicolumn{1}{|c|}{ Target Group } & \multicolumn{1}{c|}{ Description } & $\begin{array}{c}\text { Number of } \\
\text { Sessions Planned }\end{array}$ & $\begin{array}{c}\text { Target } \\
\text { Attendance }\end{array}$ \\
\hline Lenders & Individualized focused training & 30 & 150 \\
\hline Builder sales staff & Individualized focused training & 15 & 75 \\
\hline Builder lender staff & Individualized focused training & 15 & 75 \\
\hline Multiple groups & Regional seminars & 6 & 180 \\
\hline
\end{tabular}

\section{CHEERS, Inc.}

In addition to conducting rater training, CHEERS plans to work with the Building Industry Institute and CAR to sponsor and conduct intensive training for appraisers and builders. Four appraiser training workshops will be held in 1996. The workshops will be two days long and train 2 or 3 appraisers in each one. The builder/contractor training will consist of half-day on-site training. During 1996, 19 will be held in California, 6 in Nevada, and 3 in Colorado. Plans call for 30 more workshops in 1997-98.

\section{Other Marketplace Activities}

HUD field office staff participate to varying degrees as speakers and by attending home shows. For example, the Sacramento office has cosponsored workshops at trade shows with SMUD and the Sacramento Home Loan Counseling Center. Two were held in 1995, with 122 people attending the second one.

PG\&E and SCE train lenders, real estate, housing, and energy professionals using course material developed by PG\&E in 1994-1995. During 1995, these sessions were supported with CEC funds and participation is reported in Table 2-13. Requirements of the CEC subcontracts for training activities include final reports from each organization, which will document dates of training, participation/attendance, and contents. Contracts end at various times between December 31, 1995, and September 30, 1996. Other subcontractors will prepare reports on (1) a review of the status of ratings from a real estate agent's perspective and on progress made toward including ratings in MLS reports; (2) a report on potential revisions to standard appraisal practices that impact value for energy efficiency and EEMs; and (3) results of needs assessments of builders and lenders conducted at training sessions. These reports will contain both contextual information and data that should be incorporated into this document when it is revised. 
Table 2-13. CEC Training Activities with State Funds

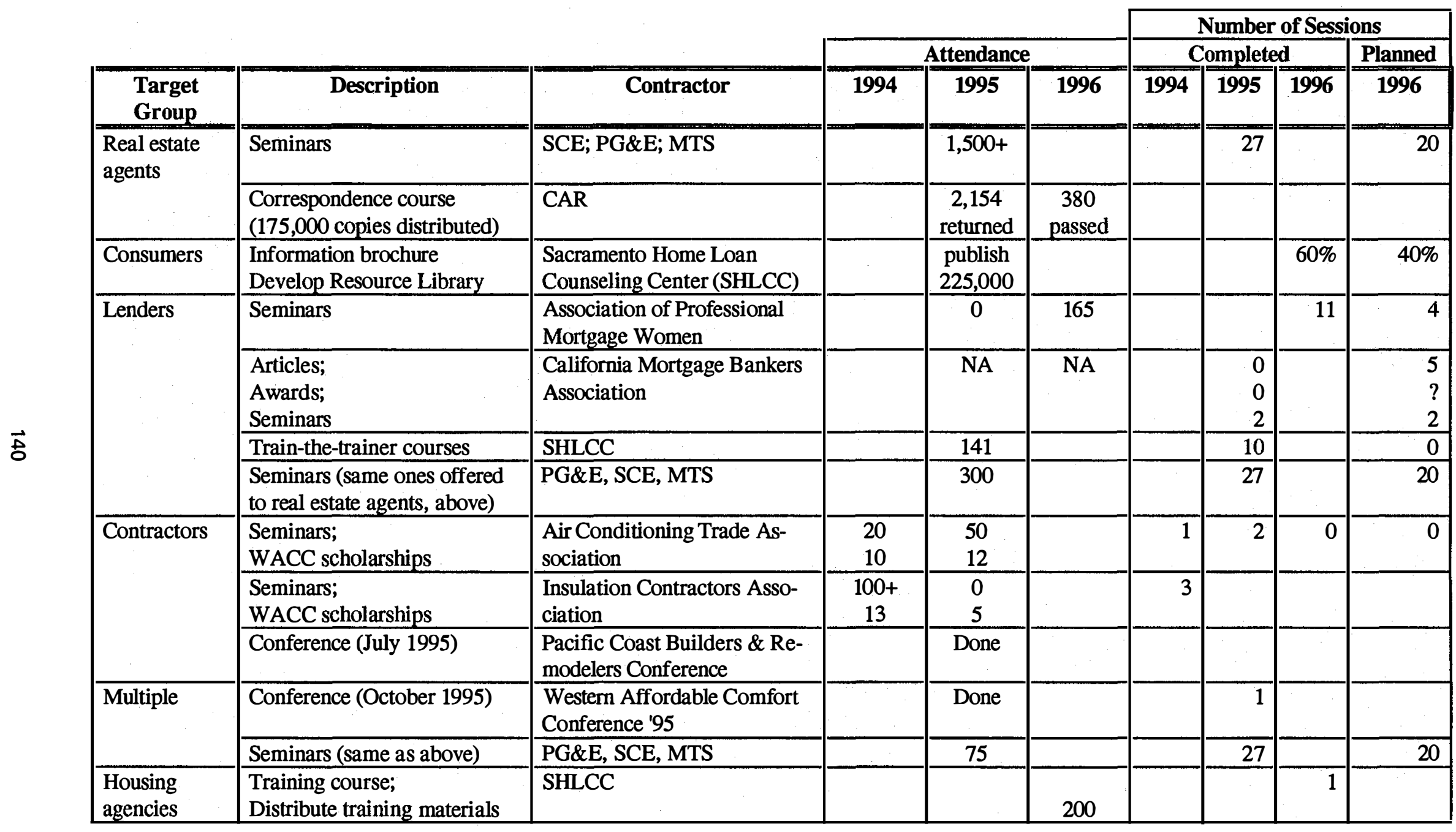




\section{Preliminary Evaluation Data and Findings}

One goal of collecting data about ratings and energy efficiency financing products is to be able to chart uses of ratings against the total ratings completed. Energy Plus links ratings exclusively with HUD EEMs and, therefore, tracks these carefully, as shown in Figure 2-1. In 1994, 51\% of the ratings resulted in completed EEMs. In 1995, their success rate increased to $66 \%$ by focusing on repossessed HUD properties. (Recall that selling repossessed properties has performance standards for staff, while EEMs do not, so there is no motivation for the latter.) Data for January through mid-March 1996 show $61 \%$ of the 62 ratings resulted in confirmed loans and $27 \%$ in process. The majority of their EEMs activities are with the Sacramento HUD field office; a few are with Fresno and Santa Ana.

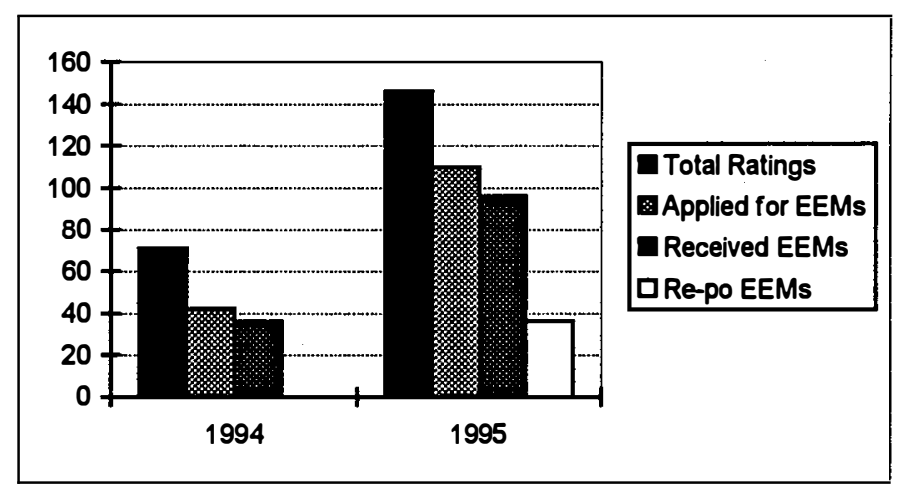

Source: Constructed by author using data from Energy Plus

Figure 2-1. Use of Energy Plus Ratings in Obtaining HUD/FHA EEMs

Early in 1994, the Executive Director of CHEERS ${ }^{2}$ encouraged raters to find out what financing products were being used by people who received ratings. The information was to be tracked by conducting a postimprovement rating, issuing an updated certificate, and sending a new file to the database. When a rater leamed of EEM activity, he was to give this information to CHEERS accompanied with the file name. At this time, however, this information is not available, although a new tracking system should be put in place by CHEERS during 1996. The data in Figure 2-2 show that 7\% of all CHEERS-rated homes had EEMs endorsed by HUD.

One device used in 1995 by CHEERS to collect data on how ratings have been used was to offer a rater $\$ 100$ for retuming a coupon within 30 days of completing a rating. However, because only 100 coupons were available, the information obtained on financing is limited. The rater had to fill in the following information:

- Address with buyer's and seller's name

- Contact information for lender, real estate agent(s), builder (if new), and rater

\footnotetext{
${ }^{2}$ Greg French, CHEERS Executive Director during 1992-94, returned to Southern California Edison, the utility from which he was detailed.
} 
- Sales price, cost of energy improvements, and total loan amount

- Type of loan (boxes to be checked for FHA EEM, VA EEM, CHEERS EEM, conventional ARM, conventional fixed, FHA Title I, line-of-credit, unsecured loan, no financing, or unknown)

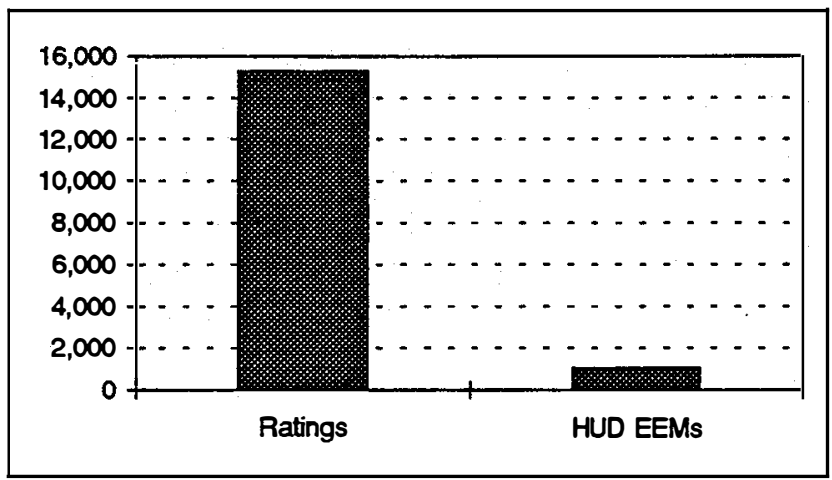

Source: Constructed by the author using data from CHEERS, Energy Plus, and HUD/FHA

Figure 2-2. Use of CHEERS Ratings for Financing Energy Efficient Mortgages, 1993-1995

Because both CHEERS and Energy Plus keep databases in which they record the details of the ratings, we can provide various descriptions of the ratings and the homes rated, shown in Tables 2-14 and 2-15.

Table 2-14. Descriptions of CHEERS Ratings, 1993-1995

\begin{tabular}{|l|r|r|r|}
\hline Measurement & Average & Median & Range \\
\hline "As is" home rating scores & 68 & 65 & 28 to 92 \\
\hline "Post improvement" rating scores & 75 & 72 & 50 to 92 \\
\hline Cost of improvements & $\$ 5,000$ & $\$ 3,500$ & $\$ 500$ to $\$ 60,000$ \\
\hline Annual energy costs & $\$ 2,400$ & $\$ 1,800$ & $\$ 800$ to $\$ 25,000$ \\
\hline Annual energy savings & $\$ 800$ & $\$ 600$ & $\$ 0$ to $\$ 10,000$ \\
\hline Year homes were built & 1970 & 1968 & 1880 to 1995 \\
\hline
\end{tabular}

Table 2-15. Description of Energy Plus Ratings, 1994-95

\begin{tabular}{|l|r|}
\hline Measurement & Data \\
\hline Average cost of improvement, 1994 & $\$ 4,300$ \\
\hline Average cost of improvement, 1995 & $\$ 4,570$ \\
\hline Age of homes, 1994-1995 & \\
$1-10$ years & $7 \%$ \\
$11-20$ & $24 \%$ \\
$21-30$ & $22 \%$ \\
$31-40$ & $25 \%$ \\
$41-50$ & $12 \%$ \\
$51-100$ & $10 \%$ \\
\hline
\end{tabular}




\section{Problems and Solutions, Successes, and Future Directions}

CHEERS provided the material presented in this section, but it reflects a statewide view of HERS/EEMs issues in Califomia.

\section{Obstacles Encountered}

1. Lack of consumer awareness

2. Real estate agent and lender resistance or inertia

3. Lack of new construction rating or financing products

4. Lack of existing-home conventional financing products

5. Lack of contractor financing products

\section{Strategies for Overcoming These Obstacles}

1. Develop a consumer marketing campaign

2. Make consumers demand HERS/EEMs from real estate agents and lenders

3. Develop applications for the new-construction market that focus on

- Selling more homes (qualify more buyers)

- Offering more options for energy upgrades that can be financed

- Creating competitive advantages through market recognition of the value of ratings

- Mitigating liabilities by linking with QA inspection services, using the CHEERS rating as a commissioning document

4. Enhance existing EEMs programs and add conventional EEM pilot and jumbo loans

5. Develop contractor-specific financing products that do not require the time and expense of a first mortgage EEM

\section{Problems Resolved}

1. CHEERS believes that the technical disputes surrounding the National Guidelines (DOE NOPR) are well on the way to joint resolution. CHEERS has submitted a proposal to Fannie Mae and Freddie Mac for single point accreditation, which may help resolve this remaining HERS industry issue.

2. The Califomia Guidelines will generally be consistent with national guidelines and will include Califomia-specific concerns. The guidelines become mandatory on August 31, 1996.

3. Improved technology, modeling, and measurement techniques have been incorporated into CHEERS 2.0 ${ }^{\mathrm{TM}}$, the new software product, which will meet the NREL BESTEST for accuracy. CHEERS believes the new software is the most advanced, most accurate, and most flexible HERS program on the market. It is the only hourly model currently available and the only program designed to meet virtually all BESTEST Tier 3 requirements. 


\section{Most Successful Aspects of the Program}

1. Broad, cross-industry interest in CHEERS and the importance of energy efficiency

2. Close and supportive regulatory relationship between CHEERS and the CEC

3. Strong and active support by utility industry

4. High level of program integrity and reliability

5. Technological superiority of CHEERS $2.0^{\mathrm{TM}}$

6. When information and financing are combined, real energy savings can be achieved

\section{CHEERS Six-Month Milestones (January-June 1996)}

1. Expand into Washington, Oregon, and Idaho

2. Be conducting 600 ratings a month by July 1996

3. Fully launch and refine a consumer marketing campaign

4. Help resolve remaining national guideline and accreditation issues

5. Have effective conventional EEMs in place

6. Have effective contractor financing programs in place

7. Establish consumer service and telemarketing system

8. Establish customer referral network for service providers

\section{CHEERS Long-Term Goals}

1. Add three more western states (Arizona, New Mexico, and Utah or Texas) in 1996; add additional states in 1997

2. Achieve 2,000 ratings per month by the end of 1997

3. Develop new construction products and applications based on ratings

4. Develop a "Water Analysis Module" to evaluate water use characteristics of home in conjunction with energy use and environmental considerations

5. Develop a "Location Efficient Rating Certificate" and a "Location Efficient Mortgage Financing Program" in 1997

6. Become self-sustaining from rating system operations by 1998 . 


\section{Epilogue: Key Activities during 1996}

During 1996, HERS/EEMs activities in California have focused on four areas: (1) continuation of training programs by the diverse organizations (described in the training section of this case study); (2) refocusing and restructuring of CHEERS; and (3) increasing the number of raters and EEM housing and energy professionals in California available to participate in the HERS/EEMs process. Motivation for the last two areas, in particular, has come from the announcement by Countrywide Funding-the largest independent residential mortgage lender and server in the U.S.-- that they would launch EEMs as a major lending tool on October 1, with the program going nationwide in January 1997. (See more detailed discussion below.)

Highlights of activities by the major entities interviewed by telephone for this case study are summanized in this addendum. ${ }^{3}$

\section{CHEERS Activities}

In April 1996, a Task Force led by PG\&E and SCE, with assistance from SMUD and SoCalGas, was formed to aid CHEERS in defining its future path and strategies for its program and organization. At issue was the continuing low number of ratings being conducted (165 through September) and the lack of a market for EEMs in California. The utilities needed to decide if they should continue subsidizing CHEERS until a market base could be developed Largely due to the entry of Countrywide into the EEM market, PG\&E, SCE, and SoCalGas agreed to continue their involvement and support by actively promoting ratings and EEMs.

The restructuring included a new Executive Director with an extensive mortgage lending background, who took over on October 1. CHEERS will focus on existing homes and providing better information to consumers. However, training efforts will be directed more specifically to lenders and first-time homebuyers. Specific programs starting in the near-term include the Freddie Mac pilot, working with HUD to reach the existing housing market, a pilot program in conjunction with nonprofit organizations, and participating in the Energy Star program. As of June 1996, CHEERS had 90 certified raters.

\section{Energy Plus Activities}

In anticipation of the Countrywide program, Energy Plus moved into new offices, changed its name to "Rated Energy Plus," and trained 16 raters. Through mid-November, the company had completed 342 ratings (their 1996 goal is 400), most of which resulted in completed EEMs. Those not completed were primarily due to applicants not qualifying.

\section{Utility Activities}

PG\&E has continued its strong commitment and support to EEMs and CHEERS. Emphasis in 1996 has been on developing consumer and lender materials for wide distribution, publishing a quarterly newsletter, printing bill stuffers about the Countrywide program, and training lenders and real estate professionals. Publications (funding support was received from DOE and Countrywide) include:

\footnotetext{
${ }^{3}$ Information in this section was obtained from CEC (Carroylin Threlkel and Randel Riedel); PG\&E (Aslina Abdullah), CHEERS (Tom Hamilton), and Rated Energy Plus (Dave Peterson) during October and November 1996.
} 
- Energy Efficient Mortgage Housing and Energy Professionals Directory-names addresses, and phone numbers of all certified raters, trade organizations, and real estate professionals who have completed a training course.

- Energy Efficient Mortgage Program Guidelines-designed to inform lenders about EEM financing programs, guidelines, and ratings.

- Energy Efficient Mortgage Home Owner Guide-definitions, examples, simplified process, and contacts.

- EEM-Power: The New Dimension for Your Business-a newsletter published quarterly with a circulation of 3,000 .

PG\&E and CHEERS has been training Countrywide's account executives in preparation for the new program. Bill stuffers about the Countrywide program were sent out in October by SCE, in November by SoCalGas, and in January 1997 by PG\&E. SCE has produced an audiotape, which is distributed by CHEERS.

\section{CEC Activities}

Most of the activities planned by the Building Industry Institute (BII) using the $\$ 90,000$ in DOE pilot state funds (grant approved in mid-1995) will occur in 1996 (the grant was extended through December 30). BII's Energy Efficient Financing Coalition has identified eight barriers to EEMs penetrating the housing market:

1. The home buying public is unaware of EEF and does not equate energy efficiency with value.

2. The lending and real estate communities view EIMs as "deal-breakers" (extra time and paperwork).

3. Primary and secondary lenders do not have a common format for EIM practices and documents.

4. Appraisers unaware or uninterested in energy-efficiency options, so no database of comparable energy efficient home sales is being generated.

5. The 200-some MLS in California do not include energy efficiency information.

6. Lenders/realtors/builders are unaware of the $2 \%$ stretch for new homes.

7. The secondary markets' proposed guidelines for EEMs discourage energy codes for new construction.

8. There are no common HERS guidelines to follow.

These barriers guided the tasks defined by BII for 1996. As of September 30, 1996, the CEC estimates that $20 \%$ of the builder/lender market in Sacramento, the Central Valley, and Los Angeles has been penetrated $(4,500$ out of 11,600$)$.

Subcontracts for the various outreach projects funded under the one-time State appropriation of $\$ 200,000$ will all be completed by the end of 1996. The status of these activities has been updated for 1996 in the tables later in this case study. 


\section{Other Marketplace Activities}

Clearly, the entry of Counrrywide into the EEM market on a large scale is the most significant event to occur during 1996. Although the program will go nationwide in 1997, it originated with top management based in Pasadena. Internal staff have been training account executives, branch office personnel, and underwriting support personnel on the technical aspects of writing EEMs. Because the Countrywide approach is providing extra services to potential clients via an 800 number, EEMs can fit easily into the range of products it offers. HERS ratings will be used with their own EEM program, Title I loans, and all FHA products. The goal for California is to be completing 200 EEMS per month by the end of 1996 . It is possible that Norwest will join Countrywide in this program.

As noted above, more raters have been trained and certified in preparation for increased demand for ratings. In addition, PG\&E lists 1,114 real estate agents who have completed a training course. 
Appendix 


\section{Appendix 2-A. California Process Evaluation}

\section{Part 1. Organization Contacts and Descriptions}

\section{California Home Energy Efficiency Rating System, Inc. (CHEERS)}

Key contact:................................... Tom Hamilton, Executive Director (1996 -

Michael F. Martin, Executive Director (1995 - 1996)

Greg French, Executive Director (1992 - 1994)

Type of organization:

Nonprofit, 501(c)(3)

Address: 1700 Adams Avenue, Suite 102, Costa Mesa, CA 92626

Phone: (714) 540-0501; (800) 424-3377 (1-800-4CHEERS)

Fax: (714) $540-2860$

Home page: http://www.cheers.org

Date formed: September 24, 1990

Number of staff: 6.25 FTE; 4 FTE to be added in 1996; plus temporary and parttime help as needed for specific short-term tasks

Mission: CHEERS, Inc., promotes cost-effective residential energy efficiency through the development and implementation of a market-driven home energy rating and labeling system for new and existing housing. CHEERS undertakes educational and communication activities to inform the public about the CHEERS program, the societal and environmental benefits of energy efficiency in residences, and facilitates the means to finance energy-efficiency measures.

Formative Sponsors:

Pacific Gas \& Electric (PG\&E), Southern California Edison (SCE), Southern California Gas Company (SoCalGas), Los Angeles Department of Water and Power (LADWP), Sacramento Municipal Utility District (SMUD); San Diego Gas \& Electric (SDG\&E), Califomia Energy Commission (CEC)

Sponsors: PG\&E; SCE; SoCalGas; LADWP; SMUD

Functions: Rate new and existing homes for energy efficiency; train raters; educate lenders, real estate professionals, and other trade allies; maintain database; produce rating information, certificates, and labels

Annual budget: 1995: $\$ 810,343$ ( $\$ 507,701$ from utilities; $\$ 35,885$ from ratings; $\$ 70,500$ from DOE; $\$ 196,257$ from interest and other sources) 
1994: $\$ 831,904$ ( $\$ 623,685$ from utilities; $\$ 184,973$ from ratings; 23,246 from interest and other)

1993: $\$ 787,647$ ( $\$ 611,484$ from five utilities; $\$ 167,710$ from ratings; $\$ 8,453$ from interest)

Staff functions:

Executive director: Oversees staff; markets program to lenders, real estate professionals, and others; supports lender needs to process EEMs; responsible for general business functions, finances, purchasing, contract negotiation, etc.

Technical Services Manager: Supports technical needs of over 80 active raters; distributes and makes appropriate changes to software; works with state and national groups to establish the technical standards for the HERS industry; is responsible for training raters and overseeing quality assurance; maintains database and rating production; directs overall data processing needs for organization; provides support to lenders processing EEMs.

Administrative Assistant: Performs clerical functions; coordinates rater training classes; schedules meetings and provides minutes; interfaces with customers, raters, and trade allies; provides administrative support to all departments.

Training and Quality Assurance Coordinator: Develops rater training curriculum and provides rater training; manages field QA activities; ensures customer satisfaction

Marketing Manager: Provides lender and Realtor education, training, and marketing support; educates and markets program to raters, consumers, and trade allies; produces newsletter, marketing support, and collateral material; manages consumer marketing campaign and media relations.

Field Marketing Coordinator: Provides on-site field support to raters, realtors, lenders, and others in the successful implementation and marketing of CHEERS programs.

Geographic coverage: States of California and Nevada; plan to expand operations to additional western states in 1996.

Method of marketing:

Booths at home shows; direct mail, if there is a need to encourage participation of raters in a particular area of the state; an 800 information number; news articles; utility promotion of CHEERS and EEMs in their service territories; co-marketing with trade allies. 


\section{Energy Plus}

Key contacts: ................................. David Peterson and Ray Nelson

Type of organization: ...................... Private

Address: ........................................ 2445 Whimore Avenue, \#102, Ceres, CA 95307

Phone: ............................................ (800) 890-7929

e-mail: ............................................ ray_nelson@msn.com

Date formed:................................... January 1994

Number of staff: ............................ 2

Mission:...................................... To determine if there is a sufficient market for ratings to make it as a small business

Functions:...................................... Conduct ratings on HUD homes identified by energy services brokers

Annual budget: ............................ Proprietary; charge $\$ 200$ for a rating

Geographic coverage:...................... Central Valley

Method of marketing:...................... Spend lots of one-on-one time with lenders and major real estate professionals; literature packet

\section{EEM Service Companies}

The following private companies act as facilitators to ease the EEMs and rating process by making referrals to raters, helping prepare paperwork for lenders, and installing measures.

e-mail: cemco1@aol.com
EEMS Inc................................. Jim Curtis, President/CEO
3121 David Avenue, Palo Alto, CA 94303
(415) 858-0888; (800) 858-0802
e-mail: eemsinc@ @etcom.com
Federal Energy Services................ Tom and Leigh Carruthers
Sacramento, CA
(800) 777-6922
e-mail: fedenrg@ns.net


H\&L Energy Savers....................... Ray Hall

Upland, CA

(800) 985-0733

e-mail: hlenergy@ix.netcom.com

\section{EEM Training}

Mortgage Training Services ........... Buzz Howard, Executive Vice President

980 Ninth Street, Suite 1450, Sacramento, CA 95814

(916) 498-8511, Ext. 228; fax (916) 498-8466

HUD Field Offices in San Francisco, Sacramento, Los Angeles, Santa Ana, San Diego, and Fresno

Key contacts:............................. Ron Johnson; Patti Anderson

Sacramento HUD Field Office

777 12th Street, Suite 200

Sacramento, CA 95814

Phone: (415) 556-3880

Fax: (415) 556-8500

Danny Mendez

San Diego HUD Field Office

2365 Northwide Drive, Suite 300

San Diego, CA 92108

(619) 557-5305

Jim McClanahan

San Francisco HUD Field Office

450 Golden Gate Avenue

San Francisco, CA 94102

(415) 436-6517

Carol Meries

Santa Ana HUD Field Office

3 Hutton Centre Drive, Suite 500

Santa Ana, CA 92707

(714) 957-7333

Tom Rose

Fresno HUD Field Office

1630 East Shaw, Suite 138

Fresno, CA 93710

(209) 487-5033 
Jackie Slayden

Los Angeles HUD Field Office

1615 West Olympic Boulevard

Los Angeles, CA 90015

(213) 251-7122

\section{California Energy Commission}

Type of organization:

Key contacts:

Address:

Phone:

(1)

State agency

. Carroylin Threlkel; Randel R. Riedel

California Energy Commission, Energy Efficiency Division, 1516

Ninth St., Sacramento, CA 95814

(916) 654-4513 (Threlkel)

(916) 654-4109 (Reidel)

Fax:

(916) 654-4304

(916) 654-5012 (Fax modem)

Functions:

Establish partnerships with trade associations affiliated with real estate sales, mortgage financing, utilities, energy service companies, home raters, and the installation of energy efficient equipment; train individuals and associations on the advantages and availability of energy efficiency financing, how to process EEMs, and how to promote energy efficiency and energy efficiency financing as business opportunities; ensure quality control.

Budget: FY 1995: $\$ 200,000$ one-time from state; $\$ 90,000$ one-time from DOE; $\$ 165,000$ internal funds for stafing

Number of staff: 2-3 FTE

Type of staff: Energy specialist: Oversees contract administration, training activities, and quality control; identify additional opportunities for promoting EEMs

Energy efficiency manager: Oversees the policy implications of HERS/EEMs; ensure successful implementation of HERS/EEMs statewide, and represent $\mathrm{CA}$ with respect to national HERS/EEMs issues

\section{Pacific Gas \& Electric Company}

Key contacts: Aslina Abdullah, Program Manager, CHEERS; David Altscher, Product Manager

Type of organization: Combined investor-owned utility 
Address: 444 Market Street, Room 1600-T16A, San Francisco, CA 94111 (Altscher) 3400 Crow Canyon Road, San Ramon, CA 94583 (Abdullah)

Phone: (415) 973-6077 (Altscher) (510) 866-5771 (Abdullah)

Fax: (415) 973-4607 (Altscher) (510) 866-5571 (Abdullah)

e-mail DXA6@pge.com (Altscher) AXA0@pge.com (Abdullah)

Number of staff: 4

Program activities: Consumer Outreach Campaign on CHEERS and EEMs Trade Professional Education Seminar on CHEERS and EEMs

Annual budget: N/A

Geographic coverage: PG\&E service territory in California, from Eureka in the north to Bakersfield in the south

Marketing activities:

A ten-step program:

1. To distribute 50,000 audio-tapes to consumers: "The Best Kept Home Loan Secret of the 90's"

2. To distribute 50,000 booklets to consumers: "Energy Efficient Mortgage Home Owner Guide"

3. Articles in monthly billing insert "Spotlight" on CHEERS and EEMs; distribution to 4.6 million residential customers (March, May, and November)

4. Direct mail on CHEERS and EEMs; distribution to 3,000 targeted residential customers (April, June, and August)

5. Newsletter ("EEM-POWER") on accomplishments of CHEERS and EEMs Circulation to 1,500 trade professionals (January, April, July, and October)

6. Flyers on FREE Consumer Information on CHEERS and EEMs; distribution of 10,000 pioces through Fairs, Homeshows, Conventions and Home Improvement Retail Stores

7. Weekly Internal Newspaper "PG\&E Week" on CHEERS and EEMs; circulation to 28,000 PG\&E employees and retirees (April, July, and September) 
8. Trade Professional Seminar: "ENERGY EFFICIENT MORTGAGE, A Money Making Advantage"; Goal: 20 classes with 1,400 attendees (April to September)

9. Correspondence Course: "ENERGY EFFICIENT MORTGAGE, A Money Making Advantage"; Goal: 2,000 participants (May to December)

10. Planned media coverage on CHEERS and EEMs-Radio, TV, and Newspaper

\section{Southern California Edison (incomplete)}

Key contact:.................................. Merry Seabold, Lender Training

Type of organization: ....................... Investor-owned electric utility

Phone: ........................................... (818) 812-7568 


\section{Part 2. Recordkeeping and Data Collection}

\section{CHEERS}

Data collected on: Ratings, use of ratings, users

Forms used: CHEERS rating data forms

Data responsibility: Robert Scott, manager of technical services

Method for storing data: Computer database; raters keep hard copies of the rating sheets

Number of ratings: 1993: $\quad 6,369$

1994: 8,307

1995: $\quad 344$

Total: 15,020 (1993-1995)

Reporting requirements: Annual report

Software: The software developed for field testing and utilized in 1993 through 1995 (CHEERS 1.0), based on Title 24. This software is being replaced by a Windows version called CHEERS $2.0^{\mathrm{TM}}$ will be phased in by March 31, 1996.

\section{Energy Plus}

Data collocted on: Ratings, subsequent actions (e.g., EEMs), reasons for not taking action

Forms used: Rating forms

Method for storing data: Computer database, similar to (compatible with?) CHEERS

Number of ratings: 1994 (March-December): 71 (36 were EEMs) 1995: 204 (>140 were EEMs)

Rating software: Developed own software, but similar to other rating software with a 0-100 scale

Reporting requirements: Internal business records only

HUD

Number and value of EEMs:

FY93: $47 \quad(\$ 5,397,462)$

FY94: $261(\$ 26,939,284)$

FY95: $740(\$ 79,491,002)$

EEM tracking method: CHUMS (source of above numbers from HUD Headquarters) 


\section{CEC}

Data collected on: ......................... Training activities for subcontracts described in Part 3

Tracking method:........................... A database lists all planned activities; as subcontractors send monthly reports to CEC, number trained and dates of training are entered and tracked on a milestone chart

Reporting requirements: .................. Contractors must provide specific deliverables and reports

\section{PG\&E}

Data collected on: EEM attendees Attendance Control Records, Evaluation Forms and Tests

Forms used:

DRE Forms

Method of storing data:

Computer database and hard copies

Reporting requirements:

CEC SB 314 Funding

Listing in Housing and Energy Professionals Directory

\section{Southern California Edison}

Not available at this time. 


\section{Part 3. Training and Education}

\section{Raters}

CHEERS

Responsibility: CHEERS, Inc., conducts training at PG\&E's Stockton training facility and other facilities in Northern and Southern California

Number trained: 213

Length of training: 5 days (classroom, in-field/lab, software, financing, and marketing)

Energy Plus

Responsibility: Owners were trained by PG\&E and CHEERS

Number trained: Owners have trained one other person and plan additional training in 1996

Length of training: Not available

\section{Lender and Real Estate Professional Training}

Sacramento Home Loan Counseling Center, contract with CEC

Description: Training course for lending institutions and housing agencies; assemble resource library; index library and make it available through CEC's Web site; develop educational tools for use by state and local policy makers

Number trained: 74 (3 sessions); ??? (1 session)

PG\&E (includes contract with CEC in 1995-96)

Description

For 1995, a course on EEMs and CHEERS entitled Add a New Dimension to Your Business with Energy Efficient Mortgages, You've Got a Role Worth Playing! was developed for lenders, real estate, housing, and energy professionals. It was approved by the California Department of Real Estate for 4-hours of Continuing Education Units for Consumer Protection. The concentration of the course was on EEMs with CHEERS as a linkage to securing EEM loans for energy-efficiency improvements. 
For 1996, the original course revamped with a new title, ENERGY EFFICIENT MORTGAGE, A Money Making Advantage into a workbook structure focusing on marketing EEMs and HERS. It is 3-hours and will be submitted for California Department of Real Estate approval. Targeted to real estate and lending professionals, as well as other housing and energy professionals, a total of 20 classes are planned. This course will also be offered as a correspondence course in order to cover the demand in PG\&E's service territory.

Developed a course for lenders and real estate professionals. It begins with a core introduction to EEMs aimed at both groups, followed by breakout sessions during which lenders and real estate agents convene separately for training specific to each group.

Number trained:

Total: 850 people for 1995

513 Real Estate Professionals

198 Lending Professionals

39 Appraisers/Home Inspectors/Raters

15 Home/Mortgage Insurance/Title

8 Builder/Developer/City/Government

75 Utility

Length of training: 7 months

Dates of training:

Total: 15 classes for 1995

March 2 Sacramento

March 30 Walnut Creek

April 17 Shell Beach

May 31 San Mateo

June 14 Berkeley

June 22 Fresno

June 29 Sacramento

July 12 San Mateo

July 26 Santa Rosa

July $31 \quad$ Hayward

August 3 Stockton

August 8 San Jose

September 14 Chico

September 26 Bakersfield

September 28 San Francisco

Total: Plan 20 classes for 1996 


$\begin{array}{ll}\text { May 24 } & \text { San Mateo } \\ \text { May 30 } & \text { Stockton } \\ \text { June 20 } & \text { Sacramento } \\ \text { June 21 } & \text { Walnut Creek } \\ \text { June 28 } & \text { Fresno } \\ \text { July 10 } & \text { San Francisco }\end{array}$

Building Industry Institute, contract with CEC (DOE funds)

Description: Focus on lenders in Sacramento, Fresno, and Santa Ana HUD regions where the housing market is most active

Number trained:

30 (3 sessions)

CHEERS, Inc.

Description: Sponsor sessions with lending associations, real estate associations, and others

Number trained:

None

Date(s) of training: New 1996 program

Length of training: 4 hours

Additional training plans: Will train individual lenders at lending organizations as appropriate, and will offer training to real estate organizations upon request

Method of marketing: Direct mail. PG\&E will market the sessions in their service territories. Lending and real estate organizations will market the training to their members throughout the state

$C A R$, contract with $C E C$

Description: 1995 course called "Energy Efficient Mortgages: The Wave of the Future"; receive three hours of continuing education credit for successfully passing the examination; approved by DRE; no cost

Number trained: 1,500 had passed as of December 31, 1995; all registrations received by December 31,1995 , were sent to CEC; exam must be taken within one year of registration

Date: Published in August 1995; 175,000 copies distributed 


\section{Building Contractors and Trade Allies}

Air Conditioning Trade Association (ACTA), contract with CEC

Number trained: 64 HVAC contractors

Date(s) of training: May 12, 1994; Sept. 10, 1994; March 26, 1995

Length of training: $11 / 2$ to 2 hours

Additional training: ACTA 10 contractors to the 1994 Western Affordable Comfort Conference and 50 to the 1995 conference.

Method of marketing: Marketed by ACTA

Institute of Heating and Air Conditioning Industries (IHACI), contract with CEC

Number trained: 40-45 contractors, manufacturing representatives, and utility personnel

Date(s) of training: May 19, 1994

Length of training: $11 / 2$ hours

Additional training: IHACI sent 13 contractors to the 1994 Western Affordable Comfort Conference and 5 to the 1995 conference.

Method of marketing: IHACI is marketing training sessions through flyers to its membership and an ad in its magazine, Indoor Comfort News

\section{Insulation Contractors Association, contract with CEC}

Number trained: $100+$

Date(s) of training: 1994

Length of training: Seminars at Lenders' Fairs

Additional training plans: None

Building Industry Institution, contract with CEC (DOE funds)

Description: For sales staff of five large production builders in Sacramento, Fresno, and Santa Ana areas

Number trained:

Dates of training: September 1995

Length of training: 
Building Industry Institution, contract with CEC (DOE funds)

Description: . For remodelers in Sacramento, Fresno, and Santa Ana areas

Number trained: 480 targeted via 46 sessions

Dates of training: . 1996 


\section{Part 4. Implementation}

\section{Obstacles to HERS/EEMs Implementation}

1. Difficult-to-reach consumers and trade allies, and to convince them to consider EEMs.

2. Consumers frequently confuse a utility audit with a CHEERS rating.

3. There is no infrastructure to link lenders, real estate agents, and appraisers; EEMs cannot be successfully promoted to consumers unless such a network is in place.

4. Limited personnel and financial resources circumscribe efforts to market EEMs, develop and conduct training for lenders and real estate professionals, and process rating data.

5. EEMs paperwork and guidelines are complex and vary from one secondary market organization to another (i.e., Fannie Mae and Freddie Mac guidelines are not consistent with FHA's; FHA and DVA do not use the same forms, and they have different approaches and qualifying limits).

6. Lenders that have processed EEMs but misunderstood the guidelines may be reluctant to process additional EEMs.

7. Personnel at bank branches may be reluctant to process EEMs even though the bank's central office is in full support of the EEMs pilot.

8. HUD's lender training did not devote enough time to explaining EEMs (only 30 minutes were allotted to EEMs out of a half-day session).

9. Most loan originators and underwriters have not seen the Mortgagee Letter on EEMs that FHA sent to lenders.

\section{Resolution of Obstacles Listed Above}

1. Staff developed a strategy to further involve lenders and trade allies: members of the CHEERS, Inc. Board of Trustees and others involved in CHEERS, Inc., development activities worked within their respective organizations to identify individuals who were supportive of the EEMs pilot. These individuals, in turn, have sought out and involved others in EEMs.

2. CHEERS, Inc., staff are still climbing the market-development curve for the rating industry and EEMs; however, they have learned to be flexible in meeting marketplace demands (e.g., adapting CHEERS software to be more user friendly, adapting to the changes brought about by the FHA pilot, and providing support for EEMs necessitated by the pilot).

3. CHEERS, Inc. staff have worked with partners and allies to raise enough money to implement the program. The organization is regulated by the State of California and, therefore, cannot receive state financial support.

\section{Most Successful Aspects of Program}

1. Did $75 \%$ more ratings than anticipated (aimed at 4,000 conducted 7,000 ). 
2. Refocused CHEERS, Inc.'s goals and objectives to support the requirements of the FHA EEMs pilot, and to meet consumer and industry information and training needs generated by the pilot; operational focus of CHEERS, Inc. shifted from research and development to the marketplace.

3. Fostered a cooperative spirit among trade allies and partners involved with CHEERS, Inc., who have put aside their respective differences to work toward what is best for the consumer.

\section{Six-Month Milestones}

1. Revamp software to make it more user friendly by adding new data fields (such as a field to identify the reason for a rating), and more responsive to EEMs data requirements so that the information will be more useful to both consumers and lenders.

2. Complete development of the lender and real estate professional training curriculum, have it approved by the California Board of Realtors as a continuing education course, and begin the training process.

3. Increase the number of lenders who ar e committed to offering EEMs.

4. Secure CEC certification of CHEERS.

\section{Long-Term Goals}

Create an infrastructure involving lenders, real estate professionals, and other trade allies that institutionalizes EEMs and through which EEMs can be marketed to consumers. 


\section{Chapter 3}

\section{The Alaska HERS/EEMs Pilot Program and Related Efforts: A Case Study Covering the Years 1981 - 1995}

Nancy E. Collins, Ph.D., $\mathbf{Q}^{4}$ Associates, Oakland, California 


\section{Acknowledgments}

The author appreciates the cooperation and contributions of the following people through interviews, telephone conversations, printed materials, data, reviews of drafts of the report, and continuing updates, July 1995 through November 1996:

- Energy Rated Homes of Alaska Program: Barbara Collins, Toni McPherson; Nancy Konop

- Alaska Housing Finance Corporation: Steve Baden, Barbara Baker, Bob Brean, Frank DElia

- Alaska Craftsman Home Program: Tim Sullivan

- HUD/FHA Anchorage Office: Gene Dobrzynski

- Alaska Appraisal Institute: Fred Ferrara

This case study was prepared under funding from the National Renewable Energy Laboratory, Barbara C. Farhar, Technical Monitor. 


\section{Executive Summary}

This report addresses the evolution, status, and future direction of efforts in Alaska to promote energy efficiency financing linked with energy ratings. It is based on information obtained from July 1995 through March 1996 from the organizations playing key roles in instituting home energy ratings systems and energy efficiency financing (HERS/EEF) in the state. The time period covered in the report begins in the early 1980's and concludes December 31, 1995, although occasional reference is made to preliminary 1996 data, activities, and goals.

Organizations highlighted in the report and whose staff were interviewed, include the Alaska Housing Finance Corporation (AHFC), AHFC's Energy Rated Homes of Alaska Program (ERHAP), Innovative Communications (the grantee for ERHAP), Energy Rated Homes of Alaska, Inc. (ERHAKI), Alaska Craftsman Homes Program, Inc. (ACHP), the U.S. Deparment of Housing and Urban Development (HUD) Federal Housing Administration (FHA) Anchorage Field Office, the Appraisal Institute of Alaska. Many other housing, lending, and consumer associations are involved in HERS/EEMs activities through these organizations, and private sector lenders and realty agencies offer their own incentives of varying types. Information on these efforts was obtained through the aforementioned interviews and are described in the report.

The Energy Rated Homes of Alaska Program is the oldest statewide operating home energy rating system in the nation. In 1984, representatives from the State of Alaska, the state's housing industry, and utilities created a committee that established the home energy rating system. That year, the Anchorage Municipal Light and Power utility, the Fairbanks North Star Borough, and the City and Borough of Juneau received $\$ 10,000$ from the State Energy Office (SEO) to modify the ERHA's rating system specific to Alaska. The effort to develop the state's rating system was boosted by the State of Alaska's effort to adopt a building energy-efficiency standard. Through a compromise between the SEO and the ASHBA, the Alaska Legislature recognized that a rating system could serve as an alternative means of compliance with the state's energy code. In 1986 the rating system was in place and ASHBA, with the SEO and the Cooperative Extension Service, spearheaded the effort that led to the formation of ACHPI. Ironically, the rating system was completed just as Alaska entered an economic depression and little was happening in the housing market. In 1989 the market began to recover and the SEO began giving grants from oil overcharge settlement funds to support the rating system and ACHP.

The SEO contracted with Innovative Communications in 1989 to market the rating program in preparation for offering loans and rebates to install ECMs beginning in 1990. ACHP also began training builders in constructing what are ACHP homes, rated as $5 \star+$. Thus the rating system incorporated ACHP certification. With the rating system in place, it was relatively simple-when state building standards became more stringent in 1995 - to move the equivalent rating from $4 \star$ to $4 \star+$.

The focus of the Alaska program through 1995 has been on rating new homes and convincing builders to build to the highest standards possible. Now that more than four out of five (83\%) new homes are being rated, the focus can shift to rating existing homes. Training of real estate agents, lenders, underwriters, and appraisers will be stepped up, with the goal of convincing them that energy efficiency adds permanent value to a home, and that it can be calculated in the same manner as, say, an additional bedroom or bath. 
From 1991-1995, 11,498 ratings were completed; nearly half (47\%) were "as is" and 15\% were conducted after energy-efficiency improvements were completed; the remainder were ACHP, new construction, and building standards. About 150 raters have been trained and about 100 retrained from 1989-1995. Although only 34 HUD EEMs were completed from 1993-95, AHFC gave rebates to 1,236 homeowners based on ratings. EEMs had a total value of $\$ 1.35$ million; AHFC rebates totaled about $\$ 4.5$ million.

Considerable coordinated effort has been made in trairing, education, and consumer information activities. Training has reached nearly 450 real estate agents, nearly 150 lenders, six appraisers, and 400 builders. In addition, ACHP courses have been attended by 4,500 people (many may have attended more than one course). These numbers should be viewed within the context of the size of Alaska and its housing market. The state's population is half a million, half of whom live in the Anchorage area. The mmber of professionals serving the housing industry is, accordingly, small-some 2,200 real estate agents, 5 multiple listing services, 35 lending institutions, 80 appraisers, and fewer than 1,000 residential contractors. 


\section{Contents}

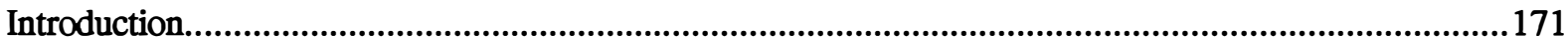

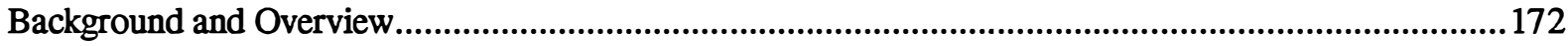

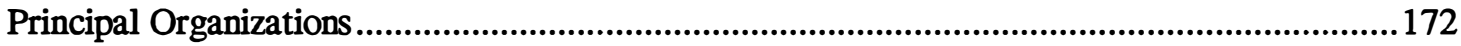

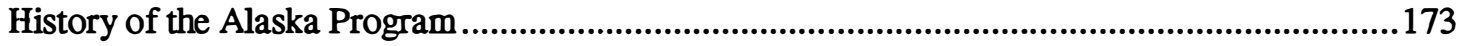

Description of Each Organization...............................................................................................176

Funding Summary, 1993-1995, Alaska ......................................................................................181

Operating Environment and Relationship to Activities at the National Level..............................182

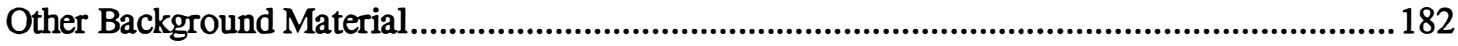

Energy Efficiency Financing Products and Incentives in Alaska...........................................................185

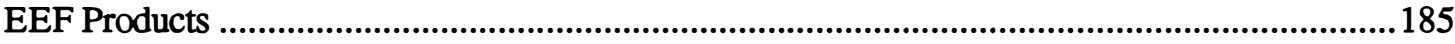

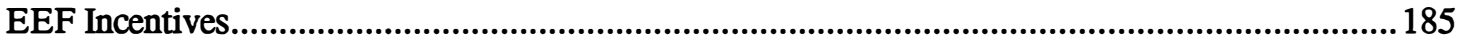

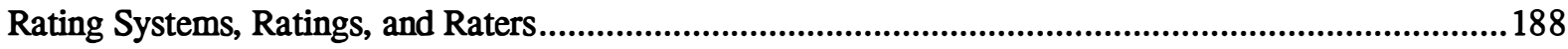

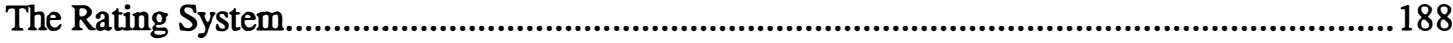

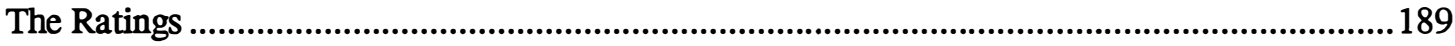

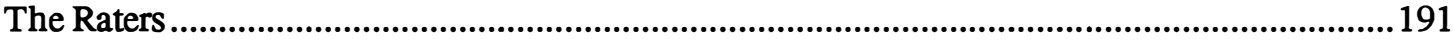

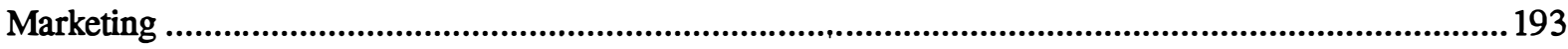

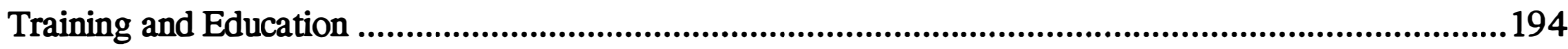

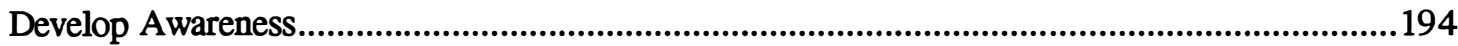

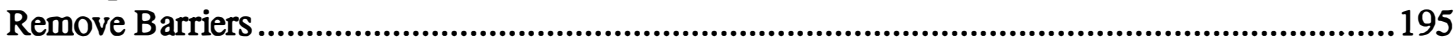

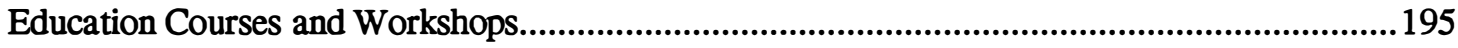

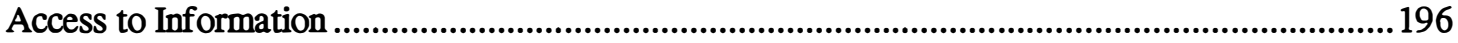

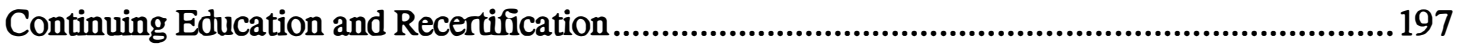

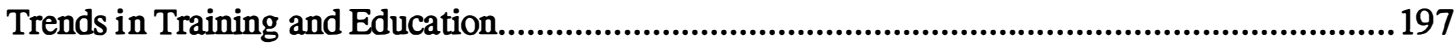

Preliminary Evaluation Data...............................................................................................................198

Problems and Solutions, Successes, and Future Directions ..........................................................202

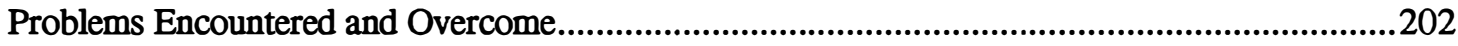

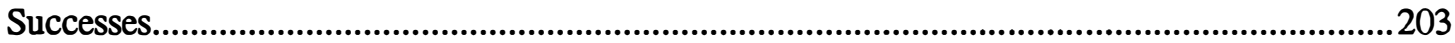

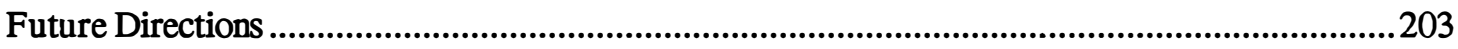

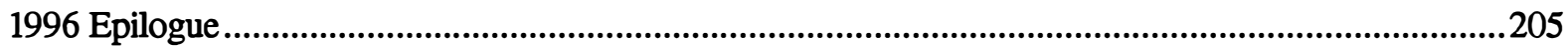

\section{Tables}

Table 3-1. Chronology of Events, Alaska HERS/EEMS ...............................................................174

Table 3-2. Funding Sources and Estimated Amounts, 1993-1995 ..................................................181

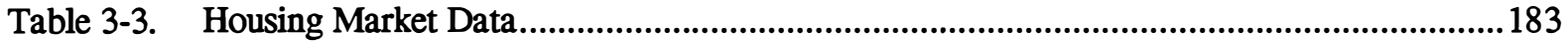

Table 3-4. HUD/FHA Mortgage and EEM Activities ..................................................................... 183

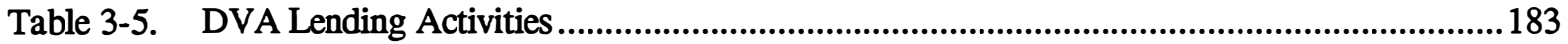

Table 3-6. Rural Housing Service Lending Activities........................................................................ 184

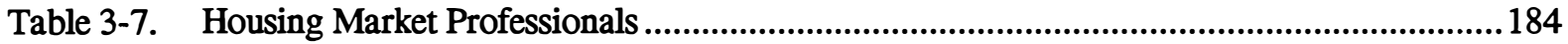

Table 3-8. Value of Financial Incentives Provided by AHFC, 1991-1995 .......................................... 186 
Table 3-9. Number of Financial Incentives from AHFC, 1991-1995 ...........................................187

Table 3-10. Type and Number of Ratings Completed in Alaska, 1991-1995 .......................................189

Table 3-11. ACHP Certified Homes Constructed, 1989-1995 ............................................................190

Table 3-12. Ratings Held Back for Problem Resolution, FY 1995 by Quarter......................................191

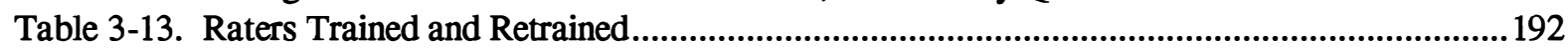

Table 3-14. Training Activities, FY 1995 .......................................................................................194

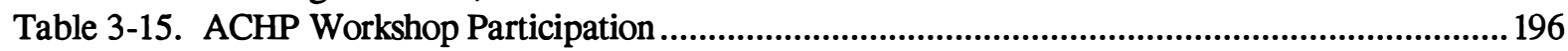

Table 3-16. Calls to the ERHAP 800 Number, by Quarter .................................................................. 196

Table 3-17. Number of Ratings Compared to EEMs and EEIs Completed ...........................................198

\section{Figures}

Figure 3-1. Improvements in Housing Energy Efficiency in Alaska...............................................188

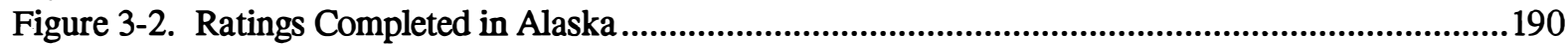

Figure 3-3. Improvements in Energy Efficiency for Houses Rated .......................................................199

Figure 3-4. Measures Installed with AHFC Rebates .............................................................................200

Figure 3-5. Dollar Investments in Measures Installed with AHFC Rebates.........................................200

Figure 3-6. Average Energy Costs and Percent Energy Saved for Homes Receiving AHFC

Rebates Based on Ratings...............................................................................................201

Figure 3-7. Cost of Energy Efficiency Measures and Annual Energy Savings ......................................201

\section{Appendix}

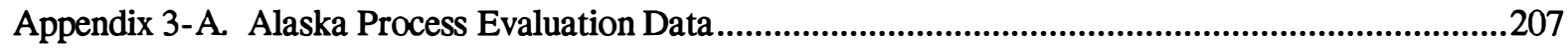

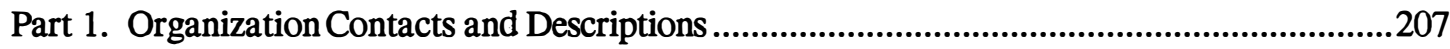

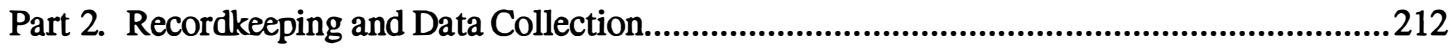

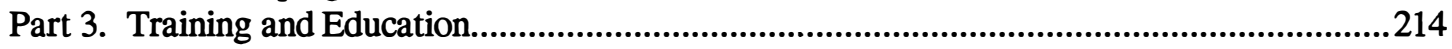

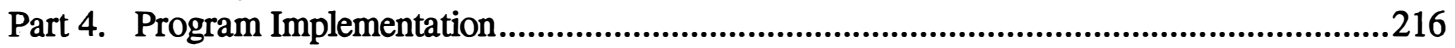




\section{Introduction}

This case study focuses on HERS and EEMs activities in Alaska from the time actions were first taken in the early 1980s through December 1995, with emphasis on events during 1993, 1994, and 1995, and particular attention to activities related to Alaska in implementing its HUD pilot state status. The author conducted on-site interviews in July 1995 with staff representing the following organizations:

- Alaska Housing Finance Corporation

- Energy Rated Homes of Alaska Program grantee

- Alaska Craftsman Home Program grantee

- HUD/FHA Anchorage field office

- Alaska Appraisal Institute

The approach taken in consolidating interview information and data was to "tell the story" of events, organizations, and progress toward achieving success in voluntarily linking HERS with EEMs. The interviews themselves focused on clarifying information that had been obtained by NREL during the last several years and understanding conflicting and confusing data. Prior to conducting interviews, copies of the list of information needed for the study were sent to those scheduled for interviews; the results are shown in Attachment 1 and are the basis for much of the narrative in the body of this case study. It was not unusual to find that each person interviewed had a slightly different version or view of certain key events, problems encountered, and degree of success of HERS and EEMs. It was this author's job to fairly and accurately describe events in Alaska based on the collective interviews, since each interview (and subsequent rounds of review and phone conversations) added new pieces to the puzzle. Due to funding limitations, not all organizations and individuals involved over the years could be interviewed. NREL provided guidance on who to talk with, and those people were helpful in obtaining information from others who were not interviewed.

Late in 1996, when it became clear that the case studies might not be printed and distributed until early 1997, those people previously interviewed were recontacted for updates on what significant events had transpired during 1996. This brief summary is found as an addendum to this case study. 


\section{Background and Overview}

\section{Principal Organizations}

The following key players and organizations and their roles in Alaska's HERS/EEMs efforts, beginning in 1981, are described in this section. Contact and summary information is in Appendix 1-A.

\section{Alaska Housing Finance Corporation (AHFC)}

The Research and Rural Development Division includes the former state energy office (SEO). It tracks ratings, offers loans and rebates for energy-efficiency improvements in new and existing housing. Specific to this case study, AHFC administers the Warm Homes for Alaskans program, which includes grants that have been used to support the rating system and the Alaska Craftsman Home Program.

\section{Energy Rated Homes [. . . ]}

Note the following distinctions among use of similar terminology; acronyms in parentheses are used by the author throughout the case study to refer to each entity. However, marketing materials distributed by all organizations use the acronym "ERHA ${ }^{\circledR n}$ as the "public persona."

- Energy Rated Homes of America, Inc. (ERHA): Owner of the trademarked term "Energy Rated Homes $^{\circledR n}$ and the copyrighted (1980s) EZ-Rater Software. Membership is limited to one entity per state, which also has the sublicense for use of EZ-Rater (an exception is Alaska, until July1, 1996). Annual fee is either $\$ 15 /$ rating or $\$ 12,000$, whichever is less.

- Energy Rated Homes of Alaska Program (ERHAP): A component of the AHFC's Warm Homes for Alaskans; some activities are funded through competitive grants (e.g., marketing) to Innovative Communications (a sole proprietorship) from 1989-1996 (grant canceled in early 1996 and responsibilities retumed to AHFC); other activities are done in-house (e.g., ratings database); through June 1996, paid the sublicense fee to ERHA for use of EZ-Rater.

- Energy Rated Homes of $\underline{\text { Alaska }}{ }^{\circledR}$ (ERHAK): A registered trademark owned by ERHAKI; used in marketing material.

- Energy Rated Homes of Alaska, Inc. (ERHAKI): A nonprofit founded in June 1994 to take the rating system into the private sector; the Alaska member of ERHA; the recipient of DOE and NREL funds for FY95.

\section{Innovative Communications}

As the AHFC grantee for ERHAP, this organization trains raters; reviews ratings/checklists for quality control; markets HERS, EEMs, and other financing products; operates an 800 number; and trains lenders and real estate agents. 


\section{Alaska Craftsman Home Program (ACHP)}

The ACHP trains consumers, owner-builders, professional builders, and raters; develops educational material; and operates an 800 number. It is funded through grants from AHFC as part of the Warm Homes for Alaskans Program. Alaska Craftsman Home Program, Inc. (ACHPI) is the name of the 501(c)(3) that has received the AHFC grants and certifies ACHP builders and $5 \star+$ homes.

\section{State Legislature}

The legislature establishes building standards, authorizes program funds, and specifies AHFC functions.

\section{University of Alaska, Cooperative Extension Service}

The Cooperative Extension is a partner in establishing ACHP; it offers workshops for consumers.

\section{HUD/FHA Anchorage Office}

The office insures (underwrites) EEMs and other financing products; participates in educational seminars, particularly for home buyers; and trains underwniters and appraisers.

\section{Alaska State Home Builders Association (ASHBA)}

This group lobbies for legislated building standards and certification of residential contractors, continued funding for ACHP and ERHAP, and the privatization of ERHAK.

\section{Housing Market Professionals}

This group includes real estate agents, lenders, and appraisers.

\section{Gas and Electric Utilities}

The utilities offer rebates for installing energy-efficiency measures; support use of ratings.

\section{History of the Alaska Program}

The Energy Rated Homes of Alaska Program is the oldest statewide operating home energy rating system in the nation. In 1984, representatives from the State of Alaska, the state's housing industry and utilities created a committee that established the home energy rating system That year, the Anchorage Municipal Light and Power utility, the Fairbanks North Star Borough, and the City and Borough of Juneau received $\$ 10,000$ from the SEO to modify ERHA's rating system specific to Alaska. The effort to develop the state's rating system was boosted by the State of Alaska's effort to adopt a building energy-efficiency standard. Through a compromise between the SEO and the ASHBA, the Alaska Legislature recognized that a rating system could serve as an alternative means of compliance to the state's energy code. In 1986 the rating system was in place and ASHBA, with the SEO and the Cooperative Extension Service, spearheaded the effort that led to the formation of ACHPI. Ironically, the rating system was completed just as Alaska entered an economic depression and little was happening in the housing market. In 1989 the market began to recover and the SEO began giving grants from oil overcharge settlement funds to support the rating system and ACHP. 
The SEO contracted with Innovative Communications in 1989 to market the rating program (under the name of ERHAK) in preparation for offering loans and rebates to install ECMs beginning in 1990. ACHPI became a 501(c)(3) organization in 1989 and began training builders in constructing what are ACHP homes, rated as $5 \star+$. Thus the rating system incorporated ACHP certification. With the rating system in place, it was relatively simple - when state building standards became more stringent in 1995-to move the equivalent rating from $4 \star$ to $4 \star+$.

The focus of the Alaska program through 1995 has been on rating new homes and convincing builders to build to the highest standards possible. Now that more than four out of five (83\%) new homes are being rated, ${ }^{1}$ the focus can shift to rating existing homes. Training of real estate agents, lenders, underwriters, and appraisers will be stepped up, with the goal of convincing them that energy efficiency adds permanent value to a home, and that it can be calculated in the same manner as, say, an additional bedroom or bath.

Table 3-1 provides a chronology of events in Alaska that are related to implementation of the rating system and associated programs.

Table 3-1. Chronology of Events, Alaska HERS/EEMS

\begin{tabular}{|c|c|}
\hline Date & Event \\
\hline 1980 & $\begin{array}{l}\text { Alaska Legislature enacted a law saying that the State could not provide financial } \\
\text { assistance for purchase or construction of a home after December } 31,1981 \text {, unless it } \\
\text { complies with energy standards. }\end{array}$ \\
\hline 1981 & $\begin{array}{l}\text { Building energy performance standards passed; must be met in order to get state } \\
\text { funds/loans. }\end{array}$ \\
\hline 1984 & $\begin{array}{l}\text { A group of Alaskan housing industry leaders brought together the key players to } \\
\text { develop a home energy rating system for the state. The group affiliated with ERHA. } \\
\text { Anchorage Municipal Light and Power and the Boroughs of Fairbanks and Juneau } \\
\text { received funding from the SEO to modify the ERHA rating system specifically for } \\
\text { Alaska. }\end{array}$ \\
\hline 1986 & $\begin{array}{l}\text { CES, SEO, and ASHBA set up ACHP-a program patterned on Canada's R-2000 } \\
\text { program. } \\
\text { Completion of ERHA software modified for Alaska (Juneau, Fairbanks, and } \\
\text { Anchorage; rest of state by end of year). } \\
\text { Alaska entered an economic depression; housing market collapsed; no more than five } \\
\text { ratings completed. } \\
\text { AHFC adopted } 2 \% \text {-ratio stretch for homes with } 4 \star \text { ratings. }\end{array}$ \\
\hline 1988 & $\begin{array}{l}\text { ASHBA won injunction against the standards; compromise negotiated by SEO and } \\
\text { changes adopted in legislation. }\end{array}$ \\
\hline
\end{tabular}

${ }^{1}$ The remaining $17 \%$ comprises (a) some builders (in the Wasilla area, for example) who prefer to calculate the actual thermal performance standards rather than use ratings and (b) people who build their own homes without ratings or inspections. 
Table 3-1. Chronology of Events, Alaska HERS/EEMS (Cont.)

\begin{tabular}{|c|c|}
\hline 1989 & $\begin{array}{l}\text { The SEO began funding ERHAP activities through contracts for marketing and data } \\
\text { processing due to staff cuts in the agency; retained control and management of } \\
\text { ERHAP. } \\
\text { ACHP became a 501(c)(3). }\end{array}$ \\
\hline 1990 & Legislation specified training requirements for contractors, effective in 1992. \\
\hline 1991 & $\begin{array}{l}\text { Home Energy Loan Program (HELP) became effective at SEO, and transferred to } \\
\text { AHFC (see Energy Efficiency Financing Products in Alaska section for } \\
\text { description); intended to be funded through 1996. }\end{array}$ \\
\hline $1991-92$ & $\begin{array}{l}\text { Alaska participated as a comember of NASEO in the HERS/EEMs National } \\
\text { Collaborative funded by DOE. }\end{array}$ \\
\hline Jan.1, 1992 & New construction required to comply with revised energy code, effective this date. \\
\hline 1992 & $\begin{array}{l}\text { Merger of all SEO housing programs with AHFC. } \\
\text { HUD recognized the related roles of ACHP, ERHAP, and higher standards. } \\
\text { Education requirements for residential contractor licensing introduced; existing } \\
\text { contractors were grandfathered in. }\end{array}$ \\
\hline 1993 & $\begin{array}{l}\text { Alaska selected as a HUD pilot state for the EEMs program. } \\
\text { AHFC took back data processing functions of the ratings; AHFC interest rate } \\
\text { dectuction program began (see Energy Efficiency Financing Products in Alaska } \\
\text { section for description). }\end{array}$ \\
\hline 1994 & $\begin{array}{l}\text { Responsibility for quality control of ratings from AHFC to grantee. } \\
\text { HUD represented Alaska on the Evaluation Working Group funded by DOE. }\end{array}$ \\
\hline June 1994 & $\begin{array}{l}\text { Energy Rated Homes of Alaska, Inc., formed as a nonprofit organization and the } \\
\text { Alaska member of ERHA. }\end{array}$ \\
\hline $\begin{array}{l}\text { Oct. } 1993 \text { - } \\
\text { Sept. } 1994\end{array}$ & 16 EEMs completed. \\
\hline $\begin{array}{l}\text { Oct. } 1994 \text { - } \\
\text { Sept. } 1995\end{array}$ & 18 EEMs completed. \\
\hline Jan.1, 1995 & inimum standards increased from $4 \star$ to $4 \star t$. \\
\hline May 12,1995 & Funding ended for AHFC's HELP, Out-Of-Pocket, and EEM financing products. \\
\hline June 30,1995 & $\begin{array}{l}\text { State legislature terminated use of Stripper Well money for future AHFC HELP } \\
\text { rebates; AHFC funded it through December } 31 \text {. }\end{array}$ \\
\hline Sept. 1995 & $\begin{array}{l}\text { Staff changes at AHFC regarding program activities; review of past and future goals } \\
\text { of programs, particularly with respect to rural areas of Alaska; expectation that the } \\
\text { AHFC grants for FY97 will be for more specific tasks and perhaps to several } \\
\text { (maybe different) grantees due to greater competition in the marketplace. } \\
\text { AHFC lead project person resigned to become Executive Director of RESNET, } \\
\text { funded through NASEO, which has contracts with EPA and DOE. }\end{array}$ \\
\hline Oct. 1995 & Quality control of ratings function moved back to AHFC from grantee. \\
\hline Dec. 31,1995 & End date for AHFC interest rate reduction program for new homes. \\
\hline Feb. 1996 & $\begin{array}{l}\text { Negotiations between AHFC and Innovative Communications to finalize a grant for } \\
\text { marketing ERHAP ended; all functions retumed to AHFC until RFPs can be issued } \\
\text { and grantee(s) selected. }\end{array}$ \\
\hline Mar. 1996 & Introduction of AKWARM, rating software developed by AHFC. \\
\hline June 30, 1996 & $\begin{array}{l}\text { End date for AHFC interest rate reduction program for existing homes. } \\
\text { Tenmination of AHFC sublicense agreement with ERHA for use of EZ-Rater. }\end{array}$ \\
\hline
\end{tabular}




\section{3-1. Chronology of Events, Alaska HERS/EEMS (Cont.)}

\begin{tabular}{|l|l|}
\hline 1996 & $\begin{array}{l}\text { All contractors (including those grandfathered in 1992) must have completed } \\
\text { necessary credits to get a license; any who have not will be dropped from the rolls. }\end{array}$ \\
\hline 1997 & $\begin{array}{l}\text { Existing homes that have been rated will begin to turn over; this is when the real } \\
\text { results and impacts of ratings will be seen. } \\
\text { The five existing MLS companies will be merged into one statewide MLS. }\end{array}$ \\
\hline
\end{tabular}

\section{Description of Each Organization}

This subsection describes the relationships among the key players as of the end of 1995. Although these relationships may change, particularly in terms of how AHFC awards grants for specific tasks related to ERHAP and ACHP, the public sees a single united program called "Energy Rated Homes of Alaska ${ }^{\circledR \text { " and }}$ the marketing activities support this perception. Similarly, ACHPI and ERHAK are mutually supportive in their marketing and training efforts. All players strive toward providing an integrated approach to educating the public and the lending, appraisal, and real estate communities about the benefits of an energy efficient home.

\section{Alaska Housing Finance Corporation (AHFC)}

The AHFC is a nonstock public corporation and government instrumentality of the State of Alaska, functioning as a principal source of residential mortgage loan financing and as a secondary lending agency. Funds used to purchase mortgage loans are generated through bonds and notes. The AHFC includes the agencies that are responsible for public and rural housing. The Research and Rural Development Division of AHFC currently administers the Warm Homes for Alaskans program-a comprehensive approach to marketing the need for affordable housing through energy efficiency-that is the umbrella for ERHAP, ACHP, the weatherization program, and financial incentives. The reason for the program lies in the fact that Alaskans spend $\$ 214$ billion a year for heating-a crippling drain on the Alaskan economy. The program is intended to coordinate information and referral services to avoid duplication of efforts, leverage staff resources, and avoid consumer confusion; it operates via grants to ACHPI (for ACHP functions) and Innovative Communications (for ERHAP marketing functions).

The AHFC role is to coordinate rating-related activities, issue the ratings, provide information to the public, and track data on ratings. For now the AHFC also provides financial incentives (rebates, interest buy downs) based on ratings; all incentives will end June 30, 1996.

Among the many functions performed by the AHFC staff are:

- Manage ERHAP

- Enter rating data from checklists and maintain the rating database ${ }^{2}$

- Ensure integrity of the rating system

- Generate rating reports and send them to homeowners

- Manage and provide funds for loan and rebate programs

- Develop software (new rating program and lender software for EEMs)

\footnotetext{
${ }^{2}$ Ratings are also sent to ERHA for archiving, per the licensing agreement.
} 
- Operate 800 number and prepare literature for distribution

- Provide rebates to lenders and raters (both have been phased out)

- Work with Legislature on budgets for programs

- Provide grants for specific aspects of ERHAP and ACHP

- Train (in participation with grantees) and certify raters

- Update rater manual

AHFC has a Technical Advisory Committee composed of experts from the Alaska building and rating industries, which addresses technical issues related to the rating system.

Staffing. Staff involved in the ratings and energy efficiency financing activities at AHFC totals about 3.0 FTE, and includes the division director (.15 FTE), program manager (1.0 FTE), grants administrator (.30 FTE), data entry staff (1.5 FTE), grant manager (.10 FTE), and loan underwriter (.02 FTE).

Funding. From Petroleum Violation Escrow (PVE) funds (Exxon, Wamer, and Stripper Well), just under $\$ 6$ million in financial incentives, 1991-1995; staffing costs and annual grants total about $\$ 600,000$.

\section{Energy Rated Homes of Alaska Program (ERHAP) Grantee}

ERHAP was founded in 1984 by a group of Alaskan housing industry leaders who worked in conjunction with state personnel. With support from the Energy Extension Service in 1985, its first activity was to develop a tool for rating the energy efficiency of homes. During 1989-95, a grantee (Innovative Communications) marketed the rating system and ERHAP's staff and completed ratings grew steadily. The ERHAP staff created a link between field personnel and the administrative program staff of AHFC.

The ERHAP staff do the following:

- Train and test raters; track the quality of their work; ensure the integrity of the rating system (jointly with AHFC).

- Resolve technical questions about the rating system; recommend how to update the system when needed

- Hold educational seminars and training sessions for members of the housing industry and for homeowners.

- Develop literature (e.g., brochures and fact sheets) for broad distribution and provide access to information via an 800 number.

- Market the concept of ratings and their financial benefits.

Staffing. ERHAP functions were conducted by a program manager, ${ }^{3}$ marketing director, technical director, and administrative assistant.

Funding. A grant of $\$ 300,000$ has been provided annually through Stripper Well funds. From FY1997 on, grant funds will be bid competitively for very specific tasks.

\footnotetext{
${ }^{3}$ From 1989 until early 1996, the project manager of ERHAP (as owner of Innovative Communications) spent 100\% of her time in this capacity, supervising a staff of three. Some confusion in terminology occurred when, in Jume 1994, she became executive director of ERHAKI. The ERHAP grant was canceled in early 1996 by AHFC.
} 


\section{Energy Rated Homes of Alaska, Inc. (ERHAKI)}

Formed in mid-1994, ERHAKI is a nonprofit organization administered by an executive director. It is the Alaska member of ERHA. As ratings become institutionalized and accepted by consumers and members of the housing industry, many people expect that ERHAKI can become self-sustaining, in part by taking on more nationally oriented activities (similar to the approach taken by CHEERS, Inc., in California). In FY96, funding from DOE supported the following activities:

- Work toward development of a national market for home energy ratings and energy efficient mortgages

- Develop infrastructure for and training to the U.S. housing industry on marketing, valuing, and financing energy efficiency in the existing housing market

- Work to create a national home energy rating system and, as necessary, adapt the ERHAK system to the national home energy rating system

- Consultation with individual states on the establishment of rating systems based on Alaska's successful model

In addition, NREL provided funds in FY96 to support evaluation activities related to the production of this case study and establishing a data tracking system for HERS/EEMs.

Policy guidance is provided by an industry council composed of representatives from the Alaska Mortgage Bankers Association, the Alaska Appraisal Institute, ASHBA, the Alaska Association of Realtors ${ }^{\circledR}$, HUD, suppliers and vendors, and utilities.

Staffing. Staff at this time is limited to its executive director.

Funding. FY1996: DOE, $\$ 175,000$; NREL, $\$ 10,000$; industry in-kind funds, $\$ 40,000$.

\section{Alaska Craftsman Home Program, Inc. (ACHPI)}

The mission of ACHPI is to promote energy efficient housing that is cost effective, healthful for occupants, and long-lasting through the education and certification of Alaska builders and contractors. It was formed in 1987 through the combined efforts of the SEO and the University of Alaska Cooperative Extension Service, later joined by the ASHBA. In 1989, ACHPI was incorporated as a 501(c)(3) nonprofit organization and since then has been the grantee receiving AHFC funds to operate the Alaska Home Craftsman Program. Its functions include:

- Hold workshops, ranging from three hours to three days

- Publish comprehensive building manuals, videos, and a newsletter

- Operate an 800 information line

- Certify homes as $5 \star+$ (i.e., ACHP)

- Certify/register builders/contractors as ACHP

- Produce informational materials

- Provide product and technical information

- Open booths at homebuilders shows (six each year)

- Build "demonstration homes," including one at the State Fair 
Builders and contractors who successfully complete the Homebuilding Workshop can choose to enter into a licensing agreement with ACHPI to use its logo and become a "builder member"-an arrangement that must be renewed every two years. Currently, there are 50 builder members located throughout the state. Although ACHPI publishes and distributes the list of members, it neither recommends nor endorses them other than recognizing their knowledge of energy efficient building technologies.

With the publication of its newly revised and expanded building manual and accompanying video and workshops, ACHPI staff believe the phase of developing the criteria for energy efficient construction practices has been completed and is a continuing and accepted aspect of the building industry in the state. ACHPI's focus will now tum to issues related to indoor air quality, such as new technologies for ensuring sufficient numbers of air exchanges and content of carpets and synthetic materials in new homes.

Staffing. At this time, the ACHPI has five full-time staff members: the executive director; technical director; workshop coordinator; energy information specialist; and financial director. A full-time workshop instructor teams with others as neaded

Funding. ACHPI has received a $\$ 300,000$ grant annually from the Alaska State Legislature, DOE Stripper Well funds, and/or state funds to run ACHP, augmented by class fees and other income. Total budget in 1994 was about $\$ 500,000$; in 1993 , about $\$ 450,000$.

\section{HUD/FHA Anchorage Field Office}

Alaska was selected as one of the five pilot states to test the concept of using ratings to determine eligibility for EEMs underwritten by HUD. The HUD field office in Anchorage endorses and underwrites all EEMs produced in the state, as well as other financing products described in the Energy Efficiency Financing Products in Alaska section. Staff often team with people from other organizations to make presentations, staff booths, hold workshops, and train appraisers. Lenders who are originating EEMs can now select appraisers and monitor the progress of EEMs by logging into the CHUMS Lender Access System (CLAS) computer program at the HUD office.

Staffing. Two people in the Anchorage office are regularly involved in the EEMS program-answering questions by phone, speaking at seminars, reviewing applications, and training appraisers. In addition, a computer analyst and an underwriter are involved as needed. When the program was new, about ten hours a week altogether were spent on EEMS; now it is closer to two hours a week because of the automated access and because the initial setup of the system is complete.

Funding. There is no specific funding in the budgets for the HUD field offices for EEMs, nor are there HUD performance goals or incentives associated with EEMs as there are for other HUD products (including selling repossessed properties).

\section{Real Estate Agent Activities}

The marketing benefits of using the ERHAK logo and number of stars to enhance the values of homes are recognized by real estate agents associated with both Coldwell-Banker and Century 21, who offer to pay for the rating if the seller lists with them. The MLS in Anchorage incorporates rating information as the first bullet in the list describing each home-perhaps the first to do so in the U.S. In 1997, the five existing MLS companies will merge into one statewide system. 


\section{Appraiser Activities}

The Alaska Appraisal Institute maintains a data system that includes energy ratings. Appraisers are beginning to credit a home's high energy rating in the appraisal (e.g., assign a value to comparable homes). As the database grows, it will be possible to assign consistent values to either specific energy improvements or to star ratings.

\section{Lenders}

The Alaska Mortgage Bankers Association meets every month and about every third meeting the topic of EEMs comes up. HUD staff attend these meetings to keep involved in the industry. The Association is working with ERHAP to develop a training and outreach program on ratings and EEMs. High turnover among lending officers makes these activities essential.

\section{Alaska State Home Builders Association (ASHBA)}

In response to poor (and energy-inefficient) building practices in Alaska in the mid-1980s, the ASHBA began voluntarily "policing" its members, requining that builders go through special training in order to become residential contractors. In addition, legislation (AS 08.18.026) enacted in 1990 required that, as of 1992, licensed residential building contractors complete course work through ACHPI, the University of Alaska, or some other qualified training course approved by AHFC. (Existing licensed contractors were grandfathered in, but, as of 1996, they will be dropped from the rolls if they have not met the education requirements.) The Association supports the use of ratings and ACHP construction practices, as well as increasingly stringent building standards. Members lobby the state legislature to ensure continued funding of ERHAP and ACHPI. Builders regularly use the rating (or the ACHPI logo) in their ads for new homes.

\section{State Legis/ature}

Following are key relevant pieces of legislation.

\section{- Building Energy Efficiency Standards (BEES), AS 18.56.096(c). This legislation states that}

"... the corporation [AHFC] may not make, participate in the making of, purchase, or participate in the purchase of a loan for a residential building if construction of the building began after December 31, 1981, unless the building complies with the thermal and lighting energy standards required by AS 46.11.040. The corporation

(1) may adopt regulations to implement this subsection; and

(2) shall, by regulation, establish

(A) procedures by which the person responsible for the construction of the building may demonstrate that the building complies with the thermal and lighting energy standards, including

$$
\text { [...] }
$$


(B) criteria by which the energy conservation standards may be met; for purposes of this subparagraph, the residential building complies with the energy standards if the residence has received a rating under the rating system developed by Energy Rated Homes of Alaska if, in the judgment of the corporation [AHFC], the rating meets or exceeds the thermal energy standards required by AS 46.11.040."

- AS 46.11.040. AS 46.11.040 restates the applicability of thermal and lighting energy-efficiency standards to residential buildings, in that state financial assistance may not be approved or granted for the construction of or purchase of a loan for a residential building if construction of the building began after December 31,1981, unless the building meets BEES; or is in compliance with building codes and thermal and lighting standards that meet or exceed BEES; or the building is constructed under an exception to the local building codes; or it is located in an area where the high cost of implementation of the standards is not justified, as determined by AHFC; or applicant agrees, in writing, that the building will meet compliance within one year of conveyance.

- AS 18.56.850. AS 18.56.850 authonizes AHFC to plan, study, implement, and assist programs for energy conservation and weatherization, including but not limited to the Home Energy Loan Program.

- AS 18.55.998. Under AS 18.55.998, AHFC provides up to a $20 \%$ match for the development of HUD housing through regional housing authorities, which may be used for energy efficient design features in homes.

\section{Funding Summary, 1993-1995, Alaska}

Although the information in Table 3-2 is incomplete and does not reflect all funding sources and in-kind contributions, the annual totals show the considerable resources required during 1993-1995 (a minimum of $\$ 6,500,000$ ) to market ratings and EEMs, train raters, and develop a support structure that encourages the use of ratings for EEMs. In addition, funding prior to 1993 probably amounts to several million dollars.

Table 3-2. Funding Sources and Estimated Amounts, 1993-1995

\begin{tabular}{|c|c|c|c|c|}
\hline Organization & 1993 & 1994 & 1995 & Total \\
\hline $\begin{array}{l}\text { Energy Rated Homes of Alaska Program } \\
\text { PVE funds via AHFC } \\
\text { DOE } \\
\text { NREL } \\
\text { Industry in-kind funds }\end{array}$ & $\frac{\mathbf{\$ 3 0 0 , 0 0 0}}{300,000}$ & $\frac{-\$ 300,000}{300,000}$ & $\begin{array}{r}\sim \$ 485,000 \\
300,000 \\
135,000 \\
10,000 \\
40,000\end{array}$ & $\begin{array}{r}\mathbf{\$ 1 , 0 8 5 , 0 0 0} \\
900,000 \\
135,000 \\
10,000 \\
40,000\end{array}$ \\
\hline $\begin{array}{l}\text { Alaska Housing Finance Corporation } \\
\text { Rebates ( } \$ 254,800 \text { in 1991-92) } \\
\text { In-house (staff) }\end{array}$ & $\begin{array}{r}\geq \$ 427,000 \\
427,000 \\
M D\end{array}$ & $\begin{array}{r}\geq \$ 1,635,000 \\
1,635,000 \\
M D \\
\end{array}$ & $\begin{array}{r}\geq \$ 2,120,200 \\
2,120,200 \\
\mathrm{MD}\end{array}$ & $\begin{array}{r}\geq \$ 4,182,200 \\
4,182,200 \\
\mathrm{MD}\end{array}$ \\
\hline $\begin{array}{c}\text { Alaska Craftsman Home Program } \\
\text { PVE funds via AHFC } \\
\text { Class fees and sales }\end{array}$ & $\begin{array}{r}\$ 450,000 \\
300,000 \\
150,000\end{array}$ & $\begin{array}{r}\mathbf{\$ 5 0 0 , 0 0 0} \\
300,000 \\
200,000\end{array}$ & $\begin{array}{r}\geq \$ 300,000 \\
300,000 \\
\text { NA }\end{array}$ & $\begin{array}{r}\mathbf{\$ 1 , 2 5 0 , 0 0 0} \\
900,000 \\
>350,000 \\
\end{array}$ \\
\hline Totals & $\$ 1,177,000$ & $\$ 2,435,000$ & $>\$ 2,905,200$ & $>\$ 6,517,200$ \\
\hline
\end{tabular}

MD: Missing data 


\section{Operating Environment and Relationship to Activities at the National Level}

The people in Alaska are very involved with HERS/EEMs activities in other states and across the country. Representatives from AHFC, ERHAKI, ACHPI, ASHBA, and HUD attend and participate in national meetings, offer advice to others wishing to start programs, and promote a consolidated nationwide program. ${ }^{4}$ They are in agreement that, if a national effort is to be sustained, the biggest of the big financing companies (lenders and secondary mortgage market) and realty companies must buy into it in order to attain critical mass with visibility and credibility. Furthermore, state-level organizations must form either formal or informal coalitions that represent state issues and politics and, therefore, create a system that works best in that context. For these reasons, many of the Alaska players support the Residential Energy Services Network (RESNET) as one way to provide other states with "models" to draw on when setting up programs, consolidating data to demonstrate effectiveness, and estimating potential impacts.

In the past, AHFC staff members worked with staff in Oregon, Washington, and Idaho to try to establish rating programs in those states, using a grant from the Regional DOE office to transfer Alaska's knowledge and experience. A grant agreement was awarded to the Oregon Deparment of Energy to set up a home energy rating system. AHFC staff coninue to provide technical assistance and RESNET has a major role in coordinating information-sharing across states.

In 1995, the treasurer of ACHPI was named to the Energy Committee of the National Association of Home Builders (NAHB). At the annual NAHB meeting, ACHPI staff met with Christine Ervin, Assistant Secretary of the Office of Energy Efficiency and Renewable Energy, U.S. DOE, who expressed considerable interest in the Alaska programs, particularly the educational components directed toward energy efficiency in new housing.

\section{Other Background Material}

Activities regarding the development of a rating system that appears to be well on its way to becoming an accepted part of marketplace activities need to be viewed within the context of the size of the housing market and number of professionals involved, giving a sense of market potential and progress made to date. Alaska has a population of 550,000 - about half of whom live in the Anchorage area. In October 1995, 21 utilities produced greater than 1 million $\mathrm{kWh}$ each. Total generation was 410 million $\mathrm{kWh}(0.2 \%$ of the total produced in the U.S.) and 132 million $\mathrm{kWh}$ were sold for residential use (32\% of production) at an average $11.1 \mathrm{c} / \mathrm{kWh}( \pm 0.6 \%$ standard deviation). Tables 3-3 through 3-7 describe Alaska from 19931995.

\footnotetext{
${ }^{4}$ In March/April 1995, NASEO invited representatives from ERHAK工, ASHBA, ACHP (represented by a rater), and an appraiser to participate in five workshops given around the country for the purpose of sharing information on the Alaska program.
} 
Table 3-3. Housing Market Data

\begin{tabular}{|l|r|r|r|}
\hline \multicolumn{1}{|c|}{ Characteristics } & CY 1993 & CY 1994 & CY 1995 \\
\hline Total single-family homes, Alaska & MD & MD & MD \\
\hline New homes constructed, Alaska & 1,000 & 1,200 & 1,150 \\
\hline Existing home mortgages, Alaska & MD & MD & MD \\
\hline Total value of mortgages, Alaska & MD & MD & MD \\
\hline
\end{tabular}

MD: Missing data

Table 3-4. HUD/FHA Mortgage and EEM Activities

\begin{tabular}{|l|r|r|r|r|}
\hline \multicolumn{1}{|c|}{ Activity } & \multicolumn{1}{c|}{ FY 1993 } & \multicolumn{1}{c|}{ FY 1994 } & FY 1995 & \multicolumn{1}{c|}{ Total } \\
\hline Number of loans & 4,287 & 6,194 & 2,620 & 6,303 \\
\hline Total value & $\$ 443,061,990$ & $\$ 626,414,243$ & $\$ 279,428,689$ & $\$ 1,349,000$ \\
\hline Average value & $\$ 103,543$ & $\$ 101,263$ & $\$ 106,530$ & NA \\
\hline & & & & \\
\hline Number of EEMs & 0 & 16 & 18 & 34 \\
\hline Total value of EEMs & NA & $\$ 1,760,700$ & $1,893,702$ & $\$ 3,654,402$ \\
\hline Average value of EEMs & NA & $\$ 110,044$ & $\$ 105,206$ & NA \\
\hline
\end{tabular}

${ }^{2}$ During FY92-FY94, 306 HUD homes were repossessed and 438 were sold.

Source: Constructed by the author using HUD/FHA data provided by NREL

Table 3-5. DVA Lending Activities

\begin{tabular}{|l|r|r|r|}
\hline \multicolumn{1}{|c|}{ DVA } & \multicolumn{1}{|c|}{ FY 1993 } & \multicolumn{1}{|c|}{ FY 1994 } & \multicolumn{1}{|c|}{ FY 1995 } \\
\hline Total Loans & & & 2,500 \\
Number & 2,304 & 3,286 & $\$ 309,000,000$ \\
Total value & $\$ 259,026,000$ & $\$ 357,781,000$ & $\$ 123,600$ \\
Average value & $\$ 112,425$ & $\$ 108,880$ & 9 \\
\hline Energy Improvement Loans & & & \\
Number & NA & 4 & $\$ 1,107,498$ \\
Total value & NA & $\$ 507,668$ & $\$ 123,055$ \\
Average value & NA & $\$ 126,917$ & \\
\hline
\end{tabular}

Source: Constructed by the author using DVA data provided by NREL 
Table 3-6. Rural Housing Service Lending Activities

\begin{tabular}{|l|r|r|r|}
\hline \multicolumn{1}{|c|}{ Activity } & FY 1993 & \multicolumn{1}{|c|}{ FY 1994 } & \multicolumn{1}{|c|}{ FY 1995 } \\
\hline Direct Loans & & & \\
$\quad$ Number & 82 & 126 & 95 \\
Total value & $\$ 3,582,000$ & $\$ 6,946,000$ & $\$ 4,340,000$ \\
Average value & $\$ 43,681$ & $\$ 55,128$ & $\$ 45,682$ \\
\hline Guaranteed Loans & & & \\
$\quad$ Number & 61 & 82 & 69 \\
Total value & $\$ 4,586,000$ & $\$ 7,010,000$ & $\$ 6,608,000$ \\
Average value & $\$ 75,183$ & $\$ 85,486$ & $\$ 95,768$ \\
\hline
\end{tabular}

Source: Constructed by the author using RHS data provided by NREL

Table 3-7. Housing Market Professionals

\begin{tabular}{|l|r|r|r|}
\hline \multicolumn{1}{|c|}{ Professional Group } & \multicolumn{1}{c|}{ CY 1993 } & \multicolumn{1}{c|}{ CY 1994 } & \multicolumn{1}{c|}{ CY 1995 } \\
\hline Real estate agents & 2,248 & 2,076 & 2,189 \\
\hline Real estate offices & 578 & 520 & 536 \\
\hline Multiple Listing Service companies & 4 & 5 & 5 \\
\hline Mortgage banking professionals & $\mathrm{MD}$ & $\mathrm{MD}$ & $\mathrm{MD}$ \\
\hline $\begin{array}{l}\text { Lending institutions (includes out-of-state lenders } \\
\text { doing refinancing only) }\end{array}$ & 47 & 49 & $35^{\mathrm{a}}$ \\
\hline Appraisers (on HUD panel or working with HUD) & $45^{\mathrm{b}}$ & 45 & 79 \\
\hline Residential contractors & $\mathrm{MD}$ & $\mathrm{MD}$ & 915 \\
\hline
\end{tabular}

MD: Missing data

'The AHFC list of approved lenders has 25, and excludes credit unions and out-of-state lenders.

bAHFC provides a number of 151 total in 1993 and agrees with the 79 number for 1995. 


\section{Energy Efficiency Financing Products and Incentives in Alaska}

The original intent of the HUD pilot programs was to forge a link between the use of ratings and energy efficient mortgages. Therefore, the NREL evaluation design began by limiting its focus to EEMs offered by FHA, VA, and RHS. However, as the design evolved, it became clear that other entities were offering financial incentives for energy efficiency that were also linked to ratings. These incentives include rebates, home improvement loans, and interest rate reductions. The range of products and incentives offered in Alaska is described in this section. The loan products unique to Alaska are described in this section of the case study. AHFC maintains a list of "participating lenders" where buyers can obtain loans and mortgages to fund energy-efficiency improvements based on ratings' recommendations ( 25 as of 12/31/95). However, every mortgage lending institution in Alaska offers FHA and DVA EEMs. Between 1993 and 1995, 34 HUD/FHA loans were closed in Alaska.

\section{EEF Products}

HUD 203(k)

HUD 203(k) finances acquisition and rehabilitation of existing homes. The owner can also get an EEM addition of $5 \%$ or no greater than $\$ 8,000$ for energy-efficiency improvements. In Alaska, 30 had been done through January 1996, financing primarily windows and furnaces.

\section{HUD Title I Home Improvement Loans}

This loan is available to any homeowner whose house is insured by FHA Up to $\$ 25,000$ can be borrowed for 15 years at (in Summer 1995) 8 or $8 \frac{1}{2} \%$ interest. The Alaska HUD office estimated that about $90 \%$ of Title I loans are used for heating system upgrades.

\section{EEF Incentives}

\section{AHFC Home Energy Loan Program (HELP)}

Begun in 1990-91, HELP funds were not available after December 31, 1995. Eligibility required that the participant be an Alaska resident and owner of a single-family detached home. The word "loan" included in the HELP acronym means that a grant, rebate, or interest reduction went to someone who had already taken out an AHFC loan and the money was applied directly to that loan by the lender. That is, the consumer saw a reduction in interest, principal, or closing costs, but did not receive money directly. HELP 1 funds were used to reduce the principal, used to buy down the interest, or applied to the down payment on the purchase of a new home; HELP 2 funds provided interest rate reductions for specific home improvements related to particular types of energy upgrades; HELP 1A funds were used for home energy improvements in existing homes. The program officially ended May 12, 1995. While it was in place, 1,364 HELP 1 loans were made for a total of $\$ 2,874,800$, averaging $\$ 3,800$ per loan. Note, however, that a rating was not required to obtain a HELP grant. 


\section{AHFC Interest Rate Reduction for Energy Efficient Homes}

For each step (i.e., half-star) improvement on an existing home made within 120 days of closing or within the last year before sale, AHFC will recuce the interest rate by $1 / 4 \%$, up to $1 \%$ for four steps or more. A two-step increase averages $\$ 7,000$. This program ended June 30, 1996.

AHFC reduced the interest rate on an AHFC loan by up to $1 \%$ if a new home was energy efficient at the following ratings: $1 / 2 \%$ for $4 \star+$ (maximum, $\$ 1,900$ ); $3 / 4 \%$ for $5 \star$ (maximum, $\$ 2,800$ ); and $1 \%$ for $5 \star+$ (maximum, $\$ 3,200$ ). The loan buydown could not excead $15 \%$ (or the dollar maximums), but could be applied to either the principal or the closing costs. This program ended December 31, 1995.

\section{AHFC "Out-of-Pocket" (OOPS) Program}

OOPS gave rebates to builders of $\$ 1,800$ for a $5 \star$ new home and $\$ 2,000$ for a $5 \star+$ home. From 19931995 , 55 rebates totaling $\$ 91,200$ were paid out. Energy costs were reduced on average by $38 \%$ in 1995 and by $22 \%$ in 1994. OOPS ended May 12, 1995.

\section{AHFC Home Energy Rebate (HER) Program}

Rebates for improvements to existing homes are one-half the cost of improvements, with maximum amounts of $\$ 800$ for 1 step, $\$ 1,250$ for 2 steps, $\$ 1,500$ for 3 steps, $\$ 1,750$ for 4 steps, and $\$ 2,000$ for 5 steps or more. Until recently, AHFC rebated half the cost of the rating so the cost of the rating could not be included in the rebate amount.

This popular program has given out 1,236 rebates since its beginning. The state has invested $\$ 1,435,500$ and homeowners have invested $\$ 2,643,751$. The average reduction in energy costs is $42 \%$ and energy ratings have increased by about 24 points, taking the average home from $2 \star+$ to $3 \star+$.

\section{AHFC EEM Rebate}

Home owners/buyers received cash back when energy efficiency was improved. The same dollar levels as HER were used. In 1994-95, \$14,000 was distributed to nine home owners. The program ended May 12, 1995. Data on numbers and value of AHFC incentives are shown in Tables 3-8 and 3-9.

Table 3-8. Value of Financial Incentives Provided by AHFC, 1991-1995 (\$000)

\begin{tabular}{|c|c|c|c|c|c|c|c|}
\hline Calendar Year & HELP 1 & HELP 1A & HELP 2 & HER & OOPS & EEM & Total \\
\hline 1991 & & & & $\$ 28.9$ & & & $\$ 28.9$ \\
\hline 1992 & & & & $\$ 225.9$ & & & $\$ 225.9$ \\
\hline 1993 & $\$ \quad 1.9$ & & & $\$ 412.1$ & $\$ 13.0$ & & $\$ 427.0$ \\
\hline 1994 & $\$ 1,253.6$ & $\$ 8.5$ & $\$ 3.1$ & $\$ 322.8$ & $\$ 38.0$ & $\$ 9.0$ & $\$ 1,635.0$ \\
\hline $1995^{a}$ & $\$ 1,619.4$ & $\$ 6.3$ & $\$ 3.5$ & $\$ 445.8$ & $\$ 40.2$ & $\$ 5.0$ & $\$ 2,120.2$ \\
\hline Total & $\$ 2,874.8$ & $\$ 14.8$ & $\$ 6.6$ & $\$ 1,435.5$ & $\$ 91.2$ & $\$ 14.0$ & $\$ 4,437.0$ \\
\hline
\end{tabular}

${ }^{2}$ Source: Constructed by the author using AHFC records. 
Table 3-9. Number of Financial Incentives from AHFC, 1991-1995

\begin{tabular}{|c|c|c|c|c|c|c|c|}
\hline Calendar Year & HELP 1 & HELP 1A & HELP 2 & HER & OOPS & EEM & Total \\
\hline 1991 & & & & 28 & & & 28 \\
\hline 1992 & & & & 200 & & & 200 \\
\hline 1993 & 1 & & & 360 & 7 & & 368 \\
\hline 1994 & 612 & 4 & 4 & 279 & 26 & 6 & 931 \\
\hline $1995^{a}$ & 751 & 3 & 2 & 369 & 22 & 3 & 1,150 \\
\hline Total & 1,364 & 7 & 6 & 1,236 & 55 & 9 & 2,677 \\
\hline
\end{tabular}

${ }^{2}$ Source: Constructed by the author using AHFC records.

\section{Free Energy Ratings}

Coldwell-Banker and Century 21 offer free energy ratings in Anchorage to home sellers who list with one of their agents.

\section{Utility Programs}

Several utilities in Alaska offer rebates, partial payment for energy ratings, and gratis low-cost or no-cost items, such as light bulbs and water heater jackets. For example, in Fairbanks, Golden Valley Electric Association has offered a "Home\$ense Program" in the past, but it seems to have saturated the market at this time. The program entailed an energy audit and rating for about $\$ 100$, plus up to three free low-cost or no-cost installed measures. In Juneau, the utility helps customers with high-use all-electric homes get audits or ratings and reduce consumption; has served fewer than 50 homes to date. Homer Electric has offered free ratings and low interest loans. 


\section{Rating Systems, Ratings, and Raters}

\section{The Rating System}

In the mid-1980s, the SEO provided a $\$ 10,000$ grant to have ERHA's five-star rating system (called EZRater) modified for Alaska. The star levels are related to points on a 100-point scale, to Alaska building energy-efficiency standards (BEES), and to the ACHP house. Average rating by year of construction is shown in Figure 3-1.

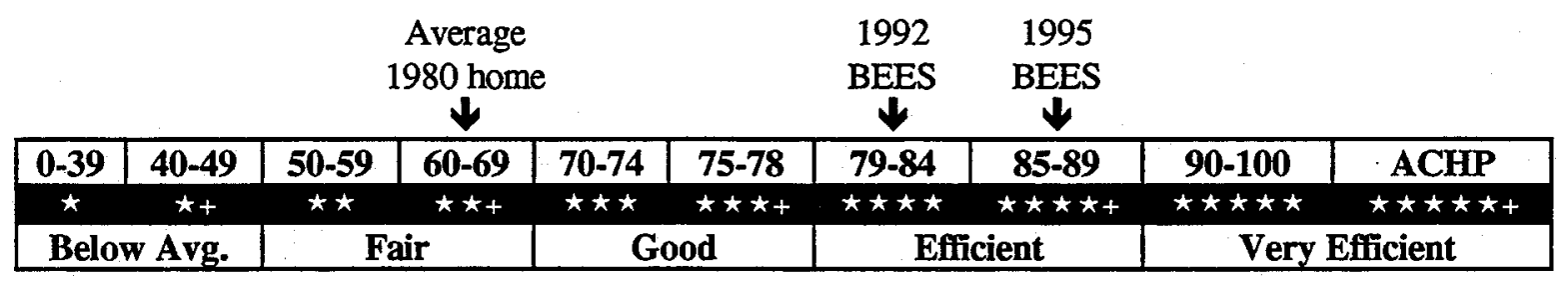

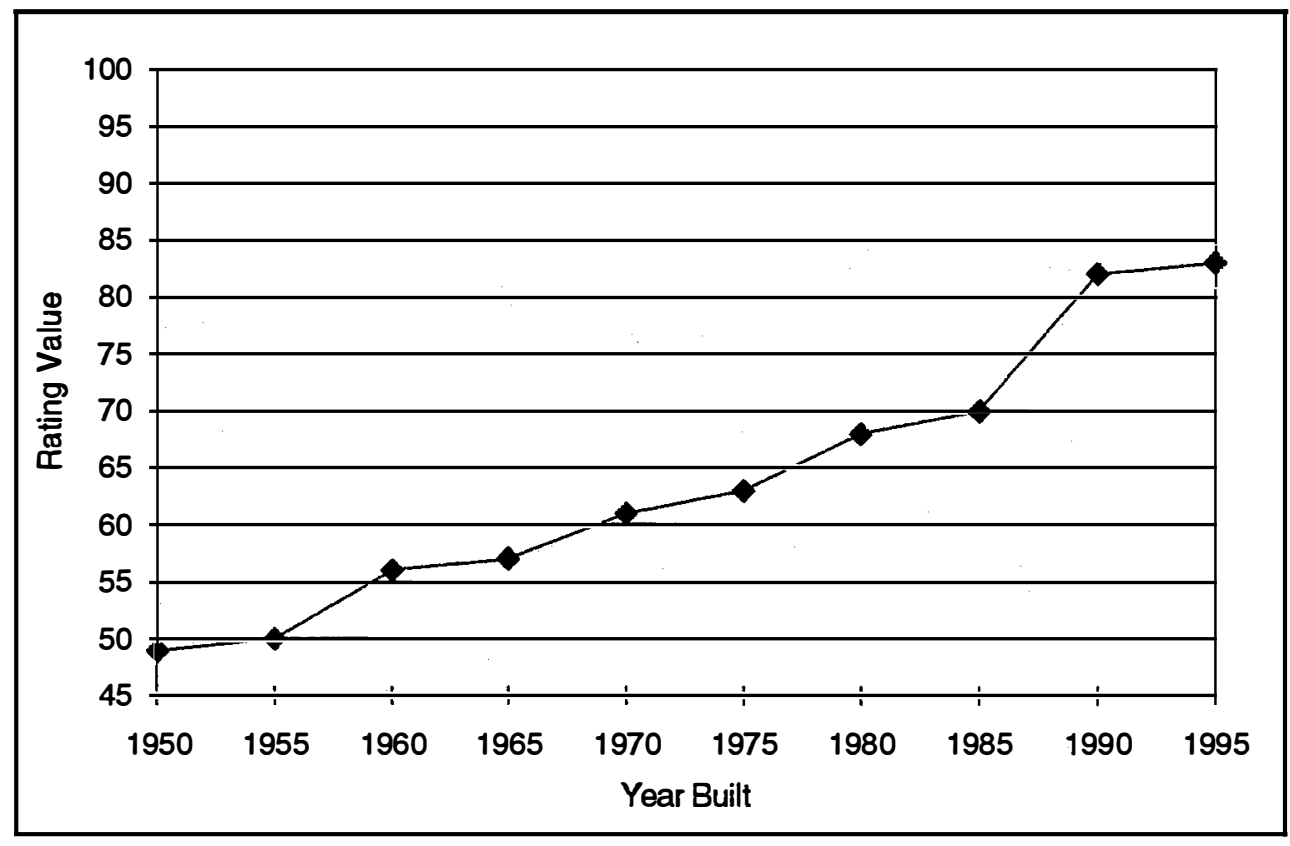

Figure 3-1. Improvements in Housing Energy Efficiency in Alaska 
ERHAP continues to use ERHA's EZ-Rater system, although changes are needed Specifically, EZ-Rater underestimates points for insulating crawl space to R-19; a choice should be allowed among windows, furnace, or infiltration measures to reach the points that would have otherwise been achieved with the previous calculations. In the meantime, AHFC has been developing new software, called AKWARM. The alpha test version was available in January 1995, and implementation is expected in March 1996, meaning EZ-Rater will no longer be sublicensed by AHFC from ERHA. AKWARM will require a year to phase in, during which its accuracy will be evaluated using pre- and post-tests. ERHAKI, as the authorized licensee of ERHA, will continue to use EZ-Rater.

In the view of ERHAKI staff, the proposed guidelines for rating systems (published in a NOPR by DOE on July 25,1995$)$ may require changes in EZ Rater in order to be compatible. The AHFC staff are of the opinion that AKWARM will not require any changes. However, they point out that, due to the diverse climatic conditions and fuel types in Alaska, the calibration of energy rating points will likely be unique to Alaska and that, if AKWARM is used for new construction, it may require a different rating scale from that proposed in the HERS guidelines. Should ERHAKI choose to continue to use EZ-Rater, there arises the possibility of competitive rating systems existing in Alaska. While this is not necessarily bad, the need for national guidelines to ensure compatibility bocomes even clearer.

Discussion of using a laptop computer to generate ratings on the spot has led to a concern that no quality control (QC) mechanism would be in place. For instance, what if a home buyer got a loan based on the rating, and later an error is found that must be corrected. Such incidents would reduce the credibility of the system - and the key to credibility is training, monitoring, and consistency. AHFC plans to deal with the potential problem of erroneous ratings by reviewing ratings both in the field and when data are entered. Additionally, AKWARM has many safeguards built into the program to minimize errors on the part of the rater.

\section{The Ratings}

The total number of ratings completed each calendar year, 1991-1995, is given in Table 3-10 for "as is," "post," and "other" ratings; Figure 3-2 summanizes ratings for 1992-1995. "Post" ratings are conducted after improvements have been made; therefore, comparing "as is" ratings to "post" shows energy-efficiency improvements. A new home's rating is estimated from the plans; a second rating ("post") is conducted after construction is complete (BEES). "Other" includes Housing Authority homes, proposed new homes, BEES, and ACHP. Data in Table 3-10 and Figure 3-2 are from the AHFC database. Data were also obtained from the ERHA archives and show similar, but slightly fewer, ratings for 1993-95, whereas the numbers for 1990-92 are higher.

Table 3-10. Type and Number of Ratings Completed in Alaska, 1991-1995

\begin{tabular}{|r|r|r|r|r|}
\hline Year & "As Is" & "Post" & Other & \multicolumn{1}{c|}{ Total } \\
\hline 1991 & 15 & 6 & 25 & 46 \\
\hline 1992 & 1,712 & 411 & 403 & 2,526 \\
\hline 1993 & 1,604 & 328 & 832 & 2,794 \\
\hline 1994 & 1,259 & 385 & 1,649 & 3,293 \\
\hline 1995 & 834 & 654 & 1,381 & 2,869 \\
\hline Totals & $\mathbf{5 , 4 2 4}$ & $\mathbf{1 , 7 8 4}$ & $\mathbf{4 , 2 9 0}$ & $\mathbf{1 1 , 4 9 8}$ \\
\hline
\end{tabular}




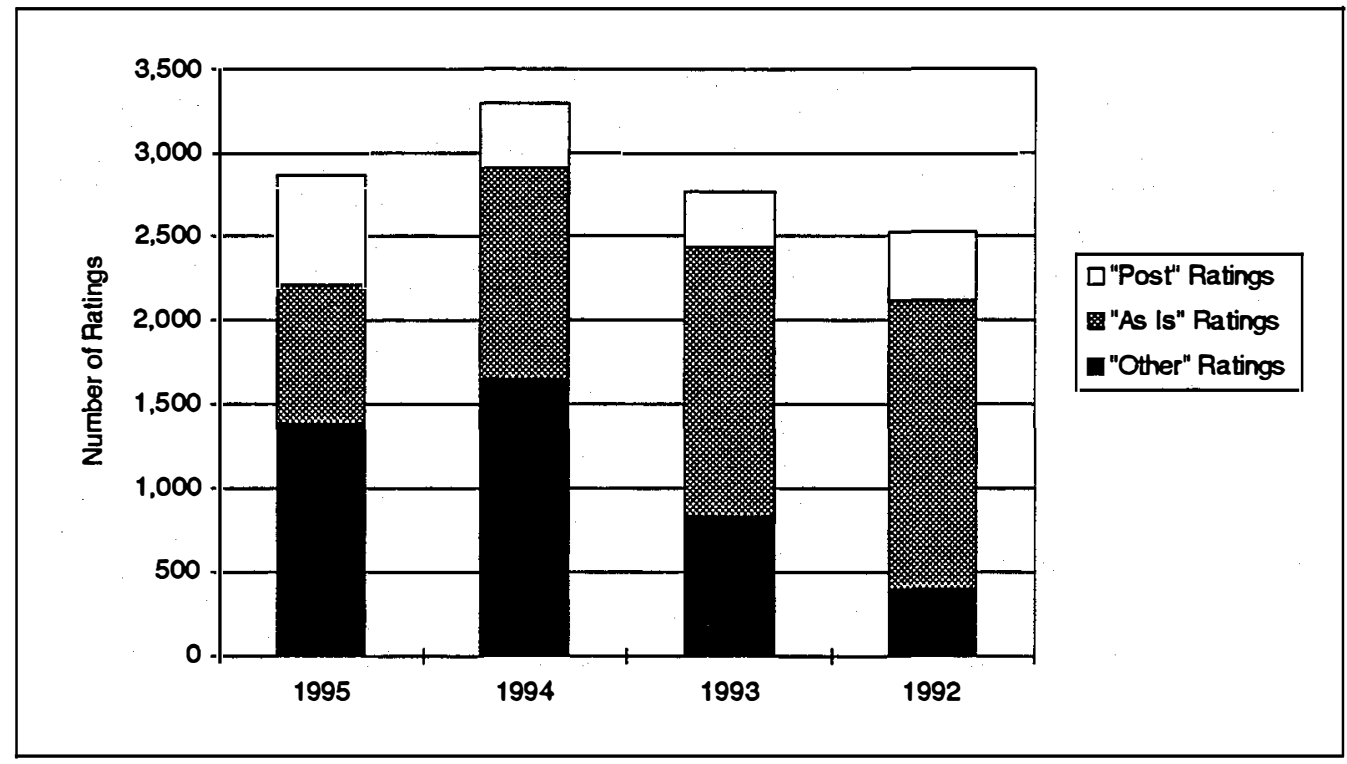

Figure 3-2. Ratings Completed in Alaska

Included in Table 3-10 are the ACHP 5 + ratings. Table 3-11 calls out the specific number of ACHP certified homes built since the program began in 1989. About 1,000 ratings were completed prior to 1989 and perhaps another 1,000 in 1989-1990, but reliable data are not available for these years.

A rating is submitted by the rater to AHFC within three days of completion. Each rating is checked for accuracy and completeness, using a form developed by AHFC (moved to the ERHAP grantee in 1994 and back to AHFC in October 1995). Ratings with problems are resolved with the raters before approval. (See Table 3-12 for the numbers of ratings held back in 1994-95.) The 26 categories of rating errors include missing client information, missing data on construction details, missing worksheet showing improvements (for "post" ratings), missing BEES certificate, incorrect rating or house type, and incorrect calculations. A rating is also held if it is for an ACHP house.

Table 3-11. ACHP Certified Homes Constructed, 1989-1995

\begin{tabular}{|c|c|c|}
\hline Year & Number & $\begin{array}{c}\text { Percent of All } \\
\text { New Homes }\end{array}$ \\
\hline 1989 & 3 & MD \\
\hline 1990 & 10 & MD \\
\hline 1991 & 10 & MD \\
\hline 1992 & 23 & MD \\
\hline 1993 & 32 & $3 \%$ \\
\hline 1994 & 60 & $5 \%$ \\
\hline 1995 & 45 & $4 \%$ \\
\hline Total & $\mathbf{1 8 3}$ & \multicolumn{2}{|c|}{} \\
\hline
\end{tabular}

MD: Missing data 
Once ratings are approved, AHFC enters the rating data and generates rating reports that are sent to the homeowners. The errors and omissions are also entered at AHFC and a monthly report summarizes error types by rater. These summaries are used to identify both random and systematic errors. The latter is then the basis for improving specific skills of the raters. At least one home rated by each rater is physically inspected every two years for additional quality control to ensure that correct rating techniques are being used and to verify authenticity of the ratings.

Table 3-12. Ratings Held Back for Problem Resolution, FY 1995 by Quarter

\begin{tabular}{|c|c|c|c|c|c|}
\cline { 2 - 3 } \multicolumn{1}{c|}{} & \multicolumn{2}{c|}{1994} & & \multicolumn{2}{|c|}{1995} \\
\cline { 2 - 3 } \cline { 5 - 6 } & Third & Fourth & & First & Second \\
\hline Number of ratings & 934 & 828 & & 570 & 672 \\
\hline Percent held back & $16 \%$ & $20 \%$ & & $14 \%$ & $8 \%$ \\
\hline
\end{tabular}

\section{The Raters}

In Alaska, a distinction must be made between "certified" raters and "trained" raters. No certification process existed prior to 1994. Before that, individuals accepted to perform ratings had to apprentice under an established rater, complete a specified number of ratings, and be recommended to the SEO by the established rater (called "Master Rater"). A rater then signs a one-year Master Rater agreement with AHFC, which provides procodures and a manual. Although the rater rebate has been canceled, agreements will be kept in place to ensure quality in the rater system. As of December 31, 1995, there were 24 certified raters in Alaska, although many more have been trained and retrained.

Raters are trained in a five-day course conducted by ERHAP and ACHP staff. Prerequisites to enrolling in the course are a three-day blower door course, two years of experience in the building market, and completion of the ACHP builders' course. The $\$ 450$ course is limited to 12 people. In 1994, eight out of ten passed; in 1995, two out of eleven passed immediately, five passed in retests, and two failed. Four of the 1995 class had gone through the 1994 course.

Raters now must be recertified every two years. The recertification process and requirements are being modified, based on feedback from raters about what is appropriate-field or written tests, location, length, and time of year. Twenty-four raters were recertified at 11/2-day sessions during June-August 1994; a class held in February 1995 resulted in 14 of 18 raters being recertified. The number trained and retrained each year since 1992 (when retraining courses began to be offered) are shown in Table 3-13.

The curriculum calls for field work each afternoon, Monday through Thursday. Classroom training is held on Monday and Tuesday mornings; written tests are on Wednesday and Thursday momings. Field tests are on Friday and Saturday. Marketing training and information on financing procucts are included in the curriculum. Certification requires that a rater average $80 \%$ on two tests (one is open book on the rating system; the other, closed book on building practices), an average of $80 \%$ on the two field tests, correct identification of housing types, and correct implementation of a blower door test. AHFC and HUD provide the houses that are used for the field work and tests. 
Table 3-13. Raters Trained and Retrained

\begin{tabular}{|r|r|r|}
\hline Year & Trained & Retrained \\
\hline 1989 & 10 & MD \\
\hline 1990 & 9 & MD \\
\hline 1991 & 8 & MD \\
\hline 1992 & 16 & 32 \\
\hline 1993 & 23 & 29 \\
\hline 1994 & 52 & 24 \\
\hline 1995 & 35 & 14 \\
\hline Total & $\mathbf{1 5 3}$ & $\mathbf{9 9}$ \\
\hline
\end{tabular}

MD: Missing data

ERHAP staff continually review the rater manual, recommending to AHFC possible areas of technical improvement, such as multifamily-building rating procectures. AHFC approves recommendations for updating the manual, including administrative and procectural changes. Raters use the ERHAP 800 number to ask for technical advice should they encounter an unusual situation. ERHAP tracks these calls by rater. A rater newsletter was begun in January 1995 to keep raters informed about current events, such as the draft guidelines published by DOE.

Certified raters work independently, but get referrals from ERHAP, ACHPI, and AHFC. In Anchorage and Fairbanks, raters are able to work full-time, but in some rural areas, a rater may have another occupation; some are also building inspectors-a situation which can speed up the process of conducting inspections for a new home by offering to do all inspections for a flat fee. Until recently, the cost of a rating (averaging $\$ 150$ per rating) was subsidized by AHFC through reimbursements to the raters. 


\section{Marketing}

Alaska distinguishes between "marketing" and "training and ecucation." "Marketing" refers specifically to outreach activities and publicity, whereas "training and education" are more formal and targeted, often including continuing education or accreditation course credit.

ERHAP does most of the marketing for ratings, and ACHPI conducts a considerable amount of marketing describing its courses and activities, which, of course, are related to ratings. The ultimate common goal of all organizations involved in HERS/EEMs is to transform the marketplace into one where energy efficiency is recognized by buyer, real estate agent, lender, appraiser, and secondary mortgage market as having extrinsic value that is regularly included in valuing the property, and where ratings are equated with housing efficiency, quality, and durability.

ERHAP developed a marketing plan that is aimed at increasing consumer demand for ratings and, concomitantly, keeping industry partners informed so that they can respond knowledgeably to requests from the public. ERHAP directs its marketing activities toward (1) educating professionals; (2) continuing to develop relationships with FHA and the secondary mortgage market; (3) developing comparables via: weekly real estate office meetings, and (4) educating consumers through home shows and home buyer classes.

An important aspect of the overall marketing strategy in Alaska concerns the inclusion of the rating in multiple listing service (MLS) ads and in builders' ads for new homes. The Alaska Appraisal Institute has been active in encouraging use of the ratings by the five MLS companies in the state. In many MLS ads, the rating appears as the first bullet in the description. Builders often use the ERHAK logo with the star rating. It is likely that, in 1997 when the MLS companies merge into a single statewide system, use of ratings will be even more common. 


\section{Training and Education}

After interviewing key players in Alaska, the author of this case study concluded that all adhere to a training and education philosophy that can be described in five steps:

1. Develop awareness of the rating process and benefits at all levels of involvement (from builders, to lenders, to housing market professionals, to consumers).

2. Remove the barriers that make it burdensome to use ratings in lending products.

3. Follow awareness efforts with detailed educational activities.

4. Provide multiple sources for obtaining consistent information.

5. Repeat training and education efforts as often as necessary, including recertification.

The organizations in Alaska work together to develop and staff training programs, give workshops, staff booths at trade shows, and teach continuing education courses, although there is a lead organization for each type of activity, as described in the following sections.

\section{Develop Awareness}

The "first level" training courses have been offered to real estate agents by ERHAP, to consumers by AHFC, HUD, and CES, to builders by ACHPI, to lenders by ERHAP and HUD, and to appraisers by ERHAP and HUD. During the period from July 1, 1994, through June 30, 1995, the following training sessions were held (Table 3-14):

Table 3-14. Training Activities, FY 1995

\begin{tabular}{|c|c|c|}
\hline Target Group & Description & Attendance \\
\hline \multirow[t]{3}{*}{ Real estate agents } & Six 2-hour for-credit courses & 130 \\
\hline & Seven 1-hour for-credit courses & 204 \\
\hline & Special requests & 113 \\
\hline \multirow[t]{3}{*}{ Consumers } & 21 AHFC home buyer seminars & 648 \\
\hline & 4 HUD presentations on EEMs at home shows & 28 \\
\hline & $\begin{array}{l}\text { Fannie Mae offers a two-day "Smart Start" class to first-time } \\
\text { home buyers; raters usually make presentations }\end{array}$ & MD \\
\hline \multirow[t]{2}{*}{ Lenders } & Seven sessions & 128 \\
\hline & Three presentations on the AHFC HELP financing. & 15 \\
\hline Appraisers & One session & 6 \\
\hline Builders & Five classes on how to build a $4 \star+$ home & 378 \\
\hline
\end{tabular}

MD: Missing data 


\section{Remove Barriers}

Several approaches have been taken to remove barriers perceived as burdensome by lenders and real estate agents. First, the ratings were equated with the building energy-efficiency standards on a 100-point scale. This meant that everyone involved could make decisions simply on the basis of the star rating, without needing to understand the complexities of the performance ratings themselves as do the raters. Since that time (mid-1980s), the star ratings have become very familiar to builders, consumers, real estate agents, lenders, and appraisers. Appraisers use the line on the sales comparison sheets to enter the star rating(s); real estate agents show the ratings in the Multiple Listing Service; builders offer packages that allow the buyer to opt for higher ratings at additional costs. All of these efforts allow the marketplace to see the added value of energy efficiency in housing values.

Second, to make the mortgage process as painless as possible for lenders, software was developed by AHFC so lenders could easily submit information to HUD on EEMs each month and the burdens associated with managing escrow accounts was avoided.

Third, because staff at all organizations keep in close touch-jointly conducting training and classes and sharing literature-consumers, lenders, and real estate agents all hear the same message no matter who is contacted. This eliminates confusion and streamlines the process for getting a rating and subsequent financing.

\section{Education Courses and Workshops}

ACHPI has been the agency providing the formal education portion of the Alaska effort. Six workshops were offered in 1995-96.

- The "Airtightness" workshop is three days long, including field training using a blower door test; the $\$ 400$ fee includes the manual and certification.

- "Advanced Cold Climate Homebuilding Techniques" is an intensive two-day workshop on construction techniques for builders, planners, and homeowners. The $\$ 350$ fee includes the manual and certification. This workshop meets the State's requirements to qualify general contractors to take the Residential Endorsement Exam.

- Builders and designers are taught how to use the "HOT 2000" computer program in a one-day workshop. The software is used to model the energy efficiency of R2000 and ACHP homes and is required to qualify for certification. The cost is $\$ 150$ plus $\$ 275$ for the software.

- A $\$ 45$ three-hour session is offered on "Recognizing and Marketing Energy Efficient Housing" for CEU credit. Emphasis is on marketing and financing products.

- Older homes are the subject of the two-day "Retrofit" workshop. The $\$ 250$ fee includes the manual.

- For $\$ 350$, builders can attend the two-day workshop on the "Design and Installation of [the ACHP] Heat Recovery Ventilation [System]." The fee includes the manual, test, and certification. 
Other workshops are offered upon request-such as train-the-trainers, for state agencies, and rater training (described in an earlier section). The "specialty" workshops offered in 1995 are "Introduction to Home Energy Efficiency" for the Alaska National Guard Youth Corps, "Finding the Balance" and "General Training" for the Alaska Weatherization Program, "Pressure Diagnostics" for ERHAP raters and ACHP trainers, and training for staff of the Public Housing Division and Regional Housing Authority. Participation through 1995 is given in Table 3-15.

Table 3-15. ACHP Workshop Participation

\begin{tabular}{|l|r|r|r|r|r|r|r|r|}
\hline \multicolumn{1}{|c|}{ Workshop } & 1995 & 1994 & \multicolumn{1}{c|}{1993} & \multicolumn{1}{c|}{1992} & \multicolumn{1}{c|}{1991} & \multicolumn{1}{c|}{1990} & \multicolumn{1}{c|}{1989} & \multicolumn{1}{c|}{ Total } \\
\hline Airtightness & 49 & 30 & 28 & 32 & 21 & - & 23 & 183 \\
\hline $\begin{array}{l}\text { Advanced Cold Climate } \\
\text { Homebuilding Techniques }\end{array}$ & 285 & 290 & 268 & 737 & 594 & 356 & 80 & 2,610 \\
\hline HOT2000 & 29 & 19 & 36 & - & - & - & - & 84 \\
\hline $\begin{array}{l}\text { Marketing Energy Efficient } \\
\text { Housing }\end{array}$ & 5 & 39 & 8 & - & - & - & - & 52 \\
\hline Retrofit & 23 & 8 & 36 & 9 & & 36 & 7 & 119 \\
\hline Heat Recovery Ventilation & 40 & 10 & 57 & 40 & 49 & 60 & 12 & 268 \\
\hline Train-the-Trainer & - & 30 & - & - & - & - & - & 30 \\
\hline $\begin{array}{l}\text { USDA Forest Service (Retrofit } \\
\text { and HOT2000) }\end{array}$ & - & 15 & - & - & - & - & - & 15 \\
\hline $\begin{array}{l}\text { Public Housing (Building } \\
\text { Sciences and Problem Solving) }\end{array}$ & - & 19 & - & - & - & - & - & 19 \\
\hline "Specialty" & 545 & - & - & - & - & - & - & 545 \\
\hline \multicolumn{1}{|c|}{ Total } & 976 & $\mathbf{5 8 5}$ & $\mathbf{4 3 3}$ & $\mathbf{1 , 2 5 1}$ & $\mathbf{6 6 4}$ & $\mathbf{4 5 2}$ & $\mathbf{1 2 2}$ & $\mathbf{4 , 4 8 3}$ \\
\hline
\end{tabular}

-: Not offered

\section{Access to Information}

Because of the close cooperation among the many key players in Alaska, information is widely available from multiple sources and the information is consistent regardless of the source or publisher. Information for the general public is available through fact sheets, flyers, brochures, newspaper articles, and toll-free 800 numbers at ACHPI, the AHFC Energy Resource and Information Center, ERHAP, the Cooperative Extension Service, the AHFC Rural Development Division, and DOE's Clearinghouse. Table 3-16 summarizes calls received by the ERHAP hotline for FY95. Comparable data are not maintained by AHFC.

Table 3-16. Calls to the ERHAP 800 Number, by Quarter

\begin{tabular}{|c|c|c|c|c|c|}
\hline \multirow[b]{2}{*}{ Calls From: } & \multicolumn{2}{|c|}{1994} & \multicolumn{2}{|c|}{1995} & \multirow[b]{2}{*}{ Total } \\
\hline & Third & Fourth & Finst & Second & \\
\hline Raters & 336 & 395 & 318 & 150 & 1,199 \\
\hline AHFC & 59 & 37 & 34 & 60 & 130 \\
\hline Out-of-state & 19 & 25 & 15 & 45 & 104 \\
\hline ACHP & 12 & 8 & 19 & 23 & 62 \\
\hline Other & 40 & 15 & 57 & 86 & 198 \\
\hline Total & 466 & 480 & 443 & 364 & 1,693 \\
\hline
\end{tabular}


Materials are distributed upon request at home shows, the state fair, and meetings of community groups and professional associations. ERHAP maintains a comprehensive list of all materials it distributes, to whom, and when. Each quarterly report also contains copies of newspaper and magazine articles, radio and television stories, and press releases. ERHAP plans to develop additional materials targeted to vendors/suppliers, building inspectors, and utilities.

ACHPI conducts searches for answers to questions by using on-line bulletin boards as well as its in-house library. In its newsletter, ACHPI usually includes titles available from its office or by contacting them through its e-mail address.

\section{Continuing Education and Recertification}

ERHAP has developed courses for real estate agents, appraisers, lenders, and homebuilders:

- Three courses (for one, two, and three CEUs) for real estate agents, who are required to take courses to maintain their certification; also, turnover is very high, so these courses need to be offered frequently.

- Appraisers can take the seven-credit course to meet their mandatory bi-annual recertification requirements.

- A "level two" course has been developed for carefully selected lender/real estate agent "Energy Star" teams. This course will be videotaped so that it can be distributed to more remote areas of the state.

\section{Trends in Training and Education}

When the participation numbers shown in Tables 3-13 and 3-14 are compared to available totals provided previously in Table 3-6, the progress made in reaching and training real estate agents, appraisers, builders is apparent. In one year (1994-95), of the 2,189 real estate agents, $20 \%$ took advantage of training opportunities; $8 \%$ of appraisers attended training; and 3,316 people in the building trades completed ACHP courses. (Note: Some of these may be repeaters, but the numbers are still quite high.) Up to this point, emphasis has been on training in major urban areas, but plans by all organizations offering courses call for expansion to rural and distant locations.

Throughout the 1990s, public/private partnerships have been building institutions to deliver ectucation and training concurrent with developing demand for such offerings. It is the opinion of AHFC staff that evidence of success in this endeavor is demonstrated by the entry of individuals and other organizations into the arena and thus fostering healthy competition. For example, some Master Raters are training builders, and the Cooperative Extension Service has expanded courses designed for consumers throughout the state. 


\section{Preliminary Evaluation Data}

The preceding sections have focused on data that summarize process evaluation issues. Available data related to the impact evaluation questions are included in this section. These data come from the databases maintained by AHFC on ratings and issuance of financial incentives and from HUD (for EEMs).

Among the items in a dBASE file kept by AHFC about each rating are these:

- ID number

- Rating type and version

- Name and address of home rated

- Region/location

- Year built, housing type, and square footage

- Energy use for portions of the house and for specific appliances

- Air change rate

- Energy consumption records

- Insulation in attic, crawl space, floor, and walls

- Number of windows and window::wall ratio

One objective of data collection about ratings and energy efficiency financing products is to be able to produce a chart that aggregates uses of ratings against the total ratings completed. At this time, we are able to do this for HUD EEMs and AHFC products dependent on ratings, but the numbers are so small relative to completed ratings that they would not be visible on a bar chart. Therefore, the numbers are in Table 3-16. HUD completed 16 EEMs in FY 1994 and 18 in FY 1995. Anecdotal information indicates that ratings are used for other financial decisions leading to energy-efficiency improvements (EEIs), (e.g., the money received after refinancing or home improvement loans), but numbers on these are not available. One might assume, however, that "post" ratings were done only on homes that applied for an EEM or EEI, meaning that $75 \%$ of the "post" ratings resulted in the HUD and AHFC total in Table 3-17 (1,334). ACHP homes are included in "other" and therefore represent only $4 \%$ of those ratings.

Table 3-17. Number of Ratings Compared to EEMs and EEls Completed

\begin{tabular}{|r|r|r|r|r|r|r|r|r|}
\hline & \multicolumn{2}{|c|}{ Number of Ratings } & HUD & \multicolumn{3}{|c|}{ AHFC } & ACHP \\
\cline { 2 - 9 } Year & "As Is" & "Post" & Other & EEMs & Rebates & OOPS & EEM & Homes \\
\hline 1991 & 15 & 6 & 25 & - & 28 & - & - & 10 \\
\hline 1992 & 1,712 & 411 & 403 & - & 200 & - & - & 23 \\
\hline 1993 & 1,604 & 328 & 832 & 0 & 360 & 7 & - & 32 \\
\hline 1994 & 1,259 & 385 & 1,649 & 16 & 279 & 26 & 6 & 60 \\
\hline 1995 & 834 & 654 & 1,381 & 18 & 369 & 22 & 3 & 45 \\
\hline Total & $\mathbf{5 , 4 2 4}$ & $\mathbf{1 , 7 8 4}$ & $\mathbf{4 , 2 9 0}$ & $\mathbf{3 4}$ & $\mathbf{1 , 2 3 6}$ & $\mathbf{5 5}$ & $\mathbf{9}$ & $\mathbf{1 7 0}$ \\
\hline
\end{tabular}

Although AHFC records any AHFC financing programs that the homeowner elected to participate in, it does not record non-AHFC financing products based on ratings, nor are any other pieces of information that might help assess how ratings are being used, such as who else is involved in the process (e.g., Did a real estate agent pay for it? Did the rater market financing products?). 
In mid-1995, the marketing director for ERHAP began contacting people who had had ratings done on their homes to learn what actions they have taken as a result, and tracking the uses of ratings with the help of rater notations on the rating sheets. With the return of the program to AHFC this project was put on hold, so no results are yet available. Another feedback mechanism used by ERHAP was a voluntary questionnaire given to people who had "as is" ratings conducted. During the period from July 1994 through March 1995, 75 of the 879 questionnaires were returned (8.5\% response rate). Of these, 68\% said they had a rating because they were planning home improvements and $19 \%$ were buying homes. Four percent planned to use the rating to get AHFC loans and 86\% planned to get AHFC rebates.

Another important area of impact evaluation is to track improvements in energy efficiency in homes that are rated, including what measures are installed and their economic benefits. The median improvements in points, in houses that received post ratings, are shown in Figure 3-3.

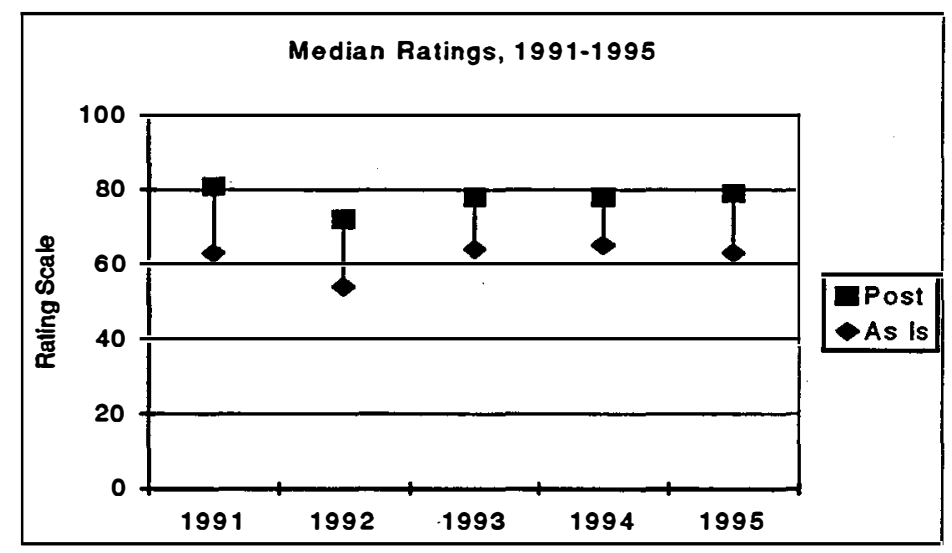

Figure 3-3. Improvements in Energy Efficiency for Houses Rated

AHFC records actions taken by recipients of AHFC financial incentives. The measures most frequently installed by homeowners receiving AHFC rebates are shown in Figure 3-4; the greatest dollar invesments are shown in Figure 3-5. Note the marked differences by year on measures installed.

In the Summer of 1994, AHFC analyzed 111 homes to determine the cost of upgrading their energy efficiency and to project the dollar savings from these upgrades (ratings for these homes are included in the previous tables). The houses were all built in the late 1970s or early 1980s. The results were formulated on the basis of the number of steps that would be upgraded and are shown in Figure 3-6. Because of possibly inaccurate calculations in the rating software, costs in Figure 3-6 may be overstated. The annual savings compared to the cost for the measures is shown in Figure 3-7.

In addition, ACHPI does an annual follow-up on the energy consumption of homes they have certified. Although the results were not available for inclusion in this case study, the information would be helpful for the national DOE-funded evaluation work on energy financing linked with ratings as well as a valuable marketing tool for ERHAP and ACHP. 


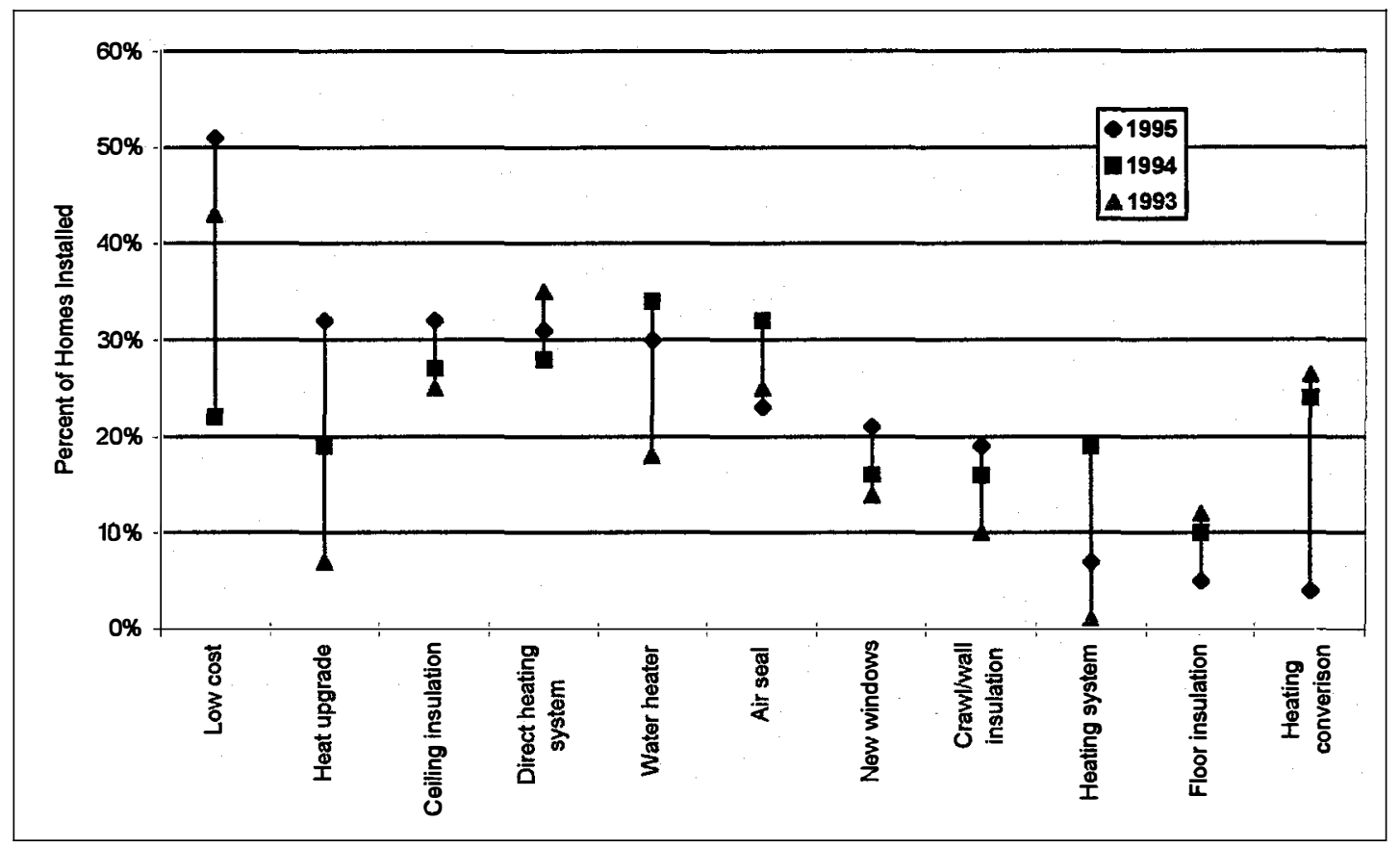

Figure 3-4. Measures Installed with AHFC Rebates

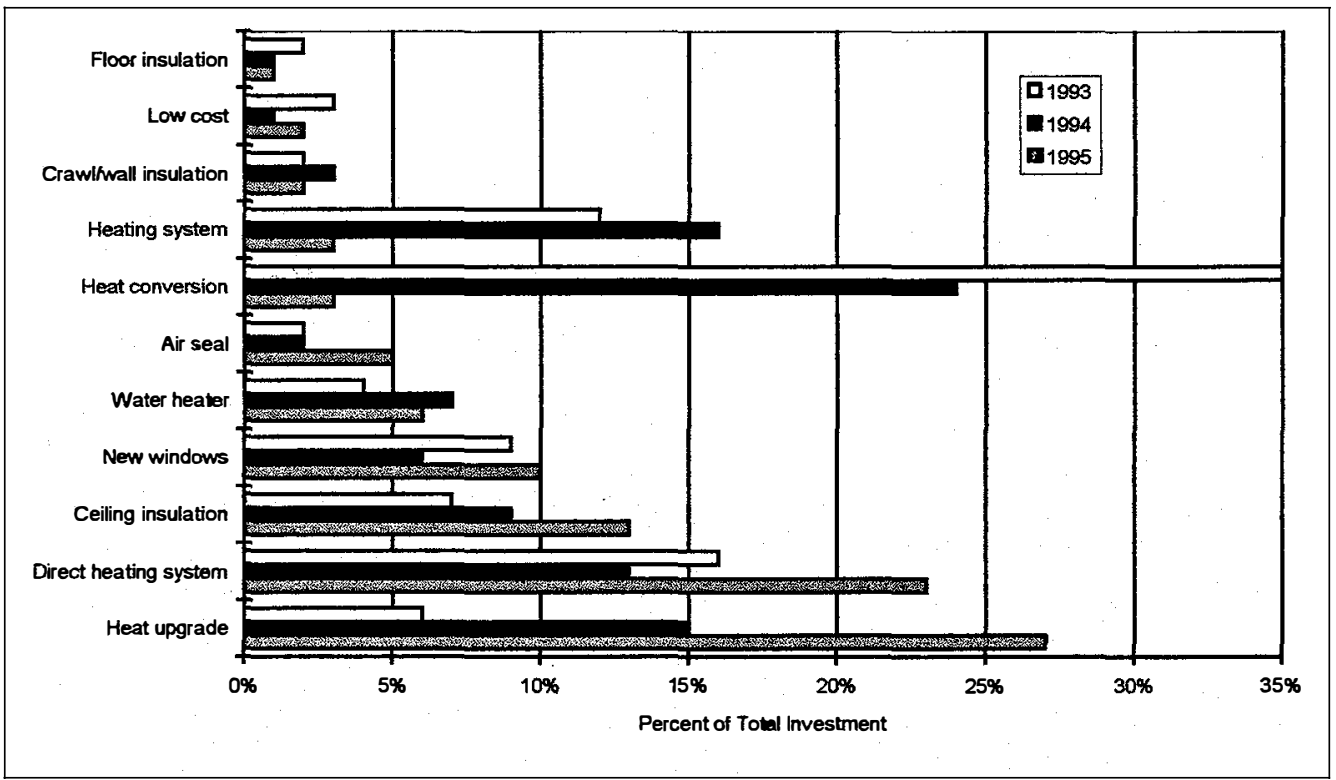

Figure 3-5. Dollar Investments in Measures Installed with AHFC Rebates 


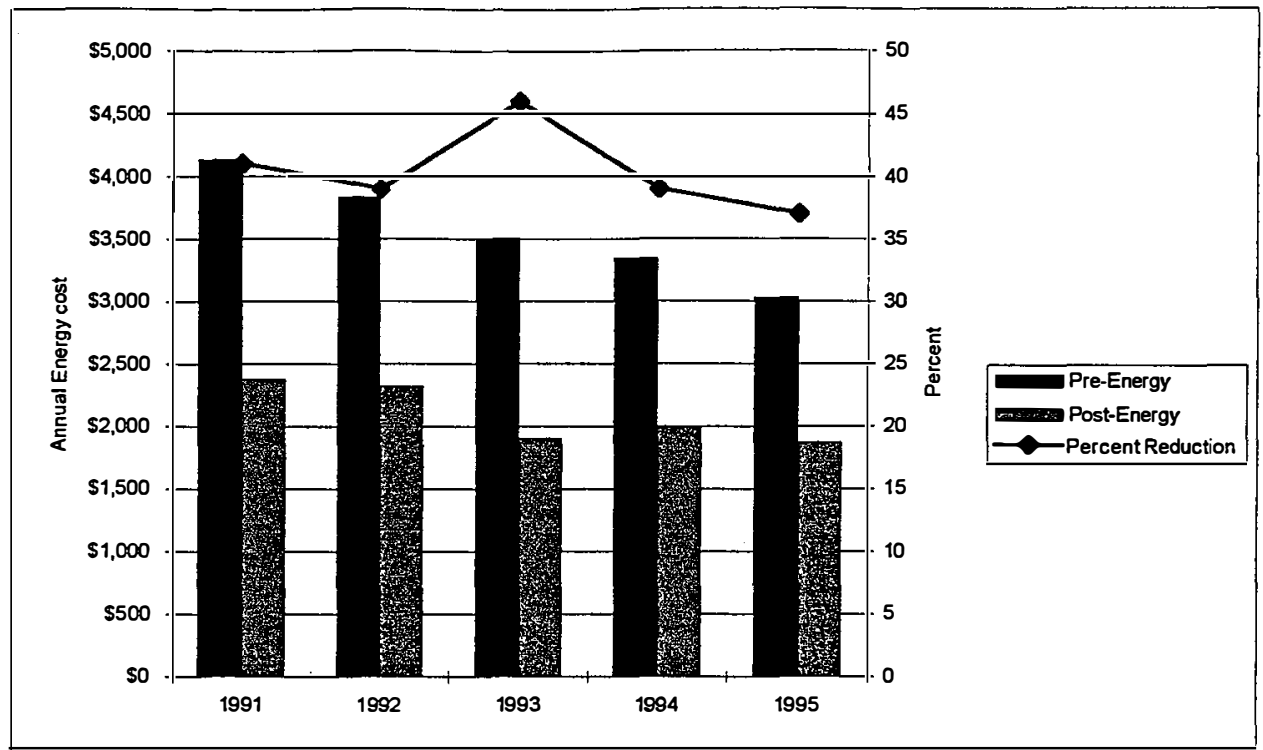

Figure 3-6. Average Energy Costs and Percent Energy Saved for Homes Receiving AHFC Rebates Based on Ratings

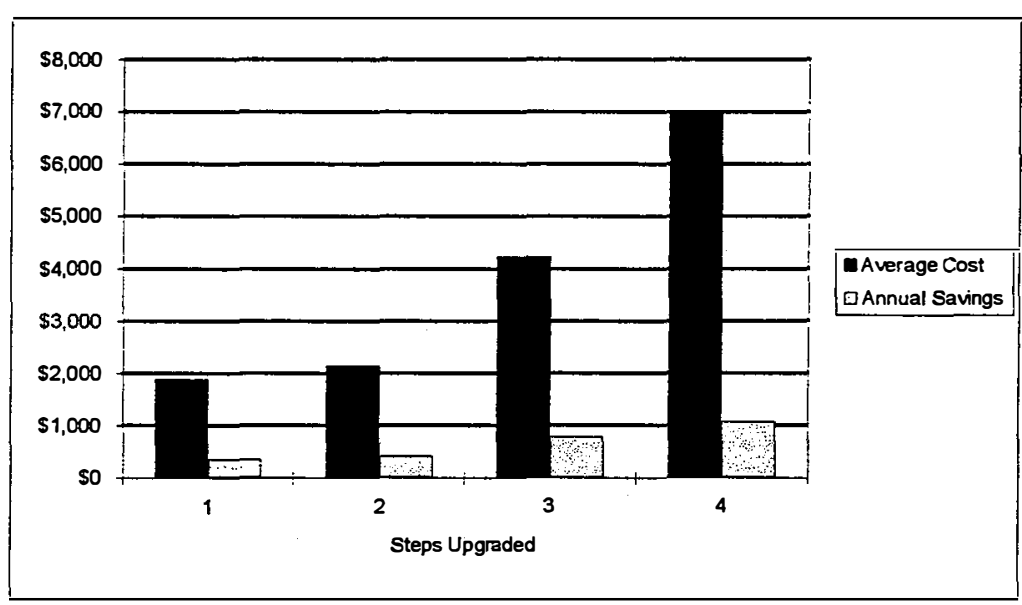

Figure 3-7. Cost of Energy Efficiency Measures and Annual Energy Savings 


\section{Problems and Solutions, Successes, and Future Directions}

A home energy rating system linked to energy efficiency financing appears to be widely accepted throughout the housing and lending communities in Alaska. Achieving this level of success, however, has not been without problems. Notably, one must question what level of achievement would have occurred without the considerable financial support provided by the state-first through the SEO and now by AHFC. This support includes the provision of many AHFC financing products well before the HUD EEMs became available. Furthermore, how the various organizations and individuals interact and their relationships to each other continue to evolve as they strive toward a self-sustained energy-efficient housing marketplace.

\section{Problems Encountered and Overcome}

1. Although all key stakeholders were involved in establishing the rating system, not all were in agreement concerning the translation of building energy-efficiency standards into the rating system. After a compromise was reached between SEO and ASHBA, ASHBA became an advocate and supporter of ERHAP and ACHP.

2. The depressed housing market in mid- to late-1980s was an unfortunate fact of the economy (true in the rest of the country as well) for which there was no solution other than to wait it out. Once the market rebounded, ratings and financing were quickly accepted.

3. As with programs in other states, reaching the real estate, lending, and appraisal professionals is both key to success and yet a most difficult task Staff at HUD and ERHAP have devoted considerable effort toward finding the opinion leaders who will champion the concept and help sell it to others. In addition, interactions focus on demonstrating what a great sales tool a rating can be.

4. Raters must do more than just conduct ratings. They must help the home owner/buyer/builder understand the value of the rating in the financing process. Toward this end, ERHAP and ACHP include sections in the training course on marketing and financing, and then encourage raters to use this information to sell their services.

5. In the Fall of 1995, individuals in AHFC responsible for managing the ERHAP and ACHP grants changed. Understandably, the new staff reviewed what had been done by the previous staff for the last 10 years and expects to take some new directions. These new directions will be because many objectives have been achieved and new needs have been identified. For example, ERHAKI and ACHPI may be able to survive on their own, so AHFC funding could be spent on other needs, such as reaching the rural areas of the state. However, such decisions will not be made until mid-1996.

6. During the preparation of this case study, it became clear that a better system is needed to track exactly what is done as a result of a rating-beyond the independent processes of keeping data on AHFC products and HUD EEMs. Some sort of coordinated effort is required.

7. A major question looms for the future: What energy efficiency financing products will be available in the marketplace once AHFC has discontinued most of its products? In two years, only 34 HUD EEMs were underwritten-hardly an indication that HUD can fill the void. 


\section{Successes}

1. The public and housing community have multiple sources of information on ratings and financing and these are broadly advertised in newspaper articles, fact sheets, and literature by all organizations.

2. Appraisers are beginning to assign added value for a home that is highly energy efficient and have established a database with this information. Eventually, this database will reach a critical mass and thus establish a baseline for such valuation.

3. Real estate agents are finding that a rating can be a valuable marketing tool that makes them stand out from other agents and therefore have begun including the rating in the MLS ad.

4. The energy efficiency of new construction has moved from a rating of 50 for a 1950 new home to 83 for a 1995 new home, with $83 \%$ of new homes rated. About one in 20 new homes are certified as ACHP, or $5 \star+$.

5. About 11,500 ratings were completed in the five year period, 1991-95. Some raters in the major cities are able to work full-time.

\section{Future Directions}

The coming years will see some interesting changes in Alaska, many of which will be indicators of whether rating systems and energy efficiency financing products have become accepted as part of the housing market in the state.

1. In 1996, AHFC will phase out many of its financial incentives. Will other organizations step in to fill the gap? What will these altematives be and how will they function? Will they be based on ratings?

2. AHFC plans to begin use of its new rating software (AKWARM) in mid-1996. If ERHAKI continues to use the ERHA software (or a modified form of it), two ratings systems will be offered. Will this situation be competitive or complementary? Will the public become confused? Will the real estate, building, and lending professionals view this as positive or negative?

3. Additional competition is emerging in the area of offering training and education to home buyers, builders, and so on. AHFC intends to take advantage of the situation by providing more, but smaller, grants supporting very specific aspects of ERHAP and ACHP through a competitive bidding process. Will this encourage further growth in the overall area of energy-efficiency ratings and financing? Will ERHAKI be a viable organization without AHFC funding support?

4. As of July 1, 1996, only ERHAKI will be allowed to use the ERHA software, name, logo, and rating sheets. With this transition, ERHAKI will achieve its goal of being a private sector program ERHAKI will carry out all of the rating services that were conducted through ERHAP but without AHFC's oversight. This oversight will, instead, be provided by the marketplace and the Board of Directors composed of leaders of the state's housing industry.

5. All residential contractors must have acquired education credits to keep their licenses. How will this affect the ability of existing organizations to keep up with demand in 1996? Will it spawn additional training organizations and activities? What will be the demand in the outyears? Will it increase the number of remodelers who strive for higher ratings? 
6. Alaska will be a state with one single MLS in 1997 . Will this improve the overall quality of data available in the state? Will it greatly improve the use of ratings in the MLS, as well as improve data on ratings used for financing home purchases? 


\section{Epilogue}

As of November 1996, decisions had not yet been made as to which state agency would manage the Energy Rated Homes of Alaska Program and the Alaska Craftsman Home Program, so both continue to fall under the Alaska Housing Finance Corporation and 1996 state funds related to RFPs had not been released.

For ERHAP, the impact has been a reduction in staff, with most functions being limited to public relations activities and training classes. Operating funds have come from the state and from DOE. The theme for publicizing the program is "A decade and this is how far we've come," continuing to be proactive and offer a single point of contact for consumers. Among new products are the EPA Energy-Star Builder Program, a new AHFC interest-rate reduction program, a Norwest Energy Star mortgage, and an FHA waiver of the origination fee up to $\$ 700$. Training focuses on first-time home buyers, sell-your-own-home classes, a course for builders on the Energy-Star program, and a course for appraisers. Continued focus on consumers includes training lenders, publishing newsletters, and mairaining a builder list for Energy Star homes.

Current issues for ERHAP include (1) the need for more raters, especially in Juneau and rural areas, (2) identifying who in rural areas can do ratings (two possibilities being pursued are staff at the rural electric cooperatives and local building contractors), and (3) how to evaluate what energy improvements to make in homes depending on location in the state.

For ACHP, stafing reductions have not been necessary due to its other sources of income. Key events in 1996 include:

1. A new advanced one-day workshop on heating and ventilation has been offered three times.

2. Letters of Agreement with Colorado and Oregon have been signed for ACHP to offer its courses in those states.

3. Development of a safe, inexpensive way to deal with heat recovery ventilation (both passive and mechanical). 


\section{Appendix}




\section{Appendix 3-A. Alaska Process Evaluation Data}

\section{Part 1. Organization Contacts and Descriptions}

\section{Alaska Housing Finance Corporation}

Type of organization State agency (includes former SEO); energy programs are in the Research and Rural Development Department

Key contacts* Bob Brean, Director of Research and Rural Development Barbara Baker, Director, Planning and Program Development

Address: 520 East 34th Avenue, Anchorage, AK 99503-4199

Phone: (907) 561-1900; (800) 478-AHFC (2432)

Fax: (907) 561-6063

Staff: Department Director (15\% of time)Data entry staff (1.5 FTE) Program manager (1.0 FTE) Grants administrator (30\% of time) Grant manager ( $10 \%$ of time) Loan underwriter ( $2 \%$ of time)

Role: AHFC's Warm Homes for Alaskans is a marketing device that refers to all of AHFC's energy programs. Included in this initiative is the Energy Rated Homes of Alaska Program (ERHAP) and related grant, the AHFC incentive programs, the grant to Alaska Craftsman Home Program (ACHP), and the Weatherization Program.

Funding: Creation of the rating system was funded with oil overcharge funds. Petroleum Violation Escrow funds are used to fund the programs (grants for ERHAP and ACHP are $\$ 300,000$ each year). State funds for loans and rebates total about $\$ 6$ million.

AHFC duties: Manage the ERHAP program

Establish standards for rater certification; raters sign a one-year master rater agreement with AHFC

Authorize training separate from either grantee

"Contact until mid-September 1995 was Steve Baden, who can now be reached in Anchorage at (907) 345-1930, fax (907) 345-2386. 
Maintain Rater Manual

Ensure integrity of the rating system

Set policy

Address technical issues related to the rating system through a Technical Advisory Committee

Develop and test new rating software (AKWARM)

Enter rating data and maintain database

Issue rating certificates

Review ratings through field audits and data review

Provided rebates to banks for submitting information on HUD EEMs (discontinued)

Provided rebates to consumers for installing energy-efficiency improvements

\section{Energy Rated Homes of Alaska Program}

Date created: 1986

Key contact:.................................. Toni McPherson, Marketing Director

Phone: (907) 345-4230 (McPherson)

Purpose:

To promote residential energy efficiency overall by offening ratings that may be voluntarily linked to market-based incentives in the housing market

Program history:

The State of Alaska entered into a public/private parnership with the housing industry to support Energy Rated Homes of Alaska. Prior to 1989 , ratings in the state were performed by two raters who had contracts with AHFC. In 1989, the SEO moved the marketing and data processing functions to two separate contractors.

Geographic coverage:...................... Began in 1986 with focus on Anchorage, Fairbanks, and Juneau; completed for rest of state by 1987; concerned about poor response from rural Alaska both in existing and new construction, so this is current area of primary emphasis.

Annual budget: $\$ 300,000$ grant 
Staff:

Grantee from 1989-95 was Innovative Communications ${ }^{\dagger}$; staff consisted of four full-time people (project director, marketing director, technical director, and administrative assistant)

Duties Provide some rater training and rater testing

Recommend technical changes to Rater Manual

Create a link between field personnel and the administrative program staff of AHFC

Respond to technical issues raised by raters and resolve inconsistencies

Provide marketing link for the program

Review ratings for quality control (1994-95)

Participate in rater training courses

Provide technical assistance to general public through an 800 number

\section{Alaska Craftsman Home Program, Inc. (ACHPI)}

Type of organization

Non-profit 501(c)(3)

Key contact:

Tim Sullivan, Executive Director

Address:

900 West Fireweed Lane, Suite 201, Anchorage, AK 99508

Phone:

(907) 258-2247; (800) 699-WARM (9276)

Fax:

(907) 258-5352

Date formed:

1986; became 501(c)(3) in 1989

Mission:

To promote energy efficient housing that is cost effective, healthy, and durable

Brief history

Based on Canada's R2000 program to focus on training builders how to construct $5 \star+$ homes using the most advanced techniques available

${ }^{\dagger}$ Project manager and contact during interviews in Alaska was Barbara Collins; current contact information is in the description of ERHAKI. 
Annual budget:

$\$ 300 \mathrm{~K}$ from AHFC to operate ACHP; additional funding from class fees and sales; total budget in 1993 of $\$ 450 \mathrm{~K}$; total budget in 1994 of $\$ 500 \mathrm{~K}$

Number of staff:

5 full-time staff:

Executive Director

Technical Director

Workshop Coordinator

Energy Information Specialist

Financial Director

Program functions:

Educate and certify/register builders/contractors as ACHP

Cerify new homes as ACHP $(5 \star+)$

Provide some training for raters

Hold workshops and courses ranging from three hours to three days

Publish comprehensive building manuals, videos, reports

Operate 800 information line

Provide product and technical information

Hold booths at homebuilders shows

Build demonstration homes

ACHP homes:

$183(1989-1995)$

Types of marketing used:

Newspaper and TV advertising; media coverage of events; booths at home shows; statewide distribution of press packets containing articles relating to energy ratings; word-of-mouth; developing continuing education courses for appraisers, real estate professionals, and builders.

\section{HUD/FHA Anchorage Field Office}

Type of organization:

Federal agency (field office)

Key contacts: Gene Dobrzynski, Chief, Single Family Housing; Kim Davis, Endorsement Clerk

Phone: Dobrzynski (907) 271-4613; Davis (907) 271-4658; (907) 271-HOME (4665) 
Fax:

(907) $271-3667$

Address:

949 East 36th Ave., Suite 400, Anchorage, AK 99503

Program functions: Appraise properties being considered for EEM financing; perform credit underwriting for home buyers seeking EEM financing; provide loan servicing if an EEM property goes into default

Annual budget:

$\$ 0$ (except for print and travel)

Number of staff:

2 (on a limited basis)

Functions:

Review staff loan decisions; promote EEMs pilot through training and outreach to lenders, real estate professionals, appraisers, and builders; coordinate promotional efforts with AHFC, ACHP, and ERHAP staff.

\section{Energy Rated Homes of Alaska, Inc. (ERHAKI)}

Type of organization: Nonprofit

Key contact: Barbara Collins, Executive Director

Address: P. O. Box 112642, Anchorage, AK 99511

Phone: (907) $345-4963$

Fax: (907) 348-0468

Staff: Barbara Collins, Executive Director

Program functions: To be the operating home energy rating system for Alaska Owns and monitors use of the trademarked Energy Rated Homes of Alaska ${ }^{\mathrm{TM}}$ name and logo

Implement marketing activities for home energy ratings in Alaska through partnerships with builders, real estate professionals, building suppliers, and media

FY1995 budget: DOE $(\$ 135,000)$, NREL $(\$ 13,000)$ 


\section{Part 2. Recordkeeping and Data Collection}

\section{AHFC}

Data collected on: Ratings; incentives

Forms used: Rating reports and applications for incentives; QC forms

Method for storing data: dBase files (two databases)

Number of ratings: 11,498 (1991 through 1995)

Rating software:

AHFC paid to develop a version of EZ-Rater tailored for Alaska; implementation of new software (AKWARM) will be completed by March 1996; AHFC expects that no significant changes need to be made to AKWARM in order to meet the new HERS guidelines.

Incentives:

AHFC offers Home Energy Rebates and, through the end of 1995, rebates for new construction. These are recorded in the AHFC databases. Completed 691 Interest Rate Reduction Loans totaling $\$ 4$ million.

Reporting requirements: Annual Report; SECP Report; Stripper Well Report

\section{ERHAP Grantee (Innovative Communications)}

Data collected on: Raters; quality control of ratings; training activities; use of 800 phone number; material distribution; surveys of homeowners who had ratings

Forms used: Training course records (computer spreadsheets); phone logs; surveys

Reporting requirements: Monthly reports to AHFC

\section{ACHP Grantee (ACHPI)}

Data collected on: ACHP homes; training and education activities; marketing activities; use of 800 phone number; post-construction energy consumption surveys

Reporting requirements: Annual report; monthly report to AHFC

HUD

Number of EEMs: 34 (FY93 through FY95) 
Method for tracking EEMs:............ Lenders can voluntarily enter data in the CLAS (CHUMS Lender Access System) computer system via the HUD Anchorage office

EEMs case numbers? ...................... Not unique to EEMs 


\section{Part 3. Training and Education}

\section{Rater Training}

Responsibility: AHFC/ERHAP grantee(s)

Number trained: 153; 99 recertified; 24 certified and active at this time

Period covered: 1986-1995

Length of training: 5 days (classroom and in-field training)

Recertification: 1-2 days; still evolving

\section{Lender Training}

Responsibility: Primarily ERHAP and HUD; some AHFC

Number trained: 230 in 1993 HUD courses; 128 in 1994-95; 15 in AHFC presentations in 1994-95

\section{Real Estate Professional Training}

Responsibility: ERHAP

Number trained: 539 (in 1993) attended $1 \frac{1}{2}$ hours as part of a 3-day licensing/relicensing course for real estate agents 130 (in 1994-95) in six 2-hour for-credit courses 204 (in 1994-95) in seven 1-hour for-credit courses 113 (in 1994-95) special requests

\section{Homebuilder and Contractor Training}

Responsibility: Alaska Craftsman Home Program

Number trained: 4,483 through 1995

Length of training: From 3 hours to 3 days

Topic of training: Currently seven courses, from the basics of energy efficient home construction to advanced techniques

\section{Appraiser Training}

Responsibility: HUD, ERHAP, Appraisal Institute

Number trained: 125 (between 1992 and spring 1994); 6 in one session in 1995 


\section{Consumer Education}

Responsibility:............................... Major lending institutions, AHFC, HUD, Fannie Mae, and ERHAP, CES

Number trained:............................. Approximately 350 first-time home buyers in $1993 ; 675+$ in 1994-95 


\section{Part 4. Program Implementation}

\section{Obstacles}

1. Initial lack of cooperation by state building industry

2. Lenders' perception of paperwork as burdensome

3. Maintaining technical integrity of raters and ratings

4. Delay between performing the rating and getting the rating report to homeowner

5. Not enough involvement in Alaska's rural areas

6. Changing priorities of the state legislature eliminated AHFC incentive programs prematurely

7. Changing AHFC staff in 1995 could mean changes in managing the program and changes in short- and long-term goals

\section{Resolution of Obstacles Listed Above}

1. Agreement with homebuilders association to modify rating system in mid-1980s

2. Lenders were given a financial incentive for submitting EEM information to AHFC and HUD

3. Continual attention is paid by AHFC and its grantee to quality control of ratings and raters; problems are resolved as they are found through special training and technical bulletins/newsletters

4. Not resolved at this time; allowing immediate printout of report at the site via laptop computer could compromise the integrity and $Q C$ of the ratings

5. Direction of the AHFC program will be expanded into rural areas

6. Once the final phase-out of incentives in mid-1996 occurs, use of ratings will become apparent

7. To be determined

\section{Most Successful Aspects of the Program}

1. Ratings are being used by builders, real estate agents, and appraisers

2. Critical mass has been reached in the new construction market, with $83 \%$ of homes being rated

3. of new homes are being constructed to ACHP criteria

4. Considerable attention given to the program by the mass media

5. Integrated approach of educating the public, lending, appraisal, and real estate community about the benefits of an energy efficient home 


\section{Six-Month Milestones}

AHFC

Develop a plan for reaching the rural areas of Alaska with the program

Continue development of AKWARM

ERHAP Implement marketing plan, with emphasis on paining real estate professionals with lenders for in-depth training

Determine what uses have been made of ratings

Start program with Fannie Mae

ACHP

Begin working more with trade allies in the building industry (i.e., building materials suppliers)

Work with young men in trouble to encourage them to consider the building trades as career opportunities

HUD ......................................... Continue promoting EEM program at builder and trade shows and with real estate industry

\section{Long-Term Goals}

AHFC:

Continue to have a successful program without the availability of AHFC loans and rebates

Ensure that AKWARM is consistent with the HERS Guidelines

ERHAP Focus on raing existing homes

Learn what happens in the market when rated homes begin to be resold ( $7-8$ years)

ACHP

Now that construction techniques are proven and accepted, focus on environmentally beneficial elements of housing (e.g., carpets and air-change rates) 


\section{Chapter 4}

\section{Process Evaluation Case Study: \\ Vermont Home Energy Rating Systems/Energy Efficiency Financing}




\section{Acknowledgments}

The author extends appreciation to all those whose cooperation and assistance contributed to the preparation of this case study. In particular, Richard Faesy, Executive Director of Energy Rated Homes of Vermont, Inc., provided a wealth of information and insights in response to numerous requests following reviews of earlier drafts. He was capably assisted by Sara Liddle, Program Assistant.

Douglas Lothrop, Director Single Family Operations, and Cathleen Gent, Director of Communications, both at Vermont Housing Finance Agency, willingly took time from their duties to retrieve facts and data required to provide a comprehensive picture of energy efficiency financing in Vermont.

In addition, funding from the National Renewable Energy Laboratory and the helpful comments and overall guidance of Dr. Barbara Farhar, Senior Social Scientist, were critical to the successful completion of this case study. 


\section{Executive Summary}

This report addresses the evolution, status, and future direction of efforts in Vermont to promote the financing of residential energy efficiency. It is based on information obtained from July through December 1995 from interviews with and information providod by key personnel in the three organizations having a major role in instituting home energy rating systems/energy efficiency financing (HERS/EEF) in the state: Energy Rated Homes of Vermont (ERH-VT); Field Office of the Federal Housing Administration (FHA) located in Burlington, Vermont; and the Vermont Housing Finance Agency (VHFA).

Energy efficiency financing linked with energy ratings in Vermont had its origin in 1986 with the allocation of $\$ 500,000$ in Petroleum Violation Escrow (PVE) funds for this purpose to the VHFA by the state legislature, through the Vermont Department of Public Service (DPS). The VHFA organized a team of energy professionals to explore a program design and form two advisory committees representing stakeholder groups. The outcome was the formation of Energy Rated Homes of Vermont (ERH-VT) in 1987. Rating services were first offered without charge. In 1989, the organization commenced a fee-forservice policy and a membership dues structure to support its activities when the PVE funds became exhausted. In 1993, ERH-VT increased active promotion of EEF as one of five pilot states participating in the Federal Housing Administration's Energy Efficient Mortgage (EEM) Program. At this time, the organization was also involved in implementing EEF products of the Deparment of Veterans Affairs (DVA) as well as the Federal National Mortgage Association (Fannie Mae). In 1994, rating activity further increased with contracts from major utilities in the state, in conjunction with demand-side management (DSM) programs implemented with DPS oversight.

ERH-VT maintains strong ties with the DPS and VHFA in particular. Maintaining and enhancing partnerships with stakeholder groups (lenders, real estate professionals, appraisers, builders/contractors) represents a critical aspect of ERH-VT's outreach work. Finding ways to enhance the involvement of real estate professionals has been the most challenging component of work with stakeholders.

Six EEF products are presently available in Vermont. In addition, four utility companies encourage energy efficiency ratings in new construction through an assessment fee incentive. Data on property transfers and housing starts suggest that the market for EEF can be exploited further; however, market research specifically on EEF is required to fully understand its potential. Barriers to implementation exist among stakeholders and in the financing process itself; they are best overcome by emphasizing appropriate incentives for stakeholders, especially lenders. ERH-VT directs its strategic marketing efforts toward overcoming these barriers.

ERH-VT completed 2,559 ratings since 1988. From 1987 through 1995, ERH-VT trained 16 raters, 14 energy specialists, 252 appraisers, 446 lenders, 1,001 real estate professionals, and 75 builders/contractors and related energy-service providers. 


\section{Contents}

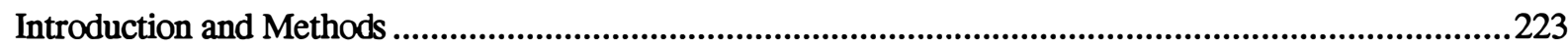

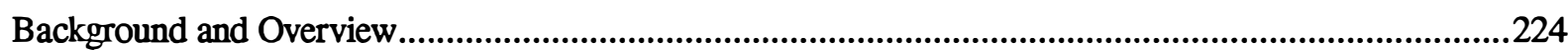

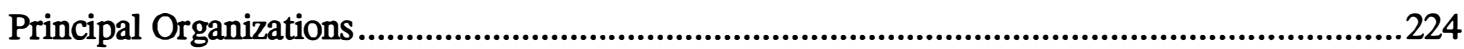

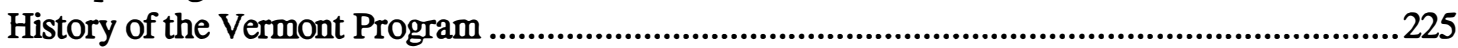

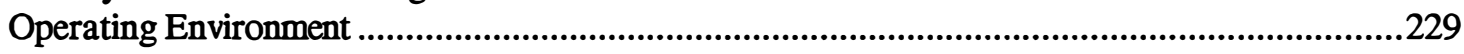

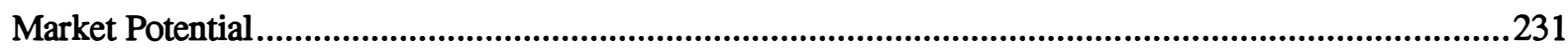

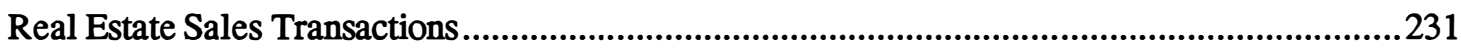

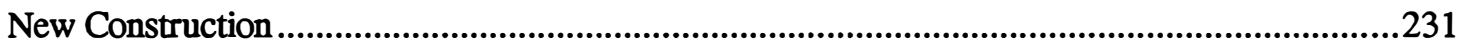

Data Limitations and Estimations .......................................................................................233

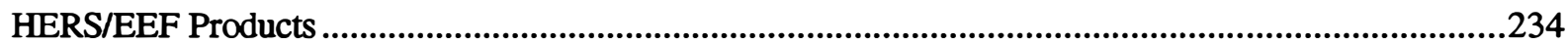

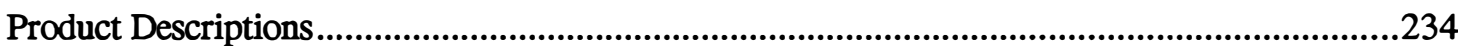

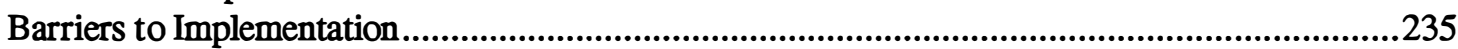

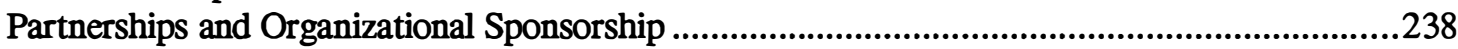

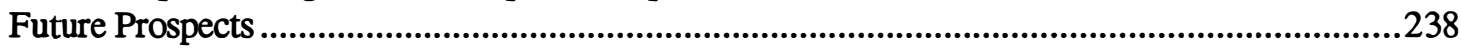

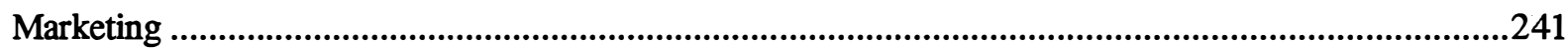

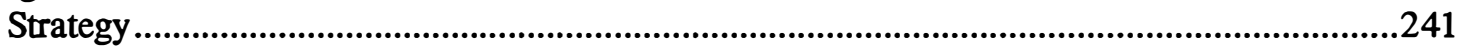

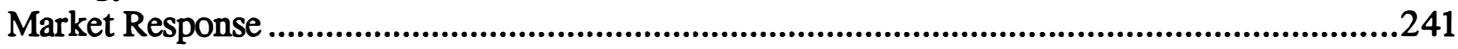

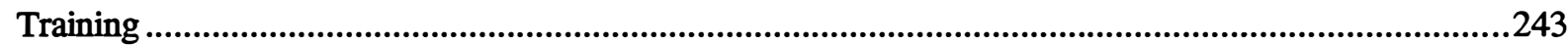

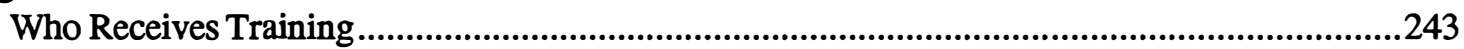

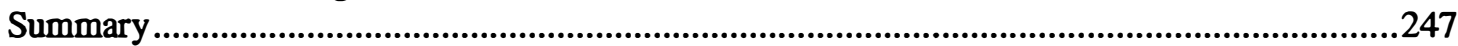

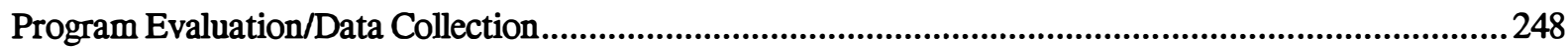

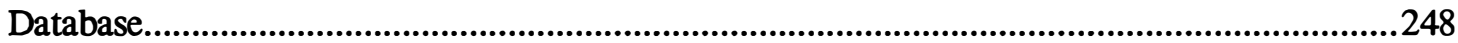

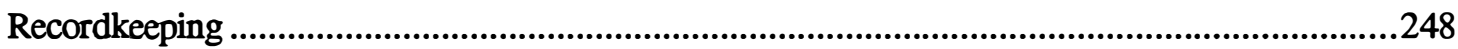

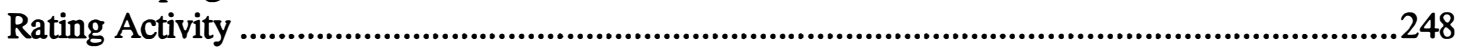

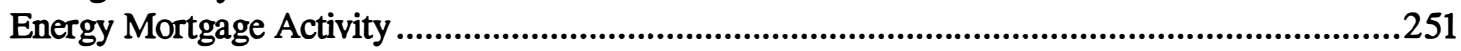

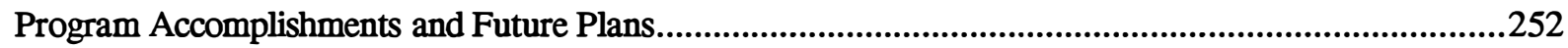

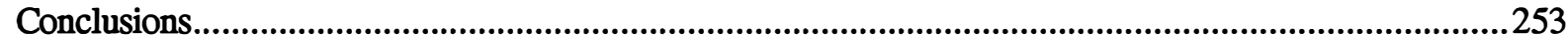

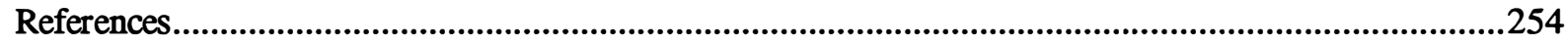

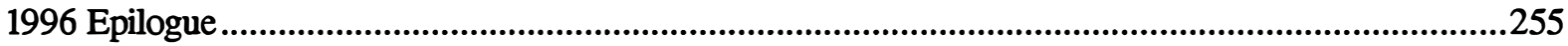

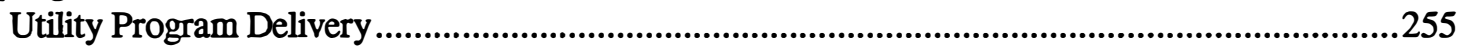

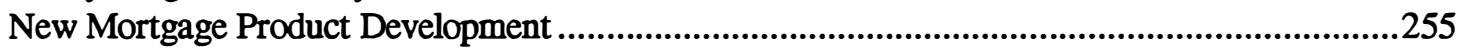

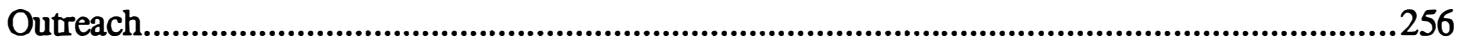

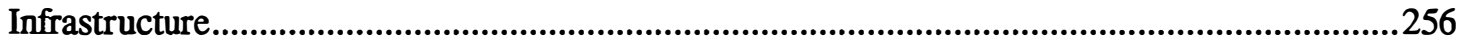




\section{Tables}

Table 4-1. Chronology of Events, Vermont HERS/EEF ............................................................225

Table 4-2. Vermont Residential Sales Volume and Median Price, Jan. 1 - June 30, 1995, by County....232

Table 4-3. 1994 Residential Building Permits: New Privately Owned Housing Units and Estimated

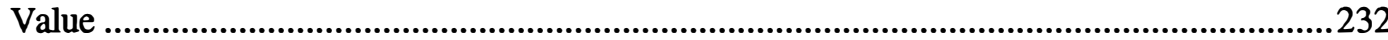

Table 4-4. Funding and Funding Sources by Fiscal Year, Energy Rated Homes of Vermont (\$) ............239

Table 4-5. Rater Training Conducted by ERH-VT, 1987-95 ..............................................................244

Table 4-6. Energy Specialist Training Conducted by ERH-VT Since Inception....................................244

Table 4-7. Appraiser Training Conducted by ERH-VT, 1987-1991 ......................................................245

Table 4-8. Lender Training Conducted by ERH-VT, 1987-89; 1993-95 ...........................................246

Table 4-9. Real Estate Professionals' Training Conducted by ERH-VT, 1987-89; 1994-95 .................246

Table 4-10. Vermont Rating and Energy Efficiency Financing Activity, 1992-1995 ...............................251

\section{Figure}

Figure 4-1. Volume of ERH-VT Rating Activity, 1988-1995

250

\section{Appendixes}

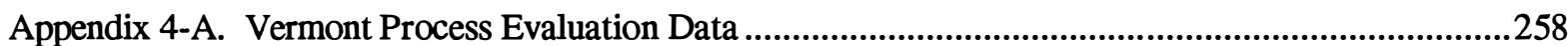

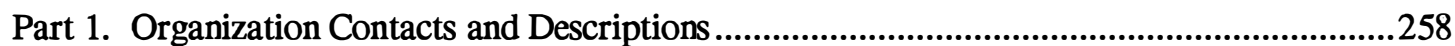

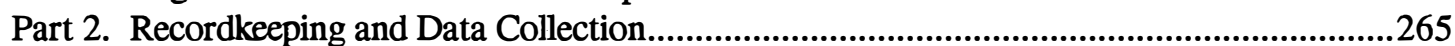

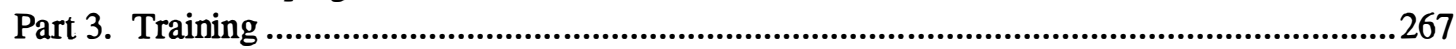

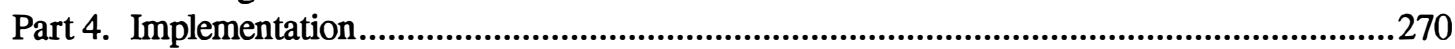

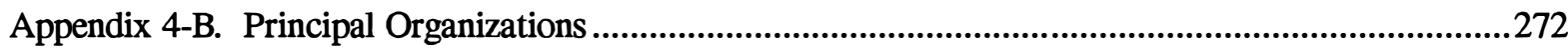

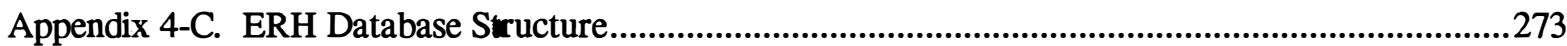

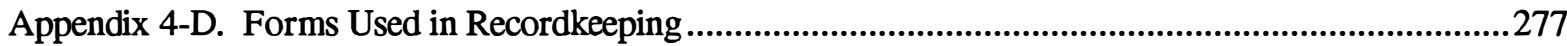




\section{Introduction and Methods}

This case study reports findings of a field study conducted from July 1995 through May 1996 that investigated the evolution and status of efforts in Vermont to promote the financing of residential energy efficiency. Study topics are those used in similar assessments conducted in Alaska, Arkansas, Califormia, Colorado, and Virginia-all states that have developed and promoted residential energy efficiency financing mechanisms as pilot states for the Federal Housing Administration's Energy Efficient Mortgage Program. Selected information appears in condensed form in Appendix 4-A, Vermont Process Evaluation Data.

Key personnel in three organizations that implement home energy rating systems/energy efficiency financing (HERS/EEF) in Vermont were interviewed and contacted for follow-up information; they are identified in Appendix 4-B. For purposes of this case study HERS/EEF is broadly defined to include the various market products, including Energy Efficient Mortgages (EEMs), that use an energy rating system as the basis for financing energy improvements in residential dwellings.

Although this case study is intended to represent as comprehensive a picture as possible, a thorough examination of the evolution, status, and future direction of HERS/EEF in Vermont would require information from a broader range of individuals, including stakeholders such as state government officials, financial institutions, the real estate sales industry, builders/contractors, and indeed consumers themselves, than has been possible in the current effort. 


\section{Background and Overview}

\section{Principal Organizations}

Three principal organizations implement HERS/EEF in Vermont: Energy Rated Homes of Vermont (ERHVT); Vermont Housing Finance Agency (VHFA); and U.S. Department of Housing and Urban Development (HUD) Field Office located in Burlington, Vermont. Appendix 4-B identifies their key personnel and contact information. A fourth organization, Vermont Energy Investment Corporation (VEIC) constitutes an important element in program implementation, but is so closely aligned with ERHVT that a separate discussion of VEIC's role is not warranted.

\section{Energy Rated Homes of Vermont (ERH-VT)}

ERH-VT administers the statewide rating system as a 501(c)(3) nomprofit organization. It is located with and contracts for staff and equipment with Vermont Energy Investment Corporation (VEIC), also a nonprofit 501(c)(3) organization which, as a separate entity, is engaged in various energy service and consulting activities. As an advocate for programs and policies which promote energy efficiency, VEIC played a key role in the formation of ERH-VT. Both organizations have been closely associated since the inception of ERH-VT in 1987.

\section{Vermont Housing Finance Agency (VHFA)}

VHFA, the state's authorized housing finance agency, promotes affordable home ownership to low- and moderate-income Vermonters through below-market mortgage rates subsidized by mortgage revenue bonds, and other mechanisms. The agency has played a central role in energy efficiency financing and, along with VEIC and others, formulated the concept of instituting a home energy rating organization in Vermont. For the first two years of its operation, ERH-VT worked out of VFHA offices.

\section{U.S. Department of Housing and Urban Development (HUD)}

HUD endorses Federal Housing Administration Energy Efficient Mortgages (EEMs) through the pilot program established by the Energy Policy Act and Housing and Community Development Act, both passed in 1992, as implemented in Vermont. The director-the sole staff member-reports to the Director of the Single Family Housing Division at the Manchester, New Hampshire HUD Field Office.

\section{U.S. Department of Energy (DOE)}

When Vermont became a pilot state for the FHA and VA programs, DOE recognized ERH-VT as a major player among rating organizations nationally. ERH-VT served as a member of the DOE HERS/EEMs National Collaborative Technical Committee, and in May, 1995, DOE awarded ERH-VT \$130,000 funding to support marketing and other outreach activities.

\section{Energy Rated Homes of America, Inc. (ERHA)}

ERHA supported ERH-VT early in its history. ERHA acted as a clearinghouse for information on establishing a rating organization, and it developed the software that ERH-VT used in conducting ratings. Since 1994, ERHA has marketed energy ratings nationally. With funding it secured from the 
Environmental Protection Agency (EPA), and through the Residential Energy Services Network (RESNET), ERHA facilitated ERH-VTs ability to promote ratings and EEF.

\section{History of the Vermont Program'}

HERS/EEF efforts in Vermont, which began in the mid-1980s, are outlined below. Table 4-1 sets forth a chronology of major events from the inception of EEF in 1986 to its status in early 1996.

\section{Planning and Development}

In the mid-1980s, advocates in the state who had been tracking earlier efforts in Vermont recognized the need to institutionalize a mechanism to finance energy improvements in the residential sector. These advocates included VEIC's co-founders, Beth Sachs and Blair Hamilton; VHFA's Executive Director, Allan Hunt; an energy consultant, Paul Cillo; and consultant Richard Faesy. They were concerned that virtually no effort replaced programs that had been in place under the federally mandated Residential Conservation Service and an earlier home energy audit program that had been a part of the Energy Extension Service. Accordingly, when these programs were effectively repealed at the federal level in the mid-1980s, they sought a state initiative.

Table 4-1. Chronology of Events, Vermont HERS/EEF

\begin{tabular}{|l|l|}
\hline Date & Event \\
\hline 1986 & $\begin{array}{l}\text { Governor Kunin's Oil Overcharge Task Force recommends to Legislature allocation of } \\
\$ 500,000 \text { in Petroleum Violation Escrow (PVE) funds to Vermont Dept. of Public Service } \\
\text { (DPS) to develop an EEF program. Memorandum of Understanding between DPS and } \\
\text { Vermont Housing Finance Agency (VHFA), gives VHFA responsibility for program design. }\end{array}$ \\
\hline $10 / 87$ & ERH-VT incorporated as nonprofit in Vermont; operates out of VHFA offices. \\
\hline $1987-88$ & Pilot program begins in four counties with four lenders. \\
\hline 1988 & ERH-VT designated as IRS 501(c)(3) organization. \\
\hline $1987-89$ & $\begin{array}{l}\text { Incentives initiated: (1) no charge for first rating; (2) one-year, \$500 interest buydown for } \\
\text { EEM; (3) free construction management and contractor arranging services up to \$500. }\end{array}$ \\
\hline 1989 & $\begin{array}{l}\text { Evaluation conducted to recommend next steps in program to support ratings in absence of } \\
\text { PVE funds. Relocation to offices of Vermont Energy Investment Corp. (VEIC). }\end{array}$ \\
\hline 1990 & Completion of 600 ratings; membership and fee schedule adopted. \\
\hline 1991 & $\begin{array}{l}\text { VHFA initiates "4-Star Mortgage" program; dropped shortly thereafter with decline in } \\
\text { market interest rates. }\end{array}$ \\
\hline $1991-92$ & Participation in the National Collaboratives HERS Technical Advisory Committee. \\
\hline $1992-93$ & $\begin{array}{l}\text { Vermont chosen as pilot state for FHA EEM Program; national VA EEM program initiated; } \\
\text { Vermont "exclusive" Fannie Mae program developed. Utilities include builder incentives for } \\
\text { energy efficient construction in DSM programs. }\end{array}$ \\
\hline $1994-96$ & Enhanced activity; energy ratings incorporated into utility DSM programs. \\
\hline
\end{tabular}

${ }^{1}$ This section draws substantially from Faesy (1988) and Faesy (1992). 


\section{Funding and Roles}

In 1986, the Vermont Legislature used $\$ 500,000$ from Petroleum Violation Escrow (PVE or oil overcharge) funds to develop a residential energy-efficiency rating and financing program. This goal was accomplished by a one-page Memorandum of Understanding between the Vermont Deparment of Public Service (DPS), the state energy office responsible for dispersing PVE funds, and VHFA. In the document, VHFA assumed responsibility for the initial program design, as well as three additional roles once the program became operational:

- Oversee the disbursement of the PVE funds for EEF program purposes

- Provide a program operator for a pilot program

- In the same manner as the Federal National Mortgage Association (Fannie Mae) and the Federal Home Loan Mortgage Corporation (Freddie Mac), purchase the mortgages of qualifying borrowers from Vermont lenders who participate in the program.

A team of energy professionals devoted more than 18 months to planning, researching, and designing a program. Among the central issues were whether to incorporate a Home Energy Rating System (HERS) as a part of an EEF program and, if so, whether to create a rating system or adopt the existing Energy Rated Homes (ERH) System developed by Western Resources Institute (WRI) of Seattle, Washington. The decision to link HERS with EEF was based on the team's desire to facilitate loan underwriting processes.

The adoption of the existing ERH System was supported for two reasons:

- To save the nearly two years' estimated time that would be required for a Vermont system to gain acceptance from Freddie Mac and Fannie Mae, which the WRI ERH System had already attained

- To aid in the advancement of a national HERS

The planning team formed two committees consisting of stakeholders:

- A Steering Committee representing lenders, appraisers, real estate sales, builders, utilities, and consumers

- A Technical Committee representing utilities, architects, engineers, energy consultants, Deparment of Public Service (DPS), and home inspectors. In addition to providing guidance on program direction, these committees reached out to stakeholder groups once ERH-VT entered energy efficiency and financing activities in the state.

\section{Early Program Implementation}

Although stakeholder groups represented on the Steering and Technical Committees supported the program, ERH-VT devoted considerable effort to program promotion, education, and training of all groups following its formation in 1987, and before launching a pilot program in the state. In its first year, the program was implemented in only four counties with the participation of four lenders. According to Faesy (1992), this strategy proved successful in that it

...provided both a testing ground and served to spark some interest from other lenders not chosen to participate in the pilot. This [approach] ended up working to our advantage in 
that non-participating [sic] lenders saw some of the benefits of offering the EEM (qualifying more marginal buyers, offering additional services to their customers, remaining competitive with the bank down the street who offered the program, Community Reinvestment Act credit, good P.R., etc.) and became anxious to become participants.... Lenders handling approximately $80 \%$ of the mortgage activity in Vermont [ultimately] became participants (p. 6).

\section{Incentives}

To generate interest in energy ratings among real estate salespersons, builders, and consumers, ERH-VT employed three incentives:

- One rating at no charge per customer for two years

- A $\$ 500$ mortgage interest "buydown" to home buyers who built an energy-efficient home based on a rating or used an energy efficient mortgage (EEM)

- Free construction management and contractor arranging services valued at $\$ 500$ or more for home buyers making energy improvements with an EEM.

During the 1987-89 period when ratings were offered at no charge, ERH-VT completed 704 ratings. No data exist on the use of the mortgage interest buydown, and only about 20 home buyers took advantage of the free contractor arranging services. ERH-VT believes the low participation in this incentive was attributable to the limited number of energy upgrades following the early rating activity, rather than a lack of perceived value on the part of homebuyers to the assistance that ERH-VT would have provided in getting the upgrades completed. Further, ERH-VT believes that the strategy was, nonetheless, successful as an assurance to lenders that the work would be performed expeditiously. For a start-up organization, however, it was not cost effective to continue this incentive.

ERH-VT notes an irony inherent in all the incentives: the more successfully they generate interest in the program, the greater the negative reaction among customer groups when they are no longer available. If customers' favorable perception of a rating organization is based on incentives that cannot be sustained, the organization runs the risk of losing the customer loyalty that is vital to its continued existence.

\section{Shift to Fee Structure}

During the first two years of the program, ERH-VT had completed more than its target 600 ratings using PVE funds. The organization then employed an evaluator to guide its directions when these funds became exhausted. The evaluator surveyed homeowners whose homes had been rated and convened focus groups with other stakeholder groups to detenmine, among other things, their willingness to pay for what formerly had been a free service (Center for Rural Studies, 1990).

ERH-VT then developed a membership policy. Organizations that joined ERH-VT as members would receive a $\$ 150$ reduction on the $\$ 250$ rating fee. Dues were based on size of the member group. Utilities' dues, for example, were $\$ .25$ per customer, while lenders' fees ranged from $\$ 500$ to $\$ 5,000$ based on the lender's assets. The cost of membership recruitment pressured the organization to increase the number of ratings to break even. The rating fee has since been raised to $\$ 300$; nonetheless, subsidies have been 
required to maintain the program. (Currently, an annual fee of $\$ 100$ is charged to any organization for the first rating ordered.)

Around this same time, in 1989, ERH-VT relocated its operations from quarters at the VHFA to VEIC. This move enabled a sharing of resources with an organization having a similar, energy-related mission, not only in terms of facilities, but also in maintaining state-of-the-art knowledge in energy-efficiency techniques.

In 1991, VHFA initiated a "4-Star Mortgage" program, offering a below-market (8.25\%) interest rate, higher than standard debt-to-income ratio, and flexible underwriting terms for loans it administered that could be classified as an EEM. When market rates declined below the $8.25 \%$ level, the incentive was no longer attractive to borrowers. VHFA supported this program with surplus funds it had available at the time. When market interest rates declined below $8.25 \%$, borrowers lost the incentive to participate, and VHFA was unable to put forward the additional funds that would be necessary to continue to offer a below-market rate.

\section{Participation in National Pilot and Utility Programs}

In 1993, FHA selected Vermont as one of five states to participate in the pilot EEM program This program, a national program for Veterans Affairs borrowers, and a pilot program exclusively in Vermont for Fannie Mae borrowers (sponsored by four of the major lending institutions in the state) held promise for institutionalizing energy efficiency through financing mechanisms, as intended in the 1986 Memorandum of Understanding. ERH-VT developed marketing and other information materials announcing the availability of all three programs.

Only the FHA and VA programs were in fact implemented. The Fannie Mae program was officially launched with some fanfare at a news conference in front of the state capitol on a snowy day. The governor announced the program's availability with 2.8 cords of wood as a backdrop to illustrate the amount of energy savings that a typical upgraded home in Vermont could save each year. According to ERH-VT, however, no EEMs have been written under the Fannie Mae program since its inception in 1993 through 1995. ERH-VT notes that it had no funds to market the program and participating lenders did not actively promote its availability to borrowers.

Douglas Lothrop', Director of Single Family Operations at Vermont Housing Finance Agency, former Chair and currently Vice Chair of the ERH-VT Board of Directors, observed that lenders' stated reason for not promoting the program was the decline in mortgage refinancing during the period when the program was in effect. He noted that during the time prior to the program being implemented, lenders expressed a desire to get involved in EEF because refinancing activity was high. Lenders believed that refinancing would provide a good opportunity to promote EEF inasmuch as the loan process is less complex than original mortgage loans. When the program was actually launched, however, mortgage rates had increased and the numbers of homeowners wanting to refinance their existing mortgages declined.

Lothrop added that in other contexts, lenders have cited a high volume of refinancing activity as a reason they are unable to promote EEF, stating that it is not cost effective during such times when there is more competition for loans and demand for fast turnover in loan processing. This apparent contradiction, he

\footnotetext{
${ }^{2}$ Lothrop noted that his comments are based on is association with ERH-VT since its inception, and do not necessarily represent the official position of VHFA.
} 
observed, points to the difficulty in getting "real answers" to questions concerning lender promotion of EEF.

Also in 1993, large electric and gas utilities in the state, as part of their demand-side management programs and with support of the DPS, began to encourage energy efficient new construction. An assessment fee ranging from $\$ 250$ to $\$ 350$ among the four participating utility companies is charged to homebuyers or builders. The fee pays for all, or nearly all, of the cost of a rating based on proposed plans and access to an energy specialist. The completed dwelling is later inspected and rated. If the unit meets or exceeds the program standards of "4 Stars Plus," the assessment fee is returned to the buyer or builder along with an additional cash incentive of $\$ 300$ to $\$ 400$ and the energy rating results. The enhanced potential for EEF follows with the ability of the buyer to qualify for an EEM.

\section{Operating Environment}

As is evident in the chronology of events surrounding HERS/EEF activity in Vermont, ERH-VT's role as a key player rests largely on external forces, many of which can be characterized as political. Leaving aside influences at the federal level, which by and large affect all states similarly, this discussion focuses on the political context within Vermont.

Agencies that promote energy efficiency and affordable housing in Vermont have been instrumental in instituting mechanisms to foster HERS/EEF in the state. Specifically, these are:

- DPS. Lead agency for energy policy and the utility regulatory body, it has linkages to the Governor and Public Service Board (PSB)

- VHFA. The central organization promoting affordable housing for low- and moderate-income home buyers

Although support from the DPS is an important element in the overall effort, the VHFA has had more direct, visible, and sustained involvement and influence. According to Douglas Lothrop, the close affiliation VHFA has with ERH-VT and the energy efficiency financing community in the state is consistent with his agency's affordable-housing mission. This is because energy efficiency has benefits beyond enabling first-time buyers who would be marginal in the traditional market to afford home ownership; it has the further advantage of assuring they are able to remain home owners by enhancing their financial stability. This is an important consideration given the long-term nature of the financial obligation they are assuming and the unpredictability of energy prices during the same time frame.

Because the VHFA participates as it does in the volatile and competitive markets of real estate sales and financing, it is not in the organization's best interest to support mandates for any element of HERS/EEF, or to adopt a program that would put it at a competitive disadvantage with other lenders. VHFA wants to be able to offer a below-market interest rate for an EEM but market conditions do not permit this to be a standard practice. In 1994, VHFA began requiring a 4-Star rating for all new construction projects that it finances. If buyers, real estate professionals, appraisers, lenders and builders all perceived the value of an energy-efficient house as greater than the value of an energy-inefficient house, then it would not be necessary for VHFA to offer a reduced rate incentive. Moreover (and more importantly, in Lothrop's view), if these parties perceived an inefficient house as a greater risk in the housing market than an efficient house, this, too, would make incentives unnecessary. 
Lothrop added that, in his view, the future of DSM programs in an increasingly competitive electric utilities business may affect the status of HERS/EEF activity in the state. He believes that without DSM, market forces alone will dictate whether the demand for energy efficiency and consequently ratings and financing mechanisms will increase, decrease, or remain the same. 


\section{Market Potential}

The market potential for HERS/EEF in Vermont is of interest not only because the state is one of the five that participated in the FHA Pilot Program but also-like only one other pilot state, Arkansas-Vermont has largely rural characteristics compared to two other pilot states, Califomia and Virginia. (The fifth pilot state, Alaska, has many unique characteristics in addition to being rural.)

Many factors associated with the housing stock and mortgage lending in Vermont might indicate the market potential for financing energy efficiency. For example, the age and quality of the existing housing stock might indicate the potential for energy efficiency financing through home improvement loans and second mortgages, and the market conditions for financing instruments might indicate support for the writing of such loans and mortgages by financial institutions.

A simpler indicator is the overall activity in the primary home mortgage market for existing dwellings resulting from real estate sales transactions, and new construction resulting from housing starts. ${ }^{3}$

\section{Real Estate Sales Transactions}

Nearly 7,700 real estate transactions took place in 1994, about a third of which were in Chittenden County, the most densely populated area of the state (Table 4-2). Data in Table 4-2 were gathered by the Vermont Department of Taxes ${ }^{4}$ for 1994 and obtained from Vermont Housing Finance Agency.

\section{New Construction}

Table 4-3 shows housing starts in Vermont according to the Vermont Department of Employment and Training, based on the U.S. Department of Commerce's Current Construction Reports which tracks the volume of building permits issued. For the same period at a little over 2,273 such permits were issued in Vermont. County data are not readily available.

\footnotetext{
${ }^{3}$ An assessment of this potential, focusing on the market as a whole, does not reflect upon the level of activity in the pilot FHA program or VA program. These programs atrracted only a segment of borrowers because of eligibility requirements for participation, and the availability of more competitively priced mortgage insurance from another source in Vermont - in particular, the Vermont Home Mortgage Guarantee Board

${ }^{4}$ Data from Multiple Listing Services serving Vermont are not readily available to nonmember organizations.

${ }^{5}$ More detailed data are available from the Survey of Housing Starc, Sales and Completions, by region and divisions, from U.S. Deparment of Commerce through micro data files, requiring separate analysis.
} 
Table 4-2. Vermont Residential Sales Volume and Median Price, Jan. 1 - June 30, 1995, by County

\begin{tabular}{|l|r|r|}
\hline \multicolumn{1}{|c|}{ County } & $\begin{array}{c}\text { Number of } \\
\text { Transactions }^{\mathbf{a}}\end{array}$ & $\begin{array}{c}\text { Median } \\
\text { Price } \\
\mathbf{( \$ )}\end{array}$ \\
\hline Addison & 366 & 94,000 \\
\hline Bennington & 427 & 93,500 \\
\hline Caledonia & 280 & 64,500 \\
\hline Chittenden & 2,524 & 117,625 \\
\hline Essex & 81 & 50,000 \\
\hline Franklin & 590 & 86,000 \\
\hline Grand Isle & 65 & 97,500 \\
\hline Lamoille & 276 & 85,000 \\
\hline Orange & 295 & $\mathbf{7 9 , 0 0 0}$ \\
\hline Orleans & 272 & 60,000 \\
\hline Rutland & 667 & 81,500 \\
\hline Washington & $\mathbf{7 0 7}$ & 86,000 \\
\hline Windham & 433 & 98,000 \\
\hline Windsor & 690 & 92,250 \\
\hline \multicolumn{1}{|c|}{ Total } & $\mathbf{7 , 6 7 3}$ & $\mathbf{1 , 1 8 4 , 8 7 5}$ \\
\hline Source Vem & &
\end{tabular}

Source: Vermont Department of Taxes, through

Vermont Housing Finance Agency.

${ }^{8}$ Excludes transfers of $\$ 1.00$ and under.

Table 4-3. 1994 Residential Building Permits: New Privately Owned Housing Units and Estimated Value

\begin{tabular}{|l|c|c|c|c|}
\hline Month & $\begin{array}{c}\text { Number of } \\
\text { Transactions }\end{array}$ & $\begin{array}{c}\text { Cumulative } \\
\text { Total Housing } \\
\text { Units }\end{array}$ & $\begin{array}{c}\text { Monthly Total } \\
\text { Estimated } \\
\text { Value (\$000) }\end{array}$ & $\begin{array}{c}\text { Cumulative } \\
\text { Total } \\
\text { Estimated } \\
\text { Value (\$000) }\end{array}$ \\
\hline Jan & 65 & 65 & 6,073 & 6,073 \\
\hline Feb & 87 & 152 & 7,540 & 13,613 \\
\hline Mar & 168 & 320 & 13,259 & 26,872 \\
\hline Apr & 214 & 534 & 20,127 & 46,999 \\
\hline May & 238 & 772 & 24,949 & 71,948 \\
\hline Jun & 250 & 1,022 & 23,895 & 95,843 \\
\hline Jul & 238 & 1,260 & 23,664 & 119,507 \\
\hline Aug & 239 & 1,499 & 21,404 & 140,911 \\
\hline Sep & 285 & 1,784 & 23,551 & 164,462 \\
\hline Oct & 230 & 2,014 & 19,951 & 184,413 \\
\hline Nov & 158 & 2,172 & 14,136 & 198,549 \\
\hline Dec & 101 & 2,273 & 10,548 & 209,097 \\
\hline
\end{tabular}

Source: U.S. Department of Commerce Current Construction Reports, through Vermont Department of Employment and Training. 


\section{Data Limitations and Estimations}

Of course, these sets of data are not mutually exclusive; moreover, many factors influenced housing market activity in the relatively short period considered here. Further examination is required to differentiate existing from new construction in the state tax data and to determine, for example, the time lag from "permitting" to the actual transaction of new residential construction. The data do suggest that in a calendar year, approximately 7,700 homes (sales volume) could be available for energy ratings and EEF and that new construction represents approximately 20 percent of this figure. Whether sales volume represents the true market potential of EEF, however, requires a focused examination of consumer demand for energy ratings.

The potential of EEF in a rural state requires examination of data by geographic regions, and of other variables affecting its utilization. These and other issues related to market potential require ongoing data collection and analysis for continued evaluation of this aspect of the EEF market. 


\section{HERS/EEF Products}

This section describes six HERS/EEF products unique to Vermont in early 1996. Loan products are broadly defined to include those that are linked to specific lending instruments and those based on ratings alone. In general, ERH-VT charges for ratings; the current fee is $\$ 300$. ERH-VT charges a $\$ 100$ annual fee for the first rating ordered by any organization. In addition, ERH-VT delivers ratings and additional services for specific utility and other programs for which fees up to $\$ 500$ per service are charged. The full fee is paid when a rating is completed as part of a specific loan product. Unless otherwise noted for each product where the rating is paid for by a third party, the cost to ERH-VT for conducting the rating is covered as a fee for service.

Anyone may order a rating from ERH-VT, whether a homeowner or seller, real estate professional, lender, or builder/contractor. Usually, a rating is ordered for one of three reasons: (1) information on energy efficiency level only, (2) with the intent to link it to a financing product, or (3) to comply with a utility program and receive an incentive. The numbered "star" system which identifies a rating is based on the efficiency of a home's specific energy features, its actual performance, and is house- and site-specific. In practice, the designation range is from one to five stars, and a Plus rating represents a level of efficiency between the integer steps.

\section{Product Descriptions}

\section{Product 1: The Vermont Energy Improvement Mortgage}

Although no mortgages have been written under this product, which has been offered by Fannie Mae exclusively in Vermont since 1993, it is nonetheless technically available through four lending institutions in the state: Chittenden Bank, Vermont Federal Bank, Banknorth Mortgage Company, and Vermont National Bank Cost-effective energy improvements up to $\$ 5,000$ may be financed by the participating lenders; the figure does not include the $\$ 300$ cost of the energy rating. Under this program, the appraised value of the home is adjusted by the calculated present value of the energy improvements over their weighted lifetime.

\section{Product 2: Home Energy Improvement Loan Program}

Energy Rated Homes of Vermont (ERH-VT), Vermont Energy Invesiment Corporation (VEIC), Vermont Housing Finance Agency (VHFA) and the Vermont Development Credit Union (VDCU) all have helped develop and implement the Home Energy Improvement Loan Program (HEILP). VEIC originated the HEILP shortly following its formation in 1983 with initial capital made available from VHFA.

The purpose of HEILP is to assist low- and moderate-income consumers to finance energy improvements. The product consists of a loan at less than market rates and an extended payment period for a home improvement loan. Terms are variable based on cost-effectiveness of energy improvements. Eligibility is determined at $140 \%$ of median income for the local area. The VDCU assumed the underwriting function of this product beginning in 1992, with capital being made available by additional local lenders. VEIC or an energy rating from ERH-VT detenmined cost effectiveness of energy improvements, although HEILP is not a major activity for the rating organization. An estimated $\$ 750,000$ in loans have been written under this product, valued at approximately $\$ 3,500$ each. 


\section{Product 3: Partnerships with Utilities}

Energy-Rated Homes of Vermont (ERH-VT) has agreements with four utility companies that have instituted energy ratings for new residential construction in their demand-side management (DSM) programs. The companies are Vermont Gas Systems, the state's only natural gas utility; Central Vermont Public Service Company and Green Mountain Power Corporation, the largest electric utilities serving the state; and Washington Electric Cooperative. Under the agreements, the utilities subsidize the cost to builders of energy ratings of newly constructed homes by paying ERH-VT directly for performing this service.

\section{Product 4: C.A.R.E. (Chittenden Affordable Real Estate)}

This product of the Chittenden Bank requires a 4-Star energy rating and is available to mortgagors of primary residences who cannot qualify for conventional financing or financing offered by Vermont Housing Finance Agency (VHFA). It offers below-market down payments and points, as well as expanded debt-toincome ratios. With an 4-Star or higher energy rating, ratios may be extended further. Few, if any, EMS have been generated under this product.

\section{Product 5: H.O.M.E. (Home Ownership Made Easy)}

Vermont Federal Bank designed this product to assist low-income mortgagors by allowing the required 5\% down payment to come from a relative or loan from a state or nonprofit agency. Rather than requining an energy rating, H.O.M.E. encourages ratings by extending qualifying debt-to-income ratios up to $5 \%$ for 4Star rated homes. As the only rating organization in the state, ERH-VT has a role in implementing this product when the stretched ratio is employed by the lender.

\section{Product 6: Vermont Housing Finance Agency (VHFA)}

As the state's housing finance agency offering below-market terms for "affordable housing" funded through mortgage revenue bonds, VHFA requires a rating of at least 4-Stars for all new construction under its programs, except for mobile homes.

VHFA expands debt-to-income ratios for properties rated 4-Star or higher to $33 \%$ for the total monthly housing expense-to-income ratio and $41 \%$ for the total monthly debt-to-income ratio. Homes rated below 4-Stars must be upgraded to the 4-Star level to enable the borrower to benefit from expanded ratios. VHFA will finance the rating fee as a part of the mortgage.

\section{Barriers to Implementation}

Institutional barriers require regular attention if they are to be overcome. It represents a challenge to ERHVT to monitor these influences and, in keeping with objectives of any strategic planning endeavor, to try and convert these obstacles to opportunities. They are (1) the general issue of reliance on stakeholders and the institutional environments they face in the market complexities of real estate sales and financing, and (2) micro-level factors that can interfere with effective program operations. 


\section{Reliance on Stakeholders in Real Estate Sales and Financing}

The integration of EEF into other functions involving home buying makes the process vulnerable to the many variables inherent in those functions: real estate construction, sales, appraising, inspecting, and financing - each with its own set of players and market conditions. The same is true for players in the energy delivery system, most notably, gas and electric utilities. This fact of life for ERH-VT first came to light in a pronounced way in 1990 when the organization could no longer offer free ratings and began to consider a fee for service structure. The adage, "the [rating] program needs the players more than the players need the program.." (Center for Rural Studies, 1990), was a conclusion of the evaluation conducted at that time and is one that ERH-VT advises should be taken seriously where such programs are being considered. The conclusion emphasizes that stakeholders can engage in their respective activities without energy ratings being conducted, but rating organizations rely on stakeholders in order to exist.

Approaches to resolving this barrier (i.e., minimizing its impact) have been tailored by ERH-VT to the specific stakeholder group, in the following ways:

- Lenders. The credibility of the VHFA plays a key role in communicating with lenders. Its participation at the outset of planning for HERS/EEF in Vermont, through the Steening Committee and later on the Board of Directors, has an important function in enlisting their support, but only if their concerns are genuinely taken into account in program implementation. A recognition of the motivation of lenders is critical. For example, it is unrealistic to expect lenders to actively promote EEMs in all loan transactions. They make sense to lenders if a borrower could not otherwise qualify for the loan and if without the energy-efficiency upgrades the loan could not be closed, meaning lost income for the financial institution and individuals who earn a commission in the process.

- Appraisers. Initially, ERH-VT attempted to enlist the support of this group by employing their services as a cost-effective means of conducting ratings. This approach was unsuccessful for the most part, due to the apparent incompatibility of energy-related work and the skills of appraisers. ERH-VT observed that despite technical training on how to conduct ratings, appraisers generally failed to perform the task according to required standards. Education of appraisers on the value of energy efficiency in housing remains an objective of ERH-VT. This is accomplished by providing appraisers with copies of rating information for specific residences, and more generically through training programs.

ERH-VT reports that although some appraisers do in fact adjust home values based on results of an energy rating, the practice is not common throughout Vermont. Moreover, if such an adjustment is made, it is usually for less than the actual cost of the efficiency improvements. The ability to replace an appraiser's determination of value with a calculated value based on energy savings helps to overcome the difficulties associated with the lack of comparables that appraisers require in their role as a part of the energy efficiency financing process. According to ERH-VT, without this value adjustment loan-to-value limits are exceeded by the addition of the improvement cost to the loan without also adding to the value of the property. From the perspective of the government entities implementing this adjustment (FHA, DVA, Freddie Mac, Fannie Mae, and VHFA), the expected proliferation of energy ratings ultimately will lead to market comparables, eliminating the need for an adjustment to be made. 
- Builders and Energy Contractors. This group includes those who are engaged in general construction and well as energy contracting work as a specialty. Builders and energy contractors relate well to the HERS component of EEF and see themselves as a trade ally. There is a kind of multiplier effect that occurs with training on HERS for the construction trades generally, as it improves their practices directly, contributing to an enhanced state-of-the-art in home building and renovation. For example, builders who assumed that one rating for development construction was sufficient became aware, through training, of the site-specific nature of energy use and the need for a separate rating for each individual unit based on both pre-construction plans and post-construction inspection.

As a largely rural state, Vermont has few tract-type developments where house designs are virtually identical. ERH-VT performs "proposed" ratings based on plans and specifications for each unique house design, including solar orientation, some of which may be duplicated in a particular development. Nonetheless, ERH-VT examines each completed unit for energy features present in the actual construction and to verify air leakage with a blower door test, recognizing that variations may occur in on-site solar orientation and construction practices among different subcontractors and work crews.

- Real Estate Professionals. This group has been the most difficult one to work with in ERH-VT's efforts to overcome the general barrier of having to enlist stakeholders. The relationship that this group has with prospective buyers holds strong potential as a marketing tool for HERS/EEF. Attempts by ERH-VT in 1992 to have a home's energy rating identified as part of the Multiple Listing Service (MLS) listings of homes for sale were unsuccessful, as was a proposal for mandatory disclosure through legislation. The real estate industry opposed the measure not so much on its merits as a potential deal-closer, but rather on the basis of the additional, up-front cost (for the rating) that would be incurred by clients. In 1995, the concept was accepted within the industry when a new MLS on-line system was adopted that accommodated a data field for an energy rating.

Recently, with funding from the U.S. Department of Energy (DOE), ERH-VT employed (half-time) a licensed real estate professional to contact local Boards of REALTORS and individual firms for training, and development of training materials for continuing education courses specifically for this group. This Outreach Coordinator devotes about 6 hours per week to working with real estate professionals.

\section{External Factors}

The following factors, that are part of the EEF process, are external to the operations of ERH-VT; accordingly, they are not subject to resolution by the organization. Nonetheless, a recognition of their existence is important to an understanding of the functioning of EEF activity.

Complexity of underwriting guidelines generally and in the mortgage process. Any streamlining of underwriting guidelines would help compensate for the fact that an EEM slows down and complicates the transaction. 
Perceived benefits of EEMs as mortgage qualifier only. ERH-VT believes that to the extent the lending community views EEMs as a mechanism for mortgage qualification alone, rather than having the added benefits of energy efficiency, EEM potential will be limited to the market segment of borrowers who fit this category. A related issue is the opportunity for energy efficiency that is forgone when the qualification aspect predominates in the loan process. Marketing efforts, ERH-VT maintains, should stress the energyrelated advantages on a par equal to the attribute of loan qualification. This is not to suggest that lenders should be persuaded to promote energy efficiency per se, but rather that they can recognize the financial advantages that reduced energy expenditures bestow on the borrower with time.

Lack of incentives to overcome barriers in lending. The lending industry generally has not directly addressed these issues through incentives. Nationally, products tied to federally assisted loan programs are underutilized

\section{Partnerships and Organizational Sponsorship}

ERH-VT has formed partnerships with four categories of organizations: (1) state-based agencies such as DPS and VHFA instrumental in supporting its formation and continuance; (2) entities associated directly and formally with HERS/EEF activity, such as federal EEM programs; 3) uilities; and (4) stakeholder groups. Appendix 4-A describes the nature of these relationships. The role these organizations have in providing financial support to ERH-VT is discussed in this section.

Table 4-4 shows calendar year funding from 1992 to 1995, and expected funding for 1996. Funding has grown from $\$ 130,979$ in 1992 to $\$ 347,406$ in 1995, but during 1993 funding was less than its 1992 level. The U.S. Department of Energy (DOE) grant of $\$ 130,000$ contributed significantly to ERH-VT's funding in 1995, as did revenue from rating work completed under agreements with utilities ("consulting" and "other"). In 1996, ERH-VT will continue to receive support from rating fees and in-state sources, along with a carryover from the Doe funding awarded in 1995.

ERH-VT also benefits indirectly from participation in activities funded by the U.S. Environmental Protection Agency (EPA). Recent activities include a December 1995 conference of the Residential Energy Services Network (RESNET) and a subcontract to cenify the EPA's "Energy Star" designation for homes with the Conservation Services Group, an organization under contract to EPA.

\section{Future Prospects}

The $\$ 130,000$ in funding from DOE in 1995 will allow ERH-VT to enhance the range of its education, training, and marketing programs that support EEF in Vermont. Additionally, with a portion of $\$ 10,000$ in funding from the National Renewable Energy Laboratory (NREL), as well as DOE funds, ERH-VT will expand its data collection efforts to enable evaluation of its work. The added data will be a part of a central electronic database that will store a wide range of data on each rating derived from the data libraries of participants in each transaction. It will include information on dates of and communication with customers, billing, and technical inputs and outputs of ratings.

Beyond these activities broader issues in the state will affect the future prospects of energy efficiency financing. Two areas currently in the forefront are utility programs and a proposed energy building code. 
Table 4-4. Funding and Funding Sources by Fiscal Year, Energy Rated Homes of Vermont (\$)

\begin{tabular}{|c|c|c|c|c|c|c|}
\hline Source & 1992 & 1993 & 1994 & 1995 & Totals & $1996^{e}$ \\
\hline Rating Fees & 44,401 & 49,472 & 101,078 & 146,541 & 341,492 & 53,915 \\
\hline Memberships & 15,770 & 10,030 & 5,500 & 2,300 & 33,600 & 400 \\
\hline Consulting & 2,250 & 7,922 & 10,297 & 11,168 & 31,637 & 30,704 \\
\hline VHFA $^{a}$ & 55,000 & 20,000 & 50,000 & 50,000 & 175,000 & 11,250 \\
\hline $\mathrm{DPS}^{\mathrm{b}}$ & 0 & 9,500 & 14,749 & 10,000 & 34,249 & 7,500 \\
\hline VEIC $^{c}$ & 0 & 10,020 & 10,875 & 10,020 & 30,915 & 7,515 \\
\hline $\mathrm{DOE}^{\mathrm{d}}$ & 0 & 0 & 0 & 130,000 & 130,000 & 0 \\
\hline NREL & 0 & 0 & 0 & 10,000 & 10,000 & 0 \\
\hline Other & 13,558 & 2,331 & 6,967 & 4,377 & 27,233 & 860 \\
\hline Totals & 130,979 & 109,275 & 199,466 & 347,406 & 814,126 & 192,884 \\
\hline
\end{tabular}

"Funded by general revenues

"Petroleum Violation Escrow (PVE) or "oil overcharge" funds

Funding is contributed fromits fund balance

${ }^{d}$ Funds awarded, not expended

${ }^{e}$ For nine months 7/1/95 through 3/31/96

\section{Utility Programs}

Of the 12 utilities conducting residential DSM programs, ERH-VT works in partnership with all four that utilize a HERS feature, including the state's two largest utilities, Central Vermont Public Service (CVPS) Corporation and Green Mountain Power (GMP) Corporation. Although these HERS features do not include the financing of energy improvements per se, they do cover the cost of the energy rating (paid directly to ERH-VT in most cases), making EEF more attractive to buyers of new homes, where applicable, and owners of existing dwellings.

New construction. CVPS recently launched a program in southern Vermont that imposes a $\$ 350$ assessment fee on new construction. ERH-VT reviews a plan, issues a proposed energy rating, and informs the builder/owner of any changes that are needed to bring the dwelling to the 4-Star-Plus level. Upon completion of construction and inspection, the utility will waive the fee and add a cash payment equivalent to its avoided costs ( $\$ 300-\$ 450)$ if the builder has implemented the recommended energy upgrades.

GMP is conducting a similar program in the central part of the state. Washington Electric Cooperative (WEC) has had a new construction program of this kind in place since 1994. Two more utilities-Vermont Electric Cooperative (VEC) and Citizens Utilities Company (CUC) began a similar pilot program in April 1996.

Existing construction. CVP is designing a "Residential High Use Program" that would cover the cost of an energy rating at the time of sale for electrically heated homes-targeted by utilities for DSM programs. An additional incentive may be provided for switching from electricity to an alternative fuel (oil, natural or propane gas). GMP and CUC are considering a similar program. 
Whether utilities continue DSM programs in a more competitive retail environment will determine whether these kinds of efforts will be expanded. At the state policy level, the governor has publicly embraced competition as advantageous to the state and the DPS has endorsed an experimental utility pricing program that offers customers a reduced per unit rate if they are large users of electricity, representing a doclining block rate structure. Although implications for HERS/EEF are speculative at this time, enhanced demand for energy efficiency among residential customers could be an outcome of this development if rate increases do in fact occur.

\section{Proposed Energy Building Code}

A proposal initiated by the governor's office would institute the Council of American Building Officials' Model Energy Code (CABO-MEC) as a requirement in Vermont. Many issues surrounding the proposal were explored by a Governor's Task Force studying its implications. Its impact on HERS/EEF in the state is potentially confusing with respect to the 4-Star standard required for EEMs, along with the fact that a house built to the current CABO-MEC level would not necessarily qualify for an EEM under existing EEF products. Should Vermont adopt a code that is stricter than CABO-MEC, it is possible that homes rated at 4-Stars will be insufficient to meet the state standard. 


\section{Marketing}

\section{Strategy}

ERH-VT has employed a variety of marketing strategies to publicize and promote the availability of HERS/EEF in Vermont. The organization hired a marketing coordinator in September 1987 when EEM promotion became a part of its activities, but it could not sustain the position on a regular basis. Subsequently, ERH-VT began to employ the part-time marketing services of a consultant. Among marketing activities, ERH-VT has traditionally emphasized liaison with stakeholder groups through a wide range of contact mechanisms, such as group information sessions; one-on-one contact; and participation at meetings, conventions, trade shows, fairs, and open houses. In 1991, ERH-VT established the following marketing goals:

- Conduct 25 ratings per month through market research, issuing press releases, and producing brochures, among other methods

- Attract foundation support for marketing and ectucational activities

- Improve membership services and outreach

- Systematize internal procecures to enhance responsiveness to members.

Although implemented in part, these plans were not fully realized because of limits on resources.

The marketing strategy included direct advertising to consumers via mass media. Until recently ERH-VT placed less emphasis on this approach because it believed that efforts not targeted to the intended audience were not cost effective. The marketing consultant believes, however, that identifying the best way to trigger consumer demand is something of a "Catch-22" situation. Stakeholders who balk at actively promoting HERS/EEF often cite a lack of consumer demand; yet because consumers are buying a "product" (energy efficiency) that is ancillary to their primary goal (housing), consumers must rely on stakeholders for information Toward this end, ERH-VT provided consumer-oriented printed material but relied on stakeholder channels for dissemination. For example, between 1987 and 1995 Vermont Housing Finance Agency (VHFA) has mailed 17,000 consumer brochures on energy efficiency financing to prospective home buyers as part of general VHFA information packets.

ERH-VT is refocusing its marketing of EEF directly to the consumer. The approach is "a comprehensive, integrated and continuous marketing campaign targeted directly to the general public," according to the recommendation of ERH-VT's marketing consultant, Debra Bouton, in a 1995 internal ERH-VT memorandum She further suggests implementation through utility programs, such as installing yard signs identifying new homes having energy ratings, and coordinating utility program marketing statewide, including an integrated campaign at "point-of-purchase" (new home sites).

A contract with the U.S. Department of Energy supports these approaches, with the addition to the ERHVT staff of a part-time Outreach Coordinator having specific marketing responsibilities.

\section{Market Response}

Although ERH-VT has adopted no systematic method for assessing market response, results of two informal measures are noteworthy: 


\section{Refinancing Promotion}

A special promotion for EEF, developed by ERH-VT and aimed at homeowners refinancing existing mortgages in 1991, met with little response. A flyer, made available to financial institutions, encouraged residential mortgage holders to take advantage of EEF at the same time as refinancing. As an added incentive a coupon valued at $\$ 25$ was made available toward the cost of the energy rating. Staff at ERHVT have noted lenders' observations that the failure of this effort was due to the backlog resulting from the large volume of refinancing activity and the perception, from both the underwriters' and consumers' perspectives, that the rating and associated additional paperwork would delay the closing of the loan.

\section{Lender Survey}

Another measure is a "blue card" (brief questionnaire) which ERH-VT began sending in October, 1990 to lending officers to obtain specific information about the lenders' utilization of energy ratings in processing mortgages and loans. ERH-VT estimates that it sent out approximately 1,050 of these surveys through December 1995, but did not have findings compiled in a readily available form. Two other findings are of interest from a marketing perspective:

- Nearly three-quarters of EEM participants were first-time home buyers

- Over $70 \%$ of all participants heard about EEF from lenders. 


\section{Training}

Training with respect to EEF in Vermont involves educating raters, energy specialists, appraisers, lenders, real estate professionals, and builders/contractors. The philosophy of ERH-VT, the primary trainer, is that well informed stakeholders will promote the benefits of EEF; and competency in energy-efficiency technologies helps reduce energy consumption. Indeed, as one of ERH-VT's most experienced energy specialists observed, the opportunity to educate homeowners who are present during an energy rating should not be underestimated.

Vermont Housing Finance Agency includes specifics on how EEMs are implemented in its training of lenders and real estate salespersons. The Director of the HUD Field Office in Burlington, Vermont states that the Manchester, New Hampshire Field Office has responsibility for EEM training under the FHA EEM Program.

\section{Who Receives Training}

This section presents specific information on training, by type of group trained All training is conducted by ERH-VT, although VHFA includes some basic information on EMS in general training it conducts for real estate professionals.

\section{Raters}

ERH-VT defines a rater as anyone who is capable of conducting a rating from start to finish; i.e., making the site visit, conducting builder education and blower door tests, completing the Vermont Energy Checklist, running rating software, and producing a final rating. Table 4-6 shows the nature and extent of rater training activity. Sixteen raters were trained in sessions of 50 hours each. ERH-VT relies on informal, word-of-mouth communication as the marketing tool for rater training. Raters do not receive any "certification" upon completion of this training. ERH-VT places names of trained raters on an internal list it uses.

As of 1996, four raters are working for ERH-VT. Two are full-time, housed at ERH-VT. One employee of VEIC conducts energy ratings for ERH-VT on a part-time basis (up to three-quarters time). ERH-VT also employs a subcontractor who does rating work part-time.

ERH-VT would develop additional training plans if rating activity were to increase, but it would conduct such training on an individual basis, similar to an apprentice position. 
Table 4-5. Rater Training Conducted by ERH-VT, 1987-95

\begin{tabular}{|l|r|r|r|r|r|r|r|r|r|}
\hline Training & \multicolumn{1}{|c|}{1987} & \multicolumn{1}{|c|}{1988} & 1989 & \multicolumn{1}{|c|}{1990} & \multicolumn{1}{c|}{1991} & 1992 & 1993 & 1994 & 1995 \\
\hline Sponsor & VEIC & ERH & NA & ERH & ERH & NA & ERH & ERH & NA \\
\hline N (16) & 4 & 7 & 0 & 1 & 1 & 0 & 2 & 1 & 0 \\
\hline Date & $10 / 87$ & MD & NA & $8 / 90$ & $1 / 91$ & NA & $3 / 93$ & $10 / 1 / 94$ & NA \\
& & & & & & & $8 / 93$ & & \\
\hline Length (hrs) & 50 & 50 & NA & 50 & 50 & NA & 50 & 50 & NA \\
\hline
\end{tabular}

$\mathrm{N}$ : Number of attendees at each session

MD: Missing data

NA: Not applicable

Sources: EEM Pilot Project Summary of Activities Reports; time cards; C. Boyd, R. Faesy.

\section{Energy Specialists}

ERH-VT defines an energy specialist as "anyone capable of conducting a blower door test, completing the Vermont Energy Checklist and educating builders" about the value of ratings. Table 4-6 shows the nature and extent of energy specialist training in 1991, 1992, and 1995. (Energy specialists were trained only in those three years.) Training increased in 1995 because utility program activity increased (a baseline study for Central Vermont Public Service Corporation, Green Mountain Power Corporation, and Citizens Utilities Company in January 1995; and a new construction program for Vermont Gas Systems in June 1995). In all, 16 persons have been trained as energy specialists. The training is marketed by word of mouth.

Table 4-6. Energy Specialist Training Conducted by ERH-VT Since Inception

\begin{tabular}{|l|r|r|r|}
\hline \multicolumn{1}{|c|}{ Training } & 1991 & 1992 & 1995 \\
\hline Sponsor & ERH & ERH & ERH \\
\hline $\mathrm{N}(16)$ & 2 & 2 & 12 \\
\hline Date & $\mathrm{MD}$ & $\mathrm{MD}$ & $1 / 11 / 95$ \\
\hline Length (hrs) & 8 & 8 & 8 \\
\hline
\end{tabular}

$\mathrm{N}$ : Number of attendees at each session

MD: Missing data

Sources: EEM Pilot Project Summary of Activities Reports; ERH-VT Quarterly Reports; time cards; C. Boyd and R.Faesy.

At this time (June 1996), the number of energy specialists in Vermont is sufficient. If ERH-VT needs to train additional specialists it would develop a certification program encouraging weatherization auditors or other existing energy service contractors who already have solid training to become ERH-VT certified. ERH-VT will also be working closely with a "Building Performance Institute" initiative (funded by DOE and others) in New York and Vermont, which is developing a certification process for energy auditors and other specialists in the field. This certification may become the standard for the energy industry and ERHVT plans to coordinate these efforts with its own training. 


\section{Appraisers}

ERH-VT defines a real estate appraiser who is also trained in conducting an energy rating as anyone capable of completing the Vermont Energy Checklist. Table 4-7 shows the nature and extent of appraiser training, 1987-1991. ERH-VT has not trained any appraisers since 1991 due to a policy change that the ERH-VT Board adopted in 1991 which required that a blower door test be conducted at each property being rated. Because of the policy change ERH-VT felt it better to work with certified energy specialists throughout Vermont in performing ratings. A total of 252 appraisers had been trained in how to complete the Checklist during the period prior to the policy change. Direct mail was used to market the training.

Table 4-7. Appraiser Training Conducted by ERH-VT, 1987-1991

\begin{tabular}{|l|r|r|r|r|r|r|}
\hline Training & 1987 & 1988 & 1989 & 1990 & 1991 & \multicolumn{1}{|c|}{ Total } \\
\hline Number trained & 38 & 90 & 32 & 5 & 87 & 252 \\
\hline Training events & 3 & 11 & 2 & 1 & 7 & 24 \\
\hline Hours in class & 16 & 8 & 8 & 8 & 8 & 48 \\
\hline
\end{tabular}

Source: EEM Pilot Project Summary of Activities Reports; ERH-VT Quarterly Reports; appraiser training sign-in sheets.

ERH-VT has no plans to train appraisers to collect information for processing energy ratings, as it had done in the past. However, ERH-VT does plan to establish an accredited course for appraiser continuing education under the jurisdiction of the state as part of its DOE grant. This course would cover the energy rating process in general and focus on the valuation of energy improvements in the appraisal process.

\section{Lenders}

ERH-VT defines lenders as employees of a lending institution who are involved with mortgage lending, typically, loan originators and undeswriters. Table 4-8 shows EHR-VT's lender training during 1987-89 and 1993-94. No lenders were trained between 1990 and 1993 because no funding was received from either the Vermont Deparment of Public Service or VHFA for specific projects. During this period 446 lenders received about 2 hours of training. Telemarketing was employed to solicit trainees.

VHFA has been including EEM information as part of its lender training sessions since 1987. According to Cathleen Gent, VHFA's Director of Communications, approximately 2 to 5 minutes per session is spent on how to qualify borrowers for EEMs (correspondence to ERH-VT dated 8/2/95). VHFA data maintained, beginning in 1991, indicate that through the end of 1995 approximately 2,900 lendinginstitution staff attended approximately 360 VHFA training sessions in which EEM information was included. Twenty-one of these sessions were held between July and December, 1995, with 340 lenders in attendance. (Information from C. Gent, 2-13-96). 
Table 4-8. Lender Training Conducted by ERH-VT, 1987-89; 1993-95

\begin{tabular}{|c|c|c|c|c|c|c|c|}
\hline Training & 1987 & 1988 & 1989 & 1993 & 1994 & 1995 & Total \\
\hline Number trained & 74 & 234 & 21 & 70 & 35 & 12 & 446 \\
\hline Training events & 1 & 13 & 3 & 6 & 2 & 3 & 28 \\
\hline Hours in class & 2 & 2 & 2 & 2 & 2 & 2 & 12 \\
\hline
\end{tabular}

Source: EEM Pilot Project Summary of Activities Reports; ERH-VT Quarterly Reports; ERH-VT internal training session tracking folder.

\section{Real Estate Professionals}

Table 4-9 shows the nature and extent of ERH-VT's training for real estate professionals. No real estate professionals were trained between 1989 and 1993 because no funding was available. ERH-VT trained approximately 1,000 persons in these sessions, using telemarketing to solicit attendees. ERH-VT does not employ a separate, formal curriculum for real estate professionals' training. The sessions have been 20 to 30 minutes in length using display boards, a slide presentation, and printed handout material describing EEMs and ratings.

VHFA held 11 training sessions for real estate professionals during 1994-95; 209 attended. Approximately 2 to 5 minutes were spent on how to qualify EEM borrowers.

As part of its $\$ 130,000$ contract with DOE, ERH-VT has agreed to design training programs for lenders and real estate professionals. Plans call for training 50 lenders and 100 real estate professionals in FY ' 96. ERH-VT has hired an Outreach Coordinator to carry out this task

Table 4-9. Real Estate Professionals' Training Conducted by ERH-VT, 1987-89; 1994-95

\begin{tabular}{|c|c|c|c|c|c|c|}
\hline Training & 1987 & 1988 & 1989 & 1994 & 1995 & Total \\
\hline Number trained & 31 & 529 & 529 & 20 & 77 & 1,001 \\
\hline Training events & 1 & 8 & 5 & 1 & 4 & 19 \\
\hline Hours in class & 2 & 2 & 2 & 2 & 2 & 10 \\
\hline
\end{tabular}

Sources: EEM Pilot Project Summary of Activities Reports; ERH Quarterly Reports; ERH-VT's internal training session tracking folder.

\section{Builders/Contractors}

ERH-VT helped to design a workshop titled the "Cold Climate Construction Workshop: Problems, Solutions and Opportunities," held on April 6, 1994. This day-long workshop was sponsored by VEIC, Champlain Valley Weatherization Service, and ERH-VT. Approximately 75 builders, energy-efficiency program administrators and energy specialists attended. Although the Cold Climate Construction Workshop is the only formal builder training that ERH-VT has conducted, technical assistance is provided to individual builders as part of the rating process; the DPS helps to fund this activity. ${ }^{6}$

${ }^{6}$ Sources: Cold Climate Construction Workshop brochure; Ken Tohinaka, VEIC Energy Specialist. 
ERH-VT plans to build on the successful 1994 Cold Climate Construction Workshop. The workshop organizers plan a builder-specific newsletter and future training sessions. For the next few years, ERH-VT will combine builder training on "house as a system" information with training on how to comply with the CABO Model Energy Code. This energy code appears likely to be adopted during the 1996 or 1997 Vermont legislative session. ERH-VT may combine forces with the Homebuilders Association of Northern Vermont (HBANV) to deliver these training sessions.

\section{Summary}

ERH-VT has trained the following groups. Some additional lenders and real estate professionals learned about EEF during general training of VHFA.

- 16 raters (1987-95)

- 16 energy specialists (1991-95)

- 252 appraisers (1987-91)

- 446 lenders (1987-95)

- $\quad 1,001$ real estate professionals (1987-95)

- 75 builders/contractors (1994 only). 


\section{Program Evaluation/Data Collection}

\section{Database}

ERH-VT has information about ratings from 1987-1993 stored in a database log. Fifty-one data fields are identified in Appendix 4-C, ERH Database Structure. The organization discontinued logging this information in 1993 to decrease its administrative costs. Currently, the information is available in paper copy and a portion (rating inputs and results only) is also part of a database maintained at Energy Rated Homes of America (ERHA).

With funding from DOE and NREL, and with the onset of a new utility new-construction program, ERHVT has put in place its own computer network and an electronic data management system (the Central Rating Information Processing Tracker [CRIPT]). This system tracks ratings using FoxPro 2.6 for Windows. As of early 1996, ERH-VT began using the system on a trial basis. Following several months experience with its use, ERH-VT intends to examine the possibilities for selling the system to other rating organizations and other interested parties.

\section{Recordkeeping}

ERH-VT has its own forms for tracking administrative and technical data associated with ratings. The forms, attached as Appendix 4-D, Forms Used in Recordkeeping, include the following:

- Washington Electric Cooperative (WEC) Scorecard \& ERH Rating Order Form

- ERH Rating Order and Billing Form

- Information Needed to Begin the New House Rating Process

- Central Vermont Public Service Corporation (CVPS) Job Tracking Form

- ERH Folder Tracking Form

- Vermont Energy Checklist

According to David Cawley, ERH-VT Director of Operations, what records are maintained reflects the nature of the program associated with ratings. For example, utilities' data requirements depend on the objectives of their respective DSM programs under regulatory oversight. Accordingly, these needs are incorporated in the ERH-VT database. In these situations, tracking of energy consumption for evaluation purposes is conducted by the sponsoring utility company.

Since its inception, ERH-VT has employed ERHA's E-Z Rater software to generate ratings. This will change in 1996 with a conversion to REM/Rate, a product of Architectural Engineering Corporation, Boulder, Colorado. A database output from this new tool will store all rating inputs and outputs.

\section{Rating Activity}

Since ERH-VT first began conducting ratings in October 1988, through December 1995, some 2,250 ratings have been ordered. Figure 4-1 depicts the volume of rating activity, by quarter. According to ERH-VT's Director, Richard Faesy, the number of ratings ordered does not differ significantly from the number of ratings completed, inasmuch as nearly all cancellations occur within a week after the order and are not counted in the final tally of rating activity. 
Fluctuations in the volume of rating activity are attributable to the program-driven (vs. market-driven) nature of energy rating work, according to ERH-VT. The steep slope leading to a peak of 175 ratings in the second quarter of 1989 reflects program start-up and free ratings offered during that period. Since the first quarter of 1990 when ERH-VT began charging for ratings, peaks are explained by rating work for large, new housing construction developments at the end of 1991, the delivery of the Vermont Gas Systems New Construction Program in 1993 and 1994, and a 200-home baseline survey conducted in early 1995. 


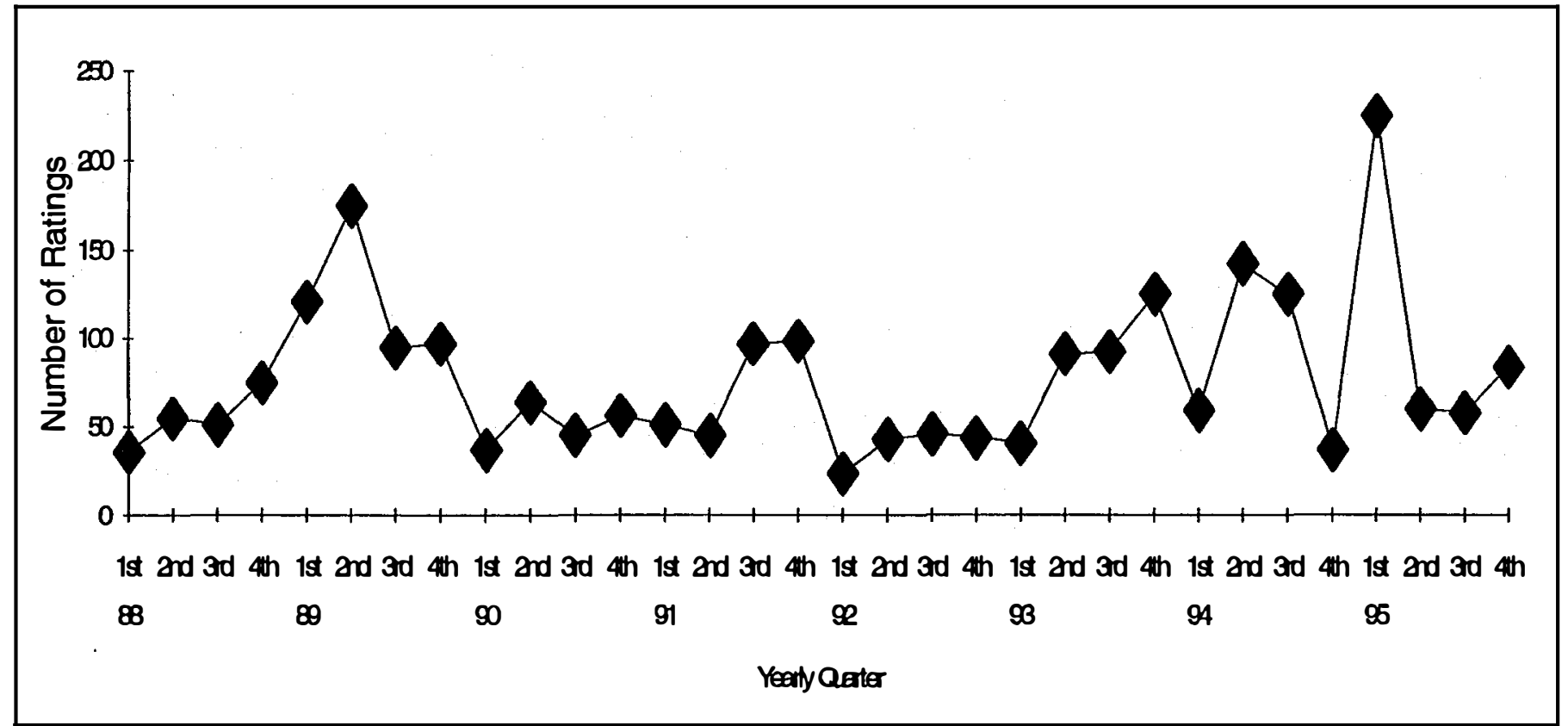

Source: Constructed by Energy Rated Homes of Vermont, Inc.

Figure 4-1. Volume of ERH-VT Rating Activity, 1988-1995 


\section{Energy Mortgage Activity}

No records have been maintained at ERH-VT on the number of energy-improved homes.

EEF activity in Vermont, as reported by HUD and DVA, reveal only a few completed EEMs, however. As shown in Table 4-10, since 1992 only 3 HUD EEMs and 2 DVA EEMS are reported, all during FY 1994. The differential between ERH-VT's estimated financing activity and that reported by HUD and DVA is illustrative of the definitional issues surrounding energy efficiency financing. The EEM's reported by lenders in the ERH-VT survey are actually stretched ratios, whereas HUD (FHA) and DVA activity represent improvements financed in the mortgage. In fact, little FHA and VA activity occurs in Vermont annually. ERH-VT reports that the bulk of its EEM activity is through the mortgages that are sold to Freddie Mac, Fannie Mae, and VHFA.

Table 4-10. Vermont Rating and Energy Efficiency Financing Activity, 1992-1995

\begin{tabular}{|l|r|r|r|r|r|}
\hline \multicolumn{1}{|c|}{ Activities } & CY 1992 & CY 1993 & CY 1994 & CY 1995 & \multicolumn{1}{c|}{ Total } \\
\hline Ratings Completed & 157 & 350 & 363 & 427 & $\mathbf{1 , 2 9 7}$ \\
\hline Completed Loans & & & & & \\
HUD EEMs & 0 & 0 & 3 & 0 & $\mathbf{3}$ \\
\hline Conventional FNMA & 0 & 0 & 0 & 0 & $\mathbf{0}$ \\
\hline Conventional Freddie & 0 & 0 & 0 & 0 & $\mathbf{0}$ \\
\hline VA & 0 & 0 & 2 & 0 & $\mathbf{0}$ \\
\hline HUD 203(k) & 0 & 0 & 25 & 0 & $\mathbf{2 5}$ \\
\hline
\end{tabular}




\section{Program Accomplishments and Future Plans}

ERH-VT cites the following program accomplishments since inception to December, 1995

- Completion of more than 2,500 home energy ratings

- Recipient of Environmental Excellence in Pollution Prevention Award from the State of Vermont

- Launching EEM pilot programs for the Federal Housing Administration and Veterans Administration

- Designation as an "Energy Efficient Mortgage Pilot State"

- Participation in affordable housing initiatives and model energy efficient developments in the state

- Participation in National Home Energy Rating System (HERS) Council deliberations as a member of its Technical Committee and founding board member

- Selection by major utilities in the state to deliver DSM programs, incorporating the delivery of ratings

- Selection as a member of the Governor's Task Force on Residential New Construction Energy Standards to develop an energy code for Vermont

- Securing a commitment from VHFA to develop and energy improvement mortgage program with an incentive to encourage participation

- Completion of a survey of 200 newly constructed homes for a baseline survey for three Vermont utility companies

ERH-VT has attempted to quantify its productivity in terms of EEMs written, jobs created, fuel savings, and reductions in carbon dioxide emissions. Because of a lack of hard data, the organization has been able to develop gross estimates based on assumptions of how ratings have been used, and average expected energy savings resulting from implementation of recommended energy upgrades in homes that have been rated. Using methodologies endorsed by several organizations in the energy/environment field ${ }^{7}$, ERH-VT cites the following results of its work:

- Savings of $\$ 570,000$ in fuel costs to Vermonters

- Prevention of nearly 5,000 metric tons of carbon dioxide from release to the atmosphere

- Creation of one job for every 10 homes made energy efficient

ERH-VT notes that, as an organization that responds to rather than influences the real estate market, it has been important to be flexible. Accordingly, it is difficult to set realistic, specific targets by which to gauge progress at a later date.

ERH-VT identifies two broad goals for its future:

- Positioning itself to be the primary energy-efficiency services deliverer for Vermont new construction programs as utility restructuring takes place.

- Taking initiatives toward developing mortgage products and programs that reward energy improvements and efficiency, with a goal of having energy ratings become a common part of the home buying and selling process, in the same way as appraisals and inspections are conducted.

\footnotetext{
${ }^{7}$ American Council for an Energy-Efficient Economy, Alliance to Save Energy, et al, 1991.
} 


\section{Conclusions}

This evaluation, although limited in scope, produced preliminary findings concerning the status of energy efficiency financing in Vermont:

- Financial subsidies were required during the start-up period for the rating organization, and diversification of services have helped contribute to self-sufficiency. Sharing of staff, location, and other resources with a companion organization (Vermont Energy Investment Corporation) has further assisted in maintaining energy rating services in Vermont.

- The role of the Vermont Housing Finance Agency as a "champion" of residential energy efficiency financing has been critical to forming linkages with state government and parties involved in the housing market (lenders, real estate professionals, appraisers, and builders/contractors).

- Generating and maintaining awareness of the role of energy ratings and financing mechanisms among buyers, sellers, lenders, real estate professionals, appraisers, and builders/contractors are an ongoing challenge for the rating organization.

- Partnerships with utility companies have proven successful in institutionalizing energy efficiency in new residential construction in the state.

Energy Rated Homes of Vermont plays a central and multi-faceted role toward achieving the goal of institutionalizing energy efficiency financing in the Vermont housing market. It serves as advocate, marketer, analyst, and technical expert in a complex setting that requires foresight and flexibility in response to ever changing conditions. It will be important to continue to follow its progress and that of similar organizations in the years ahead. 


\section{References}

American Council for an Energy-Efficient Economy (ACEEE), Alliance to Save Energy, Natural Resources Defense Council, and Union of Concemed Scientists. (1991). America's Energy Choices: Investing in a Strong Economy and a Clean Environment. 2 Vols. Washington, DC: ACEEE.

Center for Rural Studies. (1990). Energy Rated Homes of Vermont Program Evaluation. Burlington, VT: The University of Vermont.

Faesy, Richard. (1988). The Energy Efficient Mortgage: Creative Financing for Energy Improvements in Vermont. Burlington, VT: Energy Rated Homes of Vermont, Inc. (March).

Faesy, Richard. (1992). Lessons Learned From Four Years of Operating a Home Energy Rating System and Energy Efficient Mortgage Program. Burlington, VT: Energy Rated Homes of Vermont, Inc. (March). 


\section{Epilogue}

During 1996, developments pertinent to this case study include utility program delivery, new mortgage products, outreach efforts, and changes in infrastructure. These are described, as follows:

\section{Utility Program Delivery}

\section{New Construction}

ERH-VT has continued its work under contract to five utilities (CVPS, GMP, VEC, WEC, VGS) to deliver their new construction programs. This has been the organization's primary activity, resulting in more than 350 rating orders through mid-September for these utilities.

\section{New Construction Program for 1997}

ERH-VT staff has been collaborating with Vermont utilities, the Department of Pubic Service and the home builders trade association to redesign the various new construction programs into a single uniform statewide new construction program for all utilities, expected to be completed by February, 1997. ERHVT is positioning itself to be the delivery contractor in the final program design. As part of the collaborative effort, the players have all worked to build support for the adoption of a new construction energy code, which will be introduced in the Vermont legislature in January, 1997.

\section{Time of Sale}

Under contract to CVPS, ERH-VT has worked with 18 customers who are buying or selling homes with electric heat to encourage fuel switching to a less expensive heating source.

\section{New Mortgage Product Development}

\section{VHFA's Yearly Energy Savings System (YESS) Program}

ERH-VT has participated in program development and lender training for this mortgage product that will offer an interest rate incentive to buyers of existing homes who finance at least $\$ 2,500$ in energy improvements. The YESS mortgage offers an interest rate that starts at $1.5 \%$ below VHFA's standard mortgage product, then increases $.5 \%$ a year for three years when it is capped at the initial standard mortgage level.

\section{Freddie Mac/Fannie Mae EEM Pilot Program}

ERH-VT has been chosen as one of eight states to offer this new product. Final negotiations and coordination are taking place through 1996. Program development in Vermont will then follow, with a launch date expected for early in 1997.

\section{Energy Star/Norwest Mortgage}

ERH-VT has entered into a memorandum of understanding with the EPA to certify new Energy Star homes in Vermont. This will provide access to mortgage products with some beneficial incentives, such as a lower interest rate. ERH-VT is coordinating an effort with Vermont utilities to work with Norwest Mortgage to make these incentives available with a 5-Star rating. 


\section{Outreach}

ERH-VT completed development of a comprehensive Energy Mortgage lenders manual and has continued training lenders and real estate professionals. Representatives from ERH-VT regularly attended home buyer seminars and other events to reach these stakeholder groups. Marketing efforts that ERH-VT carried out included publication of the 4-Star Forum newsletter with mailings targeted to real estate professionals, lenders, and appraisers.

\section{Infrastructure}

ERH-VT became a subsidiary of Vermont Energy Investment Corporation, reporting formally to VEIC's Board of Directors. ERH-VT formed an advisory committee of its own to maintain communication with and input from representatives from real estate, lending, and home building industries. ERH-VT also enhanced its data management computer system and stepped up Energy Specialist training in 1996 
Appendixes 


\section{Appendix 4-A. Vermont Process Evaluation Data}

\section{Part 1. Organization Contacts and Descriptions \\ Energy Rated Homes of Vermont (ERH-VT)}

Key Contact:.................................. Richard Faesy, Director

Type of Organization: .................... Nonprofit 501(c)(3) membership organization

Address: ......................................... 127 Pine Street

Burlington, VT 05401-8410

Phone:

(802) $865-3926$

Fax:

(802) $658-1643$

Modem:

(802) 658-6879

Date Formed:

October 1987

Number of Staff:.

ERH-VT contracts with the Vermont Energy Investment Corporation (VEIC) to provide staffing services and consultants as needed Staffing has ranged from 2.5 FTE in 1987 to approximately 4 FTE in 1995.

Staff titles and duties:.

VEIC provides the following staff to ERH-VT:

Beth Sachs, Executive Director VEIC

Richard Faesy, Director, ERH

Sara Liddle, Program Assistant, DOE Pilot Program Manager

Carol Boyd, Energy Specialist, Rating processor

Karl Goetze, Energy Specialist, Rating procesor

Louise Andrews, Office Manager

Bob Allstadt, Outreach Coordinator

Dave Hansen, Energy Specialist, Rating processor

Andy Shapiro, Energy Specialist, Rating processor

David Cawley, Director of Operations, ERH-VT

Mission:

Increase the energy efficiency of existing and new residential buildings in Vermont (formal).

\section{Home Energy Ratings/Residential Energy-Efficiency Services and Education}

Program Head: Richard Faesy

Date Formed: October 5, 1987 
Program functions:

(1) Provide home energy-efficiency ratings on existing and new residential buildings; orient new raters to the ERH-VT rating system; train builders in the construction of energy efficient homes and deliver utility demand-side management programs.

(2) Oversee promotion and outreach for the FHA EEMs pilot, the DVA EEMs demonstration program and the two-percent stretch for new and existing homes, and the Fannie Mae Energy Efficient Mortgage (EEM) pilot for existing homes; conduct training sessions on EEMs for lenders; develop continuing education courses on EEMs for real estate agents and appraisers.

Formative sponsors(s): Vermont Housing Finance Agency (VHFA), Vermont Department of Public Service (DPS)

Program sponsors \& funding:......... Information is taken from past budgets.

Sources of Funding, 1992-1996

\begin{tabular}{|c|c|c|c|c|c|c|}
\hline Source & 1992 & 1993 & 1994 & 1995 & Total & $1996^{e}$ \\
\hline Rating Fees & 44,401 & 49,472 & 101,078 & 146,541 & 341,492 & 53,915 \\
\hline Memberships & 15,770 & 10,030 & 5,500 & 2,300 & 33,600 & 400 \\
\hline Consulting & 2,250 & 7,922 & 10,297 & 11,168 & 31,637 & 30,704 \\
\hline VHFA $^{a}$ & 55,000 & 20,000 & 50,000 & 50,000 & 175,000 & 11,250 \\
\hline DPS $^{b}$ & 0 & 9,500 & 14,749 & 10,000 & 34,249 & 7,500 \\
\hline VEIC $^{c}$ & 0 & 10,020 & 10,875 & 10,020 & 30,915 & 7,515 \\
\hline $\mathrm{DOE}^{\mathrm{d}}$ & 0 & 0 & 0 & 130,000 & 130,000 & 0 \\
\hline NREL & 0 & 0 & 0 & 10,000 & 10,000 & 0 \\
\hline Other & 13,558 & 2,331 & 6,967 & 4,377 & 27,233 & 860 \\
\hline Total & 130,979 & 109,275 & 199,466 & 347,406 & 814,126 & 192,884 \\
\hline
\end{tabular}

${ }^{2}$ Funded by general revenues

betroleum Violation Escrow (PVE) or "oil overcharge" funds

Funding is contributed from its fund balance

${ }^{d}$ Funds awarded, not expended

For nine months 7/1/95 through 3/31/96

Partnerships With Other Organizations

Dept. of Public Service (DPS)

Formal or informal:
ERH-VT was initially funded through PVE funds which were administered by the DPS. The DPS provided the primary financial oversight and support for the organization and EEM program.

Formal when administering grants; quarterly reporting and financial responsibility over ERH-VT. Informal when there is no direct grant to administer. 
Length of association:

Ongoing relationship:

Nature of partnership:

Energy Rated Homes of America

Formal or informal:

Length of association:

Ongoing relationship:

Nature of partnership:

Fannie Mae

Formal or informal:

Length of association:

Ongoing relationship:

Nature of partnership:

$\underline{H U D / F H A}$ (Burlington, VT)
Since 1986. The DPS initially jointly testified with the VHFA to obtain the approval to spend the PVE funds on establishing and supporting ERH-VT and the EEM program. DPS staff and other agencies in state government have been long-standing supporters through the involvement of DPS.

DPS staff and ERH-VT staff correspond regularly as DPS attempts to position energy ratings as part of utility DSM programs and as a permanent player in the Vermont housing marketplace. As de facto staff on energy issues to the governor, the DPS has beneficially linked ERH-VT to the governor.

DPS is a very strong advocate for ERH-VT and the EEM programs. There is a close working relationship.

ERH-VT is one of the original members of ERHA and has a seat on the Board of Directors.

Formal; Board of Director position and Chair of the Technical Committee.

Since 1987.

Corresponds regularly and has a close working relationship with ERHA staff and other member states.

Strong parmership and affiliation with similarly interested HERS organizations nationally.

During 1992 through 1994, ERH-VT staff worked with Fannie Mae to establish the Fannie Mae Vermont Energy Improvement Pilot Program.

Informal, but part of formal agreements Vermont lenders have with Fannie Mae to offer the program.

Since 1992.

Communication infrequently, as necessary.

ERH-VT provides rating information used in Fannie Mae program.

Since the inception of the FHA EEM Pilot, the staff person at FHA Burlington (Bill Peters) has been available and accessible to assist ERH-VT staff in training lenders about the program. 
Formal or informal:

Length of association:

Ongoing relationship:

Nature of partnership:

Home Builders Association of Northern VT

Formal or informal:

Length of association:

Ongoing relationship:

Nature of partnership:

\section{$\underline{\text { Utilities }}$}

Formal or informal:

Length of association:
Informal; available as needed to answer questions and be available for trainings.

Since 1993.

Open communication.

Positive and supportive working relationship.

ERH-VT and the HBANV have had a relationship since the inception of the program Representatives of HBANV have always been on the ERH-VT Board of Directors.

Formal through the HBANV board members, but generally informal otherwise.

Since 1986. HBANV representatives started out on the initial Steering Committee and currently have two board representatives.

Open communication between staff. However, recently, the HBANV and DPS have been at odds over utility programs and energy codes that incorporate energy ratings. This controversy has tended to sour the ERHVT-HBANV relationship because of the ERH-VT's link with the DPS.

On-going, generally good and can work together to further ERH-VT's mission.

ERH-VT has had mostly positive relationships with Vermont utilities. As the deliverer of a number of DSM programs for gas and electric utilities, the relationship has been a very positive one for both ERH-VT and the utilities. ERH-VT is on the brink of entering what could be a significant phase of expansion to deliver utility DSM programs for the two largest electric utilities in Vermont, among others.

Formal; ERH-VT has had contractual relationships with Vermont's one gas utility and three electric utilities since 1992. For the noncontracted utilities, the relationship has been informal; ERH-VT has provided ratings to utility customers as requested intermittently. Utilities have generally been represented on the ERH-VT Board.

Since 1987; utilities were involved on both the Technical and Steering Committees and on the Board more often than not since then. 
Ongoing relationship:

Nature of partnership:

Vermont Association of REALTORS

Formal or informal:

Length of association:

Ongoing relationship:

Nature of partnership:

Vermont Energy Investment Corporation

Formal or informal:

Length of association:
With each utility the relationship differs; a close working relationship exists with co-ops and municipals, whereas the investor-owned utilities are somewhat more formal in their relationship with ERH-VT.

Mutual respect and an attempt to cooperate wherever possible. Most of the utilities understand the benefits of a rating system, but they appear to have some concerns over their degree of control of the program and their ability to tailor the program to their noeds.

The partnership between ERH-VT and VAR has been one of congeniality, but a little skepticism exists on the part of the VAR regarding ERH-VT attempts to interfere in the house buying and selling process. However, individual real estate salespersons have worked closely with ERH-VT and utilized the energy rating and EEM services to their benefit.

Informal, although a real estate salesperson has usually been on the ERH-VT Board of Directors representing the industry.

Intermittently since 1987 . There have been a few short periods without realtor representation on the ERH-VT Board.

Depending on the particular situation, piece of legislation or issue, ERH-VT works with the VAR in order to move something ahead that is mutually beneficial. Otherwise, the relationship is for ERH-VT to have a booth at the annual VAR convention and to purchase mailing labels for the EEM Newsletter from the VAR.

There is not so much a partnership as a relationship of mutual respect and a willingness to work together where there is mutual benefit.

VEIC provides all staff, office space, and equipment to ERH-VT. VEIC worked with VHFA to develop the EEM program in Vermont and has delivered it for ERHVT's Board of Directors since the beginning.

Formal; VEIC has a contractual relationship with ERHVT for program delivery.

Since 1986, from research through development and delivery. 
Ongoing relationship:

Nature of partnership:

Vermont Housing Finance Agency

Formal or informal:

Length of association:

Ongoing relationship:

Nature of partnership:

\section{Vermont Lenders}

Formal or informal:

Length of association:
VEIC and ERH-VT staff are one and the same. The arrangement is very flexible in that during busy times, VEIC can provide more staff to ERH-VT, which is but one of its many projects, and when times are slow, it can generally provide other work for ERH-VT project staff.

VEIC feels a strong commitment to ERH-VT and has contributed financially up to $\$ 20,000 /$ year towards the operation of ERH-VT. The pannership is a very close one.

ERH-VT was formed at the VHFA as the joint concept of the Executive Director (Allan Hunt), in combination with VEIC founders (Beth Sachs and Blair Hamilton) and others (Paul Cillo, Richard Faesy).

Formal; VHFA staff serve as officers of ERH-VT as vice advisors. VHFA has contributed financially to ERH-VT since inception

Since 1986. ERH-VT director started as a VHFA staff person.

Weekly communication and informal discussions with VHFA staff.

ERH-VT was formed at VHFA and then spun off as an independent nonprofit. VHFA is committed to energy efficiency and using ERH-VT as the vehicle for delivery; the partnership is very strong.

ERH-VT has worked to a limited degree with the Vermont Bankers Association, but much more so with individual lenders. Certain Vermont lenders, including most of the largest, have had a very fruitful relationship with ERH-VT and continue to work well on an on-going basis.

Informal for the most part, but with some formal relationships for certain programs (such as the Fannie Mae EEM program) in which ERH-VT is party to an agreement with some Vermont lenders.

Lenders have always been represented by one or two individuals on the ERH-VT Board of Directors.

Since 1987 at the program inception. 
Ongoing relationship:

Nature of partnership:

Geographic coverage:
ERH-VT staff work closely on a regular basis with numerous lenders throughout the state to provide energy ratings and support EEM lending programs that utilize ratings.

Varies by lender and by loan originator within lending institution.

State of Vermont; raters have conducted ratings in every county; however, most activity takes place in the Burlington area (Chittenden County). ERH-VT is working to reach out to less active parts of the state such as the northern and central regions through a contract with DOE which supports the Outreach Coordinator's work to visit all Vermont real estate boards and conduct lender training statewide.

\section{U.S. Department of Housing and Urban Development (HUD) (Field Office)}

Key contact:.................................. Bill Peters

Type of Organization: .................... Federal agency (Vermont office).

Address: ....................................... HUD, U.S. Federal Building, Rm 244

11 Elmwood Avenue

P.O. Box 879

Burlington, VT 05402-0879

Phone:

(802) $951-6290$

Fax:

(802) $951-6298$

Staff assigned to EEMs: 


\section{Part 2. Recordkeeping and Data Collection}

Source:

David Cawley, VEIC Energy Specialist

Richard Faesey, Executive Director, EHR-VT

Briefly describe any

evaluation system employed:

ERH-VT has information about ratings from 1987- 1993 stored in a database. Logging of information stopped in 1993 due to a need to decrease ERH-VT's high administrative costs. Currently, all information is available in paper copy. However, with funding from DOE and NREL and with the onset of a new utility, new construction program, ERH-VT is working to put in place a computer network and an electronic data management system.

Forms used: ERH-VT has its own forms for tracking administrative and technical data associated with ratings.

Organizations with responsibility for

collecting and storing data:

ERH-VT and ERH America

Method for storing data: Hard copy

Number of ratings ordered: 2559 (1988-95)

Number of EEMs in system: Not known

Number of EEMs completed: 3 FHA EEMs; 2 DVA; ERH-VT estimates 1,113

EEM tracking method: "Blue card" survey mailed to lenders who order ratings

Have EEM case numbers? No

Avg. dollar value of EEMs for EEIs: No figures for actual averages of all ratings are available but the figure from past studies of smaller samples is $\$ 4,500$. The range is basically from $\$ 50$ to $\$ 12,000$, with a few outliers of very large old homes up to $\$ 20,000$.

Number of other loans for energy improvements: Home Energy Improvement Program is available through the Vermont Development Credit Union.

Any description of these loans: Vermont Energy Investment Corporation works jointly with the Vermont Development Credit Union to deliver the Home Energy Improvement Loan Program which allows low- and moderateincome Vermonters to borrow funds at low interest rates for terms up to seven years for making energy improvements to their homes. 
State or local reporting

requirements: ................................ None

Any federal reporting

requirements: ................................. None

Software used for ratings: ............... EZ-Rater (ERH of America tool).

REM/Rate (Architectural Energy Corporation) by 1996.

Number of energy-improved

homes:.

No records have been kept on the actual number of energyimproved homes. ERH of America has records on total number of "Post Improvement" ratings run.

Average dollar value of energy improvements: Unkmown 


\section{Part 3. Training}

\section{Raters}

Organization sponsoring/

conducting training: Energy Rated Homes of Vermont

Number trained: 7 work on the current ERH-VT programs

Date(s) of training: 1987: October 1990: August 1991: January 1993: March, August 1994: October

Length of training: Approximately 50 hours

Additional Training Plans:. If rating activity were to increase, there may be a need for additional raters to process ratings, and ERH-VT would provide training on an individual basis, similar to an apprentice position.

Method of Marketing: Word of mouth

\section{Lenders}

Organization sponsoring/

conducting training: Energy Rated Homes of Vermont

Number trained: $446(1987-1995)$

Date(s) of training: 1987: December 1988: 13 sessions 1989: April, May 1993: 6 sessions 1994: January (2)

Length of training: Approximately 2 hours.

Additional training plans: Train 50 lenders in 1996

Method of marketing: Telemarketing

\section{Real Estate Professionals}

Organization sponsoring/ conducting training: Energy Rated Homes of Vermont

Number trained: $1,001(1987-1995)$

Length of training: Approximately 2 hours 
Date(s) of training:

1987: 1 session

1988: 8 sessions

1989: 5 sessions

1994: 1 session

1995: 4 sessions

Additional training plans:

Train 100 real estate professionals in 1996

\section{Appraisers}

Organization sponsoring/

conducting training: Energy Rated Homes of Vermont

Number trained: $242(1987-1991)$

Date(s) of training: 1987: August, December (2)

1988: 11 sessions

1989: January, July

1990: April

1991: 7 sessions

Length of training:

2, 8-hour sessions in 1987; single 8-hour session, 1988-91

Additional training plans: Accredited course for appraiser continuing education under state sanction in 1996

Method of marketing:

Direct mail

\section{Builder/Contractors}

Organization sponsoring/

conducting training: Energy Rated Homes of Vermont

Number trained: 75

Date(s) of training: 1994: April

Length of training: One day

Additional training plans: Newsletter, additional workshop; compliance with CABO-MEC expected to be adopted in 1996

Method of marketing: Word of mouth 


\section{Marketing}

Types of marketing used: .............. Since its inception in 1987 ERH-VT has targeted lenders, realtors, builders and home buyers in its marketing techniques. Many different marketing methods have been used (see attached information). The level of intensity of marketing activity has varied from year to year. Marketing intensity has been determined by the following:

- Availability of staff and/or consultants (ERH-VT had a fulltime Marketing Director from 1987-1992 and a part-time marketing consultant from 1993-present)

- Availability of funds for marketing in the budgets

- Direction related to marketing from the ERH-VT Board of Directors

- Media and outreach work associated with the start up of EEM programs. 


\section{Part 4. Implementation}

\section{Barriers}

- Reliance on stakeholders in real estate sales and financing to generate energy rating activity, and keeping abreast of developments in these dynamic industries.

- Complexity of underwriting guidelines generally and in the mortgage process.

- Perceived benefits of EEMs as mortgage qualifier only.

- Lack of incentives to overcome barriers in lending.

\section{Solutions}

Targeted approaches, by stakeholder group:

- Lenders. Enlisted participation early through committee and board membership; recognize their motivation for writing EEMs; have realistic expectations of the role they can play in the EEM process.

- Appraisers. Seized opportunities to educate them on the value of ratings-e.g., training, and providing appraisers with copies of rating information for specific residences.

- Builders and Energy Contractors. Focused training toward this group; it produces a positive multiplier effect because of the construction trade's ability to identify with the subject matter of ratings.

- Real Estate Professionals. Hired a licensed real estate professional on a part-time basis to serve as outreach coordinator specifically for this stakeholder group.

Recognition of factors external to the rating organization that affect HERS/EEF activity:

- EEMs slow down and complicate mortgage transactions; streamlining the process will help foster EEM production.

- Emphasize to lenders that the EEM benefit to borrowers is lowered energy expenditures; the EEM does more than qualify the buyer for the loan.

- EEMs available through federally assisted programs lack the incentives necessary to fulfill their potential.

\section{Accomplishments}

- Completion of more than 2,500 home energy ratings.

- Recipient of Environmental Excellence in Pollution Prevention Award from the State of Vermont.

- Launching EEM pilot programs for the Federal Housing Administration and Veterans Administration.

- Designation as an "Energy Efficient Mortgage Pilot State."

- Participation in affordable housing initiatives and model energy efficient developments in the state. 
- Participation in National Home Energy Rating System (HERS) Council deliberations as a member of its Technical Committee and founding board member.

- Selection by major utilities in the state to deliver DSM programs, incorporating the delivery of ratings.

- Selection as a member of the Governor's Task Force on Residential New Construction Energy Standards to develop an energy code for Vermont.

- Securing a commitment from VHFA to develop an energy improvement mortgage program with an incentive to encourage participation.

- Completion of a survey of 200 newly constructed homes for a baseline survey for three Vermont utility companies.

\section{Future Plans (two broad goals)}

- Positioned as the pnimary energy-efficiency services deliverer for Vermont new construction programs as utility restructuring takes place.

- Taking initiatives toward developing mortgage products and programs that reward energy improvements and efficiency, with a goal of having energy ratings become a common part of the home buying and selling process, in the same way as appraisals and inspections are conducted. 


\section{Appendix 4-B. Principal Organizations}

(Note: Names of persons interviewed are identified. For complete list of staff, see Appendix 4-A.)

\section{Energy Rated Homes of Vermont}

127 Pine Street

Burlington, VT 05401-8410

(802) 865-3296; Fax (802) 865-1643

Richard Faesy, Executive Director

Carol Boyd, Energy Specialist

David Cawley, Data Specialist

Debra Bouton, Marketing Consultant

U.S. Department of Housing and Urban Development Federal Housing Administration Field Office

Federal Building

11 Elmwood Ave., Room 244

P.O. Box 879

Burlington, VT 05402-0879

(802) 051-6290; Fax (802) 865-6298

Bill Peters, Director

\section{Vermont Housing Finance Agency}

164 St. Paul St.

Burlington, VT 05401

(802) 864-5743; Fax (802) 864-5746

Douglas Lothrop, Director of Single Family Operations

Past Chair, currently Vice Chair, Board of Directors, Energy Rated Homes of Vermont

Cathleen Gent, Director of Communications

\section{Vermont Energy Investment Corporation}

127 Pine Street

Burlington, VT 06401-8410

(802) 658-6060; Fax (802) 658-1643

Beth Sachs, Executive Director 
Appendix 4-C. ERH Database Structure 


\section{ERH DATABASE STRUCTURE}

3. Raters

$\begin{array}{lll}1 & = & \text { C. Boyd } \\ 2 & = & \text { R. Faesy } \\ 3 & = & \text { E. Killian } \\ 4 & = & \text { K. Goetze } \\ 5 & = & \text { M. Twitchell }\end{array}$

4. - Rating Type

$\begin{array}{lll}1 & = & \text { Rated AS IS } \\ 2 & = & \text { Proposed "4 Stars Upgrade" Package } \\ 3 & = & \text { Proposed "Good Investment" Package } \\ 4 & = & \text { Post-Improvement Rating } \\ 5 & = & \text { Proposed from Plans } \\ 6 & = & \text { Final Rating } \\ 7 & = & \text { Enter Name of Upgrade Package }\end{array}$

14. House Type

Number $\quad$ House Name

$\begin{array}{lll}1 & = & \text { One story on CRAWL SPACE WTH FLOOR INSULATION } \\ 2 & = & \text { One story on:CRAWL SPACE WITH PERIMETER INSULATION } \\ 3 & = & \text { One story on slab } \\ 4 & = & \text { One story on exposed FLOOR } \\ 5 & = & \text { One story with walkout basement. } \\ 6 & = & \text { One story with FINISHED BASEMENT } \\ 7 & = & \text { One story with UNFINISHED BASEMENT } \\ 8 & = & \text { TWO story on CRAWL SPACE WITH FLOOR INSULATION } \\ 9 & = & \text { TWO story on CRAWL SPACE WITH PERIMETER INSULATION } \\ 10 & = & \text { TWO story on slab } \\ 11 & = & \text { TWO story on exposed FLOOR } \\ 12 & = & \text { TWO story with walkout basement } \\ 13 & = & \text { TWO story with FINISHED BASEMENT } \\ 14 & = & \text { TWO story with UNFINISHED BASEMENT. } \\ 15 & = & 1 \& 1 / 2 \text { on CRAWL SPACE WITH FLOOR INSULATION } \\ 16 & = & 1 \& 1 / 2 \text { on CRAWL SPACE WITH PERIMETER INSULATION } \\ 17 & = & \text { One \& } 1 / 2 \text { story on slab } \\ 18 & = & \text { One \& } 1 / 2 \text { story with exposed FLOOR } \\ 19 & = & 1 \& 1 / 2 \text { story with walkout basement } \\ 20 & = & 1 \& 1 / 2 \text { story with FINISHED BASEMENT } \\ 21 & = & 1 \& 1 / 2 \text { story with UNFINISHED BASEMENT }\end{array}$




$\begin{array}{rll}1 & = & 1 \mathrm{star}+ \\ 2 & = & 2 \mathrm{star} \\ 3 . & = & 2 \mathrm{star}+ \\ 4 & = & 3 \mathrm{star} \\ 5 & = & 3 \mathrm{star}+ \\ 6 & = & 4 \mathrm{star} \\ 7 & = & 4 \mathrm{star}+ \\ 8 & = & 5 \mathrm{star} \\ 9 & = & 5 \mathrm{star}+\end{array}$

45. Electric Utility

$\begin{array}{lll}1 & = & \text { Allied Power \& Light } \\ 2 & = & \text { AP\&L off-peak DHW } \\ 3 & = & \text { Barton Village Electric } \\ 4 & = & \text { Barton Village Demand Rate } \\ 5 & = & \text { Burlington Electric Light } \\ 6 & = & \text { Burlington time-of-day } \\ 7 & = & \text { Central Vermont Public Service Corp. } \\ 8 & = & \text { CVPS time-of-day } \\ 9 & = & \text { CVPS off-peak DHW } \\ 10 & = & \text { Citizens Utilities Company } \\ 11 & = & \text { CUC N. H. Co-op Customer } \\ 12 & = & \text { CUC PSC of N. H. Customer } \\ 13 & = & \text { Enosburg Village. } \\ 14 & = & \text { Enosburg time-of-day } \\ 15 & = & \text { Franklin Light \& Power } \\ 16 & = & \text { Green Mountain Power Co. } \\ 17 & = & \text { GMP time-of-day } \\ 18 & = & \text { Hardwick Village } \\ 19 & = & \text { Hyde Park Village } \\ 20 & = & \text { HP all electric } \\ 21 & = & \text { Johnson Village } \\ 22 & = & \text { Lyndonville Electric Dept. } \\ 23 & = & \text { LED demand rate } \\ 24 & = & \text { Morrisville Water \& Light } \\ 25 & = & \text { MWL time-of-day } \\ 26 & = & \text { Northfield Village } \\ 27 & = & \text { Orleans Village } \\ 28 & = & \text { Rochester Electric L \& P (1) } \\ 29 & = & \text { REL\&P off-peak DHW } \\ 30 & = & \text { REL\&P small electric heat }(5 \mathrm{~A}) \\ 31 & = & \text { REL\&P large electric heat }(2) \\ 32 & = & \text { REL\&P small demand (5C) } \\ 33 & = & \text { REL\&P large demand (2A) } \\ 34 & - & \text { Stowe Electric Department } \\ & & \end{array}$




$$
\begin{aligned}
& 35=\text { SED demand rate } \\
& 36=\text { SED time-of-day } \\
& 37=\quad \text { Swanton Village Electric } \\
& 38=\text { SVE off-peak:DHW } \\
& 39=\text { Vermont Electric Cooperative } \\
& 40=\text { VEC controlled heat } \\
& 41 \text {. = VEC electric heat rate } \\
& 42=\text {. Verrmont Marble Co. } \\
& 43^{\circ}=\text { Washington Electric Cooperative } \\
& 44=\text { WEC time-of-day }
\end{aligned}
$$




\section{Appendix 4-D. Forms Used in Recordkeeping}

- WEC (Washington Electric Cooperative) Scorecard \& ERH Rating Order Form (1/24/95)

- ERH Folder Tracking Form (foldrtrk wk4); 12/01/94

- CVPS (Central Vermont Public Service) Tracking Form

- Vermont Energy Checklist (7/95); 7 pp.

- ERH Rating Order and Billing Form (May 10, 1995)

- Information Needed to Begin the New House Rating Process (7/95) 
Date:

Rating Request Received

- Checklist Received

- Due Out

- Sent Out

- Follow-up

_ Follow-up

$\checkmark$ Indicates ordered BY

Indicates ordered FOR

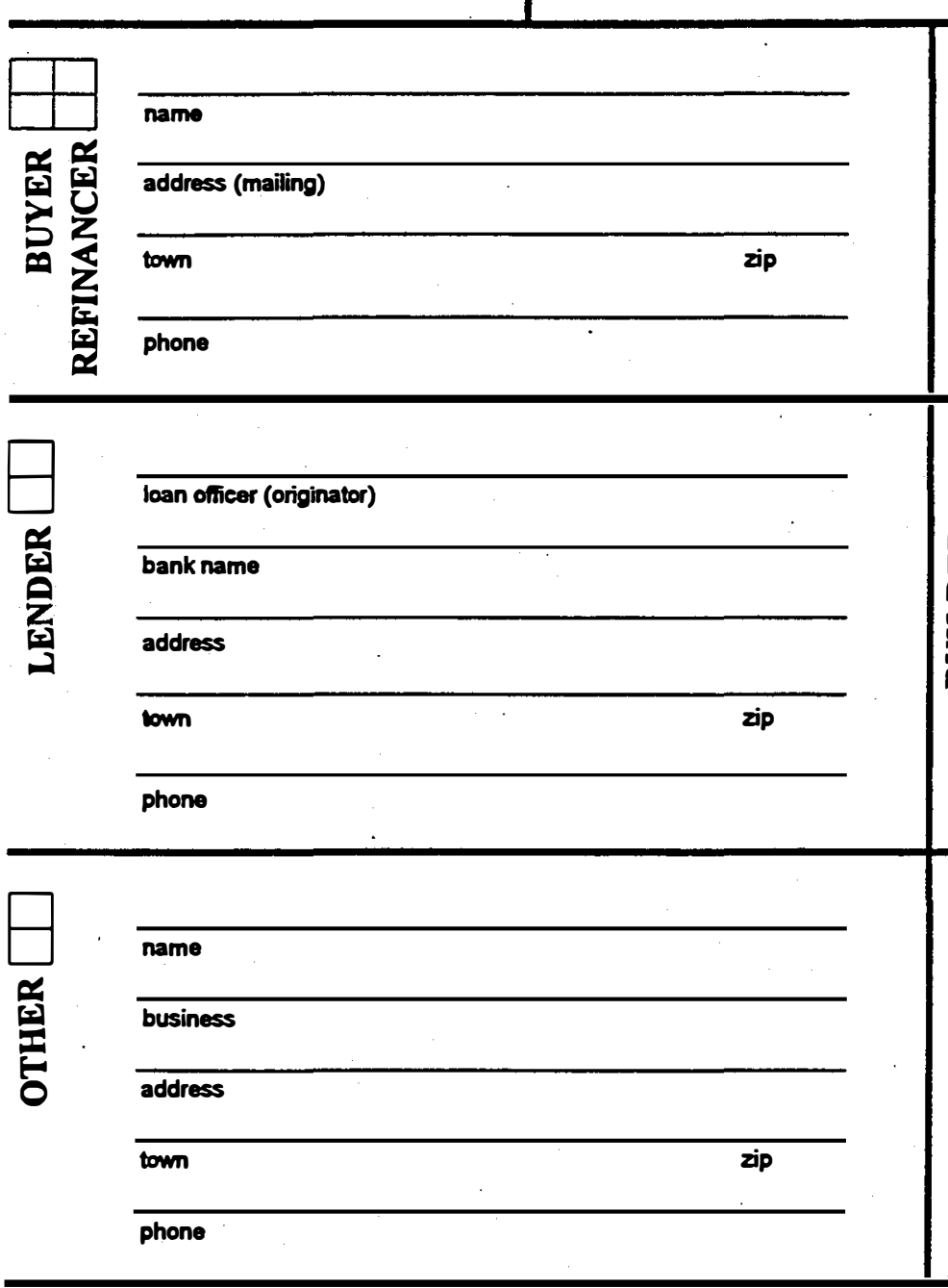

Rating \#

Date:

Completed by:

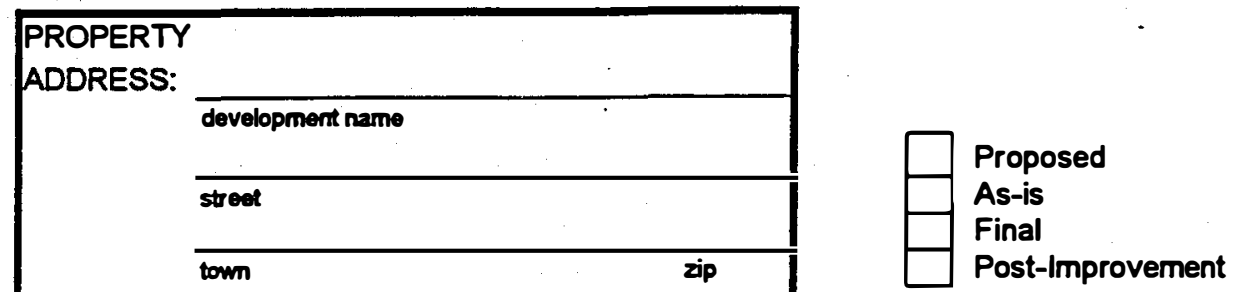

Closing Date:

Post-Improvement
Dates:

Checklist scheduled by
Checklist completed by
— Rating processed by

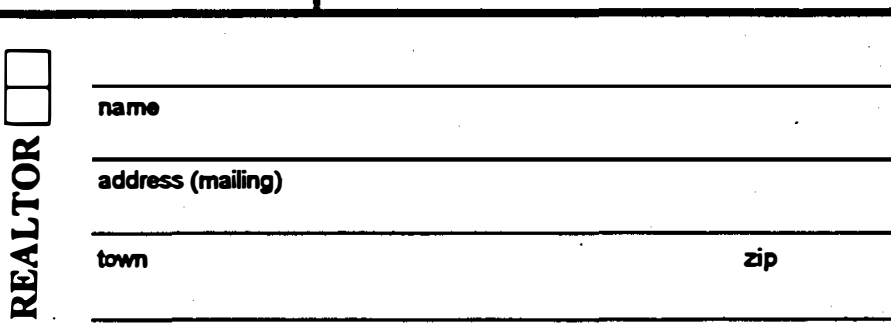

phone

name

business

address

lown

zip

phone

name

business

address

lown

zip

business

Billing: Date and initial when done:

\begin{tabular}{l|l|l|} 
To WEC: & Rating & Involce \\
\cline { 2 - 3 } Proposed (\$300): & \\
\hline Final (\$150): & & \\
\hline
\end{tabular}

Notes: 
A. Address:

B. Address:

C. Address:

D. Address:
Rating\#:

Rating \#:

Rating \#:

Rating \#:

Proposed/As-ls Rating(s):
\begin{tabular}{ll|}
\hline Proposed & Onder Date: \\
As-ls & Due Out:
\end{tabular}

Final/Post-Improvement Rating(s):

Rating Status (date and initial):

Date Checklist received in office

Date complete information received in office

Site Visit by

Rating Performed by

Checked for Accuracy by

Closed and Mailed by

Invoiced by

Logged in Database by

Notes (date and initial):

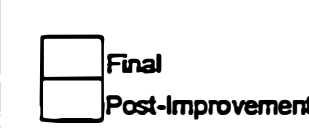

\begin{tabular}{|c|c|c|c|c|}
\hline \multirow[t]{2}{*}{ Rating Status (date and initial): } & \multicolumn{2}{|r|}{$\mathbf{A}$} & \multicolumn{2}{|r|}{$\mathbf{B}$} \\
\hline & Date & Initials & Date & Initials \\
\hline Date Ordered & & 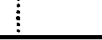 & & $\vdots$ \\
\hline \multicolumn{5}{|l|}{ Date Due Out } \\
\hline Chectlist received in office & & $\vdots$ & & $\vdots$ \\
\hline Complete info. received & & $\vdots$ & & $\vdots$ \\
\hline \multicolumn{5}{|l|}{ Site Visit } \\
\hline \multicolumn{5}{|l|}{ Rating Performed } \\
\hline \multicolumn{5}{|l|}{ Checked for Accuracy } \\
\hline \multicolumn{5}{|l|}{ Closed and Mailed } \\
\hline \multicolumn{5}{|l|}{ Invoiced } \\
\hline \multicolumn{5}{|l|}{ Logoed in Database } \\
\hline \multirow[t]{2}{*}{ Rating Status (date and initial): } & \multicolumn{2}{|r|}{ C } & \multicolumn{2}{|c|}{ D } \\
\hline & Date & Initials & Date & Initials \\
\hline \multicolumn{5}{|l|}{ Date Ordered } \\
\hline \multicolumn{5}{|l|}{ Date Due Out } \\
\hline \multicolumn{5}{|l|}{ Checklist received in office } \\
\hline \multicolumn{5}{|l|}{ Complete info. received } \\
\hline \multicolumn{5}{|l|}{ Site Visit } \\
\hline Rating Performed & & $\vdots$ & & $\begin{array}{l}\vdots \\
\vdots\end{array}$ \\
\hline \multicolumn{5}{|l|}{ Checked for Accuracy } \\
\hline \multicolumn{5}{|l|}{ Closed and Mailed } \\
\hline Invoiced & & $\vdots$ & & $\vdots$ \\
\hline Logged in Database & & & & \\
\hline
\end{tabular}

Notes (date and initial): 
- CVPS JOB TRACKING FORM

ERH NUMBER

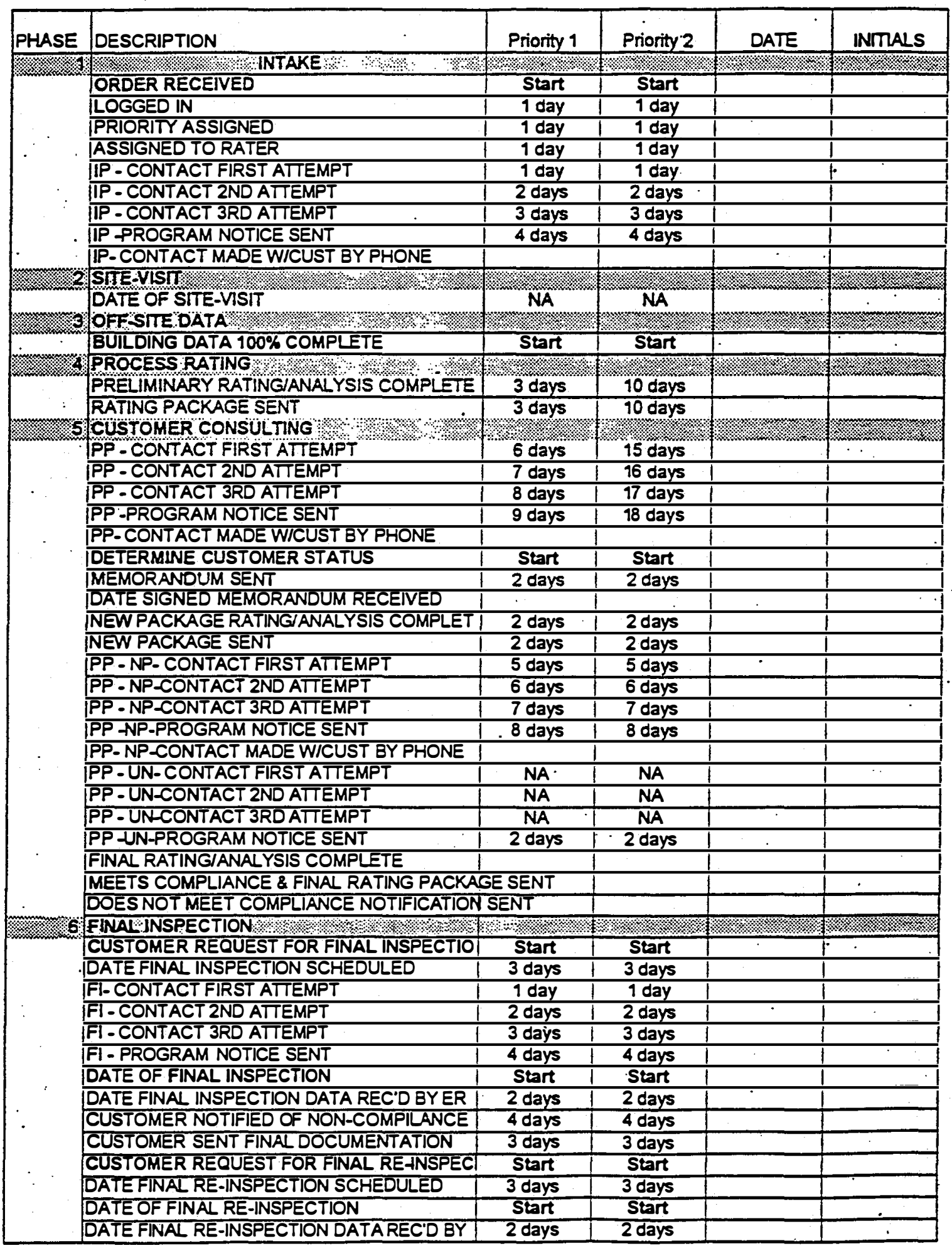


ERH serial \#

127 Pine Street

Date of inspection

Burlington, VT 05401

(802) 865-3926, FAX (802) 658-1643

Date rating needed

Mortgage closing

\section{VERMONT ENERGY CHECKLIST}

Used in completing the Energy Rated Homes Rating Sheet

Borrower:

Mailing Address:

Phone:

Homeowner or Builder (circle):

Mailing Address:

Phone:

\section{Property Address:}

Inspector:

Phone:

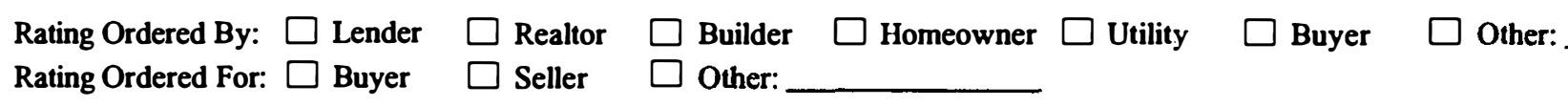

Development Name:

Builder:

Phone:

Realty Co.:

Realtor:

Phone:

Lender \& Branch:

Loan Officer:

Phone:

Sales Price:

Mortgage Type:

$\square$ Conventional

$\square$ VHFA

$\square$ VA $\square$ FHA

Do not know.

Other:

Primary Residence: $\square$ Yes $\square$ No

$\square$ Do not know

First Time Homeowner?

$\square$ Yes

$\square$ No

$\square$ Do not know

Completed from:

Plans (not built yet)

New construction (no previous occupant)

Previously Occupied (existing house)

\section{CHECK SOURCE OF INFORMATION FOR EACH SECTION WITH THE FOLLOWING CODES:

$$
I=\text { Inspected } \quad H=\text { Homeowner } \quad A=\text { Assumed/Non-Verified } \quad P=\text { Proposed/Plans }
$$

\section{HOUSE AND BASEMENT TYPE}

A. House Type:

Source of Info:

$\square \mathbf{I}$

$\square \mathbf{H}$

$\mathbf{A}$

$\square$ sing

Single Unit Detached

Duplex

Multi-Unit Attached (Condo)

1 story $\square 1.5$ story

$\square 2$ story

$\square 2.5$ story

2 story +1.5 story add-on

1.5 story +1 story add-on

2 story +1.5 story add-on

B. Floor/Basement Type:

Heated basement? $\square$ Yes $\square$ No $\%$ slab on grade

\% Unfinished basement

\% Walkout basement (heated floor area)

$\%$ Exposed floor (on piers or pilings)

C. Age of House:

Year Built

Year of Major Renovation

Source of Info:

$\square 2$ story +1 story add-on

Raised Ranch 
2. ENVELOPE EFFICIENCY LEVELS

Source of Info: $\square$ I $\square$ H $\square$ A $\square$ P

\begin{tabular}{|c|c|c|c|c|c|c|c|c|}
\hline $\begin{array}{l}\text { Building } \\
\text { Component }\end{array}$ & $\begin{array}{l}\text { Insulation } \\
\text { Location }\end{array}$ & $\begin{array}{l}\text { Insulation } \\
\text { Type }\end{array}$ & $\begin{array}{l}\text { Thickness } \\
\text { inches }\end{array}$ & $\begin{array}{l}\text { Net } \\
\text { sq. ft. }\end{array}$ & $\begin{array}{c}\mathbf{R} \\
\text { Value }\end{array}$ & Condition & $\begin{array}{c}\text { Info } \\
\text { Source }\end{array}$ & $\begin{array}{l}\text { Weighted } \\
\mathbf{R} \text { value }\end{array}$ \\
\hline \multirow[t]{4}{*}{ Ceiling } & Flat & & & & & & & \\
\hline & Slants & & & & & & & \\
\hline & Knee walls & & & & & & & \\
\hline & Knee wall floor & & & & & & & \\
\hline \multicolumn{2}{|c|}{ Attic/kneewall hatch } & & & & & & & good weatherstrip? Y N \\
\hline \multirow[t]{2}{*}{ Walls } & Exterior walls A & & & & & & & \\
\hline & Exterior walls B & & & & & & & \\
\hline Sill & Rim/Bands & & & & & & & vapor barrier? $\mathrm{Y}$ \\
\hline \multirow{2}{*}{$\begin{array}{l}\text { Foundation } \\
\text { above grade }\end{array}$} & Foundation A & & & & & & & \\
\hline & Foundation B & & & & & & & . \\
\hline \multirow{2}{*}{$\begin{array}{l}\text { Foundation } \\
\text { below grade }\end{array}$} & Foundation A & & & & & & & installed to $\_$tt. depth \\
\hline & Foundation B & & & & & & & installed to _ \\
\hline \multicolumn{2}{|c|}{ Exposed Floor } & & & & & ' & & \\
\hline \multicolumn{2}{|c|}{ Slab edge perimeter } & & & & & & & \multirow{2}{*}{$\begin{array}{l}\text { Provide sketch } \\
\text { on next page }\end{array}$} \\
\hline \multicolumn{2}{|c|}{ Underneath slab } & & & & & & & \\
\hline
\end{tabular}

\section{WINDOWS, SKYLIGHTS, AND DOORS $\quad$ Source of Info: $\square$ I $\square$ H $\square$ A $\square$ P}

\section{A. Window Characteristics}

\begin{tabular}{|c|c|c|c|c|c|c|c|c|c|c|c|}
\hline \multicolumn{12}{|c|}{ Primary Window Brand: } \\
\hline $\begin{array}{l}\text { Building } \\
\text { Component }\end{array}$ & $\begin{array}{l}\text { Window } \\
\text { Style }\end{array}$ & $\begin{array}{c}\text { Frame } \\
\text { Type }\end{array}$ & $\begin{array}{l}\text { " Layers } \\
\text { of glass }\end{array}$ & $\begin{array}{l}\text { Gap over } \\
3 / 8 * ?\end{array}$ & Low-E & $\begin{array}{l}\text { Argon } \\
\text { Gas? }\end{array}$ & $\begin{array}{c}\text { Window quilts or } \\
\text { Heat Mirror? }\end{array}$ & $\begin{array}{l}\text { Storm windows: } \\
\text { interior, ext, or none }\end{array}$ & $\begin{array}{l}\text { Storms } \\
\text { loose? }\end{array}$ & $\begin{array}{c}\text { U } \\
\text { Value }\end{array}$ & $\begin{array}{c}\mathbf{R} \\
\text { Value }\end{array}$ \\
\hline \multicolumn{12}{|l|}{ Window A } \\
\hline \multicolumn{12}{|l|}{ Window B } \\
\hline \multicolumn{12}{|l|}{ Skylights } \\
\hline Glass doors & & & & & & & & & & & \\
\hline
\end{tabular}

B. Glazing Area and Orientation (square $\mathrm{ft}$.)

\begin{tabular}{|c|c|c|c|c|c|}
\hline & South & East & West & North & Total \\
\hline \multicolumn{6}{|l|}{ Windows } \\
\hline \multicolumn{6}{|l|}{ Skylights } \\
\hline \multicolumn{6}{|c|}{ Patio/Sliders } \\
\hline \multicolumn{6}{|l|}{ Total } \\
\hline \multicolumn{6}{|c|}{ \% Shading } \\
\hline Adjusted & & & & & \\
\hline
\end{tabular}

Source of Info: $\square$ I $\square$ H $\square$ A $\square$ P

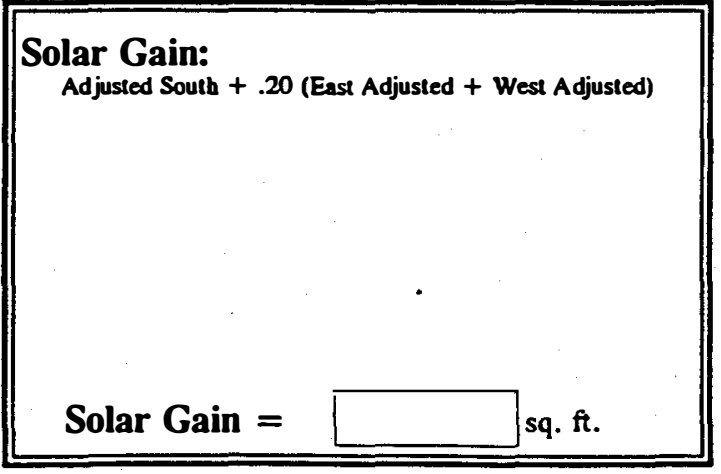

C. Door Area (total square feet) and R-value: (include glazing in "Glazing Area" above; record opaque area here) 


\section{FOOTPRINT AND ORIENTATION}

Source of Info:

$\mathbf{I}$

$\square \mathbf{H} \square \mathbf{A}$

1. Include a sketch of the footprint of the house with dimensions and orientation (i.e North arrow)

2. Show doors and windows with glazing sizes

3. If multi-unit attached, include on sketch ( $w /$ dimensions) which walls are common with other heated areas and which are exposed to outside or unheated space.

\begin{tabular}{|c|c|c|c|c|}
\hline & \multicolumn{2}{|c|}{ Area (sq. ft.) } & \multicolumn{2}{|c|}{ Volume (cu. ft.) } \\
\hline & heated & unheated & heated & unheated \\
\hline Basement & & & & \\
\hline Ist floor & & & & \\
\hline 2nd foor & & & & \\
\hline 3rd floor & & & & \\
\hline Total & & & & \\
\hline
\end{tabular}

Above grade wall area: sq. ft.

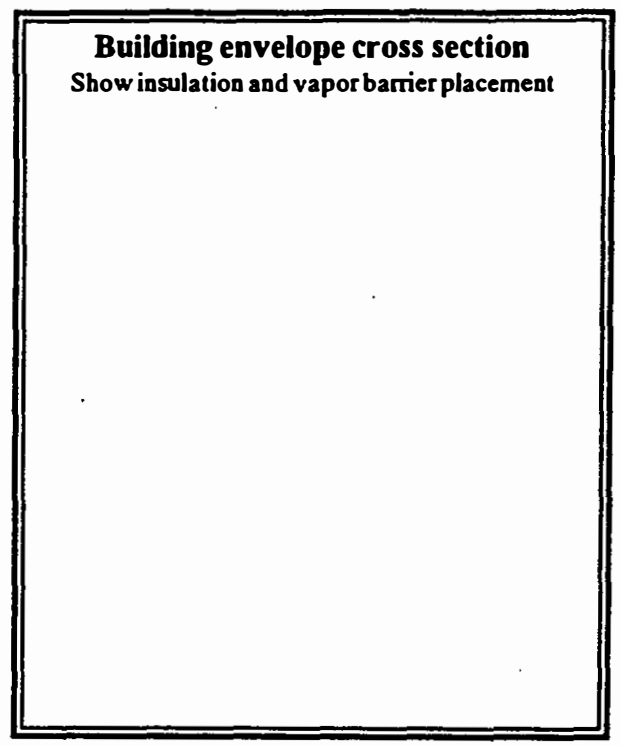

Slab detail

If slab is present, sketch with insulation locations 
5. SPACE HEATING EFFICIENCY

A. Unit Location: $\square$ Heated Space Unconditioned Space

Source of Info:

$\square$ I $\square \mathbf{H}$

$\square \mathbf{A}$ $\mathbf{P}$ Semi-conditioned Space (unheated basement)

Other

B. Fuel:

$\square$ Oil

Natural gas

$\square$ LP gas

Active solar system (attach description)

Kerosene

$\square$ Wood

Electric

C. System Type: $\square$ Furnace $\square$ Boiler

$\square$ Space heater (how many?

Other

Manufacturer:

Model:

Heat input (MBTUH):

Burner Manufacturer:

Nozzle size (gph):

Heat capacity output (MBTUH):

D. Features (check all that apply):
$\square$ Sealed combustion
$\square$ Power vented
$\square$ Atmospheric
$\square$ Mechanical Vent Damper

$\square$ Chimney vent

$\square$ Wall vent

$\square$ Electronic Ignition

$\square$ Pilot light

E. Furnace or Boiler distribution system (check all that apply):

$\square$

$\%$ Inside heated and conditioned space

$\%$ Inside unconditioned insulated space

$\%$ Inside unheated, uninsulated space

Furnace Ducts:

\begin{tabular}{|c|c|}
\hline$\square$ & $\%$ sealed \\
\hline & $\%$ not sealed \\
\hline & \% insulated $\mathrm{R}-{ }_{-}$in semi- \\
\hline
\end{tabular}

Boiler Hydronics:

$\square$ Glycol antifreeze in system

$\square$ Hot water pipes insulated

$\square$ Cold water pipes insulated

Modulating aquastat (Enertrol)

$\square$ Steam system
F. Electric system:
Baseboard
Furnace
Air source heat pump
Radiant panels
Electric storage
Ground source heat pump

G. Efficiency Calculations (completed in office):

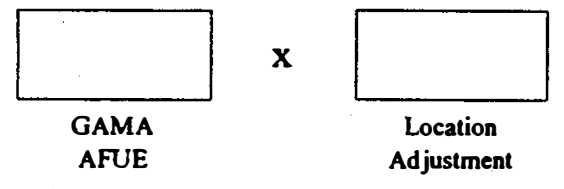

GAMA est. annual KWh:

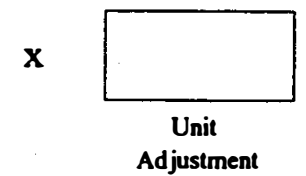

Heat pump

- 
6. WATER HEATING EFFICIENCY
A. Location:
Heated Space
Unconditioned Space
B. Fuel:
$\square$ Oil
$\square$ Electric
$\square$ Natural gas
$\square$ Solar assisted (attach description)
Semi-conditioned Space (unheated basement)
Other
C. System Type:
Kerosene
Wood
$\square$ Integrated with space heating system

\section{$\square$ Integrated with space heater as (select one):}
$\square$ tankless coil on boiler
$\square$ R-5 Indirect fired tank/intemal heat exchanger
$\square$ tankless coil plus separate summer hot water heater
$\square$ R-5 Indirect fired tank / extemal heat exchanger

Source of Info:
Manufacturer:

Model \# :

Energy factor (Ef):

$\square$ Rental unit from

\section{Features (check all that apply):}

$\square$ Sealed combustion

$\square$ Power vented

$\square$ Atmospheric

$\square$ Mechanical Vent Damper

$\square$ Electronic Ignition

$\square$ Pilot light

$\square$ Controlled (select one):

$\square$ off-peak ( for electric) or
Gallons:

Factory insulation RHeat input (MBTUH): for

$\$ /$ month

Age: Additional R-

Chimney vent

Wall vent

Cold pipes insulated off water heater: ft. Hot pipes insulated off water heater: ft.

Heat trap / check valve

Owner controlled timer clock or
Other:

E. Water Use (Faucet flow ratings)

Kitchen:__ gpm Bathroom sinks:

gpm Showers: gpm

F. Efficiency Calculations (completed in office):
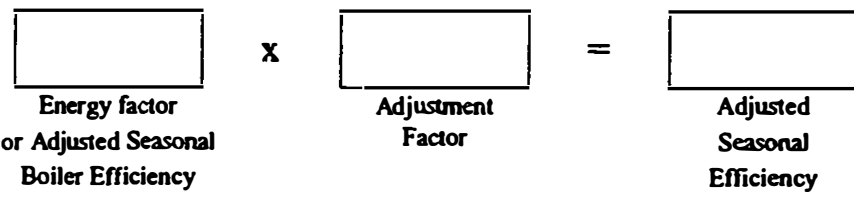

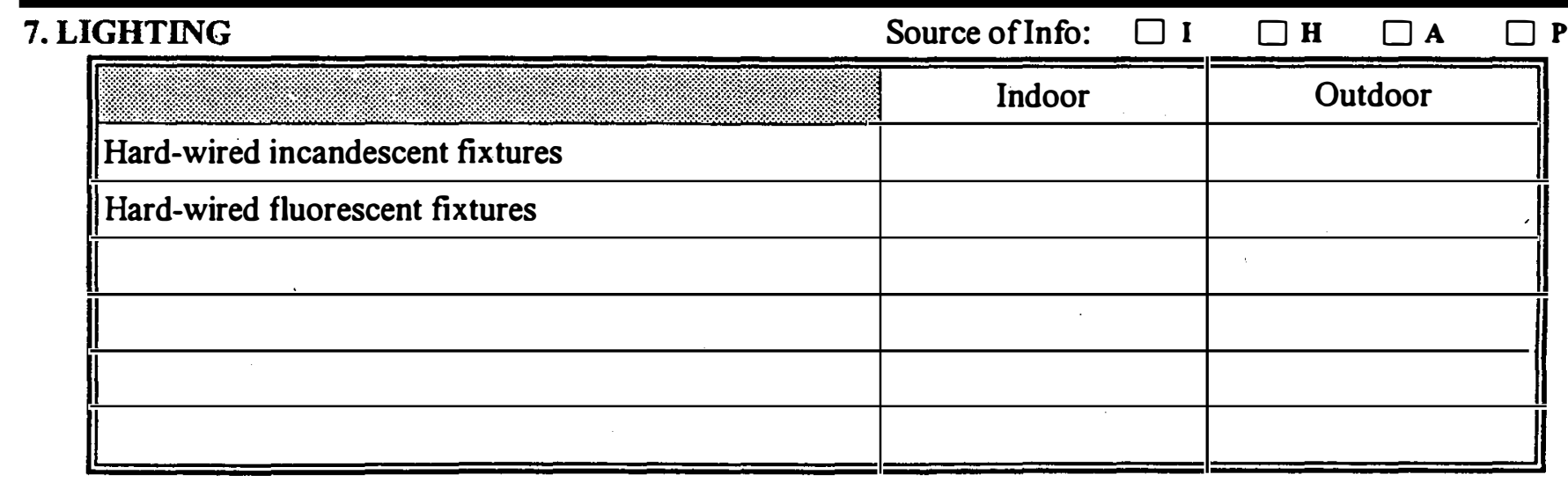

Eligible hard-wired fixture locations include kitchens, main bathrooms, hallways, entry and access ways, living rooms, front and primary exterior lights, Use your discretion for counting fixtures in laundry/utility rooms and elsewhere. Count the fixture if you believe that cost effective lighting options exist. 
8. BUILDING DETAILS Walls

\% stick frame
\% stress skin panel
$\%$ solid masonry
$\%$ log
\% back plastered
$\%$ other

\section{Foundation}

$\%$ concrete poured

$\%$ concrete block

$\%$ stone

$\%$ other
Source of Info:
I
$\square \mathbf{H} \square \mathbf{A}$
$\mathbf{A} \quad \square \mathbf{P}$
Roof / Attic
Other

\begin{tabular}{ll} 
\% open attic & $\square$ knob and tube wiring \\
\hline \% floored attic & $\square$ asbestos suspected \\
\hline \% cathedral & $\square$ heat tape on pipes
\end{tabular}

Type of access:

Type of ventilation (check appropriate):

$\square$ soffit $\square$ ridge $\square$ gable end
9. APPLIANCES AND OCCUPANT-RELATED

Cooking fuel:

Clothes dryer:

$\square$ Electric

Electric

Refrigerator: Make:

Freezer: Make:

Number of bedrooms:

Average winter building temp.:
Source of Info: $\square$ I $\square$ H $\square$ A $\square$ P

None $\square$ If electric, is there an unused gas hookup? Size: cu. ft. Age: Annual KWh Size: cu. ft. Age: Annual KWh

Number of occupants:

Months building unoccupied in past year:

\section{PHOTOGRAPHS}

Attach photographs of the following (subjects may be combined):

1. The hot water heater

2. The furnace/boiler showing the burner

3. The basement wall from the inside (incl. bulkhead entry, if present)

4. All sides of the house (may be 2 photos from opposite comers)
5. At the second floor of unfinished cape; door and top of stairs

6. A typical window from the inside

7. Any unusual conditions

\section{FUEL AND UTILITY INFORMATION}

Electric utility:

Oil supplier

LP/Natural gas supplier

Number of cords of wood burned last year

Other fuels (Kero, coal...) Type

Natural gas available on street? $\mathrm{Y} \quad \mathrm{N}$
On/Off peak rate?

Account \#

Account \#

Account \#

Wood cost per cord Quantity used last year Cost \$/unit

\section{HOMEOWNER FUEL INFORMATION RELEASE}

I authorize Energy Rated Homes of VT to receive information from my utility and fuel supplier(s) regarding actual energy consumption at my residence for the past two years.

\section{INSPECTOR'S SIGNATURE}

I have inspected this home and have determined that it contains the features and devices noted herein.

Disclaimer: Every efTort has been made to provide accurate information on this form. All entries made here represent the best professional judgement as to the house's energy features and system efficiencies, which were found to be in working condition on the day of the inspection. Any obvious def ects have been noted here. Neither this form nor any entries made on it constitute any warranty, express or implied, as to the condition or performance of energy features, the actual energy consumption, or the cost of energy for this house affer the date of the ERH inspection. 


\section{AIR SEALING CHARACTERISTICS}

Attic:

$\square$ Attic/kneewall hatches ( are / are not ) weatherstripped

$\square$ The (insulated to R-_ / uninsulated ) door at the top of the stairwell leading to an unfinished second floor ( is / is not ) weatherstripped and ( has / does not have ) a doorsweep

$\square$ Penetrations or bypasses through the top floor ceiling (are / are not) sealed

$\square$ Recessed light fixtures (are / are not) present in ceilings with insulation above them

$\square$ Whole house fan ( has / does not have ) cover, which has a (tight / loose ) seal

$\square$ Chimney frame ( sealed / not sealed )

Basement:

$\square$ Sill seal ( is / is not ) installed

$\square$ Bulkhead entry (with / without ) weatherstripping, ( with / without ) doorsweep and ( is / is not ) insulated to R-

$\square$ Sill penetrations ( are / are not) caulked or foamed

$\square$ Flue chases are ( sealed / not sealed )

Sidewalls:

$\square$ All penetrations (are / are not ) sealed with caulk or foam

$\square$ Vapor barrier ( is / is not ) present on the warm side of the wall

$\square$ All doors and windows (are / are not ) fully weatherstripped

$\square$ All door and window rough openings ( are / are not ) sealed with foam or gaskets

$\square$ Outlets and switches ( do / do not ) have gaskets

\section{AIR LEAKAGE}

\begin{tabular}{|l|c|c|c|c|c|}
\hline ODid f by & \multicolumn{6}{|c|}{ Stories above grade } \\
\hline Exposure & 1 & 1.5 & 2 & 2.5 & 3 \\
\hline Well shielded & 22.2 & 20.0 & 17.8 & 16.7 & 15.5 \\
\hline Normal & 18.5 & 16.7 & 14.8 & 13.9 & 13.0 \\
\hline Exposed & 16.7 & 15.0 & 13.3 & 12.5 & 11.7 \\
\hline
\end{tabular}

Blower door test results:

\begin{tabular}{|l|l|l|l|}
\hline Pressure & Flow & CFM & Comments \\
\hline & & & \\
\hline & & & \\
\hline & & & \\
\hline & & & \\
\hline & & & \\
\hline & & & \\
\hline
\end{tabular}

\section{MECHANICAL VENTILATION}

$\square$ Heat recovery ventilation system

$\square$ Exhaust-only" ventilation system (must include fan(s), automatic timer controls, and fresh air inlets)

$\square$ Ventilating fans present, but not set up as a system (standard on/off switch control)

No exhaust fans that vent to the outside

\begin{tabular}{|c|c|c|c|c|c|c|c|c|c|}
\hline & Location & Make & Model & Sones & CFM & Watts & Control type & Control location & Ducted out? \\
\hline \multicolumn{10}{|c|}{ Exahust Fan \#1 } \\
\hline \multicolumn{10}{|c|}{ Exhaust Fan $\# 2$} \\
\hline \multicolumn{10}{|c|}{ Exhaust Fan \#3 } \\
\hline \multicolumn{10}{|c|}{ Exhaust Fan \#4 } \\
\hline \multicolumn{10}{|l|}{ Range Hood } \\
\hline \multicolumn{10}{|l|}{ Air Inlet } \\
\hline \multicolumn{10}{|l|}{ Air Inlet $\# 2$} \\
\hline \multicolumn{10}{|l|}{ Air Inlet $\$ 3$} \\
\hline Air Inlet $/ 4$ & & & & & & & & & \\
\hline
\end{tabular}

Source of Info: $\quad \square$ I $\quad \square$ H $\quad \square$ A $\quad \square$ P (cfmSO)(60) / (oet volume) / ("divide by" $n$ ) avg. aat. AC/HR

Note air leakage areas:

Blower door model type:
$\square$ Open fan
4 holes plugged
$\square$ Low flow plate
$\square$ Indoor Temp.
$\square$ Ring A
$\square$ Ring B
$\square$ Outdoor Temp. Other

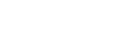

\section{Source of Info: $\square$ I $\square$ H $\square$ A $\square$ P}




\section{ERH RATING ORDER AND BILLING FORM VERMONT GAS SYSTEMS NEW CONSTRUCTION PROGRAM}

ERH Rating Information:

Rating Number

Closing Date

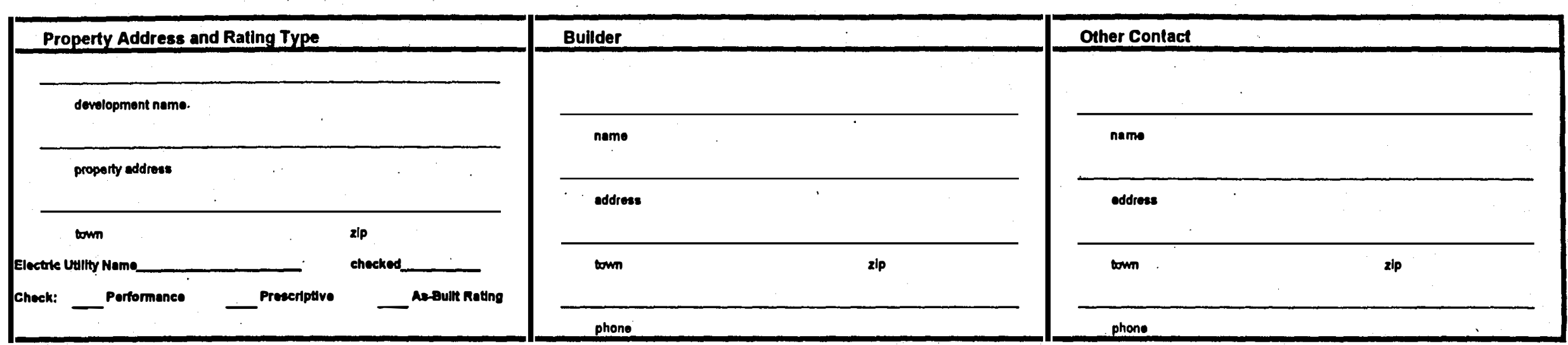

Notes:

\begin{tabular}{|c|c|c|c|c|c|c|c|c|c|c|c|c|c|c|c|c|c|c|c|}
\hline \multirow{3}{*}{$\begin{array}{l}\text { Involce Number } \\
\text { Involce Number } \\
\text { Involce Number }\end{array}$} & \multicolumn{10}{|c|}{ PERFORMANCE } & \multicolumn{9}{|c|}{ PRESCRIPTIVE } \\
\hline & \multicolumn{4}{|c|}{$\begin{array}{l}\text { Por Unk wten Singlo Trip } \\
\text { for Inspoction }\end{array}$} & & \multicolumn{5}{|c|}{$\begin{array}{l}\text { Por Unit for } 2 \text { or mora untits } \\
\text { Inspected simultancouualy }\end{array}$} & \multicolumn{5}{|c|}{$\begin{array}{l}\text { Por Unk witer Singlo Thip } \\
\text { for Inspecttion }\end{array}$} & \multicolumn{4}{|c|}{ 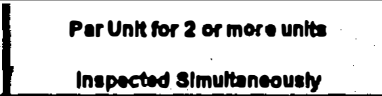 } \\
\hline & Task & Task & & Involce & & Task & Task & & Involce & & Task & Task & & Involce & & Task & Task & Involce & \\
\hline TASKS & Price & Date & Init. & Date & Init | & Price & Date & Init.| & Date & Init & Price & Date & Innt.| & Date & |nitt | & Price & Date & Inth. Date & Intt \\
\hline Technical Assistance/Bullder Energy Hol-Llne [1] & spoctal 100 & . & & & & NA * & & & & & $\$ 25$ & & & & & NA & & & \\
\hline Plan Revlew, Recommendattons \& Rating(s) for Model Unit & \$170 & & & & & INA & & & & & NA & & & & & NA & & & \\
\hline Plan Revlew \& Rating(s) (When needed) for Dupllcate Unit & \$\$30 & & & & & INA & & & & & NA & & & & & NA & & & \\
\hline Interim Inspectlon \& Bullder Feedback & $\$ 75$ & & & & & $\$ 50$ & & & & & $\$ \$ 75$ & & & & & $\$ 50$ & & & \\
\hline FInal SIte Inspection \& ERH Checkllst Completion & $\$ 100$ & & & & & \$\$75 & & & & & $\$ 100$ & & & & & $\$ 75$ & & & \\
\hline Inspectlon \& Verification of VGS Prescriptive LIst & NA & & & & & INA & & & & & $\$ 100$ & & & & & $\$ 75$ & & & \\
\hline SIte Inspectlon for Major Rehablittation & $\$ 70$ & & & & & NA & & & & & $\$ 70$ & & & & & NA & & & \\
\hline Electric Measures Verification (assuming already on silte) & $\$ 25$ & & & & & $\$ 25$ & & & & & $\$ 25$ & & & & & $\$ 25$ & & & \\
\hline Rating Only (from completed Energy Checkllst) & $\$ 100$ & & & & & $\$ 100$ & & & & & $\$ 100$ & & & & & $\$ 100$ & & & \\
\hline New Construction As-Is House - Inspection \& Rating [2] & $\$ 200$ & & & & & $\$ 175$ & & & & & $\$ 200$ & . & & & & $\$ 175$ & & & \\
\hline Re-Inspectlon (W/ approval of M. Russom) & s50mr & & & & & $\$ 50 \mathrm{mr}$ & & & & & $\$ 50 / \mathrm{hr}$ & & & & & $550 / \mathrm{hr}$ & & & \\
\hline No Show (w/ approval of M. Russom) & $\$ 50$ & & & & & NA & & & & & $\$ 50$ & & & & & NA & & & \\
\hline
\end{tabular}

Notes: [1] Prescriptlve Path Technical Assistance/Bullder Energy Hot-Line for program partlcipants could be priced hourly or at \$25 per partlcipating untt.

(2) If the existing house meets FOUR STARS PLUS criteria at first Inspectlon the charge is as ilsted, If not, regular pricing applles. 


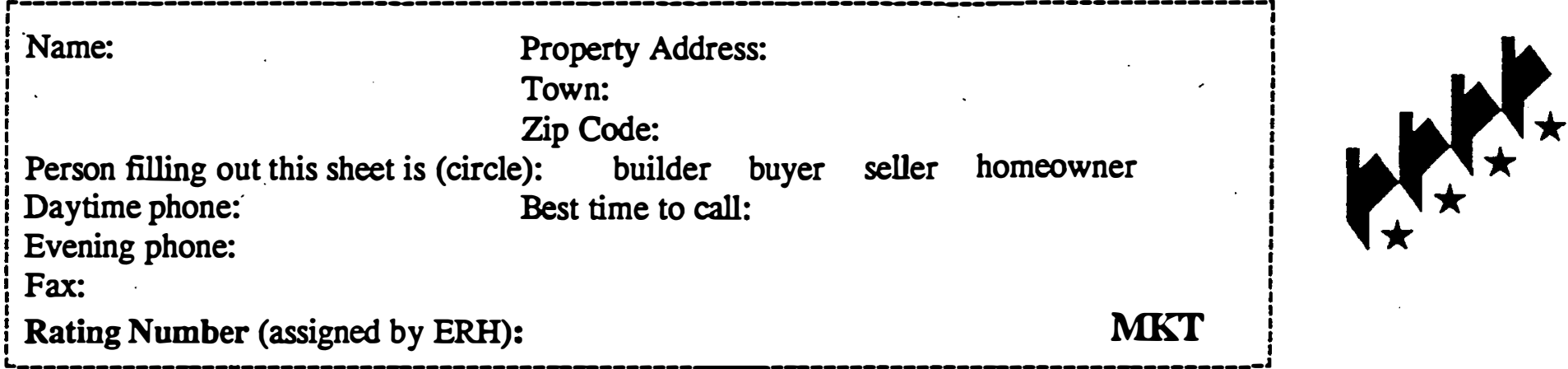

\section{Information Needed to Begin the New House Rating Process}

\section{ERH WILL BEGIN THE RATING PROCESS WHEN WE RECEIVE THIS INFORMATION!}

It is best to order an Energy Rating for a new house as early in the planning process as possible so that recommendations can be incorporated into the final plans. We need all of the information below to begin the Energy Rating process. Please assemble the information and mail, fax or call it in to an ERH Energy Specialist to start work on the "Proposed from Plans" Energy Rating.

1. House plans including dimesions and elevations (a sketch is fine; blueprints not necessary) with:

a. Window and door placement and sizes

b. Orientation of the house (which side faces south for determining solar gain)

c. Tree or other shading of the south, east and west sides that will occur during the winter (to determine solar gain):

d. How many bedrooms?

2. Specifications listing insulation type (cellulose, fiberglass, etc.), thickness (inches) for:

a. Ceiling flats: $\mathbf{R}$ inches of insulation type:

Ceiling slopes: $\mathrm{R}-$ inches of insulation type:

Sloped insulation runs from: collar ties to eaves or down kneewall and across floor

b. Walls: $\mathrm{R}-$ inches of insulation type:

c. Exposed floors: Rinches of Location (over garage, overhangs, bay windows, etc):

d. Foundation (include how far down below grade): Insulation type: $\mathrm{R}$ - _ _ inches thick, insulated to $\_$ft. below grade. Height of foundation above grade: ft. Depth below grade: ft. and glazing types: (i.e. double glazed,

e. Window brand: low-E, argon, etc.), and is the space between panes greater than $3 / 8$ inch? $\mathbf{Y} N$ Is the window frame wood, metal, or vinyl?

f. Is there a vapor barrier in the wall? $\mathbf{Y} \mathbf{N}$ In the ceiling? $\mathbf{Y} \mathbf{N}$

3. Heating system: $\square$ Boiler $\square$ Hot air Furnace a. Make: Model number:

b. Location: Fuel:

c. Is there a ducted combustion air supply? $\mathbf{Y} \mathbf{N}$ Is unit power vented? $\mathbf{Y} \mathbf{N}$

d. Is the basement intentionally heated (i.e. zone of heat, thermostat present)? $\mathbf{Y} \mathbf{N}$ Are furnace ducts being sealed? $\mathbf{Y} \mathbf{N}$ Are ducts insulated? $\mathbf{Y} \mathbf{N}$ If so, to $\mathrm{R}-$ 
4. \# of Heating zones:

\# of automatic set-back thermostats:

5. Is there a (circle, if present) wood stove or fireplace? $\mathbf{Y} \mathbf{N}$

If so, is there a ducted combustion air supply? $\mathbf{Y}$ Tight-sealing doors for fireplace? $\mathbf{Y} N$

6. Domestic hot water system:

a. Make:

Model number:

b. Location:

(i.e. basement, 1st floor, etc.)

c. Is there a ducted combustion air supply? $\mathbf{Y} \quad \mathbf{N}$ Is unit power vented? $\mathbf{Y} \quad \mathbf{N}$

d. Is it a separate storage tank integrated with the boiler? $\mathbf{Y} \mathbf{N}$

Is there pipe insulation? $\mathbf{Y}$ Tank insulation wrap? $\mathbf{Y}$ If so, to $\mathrm{R}-$

Are there low flow shower and faucet heads? $\mathbf{Y} \mathbf{N}$

7. a. Range/stove fuel:

b. Clothes dryer: Is there one? $\mathbf{Y}$ N Fuel planned:

c. Washing machine (circle one): horizontal axis or standard

d. Dishwasher: Is there one? $\mathbf{Y}$ N If so, Make:

Fuel:

8. a. Refrigerator: Size: __u. ft, Make:

Estimated \$/year from yellow Energy Label (if avail.):

b. Separate freezer: Size: cu. ft, Make:

Estimated \$/year from yellow Energy Label (if avail.):

Model number:

Model number:

9. Hard-wired (permanent) light fixtures:

Number indoor incandescent fixtures:

Number outdoor incandescent fixtures:

Number indoor fluorescent fixtures:

How many outdoor lights will have motion sensors?

10. Utility company: Electric Utility:

Is the house on Vermont Gas Systems pipeline? $\mathbf{Y} \cdot \mathbf{N}$

Will an electric hot water heater be on a controlled time of day electric rate? $Y \mathbf{N}$

11. Mechanical Ventilation: must be ducted outside
a. \# of bath fans:
Make:
b. Kitchen range hood exhaust fan vented ouside? Y
Model \#:
c. Number of dedicated fresh air inlets: Locations:
d. Automatic ventilation controls: (i.e. 24 hour timer, Airetrak, etc.)
e. Heat recovery ventilator present? $\mathbf{Y}$ If so, Make: Model:

Model number:

IF YOU HAVE ANY QUESTIONS ABOUT PROVIDING THIS INFORMATION, OR WANT TO GIVE US THE INFORMATION OVER THE PHONE, PLEASE CALL US AT:

$$
\begin{aligned}
& \text { 1-(800)-639-6069 (outside Chittenden County) or } 865-3926 \\
& \text { or fax these completed pages to us at (802)-658-1643 }
\end{aligned}
$$




\section{Chapter 5}

\section{Process Evaluation Case Study: \\ Arkansas Home Energy Rating Systems/Energy Efficiency \\ Financing}

Roberta W. Walsh, Colchester, VT 05446 


\section{Acknowledgments}

The author extends sincere appreciation to all those whose cooperation made it possible to assemble the wealth of material required for this case study. At Energy Rated Homes of Arkansas, the assistance of Carol Cales, Executive Director and Jeremiah Gardner, Senior Process Engineer, were invaluable beginning with the initial interviews and continuing throughout the process.

At the Arkansas Energy Office, Susan Recken, Program Administrator, provided additional facts and data, often on short notice, but always promptly and enthusiastically.

In addition, funding from the National Renewable Energy Laboratory and the helpful comments and overall guidance of Barbara Farhar, Senior Social Scientist, were critical to the successful completion of this case study. 


\section{Executive Summary}

This report addresses the evolution, status, and future direction of efforts in Arkansas to promote the financing of residential energy efficiency. It is based on information obtained from July through December 1995 from interviews with and information provided by key personnel in the three organizations having a major role in instituting home energy rating systems/energy efficiency financing (HERS/EEF) in the state: Energy Rated Homes of Arkansas (ERH-AR); the Arkansas Energy Office (AEO), and Little Rock Field Office of the U.S. Department of Housing and Urban Development, Single Family Housing Division (administrator of the FHA pilot EEM program in Arkansas).

The Arkansas Energy Office formulated the concept of a third party, nomprofit organization to rate residential energy efficiency. Energy Rated Homes of Arkansas was established in 1986 to be this third party; it was a part of Energy Rated Homes of America organizationally until January 1994. The Arkansas Energy Office maintains a close connection with Energy Rated Homes of Arkansas (although it no longer helps fund it) through requirements of Act 750, the enabling legislation for the establishment of an energy mortgage program in Arkansas.

The market potential for Energy Efficient Financing (EEF) far exceeds that which is currently being tapped. The AEO and ERH-AR are trying to expand the pool of people aware of energy efficiency financing by (1) educating lenders, real estate salespersons, trade association members, and appraisers about HERS/EEF; (2) educating the construction trades about energy efficiency; (3) obtaining consistent funding for the rating organization; and (4) coordinating with FHA based on experience in the pilot program.

Alliances with the U.S. Department of Energy provides some funds for education; partners such as the FHA Field Office, Entergy (a large utility company), and the Arkansas Mortgage Bankers Association have provided some other funds. Nonetheless, erratic funding limits the effectiveness of ERH-AR.

Technical training is shared among the three major organizations. ERH-AR has trained 200 raters and 95 builders/contractors (1993-95); the FHA Field Office has trained 103 lenders (1994-95); and the AEO has coordinated training of 971 real estate professionals (1993-95).

Since 1988 ERH-AR has completed 940 ratings. It has developed new partnerships and enhanced existing ones with utilities, the lending industry, and other states. Data is now being collected on conduct of ratings; in the future data collection will evaluate how effectively HERS/EEF reduces energy consumption. 


\section{Contents}

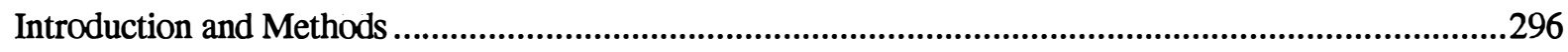

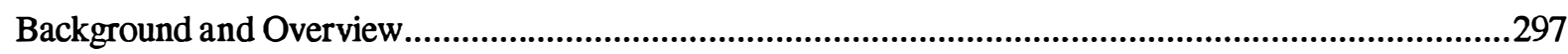

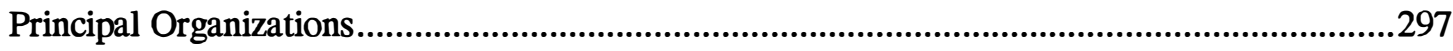

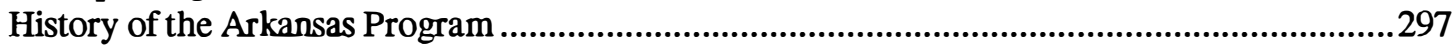

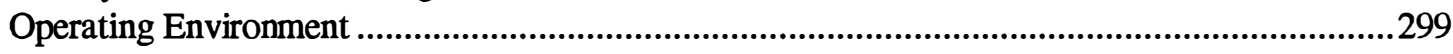

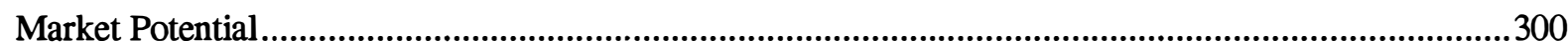

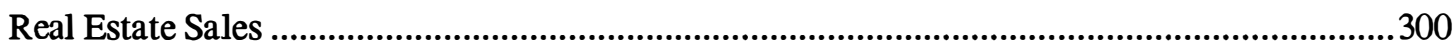

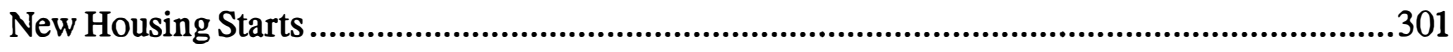

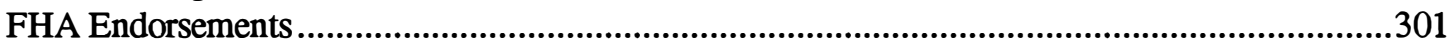

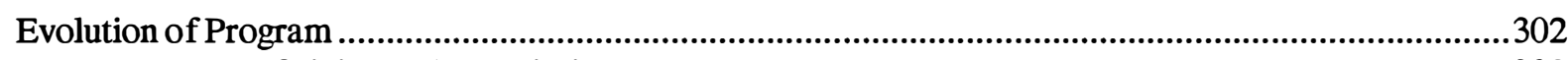

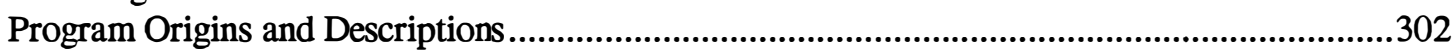

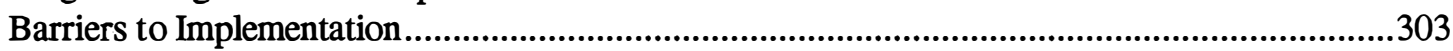

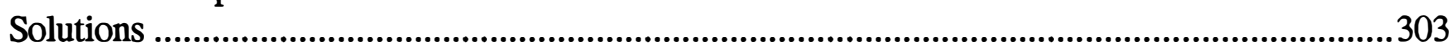

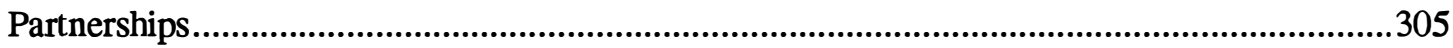

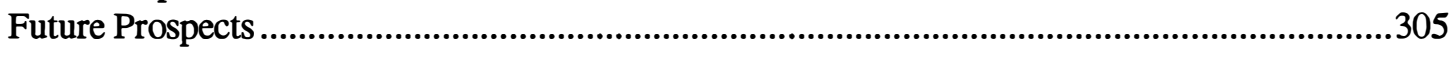

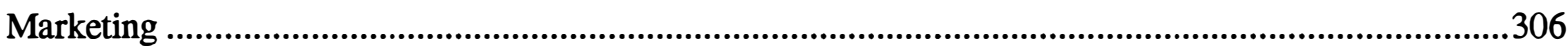

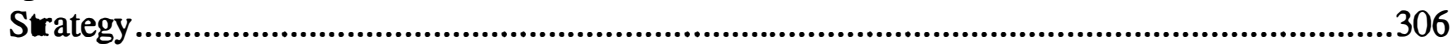

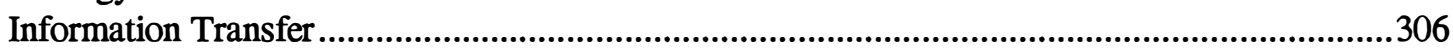

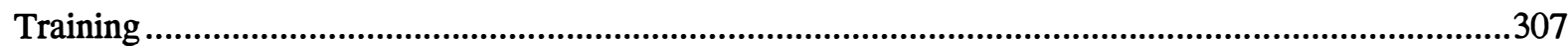

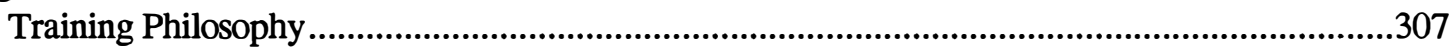

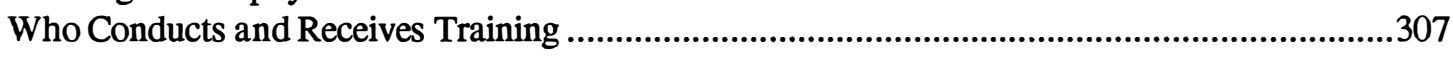

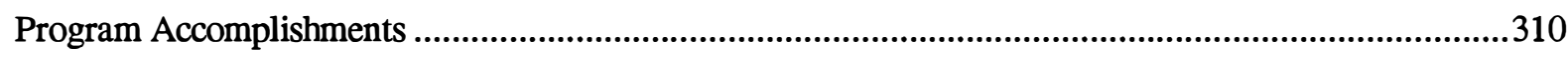

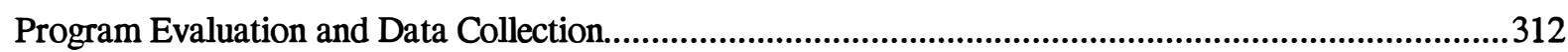

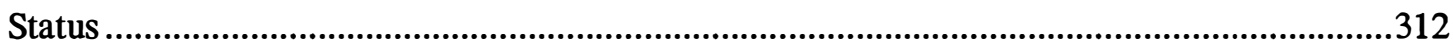

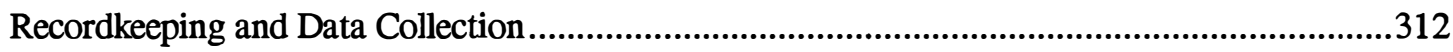

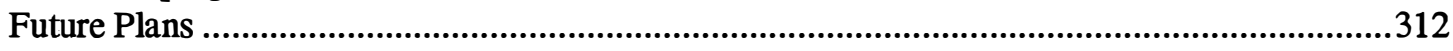

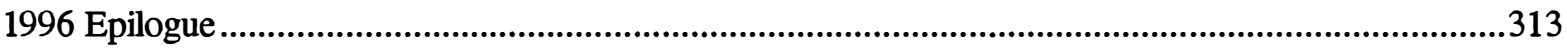




\section{Tables}

Table 5-1. Chronology of Events, Arkansas HERS/EEF ...............................................................298

Table 5-2. Arkansas Real Estate Units Sold by Quarter, 1994 and 1995 .............................................300

Table 5-3. FHA Endorsements in Arkansas, FY 1992-1995 .............................................................301

Table 5-4. Funding and Funding Sources, by Calendar Year, of Energy Rated Homes of Arkansas ........304

Table 5-5. Raters Certified by Energy Rated Homes of Arkansas ...........................................................308

Table 5-6. Arkansas Rating and Energy Efficiency Financing Activity 1992-1995 .................................310

\section{Figure}

Figure 5-1. ERH Arkansas Ratings by Year, 1988-1995 …...............................................................310

\section{Appendixes}

Appendix 5-A. Arkansas Process Evaluation Data ...............................................................................315

Part 1. Organization Contacts and Descriptions........................................................................315

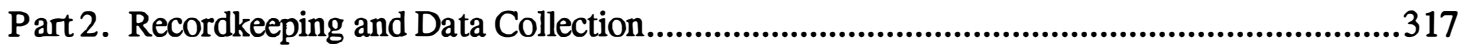

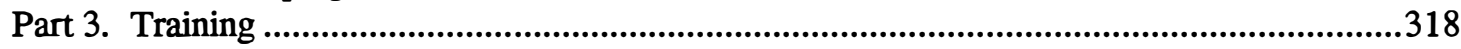

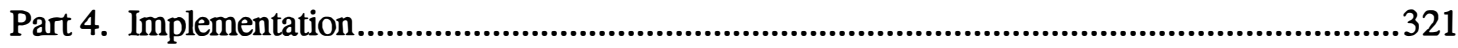

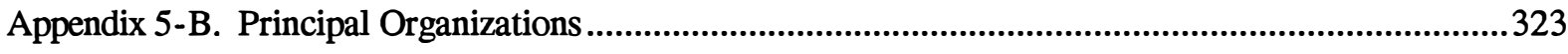

Appendix 5-C. Barriers to Implementation: EEM Pilot Program Annual Report (Draft).......................324

Appendix 5-D. Forms Used in Record Keeping ...................................................................................327 


\section{Introduction and Methods}

This report consists of findings from a field study conducted from July 1995 through mid-March 1996 concerning the evolution and status of efforts in Arkansas to promote the financing of residential energy efficiency. Topics addressed in the study are based on an outline employed for the same purpose in similar assessments being conducted in Alaska, California, Colorado, Vermont, and Virginia-all states which have promoted residential energy efficiency financing. Selected information appears in condensed form in Appendix 5-A, Arkansas Process Evaluation Data.

People in three organizations having a major role in the implementation of home energy rating systems/energy efficiency financing (HERS/EEF) in Arkansas were interviewed; they are identified in Appendix 5-A. Although this case study is as comprehensive as possible, a more thorough examination of the evolution, status, and future direction of HERS/EEMs in Arkansas would require information from a broader range of stakeholders, such as financial representatives, the real estate sales people, and consumers, than is possible in the current effort. 


\section{Background and Overview}

\section{Principal Organizations}

Three principal organizations implement HERS/EEMs in Arkansas: Energy Rated Homes of Arkansas; Arkansas Energy Office; and U.S. Department of Housing and Urban Development, Region VI Federal Housing Administration (FHA) Field Office in Little Rock, Arkansas. Their overall roles and responsibilities are described below. Key persomnel and contact information appear in Appendix 5-B.

- Energy Rated Homes of Arlansas (ERH-AR). ERH-AR administers the statewide rating system as a 501(c)(3) nouprofit orgarization HERS provider, for the purpose of assisting the Arkansas Energy Office in its energy ectucation and efficiency programs.

- Arkansas Energy Office (AEO). The AEO, located within the Arkansas Incustrial Development Commission (AIDC), was given statutory authority in 1993 from the Arkansas General Assembly (state legislature) to establish a pilot program involving energy efficient mortgages. As described below, the AEO's association with energy ratings pre-dates this legislation

- U.S. Department of Housing and Urban Development, Region VI (HUD). HUD, through its Single Family Housing Division, endorses Federal Housing Administration energy efficient mortgages in Sects. 203(h) and 203(k) loans, through the pilot program established by the Energy Policy Act and Housing and Community Development Act, both passed in 1992.

\section{History of the Arkansas Program}

The evolution of HERS/EEF in Arkansas is closely related to the national effort, inasmuch as Energy Rated Homes of America (ERHA) was launched in that state. The following description is intended as a summation from the state's perspective, irrespective of the national focus inherent in Arkansas. Table 5-1 sets forth a chronology of major events from the program's inception to early 1996.

The recognition of a need in Arkansas for a programmatic approach to promoting residential energy efficiency through a financing mechanism dates back to 1979 with the adoption of an energy code for residential construction. At that time the AEO found that utilities, under the federally mandated Residential Conservation Service (RCS) ${ }^{1}$, were not aggressively pursuing financing options for homeowners. At the same time, the state's housing industry was looking to the AEO for leadership in promoting energy-efficient construction. Because of insufficient stafing to begin a program of its own, and a reluctance to rely exclusively on the private sector to institute a financing program, the AEO sought a third-party approach to solving the problem.

\footnotetext{
${ }^{1}$ Authorized under the National Energy Conservation Policy Act (NEPCA) of 1978 (PL 95-619).
} 
Table 5-1. Chronology of Events, Arkansas HERS/EEF

\begin{tabular}{|l|l|}
\hline Date & Event \\
\hline 1979 & $\begin{array}{l}\text { Adoption of energy code for residential construction; recognition by Arkansas Energy Office } \\
\text { (AEO) of the need for a financing mechanism for homeowners. }\end{array}$ \\
\hline 1985 & $\begin{array}{l}\text { Recognition by the AEO of potential for Western Resources Institute (WRI) rating system } \\
\text { to be applied to a state program. }\end{array}$ \\
\hline 1986 & $\begin{array}{l}\text { Energy Rated Homes of Arkansas (ERH-AR) established as nonprofit HERS provider to } \\
\text { conduct ratings. Energy Rated Homes of America (ERHA) established in Arkansas to } \\
\text { promote the formation of state rating programs throughout the U.S.; commingled with ERH- } \\
\text { AR as an organization. Ron Hughes served as Director of both organizations. }\end{array}$ \\
\hline 1989 & AEO fully subsidizes cost to ERH-AR of ratings . \\
\hline 1990 & Bill proposed by Sen. Dale Bumpers to provide federal funding to ERHA. \\
\hline $1991-92$ & ERHA participated in National Collaborative on HERS/EEMs. \\
\hline $3 / 26 / 93$ & $\begin{array}{l}\text { Enactment of Act 750, charging AEO to develop and implement a pilot program to promote } \\
\text { the use of energy efficient mortgages. }\end{array}$ \\
\hline $5 / 24 / 93$ & $\begin{array}{l}\text { Arkansas chosen as one of five pilot states to participate in pilot program authorized by } \\
\text { Energy Policy Act of 1992 (P.L. 102-488). }\end{array}$ \\
\hline $1 / 1 / 94$ & ERH-AR no longer commingled with ERHA. Carol Cales named Executive Director. \\
\hline
\end{tabular}

An opportunity presented itself during the 1985 All-States Meeting of energy offices administering programs as part of the Energy Extension Service, held in Phoenix, Arizona, where HERS occupied a place on the agenda. Jim Blakely, Director of the AEO at that time, became convinced that a rating system developed by the Western Resources Institute (WRI) held promise for application to a state program. Accordingly, the AEO adopted an approach to developing a HERS program through a nonprofit contractor. Energy Rated Homes of Arkansas (ERH-AR) ultimately became that contractor, incorporating the WRI system as the basis for conducting ratings. Energy Rated Homes of America was also established in 1986 to promote the formation of state ratings organizations nationwide and was commingled with ERHA. Ron Hughes served as Director of both ERH-AR and ERHA.

In 1989 the AEO subsidized the cost to ERH-AR of ratings, enabling ratings to be available at no charge. Later, the AEO, along with other groups nationally, recognized that a rating system by itself would be insufficient to affect the market for improving energy efficiency in residences, and that a companion financing strategy was necessary. Because of the interconnectodness of the mortgage industry and the increasing role of the secondary market, including its reluctance to purchase EEMs from primary lenders, substantial resources were devoted toward soliciting other states' participation in HERS/EEMs programs in an effort to develop the critical mass of interest that would be necessary for federal action. Indeed, federal funding to assist ERHA was proposed in 1990 in a bill sponsored by Sen. Dale Bumpers (D-AR). However, the bill was not supported by the U.S. Department of Energy (DOE) and was never enacted.

In 1991 and 1992, Energy Rated Homes of Arkansas. was represented in one of the Technical Committees of the National Collaborative on HERS/EEMs convened by the National Renewable Energy Laboratory (NREL) for DOE .

A significant milestone occurred in March 1993 with the passage of Act 750 by the 79th General Assembly of the State of Arkansas, titled An Act to Require the Arkansas Office of Energy to Establish a Pilot Program to Evaluate and Implement the Energy Efficient Mortgage; and for Other Purposes. The statute charged the AEO 
"to increase the energy efficiency and reduce the energy costs of existing residential structures and increase the number of Arkansans who qualify for residential home loans by encouraging the installation of cost-effective improvements in existing residential buildings (Sect. 1)."

Among other objectives, the intent of the law was to help Arkansas meet the requirements to qualify as a pilot state consistent with the federal Energy Policy Act and the Housing and Community Development Act, both passed in 1992. Subsequently, in May of that same year, Arkansas was identified as one of the five pilot states to participate in the Federal Housing Administration's Energy Efficient Mortgage Pilot Program.

In January 1994, ERHA became a separate organization headed by Ron Hughes; Carol Cales became Executive Director of ERH-AR. ERH-AR faced the challenge of participating as a pilot state while at the same time forming its own identity with new leadership. Issues regarding credibility had to be addressed; for example, FHA Field Office staff were not convinced that ERHA was in fact a newly organized entity. Thus, forging effective working relationships was difficult, but duning 1995 these problems were overcome.

\section{Operating Environment}

Primary support for HERS/EEMs lies within the state's economic development agency (AIDC). As a part of the governor's cabinet-level Office of Established Industries, AIDC shares equal roles with the community development and international trade missions of the state. State government sees quality in housing and the environment as an important factor in attracting industry to Arkansas, and HERS/EEF as a vehicle toward achieving this goal.

The AEO regards its function as a facilitator to advocate, assist, and promote HERS/EEMs, consistent with its status as an arm of the state's utility regulatory body, the Arkansas Public Service Commission (PSC). The two agencies view their relationship as mutually supportive; however, increased competition facing utilities has led both agencies to form partnerships with other organizations. The AEO, as a state agency, has capitalized on its credibility to approach other state agencies, the real estate profession, and lenders for support. The AEO believes that EEMs are "sold" through marketing, networking, and promotional activities.

The AEO's past close alignment with ERH-AR has led some prospective partners to believe that AEO supports a monopoly entity in the rating industry within Arkansas. Although ERH-AR has indeed been the only rating organization in the state, competition does exist within ERH-AR. Independent contractors, rather than direct employees of ERH-AR, conduct the ratings. Moreover, no institutional barriers to entry exist; any organization may adopt guidelines for HERS, introducing more competition among rating organizations. 


\section{Market Potential}

Arkansas is of interest not only as one of the five states that participated in the Federal Housing Administration's Energy Efficient Mortgage Pilot Program, but also as a state which-like another pilot state, Vermont-has largely rural characteristics compared to two other pilot states, California and Virginia. (The fifth pilot state, Alaska, has many unique characteristics in addition to being rural.)

Certain factors are useful indicators of the market potential for financing energy efficiency. For example, the age and quality of the existing housing stock serve as an indicator of the potential for energy efficiency financing through home improvement loans and second mortgages; the market conditions for financing instruments indicates support for the writing of such loans and mortgages by financial institutions.

Simpler indicators of overall activity in the primary home mortgage market are real estate sales transactions of existing (including new) dwellings, and new housing starts. These indicators represent different perspectives on market potential for energy efficiency financing in that sales transactions indicate past activity, whereas housing starts point to future sales transactions. However, focus on the market as a whole does not reflect the level of activity in the pilot FHA program or VA program, which attract only a segment of borrowers due to eligibility requirements for participation.

\section{Real Estate Sales}

Real estate sales transactions in Arkansas totaled 209,000 in 1994 and 220,700 in 1995, according to the National Association of Realtors (NAR) Research Department. ${ }^{2}$ Quarterly data are set forth in Table 5-2. The data contains some limitations. Because these transactions are reported by the real estate professionals' trade association, they include only those sales made by member organizations, and they include apartments, co-ops, and condominiums as well as single and multifamily units. No geographic breakdown is available.

Table 5-2. Arkansas Real Estate Units Sold by Quarter, 1994 and 1995

\begin{tabular}{|l|r|c|}
\hline Quarter & \multicolumn{2}{|c|}{ Number (000) } \\
& 1994 & $\mathbf{1 9 9 5}$ \\
\hline First & 52.9 & 48.7 \\
\hline Second & 52.9 & 52.9 \\
\hline Third & 52.9 & 61.4 \\
\hline Fourth & 50.3 & 57.7 \\
\hline Totals & $\mathbf{2 0 9 . 0}$ & $\mathbf{2 2 0 . 7}$ \\
\hline
\end{tabular}

Source: Constructed by the author using data from the Arkansas Energy Office

\footnotetext{
${ }^{2}$ Telephone conversations with Mr. Ted Wright, February 1 and March 7, 1996.
} 


\section{New Housing Starts}

New housing starts data, collected by the Bureau of Census, are based on construction permits obtained by builders from incorporated local jurisdictions. The Arkansas Home Builders Association (AHBA) adds data from unincorporated areas in two of the state's fastest growing counties (omitting others that are unincorporated). In 1994, 12,118 dwelling units were issued permits. (Data made available by the Arkansas Energy Office.)

Notwithstanding the limitations of these data, they suggest that approximately 200,000 real estate transfers annually represent a potential market for energy efficiency financing, about $6 \%$ of which are new construction. Whether sales volume represents the true market potential of EEF, however, requires a focused examination of consumer demand for various EEF products.

\section{FHA Endorsements}

FHA endorsements represent the market potential of EEMs under the FHA program. During the past four years (Table 5-3) a high of 12,465 endorsements in FY 1994 and a low of 7,394 in FY 1995 were reported in Arkansas. ${ }^{3}$ As is the case with overall market data, factors affecting consumer demand for EEMs should be taken into account in basing conclusions about actual market potential on these data.

Table 5-3. FHA Endorsements in Arkansas, FY 1992-1995

\begin{tabular}{|c|r|}
\hline Year & Endorsements \\
\hline 1992 & $\mathbf{7 , 8 5 2}$ \\
\hline 1993 & 9,783 \\
\hline 1994 & 12,465 \\
\hline 1995 & $\mathbf{7 , 3 9 4}$ \\
\hline Totals & $\mathbf{3 7 , 4 9 4}$ \\
\hline
\end{tabular}

Source: Constructed by the author using data from the Arkansas Energy Office

\footnotetext{
${ }^{3}$ Data are reported for 72 counties, including 17 without an approved FHA lender.
} 


\section{Evolution of Program}

This section addresses generic matters related to the evolution of HERS/EEF in Arkansas, irrespective of any particular loan product. Issues unique to a specific lending product are noted. At the time of data collection, EEF products existed through three mechanisms: Federal Housing Administration 203(k) loans, EEM pilot program, and Department of Veterans Affairs.

\section{Program Origins and Descriptions}

Throughout its early history, the AEO funded ERH-AR to promote financing in the process of soliciting ratings. ERH-AR was established to promote financing of energy efficiency through mortgage mechanisms; similarly, within the FHA pilot program, EEMs could not be obtained without a rating. Thus, ratings and financing would be conducted separately but coincide in practice, providing mutual complementarity.

Specific energy efficiency financing products available in Arkansas are summarized as follows.

- Federal Housing Administration Energy Efficient Mortgage Pilot Program Energy Rated Homes of Arkansas (ERH-AR) administers these mortgages as one of five pilot states nationally. Buyers of existing one- and two-unit homes and borrowers who are refinancing mortgages may finance $5 \%$ of a home's value or $\$ 4,000$, whichever is greater, in cost-effective energy improvements with a FHA mortgage. Up to $\$ 200$ for the cost of a home energy rating report may be financed as part of the closing costs, as well as $\$ 45$ for final inspection.

A total of 47 mortgage loans have been approved through 1995. The average dollar value of the entire loan with energy improvements was $\$ 62,411$; the average value of energy improvements was $\$ 3,659$. $^{4}$

- Federal Housing Administration 203(k) Loans for Housing Rehabilitation. Energy improvements determined acceptable by regional architectural and engineering review or energy rating may be financed up to $95 \%$, if the base loan is less than $\$ 124,875$, and up to $100 \%$ if solar applications are included. Improvements must be installed before the loan is insured.

The Little Rock FHA Field Office reports that 74 of these loans were written during FY 1994 and that a portion of each was used for energy efficient upgrades. Ratings were not used, however.

- Veterans Home Loan Program Energy Rated Homes of Arkansas (ERH-AR) participates in the national Veterans Home Loan Program, which is targeted at existing single-family homes, including mobile homes. ${ }^{5}$ Even though ratings are not required, some lenders use ERH-AR's rating service to verify cost effectiveness. The program allows for up to $\$ 6,000$ in energy improvements to be financed for measures where cost-effectiveness is demonstrated and up to $\$ 3,000$ without demonstrating costeffectiveness.

\footnotetext{
${ }^{4}$ Some applications for EEMs do not receive HUD endorsement.

${ }^{5}$ Although energy efficiency improvements for mobile homes may be financed under this product, the ERH-AR rating software (E-Z Rater) is not designed for this type of dwelling.
} 
According to the U.S. Department of Veterans Affairs, in FY 94, 19 energy improvement loans were written, totaling $\$ 1,184,253$ and averaging $\$ 62,329$.

\section{Barriers to Implementation}

The benefits of HERS/EEF notwithstanding, program implementation has faced some obstacles. A detailed assessment of factors affecting six different stakeholder groups, identified from AEO staff experience with EEMs, is presented in Appendix 5-C, Barriers to Implementation: EEM Pilot Program Annual Report (Draft), prepared for the state legislature in 1995. The factors include benefits, perceived barriers, obstacles and solutions. Stakeholders include appraisers, HERS providers, contractors, real estate professionals, homeowners or buyers, and lenders. Barriers perceived by stakeholders are listed below:

- Appraisers have difficulty assigning a value to energy efficiency and the resulting interpretation of its market value.

- Contractors perceive that energy improvements make a house "too tight," and that the cost of energyimprovement construction may not be recoverable at the time of sale.

- Real estate professionals have difficulty in understanding what constitutes a cost-effective. improvement for an EEM and perceive that the EEM process will delay the sale.

- Homeowners or buyers may desire energy improvements that do not qualify for financing under EEM product requirements and that may be based on exaggerated energy savings claims by manufacturers.

- HERS providers observe that homeowners or buyers may desire energy improvements that are not cost effective.

- Lenders dislike added paperwork; are concerned that the secondary lender does not want to escrow funds for energy improvements, and they prefer shorter term EEF mechanisms (e.g., home improvement loans) rather than EEMs.

\section{Solutions}

Among proposed solutions are enhanced financial incentives to homeowners and buyers, and continued formal and informal education of appraisers, contractors, HERS providers, real estate professionals and lenders.

ERH-AR acknowledges a need to educate stakeholders about HERS/EEF. The organization's executive director endorses one-on-one contact as the most effective approach to education-beginning when a rating is ordered and continuing throughout the process, emphasizing the benefits to the stakeholder. Additionally, ERH-AR cites the need for educating FHA on the link between residential energy efficiency and housing affordability. Other barriers include inadequate funding, and problems in coordination of roles with and support from FHA (through HUD), DOE, and the secondary market. These are explained further, as follows: 
- HERS/EEMs Education. Lenders are the first priority for HERS/EEM education, followed by real estate professionals, trade association members, and real estate appraisers. Loan originators and underwriters traditionally depended on HUD training; but HUD training was deficient in two respects: it devoted insufficient time to EEMs; and few attendees at a HUD regional (multi-state) training had transactions in Arkansas, where the pilot program was in effect. To reach this group ERH-AR enlisted a representative from the Arkansas Mortgage Bankers Association, the state mortgage lenders' professional association, to serve on the ERH-AR Board of Directors.

ERH-AR believes that real estate professionals are second in importance as a vehicle to reach prospective home buyers. The heating, ventilating, and air conditioning (HVAC) industry, including sellers of heat pumps, is the key contact among trade allies. ERH-AR began work with appraisers as a stakeholder group during 1995.

- Energy Education. ERH-AR believes that knowledge about energy efficiency in the building trades underlies the motivation of this stakeholder group to promote HERS/EEMs. Although, in recent years, the construction industry has devoted greater attention to energy efficiency in general, a lack of specific information impedes program implementation.

According to ERH-AR, the Arkansas building industry, which comprises many small firms, lacks a systematic way to educate its members about the state-of-the-art in energy-efficient residential construction. The cost of such training and travel to training sites may be prohibitive. Although other trade associations such as the HERS Council have assumed this training role, they are not as effective as the trade association that builders identify with more closely. In ERH-AR's experience, builders do not make the connection between building energy-efficient homes and their ability to profit from energy-efficient construction.

- Funding A lack of continuity in funding sources poses difficulties for ERH-AR in conducting outreach activities, because of the negative impact this activity has on travel budgets. Revenue generated from ratings and other fee-for-service activities is insufficient for this purpose. The organization's 1995 budget was $\$ 188,300$, a substantial portion of which derived from a contract with the U.S. Department of Energy (DOE). Table 5-4 sets forth the recent history of ERH-AR's funding sources.

Table 5-4. Funding and Funding Sources, by Calendar Year, of Energy Rated Homes of Arkansas (\$000)

\begin{tabular}{|c|r|r|r|r|r|}
\hline FY & \multicolumn{1}{|c|}{$\begin{array}{c}\text { Arkansas Energy } \\
\text { Office }\end{array}$} & DOE & NREL & Other $^{\mathbf{2}}$ & Total \\
\hline 1992 & $\mathbf{M D}^{\mathrm{b}}$ & 0.00 & 0.00 & $\mathrm{MD}$ & $\mathrm{MD}$ \\
\hline 1993 & 116.00 & 0.00 & 0.00 & 30.00 & 146.00 \\
\hline 1994 & 54.47 & 0.00 & 0.00 & & 54.47 \\
\hline 1995 & 0.00 & 130.00 & 10.00 & 38.30 & 188.30 \\
\hline Totals & $\mathbf{1 7 0 . 4 7}$ & $\mathbf{1 3 0 . 0 0}$ & $\mathbf{1 0 . 0 0}$ & $\mathbf{6 8 . 3 0}$ & $\mathbf{3 8 8 . 7 7}$ \\
\hline 1996 & (expected) & 150.00 & & 50.00 & $\mathbf{2 0 0 . 0 0}$ \\
\hline
\end{tabular}

${ }^{a}$ Includes fee-for-service activities: training, raings/rating processing, and quality control contracts (Entergy, $\$ 31 \mathrm{~K}$ ).

bMissing data. 
- FHA Coordination. The limit of $5 \%$ of a home's value or $\$ 4,000$ (whichever is greater) on the amount of energy improvements that can be financed by FHA in its conventional loan program in turn limits the potential of EEMs, according to ERH-AR, because energy-efficiency improvements can be cost-effective beyond these limits. Additionally, from an institutional perspective, ERH-AR believes that although rewards are few for FHA personnel who actively promote EEMs, the FHA Field Office has increased its commitment to promoting EEMs, following a concerted effort between the two organizations to improve communication, coordinate respective roles, and enhance the effectiveness of working relationships.

\section{Partnerships}

ERH-AR believes that establishing ongoing, working relationships (whether formal or informal) through selective partnerships with stakeholder groups enables more direct access to other groups; without such arrangements, only indirect access is possible. ERH-AR is making progress along these lines with at least two types of private sector organizations.

The first is a partnership with Entergy, a large utility holding company with a service area encompassing some 2.5 million homes in Arkansas, Mississippi, Louisiana, and Texas. Under a quality control contract in effect from September through December 1995, Entergy employed ERH-AR as an independent source of energy data gathered in the rating of electric homes randomly selected for a baseline study of actual energy performance. ERH-AR saw the potential benefits of this partnership as triggering linkages with a broad range of trade allies compared to the narrower range of a single, smaller utility company.

A second potential partnership exists with one or two competing lenders who offer lines of credit to their customers for home improvements. This partnership would further enhance the use of ratings, with the effect of spreading and penetrating the broader market for home improvement loans, incorporating energy efficiency as a component.

Partnerships are also possible with nonprofit organizations. Housing counseling groups, for example, provide direct access to low- and moderate-income home buyers who represent a target market for EEMs and, as clients to stakeholders, they are an important point of contact.

\section{Future Prospects}

According to its executive director, ERH-AR's future relies on a source of funding to subsidize ratings. Because ERH-AR, with support of the AEO, is the primary promoter of EEMs, the agency bears the burden of program continuity. The AEO, effective in 1995, no longer funds ERH-AR activity. Its in-kind support remains a powerful force for ERH-AR, but an ongoing source of funds is nonetheless needed Without the FHA pilot and other federally sanctioned EEM programs, ERH-AR fears it would be in danger of collapse. 


\section{Marketing}

\section{Strategy}

The ERH-AR program is currently in a "rebuild" mode, and a relatively new director is establishing a new identity for the organization with the public. A committee has been formed by the ERH-AR Board of Directors to market to lenders, utilities, and builders. The committee is intended to be ongoing even though it is not part of the Board's structure.

House-shaped magnets, identifying ERH-AR and bearing the phrase, "Your Home Energy Experts!" have been distributed through a variety of mechanisms to give the organization visibility among stakeholders, especially real estate professionals and the lending community. To reach the general public, marketing techniques have included radio and television spots to 39 outlets, exhibits at shows sponsored by the home builders' trade association, and some general mailings. Entergy has mailed bill enclosures that advertise EEMs to 2.5 million households in its service area. Print media coverage describing EEMs has included an article in Rural Cooperative magazine, reaching 180,000 subscribers, and an article appearing regularly in Real Estate Weekly, distributed in 639 locations which, the publication estimates, reaches $41 \%$ of the homebuying public in Arkansas. These publications' writers prepared articles based on information they received directly from ERH-AR, including fact sheets about ratings and EEMs.

These marketing techniques have not been formally evaluated but ERH-AR believes that the payoff comes in the form of name recognition in the long run as well as actual EEMs in the short run.

\section{Information Transfer}

Both ERH-AR and the AEO believe that the major determining factor in success of information transfer has been credibility of the source. They note that in Arkansas, the general public views utility companies as reliable sources of information on energy because of the companies' visibility when they offered free audits during the implementation of the Residential Conservation Service (PL 95-169). The organizations agree that ERH-AR's nomprofit status is an asset in conveying credible information whereas information from the AEO is subject to interpretation as regulatory in nature because of its status as a state agency. 


\section{Training}

Training in HERS/EEF is closely linked with marketing. HERS/EEF training increases the particular skills of individuals involved in the process. A formal curriculum is employed that is directed to the specific occupation involved.

\section{Training Philosophy}

ERH-AR provides training in HERS/EEMs implementation designed for the specific groups that receive training. Training for raters maintains a cadre of qualified personnel to draw upon and as a means of assuring quality control. Training for stakeholder groups supports that group with infonmation necessary to fulfill its program implementation role. Bocause of high personnel tumover rates in both the lending and real estate industries, training for these groups must be repeated frequently. ERH-AR is developing a program that will grant continuing education credits on residential energy efficiency to real estate agents. Appraisers represent a group into which substantial inroads need to be made; ERH-AR is engaged in an effort that would incorporate energy-efficiency value added in to the training that leads to the licensing of appraisers in the state. Similarly, ERH-AR is working with the state's Multiple Listing Service (MLS) toward including energy rating and EEM information on MLS listing sheets for homes on the market.

\section{Who Conducts and Receives Training}

While HUD includes training on EEMs as part of its training for underwriters, the bulk of training activities rests with ERH-AR and AEO, often in conjunction with stakeholder organizations. At present ERH-AR conducts basic rater training for its own and some other states' rating programs, and trains builders and construction contractors in diagnostic energy tools (e.g., blower door technique). In 1994 ERH-AR participated with the Arkansas Industrial Development Commission (AIDC) and Arkansas Development Finance Authority (ADFC) in conducting training for contractors, inspectors, and specification writers in the Coordinated Housing Improvement Program (CHIP), a weatherization and rehabilitation program directed to older houses occupied by low-income, handicapped, and elderly persons.

A summary of all training activities conducted through 1995 appears below. Where additional detail is available, it appears in Appendix 5-A. Cooperating entities are identified where applicable.

\section{Raters}

- ERH-AR conducts the training.

- A total of 200 raters received basic training in nine different 3-day field training sessions; 4 sessions in 1993 and 5 sessions in 1994. To qualify for this training, participants must have already received training in blower door techniques.

- Since 1993 ERH-AR has certified 13 raters. ERH-AR grants certification with the successful completion of five ratings under its direction, following basic rater training. Table 5-5 shows the yearby-year data on rater certification.

- ERH-AR expects to conduct additional training on a regional basis in the Central U.S. in 1996. (Details not available). 
Table 5-5. Raters Certified by Energy Rated Homes of Arkansas

\begin{tabular}{|l|c|}
\hline \multicolumn{1}{|c|}{ Calendar Year } & Number \\
\hline 1993 & 4 \\
\hline 1994 & 5 \\
\hline $1995-7 / 31 / 95$ & 4 \\
\hline Total & $\mathbf{1 3}$ \\
\hline
\end{tabular}

\section{Stakeholders}

- Stakeholders include lenders, real estate professionals, and appraisers who received training as a group (disinct from training for specific stakeholder groups presented below).

- ERH-AR conducted the training.

- A total of 67 stakeholders received training during two sessions, beginning October 1993 through April 1994, using a formal curriculum.

- ERH-AR has no plans for further training of this kind.

\section{Lenders}

- U.S. Deparment of Housing and Urban Development, Single Family Housing Division, Region VI (FHA Field Office) conducted the training. ${ }^{6}$

- The Field Office provides one-on-one training for interested lenders upon request.

- A total of 103 persons were trained to process direct endorsements, in five 1-hour sessions designed for lenders from June 1994 to May 1995. (Dates and attendance are included in Appendix 5-A.)

\section{Real Estate Professionals}

- ERH-AR conducts training directly, and the AEO coordinates training that National Association of Realtors (NAR) instructors conduct for NAR continuing education courses on EEMs and the state energy code. ${ }^{7}$

- ERH-AR trained a total of 222 real estate professionals in four 1-week or 1-day sessions from October 1993 through January 1995.

- NAR instructors trained a total of 749 real estate professionals in seven sessions from April 1995 through December 1995. (Dates and attendance are included in Appendix 5-A.)

- AEO expects to coordinate similar training in 1996 (specific information not yet available).

${ }^{6}$ Source: Correspondence to author from Susan Finister, Director, Single Family Housing Division, U.S. Department of Housing and Urban Development, Little Rock Office, Region VI, August 10, 1995.

${ }^{7}$ Source: AEO Training Reports 


\section{Builders/Contractors}

- ERH-AR has conducted builder/contractor training in cooperation with the Coordinated Housing Improvement Program (CHIP) and the AEO.

- A total of 95 builders/contractors received training in one-week sessions conducted between October 1993 and April 1995.

\section{Other}

- ERH-AR provides additional inf ormal support in the form of technical assistance to lenders, real estate professionals, raters, builders, and others in one-on-one consultation upon request. 


\section{Program Accomplishments}

ERH-AR conducted 940 ratings from 1988 to the end of 1995. Figure 5-1 illustrates the volume of rating activity by calendar year. Ratings appear to have leveled off to approximately 100 per year in 1994 and 1995, recovering from a low of 19 in 90 and declining from a high of 367 in 1989 when ratings were offered at no charge, subsidized by funding from the AEO.

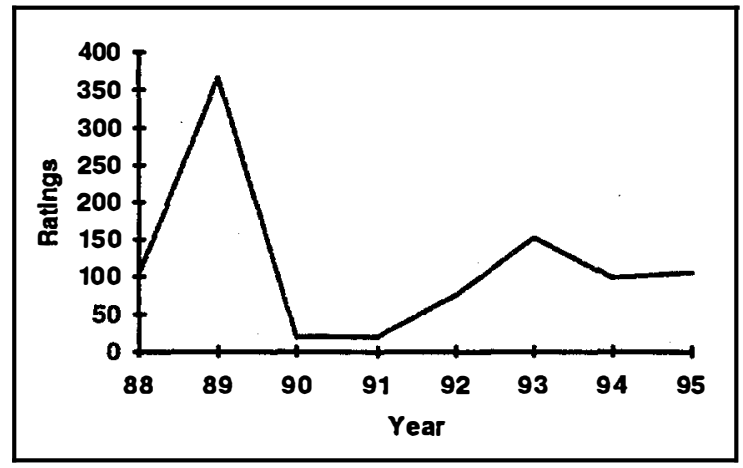

Figure 5-1. ERH Arkansas Ratings by Year, 1988-1995

Table 5-6 shows rating and financing activity over 1992-95, the period when HERS/EEF has been available in Arkansas.

Table 5-6. Arkansas Rating and Energy Efficiency Financing Activity 1992-1995

\begin{tabular}{|c|c|c|c|c|c|}
\hline Activities & 1992 & 1993 & 1994 & 1995 & Total \\
\hline Ratings Completed ${ }^{a}(\mathrm{CY})$ & 75 & 152 & 98 & 106 & 431 \\
\hline \multicolumn{6}{|c|}{ LOANS COMPLETED (FY) } \\
\hline HUD EEMs $^{\mathrm{b}}$ & 0 & 0 & 13 & 31 & 44 \\
\hline Conventional FNMA & 0 & 0 & 0 & 0 & $\mathbf{0}$ \\
\hline Conventional Freddie & 0 & 0 & 0 & 0 & $\mathbf{0}$ \\
\hline VA & 0 & 3,870 & 6,036 & 0 & 9,906 \\
\hline $203 k$ & 0 & 0 & 0 & 0 & 0 \\
\hline
\end{tabular}

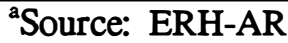

bource: CHUMS database (HUD)

In addition to the activities described earlier, ERH-AR furthers the financing of residential energy efficiency by other means:

- Providing testimony before the Arkansas Public Service Commission in support of including EEMs in the Integrated Resource Planning/Demand Side Management process for utilities. Testimony was presented by former ERH-AR director, Ron Hughes, in 1993 and present director, Carol Cales, in 1994. 
Exploning innovative financing packages with the lending community through a partnership with Arkansas Mortgage Bankers Association (AMBA). A member of AMBA sits on the ERH-AR Board of Directors, facilitating communication with the lending community.

- Cooperating with the AEO, affirming to federal banking regulators that lenders financing EEMs qualify for Community Reinvestment Act recognition.

- Entering into an agreement with the AEO to develop a compliance test for use with the 1994 Arkansas energy code, allowing ERH-AR to serve as a compliance agent for the AEO. 


\section{Program Evaluation and Data Collection}

\section{Status}

Data collected to evaluate the effectiveness of HERS/EEF in Arkansas has been limited to energyefficiency characteristics and recommendations obtained in the process of conducting ratings. This information, maintained by ERH-AR, concerns housing structure, and measures installed and their cost. Based on these data, ERH-AR reported to the AEO that in the FHA pilot program through 1995, upgrades for 43 homes averaged $\$ 3,659$ in cost; estimated energy savings averaged $\$ 520$ per house. With an average of 1,000 HUD loan applications per month for existing homes, the AEO estimated that if all such applications became EEMs, the potential annual savings and economic impact would be $\$ 6.24$ million and $\$ 43.9$ million respectively.

\section{Recordkeeping and Data Collection}

ERH-AR collects data using the "E-Z Rater" program, maintains that data, and reports it to ERHA. Data are stored in IBM-PC format Relational Paradox database and Quattro Pro 4.0 spreadsheet. Forms used to support the system and a rating report are as follows (Appendix 5-D exhibits the forms):

- EEM Pilot Data Sheet

- ERH-AR Checklist

- Rating Sheets (residential existing and new construction)

ERH-AR tracks EEMs through database archiving, by means of the rating number assigned, as well as final inspection of residences for quality control purposes.

\section{Future Plans}

Under a five-year contract executed with DOE in 1995, ERH-AR plans to enhance its overall evaluation effort, including a state evaluation that will focus on quality assurance of ratings and the market response to enhanced marketing activities, in conjunction with evaluation responsibilities of the National Renewable Energy Laboratory. The following other plans are also included in the contract:

- Accommodate changes as necessary to conform to a national home energy rating system.

- Join the Residential Energy Services Network (RESNET), working in partnership with the Environmental Protection Agency (EPA), DOE, the National Association of State Energy Offices (NASEO), and the other pilot states.

- Develop the infrastructure necessary within the building trades in Arkansas to effectively deploy the national rating system.

- Develop and implement a comprehensive media and marketing strategy to increase consumer demand for home energy ratings and energy efficiency financing. 


\section{Epilogue}

Energy Rated Homes of Arkansas reports that during 1996 a strategic decision was reached by the Board of Directors and Executive Director to lessen dependence on DOE as a source of funding and to become more business oriented. Both the organization's mission statement and internal structure were modified to reflect this shift in focus.

Other changes revolved around stakeholder education and information activities, including the development of new brochures. Adopting a regional approach that included other states, ERH-AR targeted large lenders, builders, utilities, and weatherization groups and tailored support to these groups based on their specific needs. ERH-AR representatives attended and presented HERS/EEF information at more than 30 residential homeowner meetings. Distribution of ERH-AR ecucational materials at four continuing education classes conducted at a university targeted first time homebuyers.

ERH-AR reports a slow increase in the number of ratings by the end of 1996. A new EEF product became available in 1996 with Arkansas being chosen as a pilot state for the Fannie Mae/Freddie Mac program.

Among its continuing program objectives, ERH-AR cites homebuyer education and furthering the cause of RESNET. 


\section{Appendixes}




\section{Appendix 5-A. Arkansas Process Evaluation Data}

\section{Part 1. Organization Contacts and Descriptions}

\section{Energy Rated Homes of Arkansas}

Key contact:.................................... Carol Cales, Director

Type of organization:....................... Nonprofit

Address: .......................................... 5401 JFK Boulevard, Suite I

North Little Rock, AR 72116

Phone: ............................................ (501) 771-2299

Fax:............................................ (501) 771-1498

Date formed:.................................... 1987

Number of staff: ............................... 4

Staff titles and duties:...................... Carol Cales, Executive Director:

Overall management, administration

Allan Reed, Assistant Director:

Directs energy ratings

Jeremiah Gardner, Senior Process Engineer

Data input, analysis, technical support

Evan Brown, Technical Support

Mission:.

"...to administer a state wide rating system.

...to assist the Arkansas Energy Office in providing energy education and conservation programs to the public and the housing industry....provide[s] a uniform energy rating system network to be accessed by the people of Arkansas."

\section{Home Energy Ratings/Residential Energy-Efficiency Services and Education}

Program head: Carol S. Cales, Director

Date formed: 1987

Program functions: Perform residential energy-efficiency ratings; promote energy efficient mortgages. 
Formative sponsor(s): .................... Arkansas Energy Office (AEO)

U.S. Dept. of Energy (U.S.DOE)

Energy Rated Homes of America (ERHA)

Program sponsor(s)/funding: .......... 1995: Total budget is $\$ 188,300$.

$$
\begin{aligned}
& \text { Sponsors: } \\
& \text { U.S. DOE.... 150,000 } \\
& \text { Entergy ..... } \quad 31,000 \\
& \text { Other ......... 7,300 }
\end{aligned}
$$

Annual budget:

$\$ 188,300(1995)$

Other partnerships:

Arkansas Energy Office

(Legislatively authonized, Act 750; 1993)

Entergy (utility holding company)

(contractual relationship)

Geographic coverage:

Arkansas, statewide

(include areas of concentration, if any)

\section{U.S. Department of Housing and Urban Development (HUD) (Field Office)}

Key contact:.................................... Susan Finister, Director

Single Family Housing Division

Address:

425 West Capitol Avenue, Suite 900

Little Rock, AR 72201-3488

Phone:

(501) 324-5961

Fax:

(501) 324-5900

Staff assigned to EEMs:

2 


\section{Part 2. Recordkeeping and Data Collection}

Briefly describe any

evaluation system employed: ................. Analysis through E-Z Rater only

Forms used:

EEM data sheet, checklist, rating sheet, rating report

Organizations responsible for

collecting and sorting data: ERH-AR

Method for storing data: IBM-PC (Relational Paradox database and spreadsheet); QuattroPro 4.0

Number of ratings completed: $940(1988-95)$

Number of EEMs in system: $54(1993-95)$

Number of EEMS completed: .47 endorsed by HUD (1993-95)

EEM tracking method: Quality control (post-installation inspection and database archiving

Are there EEM case numbers?

(include assignment method).

Yes; rating archive number assignment

Average dollar value of

EEMs for EEIs: $\$ 62,411$ (total, with improvements)

(Data from HUD, reported through AEO)

Number of other loans for energy

improvements:. 9 (FY 93); 19 (FY 94)

Any description of these loans: ..VA

Any state or local reporting requirements: Yes; AEO (FHA)

Any federal reporting requirements: Yes; DOE

Software used for ratings: E-Z Rater

Number of energy-improved homes:.

(11 unsuccessful EEMs)

Average dollar value of energy improvements (\# of homes : improved dollar value of EEMs).............\$3,659 (HUD endorsed) 


\section{Part 3. Training}

\section{Raters}

Organization sponsoring/

conducting training: Energy Rated Homes of Arkansas

Number trained: Approximately 200

Date(s) of training: 1993: July, August (2), October

1994: March, August, September, November

Length of training: 3 days (field-based)

Number of certified raters: 13 as of Dec. 31, 1995

Additional training plans: Regional training (central U.S.) (specifics not yet available)

Method of marketing: RESNET, ERH-AR Board (Marketing Committee), Entergy

\section{Lenders}

Organization sponsoring/ conducting training: U.S. Department of Housing and Urban Development, (HUD), Region VI, Single Family Housing Division, Federal Housing Administration.

Number trained: 103

Date(s) of training; number attending: Jun. 22, 1994

Length of training: 1-5 hours

Additional training plans: Ongoing

Method of marketing: direct mail

\section{Real Estate Professionals}

Organizations sponsoring/ conducting training: 
Number trained:

ERH-AR: 222

AEO/NAR: 749

Total: $\quad 971$

Date(s) of training;

number attending:

(if available)

ERH-AR:

1993--Oct.

1994--Jan.

1995--Mar., Apr.

AEO/NAR (1995):

Apr. $24 \quad 37$

Jun. $11 \quad 21$

Jun $20 \quad 46$

Jun $21 \quad 31$

Jun $22 \quad 21$

Aug. $9 \quad 60$

Aug. $11 \quad 85$

Aug. $15 \quad 79$

Aug. $27 \rightarrow 33$

Sept. 9

Sept. 22

328

Sept. 23

Dec. 17

8

Length of training: ........................... One week; one day

Additional training plans:................ One-day sessions

(specifics not available)

Method of marketing:...................... Mailings, via Arkansas Development Finance Authority, AEO, lenders, real estate agents.

\section{Appraisers}

Organization sponsoring/

conducting training:

Coordinated Housing Improvement Program, Arkansas Industrial Development Commission

Number trained:

19

Date(s) of training:

1993: October

1994: January

1995: March, April

Length of training:

One week; one day

Additional training plans:

Yes; specifics not available

Method of marketing: Mailings via Arkansas Development Finance Authority, ERH$\mathrm{AR}$, and $\mathrm{AEO}$. 


\section{Builders and Contractors}

Organization sponsoring/

conducting training: ........................ ERH-AR/Coordinated Housing Improvement Program Arkansas Industrial Development Commission

Number trained:.............................. 95

Date(s) of training:....................... 1993: October, December

1994: January

1995: January

Length of training:

One week

Additional training plans:

Yes; specifics not available

Method of marketing:

Word-of-mouth; AEO and ERH-AR direct mail.

\section{Marketing}

Types of marketing used: ............... Radio, home shows, TV spots, mailings; through Entergy.

Marketing strategy:....................... Target mortgage lenders, utilities, builders, public 


\section{Part 4. Implementation}

\section{Barriers:}

1. Appraisers have difficulty assigning a value to energy efficiency and the resulting interpretation of its market value.

2. Contractors perceive that energy improvements make a house "too tight," and that the cost of energy improvements will not be recoverable at the time of sale.

3. Real estate professionals have difficulty understanding what constitutes a cost-effective improvement for an EEM and perceive that the EEM process will delay the sale.

4. Homeowners or buyers may desire energy improvements that do not qualify for financing under EEM product requirements and that may be based on exaggerated energy savings claims by manufacturers.

5. HERS providers observe that homeowners or buyers desire energy improvements that are not cost effective.

6. Lenders dislike added paperwork; are concerned that the secondary lender does not want to escrow funds for energy improvements and they prefer shorter term EEF mechanisms (e.g., home improvement loans) rather than EEMs.

7. Funding from various sources lacks continuity; posing difficulties for planning and implementing outreach activities.

8. Coordination of roles with and support from FHA, DOE, and the secondary market can be problematic.

\section{Solutions}

1. Proposed: Enhanced financial incentives to homeowners and buyers.

2. Ongoing:

- HERS/EEMs education for lenders, real estate professionals, trade association members, and real estate appraisers.

- Energy education for the building trades.

- Partnerships with utilities, lenders, and nonprofit organizations, and other groups.

\section{Accomplishments}

1. Providing testimony before the Arkansas Public Service Commission in support of including EEMs in the Integrated Resource Planning/Demand Side Management process for utilities (1993 and 1994).

2. Exploring innovative financing packages with the lending community through a partnership with the Arkansas Mortgage Bankers Association (AMBA). 
3. Cooperating with the AEO, affirming to federal banking regulators that lenders financing EEMs qualify for Community Reinvestment Act recognition.

4. Entering into an agreement with the AEO to develop a compliance test for use with the 1994 Arkansas energy code, allowing ERH-AR to serve as a compliance agent for the AEO.

Future Plans (all under contract with DOE)

1. Accommodate changes as necessary to conform to a national home energy rating system.

2. Join the Residential Energy Services Network (RESNET), working in partnership with the Environmental Protection Agency (EPA), DOE, the National Association of Sate Energy Offices (NASEO), and the other pilot states.

3. Develop the infrastructure necessary within the building trades in Arkansas to effectively deploy the national rating system.

4. Develop and implement a comprehensive media and marketing strategy to increase consumer demand for home energy ratings and energy efficiency financing.

5. Promote effective communication and working relationships with FHA, DOE, and lenders. 


\section{Appendix 5-B. Principal Organizations}

[In-person interviews are denoted *; telephone interviews are denoted **.]

\section{Energy Rated Homes of Arkansas}

5401 JFK Boulevard, Suite I

North Little Rock, AR 72116

(501) 771-2299; FAX (501) 771-1498

*Carol Cales, Director

Allan Reed, Assistant Director

*Jeremiah Gardner, Senior Process Engineer

Evan Brown, Technical Support

12-15 raters

\section{Arkansas Energy Office}

One State Capitol Mall

Little Rock, AR 72201

(501) 682-1121; FAX (501) 682-7341

**Morris Jenkins, Director

*Susan Recken, Program Administrator

U.S. Department of Housing and Urban Development, Region VI, Single Family Housing Division

425 West Capitol Avenue, Suite 900

Little Rock, AR 72201-3488

(501) 324-5961

*Susan Finister, Director

*Ron Baxter

*Freda Nunez

**Johnny Wooly 


\section{Appendix 5-C. Barriers to Implementation: EEM Pilot Program Annual Report (Draft)}




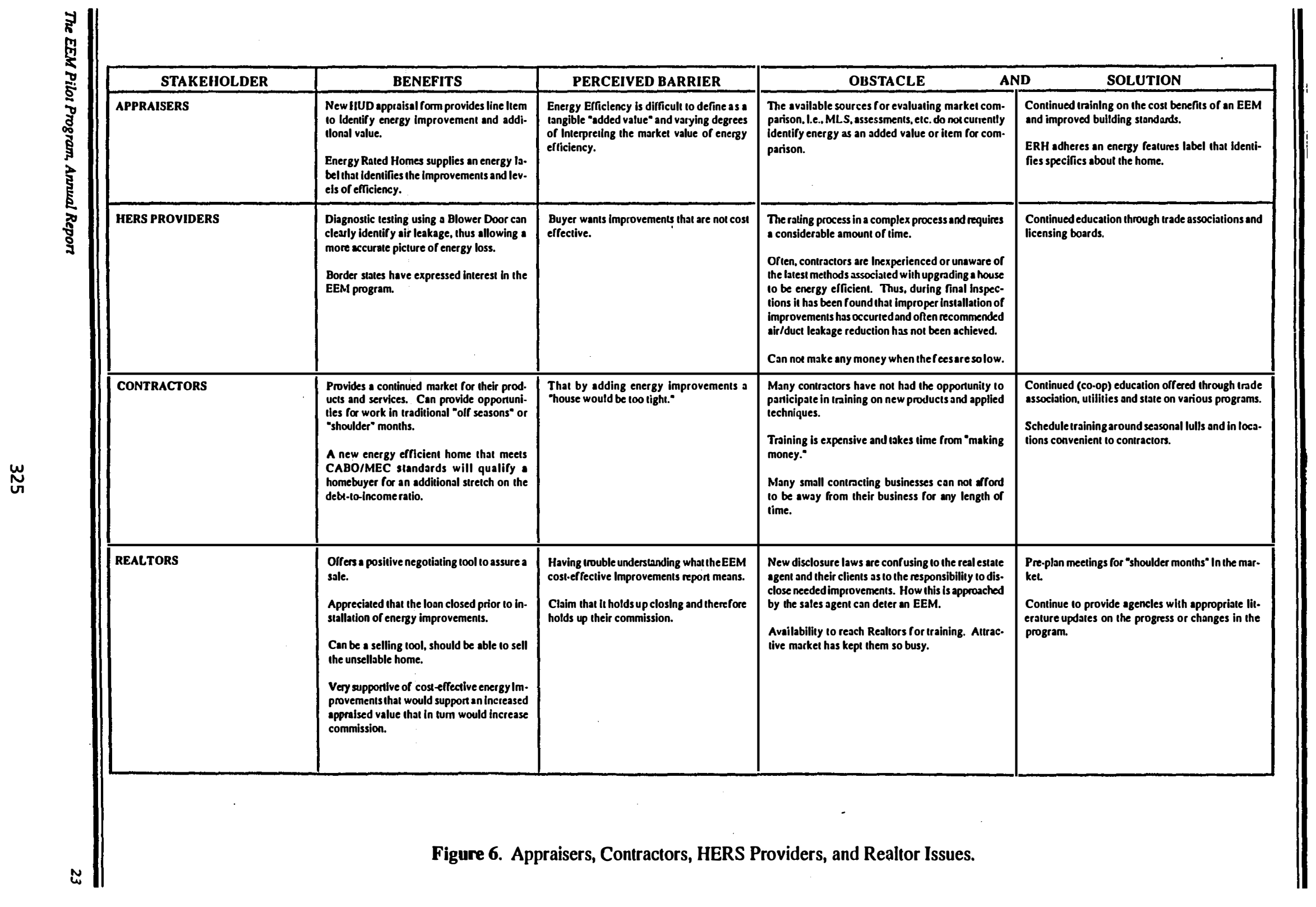




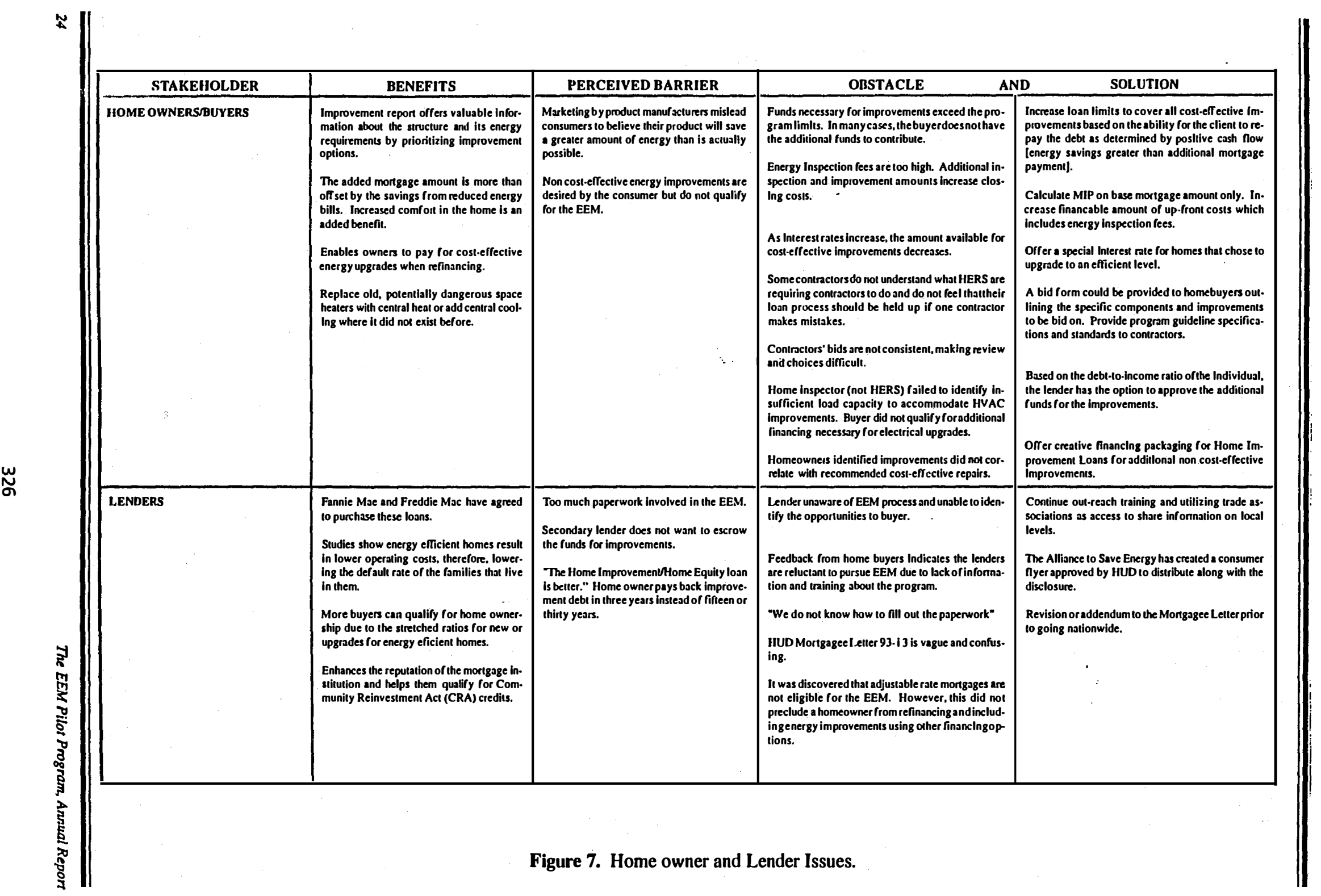


Appendix 5-D. Forms Used in Record Keeping 
File No.

City/County/Region :

Conditioned floor area:

Total cost of EEM improvements: \$

Total amount escrowed: \$

Amount cost effective: $\$$

Amount homeowner provided: $\$$

Cost of inspection/final inspection: \$

Interest Rate:

Est. Annual utility cost "As Is": \$

Est. Annual utility cost "Efficiency Options": \$

Est. Annual utility cost "Post Improvements": \$
Component costs:

Insulation: $\$$

Air Leakage: \$

Estimated energy savings:

Gas MBtu

Electric MBtu

Total estimated energy savings:

MBtu I\$

Tons of $\mathrm{CO}_{2}$ emmission reduction:

Gas tons

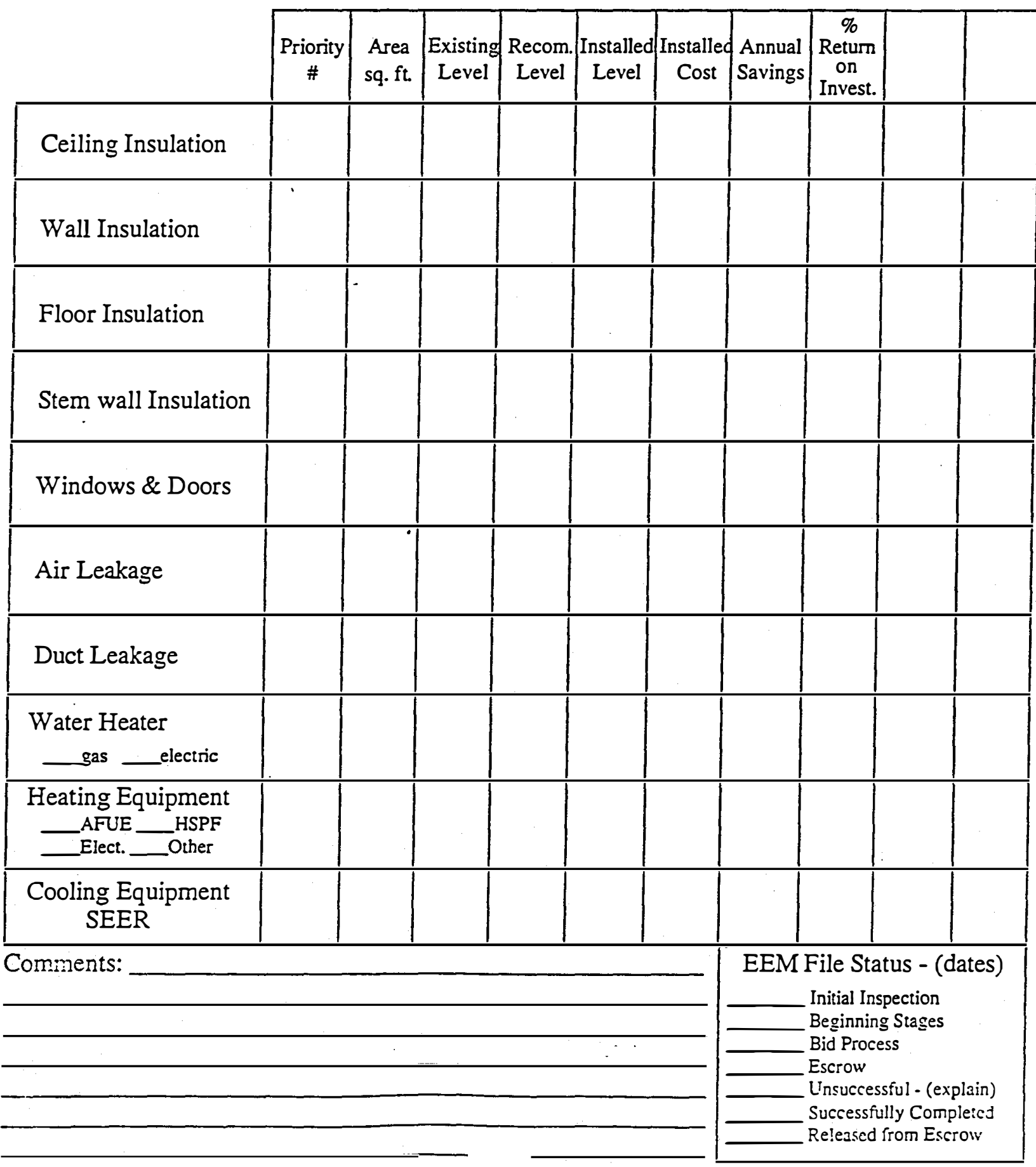




\section{Energy Rated Homes ${ }^{\mathrm{TM}}$ of Arkansas}

\section{Checklist}

Trerty Rated Romes

OFARKANSAS

ERH ID \#

Rater Name

Rater Certification \#

Site visit date

Organization

Plans rating date

Owner's name:

Property Address:

City: Zip:

Telephone number:

Mailing Address:

City:

Zip:
Rating Type
A) Rated "As Is"
B) Based on plans
C) Efficiency Options Rating
D D) Post Improvement Rating

Heated floor area (Include basement if heated) sq. $\mathrm{ft}$.

Ceiling Height

Volume cubic ft.

\section{House Type}
A A) 1 story on regular crawlspace
F) 1 story on slab
K) $1-1 / 2$ story w/daylight basement
( B) 2 story on regular crawlspace
G) 2 story on slab
L L) 1 story w/basement
C) 1 1/2 story on regular crawlspace
H) $1-1 / 2$ story on slab
D) Tri level with $1 / 2$ slab
I) 1 story w/daylight basement
M) 2 story w/basement
E) Split entry
J) 2 story w/daylight basement
N) 1-1/2 story w/basement
O) 1 story w/1/2 daylight basement

\begin{tabular}{|l|l|l|l|}
\hline Component & InsulationType & \# of Inches & Average R-Value \\
\hline Ceiling/Roof/Attic & & & \\
\hline Walls & & & \\
\hline $\begin{array}{l}\text { Exposed Concrete Wall } \\
\text { For basement homes only. }\end{array}$ & & & \\
\hline $\begin{array}{l}\text { Below Grade Wall } \\
\text { Forbasement homes only. }\end{array}$ & & & \\
\hline $\begin{array}{l}\text { Foor orer crawl or exposed } \\
\text { underfoor } \\
\text { perimeter }\end{array}$ & & & \\
\hline Slab edge & & & \\
\hline
\end{tabular}

\section{Air Leakage:}

Nach OR CFM50

If unable to reach $50 \mathrm{~Pa}$, record house pressure Climate Factor

Wind: $\square$ Well-shielded

C Normal $\square$ Exposed

Duct Leakage (Modified subtraction):

Envelope CFM150 (ducts taped)

House-to-duct pressure (ducts taped; house at $50 \mathrm{~Pa}$ )

If unable to reach $50 \mathrm{~Pa}$, use same test pressure on house as first test, record house-to-duct pressure

I give my permission for a representative of the Uniform Energy Rating System ${ }^{\mathrm{TM}}$ to receive information from my utility companies regarding the actual energy consumption and energy costs of my residence.

Utility

Account $\frac{\mu}{\pi}$

Utility

Home addiess
Account $\frac{H}{\pi}$

Owner Signature 


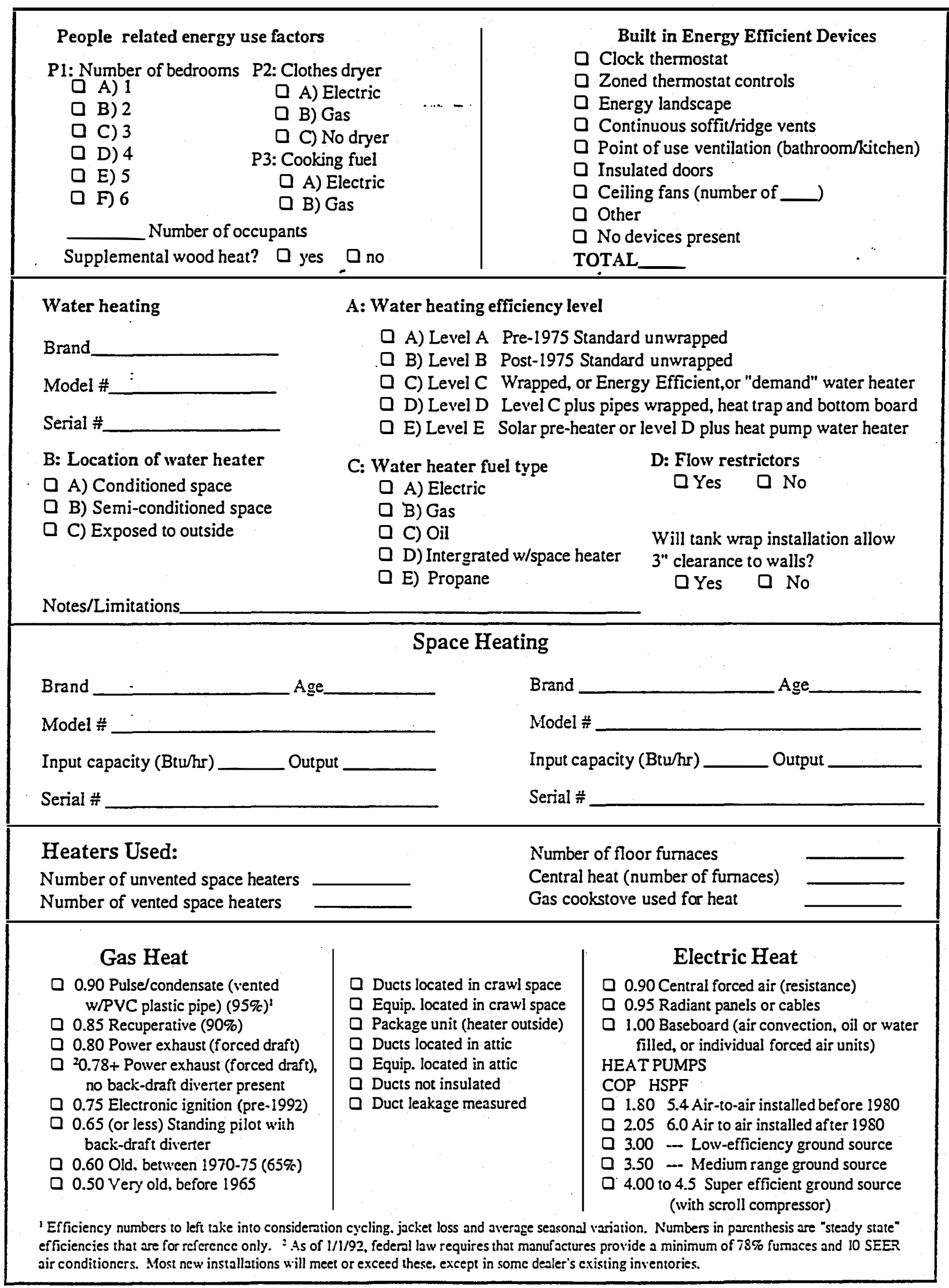

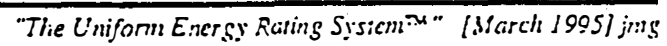




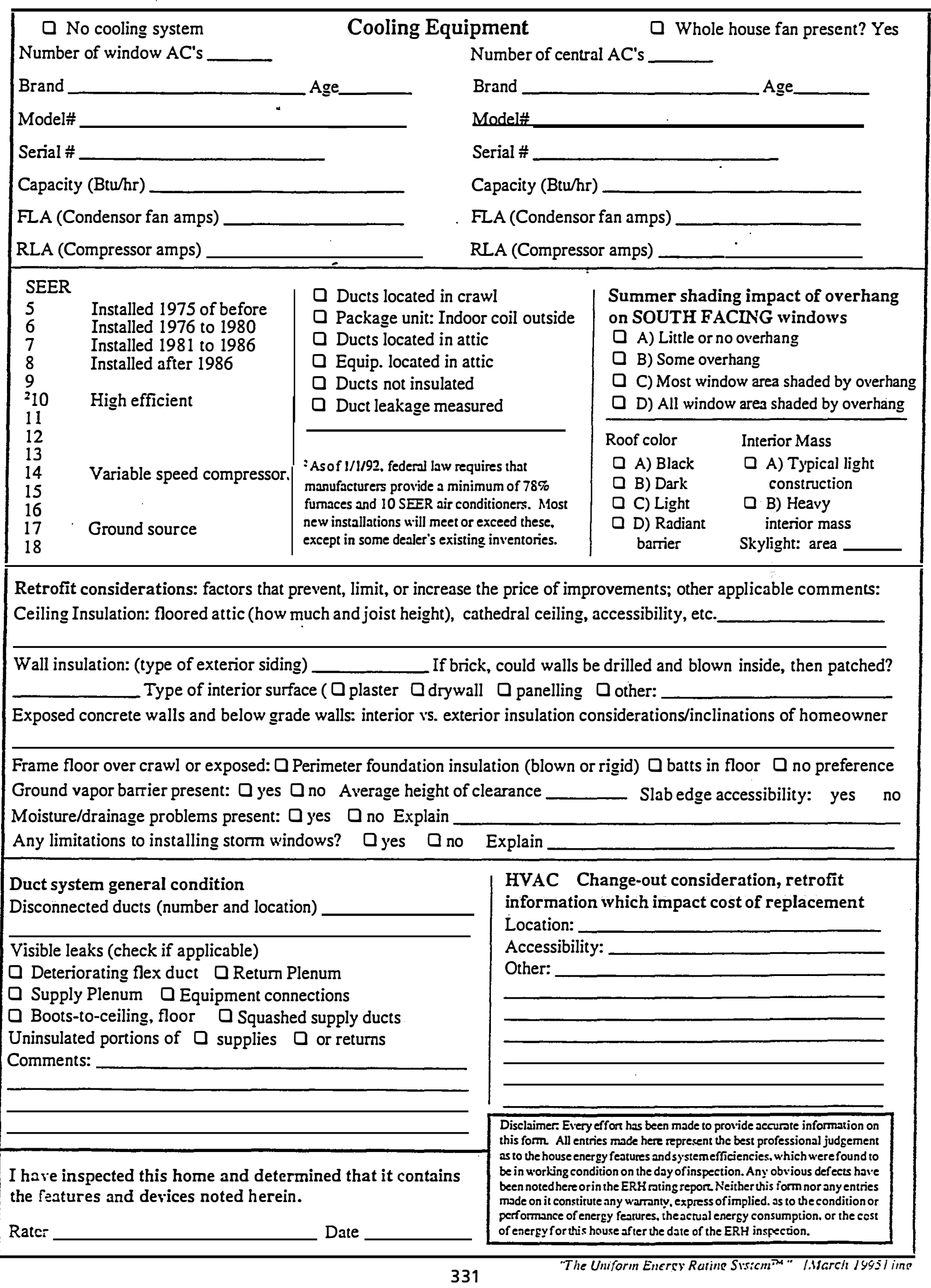




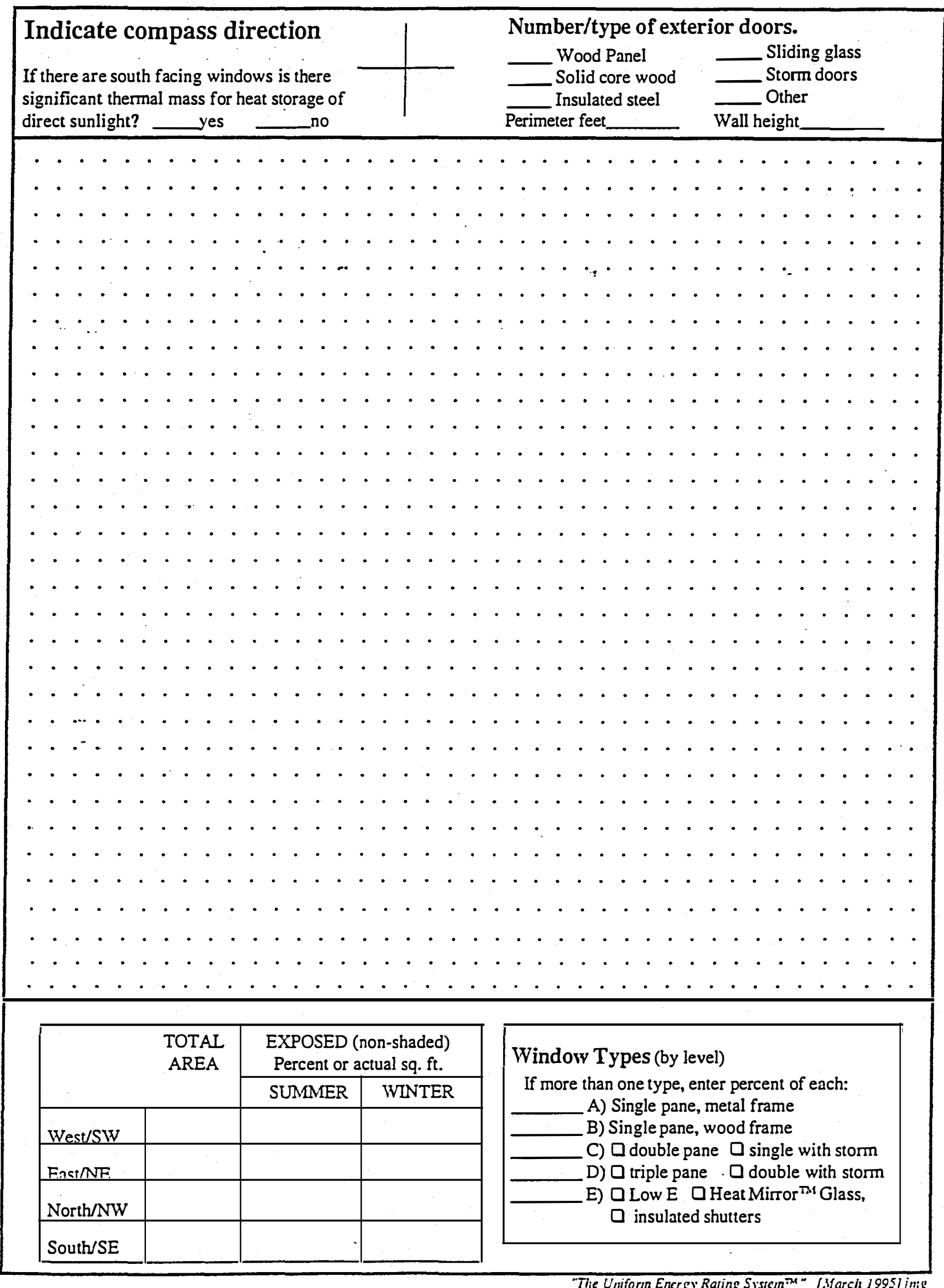




\section{Acronyms}

\begin{tabular}{|c|c|}
\hline AARP & American Association for Retired Persons \\
\hline A-EEM-SCOs & Association of Energy Efficient Mortgage Service Companies \\
\hline ACHP & Alaska Craftsman Home Program \\
\hline AEO & Arkansas Energy Office \\
\hline AFUE & Annualized fuel utilization efficiency \\
\hline AGA & American Gas Association \\
\hline AHFC & Alaska Housing Finance Corporation \\
\hline AI & The Appraisal Institute \\
\hline APPA & American Public Power Association \\
\hline ASE & Alliance to Save Energy \\
\hline ASHI & American Society of Home Inspectors \\
\hline ASHRAE & American Society of Heating, Refrigerating, and Air-Conditioning Engineers \\
\hline CABO & Council of American Building Officials \\
\hline CABO MEC & Council of American Building Officials' Model Energy Code \\
\hline $\mathrm{CCC}$ & Collaborative Consensus Committee \\
\hline $\mathrm{CE}$ & Office of Conservation and Renewable Energy (within DOE) \\
\hline CEC & California Energy Commission \\
\hline CFA & Consumer Federation of America \\
\hline CFR & Code of Federal Regulations \\
\hline CHEERS & California Home Energy Efficiency Rating System, Inc. (see also CHERS) \\
\hline CHERS, Inc. & California Home Energy Rating System, Inc. \\
\hline CHFA & Colorado Housing and Finance Authority \\
\hline COP & Coefficient of performance (ratio of heat delivered to energy consumed) \\
\hline $\mathrm{DE}$ & Virginia Department of Energy \\
\hline DOC & U.S. Department of Commerce \\
\hline DOE & U.S. Department of Energy \\
\hline DPS & Vermont Department of Public Service \\
\hline DSM & Demand-side management \\
\hline DVA & U.S. Department of Veterans Affairs \\
\hline EEBA & Energy Efficient Builders Association \\
\hline EEF & Energy efficiency financing \\
\hline EEH & Energy efficient home \\
\hline EEI & Edison Electric Institute \\
\hline EEIs & Energy efficiency improvements \\
\hline EEMs & Energy efficient mortgages \\
\hline EER & Energy efficient ratio \\
\hline EEVI & Energy efficiency value increment \\
\hline EHRAI & Energy Rated Homes of Alaska, Inc. \\
\hline EMV & Energy mortgage valuation \\
\hline EPA & U.S. Environmental Protection Agency \\
\hline EPAct & The Energy Policy Act of 1992 \\
\hline EPRI & Electric Power Research Institute \\
\hline ERHA & Energy Rated Homes of America \\
\hline ERH-AR & Energy Rated Homes of Arkansas \\
\hline ERHV & Energy Rated Homes of Virginia \\
\hline
\end{tabular}




\begin{tabular}{|c|c|}
\hline ERH-VT & Energy Rated Homes of Vermont \\
\hline Fannie Mae & Federal National Mortgage Association, (see also FNMA) \\
\hline FHA & Federal Housing Administration \\
\hline FHLMC & Federal Home Loan Mortgage Company ( see also Freddie Mac) \\
\hline FIEC & Federal Institutions Examination Council \\
\hline FNMA & Federal National Mortgage Association (see also Fannie Mae) \\
\hline Freddie Mac & Federal Home Loan Mortgage Corporation (see also FHLMC) \\
\hline FTC & Federal Trade Commission \\
\hline GNMA & Government National Mortgage Association \\
\hline GPO & Government Printing Office \\
\hline GRI & Gas Research Institute \\
\hline GSA & General Services Administration \\
\hline HBAs & Home Builder Associations \\
\hline HBAV & Home Builders Association of Virginia \\
\hline HBI & Home Builders Institute \\
\hline HDD & Heating degree days \\
\hline H.E.L.P. & Home Energy Loan Program \\
\hline HERS & Home energy rating systems \\
\hline HERS Council & Home Energy Rating Systems Council \\
\hline HUD & U.S. Department of Housing and Urban Development \\
\hline HVAC & Heating, ventilating, and air conditioning \\
\hline IAQ & Indoor air quality \\
\hline $\mathrm{kW}$ & Kilowatt \\
\hline kWh & Kilowatt-hour \\
\hline LCC & Life-cycle costing \\
\hline LTV & Loan-to-value ratio \\
\hline MBA & Mortgage Bankers Association of America \\
\hline MCS & Model Conservation Standards \\
\hline MEC & Model Energy Code \\
\hline MHCSS & Manufactured Home Construction and Safety Standards (issued by HUD) \\
\hline MICA & Mortgage Insurance Companies of America \\
\hline MTT & Massachusetts Institute of Technology \\
\hline MLS & Multiple Listing Service \\
\hline MW & Megawatt \\
\hline NAHB & National Association of Home Builders \\
\hline NAR & National Association of REALTORS ${ }^{\mathrm{TM}}$ \\
\hline NARI & National Association of the Remodeling Industry \\
\hline NASEO & National Association of State Energy Officials \\
\hline NCSL & National Council of State Legislatures \\
\hline NES & National Energy Strategy \\
\hline NESA & National Energy Specialist Association \\
\hline NGA & National Governor's Association \\
\hline N-HERO & National Home Energy and Resources Organization \\
\hline NIST & National Institute of Standards and Technology \\
\hline NOPR & Notice of proposed rulemaking \\
\hline NRDC & National Resources Defense Council \\
\hline NREL & $\begin{array}{l}\text { National Renewable Energy Laboratory (formerly the Solar Energy Research } \\
\text { Institute - SERI) }\end{array}$ \\
\hline OBT & Office of Building Technologies \\
\hline
\end{tabular}


OPA

OTFA

PG\&E

PITI

PSIC

PUC

PUD

PVE

R\&D

RESNET

RHS

$\mathrm{SC}$

SCE

SECP

SEER

SEI

SEO

SERI

TAC

TPG

VHFA

V-HERO

VREF
Office of Planning and Assessment (within DOE)

Office of Technical and Financial Assistance (within DOE)

Pacific Gas \& Electric Company

Principal, interest, real estate taxes, and hazard insurance

Passive Solar Industries Council

Public utilities commission

Public utility district

Petroleum violation escrow

Research and development

Residential Energy Services Network

Rural Housing Service, U.S. Department of Agriculture

Steering Committee of the National Collaborative

Southern California Edison

State Energy Conservation Program

Seasonal energy efficiency rating (Btu/watt hr)

Southern Electric International

State energy office

The former Solar Energy Research Institute, see NREL

Technical Advisory Committee of the National Collaborative

Thermal performance guidelines

Vermont Housing Finance Agency

Virginia Home Energy Rating Organization

Virginia Residential Energy Foundation 


\section{Glossary}

Amortization - Gradual payoff of a debt through installment payments of principal and interest. Most modern mortgages amortize monthly over the term of the loan.

Annual energy cost savings - The difference in the first year cost of energy of the proposed or existing building or facility as compared with the energy cost of its representative structure.

Applicant - A prospective mortgage borrower.

Appraisal - A report made by a qualified person setting forth an opinion or estimate of value. The term also refers to the process by which this estimate is obtained. In conventional mortgages and in the HUDFHA Direct Endorsement program, the lender receives a copy of the complete report, showing the basis for the appraiser's estimate. In VA cases and in HUD applications processed by HUD, the lender receives only a statement of the estimate of value, without any detailed supporting data.

Appraised value - An opinion of value reached by an appraiser based upon knowledge, experience, and a study of pertinent data. Distinguished from FHA value.

Appraiser - Person who gathers information about a home that is necessary to rate the energy efficiency of the home.

Appreciation - Any increase in value. The opposite of depreciation.

Audit - Analysis of a specific building's consumption and potential to conserve utility-supplied energy. An energy inspection typically associated with utility RCS (Residential Conservation Service) audits, which were mandated by Congress for larger utilities to provide until July 31, 1990.

Baseline - The point from which energy savings are measured.

Basic qualifying ratio - The maximum generally acceptable qualifying ratio for a mortgage agency; e.g., for Fannie Mae and Freddie Mac, it is presently 28/36. This ratio is often adjusted upward or sometimes downward for compensating factors such as the borrower's credit worthiness.

Borrower - A mortgagor who receives funds in the form of a loan with the obligation of repaying the loan in full with interest, if applicable.

British thermal unit (Btu) - A unit used to measure quantity of heat, defined as the quantity of energy necessary to raise the temperature of $1 \mathrm{lb}$ of water $1^{\circ}$ Fahrenheit.

Btw/ft - Energy consumption unit per square foot of building floor space.

Building code - The local regulations that control design, construction, and materials used in construction. Building codes are usually based on safety and health standards. 
Calculational systems - Systems usually based on one of the many building simulation models and an estimate of the amount of energy saved over some base case, which might be the current building code. The savings are translated into several forms: Btu/ $\mathrm{ft}^{2}$, points which are equivalent to a certain amount of usage/savings, or other designations such as "stars."

Certification programs - A program typically operated by utilities, home builders' organizations, or notfor-profit organizations representing interest parties. Energy efficiency-standards are developed using local area demographics construction practices and area climatic conditions. They usually include thermal envelope efficiency criteria and space conditioning efficiency criteria. Certification programs generally rely on a specified inspection/verification process to ensure rating consistency. Houses either pass or fail the inspection for energy efficiency.

Climate zone (CZ) - One of 16 geographic zones in Califomia, defined by the Califomia Energy Commission as having similar typical weather patterns. Climate zones are used to determine annual energy use in buildings in each climate zone.

Closing - The conclusion of a transaction. In real estate, closing includes the delivery of a deed, financial adjustments, the signing of notes, and the disbursement of funds necessary to the sale or loan transaction.

Comparables - An abbreviation for comparable properties used for comparative purposes in the appraisal process. Refers to facilities of reasonably the same size and location with similar amenities. Also properties that have been recently sold and have characteristics similar to the property under consideration, thereby indicating the approximate fair market value of the subject property.

Compensating factors - Any underwriting consideration that would justify the use of higher debt-toincome qualifying ratios. Examples are large downpayment, excellent credit history, or a demonstrated ability to accumulate savings.

Consensus - Informal, face-to-face interaction among specially chosen representatives of all "stakeholding" groups; a voluntary effort to seek "all gain" rather than "win-lose" solutions or watered-down political compromise; often requires the assistance of a neutral facilitator or mediator.

Conventional loan - A mortgage loan neither insured by HUD/FHA nor guaranteed by VA or the Farmers Home Administration.

Cost effective - Producing the most economical outcome for consumers.

Debt - A sum of money due by certain and express agreement.

Debt/equity ratio - A ratio between the amount of capital borrowed and the amount of capital invested out-of-pocket or obtained through the sale of common stock; also known as the leverage ratio.

Debt-to-income ratio - See Qualifying ratio.

Debt-to-income ratio increase - see Ratio increase.

Default - A breach or nonperformance of the terms of a note or the covenants of mortgage. 
Efficiency - The ratio of the useful energy delivered by a dynamic system (such as machine, engine, or motor) to the energy supplied to it over the same period or cycle of operation. The ratio is usually determined under specific test conditions.

Energy - The capacity for doing work. Forms of energy include thermal, mochanical, electrical, and chemical. Energy may be transformed from one form into another

Energy cost savings - The difference between a home whose energy costs are being measured and a comparable home with no energy-saving construction or improvement features. For an existing energyinefficient home, it is the difference in operating cost between the home as it exists and the home after it has received energy-saving improvements.

Energy-efficient measures - Items that reduce a home's consumption of utility-supplied energy, including measures such as insulation and low-emissivity windows and renewable energy technologies such as passive solar design and solar domestic hot water systems.

Energy efficiency rating - A centification of a home's energy efficiency or a relative indication of its energy efficiency on a graduated scale.

Energy efficient mortgages (EEMs) - When a homeowner or home buyer applies for a home loan, at the time of purchase or refinance, he or she can roll the cost of needed energy improvements into the mortgage, amortizing the cost of the improvements over the life of the mortgage.

Energy efficient mortgage program - The energy improvement programs of the VA, FHA, Fannie Mae, Freddie Mac, and the Farmers Home Administration. These are national programs that are available to all home buyers and homeowners at the time of purchase or refinance.

Energy label - Label or sticker placed on the home's energy meter stating energy efficiency rating of home.

Energy rating - A designation of the relative efficiency of a property. In a larger sense, the rating would also include a prioritized energy improvement recommendation, estimates of energy and dollar savings, and documentation of efficiency and savings for the loan file if completed in conjunction with energy-efficient mortgages.

Energy-saving construction or improvement features - Features that contribute to the lowering of energy use in a residence. They include, but are not limited to the following: insulation (e.g., wall, ceiling, floor, slab, crawl, basement, window, door); air infiltration reduction (e.g., gaskets, caulking, weatherstripping, controlled mechanical ventilation); heating and cooling equipment (e.g., setback thermostats and highefficiency furnace, air conditioner, water heater, and fireplace); duct loss reduction; glazing (e.g., amount of glazing, R-value, solar fraction, solar orientation); and passive and active solar features.

Energy-saving measure - Any device, equipment, material, process, construction method, system, structure or combination thereof that will result in a reduction of energy usage, when compared with conventional energy-related practice in the area of the project.

Equity - Net ownership; the difference between fair market value and current indebtedness, usually referred to as the owner's interest. 
Escrow - (1) A transaction in which a third party, acting as the agent for the buyer and seller, carries out instructions of both and assumes the responsibilities of handling all the paperwork and disbursement of funds in a transfer of title and mortgage loan transaction. Escrows may also be established for any purpose, at any time, as for example, in the administration of funds set aside to effect a "buy-down" agreement among seller, buyer, and lender. (2) Funds included in the monthly mortgage payments to accumulate amounts necessary to pay property taxes, insurance premiums, etc. in the future are held in escrow, but the lender often acts as the escrow agent, especially if the lender is a depository institution.

Escrow account - The segregated trust account in which escrow funds are held. The term is also used to describe the accounting of such funds.

Escrow arrangements - Procedures followed and agreements made in conjunction with establishing and scheduling disbursements from an escrow account.

External load controls - Fixed or movable shading elements (e.g., awnings, wing walls, overhangs, eaves, shade screens) that control solar heat gain to exterior envelope components.

Fannie Mae - Term commonly used in referning to the Federal National Mortgage Association.

Farmers Home Administration (FmHA) - A government agency within the Department of Agriculture that operates under the Consolidated Farm and Rural Development Act of 1921 and Title V of the Housing Act of 1949. This agency provides financing to farmers and other qualified borrowers who are unable to obtain loans elsewhere.

Federal Home Loan Mortgage Corporation (FHLMC) - A quasi-government agency that purchases conventional mortgages in the secondary mortgage market from insured depository institutions and HUDapproved mortgage bankers. It sells mortgage participation certificates (PCs) secured by pools of conventional mortgage loans. Popularly known as Freddie Mac.

Federal Housing Administration (FHA) - A division of the Department of Housing and Urban Development. Its main activity is the insuring of residential mortgage loans made by private lenders. It sets standards for construction and underwriting. FHA neither lends money, plans, nor constructs housing.

Federal National Mortgage Association (FNMA) - A congressionally chartered corporation with private stockholders, that purchases residential mortgages insured by FHA or guaranteed by VA, as well as conventional home mortgages. Popularly known as Fannie Mae.

Freddie Mac - Term commonly used in referning to the Federal Home Loan Mortgage Corporation.

Fuel neutral - Rating system that factors in heating and cooling equipment efficiency without favoring one energy type or technology.

Hazard insurance - A contract whereby an insurer, for a premium, undertakes to compensate the insured for loss on a specific property due to certain hazards.

Heating, ventilating, and air conditioning system (HVAC) - A system that provides heating, ventilating, and/or cooling within or associated with a building. 
Home energy rating systems (HERS) - HERS measure and rate, on a scale, the relative energy efficiency of any house, regardless of age, efficiency, or fuel use. The rating is based on the efficiency of the thermal envelope and the heating, ventilating, and air conditioning (HVAC) system and is obtained by on-site inspection and calculations. HERS calculations include estimates of annual energy performance and costs and recommendations for cost-effective energy-efficiency improvements.

HERS characteristics - (1) Designed to rate, on a scale, the relative energy efficiency of any house-new and existing, efficient and inefficient; (2) provides a rating based on efficiency of the thermal envelope, space heating and cooling efficiency, and water-heating efficiency; (3) estimates annual costs; (4) recommends improvement measures; (5) is fuel neutral; (6) requires on-site inspections and quality control; (7) typically, is state sponsored (or approved) and third-party delivered; (8) has goal of providing voluntary, market-driven incentives to encourage increased efficiency; (9) provides documentation that a house meets or exceads a minimum standard for efficiency designated at a point on the scale.

Home energy rater - The person trained and possibly certified to inspect a residence to collect all information needed to complete a home energy rating.

Housing and Urban Development, Department of (HUD) - The Department of Housing and Urban Development was established by the Housing and Urban Development Act of 1965 to supersede the Housing and Home Finance Agency and give Cabinet status to the administration of the nation's housing and urban development programs. It is responsible for the implementation and administration of government housing and urban development programs. The broad range of programs includes community planning and development, low-rent public housing, mortgage insurance for residential mortgages (FHA), equal opportunity in housing, and research and technology.

Indemnify - To protect against loss or damage; insure. To make compensation to for loss or damage.

Insulation, thermal - A material having a relatively high resistance of heat flow and used principally to retard heat flow.

Loan-to-value ratio (LTV) - (1) The relationship between the amount of the mortgage loan and the appraised value of the security, expressed as a percentage of the appraised value. (2) In HUD-FHA transactions, the relationship between the amount of the mortgage loan and "FHA value," which is the sum of the appraised value of the property and the estimated closing costs. See also FHA value.

Low-e - A special coating that reduces the emissivity of a window assembly, thereby reducing the heat transfer through the assembly.

Manufactured house - see Modular house and Mobile home.

Market value - The most probable price that a property should bring in a competitive and open market under all conditions requisite to a fair sale, the buyer and seller each acting prudently and knowledgeably, and assuming the price is not affected by lender stimulus.

Mechanical systems - See Heating, ventilating and air conditioning (HVAC) system.

Mobile home - A factory-assembled residence consisting of one or more modules in which a chassis and wheels are an integral part of the structure and that can be made ready for occupancy without removing the chassis and/or wheels. See also Modular house. 
Modular house - A factory-assembled residence built in units or sections, transported to a permanent site, and erected on a foundation. The term excludes mobile homes. See also Mobile home.

Mortgage - A conveyance of an interest in real property given as a security for the payment of a debt. In its simplest form, the mortgage permits foreclosure if the debt is not paid, but the foreclosure is usually a judicial proceading, in court. After foreclosure, the property is then sold, usually by an officer of the court, to satisfy the debt.

National/ocal threshold - That point on the uniform scale at which energy-efficient mortgage benefits kick in This would be a national threshold if it is set nationally, a local threshold if it is set locally.

Passive solar gain - Solar energy that enters the building, providing heating and/or daylighting to the building.

Passive solar technologies - Technologies that combine architecture to benefit from solar radiation incidence on buildings for heating, cooling and lighting, with good conservation techniques for the building envelope and energy-efficient equipment and controls. Passive solar technologies are typically sunspaces, direct gain systems, and thermal storage wall systems.

Pass/fail rating - A rating system in which an appraised home will "pass" if it meets or exceeds a predetermined level of energy efficiency.

PITI - Principal, interest, taxes, and insurance.

PITI + E - A borrower qualification method that incorporates energy efficiency in the debt-to-income ratios by adding the energy operating cost for the candidate house to other elements of the housing expense.

PITI - ES - A borrower qualification method that incorporates energy efficiency in the debt-to-income ratios by decucting the energy cost savings of the candidate house from other elements of the housing expense.

Principal - The amount of debt, exclusive of accrued interest remaining on a loan. Before any principal has been repaid, the total loaned amount is the principal.

Private mortgage insurance - Insurance written by a private company protecting the mortgage lender against loss occasioned by a mortgage default.

Processing - The preparation of a mortgage loan application and supporting documents for consideration by a lender or insurer.

Quality assurance - A system of controls and actions that ensure and verify conformity (within agreed upon tolerance) to a set of values, norms, standards, or expectations established by a recognized authority.

Qualifying ratio - Percentage ratios that compare the borrowers' anticipated monthly fixed housing expense and total monthly obligations to the borrowers' stable monthly gross income for the purpose of evaluating the likelihood of meeting expenses involved in home ownership.

Rater - A person trained and certified to complete energy ratings of buildings under an approved rating system. 
Rating - A designation of a specific home on a rating scale designed to communicate its level of energy efficiency.

Rating tool - A certified procechure for calculating total annual energy consumption and costs of a home and for assigning a rating that establishes how a given home compares with the efficiency of all other homes.

Ratio increase - The process of increasing the standard debt-to-income ratio in the mortgage transaction by an incremental addition based on favorable financial attributes of a particular borrower.

Refinancing - The repayment of a debt from the proceeds of a new loan using the same property as security.

Remodeling - Additions, modernization.

Renewable energy technologies - The use of, as resources, the energy inherent in sunlight and the direct and indirect results of its impact on our planet (photons, wind, falling water, temperature differentials, and plant matter), gravitational forces (the tides), and the Earth's heat. These technologies at the sites of homes tend to be limited to: passive solar space heating, cooling, and lighting; solar water heating; active solar space heating; photovoltaic generation of electricity; biofuel appliances; and wind generation of electricity.

Renovation - Major rebuilding of existing building.

Retrofit - A modification to an existing building. An energy retrofit is a retrofit that affects the energy performance of the building.

Risk - Two kinds of risk are recognized by the mortgage-lending community: (1) underwriting risk-the degree of probability of default by a borrower; and (2) default risk-the amount or quantity of loss due to default or nonpayment.

Scoring system - A rating system in which points can be obtained for particular levels of various energyefficiency features.

Secondary mortgage market - A system whereby lenders and investors buy existing mortgage or mortgage-backed securities and in doing $s 0$ provide greater availability of funds for additional mortgage lending by banks, mortgage bankers, and savings and loan associations.

Stretch mortgages - Enhanced qualification ratios.

Submetering - Breaking down the utility metering of a building to determine the proportionate energy use of specific building systems and appliances.

System - A combination of equipment and/or controls, accessories, interconnecting means, and terminal elements by which energy is transformed to perform a specific function, such as climate control, service water heating, or lighting (see California Code of Regulations, Title 24, Section 2-5302).

Temperature - Degree of hotness or coldness measured on one of several arbitrary scales based on some observable phenomenon (such as the expansion of mercury).

Thermal envelope - The building's shell—walls, foundation, floors, ceiling, windows, doors, and roof. 
Thermostat - An automatic control device designed to be responsive to temperature and typically used to maintain set temperatures by cycling the heating, ventilating, and air conditioning system.

Third party - An individual or group that does not have any financial interest in the mortgage transaction.

Title - The evidence of the right to or ownership in property. In the case of real estate, the documentary evidence of ownership is the title deed that specifies in whom the legal estate is vested and the history of ownership and transfers. Title may be acquired through purchaser, mortgagee, or otherwise.

Underwriting - The analysis of risk and the matching of it to an appropriate rate and term Underwriting involves an analysis of the property, as revealed in the appraisal report, as acceptable and adequate security for the loan and an analysis of the borrower's ability and probable willingness to repay the loan. Risk may also be affected by other factors, such as loan-to-value ratios, the presence or absence of mortgage insurance, etc.

Uniform - Common, standardized, with no variations in material characteristics.

Utility audit - A formal review of a house's energy use conducted by a utility company representative, with recommendations for energy-efficiency measures, such as weatherstripping, caulking, and insulation.

Valuation - Estimation of value or price though appraisal.

Veterans Administration (VA) - An independent agency of the federal government created in 1930. The Servicemen's Readjustment Act of 1944 authorized the agency to administer a variety of benefit programs designed to facilitate the adjustment of returning veterans to civilian life. The VA home loan guaranty program is designed to encourage lenders to offer long-term, low down payment mortgages to eligible veterans by guaranteeing the lender against loss. VA losses, if any, are paid with the appropriated funds. The VA is now the U.S. Department of Veterans Affairs (DVA).

Whole-house fan - A system capable of cooling a house by exhausting a large volume of warm air when outside air is cool. 


\section{Bibliography}

Farhar, B., N. Collins, and R. Walsh, 1996. Linking Home Energy Rating Systems with Energy Efficiency Financing: Progress on National and State Programs, NREL/TP-460-21322. Golden, CO: National Renewable Energy Laboratory.

Collins, N., B. Farhar, W. Babiuch, and J. Eckert, 1994. A Plan for Evaluating Alternative Approaches to Financing Energy Improvements in Housing (Final Draft), NREL/TP-461-6688. Golden, CO: National Renewable Energy Laboratory.

Farhar, B., and J. Eckert, 1993. Energy-Efficient Mortgages and Home Energy Rating Systems: A Report on the Nation's Progress, NREL/TP-461-5478. Golden, CO: National Renewable Energy Laboratory.

National Collaborative. 1992. A National Program for Energy Efficient Mortgages and Home Energy Rating Systems: A Blueprint for Action, Review Draft. Final Report of the National Collaborative on Home Energy Rating Systems and Mortgage Incentives for Energy Efficiency. Washington, DC: National Renewable Energy Laboratory, March.

National Collaborative. 1992. Going National with HERS and EEMs: Issues and Impacts. The Collected Papers of the National Collaborative. NREL/TP-261-4706. Golden, CO: National Renewable Energy Laboratory. 


\section{Appendix A: Pilot States' Plans for Evaluation}

Introduction

Each HERS provider organization developed a plan to improve their databases and evaluation processes as a part of its contractual obligations to NREL. Each sent NREL a brief letter report describing the progress they had made in developing evaluations for the HERS/EEF programs in their states.

\section{Letters from Pilot States on Evaluation Processes}

The letter reports are presented in alphabetical order by state in this appendix. 


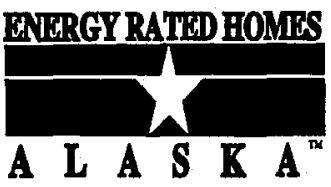

Energy Rated Homes of Alaska, Inc.

P.O. Box 112642

Anchorage, AK 99511

July 10,1996

Dr. Barbara Farhar

National Renewal Energy Laboratory

1617 Cole Blvd.

Golden, Colorado 80401-3393

Dear Barbara:

This letter report for the National Renewable Energy Laboratory, the last deliverable for this project, describes the Energy Rated Homes of Alaska, Inc. system for gathering and evaluating data on the use of residential energy mortgage programs in Alaska, especially as in conjunction with the home energy rating system. The data gathered will be used in a variety of ways including: gauging the success/failure of different types of energy mortgages; measuring participation in these types of programs; evaluating the types of upgrades most commonly made in existing homes; evaluating the effectiveness of the energy mortgages in saving money and energy; tracing the most effective methods of getting consumers to use the energy mortgage products; developing new and more effective energy mortgage programs which are both lenderand consumer-friendly; tracking statewide trends in Alaska; providing a real measurement for the use of the HERS/EIMs in improving the state's housing stock.

In order to complete a meaningful evaluation of energy mortgage activities, the use of home energy ratings must be tracked by a reliable system for data collection. Unfortunately, there currently is no uniform and ongoing national tracking system of energy mortgages by the federally sponsored secondary mortgage markets. Even the national systems that exist do not do a very good job tracking the effectiveness of the mortgage programs which offer extra funds to the home owner who is upgrading the energy efficiency of his home.

Tracking has been made even more difficult by a general confusion over terminology. The traditional term of "energy efficient mortgage" has been used interchangeably to refer to mortgages which recognize the lower cost of a home that is already energy efficient and to mortgages used to finance upgrades to homes which are not energy efficient. This leads to misunderstandings and the inclusion of data that is not entirely accurate.

The National Residential Energy Services Network (RESNET), in conjunction with existing HERS (including ERHA), has developed a common set of definitions for energy mortgages. The term "energy mortgages" is the generic term referring to all forms of mortgage programs which 
foster energy efficiency through the mortgage. "Energy Efficient Mortgage" (EEM) is the term describing mortgage programs which promote the purchase of already efficient homes (rated 4 Star or above on the ERHA rating scale). Examples include the $2 \%$ Debt-to-Income Ratio Stretch and the New Construction Mortgage Program which FHA recently introduced. Mortgage programs which allow the buyers to finance energy improvements and upgrade inefficient homes through the mortgage process are defined as "Energy Improvement Mortgages" (EIMs). The FHA and VA mortgage programs which allow buyer to borrow up to $\$ 8,000$ and $\$ 6,000$ respectively for energy upgrades fall into this category.

Unfortunately, not all secondary lenders have defined what constitutes an "inefficient" home. In the energy mortgage programs which they are now piloting, Fannie Mae and Freddie Mac allow an existing home (more than one year old) with a 3 Star Plus rating to qualify for its $2 \%$-stretch EEM. However, the consistent set of definitions for the energy mortgages should make documentation easier.

Tracking energy mortgages is a difficult proposition. For example, FHA can easily track its EIM program which is designed specifically for upgrading existing homes, because of the way the loans are coded. However, other FHA mortgage loan programs, such as the 203(k) and the Title 1 , which include provisions for financing energy upgrades, must be reviewed on an individual basis to see how much, if any, of the mortgage loan went toward the upgrading of the home's energy efficiency. Another problem with these types of loans is the lack of a before- and afterimprovement energy rating or other measurement which can demonstrates the effectiveness of the upgrades on reducing energy usage.

Energy Rated Homes of Alaska, Inc. has developed a multi-faceted approach for gathering information about the use and success of energy mortgages. Mortgage lenders, energy raters, secondary lenders, along with ERHA, all have roles in this information-gathering process:

- Along with information on various energy mortgage programs, mortgage lenders are given copies of the Energy Mortgage Tracking Sheet, asked to fill them out and to fax or mail them to ERHA's offices. To help encourage the lenders to do so, ERHA plans to employ a variety of techniques recognizing lenders who use energy mortgages, including press releases to business sections and professional newsletters, and awards which will stimulate interest in using energy mortgages by lenders and their customers. Another incentive - RESNET will post on its web page on the Internet a list of all the lenders who have been trained by ERHA and are part of their Energy Star Lender Program.

- Energy raters receive copies of the Energy Mortgage Tracking Sheet. Part of their responsibility as raters is to fill out a Tracking Sheet for every rating they perform in which the home owner/buyer is using one of the energy mortgage programs. Where once, existing home owners in Alaska had the incentive of a rebate for energy upgrades made to their homes, the disappearance of this rebate program has reduced considerably the number of As-Is and Post-Improvement ratings being performed. Since the gathering of the data and its use in marketing will help boost the number of ratings they do, particularly on existing homes, the raters appreciate the value of the Tracking Sheets as a method to increase the ratings done on existing homes and are 
conscientious about turning them in to ERHA.

- Members of the Secondary Mortgage Market (FHA, VA, Fannie Mae, Freddie Mac) which operate in Alaska will be given the Tracking Sheets for distribution to their lender members. Periodically, ERHA will meet with the providers of energy mortgage programs in Alaska to share and compare data bases. ERHA will also work with the Secondary Market Members to create the lender recognition that is key to their participation in the data gathering process.

- ERHA is the lynch pin of this data-gathering process. All the Tracking Sheets (which are color-coded for lenders, raters and secondary mortgage market) are returned to the ERHA offices and entered into the energy mortgage data base there. ERHA manages the gathering, analysis and distribution of the data on energy mortgage programs. ERHA also takes the lead in the marketing of the growing number of opportunities available under the energy mortgage standard. Periodically, ERHA staff will evaluate the Tracking Sheets and call participants - both lenders and home buyers - to discuss their experiences with the energy mortgage programs, as well as gather specific information about costs, savings and improved efficiencies. Besides broadening the data bank, this information helps ERHA in its advisory role to the development of energy mortgage programs across the country.

With the approval of ERHA's application to be included in Fannie Mae/Freddie Mac's pilot energy mortgage project, Alaska home buyers will have other options when choosing an energy mortgage program. This data compilation program will be modified as necessary to include the gathering of specific information required by the introduction of these new energy mortgage programs by the fall of this year.

If you have any questions or need more information, please feel free to call me at any time at $907 / 345-4963$. Thank you for your continued support of our activities.

Sincerely,

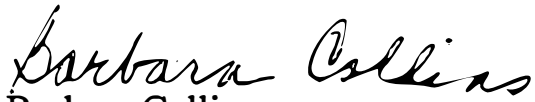

Barbara Collins

Executive Director 


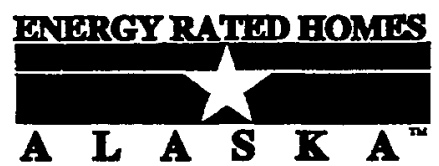

\section{ENERGY MORTGAGE TRACKING SHEET}

NAME

ADDRESS

PHONE NUMBER

YEAR HOUSE BUILT

RATER

BEES (points/stai)

AS-IS

POST-IMPROVEMENT

\section{LENDER}

(Company/Individual)

PHONE/ADDRESS

TYPE OF ENERGY MORTGAGE

MORTGAGE AMOUNT INTEREST RATE

MONTHLY PAYMENT (Pre-EIM) (Post-EIM)

AMOUNT ADDED FOR ENERGY UPGRADES

AS-IS ENERGY COSTS POST ENERGY COSTS IMPROVEMENTS/COSTS

COMMENTS (Continue on back if necessary) 


\section{ENERGY RATED HOMES OF ARKANSAS}

"The uniform system of evaluating and rating home energy efficiency"

National Renewable Energy Laboratory

Attention: Dr. Barbara Farhar

1617 Cole Boulevard

Golden, CO 80401

\section{Dear Barbara:}

I am writing this letter in response to the final action on our contract (Contract \# ACD-515306-01) for NREL.

This past year we have set up a system by which we collect data on the ratings that we do for the Energy Efficient Mortgage Program. From the data collected on each of the ratings with this system we are able to "evaluate" our progress as well as evaluate the progress of our customers. The relational database that we use is very simple in context to the evaluation that NREL has done this past year, but it supplies us with the information that we need for our program evaluation and for Department of Energy (DOE).

I have enclosed a sheet that we use in the collection of our data. From this sheet you will see that we have chosen the items that have the greatest effect on the rating of the home. We can gather from this information a great deal of data for our goals that are set by the DOE. We also regularly report to the Arkansas State Energy Office as they must report to the state legislature each year on the progress of this program. We work with updates on this information quarterly so our data stays more current when doing the evaluation in house.

We also regularly keep a calendar of events that gives us additional information on how many people are at training's, home shows educational meetings, etc. This has proved invaluable for the evaluation process. We hope to include this in new and revised database collection tools that will evolve through the years.

If you have any questions or need more information, please feel free to call me at any time. Thank you for your continued support of our activities.

Sincerely,

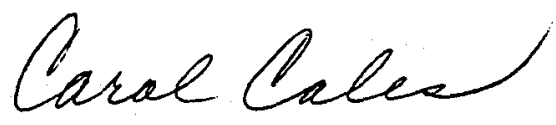

Carol Cales

Executive Director 


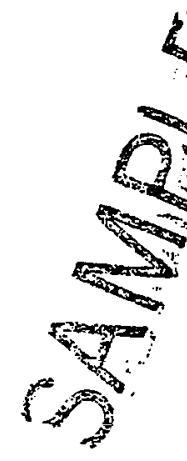

City/County/Region :

File No.

Conditioned floor area:

Component costs:

Total cost of EEM improvements: \$

Total amount escrowed: \$

Amount cost effective: $\$$

Amount homeowner provided: $\$$

Cost of inspection/final inspection: \$

Interest Rate:

Insulation: \$

Air Leakage: $\$$

Windows: $\$$

Estimated energy savings:

Gas MBtu_ I _ \$

Electric MBtu

HVAC: $\$$

Est. Annual utility cost "As Is": \$

Est. Annual utility cost "Ef ficiency Options": \$

Est. Annual utility cost "Post Improvements": \$

timated energy savings:

$$
\text { MBtu_ I } \$
$$

Tons of $\mathrm{CO}_{2}$ emmission reduction:

$$
\text { Eas_tricity tons }
$$

\begin{tabular}{|c|c|c|c|c|c|c|c|c|c|}
\hline & $\begin{array}{c}\text { Priority } \\
\#\end{array}$ & $\begin{array}{l}\text { Area } \\
\text { sq. ft. }\end{array}$ & $\begin{array}{c}\text { Existing } \\
\text { Level }\end{array}$ & $\begin{array}{c}\text { Recom. } \\
\text { Level }\end{array}$ & $\begin{array}{c}\text { Installed } \\
\text { Level }\end{array}$ & $\begin{array}{c}\text { Installec } \\
\text { Cost }\end{array}$ & \begin{tabular}{l|} 
Annual \\
Savings
\end{tabular} & $\begin{array}{c}\% \\
\text { Recum } \\
\text { on } \\
\text { Invest. }\end{array}$ & \\
\hline \multicolumn{10}{|l|}{ Ceiling Insulation } \\
\hline \multicolumn{10}{|l|}{ Wall Insulation } \\
\hline \multicolumn{10}{|l|}{ Floor Insulation } \\
\hline \multicolumn{10}{|l|}{ Stem wall Insulation } \\
\hline \multicolumn{10}{|l|}{ Windows \& Doors } \\
\hline \multicolumn{10}{|l|}{ Air Leakage } \\
\hline \multicolumn{10}{|l|}{ Duct Leakage } \\
\hline \multicolumn{10}{|l|}{$\begin{array}{l}\text { Water Heater } \\
\text { gas___electric }\end{array}$} \\
\hline \multicolumn{10}{|l|}{$\begin{array}{l}\text { Heating Equipment } \\
\text { AFUE__HSPF } \\
\text { Elect.__Other }\end{array}$} \\
\hline \multicolumn{10}{|c|}{$\begin{array}{c}\text { Cooling Equiphen } \\
\text { SEER }\end{array}$} \\
\hline Comments: & & & & & $\therefore$ & & $\begin{array}{l}\text { EEM } \\
\\
\\
\\
\end{array}$ & $\begin{array}{l}\text { File St } \\
\text { Initial In } \\
\text { Beginnir } \\
\text { - Bid Proc } \\
\text { Escrow } \\
\text { - Unsucce } \\
\text { Successf } \\
\text { Released }\end{array}$ & $\begin{array}{l}\text { atus - (dates) } \\
\text { ispection } \\
\text { ng Stages } \\
\text { cess } \\
\\
\text { ssful - (explain) } \\
\text { fully Completed } \\
\text { dfrom Escrow }\end{array}$ \\
\hline
\end{tabular}

Total $\mathrm{CO}_{2}$ reduced: _tons 
California Home Energy Efficiency Rating System, Inc.

March 19, 1996

Barbara C. Farhar, Ph.D.

Center for Renewable Systems

NREL

1617 Cole Boulevard

Golden, CO 80401-3393

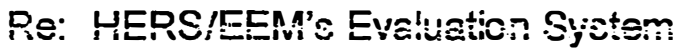

Dear Barbara:

The HERS/EEM's evaluation system for California will include several components. Our summation includes the current status of each. Information will be compiled on ratings performed by CHEERS in California, Nevada and additional states as added.

CHEERS is working with Energy Plus, the California Energy Commission ("CEC"), and the HERS Council Implementation and Accreditation Committee to define and resolve the remaining issues. This evaluation system is intended to comply with the pending DOE HERS Guidelines and CEC Regulations. As such, it is still a work in progress.

A. Rating Tool Accuracy Evaluation Data:

1. Property specific information captured by rating system from internal data base which is part of rating tool software under HERS Guideline 17.

2. Non-property specific information provided to the CEC in a yet to be defined format for publicly accessible HERS Provider Information.

3. Full data records on all ratings performed, all training materials utilized, and all

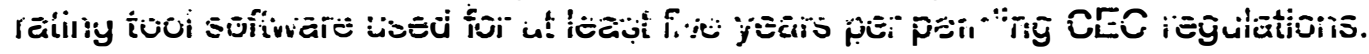

B. Appraiser/Realtor@ Accessible Property Data:

1. Information will be collected by CHEERS and provided to one or more of the commercially available appraisal data suppliers (Metro Scan, TRW-REDI, Data Quick/CMDC) as is required by Freddie Mac under the EEM/EIM Pilot Program.

2. CHEERS is working with the California Association of Realtors $₫$ MLS Policy Committee to include the Energy Rating Score in all 250+ independent MLS systems. As there is no central system or authority, this is a long term task.

C. Research and Statistical Evaluation Data:

1. CHEERS currently retains all information used to input and calculate the recommendations and energy data included on the rating certificate.

2. Ratings performed under CHEERS 2.0 will include additional information related to the type of financing utilized and improvements financed.

1700 Adams Avenue • Suite 102 • Costa Mesa, CA 92626

(714) $540.0501 \cdot \mathrm{FAX}(714) 540.2860$ 
Each of these data collection and evaluation components have their own requirements and applications, many of which are still being defined. The following is a summation of the current status of each of these HERS/EEM's Evaluation System components.

CHEERS and our attorney are currently working on a Consumer Release which will meet the requirements of A-1 (Utility Bills Release), A-2 (CEC Annual HERS Provider Reports), B-1 (Property Specific Appraisal Information Release), B-2 (MLS Rating Score Release), and C (Research and Statistical Evaluation Data Release). The challenge is to develop a Consumer Release which allows CHEERS to provide the necessary information to all the parties who need (or want) access to this data, while still being sufficiently narrow that the consumar might be willing to sign it.

CHEERS is currently in discussions with several commercially available data suppliers on the technical, legal, financial, and practical implications of adding energy efficiency and other improvement information to the current appraiser data bases. This process should be successfully concluded by June, 1996.

CHEERS is continuing to work with the MLS Policy Committee at CAR and individual MLS system providers to encourage each provider to modify their software to include the Energy Rating "Star" Score in their MLS system. Since the MLS Policy Committee has no enforcement authority over the MLS system providers, they have thus far declined to issue a recommendation endorsing this change since it would be "nonbinding." However, they had no objection to the proposal and, in fact, many of the committee members thought it was a good idea.

Enclosed is where we ended up last year with the MLS Policy Committee. They now have a new Committee which I plan to volunteer to participate on as a REALTOR® member rather than as an affiliate "supplicant." However, there are currently higher priorities related to the survival of the HERS Industry which are taking my attention.

Assuming that we can clear the remaining hurdles to achieving industry viability in California, we will have a much better reporting and evaluation capability for our 1996 rating activity. If you need any additional information on the development of a HERS/EEM's Evaluation System for California, please give me a call.

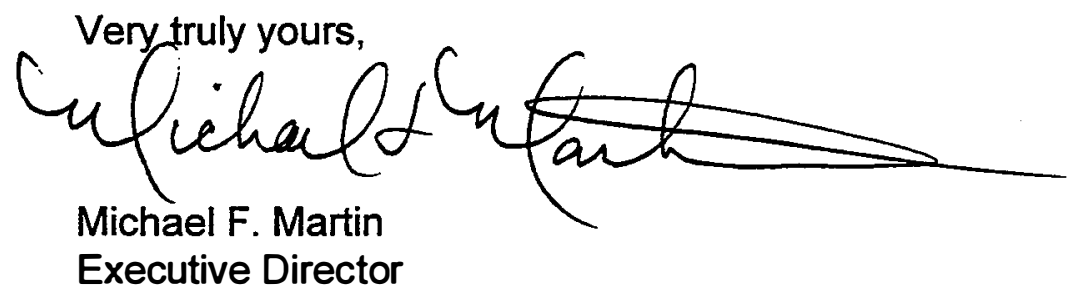

cc: Nancy Collins, Q-4 Associates 


\section{Issues Briefing Paper}

Multiple Listing Service Committee

September 19, 1995

\section{Energy Rating System Data Field for MLS}

The following is for study only and has NOT been approved by the Multiple Listing Service Committee, the Executive Committee or the Board of Directors.

Issue: $\quad$ Should C.A.R. recommend that local MLS's include an energy efficiency rating field in their data bases?

\section{Background:}

A non-profit organization called CHEERS approached the California MLS committee leadership to urge all California MLS's to include an energy efficiency rating in all MLS's. This organizations proposal is attached to this issues briefing paper.

C.A.R. does not mandate the inclusion of any field in a local MLS. Any such decisions are based on market and business needs at the local MLS level. C.A.R. has recommended the inclusion of certain fields for legal and NAR policy reasons on occasion such as during the agency law transition and relating to dual and variable commissions.

The CHEERS organization believes that a strong policy statement from C.A.R. recommending that energy ratings be included in MLS's will be effective in getting local MLS's to adopt the energy rating field.

Should the MLS committee make such a recommendation. 


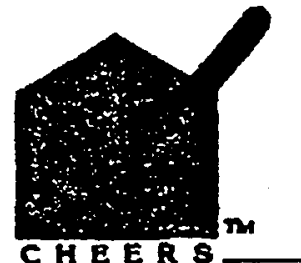

TO:

FROM: Michael Martin, Executive Director

DATE: September 18, 1995

RE:

As proposed at the June 6, 1995, MLS Policy Committee meeting of CAR, CHEERS is requesting adoption on 9/21/95 of an MLS Policy Committee recommendation that all California MLS's add an Energy Rating Score field to their data base. A single, fourcharacter alpha-numeric field is all that is required.

Our reasons for this request are as follows:

1. This is the most common request of Realtors who have completed the DRE accredited training courses on Home Energy Rating Systems and Energy Efficient Mortgages ("HERS/EEMs"): Where can we find the rating score on the MLS. Without the rating score, Realtors cannot properly counsel their clients as to the relative efficiency and cost of operation of comparable properties. This question will become even more common as Realtors complete the continuing education course on HERS/EEMs included in last month's CAR magazine.

2. The current lack of information is inconsistent with the intent of paragraph 7a of the CAR contract providing the home purchaser with the right to inspect the home's energy efficiency and with paragraph 11 e under property disclosures providing for distribution of the Califomia Energy Commission's home energy rating booklet, when available.

3. California was chosen as one of five states nationally to participate in the VA and FHA pilot program for energy efficient mortgages ("EEMs"). According to FHA's records, California has done over $75 \%$ of the national pilot's loans. Following this successful FHANA pilot, Fannie Mae and Freddie Mac have initiated a conventional EEM pilot which CHEERS has requested be made available in California. One of Freddie Mac's guidelines for this is that the MLS's or other data sources include energy rating scores. 
4. The national HERS guidelines published $7 / 25 / 95$ in The Federal Register by the Department of Energy ("DOE") also contain this recommendation in Section $\mathbf{4 3 7 . 4 ( b )}$ (pg. 37960) that one of the purposes of a rating system is to permit "(b) each multilisting service (MLS) include available home energy rating information on any applicable listing."

In describing this section (pg. 37952), DOE states "proposed section 437.4 (b) provides for encouraging multiple listing services to include available home energy rating information. ... However, the Department is not proposing that such a rating should be a prerequisite to listing a home."

5. The California Energy Commission's ("CEC") Draft HERS Regulations proposed for public comment 9/14/95 have extensive reporting and data collection requirements for HERS provider. While the CEC does not specifically mention MLS's, they are participating in the national rule making process and will seek a consensus between state and federal regulations where possible. An MLS energy rating data field is entirely consistent with the CEC's statutory requirements under Public Resource Code Section 25942.

Enclosed is a copy of Freddie Mac's requirements and CHEERS request and representations.

While CHEERS is very sensitive to the many competing demands for data items in California's independent MLS's, we feel strongly that the benefits of a four-character field for the energy rating score are substantial. Not only does the Realtor and their client benefit by having access to this information, it also opens financing doors for California home owners. Beyond the immediate and tangible benefits are the public policy issues for energy conservation reflected in the proposed federal guidelines, state regulations, and existing CAR contract.

We strongly believe that a positive recommendation from the MLS policy committee is essential to advance the interests of their Realtor members and the California home buying public. 


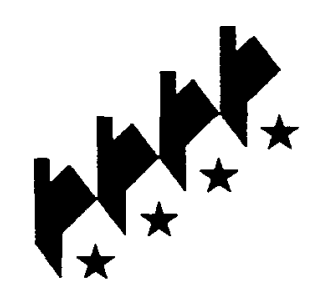

Barbara Farhar

National Renewable Energy Laboratory

1617 Cole Blvd.

Golden, CO 80401-:;393

March 29, 1996

re: Letter Report on the Development of Home Energy Rating Systems(HERS)/Energy Efficient Mortgage (EEM) Evaluation System

Dear Barbara:

This letter reports on Energy Rated Homes of Vermont's (ERH-VT) progress in designing and implementing a system for data collection for evaluation purposes, as required under our grant agreement.

Until this time, rating-related files have been kept in hard copy and separate electronic files. Only limited technical information has been stored in an Energy Rated Homes of America database system. As part of the National Renewable Energy Laboratory (NREL) and Department of Energy (DOE) Pilot States grants, ERH-VT has designed and begun to implement data collection systems that will greatly aid in future reporting and evaluation efforts.

ERH-VT has installed a local area network (LAN) in our central office that allows all staff to communicate electronically. This has enabled us to share and transfer rating-related files, and to store information from them in a central database.

At the same time, we have worked extensively with a local computer programmer to develop the Central Rating Information Processing Tool (CRIPT). This customized data management system is designed to move ERH-VT from having a paper-based rating processing and storage system to having one that is primarily electronically-based. The CRIPT relies on the LAN and allows both central and remote of fice raters to:

1. intake new: rating orders,

2. track rating status (who has which file, the stage the rating is at, site scheduling, etc.),

3. provide customer service (any correspondence with customers is noted and tracked),

4. invoice ratings,

5. merge customer information into rating report documents, and

6. generate status reports. 
We have transferred most of our old rating processing systems into the CRIPT system. Historically, we have had many separate applications and files, but now all customer and technical information can be stored in one location, merged into the numerous files that go into each rating report and stored in a database which can be queried for various types of information.

Our main focus has been to move our larger-volume utility rating programs into the CRIPT. To date, most of these utility programs have been centralized and we are currently moving all other rating programs into the system. We anticipate completion of these efforts by the end of June.

Having all of this rating information centralized in an electronic database will greatly aid in future evaluation efforts of ERH-VT and the Energy Mortgage programs we support. Eventually, if funding is available, we hope to be able to move information from past ratings into the CRIPT. However, thanks to assistance from NREL and DOE, we have set the stage for central rating storage that will make future evaluation efforts significantly easier.

Sincerely,

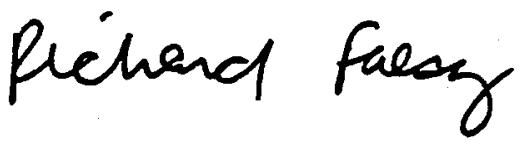

Richard Faesy

Director

cc: Debra Blunt 


\section{SUBCONTRACT NO. ACD-5-15310-01 \\ NREL AND V-HERO}

Final Report

June 7, $\$ 996$

\section{Completion of Contributory Role.}

\section{Report on the Changes to the \\ Evaluative Processes Used by V-HERO \\ as a Result of the Performance of this \\ Subcontract with NREL.}

Vingin.s. Virginia Home Energy Rating Organimation, Inc.
Due to complications in NREL's DOE funding, this program was necessarily slowed down in its completion date, and the subcontract was rewritten to reflect a new program completion date of September, 1996.

However, all of the deliverables and tasks assigned to the Virginia Home Energy Rating Organization under this contract have at this time been fulfilled, with the exception of this final report. The subject matter contained herein pertains to the development and refinement of the evaluative procedures used by V-HERO in its dayto-day business as a result of the experience of compiling and structuring the necessary background data for submission to Dr. Farhar for inclusion in her paper.

First and foremost the very action of gathering the data; both computerized and hard copy, which was required to answer the multitudinous questions inherent in a complete exploration of the topic of HERS provision, and of the stages of development necessary to success of an industry for which initially there was no market, created an unexpected impact on those V-HERO staff members who have been so deeply involved with the process since its inception. The volume of paperwork, records, correspondence, media, training records, as well as the actual rating data, spoke volumes about the nature and difficulty of the task we had undertaken. Additionally, that effort left us with a suddenly awakened appreciation for how far we had come and how much we had already accomplished. This perspective is often lost in the day to day struggle to attain self-sufficiency.

Many of the components of the V-HERO program have been impacted by this year long effort to expeditiously report on the progress of this federal initiative. To understand the influences, it might be helpful to explore the experiences and factors which the staff reported as having the most effect on their thinking:

1) It became crystal clear quickly, that many of the difficulties experienced in writing this report would have been made simpler by even one of the involved party having a quality tool and efficient methodology for gathering the necessary data. Almost all of the HERS providers in the country are using obsolete or deficient software, which makes it difficult to even retrieve much less correlate 
NREL

Final Report

June 7, 1996

stored data. HUD had great difficulty identifying EEMs for a variety of reasons, among them, lack of lender understanding of the importance of coding these new mortgages so that they could be tracked.

2) V-HERO's staff and Board of Directors were staggered to discover how many lenders the program had actually worked with on existing mortgages. Even beyond that there was a surprising number of repeat loan originators who had gone unnoticed due to the volume of work and to the fact that the software then used did not ask for nor store data on the lender (or the type or details of the loan product). Discovering these partner lenders allowed staff to recontact them and reinforce the :; working relationship, a nicety which often goes neglected under pressure.

3) Geographic and demographic patterns of development were rediscovered which led to the institution of previously successful initiatives in areas of the state which were previously inactive. As a result, many Raters had to be retrained because it had been so long since their initial training they had forgotten how to perform the Rating data collection.

4) I believe that the underlying reasons for many of the difficulties experienced by the program in institutionalizing energy efficiency became clearer during the process. Because we were analyzing such disparate records at the same time, correlations which had gone unnoticed were suddenly evident. Fir instance, in almost all cases where Realtors were involved in the HERS process, either their own home or that of a coworker in their office had been Rated and improved prior to their referral of a client.

5) Generally, everyone involved has reported a feeling of well-being. That I think comes from the before mentioned experienced at being forced to take the time to review earlier reports and thus seeing how much progress has been made.

I think many components will be changed in the future due to the experience of participation in evaluation, and these will be over and above the simple change in marketing strategies which will now be able to be thought out in light of the first quality market data available in the U.S. on this subject.

The first, and perhaps largest of these changes, is in the fact that V-HERO during the development of this research study has been cooperatively working with Volt VIEWtech, a California corporation to produce a Rating software not only stateof-art in its ability to model and project energy usage, and not'only in conformance with the National Voluntary Guidelines of the Department of Energy, but also capable of retaining, correlating and reporting on several hundred aspects of the clients and 
NREL

Final Report

June 7, 1996

process of providing home energy Ratings and energy efficiency financing throughout Virginia, and through its sister corporation, the National Home Energy \& Resources Organization, throughout the country. It is hoped that soon, with its use being widely spread throughout the country, RateVIEW will accumulate the largest data bank on energy and our housing stock available anywhere. 


\section{REPORT DOCUMENTATION PAGE}

Public reporting burden for this collection of information is estimated to average 1 hour per response, including the time for reviewing instructions, searching existing data

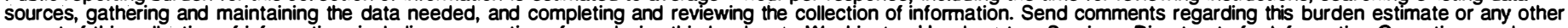
aspect of this collection of information, including suggestions for reducing this burden, to Washington Headquarters Services, Directorate for Information Operations and Reports, 1215 Jefferson Davis Highway, Suite 1204, Arlington, VA 22202-4302, and to the Office of Management and Budget, Paperwork Reduction Project (0704-0188), Washington, DC 20503.
1. AGENCY USE ONLY (Leave blank)

\section{REPORT DATE} May 1997
3. REPORT TYPE AND DATES COVERED Technical Report

\section{TITLE AND SUBTITLE}

Case Studies of Energy Efficiency Financing in the Origianl Five Pilot States, 1993-1996

5. FUNDING NUMBERS

AS575440

BE514102

6. $\operatorname{AUTHOR}(S)$

Farhar, Barbara C., Collins, Nancy E., and Walsh, Roberta Ward

7. PERFORMING ORGANIZATION NAME(S) AND ADDRESS(ES)

National Renewable Energy Laboratory

1617 Cole Boulevard

Golden, Colorado 80401-3393

8. PERFORMING ORGANIZATION REPORT NUMBER

TP-550-22355

DE97000219

9. SPONSORING/MONITORING AGENCY NAME(S) AND ADDRESS(ES)

10. SPONSORING/MONITORING AGENCY REPORT NUMBER

U.S. Department of Energy

1000 Independence Ave., SW

UC Category 920

Washington, DC 20585

11. SUPPLEMENTARY NOTES

12a. DISTRIBUTION/AVAILABILITY STATEMENT

National Technical Information Service

U.S. Department of Commerce

5285 Port Royal Road

Springfield, VA 22161 12b. DISTRIBUTION CODE

13. ABSTRACT (Maximum 200 words) The National Energy Policy Act of 1992 and the Housing and Community Development Act of 1992 required that the Federal Housing Administration of the U.S. Depart of Housing and Urban Development conduct an energy efficient mortgage (EEM) pilot program in five states. As a basis for comparative analysis, the National Renewable Energy Laboratory and the home energy rating system provider organizations in the pilot states developed case studies documenting EEMs implementation. The case studies focus on the years 1993-1996 when the EEMs program was originally being tested and additional energy efficiency financing products were being developed. This report contains the case studies for the five pilot states.

\section{SUBJECT TERMS}

energy efficiency financing, home energy rating systems, energy efficient mortgages, housing and urban development
17. SECURITY CLASSIFICATION
OF REPORT
unclassified

18. SECURITY CLASSIFICATION
OF THIS PAGE
unclassified
SECURITY CLASSIFICATION unclassified
19. SECURITY CLASSIFICATION OF ABSTRACT unclassified

15. NUMBER OF PAGES 358

16. PRICE CODE 